\title{
LA DEMOCRACIA en América Latina
}

Hacia una democracia de ciudadanas y ciudadanos

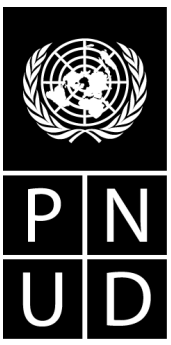

Publicado para el 
El análisis y las recomendaciones políticas de este Informe no reflejan necesariamente las opiniones del Programa de las Naciones Unidas para el Desarrollo, de su Junta Ejecutiva ni de sus Estados Miembros. El Informe es una publicación independiente preparada por encargo del PNUD. Es el fruto de la colaboración entre un conjunto de prestigiosos consultores y asesores y el equipo del Informe de la Democracia en América Latina.

(c) Programa de las Naciones Unidas para el Desarrollo, 2004

1 UN Plaza, New York, New York, 10017, Estados Unidos de América

(C) De esta edición:

Aguilar, Altea, Taurus, Alfaguara, S.A., 2004

Beazley 3860, (1437) Buenos Aires

www.alfaguara.com.ar

\author{
Dirección editorial: Fernando Esteves \\ Coordinación editorial: Mercedes Sacchi \\ Idea de portada: Fischer América Argentina \\ Diseño de interiores: María Isabel Barutti \\ Edición: Graciela Pérez Aguilar, Lenguaje Claro Consultora, Mónica Deleis \\ Diagramación: María Isabel Barutti, Lenguaje Claro Consultora, Gabriela Astengo \\ Corrección: Carolina Tosi, Lenguaje Claro Consultora, Mónica Deleis
}

Programa de las Naciones Unidas para el Desarrollo
La democracia en América Latina: hacia una democracia de ciudadanas y ciudadanos. - 2a ed. - Buenos Aires :
Aguilar, Altea, Taurus, Alfaguara, 2004.

288p. + 1 CD-Rom; 21 x 29,7

ISBN 987-04-0032-9

1. Programa de las Naciones Unidas para el Desarrollo. I. Título.

CDD 307.76

ISBN: 987-04-0032-9

Hecho el depósito que indica la ley 11.723

Impreso en la Argentina. Printed in Argentina

Primera edición: abril de 2004

Segunda edición: diciembre de 2004

Este documento ha sido elaborado con la ayuda financiera de la Unión Europea. En ningún caso debe considerarse que los análisis y recomendaciones del mismo reflejan la opinión oficial de la Unión Europea.

Todos los derechos están reservados. Esta publicación y sus materiales complementarios no pueden ser reproducidos, en todo ni en parte, ni registrados en o transmitidos por un sistema de recuperación de información, en ninguna forma ni por ningún medio, sea éste mecánico, fotoquímico, electrónico, magnético, electroóptico, por fotocopia o cualquier otro, sin el permiso previo por escrito de la editorial.

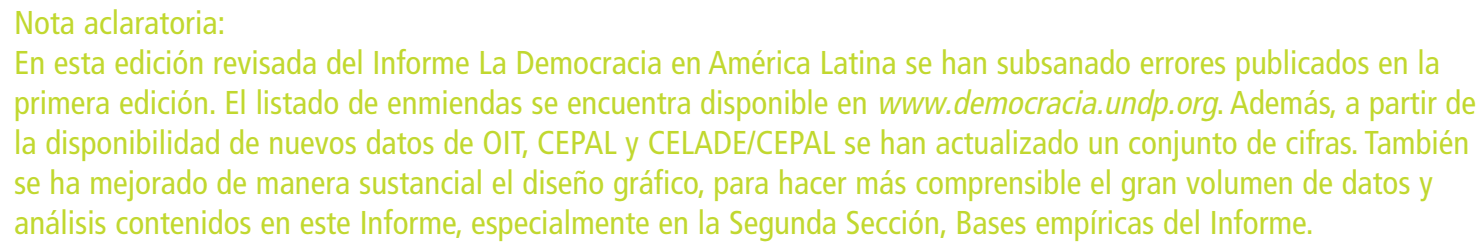




\title{
Programa de las Naciones Unidas para el Desarrollo (PNUD)
}

\author{
Administrador \\ Mark Malloch Brown \\ Administrador Asociado \\ Zéphirin Diabré
}

\section{Administradora Auxiliar \\ y Directora Regional para América Latina y el Caribe \\ Elena Martínez}

Representante Residente en Argentina

Carmelo Angulo Barturen (hasta abril 2004)

Carlos Felipe Martínez (desde mayo 2004)

$$
\begin{aligned}
& \text { Coordinador } \\
& \text { del Programa Regional } \\
& \text { Freddy Justiniano }
\end{aligned}
$$

Asesora de Gobernabilidad

del Programa Regional

Myriam Méndez Montalvo

Director del Proyecto

Dante Caputo 
Este Informe no se habría podido preparar sin la generosa colaboración de muchas personas y organizaciones, a las que se expresa agradecimiento. Una lista detallada aparece en la página 201 de esta publicación. 


\title{
- Proyecto sobre la Democracia en América Latina
}

\author{
Director del Proyecto \\ Dante Caputo
}

\section{Consultores por áreas}

\section{Marco teórico}

Guillermo O'Donnell, con los comentarios de Bruce Ackerman, Andrew Arato, Renato Boschi, Fernando Calderón, Catherine Conaghan, Julio Cotler, Larry Diamond, José Eisenberg, Manuel A. Garretón, David Held, Céli Regina Jardim Pinto, Jennifer McCoy, Adalberto Moreira Cardoso, Juan Méndez, José Nun, Pierre Rosanvallon, Alain Touraine, Laurence Whitehead.

\section{Estudio de opinión}

Jorge Vargas coordinó el equipo integrado por Miguel Gómez Barrantes, Tatiana Benavides, Evelyn Villarreal y Lorena Kikut, para el diseño y análisis de la encuesta Latinobarómetro/PRODDAL 2002.

\section{Indicadores}

Gerardo Munck coordinó el equipo integrado por David Altman, Jeffrey A. Bosworth, Jay Verkuilen y Daniel Zovatto.

\section{Ronda de consultas}

Diego Achard, Augusto Ramírez Ocampo, Edelberto Torres Rivas, Gonzalo Pérez del Castillo, Claudia Dangond, Raúl Alconada Sempé, Rodolfo Mariani, Leandro García Silva, Adriana Raga, Luis E. González, Gonzalo Kmeid, Pablo Da Silveira, y un equipo dirigido por Hilda Herzer e integrado por Verónica De Valle, María M. Di Virgilio, Graciela Kisilesky, Adriana Redondo y María Carla Rodríguez.

\section{Coordinadores}

\section{Coordinador Países Andinos}

Augusto Ramírez Ocampo, con la colaboración de Claudia Dangond, Elisabeth Ungar y Amalfy Fernández.

\section{Coordinadores Países}

del MERCOSUR

Dante Caputo y Raúl Alconada Sempé.
Coordinador de Países del Istmo

Centroamericano y de República

Dominicana

Edelberto Torres Rivas, con la colaboración de Claudio Luján.

Coordinador institucional

Gonzalo Pérez del Castillo. 
Oficial de Programa PNUD:

Rosa Zlachevsky.

Equipo de apoyo:

María Eugenia Bóveda y Fabián de Achaval.
Equipo técnico:

Leandro García Silva, Rodolfo Mariani y Thomas

Scheetz.

Colaboradores especiales:

Fabián Bosoer y Daniel Sazbón.

\section{Difusión del Informe}

Milena Leivi, Milagros Olivera, Sandra Rojas, Emilio Sampietro.

\section{Asesores}

José Luis Barros Horcasitas, Fernando Calderón, Alberto Couriel, Joaquín Estefanía, Gustavo Fernández Saavedra, Enrique Ganuza, Manuel Antonio Garretón, Edmundo Jarquín, Marta Lagos,

Marcos Novaro, Vicente Palermo, Arturo O'Connell, Guillermo O’Donnell, Carlos Ominami.

\section{Consultores}

Gloria Ardaya, Horacio Boneo, Sebastián Campanario, Eva Capece, Julio Godio, Luis Eduardo González, Juan Carlos Herrera, Néstor Lavergne, Norbert Lechner, Silvia Lospennato, y Luis Verdesoto.

\section{Grupo de lectores del Informe}

Carmelo Angulo Barturen, Víctor Arango, Marcia de Castro, Juan Pablo Corlazzoli, Juan Alberto Fuentes, Enrique Ganuza, Freddy Justiniano (Coordinador), Thierry Lemaresquier, Carlos Lopes, Carlos F. Martínez, Magdy Martínez, Myriam Méndez-Montalvo, Gerardo Noto, William Orme, Stefano Pettinato, Juan Rial, Harold Robinson, Martín Santiago, Luis Francisco Thais. 


\section{Índice}

$13 \square$ Prólogo del Administrador del PNUD

17 Prefacio de la Directora Regional para América Latina y el Caribe del PNUD

$21 \square$ Presentación

21 Libertad, democracia y política

$25 \square$ Resumen

25 Introducción

26 La democracia y la idea de democracia en América Latina

27 Balance de la ciudadanía integral

29 Percepciones y apoyo de líderes y ciudadanos

30 Elementos para una agenda

$31 \quad$ Metodología del Informe

PRIMERA SECCIÓN

33 El desarrollo de la democracia en América Latina

35 El desafío: de una democracia de electores a una democracia de ciudadanos

39 Democracia, pobreza y desigualdad: un triángulo latinoamericano

$41 \quad$ Balance entre reformas y realidades

45 Los organismos internacionales y la promoción de la democracia

49 Exploración sobre el desarrollo de la democracia

50 Un debate incompleto

$52 \quad$ Fundamentos teóricos

La idea de democracia

Los déficit de la sociedad como déficit de la democracia

Alcances de la democracia en el Informe

Democracia, régimen político y Estado

Los ciudadanos, fuente y justificación de la autoridad del Estado democrático

El ciudadano, sujeto de la democracia

La ciudadanía va más allá de los derechos políticos, la democracia también

Estado y ciudadanía 
67 Especificidad histórica de las democracias latinoamericanas

70 Cuánta ciudadanía precisa una democracia

\section{SEGUNDA SECCIÓN}

\section{Bases empíricas del Informe}

\section{Indicadores de desarrollo de la democracia}

77 Ciudadanía política, civil y social

$78 \quad$ Ciudadanía política

Indice de democracia electoral

Otros indicadores del régimen democrático de acceso al gobierno

Participación electoral

Competencia electoral y selección de candidatos

Representación electoral

90

Balance del régimen de acceso democrático al gobierno

Otras dimensiones de la ciudadanía política

Poderes constitucionales clásicos

Agencias especializadas de control

Mecanismos de democracia directa

La corrupción en la función pública

Clientelismo

100 Conclusiones sobre la ciudadanía política: logros y deficiencias

102

$$
\text { Ciudadanía civil }
$$

Igualdad legal y protección contra la discriminación

Derecho a la vida, la integridad física y la seguridad

Administración de justicia

Libertad de prensa y derecho a la información

Conclusiones sobre la ciudadanía civil: logros y deficiencias

118

Ciudadanía social

Necesidades básicas

Integración social

La sociedad civil como promotora de la ciudadanía social

Conclusiones sobre la ciudadanía social: logros y deficiencias

\section{Cómo ven los latinoamericanos a su democracia}

Tres orientaciones hacia la democracia: demócratas, ambivalentes y no demócratas

Magnitud de las orientaciones hacia la democracia

Distancia entre las orientaciones hacia la democracia

Perfil social de las personas que sustentan las orientaciones hacia la democracia Heterogeneidad 
Modos de participación ciudadana en la vida política

Participación ciudadana y orientaciones hacia la democracia

Perfiles de intensidad de la ciudadanía

146 El Índice de Apoyo ciudadano a la Democracia

149 La percepción de la dirigencia latinoamericana

149 Perfil de los actores consultados

$150 \quad$ El punto de partida conceptual

150 Condiciones necesarias para la democracia

La expansión de la participación política

La expansión de los controles al ejercicio del poder

Opiniones sobre el carácter de la democracia

155 Causas de las limitaciones de las democracias latinoamericanas

Poderes institucionales y poderes fácticos

El papel de los partidos políticos

Los poderes fácticos

Empresas

Los medios de comunicación

Los factores extraterritoriales

Las iglesias

El sindicalismo

Los poderes ilegales

Los poderes políticos formales

El Poder Ejecutivo

Las Fuerzas Armadas

La visión de los presidentes y vicepresidentes

Valoración de la figura del presidente en el mapa del poder de cada región

Presiones de los poderes fácticos sobre la autoridad presidencial

El papel de los medios de comunicación

Valoración de las organizaciones sociales en la vida política del país

El fortalecimiento de la democracia

La construcción de la agenda pública en América Latina

La agenda futura

Los desafíos

170 Alcances de la democracia en América Latina. Un balance

¿Cómo se ejerce el poder en estas democracias?

$171 \quad$ Síntesis de la ronda de consultas

TERCERA SECCIÓN

173 Hacia la democracia de ciudadanía

175 Cuatro temas para una agenda de debate

176 La política, primera condición

181 La necesidad de una nueva estatalidad

185 Una economía para la democracia 
191 Poder y políticas democráticas en la globalización

$194 \quad$ En síntesis

197

Reflexiones finales

$197 \quad$ El eterno desafío

\section{Agradecimientos}

Instituciones que colaboraron en la elaboración y discusión del Informe

Autores de artículos sobre temas de la agenda

Participantes en la Ronda de Consultas

Participaciones especiales

Funcionarios de la Oficina del Administrador del PNUD

Funcionarios de la Dirección para América Latina y el Caribe del PNUD

Funcionarios de la Oficina de Enlace del PNUD en Bruselas

Funcionarios de la Oficina del PNUD en la Argentina

Representantes residentes, adjuntos y auxiliares de las Oficinas del PNUD en América Latina

Los funcionarios de las Oficinas del PNUD en América Latina

Participantes en seminarios y reuniones
Reunión con el Secretario General de la ONU
Reunión con el Administrador del PNUD
Apoyo en la preparación de reuniones y seminarios
Producción y traducción

207 Nota técnica sobre el Índice de Democracia Electoral (IDE)

207 Construcción del IDE

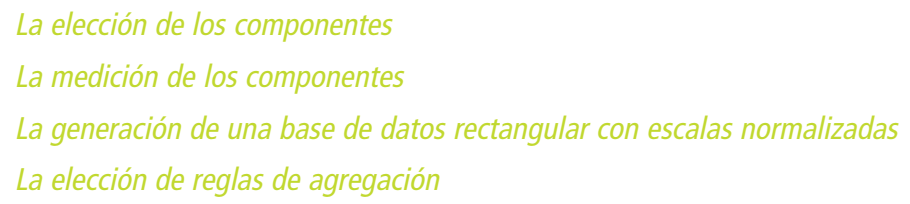

Probando el IDE

Confiabilidad entre codificadores y estimación de error

La solidez de las reglas de agregación

El carácter dimensional de los elementos componentes

Interpretando y usando el IDE

215 Nota técnica sobre los índices derivados del análisis de la encuesta Latinobarómetro 2002. La construcción del Índice de Apoyo a la Democracia (IAD)

215 Presentación

$215 \quad$ Estudio de opinión sobre la democracia

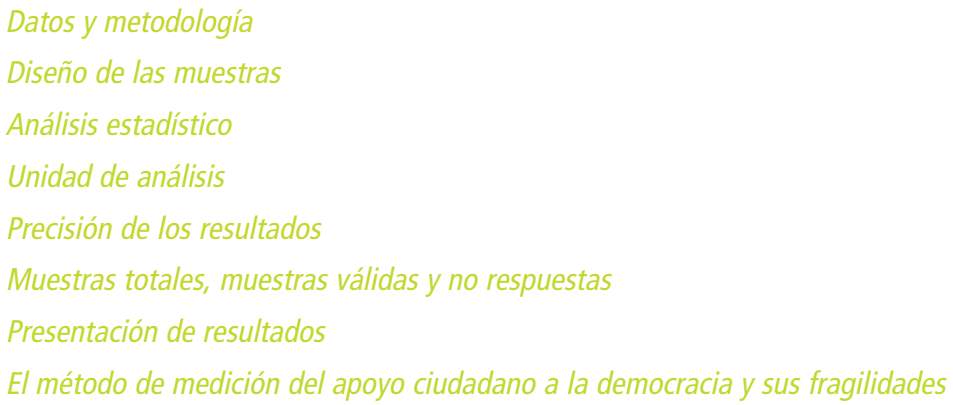


Las tres dimensiones del IAD

Primera dimensión: tamaño de una orientación

Segunda dimensión: activismo político de las orientaciones

Clasificación de modos de participación

Tercera dimensión: distancia entre las orientaciones

La regla de agregación del IAD

La interpretación del IAD

Validación y confiabilidad del IAD

Supuestos y limitaciones del IAD

235 Bibliografía

$265 \quad$ Abreviaturas

267 Índice de recuadros

$271 \square$ Índice de tablas

275 Índice de gráficos

277 Contenido del CD-Rom que acompaña este Informe 



\section{Prólogo del Administrador del PNUD}

mérica Latina presenta actualmente una extraordinaria paradoja. Por un lado, la región puede mostrar con gran orgullo más de dos décadas de gobiernos democráticos. Por otro, enfrenta una creciente crisis social. Se mantienen profundas desigualdades, existen serios niveles de pobreza, el crecimiento económico ha sido insuficiente y ha aumentado la insatisfacción ciudadana con esas democracias - expresada en muchos lugares por un extendido descontento popular-, generando en algunos casos consecuencias desestabilizadoras.

Este Informe representa un esfuerzo importante para comprender y superar esta paradoja. Mediante la combinación de indicadores cuantitativos, entrevistas, encuestas y un diálogo con un amplio número de prominentes líderes y formadores de opinión a lo largo de toda la región, el Informe ofrece un análisis comprehensivo del estado de la democracia en América Latina. Pero, además, busca ir más allá de sólo diagnosticar los problemas existentes, y propone nuevos enfoques para abordar los desafíos que actualmente ponen en riesgo muchos de los avances logrados en los últimos veinticinco años.

El Informe es el resultado del trabajo de un grupo de expertos independientes; por ende, no es un documento oficial sobre las políticas del Programa de las Naciones Unidas para el Desarrollo (PNUD) o de las Naciones Unidas. Consideramos que constituye un valioso aporte para la conformación de una agenda ampliada para los países de América Latina, el PNUD y los socios en el desarrollo para los meses y años venideros. Por esta razón, el PNUD se encuentra muy complacido de haber apoyado esta iniciativa.

El corazón del problema es que si bien la democracia se ha extendido ampliamente en América Latina, sus raíces no son profundas. Así, el Informe advierte que la proporción de latinoamericanas y latinoamericanos que estarían dispuestos a sacrificar un gobierno democrático en aras de un progreso real socioeconómico supera el cincuenta por ciento.

Existen varias razones para esta tendencia. La más importante es que la democracia es, por primera vez en la historia de América Latina, la forma de gobierno en el poder. Así, los gobernantes son culpados cuando las cosas van mal en materia de empleo, ingreso y muchos servicios básicos, que no alcanzan a satisfacer las crecientes expectativas de la ciudadanía.

El panorama se torna aun más complejo si se tiene en cuenta que varios factores indispensables para la gobernabilidad democrática, tales como una prensa libre, una sólida protección de los derechos humanos, un Poder Judicial independiente y vigoroso, requieren todavía ser 
sustancialmente fortalecidos. Y muchos grupos tradicionalmente excluidos no tienen acceso al poder a través de los canales formales y, por ende, manifiestan sus frustraciones por vías alternativas, en algunas ocasiones, por medio de expresiones violentas.

Existen, sin embargo, en el trasfondo de esta situación, algunos signos muy alentadores. Primero, a pesar de las crisis, los países de la región no han buscado un regreso al autoritarismo; en cambio, han ampliamente sostenido sus instituciones democráticas. Segundo, las ciudadanas y los ciudadanos empiezan a distinguir entre la democracia como sistema de gobierno y el desempeño de los gobernantes en particular. Muchos de estos ciudadanos son simplemente "demócratas insatisfechos", un fenómeno bien conocido en muchas democracias establecidas que explica parcialmente por qué los movimientos de oposición no tienden hoy hacia soluciones militares sino hacia líderes populistas que se presentan como ajenos al poder tradicional y que prometen perspectivas innovadoras.

Asimismo, la gente diferencia cada vez más entre las distintas instituciones a la hora de identificar responsables. Mientras los cuerpos legislativos y los partidos políticos reciben el apoyo de menos de un cuarto de la población, el Poder Judicial, el Ejecutivo y los servicios de seguridad muestran una imagen algo mejor.

Para que la democracia no languidezca y crezca, América Latina necesita trabajar sin descanso para que las instituciones democráticas -desde las legislaturas a las autoridades locales- sean transparentes, den cuenta de sus acciones y desarrollen las habilidades y capacidades necesarias para desempeñar sus funciones fundamentales. Esto significa que hay que asegurar que el poder en todos los niveles de gobierno se estructure y distribuya de tal forma que dé voz y participación real a los excluidos y provea los mecanismos por los cuales los poderosos -sean líderes políticos, empresarios u otros actores- estén obligados a rendir cuenta de sus acciones.

En esta tarea no hay atajos; consolidar la democracia es un proceso, no un acto aislado. Pero hacer que las instituciones públicas se desempeñen efectivamente es sólo una parte del desafío. La otra es demostrar a ciudadanas y ciudadanos que los gobiernos democráticos trabajan en las cuestiones que verdaderamente preocupan a la gente, que son capaces de dar respuesta a esas cuestiones y que están sujetos al efectivo control ciudadano cuando no cumplen.

En la práctica, el desafío también implica construir instituciones legislativas y judiciales que protejan los derechos humanos y generen un espacio para un debate político vigoroso pero pacífico; una fuerza policial que garantice calles y fronteras seguras; un poder descentralizado para que la gente en cada localidad pueda movilizarse para asegurar escuelas con maestros bien capacitados y hospitales con equipo y medicamentos apropiados; una floreciente sociedad civil y una prensa libre que participen plenamente en la profundización de la democracia y estén en la vanguardia de la lucha contra la corrupción y la mala administración de los gobiernos y empresas por igual.

Los Objetivos de Desarrollo del Milenio (ODM) de las Naciones Unidas -que van desde reducir a la mitad la pobreza extrema y el hambre, a asegurar que todas las niñas y los niños asistan a la escuela para el año 2015- brindan un vehículo para ayudar a atender estas cuestiones a nivel nacional y regional. En un sentido muy real, los ODM constituyen el primer manifies- 
to global para mujeres y hombres, niñas y niños de todo el mundo: un conjunto de cuestiones concretas, sintéticamente enunciadas y medibles que cualquiera puede comprender y honrar.

Como parte de un pacto global entre países ricos y pobres, y por el compromiso asumido por el mundo desarrollado de apoyar a las naciones en desarrollo que realizan reformas de buena fe, los ODM ofrecen una oportunidad real para canalizar el apoyo externo en términos de acceso a mercados, alivio de la deuda y mayor asistencia, que tantos países latinoamericanos necesitan desesperadamente para impulsar sus propios esfuerzos.

Si América Latina, y el mundo, aprovechan esta oportunidad, existe entonces una posibilidad contundente de construir un nuevo círculo virtuoso a través del cual un crecimiento económico renovado empuje los ODM y, simultáneamente, ayude a construir y sostener democracias más efectivas y capaces de acelerar un progreso social y económico equitativo. Para hacer realidad esta visión, las latinoamericanas y los latinoamericanos y, en especial, los líderes en todos los ámbitos, tendrán que confrontar decididamente las cuestiones críticas que afectan la gobernabilidad democrática y deberán asegurar que desarrollo y democracia no continúen siendo entendidos como alternativas sino como dos caras de la misma moneda.

\section{Mark Malloch Brown}

Administrador del PNUD 



\section{Prefacio de la Directora Regional para América Latina y el Caribe del PNUD}

ubo un momento, no lejano, en que muchos creyeron que la política había muerto: el mercado impersonal y el saber tecnocrático se encargarían de llevarnos al desarrollo. Pero el mercado supone la seguridad jurídica que dan las instituciones. Y la tecnología no dice para qué ni para quién, sino cómo.

Por eso en estos últimos años, los economistas y las agencias de desarrollo han vuelto la mirada sobre las instituciones, sobre las opciones y sobre los conflictos. Vale decir: han vuelto a descubrir la política (aunque prefieren no decirlo).

Este Informe hace parte y a la vez quiere ayudar al redescubrimiento -por tanto, reinvención- de la política como sustento del desarrollo latinoamericano.

En efecto, a petición de los gobiernos, el PNUD ha venido dedicando más y más atención al desafío de consolidar la democracia en América Latina y el Caribe. De hecho, la mayor parte de los programas nacionales de cooperación apuntan a ese propósito mediante la modernización del Estado en sus distintas ramas, la reforma política, la gobernanza local y la adecuada inserción en la aldea global. En no menos de diecisiete países hemos acompañado diálogos que ayudan a construir consenso entre autoridades, fuerzas políticas, sociedad civil y actores no tradicionales. Porque somos una organización de conocimiento, varios proyectos regionales y nacionales se han ocupado o se ocupan de evaluar alternativas y difundir buenas prácticas en materia de gobernabilidad.

En este contexto, la Junta Ejecutiva del PNUD aprobó el II Marco de Cooperación Regional para el período 2001-2005, donde se incluye "la preparación de un informe sobre el estado de la democracia en América Latina [que] será resultado de actividades conjuntas de académicos y agentes políticos y sociales de la región". 1 El texto que hoy me honro en presentar es el primer resultado de dicho proceso, donde participaron más de un centenar de analistas, treinta y dos presidentes o ex presidentes, más de doscientos líderes políticos o sociales y casi diecinueve mil ciudadanas y ciudadanos encuestados en dieciocho países.

1 Junta Ejecutiva del Programa de las Naciones Unidas para el Desarrollo y del Fondo de Población de las Naciones Unidas, Primer Período Ordinario de Sesiones de 2002. 
En su sentido más elemental, la democracia no es otra cosa que "el gobierno del pueblo". Este Informe quiere tomar en serio esa idea vieja, para ponerla en diálogo con el presente y con el futuro de nuestra América:

- Gobierno del pueblo significa que las decisiones que nos afecten a todos sean tomadas por todos. En el contexto de América Latina, hay pues que celebrar la existencia de gobiernos elegidos por voto popular y los avances de representación y participación en la esfera política de las últimas décadas. Pero subsiste el desafío de agrandar la política, es decir, de someter a debate y decisión colectiva todas las materias que afectan el destino colectivo, lo cual a su vez implica más diversidad de opciones y más poder al Estado para que pueda cumplir los mandatos ciudadanos.

- Gobierno del pueblo significa entonces un Estado de ciudadanas y ciudadanos plenos. Una forma, sí, de elegir a las autoridades, pero además una forma de organización que garantice los derechos de todos: los derechos civiles (garantías contra la opresión), los derechos políticos (ser parte de las decisiones públicas o colectivas) y los derechos sociales (acceso al bienestar). Es la democracia de ciudadanía que propone el Informe, y que sirve como el eje ordenador de sus análisis.

Y así, la idea seminal y la invitación esencial del texto que presento es avanzar hacia una democracia de ciudadanas y ciudadanos mediante la ampliación de la política.

¿Habrá necesidad de advertir que "política" no es sólo (ni es siempre) lo que hacen los políticos, sino lo que hacen las ciudadanas y ciudadanos y sus organizaciones cuando se ocupan de la cosa pública?

¿O habrá necesidad de añadir que, así entendida, la democracia es una forma del desarrollo humano? Si desarrollo humano, como una y otra vez han dicho los informes del PNUD, es "el aumento de las opciones para que las personas puedan mejorar su vida",2 diría yo que democracia es desarrollo humano en la esfera de lo público, es aumentar las opciones de carácter colectivo que inciden sobre la calidad de nuestras vidas. Y así, el aserto de Amartya Sen, "desarrollo humano es el proceso de expansión de las libertades reales que goza un pueblo",3 viene en efecto a ser una definición de la democracia.

El debate está abierto. ¿Cómo mantener la vigencia y perfeccionar el régimen democrático del que ahora disfrutan nuestros países? ¿Cómo expandir la ciudadanía social, cómo reducir la pobreza y la desigualdad, que siguen siendo nuestra gran mancha y la gran amenaza para ese régimen democrático? ¿Cómo ampliar la política, o cómo recuperar lo público para el debate y la participación de la gente? ¿Cómo devolverle la economía a la política, o cómo poner, sin populismos, el mercado para y al servicio de la ciudadanía? ¿Cómo hacer que el Estado se empeñe en democratizar la sociedad? ¿Cómo lograr que él se imponga sobre los poderes fácticos? ¿Cómo hacer, en fin, que la aldea global sea gobernada, y ese gobierno represente también a las latinoamericanas y a los latinoamericanos?

2 Esta definición se propuso por primera vez en el Informe sobre Desarrollo Humano 1990, Bogotá, Tercer Mundo, p. 33. 3 Desarrollo y libertad, Madrid, Planeta, 2000, p. 13. 
Este Informe no pretende dar las respuestas, sino ayudar a precisar las preguntas. Más aún: este texto es apenas un pretexto, tanto en el sentido de texto previo que quiere ser mejorado, como en el sentido de disculpa u ocasión para continuar un diálogo ya iniciado.

Dicho diálogo es la razón de ser del Proyecto sobre el Desarrollo de la Democracia en América Latina (PRODDAL) que el PNUD lleva a cabo con el apoyo generoso de la Unión Europea y de gobiernos, instituciones y personas a quienes no alcanzo a enumerar pero sí, ciertamente, a agradecer.

Un fruto de sus esfuerzos es este Informe. Otros frutos, que esperamos estimulen y enriquezcan un debate urgente (yo lo llamaría "debate sobre la democratización de nuestras democracias"), son: el libro donde veintiséis intelectuales destacados avanzan en dar respuestas, el Compendio Estadístico que permite un escrutinio integral de las ciudadanías, y los ensayos académicos que sustentan nuestro modo de entender la democracia.

Latinoamérica es múltiple, y es una. Por eso el debate político tiene que darse desde las realidades y los sueños propios de cada país, y por eso hemos previsto encuentros en cada uno de ellos. Una serie de eventos regionales, la red de actores de gobernabilidad que acompaña al PRODDAL y, por supuesto, la "e-comunicación" interactiva, son otros tantos escenarios donde queremos proseguir ese diálogo. ¡Bienvenidos!

\section{Elena Martínez}

Administradora Auxiliar y Directora Regional

para América Latina y el Caribe del PNUD 



\section{Presentación}

\section{Libertad, democracia y política}

Este Informe sobre la democracia en América Latina propone algunas respuestas a las incertidumbres y los cuestionamientos de las sociedades latinoamericanas sobre su democracia. Hemos hecho esta exploración teniendo en cuenta, prioritariamente, la demanda: esto es, los interrogantes que nuestras mujeres y hombres se plantean y que no están suficientemente tratados en el debate político.

Nuestra ambición es que se constituya en una herramienta para el debate de las sociedades, que llegue a ellas, que les sirva para entender mejor sus democracias y sus necesidades de mejoramiento.

No hay malestar con la democracia, pero hay malestar en la democracia. Y para resolverlo es indispensable hacer uso del instrumento más preciado que ella nos brinda: la libertad. Libertad para discutir lo que molesta, lo que algunos preferirían que se oculte. Libertad para decir que el rey está desnudo y tratar de entender por qué. Libertad para saber por qué un sistema que es casi un sinónimo de igualdad, convive con la desigualdad más alta del planeta, para saber si lo que discutimos es lo que precisamos discutir o lo que otros nos han impuesto, para saber cuáles son nuestras urgencias y prioridades.

En definitiva, conociendo sus limitaciones, éste es un informe para ejercitar la libertad, lo que en política significa centralmente ejercer la capacidad para conocer y decidir lo que queremos hacer con nuestras sociedades, porque la crisis de representación de la política, en parte, se ataca mejor si sabemos qué demandar, qué exigir a nuestros representantes.

Por cierto, no es un texto por sí mismo el que logrará ese objetivo. Además, es indispensable promover activamente el debate, e incorporar en la cotidianidad de las decisiones de las organizaciones sociales los temas que aquí se proponen y otros que quizá hemos omitido. Provocar una nueva discusión.

Para ese fin, el Informe contiene un análisis crítico de la situación de nuestras democracias hecho desde la democracia. Eso nos llevó necesariamente a señalar déficit y carencias.

Pero existe un peligro en el ejercicio de explorar lo que falta: olvidar lo que tenemos. Los déficit, las lagunas, las asechanzas que se ciernen sobre nuestras democracias no deberían llevarnos a olvidar que hemos dejado atrás la larga noche del autoritarismo. La historia de los 
miedos, los asesinatos, las desapariciones, las torturas y del silencio aplastante de la falta de libertad. La historia donde unos pocos se apropiaron del derecho de interpretar y decidir el destino de todos.

Tenemos problemas, muchos y algunos muy graves, pero guardamos la memoria de ese pasado y querríamos que no se agote en nosotros, que nuestros hijos sepan que la libertad no nació espontáneamente, que protestar, hablar, pensar y decidir con la dignidad de mujeres y hombres libres fue una conquista dura y prolongada.

Precisamos ser críticos con nuestra democracia, porque esos recuerdos nos obligan a custodiarla y perfeccionarla.

La construcción democrática se plasma a través de la política. Y aquí sucede algo similar a lo que acabo de señalar: también la política tiene graves carencias, lo que ha producido un rechazo creciente en nuestras sociedades hacia quienes la ejercen. Este Informe no es benévolo a la hora de mostrar la gravedad de la crisis de la política y los políticos. Pero estos políticos son los que han dado las luchas, los que han optado entre costos, los que han pagado con su prestigio u honor sus defectos o faltas. No tienen la pureza de quienes sólo asumen el riesgo de opinar. Muchos tienen la sencilla valentía de pelear en un escenario donde, las más de las veces, lo que se confronta no son grandes ideas, sino pasiones y miserias. Algunos temen y abandonan, otros cometen errores y -de una u otra manera- pagan por ellos, pero una mayoría hizo algo más que opinar acerca de cómo deberían ser hechas las cosas. Lo intentaron, apostaron, perdieron, y muchos volvieron a intentarlo. Algunos con éxito.

Nada hay aquí de reivindicación sentimental de los políticos, sino la sencilla advertencia de que la democracia no es una construcción idílica. Requiere mujeres y hombres dispuestos a luchar en ese turbulento territorio donde se desenvuelven los intereses y las pasiones, las luchas reales, que son las luchas del poder.

La democracia se hace con la política, la única actividad que puede reunir la dura y maravillosa tarea de lidiar con la condición humana para construir una sociedad más digna.

"La política consiste en una dura y prolongada penetración a través de tenaces resistencias, para la que se requiere, al mismo tiempo, pasión y mesura. Es completamente cierto, y así lo prueba la historia, que en este mundo no se consigue nunca lo posible si no se intenta lo imposible una y otra vez. Pero para ser capaz de hacer esto no sólo hay que ser un caudillo, sino también un héroe en el sentido más sencillo de la palabra. Incluso aquellos que no son ni lo uno ni lo otro han de armarse desde ahora de esa fortaleza de ánimo que permite soportar la destrucción de todas las esperanzas, si no quieren resultar incapaces de realizar incluso lo que hoy es posible. Sólo quien está seguro de no quebrarse cuando, desde su punto de vista, el mundo se muestra demasiado estúpido o demasiado abyecto para lo que él le ofrece; sólo quien frente a todo esto es capaz de responder con un 'sin embargo', sólo un hombre construido de esta forma tiene 'vocación para la política." 1

Finalmente, una advertencia sobre las limitaciones de este trabajo. El Informe sobre el desarrollo de la democracia en América Latina aborda el análisis de nuestra situación, aporta una amplia base empírica y propone un temario sobre sus desafíos centrales. No obstante, es 
un esfuerzo parcial. La democracia es un fenómeno cuya dimensión humana y cultural es central. La historia que recibimos, los impulsos sociales suscitados por las esperanzas y frustraciones, las pasiones que se desenvuelven en torno a las relaciones de poder contienen, a menudo, pistas o explicaciones sobre las cuales los datos y análisis no dan cuenta acabada. Advertimos sobre esta ausencia para indicar que somos conscientes de ella y para subrayar nuestra reticencia a encerrar en categorías analíticas y en cifras la inmensa complejidad de los fenómenos humanos. Sólo hemos trabajado sobre un segmento -importante y necesario- de la vasta experiencia que encierra la democracia.

\section{Dante Caputo}

Director del Informe 



\section{Resumen}

\section{Introducción}

El presente Informe sobre La democracia en América Latina: Hacia una democracia de ciudadanas y ciudadanos, se enmarca en la estrategia del Programa de las Naciones Unidas para el Desarrollo (PNUD) dirigida a fortalecer la gobernabilidad democrática y el desarrollo humano. Elaborado por el Proyecto sobre el Desarrollo de la Democracia en América Latina (PRODDAL), es un primer insumo de un proceso de más largo aliento de análisis y diálogo social. Su propósito es evaluar la democracia en América Latina, no sólo como régimen electoral, sino como una democracia de ciudadanos. A partir de este enfoque seidentifican logros, límites y desafíos y se plantea una agenda de reformas para fortalecer el desarrollo de la democracia en la región.

Aunque 140 países del mundo viven hoy bajo regímenes democráticos - hecho valorado como un gran logro-, sólo en 82 existe una democracia plena. ${ }^{1}$ En efecto, muchos gobiernos elegidos democráticamente tienden a sostener su autoridad con métodos no democráticos, por ejemplo, modificando las Constituciones nacionales en su favor e interviniendo en los procesos electorales y/o restando independencia a los poderes Legislativo y Judicial. Estos hechos demuestran que la democracia no se reduce al acto electoral sino que requiere de eficiencia, transparencia y equidad en las instituciones públicas, así como de una cultura que acepte la legitimidad de la oposición política y reconozca, y abogue por, los derechos de todos.

Paralelamente a lo anterior, en muchos casos, la creciente frustración por la falta deoportunidades y por los altos niveles de desigualdad, pobreza y exclusión social, se expresa en malestar, pérdida de confianza en el sistema político, acciones radicalizadas y crisis de gobernabilidad, hechos que ponen en riesgo la estabilidad del propio régimen democrático.

Como sostiene el Informe sobre Desarrollo Humano 2002, la democracia no sólo es un valor en sí mismo sino un medio necesario para el desarrollo. Para el PNUD, la gobernabilidad democrática es un elemento central del desarrollo humano, porque a través de la política, y no sólo de la economía, es posible generar condiciones más equitativas y aumentar las opciones de las personas. En la medida en que la democracia hace posible el diálogo que incluye a los diferentes grupos sociales, y en tanto las instituciones públicas se fortalezcan y sean más eficientes, será posible lograr los $\mathrm{O}$ bjetivos de $\mathrm{De}$ sarrollo del Milenio, sobre todo en lo tocante a reducir la pobreza. En este sentido, la democracia es el marco propicio para abrir espacios de participación política y social, en especial para quienes más sufren: los pobres y las minorías étnicas y culturales. 
El Informe valora los principales

a va nces de la democra cia como

régimen político en América

La tina, e identifica a la

desigualdad y la pobreza como

sus p rincipa les deficiencia s.

Esta contribución se organiza alrededor de tres preguntas: ¿cuál es el estado de la democracia en América Latina?, ¿cuáles son las percepciones y cuán fuerte es el apoyo de líderes y ciudadanos a la democracia?, ¿cuáles serían los principales temas para un debate orientado a lograr un mayor avance en la democracia de ciudadanos?

Se ha procurado responderlas a lo largo de las secciones en las que está estructurado el Informe. En la primera sección se precisa la base conceptual utilizada en el estudio y se contextualiza el desarrollo dela democracia en una re gión con altos niveles de pobreza y desigualdad. En la segunda sección se analizan los datos obtenidos a través de diversos instrumentos empíricos aplicados: indicadores e índices de las ciudadanías política, civil y social; una encuesta de opinión respondida por 19.508 ciudadanos de los 18 países, y una ronda de consultas a 231 líderes sobre los retos de la democracia en América Latina. La tercera sección busca ampliar la agenda pública sobre el desarrollo de la democracia, centrada en la crisis de la política, las reformas estatales y estructurales de la economía y el impacto de la globalización en la región.

\section{La democracia y la idea de democracia en América Latina}

Los dieciocho países de América Latina considerados en este Informe cumplen hoy los requisitos fundamentales del régimen democrático; de ellos, sólo tres vivían en democracia hace veinticinco años. Sin embargo, al tiempo que las latinoamericanas y los latinoamericanos consolidan sus derechos polí- ticos, se enfrentan a altos niveles de pobreza y a la desigualdad más alta del mundo. Así, se plantea que existen fuertes tensiones entrela expansión de la democracia y la economía, la búsqueda de la equidad y la superación de la pobreza.

El Informe valora los principales avances de la democracia como régimen político en Amé rica Latina, e identifica a la desigualdad y la pobreza como sus principales deficiencias. Plantea, además, la urgencia de una política generadora de poder democrático, cuyo objetivo sea la ciudadanía integral.

¿Q ué debemos entender por "ciudadanía integral"? Como habrá inferido el lector, ésta abarca un espacio sustancialmente mayor que el del mero régimen político y sus reglas institucionales. Hablar de ciudadanía integral es considerar que el ciudadano de hoy debe acceder armoniosamente a sus derechos cívicos, sociales, económicos y culturales, y que todos ellos conforman un conjunto indivisible y articulado.

El presente estudio asume y resalta, como elementos importantes para el análisis, las marcadas diferencias entre los países de la región, pero también plantea que en materia de democracia hay problemas regionales comunes y diversidad nacional en las respuestas.

A partir de los fundamentos teóricos, se argumenta que la democracia:

- supone una idea del ser humano y de la construcción de la ciudadanía;

- es una forma de organización del poder que implica la existencia y buen funcionamiento del Estado;

- implica una ciudadanía integral, esto es, el pleno reconocimiento dela ciudadanía política, la ciudadanía civil y la ciudadanía social;

- es una experiencia histórica particular en la región, que debe ser entendida y evaluada en su especificidad;

- tiene en el régimen electoral un elemento fundamental, pero no se reduce a las elecciones. 


\section{Balance de la ciudadanía integral}

Para medir los avances en ciudadanía política se utilizó el Índice de Democracia Electoral (IDE) que, aunque mide sólo un aspecto del sistema político, corresponde a la dimensión o condición mínima para que pueda hablarse de democracia. Los datos muestran que en la región existen hoy "democracias electorales". M ás puntualmente, ellos indican que:

- En todos los países se reconoce el derecho universal al voto.

- A pesar dealgunos problemas, en general las elecciones nacionales fueron limpias entre 1990 y 2002.2

- En ese mismo período se dieron restricciones importantes a la libertad electoral en 10 de 70 elecciones nacionales, pero la tendencia general fue positiva.

- Seavanzó en la cuestión de quelas elecciones sean un medio de acceso a cargos públicos: el traspaso del mando presidencial se convirtió en una práctica común, aunqueen algunos casos se haya dado en me dio de complejas crisis constitucionales.

Sin embargo, los datos también muestran que la participación electoral es irregular -en algunos países presenta niveles muy bajos- y que existen barreras de entrada para nuevos actores a la competencia electoral. Un logro importante es la apertura de espacios políticos para las mujeres a través de cupos o cuotas en las listas de los partidos. Empero, la representación de pueblos originarios y afrodescendientes en el Parlamento es, en general, aún muy reducida. Asimismo, los partidos políticos como agentes de representación atraviesan una crisis severa, que se expresa en el hecho de que la gente desconfía de ellos porque los percibe como distantes, como un actor ajeno y profesionalizado que no encarna un proyecto de futuro compartido.

En cuanto a los mecanismos de control político más allá de las elecciones, el Poder Ejecu- tivo mantiene una interferencia importante en la Corte Suprema de varios países, aunque hubo logros en las reformas constitucionales para fortalecer la independencia y profesionalización del Poder Judicial. Asimismo, en losúltimosaños se crearon organismos especializados como contralorías, fiscalías y defensorías del pueblo. Sin embargo, la insuficiencia de recursos y, en algunos casos, la escasa autonomía del Poder Ejecutivo limitan la eficacia de estos entes. Finalmente, un logro importante a destacar es la menor influencia o gravitación política de las Fuerzas Armadas en casi todos los países.

Por consiguiente, aunque se avanzó en relación al funcionamiento electoral y hubo logros en términos institucionales, persisten serias deficiencias respecto del control que podrían ejercer los ciudadanos de la acción estatal. Los partidos políticos enfrentan un momento de alta desconfianza como agentes de representación, lo cual es un desafío clave para el desarrollo democrático. Así, la representación de amplios grupos poblacionales es, en general, baja, y la asistencia a las urnas, irregular.

Con respecto a la ciudadanía civil, se registran logros importantes en materia de legislación, pe ro preocupa la escasa capacidad de los Estados para garantizar estos derechos en la práctica.

La mayoría de los países ratificó los principales tratados internacionales y avanzó en la normativa nacional tocante a la igualdad legal y la protección contra la discriminación, así como en los derechos dela mujer. También se avanzó en la defensa de los derechos laborales y de los niños. Aunque existe un rezago en la ratificación de la Convención sobre los pueblos indígenas, varias Constituciones reconocieron estos derechos.

No ocurrió lo mismo con los tratados internacionales ni, en especial, con la vigencia del derecho a la vida, la integridad física y la seguridad. No se registró el descenso esperado en este tipo de violaciones de los derechos humanos, aunque ya no son cometidas desde la cúspide estatal, sino más bien por fuerzas paraestatales que el Estado no ha sido capaz de controlar. 
El desa rrollo de la democra cia

depende de que se amplíe de

manera decidida la ciudadanía

social, sobre todo a partir de la

lucha contra la pobreza y la

desigualdad y de la creación de

empleo de buena calidad.

A pesar de los avances normativos, la no discriminación aún no está suficientementegarantizada, ya que: se mantienen fuertes desigualdades en el trato a personas pertenecientes a distintos grupos, las leyes que protegen a los niños en el trabajo son frecuentemente desobedecidas y los trabajadores han visto disminuir su protección social. Un logro en el ámbito laboral, empero, es la tendencia al aumento en la equidad de género.

En relación con los sistemas de administración de justicia se observa que la carencia de re cursos económicos y humanos los hace frágiles. Asimismo, un tema preocupante es el de la población carcelaria, pues los derechos de los reos son escasamente respetados, al punto de que más de la mitad de los presos carece de condena.

En cuanto a la libertad de prensa, el Informe detecta que América Latina aún enfrenta fallas importantes. Los avances en cuanto al derecho a la información son más alentadores, ya que el acceso a las fuentes públicas de datos es legalmente reconocido en la mayoría de los países.

En síntesis, aunque mejoró la situación de los derechos humanos en comparación con el período no democrático, y se ratificaron convenciones internacionales relativas a los derechos civiles e incluso se generaron normativas nacionales en este sentido, los datos muestran debilidades, hecho que debería ser una señal de alerta. El progreso en relación al respeto del derecho a la vida, la integridad física, la seguridad y la no discriminación ha sido irregular y en algunos casos insuficiente.

Por otra parte, las tendencias halladas en relación con la ciudadanía social son realmente preocupantes y constituyen el principal desafío de las democracias latinoamericanas, porque, además, los grupos más excluidos del ejercicio pleno de la ciudadanía social son los mismos que sufren carencias en las otras dimensiones de la ciudadanía.

Los problemas centrales en este plano son la pobreza y la desigualdad, que no permiten que los individuos se expresen como ciudadanos con plenos derechos y de manera igualitaria en el ámbito público, y erosionan la inclusión social. Los indicadores muestran que todos los países de la región son más desiguales que el promedio mundial. En 15 de los 18 países estudiados, más del 25 por ciento de la población vive bajo la línea de pobreza y en 7 de ellos más de la mitad de la población vive en esas condiciones; ello, incluso, aunque en 12 de los países considerados la pobreza disminuyó y en 15 aumentó el PIB per cápita entre 1991 y 2002.

No obstante, cabe destacar algunos avances en términos de salud (la desnutrición infantil disminuyó en 13 de los 18 países, se redujo la mortalidad infantil y se incrementó la expectativa de vida) y de educación (la tasa de analfabetismo bajó en todos los países y aumentó el nivel de escolarización, pero la calidad educativa en general es baja).

Un tema central es el desempleo, pues el trabajo es un mecanismo clave de inclusión social y del mismo ejercicio de la ciudadanía, que tiene un componente económico. El alza en los índices de desocupación durante la década de 1990 es, por ende, una de las más grandes carencias de las democracias latinoamericanas. Es más: la protección social de los trabajadores disminuyó y aumentó el empleo informal, en general de baja calidad y escasa utilidad social, e insuficiente para generar una integración social que garantice un mínimo de bienestar.

En síntesis, el desarrollo de la democracia depende de que se amplíe de manera decidida la ciudadanía social, sobre todo a partir de la lucha contra la pobreza y la desigualdad y de la creación de empleo de buena calidad. Sólo si se reduce la desigualdad se podrá disminuir la pobreza sosteniblemente y mejorar las posibilidades de crecimiento económico. 


\section{Percepciones y apoyo de líderes y ciudadanos}

Pese a los avances, incluso en condiciones muy precarias, debe reconocerse que tanto en el plano de la evolución democrática como en el de la dinámica económica y social, la región vive un momento de cambio, que en muchos casos asume las características de una crisis generalizada. Por consiguiente, se abre un período de transformación tanto en los contenidos de la democracia cuanto en sus vinculaciones con la economía y la dinámica social, en un contexto global también de cambio, de concentración de riqueza y de internacionalización creciente de la política. La cuestión es que ésta, como se constata en varias partes del Informe, tiene importantes límites y está en crisis.

Dicha crisis se expresa en el divorcio entre los problemas que los ciudadanos reclaman resolver y la capacidad de la política para enfrentarlos. La política tiende a perder contenido por la disminución de soberanía interior del Estado, atribuible a:

- El desequilibrio en la relación entre política y mercado.

- La presencia de un orden internacional que limita la capacidad de los Estados para actuar con razonable autonomía.

- La complejización de las sociedades que los sistemas de representación no pueden procesar.

En este sentido, los líderes latinoamericanos consultados coinciden en varias cuestiones al formular su diagnóstico sobre la democracia. Por un lado, valoran la democratización durante la última década y el hecho de que, al menos en el plano formal, los países de la región cumplen con los requisitos mínimos de la democracia. Perciben, además, que aumentaron la participación y los controles al ejercicio del poder y que disminuyeron las amenazas a la democracia como régimen, junto a los clásicos riesgos de insubordinación militar.

Por otro lado, detectan problemas en relación con los partidos políticos y los poderes fácticos. En cuanto a los primeros, una de las dificultades centrales percibidas es que no logran canalizar plenamente las demandas de la ciudadanía. Asimismo, la relación entre partidos y organizaciones de la sociedad civil suele ser conflictiva. Para los líderes consultados, la solución a estas dificultades está dentro de la política a través del fortalecimiento de los partidos. En cuanto a los poderes fácticos (sobre todo el sector económico y financiero y los medios de comunicación), son percibidos como factores que condicionan la capacidad de los gobiernos para dar respuestas a la ciudadanía. Entre las tensiones con otros poderes fácticos, existe preocupación por la pérdida de autonomía gubernamental respecto de Estados Unidos y los organismos multilaterales, así como coincidencia en la amenaza que representa el narcotráfico.

Por su parte, la encuesta de opinión pública realizada para el Informe muestra una tensión entre la opción por el desarrollo económico y la democracia. Los datos obtenidos indican que:

- La preferencia de los ciudadanos por la democracia es relativamente baja.

- Gran parte de las latinoamericanas y los latinoamericanos valora el desarrollo por encima dela democracia e incluso le quitaría su apoyo a un gobierno democrático si éste fuera incapaz de resolver sus problemas económicos.

- Las personas no demócratas pertenecen en general a grupos con menor educación, cuya socialización se dio fundamentalmenteen períodos autoritarios, tienen bajas expectativas de movilidad social y una gran desconfianza en las instituciones democráticas y los políticos.

- Aunque los demócratas se distribuyen en variados grupos sociales, en los países con menores niveles de desigualdad los ciudadanos tienden a apoyar más la democracia. Sin embargo, estas personas no seexpresan a través de las organizaciones políticas.

A partir de los datos de la encuesta, con el objetivo de proporcionar una estimación del 
grado de respaldo ciudadano a la democracia, se elaboró el Índice de Apoyo a la Democracia (IAD), que ofrece una visión sintética sobre el apoyo y la posi ble vulnerabilidad de las democracias latinoamericanas.

En conclusión, la información empírica encontrada, los resultados de la encuesta de opinión pública y las opiniones de diversos líderes políticos registradas en el Informe coinciden tanto en la necesidad de reconocer que la región vive un momento de inflexión y crisis, como en la de valorizar el sentido de la política, es decir, su capacidad de crear opciones para promover nuevos proyectos colectivos viables. En el corazón de tal confluencia está instalado el fortalecimiento de la ciudadanía.

\section{Elementos para una agenda}

El Informe plantea que el punto de partida para fortalecer la democracia pasa por revalorizar el contenido y la relevancia de la política, argumenta que las soluciones a los problemas y desafíos de la democracia tendrían que buscarse dentro y no fuera de las instituciones democráticas, y encuentra que debe recuperarse un papel constructivo de la política como ordenadora de las decisiones de la sociedad.

En este sentido, continúa la línea argumentativa sobre la que viene insistiendo el PNUD. Como sostiene su Administrador, Mark Malloch Brown, en el prefacio del InformesobreDe sarrollo Humano 2002: “[...] la política es tan importante para el éxito del desarrollo como la economía. La reducción sostenible de la pobreza requiere que haya un crecimiento equitativo, pero también requiere que los pobres tengan poder político. La mejor manera de conseguirlo de forma coherente con los objetivos del desarrollo humano es erigir formas firmes y profundas de gobernabilidad democrática en todos los niveles de la sociedad". 3

La revalorización de la política pasa por aplicar medidas que promuevan una institucionali- dad legítima, fortal ezcan una sociedad civil activa y, sobre todo, promuevan un amplio debate sobree Estado, la economía y la globalización.

La agenda que propone el Informe apunta a la expansión de la ciudadanía. Para hacerla sostenible es fundamental desarrollar una política que encarne opciones, agrupe voluntades y cree poder democrático.

Urge proseguir con la reforma de las instituciones; empero, estas iniciativas necesitan de un hilo que robustezca la participación ciudadana. Sólo ésta podrá hacer más legítimas y eficientes tales reformas. En este sentido, un aspecto institucional clave son las reformas electorales que aseguren un mejor balance entre gobernabilidad y representación.

Si bien experimentaron importantes cambios, los sistemas de partidos tienden a ser instrumentales u operativos, mientras que lo que necesitan es fortalecerse para ampliar la eficacia, la transparencia y la responsabilidad. Ésta es, a juicio del Informe, la mejor manera de reafirmar el rol indispensable de representación de la sociedad que ellos expresan. En tal sentido, los partidos políticos tendrían que comprender mejor los cambios en las sociedades contemporáneas, proponer nuevos proyectos de sociedad y promover debates públicos.

Existe una importante relación entre la ciudadanía y las organizaciones de la sociedad civil. Ellas son sujetos relevantes en la construcción democrática, en el control de la gestión gubernamental y en el desarrollo del pluralismo. Resulta fundamental promover estrategias de fortalecimiento de la sociedad civil y de su articulación con el Estado y los partidos políticos. El Informe aboga por formas alternativas de representación que, sin reemplazar a las tradicionales, las complementen y fortalezcan.

Una propuesta central es construir una nueva legitimidad del Estado, ya que no existiría una democracia sostenible sin un Estado capaz de promover y garantizar el ejercicio ciudadano. Con Estados débiles y mínimos sólo puede aspirarse a conservar democracias electorales.

3 PNUD 2002, op. cit. 
La democracia de ciudadanas y ciudadanos requiere de una estatalidad que asegure la universalidad de los derechos.

Por eso, el Informe invita a debatir sobre la necesidad de un Estado capaz de conducir el rumbo general de la sociedad, procesar los conflictos conforme a reglas democráticas, garantizar eficazmente el funcionamiento del sistema legal, preservar la seguridad jurídica, regular los mercados, establecer equilibrios macroeconómicos, fortalecer sistemas de protección social basados en los principios de universalidad y asumir la preeminencia de la democracia como principio de organización social. La reforma del Estado tendría que orientarse a resolver la pregunta sobre qué tipo de nación aspira a construir una determinada sociedad. Lo que se proponeaquí, entonces, es un Estado en función de la ciudadanía.

Otro tema central a debatir es el de las posibilidades de una economía congruente con la democracia, es decir, una economía que promueva la diversidad para fortalecer las opciones ciudadanas. En esta perspectiva, el debate sobre la diversidad deformas de organización del mercado debe ingresar en la agenda de discusión pública. La discusión sobre el futuro de la democracia no puede ignorar las opciones económicas. La economía es clave porque de ella depende el despliegue de la ciudadanía social.

En la perspectiva del Informe, el Estado y el mercado son susceptibles de ser combinados de diversas maneras, resultando de ahí una variedad deformas que pueden adaptarse en función del desarrollo humano. El tipo de economía debe estar en el centro del debate público y no ser relegado a una mera cuestión técnica. En breve, los avances en la democracia y en establecer normas macroeconómicas claras y legítimas de ben ser vistos como complementarios.

El Informe propone ampliar el debate sobre el proceso de globalización. Es peligroso, se advierte, caer en una suerte de fatalismo frente a este fenómeno; al contrario, es preci-
Con Esta dos débiles y mínimos

sólo puede aspirarse a conserva r democra cias electorales. La democracia de ciudadanas y ciudada nos requiere de una estatalidad que asegure la universalidad de los derechos.

so discutir acerca de su impacto real sobre la soberanía interior de los Estados y acerca de las mejores estrategias para fortalecer a las naciones latinoamericanas en el espacio de la aldea global. Justamente la política es la fuerza que puede construir espacios autónomos.

\section{Metodología del Informe}

Para llevar a cabo este Informe, el PRODDAL contó con el auspicio dela Dirección deAmérica Latina y el Caribe del PN UD y con la colaboración de destacados intelectuales y académicos, así como de ex presidentes y otras muchas personalidades de la región.

El estudio abarcó dieciocho países (Argentina, Bolivia, Brasil, Chile, Colombia, Costa Rica, Ecuador, El Salvador, Guatemala, Honduras, M éxico, Nicaragua, Panamá, Paraguay, Perú, Re pública Dominicana, Uruguay y Venezuela). ${ }^{4} \mathrm{El}$ marco conceptual fue ampliamente consultado, y orientó la búsqueda de información empírica, la cual incluye:

- Una encuesta de opinión de alcance re gional (en colaboración con Latinobarómetro).

- La elaboración deindicadores sobreel estado de la democracia.

- Entrevistas a líderes e intelectuales de América Latina.

4 Estos países tienen regímenes democráticos, en su mayoría establecidos a través de procesos de transición desarrollados durante los últimos veinticinco años, y sus gobiernos aceptaron incorporarse al PRODDAL. 
Para la elaboración del Informe se partió de un análisis conceptual e histórico de las democracias latinoamericanas, a partir de una amplia revisión bibliográfica de los múltiples estudios nacionales. Además, se realizaron talleres de discusión de los distintos componentes del proyecto, se solicitaron opiniones y escritos a académicos y personalidades políticas sobre distintas facetas del desarrollo dela democracia en la región.

El Informe no pretende evaluar los gobiernos o los países ni elaborar alguna suerte de ránking nacional de la democracia; su interés es identificar los grandes retos y promover una discusión amplia en torno a ellos. Asimismo, se reconoce la dificultad de abordar los dilemas de la democracia, pues ella está influenciada por múltiples factores (políticos, económicos y sociales, nacionales e internacionales), al gunos de los cuales o no fueron tratados o lo fueron de manera muy preliminar.

Además del Informe como tal, se han preparado para difusión masiva otros productos complementarios, a saber:

- Un libro con los artículos elaborados por políticos y académicos destacados que aportan "ideas y posiciones para un debate sobreel desarrollo de la democracia en América Latina".
- Un Compendio Estadístico que reúne información, hasta ahora dispersa, en cuanto a democracia y ciudadanía integral en los países deAmérica Latina, junto con los índices construidos para este Informe y los resultados de la encuesta deopinión.

- Los materiales que alimentan el marco conceptual del Proyecto y su manera de entender la democracia, junto con opiniones críticas de distinguidos analistas.

- Los resultados de la ronda de consultas a dirigentes latinoamericanos.

Para concluir, el Informe muestra que, aunque muy valiosos, los avances logrados en términos de desarrollo de la democracia en América Latina no son suficientes. Hay que profundizar tanto la gobernabilidad democrática, entendida como el fortalecimiento institucional del régimen, como, sobre todo, la cultura política, que supone construir espacios de participación equitativa principalmentede aquellos más desfavorecidos en las sociedades latinoamericanas. Para ello senecesita voluntad política, dirigentes comprometidos con sus países y con la región, y ciudadanas y ciudadanos decididos a confrontar los problemas y desafíos para vivir cada vez con más y mejor democracia. 


\section{El desarrollo de la democracia en América Latína}

n esta sección se presenta el tema del Informe, a partir de la conquista de la democracia en los

países considerados, destacando que en América Latina la democracia se instala en sociedades con altos niveles de pobreza y desigualdad. Una primera mirada a la democracia desde la democracia revela que muchos derechos civiles básicos no están asegurados y que la pobreza y la desigualdad muestran a nuestras sociedades entre las más deficitarias del mundo.

El Informe comienza con una definición del desarrollo de la democracia y sus carencias principales en la región, contrastando las reformas que han sido aplicadas con las realidades políticas y económicas. A partir de esto, surge un conjunto de interrogantes: ¿cuánta pobreza y cuánta desigualdad toleran las democracias?, ¿cómo afectan estos contrastes la cohesión social de las naciones?, ¿qué relevancia tiene la democracia para los latinoamericanos? Los resultados de la encuesta de opinión revelan que el 54,7 por ciento de los latinoamericanos estaría dispuesto a aceptar un gobierno autoritario si éste resolviera la situación económica (ver Segunda Sección, "Cómo ven los latinoamericanos a su democracia" ). Las razones que explican este dato preocupante quizá se encuentren en los contrastes señalados.

Esta sección contiene también una referencia a los fundamentos teóricos en que se basa el Informe. Las consecuencias prácticas del marco teórico adoptado son importantes, porque sustentan las descripciones, el análisis y las propuestas en razones sistemáticas y rigurosas.

Los desafíos de la democracia en América Latina son históricamente singulares. Resolverlos demanda una comprensión novedosa y una discusión abierta, a las que el Informe aspira a contribuir. Ello requiere precisar los fundamentos teóricos: los conceptos de democracia, ciudadanía y sujetos en la democracia, Estado y régimen. Los cuatro argumentos centrales son: 1) la democracia implica una concepción del ser humano y de la construcción de la ciudadanía; 2) la democracia es una forma de organización del poder en la sociedad, que implica la existencia y el buen funcionamiento de un Estado; 3) el régimen electoral es un componente básico y fundamental de la democracia, pero la realización de elecciones no agota el significado y los alcances de aquélla, y 4) la democracia latinoamericana es una experiencia histórica distintiva y singular, que debe ser así reconocida y valorada, evaluada y desarrollada. 



\section{El desafío: de una democracia de electores a una democracia de ciudadanos ${ }^{1}$}

La democracia es una inmensa experiencia humana. Está ligada a la búsqueda histórica de libertad, justicia y progreso material y espiritual. Por eso es una experiencia permanentemente inconclusa.

Éste es un Informe sobre la tarea inconclusa de la democracia, sobre sus desafíos, sobre lo que debería constituir las metas de una nueva etapa, en cuya construcción se pondrá en juego su propia sustentabilidad y perduración.

Cualquiera que haya sido la forma, el ritmo o el resultado, la búsqueda por la libertad, la justicia y el progreso comparte toda la historia social del ser humano. Hemos participado de esta búsqueda con mayor o menor conciencia de nuestros objetivos, con avances y retrocesos; en suma, con toda la diversidad de incidentes que llena nuestra historia. Aun en las circunstancias más difíciles, a pesar de prolongados letargos, la lucha renació y renacerá, ya sea para pasar de esclavos a personas libres, ya sea para ampliar cada día el espacio de la libertad.

Pero también poseemos, expresado de la manera más diversa y en los distintos ámbitos de nuestra vida, otro impulso, tan vital como los anteriores: el impulso por la dominación y por el poder que permite ejercerla.

En gran medida, nuestra vida en sociedad se construye en la trama de estos impul sos centrales: sabemos que allí donde no haya libertad, justicia y progreso nacerá la lucha para alcan-
RECUADRO 1

\section{La democracia: una búsqueda permanente}

Deben tenerse en cuenta los incumplimientos, las fracturas, las tensiones, los límites y las denegaciones que constituyen la contrapartida de la experiencia de la democracia. La democracia plantea una pregunta que permanece por lo tanto continuamente pendiente: jamás parece poder dársele una respuesta perfectamente adecuada. La democracia se presenta como un régimen siempre marcado por formas inacabadasy de no cumplimiento.

Pierre Rosanvallon, texto elaborado para el PRODDAL, 2002.

zarlos y que en esa lucha se confrontarán intereses, pareceres y métodos.

Nuestra búsqueda por la libertad, la justicia y el progreso, y la lucha por el poder que se desarrolla cuando unosy otros tratamos de imponer nuestros intereses y pareceres sobre esos asuntos, han dado lugar a diversas maneras de organización de los seres humanos. Una de ellas es la democracia.

La democracia se ha convertido en un sinónimo de libertad y justicia. Es, a la vez, un fin y un instrumento. Contiene, básicamente, una serie de

1 Este texto es una edición revisada del Informe La democracia en América Latina. El listado de enmiendas se encuentra disponible en www.democracia.undp.org. 
RECUADRO 2

\section{La democracia: un ideal}

La democracia es, antes que nada y sobre todo, un ideal. [...] Sin una tendencia idealista una democracia no nace, y si nace, se debilita rápidamente. Más que cualquier otro régimen político, la democracia va contra la corriente, contra las leyes inerciales que gobiernan los grupos humanos. Las monocracias, las autocracias, las dictaduras son fáciles, nos caen encima solas; las democracias son difíciles, tienen que ser promovidas y creídas.

Giovanni Sartori, 1991, p. 118.

procedimientos para el acceso y el ejercicio del poder, pero es, para los hombres y las mujeres, también el resultado de esos procedimientos.

En esta perspectiva, la democracia excede a un método para elegir a quienes gobiernan, es también una manera de construir, garantizar y expandir la libertad, la justicia y el progreso, organizando las tensiones y los conflictos que generan las luchas de poder.

M ás allá de las diferencias que se expresan en el plano de la teoría sobre los al cances de la idea de democracia, la historia revela que las aspiraciones por ensanchar las fronteras de las libertades ciudadanas y alcanzar mayores niveles de justicia y progreso han estado siempre en el corazón de las luchas sociales y políticas ligadas, de un modo u otro, a la idea de democracia. Con períodos de expansión y retracción, de movilización o quietud, la historia nos muestra que allí donde no había libertad se peleó por ella, donde no había justicia se luchó por lograrla y donde no había progreso se buscó alcanzarlo. M ás allá de los retrocesos y letargos, el reconocimiento de la igual dad y la búsqueda de su realización social, en términos de libertad, justicia y progreso, constituyen un impulso histórico sustancialmenteligado a la idea de democracia.

Esta forma de organización ha entrado y sa- lido de nuestra historia. Surgió hace dos mil quinientos años en Grecia pero luego desapareció. "Como el fuego, la pintura o la escritura, la democracia parece haber sido inventada más de una vez y en más de un lugar."2

En América Latina se ha alcanzado la democracia electoral y sus libertades básicas. Se trata ahora de avanzar en la democracia de ciudadanía. La primera nos dio las libertades y el derecho a decidir por nosotros mismos. Trazó, en muchos de nuestros países, la división entre la vida y la muerte. La segunda, hoy plena de carencias, es la queavanza para queel conjunto de nuestros derechos se tornen efectivos. Es la que nos permite pasar de electores a ciudadanos. La queutiliza las libertades políticas como palanca para construir la ciudadanía civil y social.

Para las mujeres y los hombres, la democracia genera expectativas, esperanzas y decepciones por la manera en que contribuye a organizar sus vidas en sociedad, por el modo en que garantiza sus derechos y por la forma en que permite mejorar la calidad de sus existencias. La democracia hace a la vida, es mucho más que un régimen de gobierno. Es más que un método para elegir y ser elegido. Su sujeto, más que el votante, es el ciudadano.

En América Latina, en doscientos años de vida independiente, la democracia nació y murió decenas de veces. M ientras se la consagraba en las constituciones, se la destruía en la práctica. Guerras, tiranías y breves primaveras componen gran parte de esta historia independiente, durante la cual hasta las violaciones a la democracia fueron hechas en su nombre. América Latina es, probablemente, la región del mundo que más ha reivindicado la democracia en los últimos dos siglos, aun para interrumpirla invocando su futura instauración.

Los latinoamericanos, que tantas veces vimos cómo se nos negaba 0 arrebataba la voluntad de ser parte de la construcción de la democracia, somos ahora, finalmente, actores que asumen sus desafíos y desarrollo.

Tras dos décadas de diversas formas de tran- 
sición, los regímenes democráticos están ampliamente extendidos en América Latina. Hace veinticinco años, de los dieciocho países incluidos en el Informe, sólo Colombia, Costa Rica y Venezuela eran democráticos. Un cuarto de siglo después, todos nuestros países cumplen con los criterios básicos del régimen democrático, en su dimensión electoral y política.

Las libertades que hoy poseemos son un bien invalorable; ésta es una conquista lograda con el impulso, la lucha y el sufrimiento de millones de seres humanos. Somos testigos del avance más profundo y amplio que la democracia ha tenido desde la independencia de nuestras naciones. Pero, como se verá en este Informe, lo conquistado no está asegurado.

La preservación de la democracia y su expansión no son hechos espontáneos. Son construcciones voluntarias, formuladas en proyectos, modeladas por liderazgos e investidas del poder que proviene del apoyo popular. Requieren partidos políticos que construyan opciones sustantivas, un Estado con poder para ejecutarlas y una sociedad capaz de participar en una construcción que exceda los reclamos sectoriales. Una política que omite los problemas centrales, vacía de contenido las opciones ciudadanas; un Estado sin poder transforma el mandato electoral en una expresión de voluntades sin consecuencias, y una sociedad sin participación activa lleva, tarde o temprano, a una peligrosa autonomía del poder, que dejará de expresar las necesidades de los ciudadanos.

Parecería que nos alejamos de los riesgos de los gol pes militares de Estado, pero surgen otros peligros: la democracia parece perder vitalidad; se la prefiere aunque se desconfía de su capacidad para mejorar las condiciones de vida; los partidos políticos están en el nivel más bajo de la estima pública; ${ }^{3}$ el Estado es mirado con expectativa y recelo a la vez, y, en al gunos casos, el ímpetu democrático que caracterizó las últimas décadas del siglo pasado se debilita. La sociedad está en las calles, pero sin un objetivo que unifique sus reivindicaciones y demandas.
La democra cia es una inmensa experiencia humana. Está ligada a la búsqueda histórica de libertad, justicia y progreso materia I y espiritua I. Por eso es una experiencia permanentemente inconclusa .

¿Cuán graves son esas nuevas fragilidades? Si la democracia pierde rel evancia para los latinoamericanos, si se divorcia de sus necesidades, ¿puede resistir a los nuevos peligros, a sus adversarios, a las frustraciones?

Analizar, como nos proponemos, el desarroIlo de la democracia en América Latina nos conduce a auscultar la vigencia de los derechos de los latinoamericanosy el nivel de concreción de las esperanzas que éstos depositan en sus representantes. También, a indagar la sustentabilidad de la democracia, es decir, su capacidad para perdurar y perfeccionarse, a partir de la legitimidad quegenera en sus ciudadanos. Nos lleva, en fin, a identificar las acechanzas y los desafíos de la democracia.

¿Cómo se resuelven las tensiones entrela expansión democrática y la economía, entre la libertad y la búsqueda de la igualdad, entre crecimiento y pobreza, entre las demandas públicas expresadas libremente y las reformas económicas que demandan ajustes y sacrificios? ¿Cuáles son las claves que explican la crisis de representación, la desconfianza de la sociedad hacia la política? ¿Por qué la esperanza democrática no se ha traducido en avances en los derechos civiles y sociales acordes con las expectativas que promovió? ¿Por qué el Estado carece del poder necesario? ¿Por qué el derecho a elegir gobernantes no se tradujo, en muchos casos, en mayor libertad, mayor justicia y mayor progreso?

Éstos son dilemas cuya solución es compleja, como lo demuestra nuestra propia historia 
En América Latina, la reflexión y

el debate políticos requieren ser

renovados y promovidos porque

han perdido vitalidad y

contenido. reciente. Y no podrán ser resueltos si no se sitúan en el centro del debate público y de las opciones que ofrecen los partidos. D esafortunadamente, en más de una ocasión parecería que existe un debate prohibido en América Latina. Cuestiones sobre las que es inconveniente hablar o-más grave aún- delas que no se debehablar. El silencio de la política y de los que construyen la agenda del debate público no puede continuar indefinidamente ignorando el clamor de centenas de millones, a menos que se esté dispuesto a pagar el precio del languidecimiento de la democracia latinoamericana.

Este Informetrata de esas cuestiones, llegando a identificarlas no por un mero ejercicio intuitivo, sino a través del análisis teórico, de la observación empírica y del pensamiento de intelectuales y políticos.

Atacar estos dilemas demanda la mayor información posible para iluminar los criterios con que se formulan las políticas. La falta deinformación y de debate constituye una carencia grave, porque la democracia - que se basa en la reflexión y el debate de los ciudadanos y sus líderes- es la única forma deorganización política que tiene capacidad para rectificarse a sí misma. Ésa es la principal ventaja para hacer de la democracia un sistema justo y eficaz. La libertad que garantiza la democracia es, a la vez, el principal instrumento que ella tiene para perfeccionarse como sistema. Pero la libertad, o en otras palabras la capacidad de optar, requiere que la materia de la opción esté presente. En América Latina, la reflexión y el debate políticos requieren ser renovados y promovidos porque han perdido vitalidad y contenido. Esto ocurre en el período demayor difusión dela democracia y en un mundo donde la globalización hace cada vez más perentorio saber qué queremos como sociedades y como naciones.

Nuestras democracias precisan, urgentemente, retomar su impulso inicial. Sus déficit no son su fracaso, son sus desafíos. Lo queno hemosalcanzado es lo que debe constituir la sustancia de las políticas que permitan encender la segunda etapa de la democracia latinoamericana.

Éstees el hilo conductor que debería guiar al lector en los materiales que proponeel Informe: la búsqueda de los temas cruciales en los que se pondrá a prueba nuestra capacidad para pasar de la democracia electoral a la democracia de ciudadanía. En esa transformación se dirimirá la capacidad latinoamericana para hacer de la democracia un sistema que se estabilice, regenere y expanda.

Nos proponemos demostrar que, una vez que la apuesta está en el tránsito de la democracia electoral a la de ciudadanía, es ineludible una seria reflexión conceptual, que genere las ideas que orienten la observación de la realidad y la recolección de datos que, a su vez, construyan la base empírica del Informe. De allí, de la suma de esos dos componentes saldrá la proposición del núcleo de temas queconfiguran los desafíos de la agenda ampliada para el desarrollo de la democracia en América Latina.

Estos objetivos, que constituyen la razón de esta obra, encontrarán aquí una primera aproximación, un inicio. El Informe es el comienzo de una tarea, de un debate que el Programa de las Naciones Unidas para el Desarrollo (PNUD) busca promover entre los latinoamericanos. Sólo descorreel primer velo, para que la construcción de alternativas y políticas concretas sea tomada por los actores sociales y políticos que deben relanzar y regenerar nuestras democracias.

Estas reflexiones, observaciones y consecuencias partirán de un reconocimiento inicial: la singular realidad de la democracia en nuestra región. El libro de los desafíos es nuevo porque también es nueva la realidad que expone una región quea la vez que democrática es pobrey desigual. A partir de ese triángulo -democracia electoral, pobreza y desigualdad- iniciamos nuestra exploración. 


\section{Democracia, pobreza y desigualdad: un triángulo latinoamericano}

Para entender las necesidades de expansión de la democracia en América Latina y percibir sus fragilidades es indispensable apreciar lo que la democracia posee aquí de propio y original.

En América Latina, las reglas e instituciones del régimen son similares a las de los países democráticamente más maduros, pero sus sociedades son profundamente diferentes de las de aquéllos.

En América Latina, construir y ampliar los derechos ciudadanos es una tarea que se desenvuelveen un contexto novedoso. En estos últimos veinte años se ha producido un conjunto de grandes transformaciones. Por primera vez en la historia, una región en desarrollo y con sociedades profundamente desiguales está, en su totalidad, organizada políticamente bajo regímenes democráticos. Así se define, en América Latina, una nueva realidad sin antecedentes:4 el triángulo de la democracia, la pobreza y la desigualdad.

El primer vértice del triángulo esla difusión de la democracia electoral en la región. Todos los países que la integran satisfacen los requisitos básicos del régimen democrático. Sólo los países agrupados en la O rganización de Cooperación y Desarrollo Económico (OCDE) comparten este rasgo.

El segundo vértice es la pobreza. En 2002, la región contaba con 218 millones de personas ( 0 un 42,9 por ciento) cuyos ingresos se situaban por debajo de la línea de pobreza. Por cierto, esta situación varía de país en país. A pesar de estas diferencias, comparada con las otras grandes regiones democráticas del mundo, América Latina ofrece la singularidad de la cohabitación de las libertades políticas con las severas privaciones materiales de muchos. Democracia y riqueza, democracia y pobreza son dos combinaciones que generan necesidades, dificultades y riesgos diferentes.
Por primera vez en la historia, una región en desarrollo y con sociedades profund a mente desiguales está, en su totalidad, organizada políticamente bajo regímenes democrá ticos.

El tercer vértice es la desigualdad. Las sociedades latinoamericanas son las más desiguales del mundo. Como en el caso de la pobreza, no sólo se observa la profundidad de la desigualdad en la región en comparación con el resto del mundo, sino también su persistencia a lo largo de las últimas tres décadas.

Por primera vez conviven estostres rasgos, y la democracia enfrenta el desafío de su propia estabilidad coexistiendo con los retos de la pobreza y la desigualdad. Los riesgos que derivan de esta situación son distintosy más complejos quelos tradicionales del golpe militar deEstado, que, por lo demás, tampoco han desaparecido totalmente.

Sin embargo, a pesar de lo particular de esta situación, es habitual que se piense en América Latina a partir de la experiencia histórica de las democracias desarrolladas, desconociendo quela estabilidad y la expansión democráticas tienen aquí contenidos y dilemas distintos, resultado de su propia originalidad. Éstas son democracias pobres y desiguales, cuyos hombres y mujeres, a la vez que consolidan sus derechos políticos, deben también completar sus ciudadanías civil y social.

La escasa comprensión de esta realidad singular puedellevar a dos consecuencias graves para la democracia. La primera, ignorar la necesidad de la viabilidad económica de la democracia. Esto es ignorar la necesidad de construir bases sólidas de una economía que permita atacar la pobreza y la desigualdad. Por ejemplo, para muchos ciudadanos latinoamericanos alcanzar mayores niveles de desarrollo en sus países es una aspira-

4 No afirmamos aquí que no se verifique la existencia conjunta de democracia, pobreza y desigualdad en otros países o regiones del planeta. Lo que señalamos es que la democracia latinoamericana convive en la totalidad de una región con niveles extensamente difundidos de pobreza y situaciones de desigualdad extremas. 


\begin{tabular}{|c|c|c|c|c|}
\hline \multicolumn{4}{|c|}{ DEMOCRACIA, POBREZA Y DESIGUALDAD } & \multirow{2}{*}{ PBI per cápita } \\
\hline Región & Participación electoral (1) & Desigualdad (2) & Pobreza & \\
\hline América Latina & 62,7 & $0,552(3)$ & $42,8(6)$ & 3792 (9) \\
\hline Europa & 73,6 & $0,290(4)$ & $15,0(7)$ & $22600(10)$ \\
\hline EE.UU. & 43,3 & $0,344(5)$ & $11,7(8)$ & 36100 \\
\hline
\end{tabular}

Notas:

(1) Votantes con base en la población con derecho a voto 1990-2002. Ver Tabla 7.

(2) Coeficiente de Gini. Las cifras más altas del coeficiente de Gini corresponden a un grado más alto de desigualdad.

(3) Promedio simple para la década de los 90. Perry et al., 2004, p. 57.

(4) Eurostat PCM-BDU, diciembre de 2002.

(5) Fuentes: OCDE 2002, Social Indicators and Tables.

(6) Promedio ponderado por población de los datos de pobreza entre 1998-2002, CEPAL, 2004.

(7) Eurostat PCM-BDU, diciembre de 2002.

(8) Fuente: US Census Bureau 2001, Poverty in the United States 2002.

(9) Elaboración propia en base a datos de CEPAL, 2004 (en dólares constantes).

(10) Europa occidental (EU15) y EE.UU., PBI per cápita 2002. Fuente: OCDE (en dólares corrientes).

Dada la multiplicidad de fuentes y las diversas metodologías de elaboración de datos implicadas se sugiere tomar los datos de esta tabla como referencias indicativas.

ción tan importante que muchos estarían dispuestos a apoyar un régimen autoritario si éste pudiere dar respuesta a sus demandas de bienestar. La segunda es desconocer la viabilidad política de los programas económicos. Esto es ignorar que esos programas se aplican en sociedades donde las demandas ciudadanas y el juicio sobre dichas políticas se expresan libremente.

En efecto, no es menos común deslizarse hacia el error de pensar en términos de reforma económica como si no existiera democracia. Como si los difíciles y dolorosos procesos de ajuste estructural fueran neutrales en las decisiones que toman las mayorías -sometidas a condiciones de pobreza y alta desigualdad- al momento de votar o de expresar su apoyo o rechazo a un gobierno, o como si se pudiera llevar adelante un plan económico sin apoyo de la población, o, aun peor, a pesar de su hostilidad manifiesta.

Esta forma de pensar la democracia latinoamericana independientemente de su economía o, simétricamente, pensar su economía separadamente de su democracia, parece un error ingenuo, pero no por ello es menos recurrente y preocupante para la suerte de la democracia y dela economía, si miramos la experiencia de las últimas décadas en la región.
En consecuencia, el debate sobre la estabilidad democrática no debe ignorar la pobreza y la desigualdad, ni las políticas de crecimiento deben soslayar que, pobres y desiguales, los ciudadanos ejercen su libertad para aceptar o rechazar esas políticas. Deaquí surge el desafío de resolver las tensiones entre economía y democracia. Ese desafío parte de la necesidad de no pensar la economía como si no hubiera democracias pobres ni atacar los problemas de la estabilidad democrática independientemente de las necesidades de resolver las cuestiones del crecimiento. Es probableque un debatequeignore una cuestión tan elemental termine llevando a recomendaciones sencillamente impracticables.

Estas características de América Latina han sido utilizadas como argumento para concluir que la democracia sería inviable hasta tanto no se resuelvan los problemas de la pobreza y selogre un mínimo aceptable de igualdad. En más deuna ocasión, regímenes autoritarios se instalaron con un discurso "restaurador" del régimen democrático: "Asumimos el gobierno para crear las condiciones para quela democracia se instale sólidamente en el futuro". Supuestamentehabía que alcanzar un cierto umbral de riqueza 
para acceder a la democracia. Contra esta visión, este Informe sostiene que sólo con más y mejor democracia las sociedades latinoamericanas podrán ser más igualitarias y desarrolladas. La razón es que sólo en democracia, quienes carecen de niveles mínimos de bienestar y sufren las injusticias de la desigualdad pueden reclamar, movilizarse y el egir en defensa de sus derechos. Para que eso se concrete es indispensable indagar caminos no explorados y abrir nuevos debates en América Latina, porque - reiteramos- el gran desafío es combatir la pobreza y la desigualdad, con los instrumentos de la democracia, para crear las bases de cohesión y estabilidad social, que son los requisitos del crecimiento económico.

En América Latina han tenido lugar procesos de reforma en el plano político y económico. Si bien estos procesos han producido algunos progresos importantes, sobre todo en la expansión de la democracia electoral, subsiste un notorio contrasteentre las reformas llevadas adelante durante las dos últimas décadas y una realidad que continúa signada por grandes carencias en el plano de las distintas ciudadanías, particularmente la social.

Éstos no fueron sólo años de transformaciones políticas. También la economía, sobre todo en la década de 1990, vivió un proceso de cambios profundos, de apertura, reformas y desregulaciones, lo que se ha conocido con la denominación genérica de ajustes estructurales. Así, con algunas excepciones, "la nueva oleada de democratización en la región que se inició a mediado de los años ochenta asumió las reformas económicas orientadas a la ampliación de las esferas del mercado como su propia agenda". 5

Como consecuencia de estas transformaciones, las sociedades latinoamericanas resultan ser sociedades en vías de desarrollo, donde las demandas sociales se expresan librementey la economía se organiza en torno al mercado. De este modo, demandas sociales expresadas en un contexto de libertad política (democra-
Sólo con más y mejor democracia

las socieda des la tinoa merica nas pod rá n ser má s igua lita ria s y desa rrolla das.

cia) y libertad económica (mercado) forman otro triángulo singular. Un triángulo que de bió ser virtuoso y que, a la luz de los últimos veinte años, presenta complejas dificultades que requieren un pensamiento renovado. La combinación entre libertad política y libertad económica en contextos de pobreza y desigualdad puede no generar como resultado el fortalecimiento de la democracia y el desarrollo de la economía.

En las páginas que siguen se muestra una fotografía en la que contrastan reformas y realidades. Ésa es también una primera fotografía del déficit democrático deAmérica Latina, un indicio de la clave de las frustraciones, una evidencia sobre la urgencia de construir la democracia de ciudadanía.

\section{Balance entre reformas y realidades}

Para este balance se tomaron siete indicadores básicos: las reformas estructurales en la economía, las reformas democráticas, la evolución del producto bruto interno (PBI) per cápita, la pobreza, la indigencia, la concentración del ingreso y la situación laboral.

Antes de iniciar la presentación de la tabla que muestra un resumen de esos indicadores básicos, es necesario hacer al gunas aclaraciones. En primer lugar, el Informe no afirma que necesariamente existeuna relación causal entrelas variables que se utilizarán. Sostiene, en cambio, que los ciudadanos latinoamericanos han experimentado en forma más o menos simultánea los efectos de esas variables. 
REFORMAS Y REALIDADES

Índice de Crecimiento del

Indice de Reforma Democracia PBI real per cápita Pobreza Indigencia Coeficiente de Desemple

\begin{tabular}{|c|c|}
\hline Econón & $\begin{array}{l}\text { Dem } \\
\text { Elect }\end{array}$ \\
\hline
\end{tabular}

Subregión Cono Sur (Argentina, Chile, Paraguay, Uruguay)

$1981-90$

1991-97

0,66

0,44

$-0,8 \%$

0,82

0,88

$1,3 \%$

25,6

7,1

0,502

8,8

1998-02

0,84

0,91

$1,0 \%$

21,2

7,1

0,502

8,7

Brasil

$1981-90$

$0,52 \quad 0,70$

32,3

12,9

0,558

12,1

\section{1-97}

$\begin{array}{ll}0,75 & 1,00\end{array}$

$1,7 \%$

48,0

23,4

(1)

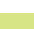

1998-02

$0,79 \quad 1,00$

$\begin{array}{ll}1,00 & 0,4 \% \\ 1,00 & 1,1 \%\end{array}$

40,6

17,1

0,603

5,2

37,5

13,1

0,640

5,3

7,1

\section{Subregión Andina (Bolivia, Colombia, Ecuador, Perú, Venezuela)}

1981-90

1991-97

1998-02

\section{0,53}

0,76

0,82

0,83

0,86

$-0,6 \%$

$0,9 \%$

$0,1 \%$

\section{2,3}

50,4

52,7

22,1

18,1

25,0
8,8

8,3

12,0

$\begin{array}{llllllll}\text { México } & & & & & & \\ 1981-90 & 0,61 & 0,31 & 1,7 \% & 47,8 & 18,8 & 0,521 & 0,2 \\ 1991-97 & 0,78 & 0,70 & 0,4 \% & 48,6 & 19,1 & 0,539 & 4,0 \\ 1998-02 & 0,81 & 1,00 & 2,2 \% & 42,5 & 15,4 & 0,528 & 2,6\end{array}$

\section{Subregión Centroamérica (C. Rica, El Salvador, Guatemala, Honduras, Nicaragua, Panamá, Rep. Dom.)}

$\begin{array}{llllllll}1981-90 & 0,55 & 0,59 & 4,1 \% & 55,3 & 35,6 & 0,532 & 9,1 \\ 1991-97 & 0,80 & 0,89 & -3,5 \% & 52,0 & 27,8 & 0,524 & 9,1 \\ 1998-02 & 0,85 & 0,97 & 2,8 \% & 54,0 & 29,7 & 0,546 & 8,8\end{array}$

\begin{tabular}{|c|c|c|c|c|c|c|c|}
\hline \multicolumn{8}{|c|}{ Región Latinoamericana } \\
\hline $1981-90$ & 0,58 & 0,64 & $0,7 \%$ & 46,0 & 20,4 & 0,551 & 8,4 \\
\hline 1991-97 & 0,79 & 0,87 & $0,6 \%$ & 42,8 & 18,3 & 0,574 & 8,8 \\
\hline 1998-02 & 0,83 & 0,92 & $1,2 \%$ & 42,8 & 17,7 & 0,577 & 10,4 \\
\hline
\end{tabular}

Notas:
(1) Promedio simple.
(2) Ponderado por población.
(3) De período a período.

El índice de reforma económica se conforma de cinco componentes: políticas de comercio internacional, políticas impositivas, políticas financieras, privatizaciones y cuentas de capitales. El índice va de 0 , que indica una falta de reformas orientadas al mercado, a 1, que indica la aplicación de reformas fuertemente orientadas al mercado. El "Índice de Democracia Electoral” va de 0 (igual a falta de democracia electoral) a 1 (indica que los requisitos de democracia electoral se cumplen). La tasa de crecimiento del PBI real per capita anualizado se calculó de la siguiente manera: a) se sumaron los PBI reales (base dólares 1995) para los años del período bajo análisis, y se dividió por el número de años en el período; b) se dividió por la población promedio del período; c) se dividió el PBI per cápita de este período por el del período anterior, sacando luego la raíz geométrica según el número de años en el período analizado.

En todos los casos, las columnas sobre Pobreza e Indigencia abarcan el porcentaje mayor del territorio que se ofrece en la base de datos CEPAL. En tal sentido y para ciertos paises se utilizaron series con cobertura espacial distinta con el criterio de utilizar el dato mas abarcativo. Esto implica que los datos de Pobreza e Indigencia puedan estar subestimados y que para esos paises los saltos de la serie pueden no reflejar necesariamente saltos en los niveles de Pobreza e Indigencia. La actualización de este cuadro se hizo en base a los nuevos datos provistos por la CEPAL y los nuevos datos poblacionales de CELADE. A partir de los censos más recientes, el CELADE reestimó los datos poblacionales para la década de los 90 . Por consiguiente esto afectó todos los datos ponderados por población y los datos per cápita. Este ejercicio agregó varias millones de personas a los datos oficiales anteriores. Fuentes: Los datos sobre el Índice de Reforma Económica provienen de M orley, Machado, y Pettinato, CEPAL 1999; Lora 2001, y comunicación con Manuel Marfán, director de la División de Desarrollo Económico de CEPAL, 4 de febrero de 2003.

La metodología y los datos del Índice de Democracia Electoral se presentan en el Compendio Estadístico. Los otros datos provienen de múltiples publicaciones de CEPAL, con la excepción de los datos sobre el coeficiente de Gini antes de 1990, cuya fuente es Deininger y Squire 1998. Las cifras de crecimiento real del PBI per cápita están calculadas con base en dólares 1995. Las cifras sobre pobreza, indigencia y el coeficiente de Gini son promedios de sólo algunos años. Los datos sobre pobreza, indigencia, coeficientes de Gini y desempleo urbano no son estrictamente comparables, ya que no todos están basados en encuestas nacionales. 
En segundo lugar, en la democracia, los ciudadanos tienen expectativas respecto del funcionamiento de la economía. Ellas provienen de la ideología igual itaria subyacente a la democracia, de la prédica de los políticos nacionales, de los medios de comunicación, de las organizaciones internacionales, etc. Durante la década de 1990 se instaló como promesa de desarrollo un modelo económico del quehoy muchos se sienten defraudados.

En tercer lugar, la percepción de una parte importante de los ciudadanos es que las políticas seguidas "produjeron" insuficiente crecimiento aceptable, pobreza y desigualdad crecientes y desmejoramiento de la situación laboral (con su consiguiente impacto sobre la desigualdad y los ingresos futuros previsionales).

1. El índice de reforma económica señala un avance sostenido de esas reformas; medido entre 0 y 1 , pasa de 0,58 en los años ochenta a 0,83 como promedio entre 1998 y 2002 . Este índice se conforma de cinco subíndices: "políticas de comercio internacional", "políticas impositivas", "políticas financieras", "privatizaciones" y "cuentas de capitales", todos relacionados con el luego Ilamado Consenso deWashington.

2 En América Latina se reconoce hoy el derecho al voto universal, sin restricción alguna depeso significativo. Éste es un logro notabley sumamente importante. El índice de democracia electoral (IDE) elaborado por el Proyecto sobre el Desarrollo de la Democracia en América Latina (PRODDAL) muestra que, en términos electorales, la democracia tuvo un mejoramiento constantea lo largo del período considerado. Los procesos de democratización y reforma del mercado, si bien de naturaleza distinta, avanzaron de manera sostenida, provocando una gran expectativa que contrastó notablemente con la evolución de los hechos.

3. El promedio regional del PBI per cápita no varió de manera significativa en los últimos veinte años. En 1980, mientras el índice de reforma económica era de 0,55; el PBI per cápita era U \$S 3.734 a valores constantes de 1995. Veinte años más tarde, en el año 2000, habiéndose avanzado considerablemente en la aplicación de las reformas, el índiceera de 0,83 y el PBI per cápita, de U \$S 3.920, un avance casi irrelevante.

4. Los niveles de pobreza experimentaron una le vedisminución en términos relativos. En 1990, el porcentaje de pobres 6 ponderado por tamaño de población representaba para los dieciocho países el 46 por ciento; entre 1998 y 2002, ese porcentaje había descendido al 42,8 por ciento. Este avance se produjo fundamental mente por las mejorías relativas de Brasil, Chile y M éxico. Sin embargo, en términos absolutos, el número de habitantes que se situaba por debajo de la línea de pobreza aumentó. En el año 1990, 191 millones de latinoamericanos eran pobres. En el año 2002, cuando la población era de 508 millones de habitantes, la cantidad de pobres ascendía a 218 millones. Podría añadirse que, incluso en términos relativos, la pobreza se incrementó durante este período en el Cono Sur (de 25,6 a 32,3 por ciento) y en los países andinos (de 52,3 a 52,7 por ciento).

5. No se redujeron los niveles de desigualdad. En el año 1990, el coeficiente de Gini ${ }^{7}$ (promedio regional ponderado por población) era de 0,554. En 2002 este coeficiente subió a 0,576. El promedio mundial para los años noventa

6 La medición de la pobreza con el método de la “Línea de Pobreza” (LP) elaborada por CEPAL consiste en establecer, a partir de los ingresos de los hogares, su capacidad para satisfacer - por medio de la compra de bienes y servicios- un conjunto de necesidades alimentarias y no alimentarias consideradas esenciales.

7 Este coeficiente es una medida que surge de una representación gráfica de la distribución del ingreso llamada Curva de Lorenz. Para el coeficiente de Gini, 0 representa la igualdad perfecta de distribución y 1 la desigualdad absoluta. Puede considerarse un coeficiente de Gini de 0,25-0,35 como una distribución "razonable", y un coeficiente de Gini de 0,55 representa una desigualdad extrema. 
fue de 0,381 y el de los países desarrollados 0,337. La alta desigualdad también se expresa en la relación entrelos niveles superiores einferiores de ingreso. En el año 1990, el 10 por ciento de la población latinoamericana deingresos más elevados tenía 25,4 veces el ingreso del 10 por ciento dela población demenores ingresos. En 2002, esa relación era de 40 veces. ${ }^{8}$ En 2002 , el 20 por ciento de la población de la región de más altos ingresos recibió casi 54,2 por ciento del ingreso total y el 20 por ciento del sector de menores ingresos, sólo el 4,7 por ciento. La región posee los niveles de desigualdad más altos del mundo en la distribución del ingreso.

6. Durantelosúltimos quinceaños, la situación laboral ha desmejorado en casi toda la región. El desempleo y la informalidad aumentaron significativamente. Además, cayó la protección social (salud, pensiones y sindicalización) de los trabajadores. Esto se vincula a un desmejoramiento de la distribución del ingreso y a un aumento de la pobreza actual, configurando un cuadro cuyos efectos tendrán consecuencias muy negativas en el mediano y largo plazo.

Esta primera visión es un indicio de la inmensidad y complejidad de las tareas que América Latina debería asumir. Hace veinticinco años, la región tenía un desafío a la vez difícil y simple. Requería audacia e imaginación para alcanzarlo, pero no había duda acerca de cuál era su contenido: vencer a las dictaduras, superar las guerras y alcanzar la democracia y la paz. Nadie dudaba cuál era la agenda de la democracia.

Hoy, regenerar su contenido, dar impulso a una nueva etapa, es una meta mucho más vasta y plena de incertidumbres. ¿Q ué quiere decir en concreto ir hacia la democracia de ciudadanía, cuáles son los temas centrales, qué condiciones requerimos para resolverlos? ¿Quiénes son los nuevos adversarios de la democracia ampliada?
Ninguna de estas cuestiones tiene la claridad de aquella opción binaria de los setenta: democracia-dictadura, libertad-opresión, vida-muerte.

M ovilizar la imaginación, el conocimiento y la política es, como nos ilustran estos contrastes que acabamos de mostrar, una tarea difícil, ardua e incierta. La primera condición, a la que apuntamos en esta obra, es tomar conciencia de hasta qué punto es inexcusable no encararla. La tarea incluye, por cierto, la necesidad de enfrentar el legado histórico de atraso económico y tecnológico, de fractura social y de inserción secundaria y desventajosa en el sistema internacional.

Las páginas que siguen inician la exploración sobre estas cuestiones, sobre la natural eza de los desafíos para el desarrollo dela democracia, sobre la centralidad de los derechos del ciudadano para la etapa que se abre y sobre al gunos temas -la noción misma de democracia y del papel del Estado- que constituyen el punto de partida de nuestras proposiciones.

No se trata de un desarrollo teórico en el sentido estricto, sino más bien de algunos hitos básicos que están en los fundamentos teóricos de nuestro trabajo.

Ingresamos en estecampo no porque el objetivo del Informe sea una indagación académica sobre la democracia, sino porque las consecuencias prácticas de las diferentes concepciones son sustantivas a la hora deimaginar las políticas y las estrategias de sustentabilidad democrática. Esas diferencias serefieren a las condiciones de expansión de la democracia, a sus riesgos de desaparición, a la manera como se ven y formulan ciertas políticas públicas, a las diferencias socioculturales y de género, a la visión del Estado y sus transformaciones 0 al rol de la política y sus organizaciones. También, según nos situemos en una u otra visión dela democracia, resultarán fuertes diferencias en lo que esperamos de otra forma de organización dela sociedad: la economía.

En otras palabras, si la democracia sólo fuera un régimen podríamos arribar a la paradoja extrema de la existencia de una sociedad pobre 


\section{La democracia y la promesa de los derechos ciudadanos}

No obstante la instauración del régimen democrático, no se logró modificar la naturaleza y el funcionamiento del Estado por la presencia de factores internos y externos que obstaculizaron el cumplimiento de los derechos ciudadanos. De ahí que las expectativas depositadas en tal ordenamiento se hayan visto frustradas, porque el desempeño de las representaciones políticas y de las instituciones públicas no se corresponden con las expectativas de la mayoría de la población, sujeta históricamente a las condiciones de "pobreza" y de "exclusión" -denominaciones tecnocráticas que esconden las relaciones sociales generadoras de estas situaciones-; más aún porque en las nuevas circunstancias internacionales el régimen y el Estado refuerzan tales condiciones, a contrapelo de las proclamas democráticas y liberales, y de las promesas de los dirigentes políticos.

Por tales motivos, el descrédito del régimen democrático "realmente existente" propicia que amplios sectores sociales, particularmente los pobres y los excluidos del imaginario como de la acción político-estatal, asuman comportamientos “informales”, si no ilegales, para satisfacer sus aspiraciones individuales y colectivas, que el Estado es incapaz de controlar por no contar con los recursos materiales ni con el respaldo de la población. La fragmentación de los intereses sociales y de las representaciones políticas que acarrea esta conducta agudiza los problemas de la acción colectiva, al tiempo que la proliferación de "gorreros" (free-riders), que de manera irresponsable ofrecen resolver las demandas sociales mediante propuestas oportunistas de corto plazo, procuran el desconcierto y el desasosiego general. En esta coyuntura, no es de extrañar la existencia de voces que auguran desenlaces dramáticos; sin embargo, a pesar de tales oscuros presagios se observa la presencia de actores que, a pesar de todo, persisten tercamente en defender la validez del régimen democrático, para lo cual aducen que este régimen constituye el único marco para nacionalizar y democratizar el Estado y la sociedad. Como hace poco decía un dirigente sindical peruano: "La democracia no asegura la justicia social, pero es el único espacio que permite luchar para conseguirla".

Julio Cotler, texto elaborado para el PRODDAL, 2002. en términos de los derechos sociales y económicos de sus ciudadanos, incluso pobre en sus derechos civiles básicos, pero plenamente democrática.

Otra consecuencia importante, derivada de una comprensión de la democracia limitada a su régimen, es la visión segmentada de las políticas públicas. Así, habría políticas recomendables para asegurar las buenas condiciones del funcionamiento del régimen democrático, otras aconsejables para el adecuado funcionamiento de la economía y otras que recomienden las reformas apropiadas de, por ejemplo, la organización estatal.

En esta visión fragmentada se creería fortalecer a la democracia con el solo recurso de mejorar el funcionamiento de su régimen y se desconocería el impacto que tendrían sobre ella, por ejemplo, las reformas del Estado o las reformas estructurales en la economía.

Tampoco se observarían hechos tales como que las políticas de reforma del Estado o de la economía sean, en última instancia, evaluadas por mayorías que medirán sus resultados en términos del progreso de sus vidas o de una mayor justicia en la distribución de los bienes. De modo que el juicio ciudadano es una parte sustancial dela viabilidad de las políticas de reforma.

\section{Los organismos internacionales y la promoción de la democracia}

El Informe se inspira en la letra y el espíritu de diferentes documentos de las Naciones Unidas:

- La Declaración Universal de los Derechos Humanos aprobada por las Naciones Unidas en 1948 establece una concepción amplia de la ciudadanía, abarcando dere chos civiles, políticos y sociales.

- La Declaración y Programa de Acción de Viena, de 1993, establece que "la comunidad internacional debe apoyar el 
RECUADRO 4

\section{Declaración Universal de Derechos Humanos}

Las Naciones Unidas han reafirmado en la Carta su fe en los derechos fundamentales del hombre, en la dignidad y el valor de la persona humana y en la igualdad de derechos de hombres y mujeres; y se han declarado resueltas a promover el progreso social y a elevar el nivel de vida dentro de un concepto más amplio de la libertad.

ONU, 1948.

fortalecimiento y la promoción de la democracia, el desarrollo y el respeto de los derechos humanos y de las libertades fundamentales en el mundo entero".

- La promoción del derecho a la democracia ha sido proclamada por la Comisión de Derechos Humanos de las Naciones Unidas en su resolución 1999/57.

- Adicionalmente, en el año 2000, la Asamblea General de las Naciones Unidas, en la Declaración del Milenio, establece que "no escatimaremos esfuerzo al guno por promover la democracia y fortalecer el imperio del derecho y el respeto de todos los derechos humanos y libertades fundamentales internacionalmente reconocidos, incluido el derecho al desarrollo".

El sistema de las Naciones Unidas, a través de todos sus organismos y programas, promueve el respeto de los derechos humanos, la realización de elecciones libres y limpias. A través de la Declaración del Milenio, la ONU y otros organismos internacionales de cooperación y financiamiento han reforzado su llamado para la promoción de la democracia, el fortalecimiento del estado de derecho y el desarrollo sostenible. El Programa de las $\mathrm{Na}$ ciones Unidas para el Desarrollo (PNUD), a través de sus programas de gobernabilidad, incluye la promoción de diálogos democráticos, programas de reforma del Estado y de promoción del desarrollo económico. Para el PNUD, democracia y desarrollo humano comparten una visión y un propósito común: el desarro-

RECUADRO 5

\section{Los derechos democráticos}

La Comisión de Derechos Humanos de las Naciones Unidas afirma que entre los derechos a una gestión pública democrática figuran los siguientes:

a. El derecho a la libertad de opinión y de expresión, de pensamiento, de conciencia y de religión, de asociación y de reunión pać́ficas.

b. El derecho a la libertad de investigar y de recibir y difundir informacionese ideas por cualquier medio de expresión.

c. El imperio de la ley, incluida la protección jurídica de los derechos, intereses y seguridad personal de los ciudadanos y la equidad en la administración de la justicia, así como la independencia del Poder Judicial. d. El derecho al sufragio universal e igual, así como a procedimientos libres de votación y a elecciones periódicas libres.

e. El derecho a la participación política, incluida la igualdad de oportunidades de todos los ciudadanos para presentarse como candidatos.

f. Instituciones de gobierno transparentes y responsables.

g. El derecho de los ciudadanos a elegir su sistema de gobierno por medios constitucionales u otros medios democráticos.

h. El derecho de acceso, en condiciones de igualdad, a la función pública en el propio país.

ONU, Comisión de Derechos Humanos, 1999. 


\section{La democracia requiere más que elecciones}

La democratización verdadera es algo más que las elecciones. [...] El hecho de conceder a todas las personas una igualdad política oficial no basta para crear en la misma medida la voluntad o capacidad de participar en los procesos políticos, ni una capacidad igual en todos de influir en los resultados. Los desequilibrios en los recursos y el poder político socavan a menudo el principio "una persona, un voto", y la finalidad de las instituciones democráticas.

PNUD, 2002c, pp. 4 y 14.
Las elecciones no son eventos aislados sino parte de un proceso más amplio.

Kofi Annan, Secretario General de la ONU, 2003.

Las elecciones libres y justas son necesarias, pero no son suficientes. No apreciamos plenamente el valor de la democracia cuando celebramos elecciones como evidencia de que existe una democracia.

Mark Malloch Brown, Administrador del PNUD, 2002.
Ilo humano es un proceso para fortalecer las capacidades del ser humano, que expande las oportunidades de cada persona para alcanzar una vida respetable y valiosa, por lo que necesita como correlato una forma política que lo asegure; a saber, la democracia.

Asimismo, es destacable el papel de varios organismos e iniciativas regionales que han puesto prioridad a la defensa y el fortalecimiento de la democracia. En este sentido, es notable el compromiso con la democracia que han asumido los países en la región por medio de la Organización de Estados Americanos (OEA). La OEA dio un paso fundamental en su reunión en Santiago de Chileen 1991, cuando sus países miembros adoptaron mecanismos para reaccionar ante situaciones en las que la democracia fuera interrumpida. Otro paso clave lo constituyó la aprobación de la Carta Democrática Interamericana en 2001. Sin lugar a duda, la coordinación de esfuerzos en pos de la democracia por parte de líderes latinoamericanos, especialmente a través de organizaciones internacionales, es un hito fundamental que fortalece a las democracias en América Latina.

También cabe destacar el trabajo llevado a cabo por el Grupo de Río, las Cumbres I beroamericanas de los J efes de Estado y de Gobierno y la OEA a través de la Unidad para la Promoción de la Democracia en torno a temas clave para la democracia. M ás específicamente, estas iniciativas vienen impul sando la definición de una agenda política para la región que resalta la importancia de la política y de los partidos políticos, las organizaciones de la sociedad civil y la participación ciudadana en los diversos procesos de la vida pública, la cultura democrática, las instituciones garantes de la transparencia y eficacia gubernamental, la gobernabilidad democrática, el estado de derecho, la reducción de la pobreza, y el impacto de la nueva economía sobre el desarrollo económico.

Estas iniciativas internacionales, vale la pena subrayar, no se restringen a promover la democracia en su aspecto electoral. Por el contrario, haciendo eco de las preocupaciones de los ciudadanos, los organismos internacionales globales y regionales incluyen en sus metas tanto el estado de derecho como el desarrollo económico. Cada vez más, la comunidad internacional está convergiendo hacia la visión más amplia de la democracia, que este Informe propone, y hacia la idea de que, para prevenir retrocesos en el proceso democrático, es necesario analizar el régimen democrático como parte, y no aisladamente, del marco de las ciudadanías política, civil y social. El gran reto está en consolidar este consenso emergente y traducirlo en apoyo a reformas que fortalezcan las democracias latinoamericanas. 



\section{- Exploración sobre el desarrollo de la democracia ${ }^{9}$}

Mientras mayores grados de democracia, mejor. Tal es la idea que guía nuestra exploración del desarrollo de la democracia en América Latina. Pero aun así, in dubio pro democratia.

Si bien éste es un criterio general válido, no resuelve la discusión teórica y política sobre dos cuestiones: ¿cuánta democracia y dónde?

¿A qué esferas deberían extenderse los mecanismos democráticos de toma de decisiones y el principio y los derechos de ciudadanía? ¿Qué costos, en términos de otros objetivos sociales, estamos dispuestos a pagar para avanzar en la democratización? ¿D eberían los mecanismos democráticos y los principios de ciudadanía extenderse a, digamos, el funcionamiento interno de los partidos y sindicatos, pero no a empresas, universidades, organizaciones internacionales y familias? ¿Pueden existir criterios razonablemente consistentes y ampliamente aceptados acerca de dónde aplicar y dónde no, los mecanismos y principios de la democracia?Y, tal vez, aun más enigmático, ¿quién y mediante qué procesos debería decidir este tipo de cuestión?

Los demócratas sinceros de variadas escuelas y tradiciones debatirán siempre sobre dónde, có- mo, cuándo y por quiénes deben ser situados los límites de la democracia. La política, especialmente la política democrática, debate centralmente sobre los límites mismos de la política y, conseCuentemente, también del Estado. ${ }^{10}$ ¿Cuáles son males sociales prevenibles? ¿Cuáles de ellos deberían ser resuel tos por la política y el Estado adecuado? ¿Cuáles son los hechos ineluctables o que conviene dejar librados al mercado o a la buena voluntad de al gunos actores sociales?

Estas preguntas no admiten ser tratadas por fuera de las circunstancias específicas de cada país. Sin embargo, en el contexto del presente informe no podemos dejar de registrar la manera en que los límites de la política, de la democracia y del Estado han sido reducidos en la historia reciente de América Latina.

\footnotetext{
Gran parte de la teoría contemporánea de la democracia se restringe a caracterizarla como un régimen político. Esta restricción refleja, y refuerza, una concepción general de lo que la política, específicamente la política democrática, trata. Tales visiones expulsan la democracia y, en general, la política, de cualquier relación activa frente a la
}

9 Esta sección se basa principalmente en los documentos preparados por Guillermo O'Donnell para este Informe: "N otas sobre el estado de la democracia en América Latina” y “Acerca del Estado en América Latina contemporánea: Diez tesis para su discusión". También este último documento es de gran importancia en la Tercera Sección del Informe, sobre todo en la parte titulada "La necesidad de una nueva estatalidad."

10 Del mismo modo, S. N . Eisenstadt (2000, p. 14) hace la importante observación de que uno de los "aspectos centrales del proceso político democrático [... [ ] es] una lucha continua sobre la definición del ámbito de la política. En verdad, es sólo con el advenimiento de la modernidad que el trazado de los límites de la política se transforma en uno de los mayores foci de la lucha y contestación política abierta". 


\section{Los cimientos de la democracia}

No hay nada misterioso respecto de los cimientos de una democracia saludable y fuerte. Las cosas básicas esperadas por nuestro pueblo de sus sistemas político y económico son simples.

Ellas son:

- La igualdad de oportunidad para los jóvenes y los demás.

- Un empleo para losque pueden trabajar.

- La seguridad (social) para los que la precisan.

- El fin del privilegio especial para unos pocos.

- La preservación de las libertades civiles para todos.
- La participación en los frutos del progreso científico, en un estándar de vida constantemente creciente y ampliamente compartido.

Éstas son las cosas sencillas y básicas que nunca deberían perderse de vista en el tumulto y complejidad increíble de nuestro mundo moderno. La fuerza interior y duradera de nuestros sistemas económico y político depende del grado en que cumplen con estas expectativas.

Franklin Delano Roosevelt, "Discurso de las Cuatro Libertades", enero de 1941. gran injusticia social expresada en la carencia extendida de derechos sociales y también civiles, así como por la anemia de un Estado que se muestra ineficaz y, como tal, pierde credibilidad ante mayorías fluctuantes de sus respectivas sociedades.

Esa reducción de la capacidad creadora de la democracia es producto, entre otras cosas, de una deficiencia conceptual: juzgar la democracia como la democracia del elector. Cuando se coloca la ciudadanía como fundamento de la democracia, cambia la manera de evaIuarla. En efecto, se abre una dimensión diferente de reflexión y de acción si el desarrollo de la democracia se mide por su capacidad para garantizar y expandir la ciudadanía en sus esferas civil, social y política.

La noción de ciudadanía implica un estatus para cada persona como miembro de pleno derecho de una comunidad, y abarca diversas esferas que se expresan en derechos y obligaciones. La expansión de la ciudadanía es una condición del éxito de una sociedad y de la satisfacción de sus aspiraciones. Es en torno a esto que se debe juzgar la calidad de la democracia.

La medida del desarrollo de una democracia está dada, por lo tanto, por su capacidad de dar vigencia a los derechos de los ciudadanos y constituir a éstos en sujetos de las decisiones que los afectan.
En síntesis, cuando este Informe analiza el grado de desarrollo de la democracia, sus logros y carencias, se está interrogando sobre el sistema que permite acceder a los cargos públicos, sobre la organización social que genera la democracia -el Estado, los partidos, el poder- y sobrela calidad de la ciudadanía civil, social y política de las mujeres y hombres que integran una Nación.

\section{Un debate incompleto}

Durante casi dos décadas, particularmente en los años noventa, la agenda y las políticas públicas en América Latina han tratado la cuestión del fortalecimiento democrático, la crisis de la política, las reformas del Estado, las reformas estructurales de la economía y el impacto de la globalización en la región. Sin embargo, aunque se abordaron aspectos sustantivos de estas cuestiones, el debate marginó otros que, a la luz del análisis presentado en este Informe, deberían situarse en el centro dela discusión.

La democracia fue observada esencialmente en su dimensión electoral; la política vista a través de la crisis que expresaban sus partidos, las estructuras clientelísticas, la corrupción o los regímenes electorales; la problemática del Estado se centró en la cuestión de los equilibrios fiscales, la modernización burocrática y la disminución desu interferencia en la econo- 
ELECTORALES POR GOBERNANTES, AMÉRICA LATINA, 2002

Cumplimiento de promesas

Personas (\%)

\begin{tabular}{lc}
\hline Los gobernantes cumplen con sus promesas electorales & 2,3 \\
\hline No cumplen porque ignoran lo complicado que son los problemas & 10,1 \\
\hline No cumplen porque aparecen otros problemas más urgentes & 9,6 \\
\hline No cumplen porque el sistema no los deja cumplir & 11,5 \\
\hline No cumplen porque mienten para ganar las elecciones & 64,7 \\
\hline Ninguna de las anteriores & 1,7
\end{tabular}

Nota: $\mathrm{n}=19.279$.

Fuente: Pregunta P25U de la Sección Propietaria del PNUD en Latinobarómetro 2002.

mía; la economía tuvo como tema casi excluyente la cuestión de sus equilibrios y las reformas estructurales supuestamente necesarias para lograrlos; y, finalmente, la globalización fue vista ya sea como el origen de males inevitables o como fuente de beneficios inmensos, poniendo incluso en duda el sentido de la continuidad de los Estados nacionales en un mundo que marchaba hacia "la aldea global".

Como dijimos, esos debates eran, en su momento, imprescindibles. Ahora son insuficientes. El desarrollo de la democracia es mucho más que la perfección de su sistema electoral.

Lacrisis dela política se expresa tanto en la baja credibilidad y prestigio de los partidos como en la poca eficacia de los gobiernos para abordar las cuestiones centrales que se detectan como dé ficit de ciudadanía, en particular los referidos a los derechos civiles y sociales. Ambas dimensiones dela crisis dela política-instituciones y contenidos- son vitales, dado que es la política la que debe formular opciones, representar a los ciudadanos y generar los nexos entre Estado y sociedad para gestar poder democrático.

Gran partedelas cuestiones que constituyen

\section{El desarrollo de la democra cia es mucho más que la perfección de su sistema electoral.}

carencias centrales se ubican en el plano de la estatalidad - la que entendemos como la capacidad del Estado para cumplir con sus funciones y objetivos independientemente del tamaño y la forma de organización de sus burocracias-. En losúltimos tiempos, el tema del Estado se ha reducido, a la hora de la discusión y las propuestas públicas, a cuestiones relacionadas con su capacidad burocrática y su estructura de gastos y recursos, es decir, la cuestión del déficit fiscal. Ha quedado fuera de la discusión la existencia deEstados con legalidades truncas, incapaces de monopolizar la coerción, carentes del poder ne cesario para llevar a la práctica el mandato electoral y que, en general, han encontrado serias dificultades para cumplir su crucial responsabilidad de construir democracia.11

La cuestión económica tienecaminos y diversidad de opciones que el pensamiento único ig-

11 Desde la perspectiva de George Soros, esta cuestión se expresa así: “El capitalismo crea riqueza, pero no se puede depender de él para garantizar la libertad, la democracia y el Estado de derecho. Las empresas están motivadas por el beneficio, no tienen por objetivo salvaguardar los principios universales. Hasta la protección del mercado requiere mucho más que el beneficio propio: los participantes en el mercado compiten para ganar, y si pudieran eliminarían a la competencia" (Soros, 2001). 
RECUADRO 8

\section{Ciudadanía y comunidad de ciudadanos}

La ciudadanía caracteriza una situación de inclusión en una "comunidad de ciudadanos". Pero esta última no puede ser definida simplemente por el derecho de voto y la garantía de ver protegido cierto número de libertades individuales. La ciudadanía se caracteriza también por la existencia de un mundo común. Tiene necesariamente en otros términos una dimensión societal. Tocqueville fue el primero en subrayar que la democracia caracterizaba una forma de sociedad y no sólo un conjunto de instituciones y de principios políticos.

Pierre Rosanvallon, texto elaborado para el PRODDAL, 2002.

nora, y la relación entre economía y democracia es presentada en el debate actual a partir del impacto de la segunda sobre la primera. De este modo, la democracia ocupa en el análisis una posición subordinada a los objetivos del crecimiento económico. Es preciso invertir los términos y preguntarnos qué economía es necesaria para fortalecer a la democracia. De ese modo podremos debatir tanto el papel de la economía en el desarrollo de la democracia, a partir de su impacto en los derechos sociales, como la capacidad de la democracia para influir sobre la organización de la economía y hacer posible la diversidad de opciones que ofrece la economía de mercado.

Finalmente, aunque no debe ser ignorada en sus importantes consecuencias, la globalización no debería conducir a conclusiones fatalistas. Los espacios de participación y decisión democráticas son esencialmente nacionales y si bien la globalización impone fuertes restricciones a la capacidad de acción de los Estados nacionales, lejos de caer en la impotencia es preciso centrar el debate sobre el modo de generar nuevos espacios de autonomía nacional a partir de los ámbitos regionales de cooperación e integración.

Para discutir, por lo tanto, las condiciones para el desarrollo de la democracia proponemos ampliar los contenidos de la agenda que ha sido dominante en los últimos tiempos. O bviamente, no es el objeto de este Informe proponer políticas nacionales; cada país tiene tiempos y situaciones diversos. Pero esas especificidades afectan el tipo de solución a aplicar en cada caso, no la relevancia de los problemas. Las diversas respuestas posibles a esos problemas no alteran la comunidad de los interrogantes que planteamos, entre ellos, y muy principalmente, la necesidad de elaborar una nueva agenda de reformas democráticas para América Latina.

Ahora bien, ¿de qué hablamos cuando nos referimos a la democracia? ¿A partir de qué marco conceptual planteamos la idea de desarrollo de la democracia? ¿Qué democracia tenemos los latinoamericanos? Y, finalmente, ¿qué agenda es necesario debatir para desarroIlar nuestras democracias y expandir nuestras ciudadanías?

\section{Fundamentos teóricos}

En este apartado se presentan al gunos delos conceptos, argumentos y cuestiones de debate que pertenecen al campo teórico del Informe,12 partiendo de la base de que la definición de los sentidos de la democracia también forma parte de las tareas que permiten transformarla y enriquecerla.

Cuando nos enfrentamos a la complejidad de las cuestiones que están en juego, cuando observamos nuevas realidades que no pueden ser abordadas por la mera intuición, tomamos conciencia de las carencias teóricas que tenemos. Por cierto, no estamos afirmando que la

12 Los datos estadísticos y de opinión pública que se presentan en este Informe están originados en un marco conceptual. Sin ese marco no podríamos haber identificado los indicadores relevantes para dar cuenta del desarrollo de la democracia. Los indicadores y la encuesta que se utilizan en este Informe son el resultado de una determinada concepción de la democracia. Esa teoría justifica y explica el método adoptado en su elaboración. 
práctica de la política sea el corolario de una teoría apropiada; sólo insistimos que se requieren serios y fundados conocimientos y debates para que la práctica política pueda orientar exitosamente el futuro de nuestros países. La teoría no es una manera de recluirse en un mundo ajeno a la práctica, sirve para entender cómo estamos, hacia dónde vamos y qué sería prioritario transformar.

La teoría política y, dentro de ella, la teoría democrática han hecho contribuciones sustantivas al análisis de nuestra realidad. Sin embargo, es probable que no haya un ejemplo más elocuente de la lejanía entre teoría y práctica como el que ofreceel mundo dela política. Por un lado, frecuentemente se discuten ideas sobre el complejo desarrollo político delas sociedadesy, por el otro - casi como si esas ideas pertenecieran a otro universo-, se practica la política.

La manera en que a veces el análisis teórico es desvalorizado, más que un afán por volcarse inmediatamente a cosas prácticas puede ser un modo de evitar el cotejo de las decisiones con las razones que las fundan o una forma de encubrir las verdaderas motivaciones de quienes ejercen el poder, público o privado. La desvalorización de la teoría suele ser un recurso que allana el camino al pensamiento mágico, ese recurso a ideas que, por su atracción, parecen no requerir demostración.

Este Informe se propone fundar en razones sistemáticas y rigurosas sus descripciones, análisisy propuestas. No es su intención abarcar la totalidad del debate sobre la democracia, sino fundamentar las afirmaciones y propuestas que contiene.

\section{La idea de democracia}

Se parte aquí de una idea básica y general de democracia, pero no seutiliza una definición taxativa y cerrada, sino que más bien se trata de ver en las distintas esferas de la vida social qué es lo propio en ellas que afecta y es afectado por la democracia. En estesentido, la democracia es un resultado de la historia de las sociedades y no sólo de sí misma.

La democracia es el resultado de una intensa y denodada experiencia social e histórica
RECUADRO 9

\section{La democracia: una construcción permanente}

Debemos recordar que tras los prometedores comienzos la democratización no evolucionó siguiendo un camino ascendente hasta nuestros días. Hubo subidas y recaídas, movimientos de resistencia, rebeliones, guerras civiles, revoluciones. Durante algunos siglos [...] [se] invirtió alguno de los avances anteriores. Volviendo la vista atrás sobre el ascenso y caída de la democracia, está claro que no podemos contar con que las fuerzas sociales aseguren que la democracia siga siempre avanzando. [... La democracia, tal parece, es un tanto incierta. Pero sus posibilidades dependen también de lo que nosotros hagamos. Incluso, aunque no podamos contar con impulsos benignos que la favorezcan, no somos meras víctimas de fuerzas ciegas sobre las que no tenemos ningún control. Con una adecuada comprensión de lo que exige la democracia y la voluntad de satisfacer sus requerimientos, podemos actuar para satisfacer las ideas y prácticas democráticas y, aun más, avanzar en ellas.

Robert Dahl, 1999, pp. 32-33.

que se construye día a día en las realizaciones y frustraciones, acciones y omisiones, quehaceres, intercambios y aspiraciones de quienes son sus protagonistas: ciudadanos, grupos sociales y comunidades que luchan por sus derechos y edifican de manera incesante su vida en común.

La democracia implica una forma de concebir al ser humano y garantizar los derechos individuales. En consecuencia, ella contiene un conjunto de principios, reglas e instituciones que organizan las relaciones sociales, los procedimientos para elegir gobiernos y los mecanismos para controlar su ejercicio. También es el modo como la sociedad concibe y pretende hacer funcionar a su Estado.

Pero eso no es todo. La democracia estambién un modo de concebir y resguardar la memoria colectiva y deacoger, celebrándolas, diversasidentidades de comunidades locales y regionales. 
RECUADRO 10

\section{Democracia e igualdad}

Ninguna teoría de la democracia que omite dar a la idea igualitaria un lugar central puede posiblemente arrojar una representación fehaciente del peso extraordinario de la democracia en la imaginación política moderna. [...] Debemos tener en mente que históricamente uno de los objetivos principales de los movimientos democráticos ha sido buscar compensación en la esfera política para los efectos de las desigualdades en la economía y en la sociedad.

C. R. Beitz, 1989, pp. xi, xvi.

\section{Democracia y soberanía}

El ejercicio de la democracia es una afirmación de la soberanía de una nación: se requiere de un marco democrático que le devuelva a la noción mermada de soberanía su sentido político prístino: no hay nación soberana en el concierto internacional si no es soberana en el orden nacional, es decir, si no respeta los derechos políticos y culturales de la población concebida no como simple número sino como compleja calidad, no como cantidad de habitantes sino como calidad de ciudadanos.

Carlos Fuentes, 1998, p. 9.

La democracia es cada una de estas definiciones y tareas, así como las variadas maneras en que ellas se encarnan en reglas e instituciones.

Sostenemos que la democracia es más que un conjunto de condiciones para elegir y ser electo, al que llamamos democracia electoral. También es, como lo hemos señalado, una manera de organizar la sociedad con el objeto de asegurar y expandir los derechos, de los cuales son portadores los individuos. Este segundo aspecto es lo que define la democracia de ciudadanía.
Estos dos rostros de la democracia están íntimamente vinculados y el grado de desarrollo deambos incide de manera sustantiva en su calidad y sustentabilidad.

La distinción entre democracia electoral y de ciudadanía contiene cuatro argumentos básicos que guían este Informe:

1. La democracia encuentra su fundamento filosófico y normativo en una concepción del ser humano como sujeto portador de derechos. En ella se distingue la idea del ser humano como un ser autónomo, razonable y responsable. Esta concepción subyace a toda noción de ciudadanía, incluso de la ciudadanía política.

2. La democracia es una forma de organización de la sociedad que garantiza el ejercicio y promueve la expansión de la ciudadanía; establece reglas para las relaciones políticas y para la organización y el ejercicio del poder que son consistentes con la ya mencionada concepción del ser humano.

3. Las eleccioneslibres, competitivas einstitucionalizadas, y las reglas y los procedimientos para la formación y el ejercicio del gobierno (conjunto al quellamamos democracia electoral) son componentes esenciales de la democracia y constituyen su esfera básica. Pero ni en sus alcances ni en sus posibilidades de realización la democracia se agota en esta esfera.

4. El desarrollo de la democracia en América Latina constituye una experiencia histórica única, caracterizada por especificidadesíntimamente relacionadas con los procesos de construcción de la Nación y de las sociedades latinoamericanas, incluyendo sus diversas identidades culturales.

\section{Los déficit de la sociedad como déficit de la democracia}

Un corolario relevante de esta manera de entender la democracia y su desarrollo es observar los déficit sociales como carencias dela democracia. Así, la pobreza y la desigualdad no son sólo 
"problemas sociales", sino también déficit democráticos. Por lo tanto, resolverlos es atacar una de las cuestiones básicas de la sustentabilidad democrática. De donde se derivará en nuestro análisis una crítica a la peligrosa escisión entre "política económica", "política social” y fortalecimiento de la democracia, los quea menudo son tratados como compartimentos estancos. El principal corolario de esta crítica es que no debe haber una agenda económica social divorciada de la agenda democrática.

La democracia apela como fundamento de los mecanismos e instituciones que contiene a una cierta visión de la condición humana y su desarrollo: todos los seres humanos nacen libres eiguales en dignidad y derechos, dotados de razón y conciencia. 13

Los principios que de allí emanan se proyectan al conjunto de la sociedad. La escuela, la familia, la economía y, en general, todas las formas de organizar la sociedad más allá de las instituciones propias de la democracia son alcanzadas por los principiosinherentes a ésta. El desarrollo de la democracia tiene que ver con la intensidad con que estos principios logran impregnar los distintos campos de la vida social. Por eso es que la democracia no aparece sólo en su dimensión institucional; es también una promesa civilizadora que instala la expectativa de expansión dela libertad, la igualdad, la justicia y el progreso.

\section{Alcances de la democracia en el Informe}

En la perspectiva que hemos adoptado, la democracia supone un conjunto de características esenciales que definen sus condiciones necesarias. Estas características rara vez existen plenamente, más bien se combinan en diversos grados y alcances. Importa señalar que el análisis del grado de realización de cada uno deestos elementos es ineludible a la hora de evaluar el grado de desarrollo de una democracia. ${ }^{14}$ La de mocracia incluye como uno de sus elementos centrales una delegación libre de la soberanía popular en un gobierno, para ejecutar la opción mayoritaria de la ciudadanía. Para que este procedimiento sea efectivo se requiere el conjunto de condiciones que describimosa continuación.

1. La democracia presupone como condición necesaria la existencia de un régimen político que se desenvuelve en un Estado y una $\mathrm{Na}$ ción quedelimitan una población, un territorio y el poder que se ejerce en su interior. Ese régimen contiene un conjunto de instituciones y procedimientos que definen las reglas y los canales de acceso a las principales posiciones del Estado, el ejercicio del poder estatal y el proceso de toma de decisiones públicas. En la ciencia política contemporánea hay consenso sobre las condiciones que deben cumplirse para que el acceso al gobierno de un Estado pueda considerarse democrático: 15

- Autoridades públicas electas.

- Elecciones libres y limpias.

- Sufragio universal.

- Derecho a competir por los cargos públicos.

- Libertad de expresión.

- Acceso a información alternativa.

- Libertad de asociación.

- Respeto por la extensión de los mandatos, según plazos constitucionalmenteestablecidos.

- Un territorio que define claramenteel de mos votante.

- La expectativa generalizada dequeel proceso electoral y las libertades contextuales se mantendrán en un futuro indefinido.

2. La democracia implica el acceso sustantivo al poder del Estado, es decir, que no haya en el territorio otra organización (formal o no) con poder igual o superior al mismo Estado. Esto define la soberanía interior, atributo que implica: el monopolio del uso efectivo y

13 Declaración Universal de los Derechos Humanos de las Naciones Unidas (ONU, 1948).

14 Estos rasgos que se resumen a continuación fueron presentados y discutidos con un amplio conjunto de personalidades académicas.

15 Según surgen de los aportes de Robert Dahl y Guillermo O'D onnell. 


\section{Una definición de poliarquía}

Poliarquía deriva de las palabras griegas que significan "muchos" y "gobierno", se distingue así el "gobierno de los muchos" del gobierno de uno, o monarquía, o del gobierno de los pocos, aristocracia u oligarquía. [... Una democracia poliárquica es un sistema político dotado de las instituciones democráticas [descriptas]. La democracia poliárquica es, pues, distinta de la democracia representativa con sufragio restringido, como la del siglo XIX. Es también diferente de las democracias y repúblicas más antiguas, que no sólo tenían sufragio restringido sino que carecían de muchas de las otras características cruciales de las democracias poliárquicas, tales como partidos políticos, derecho a formar organizaciones políticas para influir en u oponerse a los gobiernos existentes, grupos de interés organizados, etc. Es también distinta de las prácticas democráticas propias de unidades tan pequeñas que permiten el establecimiento de una asamblea directa de sus miembros y su decisión (o recomendación) directa de las políticas o leyes.

Robert Dahl, 1987, p. 105. legítimo de la fuerza; la capacidad para impartir justicia de modo efectivo y definitivo, normar las conductas de los individuosy organizaciones, procurarselos medios-económicos y organizativos- necesarios para el cumplimiento desus fines, y ejecutar las políticas decididas. En una democracia, la capacidad de soberanía del Estado deriva de la renovada legitimidad otorgada por los miembros de la sociedad.

Este acceso al poder efectivo estatal requiere también una cierta manera de interrelación con los otros Estados soberanos, de modo que los objetivos planteados por la sociedad en ejercicio desus opciones no estén sustancialmente alterados por imposiciones de otros poderes fuera del territorio, que no sean la consecuencia de delegaciones libres de soberanía a órganos multilaterales.

3. La democracia también implica la vigencia del estado de derecho. Esto supone la independencia de los poderes y un sistema legal que es democrático en tres sentidos: protege las libertades políticas y las garantías de la democracia política, protege los derechos civiles del conjunto de la población y establece redes de responsabilidad y rendición de cuentas por las cuales los funcionarios públicos, incluyendo los cargos más al tos del Estado, estén sujetos a controles apropiados sobre la legalidad de sus actos. Supone ade- más el sometimiento de la acción del Estado y sus poderes a las normas emanadas de poderes designados democráticamente.

4. La democracia supone una cierta forma de organizar el poder en la sociedad. En democracia, las relaciones de poder, entre el Estado y los ciudadanos, los ciudadanos entre sí y entre el Estado, las organizaciones y los ciudadanos, deben estar enmarcadas en el ejercicio de los derechos políticos, civiles y sociales de tal manera quela imposición de una conducta (imperio del poder) no vulnere esos derechos. Lo sustantivo de una democracia es que el poder - sea público o privado- esté organizado de modo que no sólo no vulnerelos derechos, sino que también sea un instrumento central para su expansión. El juicio acerca de esa relación entre poder y derechos debe ser objetivo, esto es, definido por la propia mayoría de los miembros de una sociedad.

5. La democracia requiere que las opciones ciudadanasaborden las cuestiones sustantivas. Las reglas y condiciones de competencia buscan asegurar una elección libre entre candidatosy programas de gobierno. Ellos determinan el rango efectivo deopciones que poseeel ciudadano para elegir. Estetemario electoral o agenda pública excedeal régimen pero es sustantivo a la democracia, parte de su organización. 
Supuesta la ausencia de limitaciones sobrela capacidad de el egir, nos interesa indagar cuál es el rango efectivo de opciones y cómo se construye. De esto trata la cuestión de la agenda pública. Ella contiene, nada menos, queel temario de los problemas que una sociedad debe resolver y los métodos para encararlos. La agenda identifica, para el ciudadano, las metas deseables de un gobierno y el camino para alcanzarlas.

¿Elegir sobre qué y entre qué? ¿Esa elección contiene todas las opciones necesarias, reales, para garantizar y expandir la ciudadanía en un momento dado? ¿0 esas opciones, sometidas a las elecciones, son sólo una parte de lo necesario para el desarrollo de la ciudadanía y excluyen otras esenciales?

Si éste fuera el caso, podríamos tener reglas de competencia perfectas, condiciones óptimas para la elección, pero temas de elección sesgados o limitados. En esas condiciones puede que lo sustantivo esté fuera de la elección y lo marginal centre el debate de la decisión electoral. El régimen tendería, entonces, a girar en el vacío, a separarse del desarrollo de la ciudadanía, a tornarse irrelevante.

Por lo tanto, la agenda pública, entendida como el rango efectivo de opciones del que disponen los ciudadanos de acuerdo con las referencias anotadas más arriba, constituye un componente central dela organización democrática. Esa agenda contiene el conjunto de cuestiones prioritarias alrededor del cual se centran el debate público, la definición y las opciones de políticas de la opinión pública.

La agenda debería contener los desafíos centrales para los intereses individuales, de las organizaciones y el conjunto de la sociedad. Lo que se puede elegir está dentro de la agenda. La agenda define el campo de la opción.

Pero esta agenda no se construye idealmente, con independencia de las relaciones de poder. ¿Seelige la política económica? ¿Sedebaten las reformas fiscales? ¿Están claras las opciones para combatir la pobreza y la desigualdad?Y si tales temas estuvieran fuera de la oferta electo- ral, de su agenda, ¿cómo se vincula la democracia con las necesidades reales de expansión de la ciudadanía social?

Esta cuestión, lo que se debate en una socie dad y en una región, es uno de los intereses centrales de esteInforme. Promover un debate sobre nuestra agenda, para saber si ella contiene nuestros problemas, o si hay cuestiones omitidas, diluidas, ignoradas 0 , sencillamente, prohibidas es la primera condición para utilizar nuestras capacidades para sortear los peligros y desarrollar nuestra democracia. Discutir los al cances del debate público, sus formas de abordarlo y recuperar lo que se escamotea e ignora es una condición necesaria de las reformas democráticas que requiere nuestra región. La relevancia o no del contenido de la agenda pública es determinante para nuestro futuro democrático.

\section{Democracia, régimen político y Estado}

En un régimen democrático, el acceso a las principales posiciones gubernamentales (con la excepción del Poder Judicial, las Fuerzas Armadas y eventualmente los bancos centrales) se logra mediante elecciones limpias e institucionalizadas. Por elecciones limpias se entiende aquí las que son competitivas, libres, igualitarias, decisivas e inclusivas, y en las cuales se respetan las libertades políticas. ${ }^{16}$ Estas libertades son esenciales no sólo durante las elecciones sino también para los períodos que median entre ellas. Delo contrario, el gobierno de turno podría fácilmente manipular o cancelar elecciones futuras. Los individuos que gozan de estas libertades están habilitados y protegidos para el ejercicio de sus derechos de participación. Esto significa que a todos los ciudadanos les es asignado el derecho de participar en el Estado y el gobierno, no sólo mediante las elecciones sino también mediante la toma de decisiones, ya sea de manera conjunta o individual, vinculantes en todo el territorio. Por su parte, el requisito de inclusividad de las elecciones bajo un régimen democrático indica que todos los adultos que satisfacen el criterio de

16 De acuerdo con Dahl (1989 y 1999), las libertades políticas relevantes son las de expresión, asociación y acceso a información de carácter pluralista. Para una lista detallada ver Diamond (1999). 
ciudadanía tienen derecho de participar en dichas elecciones. 17

Además, las el ecciones en un régimen democrático están institucionalizadas: la gran mayoría de los ciudadanos da por descontado que, en el futuro, las elecciones limpias continuarán siendo realizadas en las fechas $u$ ocasiones legalmente preestablecidas.

Existen cuatro aspectos centrales de la democracia: 1) elecciones limpias e institucionalizadas, 2) inclusividad, 3) un sistema legal que sanciona y respalda los derechos y las libertades políticas, y 4) un sistema legal que prescribe que ninguna persona 0 institución retenga el arbitrio de eliminar o suspender los efectos de la ley o evadirse de los alcances de la misma. Vemos entonces que, mientras los dos primeros aspectos corresponden al régimen, los dosúltimos corresponden al Estado. El Estado no es un elemento ajeno o extrínseco a la democracia, es uno de sus componentes intrínsecos. Por eso, según el esquema conceptual que aquí proponemos, es importante indagar acerca de la democraticidad del Estado, no sólo la del régimen.

La relación entre régimen democrático y Estado se fundamenta en la existencia de un sistema legal estatal quesecaracteriza por dos rasgos: primero, sanciona y respalda los derechos y libertades implicados por el régimen democrático; segundo, coloca bajo ese sistema legal a la totalidad delas instituciones y losfuncionarios del Estado. Bajo este prisma se organiza el Estado según el principio dela división, interdependencia y control de sus poderes, la existencia de un Poder Judicial independiente, la supremacía del poder civil sobre el militar y la responsabilidad de los gobernantes frente a la ciudadanía.

Un aspecto crucial del sistema legal es su efectividad, el grado en que el Estado realmente organiza relaciones sociales. En un sistema legal democrático, ninguna institución estatal o funcionario debería sustraerseal control legal de sus acciones. En una dimensión territorial se supone que el sistema legal se extiende homogéneamente a lo largo del espacio delimitado por el

RECUADRO 13

\section{Democracia y responsabilidad de los gobernantes}

En una democracia, se espera que los gobernantes estén sometidos a tres tipos de rendición de cuentas18: a) la "vertical electoral", que resulta de las elecciones limpias e institucionalizadas, a través de las cuales los ciudadanos pueden cambiar el partido y funcionarios de gobierno; b) otro tipo de rendición de cuentas "vertical, de tipo societal", es ejercida por individuos o grupos con el objetivo de movilizar al sistema legal para plantear demandas al Estado y al gobierno con el fin de prevenir, compensar o condenar acciones (o inacciones) presumiblemente ilegales perpetradas por funcionarios públicos; c) un tercer tipo de rendición de cuentas, "horizontal", se practica cuando algunas instituciones debidamente autorizadas del Estado actúan para prevenir, indemnizar o sancionar acciones o inacciones presumiblemente ilegales de otras instituciones 0 funcionarios estatales.
Nótese, sin embargo, que hay una diferencia importante entre estos tipos de rendición de cuentas. La vertical-electoral debe existir por definición misma del régimen democrático; sin ella ese régimen simplemente no existiría. En cambio, el grado y la efectividad de la rendición de cuentas societal y de la horizontal son variables entre casos y en el tiempo. Estas variaciones son relevantes para evaluar el desarrollo de la democracia; por ejemplo, la inexistencia de una sociedad vigorosa y autónoma, o la imposibilidad o falta de voluntad de ciertas instituciones del Estado para ejercer su autoridad sobre otras instituciones estatales son indicadores de una democracia de escaso desarrollo.

Guillermo O'Donnell, texto elaborado para el PRODDAL, 2002c.

17 La inclusividad es un logro bastante reciente de los trabajadores urbanos, los campesinos, las mujeres y varios tipos de minorías y sectores discriminados.

18 Por este concepto se entiende el equivalente a la expresión del inglés accountability. 
Estado. En igual sentido, se espera queel sistema jurídico tratelos casos similares de la misma manera, independientemente de consideraciones de clase, género, etnia u otros atributos de los actores respectivos. En todas estas dimensiones, el sistema legal presupone un Estado eficaz, 19 lo cual no depende sólo de una legislación apropiada sino también de una red de instituciones estatales que operan para garantizar el efectivo imperio de un sistema legal democrático.

La eficacia del sistema legal depende del entrelazamiento de sus reglas con una red de instituciones que, en democracia, deben actuar con propósitos y resultados consistentes con un Estado democrático de derecho.

\section{Los ciudadanos, fuente y justificación \\ de la autoridad del Estado democrático}

En democracia, el sistema legal, comenzando por sus más al tas reglas constitucionales, establece que los ciudadanos, al votar en elecciones limpias e institucionalizadas, son la fuente dela autoridad queejercen sobre ellos el Estado y el gobierno. Los ciudadanos no son sólo portadores de derechos y obligaciones; ellos son también la fuente y justificación de la pretensión de mando y autoridad que el Estado y el gobierno invocan cuando toman decisiones colectivamente vinculantes.

Ésta es otra característica específica de la democracia; todos los otros sistemas políticos fundamentan el derecho a gobernar en fuentes distintas de la soberanía popular expresada en elecciones limpias e institucionalizadas.

De lo dicho se desprende que un individuo no es, y nunca debería ser tratado como un súbdito, un suplicante de la buena voluntad del gobierno y el Estado. Este individuo - portador de un conjunto de derechos civiles, sociales y políticos- tiene pretensión legalmente sustentada de ser tratado con plena consideración y respeto. ${ }^{20}$ Asimismo, ese trato debe estar basado en la implementación de las leyes y regulaciones que son preexistentes, claras y discernibles para todos los ciudadanos, ${ }^{21}$ y sancionadas de manera concordante con los procedimientos democráticos. En la medida que las instituciones estatales reconocen estos derechos, ellas pueden ser consideradas más o menos democráticas, o consistentes con las obligaciones impuestas a ellas por la ciudadanía.

En verdad, este aspecto de las relaciones directas y cotidianas de los ciudadanos con el Estado es uno de los más problemáticos de la democracia en nuestra región. En relación con las elecciones limpias y, normalmente, con el ejercicio de los derechos políticos, los ciudadanos son colocados en un nivel de igualdad genérica. En cambio, al tratar con burocracias estatales, los ciudadanos están frecuentemente colocados en situaciones de aguda desigualdad de facto. Suelen enfrentar burocracias que actúan sobrela base de reglas formales einformales-que no son transparentes ni fácilmente entendibles- y que toman decisiones (o las omiten) con consecuencias importantes para los ciudadanos. Éste es un problema en todas partes, pero es mucho más serio y sistemático en sociedades castigadas por la pobreza y la desigualdad. Estos males expresan y cultivan el autoritarismo social, 22 y repercuten en la manera descomedida con que las burocracias estatales a veces tratan a muchos ciudadanos, más aún a inmigrantes y extranjeros. Aunque sela sueleignorar, ésta es otra dimensión crucial dela de-

19 O'D onnell, 2000, 2002a.

20 De acuerdo con este punto, Dworkin afirma que “una demanda particular de moralidad política [... ] requiere de los gobiernos hablar con una voz, a actuar de manera coherente y con principios hacia todos sus ciudadanos, [y] extender a todos los estándares de justicia sustantiva o de equidad que usa para algunos".

21 Aun en situaciones en donde esta desigualdad es lo más aguda posible (como bajo encarcelamiento), permanecela obligación moral de respetar la agencia. Hoy en día, ésta es también una obligación legal, aunque sea muchas veces ignorada. 22 Aristóteles (1968, p. 181) sabía esto: "Aquellos que disfrutan de demasiadas ventajas - fuerza, riqueza, conexiones, etc.- no están dispuestos a obedecer [el derecho] y son ignorantes de cómo obedecer". 
Los ciuda da nos no son sólo

porta dores de derechos y

obliga ciones; ellos son ta mbién la

fuente y justifica ción de la

pretensión de mando y a utoridad

que el Estado y el gobierno

invocan cua ndo toman decisiones

colectiva mente vincula ntes.

mocracia: el grado en que las instituciones estatales efectivamente respetan los derechos de todos los habitantes, ciudadanos o no.

\section{El ciudadano, sujeto de la democracia}

La democracia reconoce en cada individuo una persona moral y legal, portadora de derechos y responsable de cómo ejercita tales derechos y sus obligaciones correlativas. En tal sentido, concibeal individuo como un ser dotado de la capacidad para elegir entre opciones diversas, asumiendo responsablemente las consecuencias de tales elecciones, es decir, como un ser autónomo, razonable y responsable. ${ }^{23}$ Esta concepción del ser humano no sólo es filosófica y moral, también es legal: considera al individuo como portador de derechos subjetivos que son sancionados y garantizados por el sistema legal.

La potencialidad inherente a esta concepción del individuo, cuyos derechos no son derivados de la posición que ocupa en la jerarquía social sino de su capacidad de comprometerse, voluntaria y responsablemente, a cumplir las obligaciones que libremente asume - con su correlato del derecho a demandar el cumplimiento delas obligaciones contraídas-, desencadenó consecuencias trascendentales para las luchas por la expansión de la ciudadanía.

Entendemos por ciudadanía un tipo deigualdad básica asociada al concepto de pertenencia a una comunidad, que en términos modernos es equivalente a los derechos y obligaciones de los que todos los individuos están dotados en virtud de su pertenencia a un Estado nacional. 24 Destacamos varios atributos de la ciudadanía así definida:

a. carácter expansivo, basado en la concepción, moral y legalmenterespaldada, del ser humano como responsable, razonabley autónomo;

b. condición legal, de estatus que se reconoceal individuo como portador de derechos legalmente sancionados y respaldados;

c. sentido social o intersubjetivo que suele resultar de la pertenencia a un espacio social común;25

d. carácter igualitario, sustentado en el reconocimiento universal de los derechos y deberes de todos los miembros de una sociedad democráticamente organizada;

e. inclusividad, ligada al atributo de nacionalidad que implica la pertenencia de los individuos a los Estados nacionales;

f. carácter dinámico, contingente y abierto, en tanto producto y condición de las luchas his-

23 Según el concepto desarrollado por O’Donnell (2002c), la democracia considera al ser humano como un agente. “Un agente es un ser dotado de razón práctica: usa su capacidad cognitiva y motivacional para elegir opciones que son razonables en términos de su situación y sus objetivos, para las cuales, excepto prueba concluyente en contrario, es considerado ser el mejor juez. Esta capacidad hace del agente un ser moral, en el sentido que normalmente se sentirá, y será considerado por otros seres rel evantes, como responsable por la elección de sus opciones, al menos por las consecuencias directas derivadas de tales opciones."

24 T. H. M arshall (1965) señala que “la ciudadanía moderna es, por definición, nacional”.

25 Este aspecto de la ciudadanía remite a una concepción de la política como espacio común, en el cual nos reconocemos como participantes de una comunidad política dirigida a la construcción y realización intersubjetiva de un bien público. Esta concepción ha sido ampliamente desarrollada por la tradición del republicanismo cívico, cuyos orígenes se remontan al pensamiento griego y romano, y que adquiere una renovada vigencia en los debates contemporáneos entre liberales y comunitaristas. 
tóricas por enriquecer, o menguar, su contenido y aumentar, o disminuir, el número de aquellos a los que se reconoce.

Podemos identificar tres conjuntos de derechos de ciudadanía, 26 cada uno de ellos referido a un área diferente de la sociedad: civiles, políticos y sociales. 27

Con bastante anticipación a la expansión universal de la ciudadanía política, la formulación de una visión legal y moral del individuo como portador de derechos subjetivos contó con una larga trayectoria de elaboración a través de diversas doctrinas - religiosas, éticas, legales, filosóficas-.28 Esta concepción del ser humano fue proyectada al ámbito político por los grandes teóricos del liberalismo 29 y posteriormente se transmitió a las dos grandes constituciones modernas, las de los Estados Unidos y Francia.

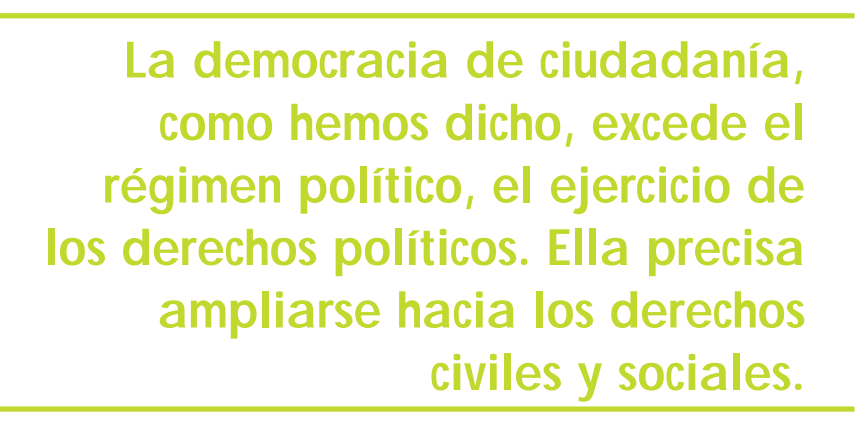

La ciudadanía va más allá de los derechos

La democracia de ciudadanía, como hemos dicho, excede el régimen político, el ejercicio de los derechos políticos. Ella precisa ampliarse hacia los derechos civiles y sociales. Éste es un punto central de nuestro análisis, del cual sederiva la justificación de concebir a la democracia abarcando un campo más amplio y complejo. Como anotamos, las consecuencias prácticas de sostener esta tesis son considerables.

26 Esta enunciación no implica que ignoremos que al gunas discusiones actuales proponen agregar otras "generaciones" de derechos a los que aquí enunciamos. Entre ellas, dadas las circunstancias de América Latina, especialmente las relacionadas con sus pueblos indígenas, nos parecen particularmente importantes las propuestas de agregar un área específica de derechos culturales. Sin embargo, para facilitar esta primera exposición de un tema muy complejo, hemos preferido mantener la clasificación de derechos tradicional. Esto no obsta para queel tema de los pueblos indígenas nos ocupe en otras partes de este Informe, ni que en futuras versiones del mismo revisemos la clasificación aquí utilizada.

27 “Comenzaré proponiendo una división de la ciudadanía en tres partes. [...] Llamaré a cada una de estas tres partes o elementos, civil, política y social. El elemento civil se compone de los derechos para la libertad individual: libertad de la persona, de expresión, de pensamiento y religión, derecho a la propiedad y a establecer contratos válidos y derechos a la justicia. Esteúltimo es deíndoledistinta de los restantes, porque se trata del derecho a defender y hacer valer el conjunto de los derechos de una persona en igualdad con los demás, mediante los debidos procedimientos le gales. Esto nos enseña que las instituciones directamente relacionadas con los derechos civiles son los tribunales de justicia. Por elemento político entiendo el derecho a participar en el ejercicio del poder político como miembro de un cuerpo investido de autoridad política o como el ector de sus miembros. Las instituciones correspondientes son el Parlamento y las juntas del gobierno local. El elemento social abarca todo el espectro, desde el derecho a la seguridad y a un mínimo de bienestar económico al de compartir plenamente la herencia social y vivir la vida de un ser civilizado conforme los estándares predominantes en la sociedad. Las instituciones directamente relacionadas son, en este caso, el sistema educativo y los servicios sociales." M arshall, 1965, pp. $22-23$.

28 "El reconocimiento institucionalizado (i.e. legalmente sancionado y respal dado, y dado ampliamente por descontado) del individuo como portador de derechos subjetivos recorrió un largo y complicado camino, cuyo origen se extiende históricamente hasta algunos sofistas y los estoicos y Cicerón, atraviesa la tradición del derecho romano y los legistas medievales, para luego ser refinado por los teóricos del derecho natural, y ser finalmente reapropiado y, por así decir, politizado, a pesar de sus diferencias en otros aspectos, por los grandes pensadores liberales - especialmente Hobbes, Locke y Kant-, así como también no-liberales como Espinoza y Rousseau". O'D onnell, 2000.

29 Pierre Rosanvallon (1992, p. 111) comenta que antes del advenimiento del liberalismo "esta visión de autonomía de la voluntad ciertamente ya había aparecido jurídicamente formulada en el derecho civil". Esto, a su vez, era parte de cambios en la misma concepción de moralidad; como Schneewind (1998, p. 27) apunta: "durante los siglos XVII y XVIII las concepciones establecidas de moralidad como obediencia comenzaron a ser fuertemente contestadas por concepciones emergentes de moralidad como auto-gobierno [... ] centradas en la creencia de que todos los individuos normales son igual mente capaces de vivir juntos en una moralidad auto-gobernada". 
Si los derechos propios del ser humano están basados en su capacidad en tanto ser moral, ¿por qué entonces atribuirlos sólo a ciertas esferas de la vida social y política? Ya que la autonomía responsable implica elegir, ¿qué opciones reales, o capacidades, serían razonablemente consistentes con la condición que la democracia le asigna al individuo? En otros términos, ¿cuáles son las condiciones reales del ejercicio de tales derechos?

Estas preguntas apuntan a uno de los argumentos centrales en el análisis que propone estel nforme: plantear la cuestión de las capacidades en la esfera política implica ir más allá de la atribución universal de los derechos de ciudadanía política, lleva a preguntarnos sobre las condiciones que pueden permitir o no el ejercicio efectivo de estos derechos.

Aunque, claro está, bajo diferentes condiciones históricas, en todos los países la respuesta a tales preguntas se desplegó en numerosas luchas por la progresiva expansión de los derechos políticos, civiles y sociales, 30 destacando, entre éstos, el derecho de sufragio hasta alcanzar su presente inclusividad. Esta historia se construyó a través de múltiples conflictos, al final de los cuales, los sectores sociales marginados fueron siendo incluidos en la democracia, esto es, obtuvieron finalmente la ciudadanía política. 31

En los países centrales, estos procesos provocaron inicialmentela expansión adicional de derechos en la esfera civil, en el doble sentido de una mayor especificación de derechos y de incorporación de otros nuevos, que no eran aún los derechos de participación propios de la democracia inclusiva, sino derechos civiles concernientes a las actividades sociales y económicas privadas. 32 En lo que respecta a estos derechos, se reconoció de maneras diversas que su ejercicio implica elección, y elección implica libertad para elegir entre las distintas alternativas quecada individuo tiene razones para valorar. Esto presupone la vigencia de un criterio de equidad: ha de existir un piso mínimo de igualdad entre los miembros de la sociedad que otorgue a todos un rango razonable de opciones para ejercer su capacidad de elección y su autonomía.

Por otro lado, también en los países centrales, el mencionado criterio de equidad fue muy importante para el surgimiento de los derechos sociales. 33 De nuevo, a lo largo de luchas frecuentemente arduas, diversos sectores que habían sido políticamente excluidos terminaron por aceptar la democracia política contra los beneficios del Estado de bienestar.

30 El proceso de progresiva expansión de derechos, que en los países centrales incluyó la extensión de la ciudadanía civil previa a la expansión de la ciudadanía política, aportó el trasfondo histórico de la idea central del liberalismo político: el gobierno y el Estado deben ser limitados y constitucionalmente regulados ya que ambos existen para, y en nombre de, individuos portadores de derechos subjetivos sancionados y respaldados por el mismo sistema legal que el Estado y el gobierno deben obedecer y del cual derivan su autoridad.

31 Ciudadanos políticos son aquellos quienes, dentro del territorio de un Estado que incluye un régimen democrático, cumplen con el criterio respectivo de nacionalidad. Asimismo, como derivación del régimen democrático, los ciudadanos políticos poseen dos tipos de derechos. Primero, libertades tales como las de asociación, expresión, movimiento, acceso a información pluralista y otras que, aunque en última instancia sean no definibles ex ante, conjuntamente hacen posible la realización de elecciones limpias, institucionalizadas y - hoy en día- inclusivas. El segundo tipo de derecho es de carácter participativo: elegir y eventualmente ser elegido o nombrado en cargos estatales. Los ciudadanos políticos, así entendidos, son el lado individual de un régimen democrático, y ninguno de ellos puede existir sin el otro. 32 Como apunta T. H. M arshall (1965, p. 18): "La historia de los derechos civiles en su período formativo es una de adición gradual de nuevos derechos a un estatus que ya existía y que ya pertenecía a todos los miembros adultos de la comunidad". Estos derechos civiles son, en su definición clásica de ciudadanía civil, "Ios derechos necesarios para la libertad individual-libertad personal, libertad de palabra, pensamiento y fe, el derecho a poseer propiedad y a terminar contratos válidos, y el derecho a la justicia" (ibid., pp. 10-11).

33 Una vez más de acuerdo con M arshall (1965, p. 72), los derechos sociales incluyen "desdeel derecho al bienestar y seguridad económica básica hasta el derecho a participar plenamente del patrimonio social y vivir la vida de un ser civilizado de acuerdo con el estándar prevalecienteen la sociedad". Para una discusión útil y detallada de M arshall con respecto a estos derechos, ver José N un, 2001. 
Por medio de la legislación social, y con avances y retrocesos en términos de las relaciones de poder respectivas, estas visiones de equidad fueron incorporadas a los sistemas legales. Los derechos sociales, sancionados por la legislación correspondiente, se aunaron al derecho civil para expresar que la sociedad, y especialmente el Estado, no deben ser indiferentes, al menos en casos en los que existe severa privación de capacidades relevantes.

En síntesis, en los países centrales la cuestión de las capacidades que habilitan ejercer la libertad de los individuos fue encarada en el ámbito delos derechos civiles y sociales. La idea que subyace a estas construcciones legales es la de equidad, que, en términos de capacidades disponibles y de ausencia de coerción perentoria, considera a los individuos como seres libres y responsablemente capaces de elegir. Esta visión quedó inscripta en la conciencia moral de la humanidad por la Declaración Francesa de Ios Derechos del Hombre y del Ciudadano. 34 Importa señalar que la mayoría de estos derechos no fueron simplemente otorgados, ellos fueron conquistados por medio de múltiples luchas Ilevadas adelante por sectores sociales oprimidos, explotados y discriminados.

Por estos complejos caminos - tan simplificadamente resumidos- fueron surgiendo, en los países centrales, las instituciones y prácticas que hoy reconocemos como democráticas. Pocos países de América Latina (Chile, Costa Rica y Uruguay) siguieron derroteros más o menos similares; en los demás, y aunque cada uno con sus significativas particularidades, nos encontramos con una situación muy diferente de la descripta: hemos hecho la enorme conquista de los derechos políticos pero aún falta mucho para lograr, para todos, una expansión satisfactoria de los derechos civiles y sociales. Esta circunstancia recalca aún más la enorme importancia que la democracia y sus derechos
La democra cia y sus derechos políticos tienen una enorme importancia para América Latina: ellos son, tienen que ser, el principal punto de apoyo para las luchas por el logro de los otros derechos.

políticos tienen para América Latina: ellos son, tienen que ser, el principal punto de apoyo para las luchas por el logro de los otros derechos, aún tan limitados y sesgadamente asignados en la práctica. Veremos ecos de estas afirmaciones en las secciones empíricas de este Informe.

\section{Estado y ciudadanía}

El Estado es un fenómeno histórico contemporáneo, en el queconfluyen las luchas por el poder y las luchas por los derechos. Su emergencia estuvo marcada por la expropiación, por parte de los gobernantes, de un centro de poder emergente, de los medios de coerción, de administración y de legalidad que habían sido hasta entonces controlados por otros actores. El surgimiento del Estado fue coetáneo a la expansión del capitalismo, queincluyó otra expropiación, la delos productores directos de los medios de producción. Ese surgimiento fuetambién coetáneo a la construcción política de la Nación como referente privilegiado de las decisiones estatales. Todos los Estados sostienen que su autoridad emana de ser Estados-para-la-Nación (o, en al gunos casos, para-el-pueblo), cuya misión es el logro del bien común -o el interés general- deuna Nación interpretada homogéneamente, a la que tanto gobernantes como gobernados supuestamente deben prioridad en sus lealtades.

Por Estado entendemos un conjunto de instituciones y relaciones sociales que cubre el

34 Podemos agregar: el Prólogo y la Primera Enmienda de la Constitución de los Estados Unidos, y más tarde, la Declaración Universal de los Derechos Humanos de las Naciones Unidas, el Acuerdo Internacional sobre Derechos Civiles y Políticos; el Acuerdo Internacional sobre Derechos Económicos, Sociales y Culturales; Ia Declaración de Derechos Humanos deViena, y muchos otros tratados y protocolos internacionales y regionales, todos ellos ratificados por un gran número de países. 
RECUADRO 14

\section{Estado liberal y Estado democrático}

El Estado liberal no es solamente el supuesto histórico sino también jurídico del Estado democrático. Estado liberal y Estado democrático son interdependientes en dos formas: 1) en la línea que va del liberalismo a la democracia, en el sentido de que son necesarias ciertas libertades para el correcto ejercicio del poder democrático; 2) en la línea opuesta, la que va de la democracia al liberalismo, en el sentido de que es indispensable el poder democrático para garantizar la existencia y la persistencia de las libertades fundamentales. En otras palabras: es improbable que un Estado no liberal pueda garantizar un correcto funcionamiento de la democracia y, por otra parte, es poco probable que un Estado no democrático sea capaz de garantizar las libertades fundamentales. La prueba histórica de esta interdependencia está en el hecho de que el Estado liberal y el Estado democrático cuando caen, caen juntos.

Norberto Bobbio, 1992, pp. 15-16. de estas dimensiones en cada caso es una variable históricamente contingente y, por cierto, problemática (O'D onnell, 2002b).

Por lo tanto, el Estado es:

a. Un ámbito en que se concentra y reconocela identidad colectiva para todos o casi todos los habitantes del territorio; invita al reconocimiento generalizado de un "nosotros", los miembros de la Nación.

b. Un sistema legal, una trama de reglas jurídicas que aspira a regular numerosas relaciones sociales. 35

c. Estambién un conjunto de entes burocráticos, una trama institucional y administrativa con responsabilidades que formalmente apuntan a lograr y proteger algún aspecto del bien común. Juntos, las burocracias del Estado y su legalidad pretenden generar, para los habitantes de su territorio, el gran bien público del orden y la previsibilidad delas relaciones sociales en las que los habitantes están inmersos. De esta forma, el Estado también pretende garantizar la continuidad histórica de la unidad territorial respectiva, usualmenteconcebida como una Nación.

Estos aspectos del Estado son tendencias que ninguno ha logrado completamente. En lo que respecta al Estado como foco de identidad colectiva, su pretensión de ser verdaderamente un Estado-para-la Nación puede ser escasamente verosímil para buena parte de su población. En cuanto al sistema legal, puede per se tener carencias y/o no extenderse efectivamente a diversas relaciones sociales y aun

35 Aun bajo un régimen democrático, la legal idad del Estado es una mezcla compleja de igualdad y desigualdad. Por una parte, esta legalidad sanciona los derechos universales de la ciudadanía política y civil. Por otra, esta misma legalidad sanciona dos tipos de desigualdades: una, la resultante de la organización jerárquica, legalmente regulada, delas instituciones burocráticas del Estado, así como del respaldo o autorización que el sistema legal otorga a otras instituciones privadas que también están jerárquicamente organizadas; otra, la desigualdad que resulta del hecho de que esta misma legalidad da forma a la condición capitalista de la sociedad. Esta forma sanciona y respalda un orden social que incluye de varias maneras la dominación social de quienes controlan los medios de producción así como también, y con creciente importancia en el mundo contemporáneo, el control de los circuitos del capital financiero. Esto nos lleva a considerar el papel crucial queel Estado juega, en sus varias dimensiones, en la corrección o reproducción de estas desigualdades, al mismo tiempo que promulga al gunas igualdades democráticas fundamentales. 
RECUADRO 15

\section{El Estado: presupuesto de la democracia}

El Estado -en tanto institución en la que se reconoce la identidad colectiva, no voluntaria, basada en un territorio, sustentada en última instancia por su capacidad de coerción, altamente burocratizada y densamente legalizada- es el asentamiento histórico y social de la democracia. Desde sus comienzos, la democracia política contemporánea implica una ciudadanía de doble faz: la ciudadanía (potencialmente) activa y participativa propia de la democracia, y la ciudadanía adscriptiva, que resulta del hecho de pertenecer a una nación.

Guillermo O'Donnell, “Acerca del Estado en América Latina contemporánea. Diez tesis para la discusión", documento elaborado para el PRODDAL, 2002c.

a vastas regiones. $Y$ en lo que respecta al Estado como conjunto de burocracias, su desempeño puede desviarse seriamente de cumplir las responsabilidades que le han sido formalmente asignadas.

Cualesquiera que fueren los logros y carencias en estas tres dimensiones, nos interesa recalcar que la democracia política surgió y ha continuado existiendo con y en el marco del Estado nacional. Fue debido a esta intersección que la "democracia nació con un sentido de nacionalidad. Las dos están fundamentalmenteinterrelacionadas y ninguna puede ser propiamente entendida independientemente de esta conexión". 36 Esto resalta la importancia que el Estado y la Nación han tenido y siguen teniendo para la existencia y el funcionamiento de la democracia. 37
En las dos últimas déca da s el Esta do se ha debilitado enormemente $y$, en algunas zonas dentro de nuestros países, virtua Imente se ha evaporado.

\section{Estatalidad trunca y fragilidad democrática}

Como ya vimos, por primera vez en dos siglos de vida independiente, prácticamente todos los países latinoamericanos satisfacen la definición mínima de democracia. Ellos comparten dos características: por un lado, celebran elecciones razonablementelimpias, institucionalizadas einclusivas, y sancionan los derechos participativos correlativos a tales elecciones; por otro, sostienen la vigencia de algunas libertades políticas fundamentales, especialmente de opinión, expresión, asociación, movimiento y acceso a medios de comunicación razonablemente libres y plurales, y afirman la supremacía de los poderes constitucionales por sobre los poderes fácticos.

Sin embargo, hay variaciones en cuanto al grado en que los atributos mencionados son efectivamentecumplidos, así como también hay variaciones significativas en cuanto al grado en que el Estado y su sistema legal cubren la totalidad del territorio de estos países. En estecontexto, la evaluación social sobre el rendimiento institucional y el grado de desarrollo de nuestras democracias es sumamente crítica. En general, la mirada de la opinión pública indica que las instituciones y los gobernantes no seestán desempeñando bien. Una razón deello esque, con frecuencia, losgobiernos elegidos democráticamente a veces parecen incapaces 0 no dispuestos a encarar cuestiones básicas de desarrollo, así como de desigualdad y deinseguridad. Creemos que a esta imagen subyace otro hecho que se ha descuidado demasiado en las recientes discusiones: el queen las dosúltimas

36 Greenfeld, 1992, p. 7.

37 M aíz, 2002a y Canovan, 1996. John Gray (2000, p. 123) concuerda: “El Estado-nacional soberano es la gran premisa no examinada del pensamiento liberal. [... ]La institución del Estado-nación es tácitamente presupuesta por los ideales liberales de la ciudadanía". 


\section{Estado y globalización}

La globalización económica de ninguna manera se traduce necesariamente en la disminución del poder del Estado; más bien, está transformando las condiciones bajo las cuales el poder del Estado es ejercido. [...] Hay muchas buenas razones para dudar de las bases empíricas y teóricas de algunas afirmaciones [sobre] que el Estado-nación está siendo eclipsado por los patrones contemporáneos de la globalización.[...] [Sin embargo, hay que reconocer que Ios] nuevos patrones de cambio regional y global están transformando el contexto de la acción política, creando un sistema de centros de poder múltiples y esferas de autoridad superpuestas -un orden pos-Westfalia-.

David Held, 1999, p. 441. décadas el Estado se ha debilitado enormemente y, en al gunaszonas dentro denuestros países, virtualmente se ha evaporado.

Crisis económicas, el ferviente antiestatismo de muchos de los programas de reformas económicas, la corrupción y el clientelismo ampliamente extendidos en no pocos países, son algunos de los factores que han confluido en generar un Estado anémico. Esta anemia también se manifiesta en el sistema legal. De hecho, muchos de nuestros países tienen un régimen democrático que coexiste con una legalidad intermitentey sesgada. Simplemente, la legalidad del Estado no seextiende a vastas regiones de nuestros países (y parte de susciudades), donde otros tipos de legalidad, básicamente variaciones de legalidad mafiosa, son los que operan en la práctica.

Asimismo, aun en regiones dondeel sistemalegal tienealcance, sueleser aplicado con sesgos discriminatorios contra varias minorías y también mayorías, tales como las mujeres, ciertas etnias y los pobres. Este sistema legal truncado genera lo que se ha llamado una ciudadanía de baja intensidad. 38 Todos tenemos los derechos políticos y las libertades quecorresponden al régimen democrá- tico; sin embargo, muchos carecen de derechossociales básicos. Asimismo, a estos sectores se les nie gan de hecho derechos civiles no menos básicos: no disfrutan deprotección contrala violencia policial y varias formas de violencia privada; no logran acceso igualitario y respetuoso a las burocracias del Estado, incluso losjuzgados; sus domicilios son allanados arbitrariamente, y, en general, están forzados a vivir una vida no sólo de pobreza sino también de recurrente humillación y miedo a la violencia.39 Estos sectores no son sólo materialmente pobres, sino también legalmentepobres.

Con tan importantes déficit en la eficacia de sus instituciones, en la efectividad de su sistema legal y, no menos importante, en su credibilidad como Estado-para-la-Nación, con pocasy parciales excepciones el Estado latinoamericano actual, al mismo tiempo que cobija regímenes democráticos, tiene gran dificultad en proyectar un futuro que, aunque no pueda resolver rápidamente muchas de las injusticias y desigualdades existentes, aparezca a la mayoría de la población como realizabley valioso.

Estetipo deEstado debaja capacidad esun viejo problema de América Latina. Sin embargo, se

38 Ver O'D onnell (1993) donde se traza un mapa metafórico de "zonas azules, verdes y marrones", de las cuales la marrón se refiere a zonas en las que la legalidad del Estado es apenas efectiva.

39 Los informes de varios organismos de derechos humanos repetida y abundantemente documentan la amenaza permanente de violencia a la que la gente está sometida. Para el caso de Brasil ver, entre otros, Dellasoppa et al. (1999), quienes documentan que la incidencia de muertes violentas en las regiones más pobres de la ciudad de San Pablo es dieciséis veces mayor que en las regiones más ricas; para datos sobre la Argentina ver, entre otros, CELS 2001. M ás en general, un estudio que analiza varios conjuntos de datos sobre crimen violento encontró en todos ellos una correlación positiva, fuertey persistente, de ésta con la pobreza y la desigualdad del ingreso (H sieh y Pugh, 1993). 
ha transformado en un problema aún más serio en los últimos años y en varios casos esto ha ocurrido bajo la democracia. El déficit decredibilidad del Estado resulta de la ineficacia operacional de sus institucionesy, a veces, de la ostensiblecolonización de éstas por parte deintereses privados que difícilmente puede argumentarse sean consistentes con al gún tipo deinterés general. Estedéficit se vuelveaún másagudo si partedeestosintereses no es en absoluto de corte nacional; más bien, ellos son parte de intereses extraterritoriales - públicos y privados- y delastendencias relativamenteanónimas de la globalización económica.

Es por todo esto que creemos tan importante inscribir la discusión sobreel Estado (incluyendo por qué, para quéy con quiénes reformarlo) en la perspectiva estratégica, eminentemente política, del desarrollo de la democracia.

Sin embargo, es preciso señalar que no existe Estado neutral. En sus tres dimensiones, el Estado es un espacio de condensación compleja y de mediación defuerzas sociales. Dehecho, la visión neutralista es una manera de argumentar a favor de un tipo de Estado que mediante sus políticas y, por cierto, de sus omisiones, es un activo reproductor dela desigualdad y una seria traba a la expansión de derechos civiles y sociales.

Algunos han intentado explicar el debilitamiento de los Estados en América Latina como una consecuencia ineludible de la globalización, frente a la cual sólo sería posible y deseable una adaptación pasiva. Esto es equivocado y, en ocasiones, interesado. Debido a que los vientos de la globalización son tan fuertes, los países necesitan más que nunca Estados-para-sus-naciones. Éste no deber ser un Estado grande o pesado. Pero sí un Estado fuerte, en el sentido de que sea capaz de procesar los impactos de la globalización, adaptándose selectivamente a los más irresistibles y digiriendo y reorientando otros.

En este sentido, la observación de los Estados de países centrales que cuentan con arraigadas instituciones y prácticas democráticas muestra cuán activamenteellos tratan de procesar, digerir y reorientar muchos aspectos y consecuencias de
Debido a que los vientos de la globaliza ción son tan fuertes, los países necesitan más que nunca Esta d os-pa ra-sus-na ciones.

la globalización. Pero una condición necesaria para un Estado capaz de construir democracia y equidad social es que al cance niveles razonables de eficacia, efectividad y credibilidad. En América Latina, estelogro está trabado por factores que, aunque aludidos en la discusión precedente, requieren especial consideración.

\section{Especificidad histórica de las democracias latinoamericanas}

Los problemas que hemos planteado hasta ahora son compartidos por muchas de las nuevas y no tan nuevas democracias en el mundo contemporáneo. ¿Quétienela teoría democrática que decir al respecto? Desafortunadamenteno mucho. En gran medida esto se debe a que la mayoría de las teorías sobre la democracia han sido formula das en el marco de la experiencia histórica de los países europeosy deEstados Unidos. Estas teorías dejan implícito que, en esos países, los derechosciviles eran razonablemente efectivos y estaban extendidos prácticamentea lo largo detoda la sociedad antes de la adopción de la inclusividad y la universalización de los derechos políticos. Además, presuponen quela legalidad del Estado seextiendehomogéneamentea lo largo del territorio y que, consecuentemente, no sólo los regímenes na cionales sino también los subnacionales son democráticos. ${ }^{40}$ Debería ser obvio a estas alturas que estas presunciones no se ajustan a la trayectoria histórica y a lasituación actual deAmérica Latina.

En términos de las trayectorias históricas de la democracia, América Latina muestra un patrón bastanteúnico. Por ello, una conceptualización de la democracia restringida al régimen puede ser

40 En realidad, Estados Unidos es una excepción parcial, aunque importante, a esta afirmación. Pero no podemos detenernos en este aspecto en el presente Informe. 
"Los derechos humanos y el

desa rrollo huma no comparten una

visión común y un propósito

común: a segura r la liberta d, el

bienestar y la dignidad de todas

las personas en todos la dos."

aceptable en tanto presuponga que la ciudadanía civil y social no son problemáticas. Pero cuando estas dimensiones de la ciudadanía son intermitenteso están distribuidasirregularmentea lo largo de diversos sectores sociales o incluso del propio territorio del Estado, es crucial tomarlas en cuidadosa consideración, si esquesequiereentender el funcionamiento de las respectivas democracias y los principales desafíos para su desarrollo.

"Nadie [... ] puede disfrutar completamente ningún derecho que supuestamente poseesi carece de los elementos esenciales para una vida razonablemente saludabley activa." 41 En consecuencia, "sería inconsistente reconocer derechos referidos a la vida o a la integridad física cuando los medios necesarios para el disfrute y ejercicio de estos derechos son omitidos".42 Estas afirmaciones se refieren a las capacidades que facilitan, o dificultan, el ejercicio delos derechos inherentes a la condición de ciudadanos. ¿Dóndey sobrela base de quécriterio podríamos trazar una línea firme y clara por sobre la cual la ciudadanía podría ser razonablemente ejercida en términos de derechos y capacidades? ¿Cuáles derechos y cuáles capacidades serían imprescindibles para gozar plenamente de la ciudadanía?
Estas cuestiones han dado lugar a extensos de bates. ${ }^{43}$ En este punto es necesario volver a un aspecto de esas discusiones, el referido a las libertades políticas. Sobre este tema sostenemos dos afirmaciones: una, que el conjunto mínimo y suficiente de estos derechos es imposible de definir teóricamente de manera general y universal; y la segunda, que estas libertades (de expresión, asociación, movimiento y similares) son, en realidad, segmentos demásamplios-y antiguos- derechos civiles. ${ }^{44}$ Ya argumentamos que estos derechos corresponden a todos los seres humanos, y que los derechos de ciudadanía en la esfera política difícilmente pueden ser realizados si los individuos carecen de derechos sociales y civiles "básicos". 45

Por serlo, un ciudadano tiene derecho a ser respetado en su dignidad, también tiene derecho a la provisión social de las condiciones necesarias para ejercer libremente todos los aspectos y las actividades de su sociabilidad. Someter a este individuo a violencia física o a la privación de necesidades material es básicas, o suprimir sus derechos políticos, son todos actos que niegan severamente su condición de ciudadano, sujeto-actor dela democracia. Esta visión de las condiciones mínimas que habilitan la capacidad para elegir entre opciones diversas, asumiendo responsablemente las consecuencias de tales elecciones, es clara ya en los orígenes de la tradición de derechos humanos y, más recientemente, se ha hecho también explícita en el pensamiento sobre el desarrollo humano. Como dice Amartya Sen en el Informe de Desarrollo Humano de 2000: "Los derechos humanos y el desarrollo humano comparten una visión común y un propósito común: asegurar la liber-

41 Shue, 1996, p. 7 (bastardillas en el original).

42 Vázquez, 2001, p. 102.

43 Véanse Shue, 1996; N ussbaum, 2000b.

44 En los países europeos y en Estados Unidos estos derechos fueron realizados como derechos civiles mucho antes de que fueran "promovidos" a la condición de derechos políticos. También estos derechos son ejercidos en espacios sociales muy diversos, más allá del ámbito del régimen.

45 Como escribe Habermas (1999, p. 332), “sin derechos básicos que garanticen la autonomía privada de los ciudadanos, tampoco habría ningún medio para la institucionalización legal delas condiciones bajo las cuales estos ciudadanos harían uso de su autonomía pública”. Este autor (1998, p. 261) afirma que: “Por lo tanto la autonomía pública y privada se presuponen mutuamente detal manera que ni los derechos humanos ni la soberanía popular pueden reclamar primacía por sobre su contraparte". 


\section{Los Objetivos de Desarrollo del Milenio}

1. Erradicar la pobreza extrema y el hambre - Reducir a la mitad, entre 1990 y 2015, el porcentaje de personas con ingresos inferiores a 1 dólar diario.

- Reducir a la mitad, entre 1990 y 2015, el porcentaje de personas que padecen hambre.

2. Lograr la enseñanza primaria universal

- Velar por que, para el año 2015, los niños y las niñas de todo el mundo puedan terminar un ciclo completo de enseñanza primaria.

3. Promover la equidad de género y la autonomía de la mujer

- Eliminar las desigualdades entre los géneros en la educación primaria y secundaria, preferiblemente para el año 2005, y en todos los niveles de la educación antes del final de 2015.

4. Reducir la mortalidad infantil

- Reducir en dos terceras partes, entre 1990 y 2015, la tasa de mortalidad de los niños menores de 5 años.

5. Mejorar la salud materna

- Reducir, entre 1990 y 2015, la tasa de mortalidad materna en tres cuartas partes.

6. Combatir el VIH/SIDA, el paludismo y otras enfermedades

- Detener y comenzar a reducir, para el año 2015, la propagación del VIH/SIDA.

- Detener y comenzar a reducir, para el año 2015, la incidencia del paludismo y otras enfermedades graves.

7. Garantizar la sostenibilidad ambiental

- Incorporar los principios del desarrollo sostenible en las políticas y los programas nacionales e invertir la pérdida de recursos ambientales.

- Reducir a la mitad, para el año 2015, la proporción de personas que carecen de acceso sostenible a agua potable.

- Mejorar considerablemente, para el año 2020, la vida de por lo menos 100 millones de habitantes de los barrios más precarios.

8. Fomentar una asociación mundial para el desarrollo

- Desarrollar aún más un sistema comercial y financiero abierto, regulado, previsible y no discriminatorio.

- Atender las necesidades especiales de los países menos adelantados.

- Atender las necesidades especiales de los países sin litoral y de los pequeños Estados insulares en desarrollo.

- Encarar de manera general los problemas de la deuda de los países en desarrollo con medidas nacionales e internacionales a fin de hacer la deuda sostenible a largo plazo.

- En cooperación con los países en desarrollo, elaborar y aplicar estrategias que proporcionen a los jóvenes un trabajo digno y productivo.

- En cooperación con las empresas farmacéuticas, proporcionar acceso a los medicamentos esenciales a precios asequibles en los países en desarrollo.

- En colaboración con el sector privado, velar por que se puedan aprovechar los beneficios de las nuevas tecnologías, en particular, los de las tecnologías de la información y de las comunicaciones.

ONU, 2003b, y PNUD, 2003. tad, el bienestar y la dignidad de todas las personas en todos lados". 46

Si bien las constituciones de América Latina consagran los derechos a la educación, la salud y el empleo, otras dimensiones como la satisfacción de las necesidades básicas - alimentación y hábitat, la seguridad social y el medio ambiente- reciben tratamientos desiguales, tanto reales como formales, en los distintos países. Precisamente, esta priorización se corresponde con los objetivos de desarrollo que emanan de la Declaración del Milenio adoptada por la Asamblea General de las Naciones Unidas en 2000.

Lograr los Objetivos del Milenio en la región Latinoamericana implica llevar adelante una serie de políticas públicas muy precisas, tales como invertir en la infraestructura básica, incrementar la productividad agrícola, promover la mediana y pequeña empresa, fomentar la industria, invertir en salud y educación, llevar adelante una política pública de sostenibilidad 
ambiental. Esas políticas requieren un Estado con capacidad de acción, lo que refierea la necesidad de lograr consensos políticos, a mantener la democracia en el estado de derecho y profundizarla tomando como meta el logro de una sociedad dondela ciudadanía sea integral, donde los derechos y las obligaciones no se limiten al campo político y civil, sino que comprendan el área social. Implican la acción del ciudadano como individuo, como actor político quese expresa a través de representantes $\mathrm{y}$-en las circunstancias previstas- directamente, y como integrante dela sociedad, actuando en su comunidad y en las asociaciones voluntarias que conforman el rico entramado de la sociedad civil.

Ésta es la misma visión que, como vimos, subyace a nuestra concepción de la democracia. Todos estos derechos - los derechos civiles y su conexión con los derechos humanos, los derechos sociales y su conexión con el desarrollo humano, y los derechos políticos y su conexión con la democracia- facilitan y promueven el ejercicio de la ciudadanía. Esto es así precisamente porque cada uno de ellos, o alguna combinación deellos, "empuja" hacia el logro de los otros, o al menos crean favorables oportunidades para su conquista. Asimismo, como veremos más adelante, el criterio relevante para la asignación de derechos civiles, sociales y políticos ha cambiado a lo largo del tiempo. Por ejemplo, incluso los países centrales convivieron por largos períodos con tremendas desigualdades, quejustificaban con el argumento de que trabajadores, mujeres y otros eran, por alguna razón, intrínsecamente"inferiores". A pesar de los muchos horrores y desigualdades aún existentes, la creciente aceptación de que todos los seres humanos somos, en algún sentido fundamental, iguales, es una gran conquista de la humanidad.

\section{Cuánta ciudadanía precisa una democracia}

Las afirmaciones del ítem anterior omiten considerar varias discusiones filosóficas y éticas que se centran en la cuestión del balance entre libertad e igualdad. Éstas son cuestiones extremadamente importantes que exceden el marco del presenteInforme.

En los países centrales, esas discusiones tratan acerca de qué principios de libertad y/o de equidad deberían regular la asignación de bienes sociales una vez que todos los ciudadanos, o una gran mayoría, han obtenido un nivel básico de derechos y capacidades. 47 En cambio, en América Latina, la cuestión principal se refiere a los que no gozan de esos derechos y capacidades básicos. Esto plantea la pregunta acerca de si existen buenas razones para afirmar un derecho universal para el logro de un nivel, o conjunto, básico de derechos y capacidades. Sostenemos que estas razones existen y que su fundamento es la visión de los ciudadanos y, en general, los individuos como seres autónomos, razonables y responsables. Esas razones hacen referencia a un aspecto primario de la equidad: no plena igualdad, sino igualación básica. Por igualación básica entendemos el derecho de cada uno a, por lo menos, dos cosas: ser tratado con la equidad y consideración debidas a su condición de ser humano y lograr, si fuera necesario a través del Estado o de la provisión social, un piso básico de derechos y capacidades queeliminen, al menos, las privaciones que impiden el ejercicio de las opciones responsables y las libertades que ellas implican.

Reconocemos que en este plano se suscitan complejas y arduas disputas. Sin embargo, nos parece ineludible la pregunta acerca de si hay 0

47 D asgupta (1993, p. 45, nota al pie) comenta correctamente: “La mayor parte de la teoría ética contemporánea asume al comienzo de la indagación que estas necesidades [básicas] han sido realizadas". Esta presunción es explícita en los trabajos de filosofía política que, puede decirse, han sido los más influyentes en las últimas décadas, al menos en el mundo anglosajón (Rawls, 1971, pp. 152, 542-543; su teoría de la justicia es considerada aplicable en países donde "solamente las necesidades materiales menos urgentes quedan por ser satisfechas"; por una reafirmación explícita de esta suposición ver Rawls, 2001). A su vez, aunque menos explícita, la misma suposición está claramente contenida en el trabajo de Habermas. La cuestión que queda pendiente es qué se puede decir de países, aun aquellos que incluyen un régimen democrático, que no cumplen con esta suposición. 
RECUADRO 18

\section{La democracia: una tensión entre hechos y valores}

Lo que la democracia es no puede ser separado de lo que la democracia debería ser. [...] En una democracia la tensión entre hechos y valores alcanza el punto más alto.

Giovanni Sartori, 1967, p. 4.

no obligación moral, y también derechos accionables, para demandar derechos y capacidades básicos que faciliten a todos los ciudadanos el ejercicio de su ciudadanía. Cualquiera que fuere la respuesta a esta cuestión, parece innegable quela democracia provee el mejor contexto posible para que la misma sea discutida. Al respecto, Sen argumenta que"la participación [democrática] política y social tiene valor intrínseco para la vida humana y el bienestar, [ así como también] valor instrumental al mejorar la posibilidad de la gente de ser escuchada [ ... ] en sus reclamos de atención política [incluyendo demandas sobre necesidades económicas]". Este autor, además, sostien e $^{48}$ quela democracia tiene valor constructivo, ya que "aun la idea de 'necesidades', incluyendo el entendimiento de 'necesidades económicas', requiere discusión pública e intercambio de información, visiones y análisis [... ]. Los derechos políticos, incluyendo la libertad de expresión y discusión, no son sólo fundamentales en inducir respuestas sociales a necesidades económicas, ellos son también centrales para la conceptualización de las necesidades económicas en sí mismas".49

Por eso, el contenido delos derechos, su grado de especificidad, su alcance, la prioridad relativa de al gunos sobre otros y otras cuestiones de este tipo, son y siempre serán disputables. $\mathrm{H}$ ay demasiadas preferencias encontradas, teorías sobre lo que es justo o equitativo, e intereses sociales y posiciones, para que cual quiera de estas cuestiones sea clara y firmemente resuelta. Éste es un hecho de la vida social, una consecuencia de la libertad y de la diversidad de proyectos de vida, puntos de vista, intereses y espacios sociales que ella sustenta. Corresponde a la democracia, y específicamente a la política democrática, celebrar y promover las disputas y los acuerdos que tal pluralidad de voces eintereses conlleva. Es por esto también que la democracia es y admite ser un horizonte abierto, en el que se juegan incesantemente las luchas por la definición y redefinición de derechos y obligaciones. 50

¿Cuál es la respuesta a estos problemas, restricciones e incertidumbres? Simplemente, más democracia. La cuestión crucial es quién decide, cómo y sobre la base de qué, qué derechos son sancionados e implementados, y con qué intensidad y alcance, mientras otros derechos no son inscriptos en el sistema legal o permanecen como letra muerta. Aun cuando estén basados en características universales del ser humano, determinar cuáles son los reclamos y las necesidades que se deben transformar en derechos, en qué medida se implementan y cuál es el balance que se establece con otros derechosy obligaciones, es una construcción social que resulta de la política, al menos de la política en sus mejores expresiones.

Nos parece importante recalcar lo antedicho porque, paradójicamente, es en los países donde más se necesita discusión amplia sobre necesidades y demandas y su posible conversión en derechos accionables, donde es más difícil incorporar estas cuestiones a la agenda pública. ¿Quésería "un mínimo social decente",51 en términos de un conjunto básico de derechos civiles y sociales para todos los habitantes? Asimis-

48 Sen, 1999a, p. 10 (bastardillas en el original).

49 lbid., p. 11.

50 Ver Tilly, 1990, 1996, 1998b. Este autor (1998b, p. 55) concluye que “Ios derechos [ son] productos históricos, resultados de las luchas".

51 Nussbaum, 2000a, p. 125. 
RECUADRO 19

\section{La información: una necesidad básica}

Aun la idea de necesidades, incluyendo el entendimiento de necesidades económicas, requiere información pública e intercambio de información, visiones y análisis. [...] Los derechos políticos, incluyendo la libertad de expresión y discusión, no son sólo fundamentales en inducir respuestas sociales a necesidades económicas, ellos lo son para la conceptualización de las necesidades económicas en sí mismas.

Amartya Sen, 1999a.

mo, si un país es pobre y tiene un Estado ané mico y un sistema legal truncado, ¿qué secuencias y trayectorias serían adecuadas para el logro de ese mínimo?52

Las necesidades y privaciones respectivas no son sólo el sufrimiento de individuos aislados; éstas son cuestiones sociales, que deben ser tratadas en términos del reconocimiento de responsabilidades estatales y colectivas. Asimismo, son cuestiones políticas, imbuidas de distintos valores e ideologías, de teorías más o menos implícitas sobre el funcionamiento de una sociedad dada y, hoy en día, crecientemente también sobre el funcionamiento del sistema global. Es necesario promover el abordaje de estos temas en la agenda pública porque es ahí donde se definen cuáles son las necesidades "reales" que un país enfrenta, ignora, o reprime.

En la experiencia histórica de la humanidad, los avances en los derechos civiles y sociales de los sectores populares hicieron muy difícil resistir las demandas por ciudadanía po- lítica; su extensión dio a las mujeres y a algunas minorías un resorte importante para adquirir otros derechos civiles y sociales; la extensión de derechos civiles ayudó a la conquista de derechos sociales y políticos;;3 la disponibilidad de derechos políticos ha prevenido las hambrunas. 54 Estos y muchos otros procesos muestran cómo diversos derechos tienden a invocarse y reforzarse entre sí; hay una clara afinidad electiva entre los derechos civiles, sociales y políticos. La fuerza que impulsa estas relaciones es finalmente moral: el reconocimiento de que una persona no debe ser privada de ninguno de los derechos y capacidades que normalmente lo habilitan a actuar de modo libre y responsable.

En lo que respecta a América Latina, ahora que contamos con una notable extensión de los derechos políticos deberíamos usarlos no sólo con referencia al régimen sino también como palanca para la muy necesaria extensión de derechos civiles y sociales.

En este análisis, la noción de desarrollo de la democracia se sostiene sobre un presupuesto fundamental: la existencia de un régimen democrático. En este régimen encontramos al ciudadano legalmente respaldado y reconocido como sujeto en la democracia política. Por su lado, la noción de ciudadanía nos indicó que la democraticidad es también un atributo del Estado. Prosiguiendo esta búsqueda, encontramos las características y raíces comunes de los derechos políticos, civiles y sociales. Esta tesis fue sustentada en la afirmación de que la democracia implica no sólo ciudadanía política sino también civil y social. Asimismo, afirmamos que la existencia de un contexto diverso y plural, respaldado por un sistema legal consonante con el mismo, es otro aspecto fundamental de la democracia, especialmente en tanto sustenta las liberta-

52 Como Tavares de Almeida (2002) argumenta, aun dentro de América Latina hay variaciones importantes en esta cuestión, las cuales deberían ser tomadas en cuenta al trazar posibles secuencias y trayectorias. Una discusión detaIlada de esta cuestión depende de una evaluación país por país, lo cual es una tarea que excede las posibilidades del presente Informe.

53 Por ejemplo, Touraine (1994) nota que los trabajadores europeos obtuvieron sus derechos sociales luchando por principios generales, como la libertad y la justicia.

54 Como argumenta Sen (1999a). 
des que son la cara social de los derechos individuales de ciudadanía.

En la mayoría de estos aspectos encontramos que las democracias de la América Latina contemporánea exhiben deficiencias. Pero, por otro lado, mostramos las potencialidades políticas y normativas de la democracia, aun en el marco de las restricciones existentes en la actualidad. Considerada desde este ángulo, la democracia puede concebirse como un conjunto de principios generales de organización de la sociedad. Ella es también la principal palanca para intentar superar injusticias y desigualdades. La posibilidad que la democracia crea con sus libertades para luchar contra esas injusticias y desigualdades hace de ella un horizonte siempre abierto. Esta apertura, y la dinámica que permite, hace que la democracia, aun las que sufren serias deficiencias, sean un bien inmensamente valioso por el que vale la pena esforzarse en preservarlo y expandirlo.

El próximo paso consiste en la observación empírica del régimen democrático, del desarrollo de la ciudadanía y del poder.

Hemos hecho explícito hasta aquí el hilo conductor que guía este Informe. Hemos explorado de manera sucinta las bases conceptuales en las que se funda la afirmación de que el desafío global del relanzamiento democrático es el pasaje de la democracia electoral a la democracia de ciudadanía y se han desarrollado los argumentos principales de la íntima

\section{El desafío global del rela nza miento democrático es el pasaje de la democracia electoral a la democracia de ciudadanía.}

vinculación entre la idea de democracia, ciudadanía y Estado. Estas ideas han fundado, a su vez, una búsqueda empírica. Sin ellas, la observación de datos resultaría desarticulada y probablemente no nos guiaría en nuestra búsqueda. De modo que indagar cómo perciben los ciudadanos a la democracia en sus vidas, construir los indicadores del régimen político y desarrollo de ciudadanía y, finalmente, consultar a los que conocen el poder, los límites del Estado y los gobiernos, constituyen los ejes de la investigación empírica que se desarrolla en el capítulo siguiente. Allí encontraremos la materia de estas tesis que hemos sobrevolado hasta aquí.

Finalmente, el lector verá reunidas las ideas de estas primeras páginas con los resultados empíricos de la segunda sección, en la tercera parte de este Informe, donde se elaborarán las ideas centrales que contienen los dos desafíos principales de la democracia latinoamericana: asegurar la libertad y ampliar la ciudadanía de sus habitantes. 



\section{Bases empíricas del Informe}

partir de la presentación de los fundamentos teóricos del Informe y de la caracterización de la singularidad de las democracias latinoamericanas, se indaga y analiza su correlato empírico. Esta sección contiene:

a. Una mirada al régimen democrático en sentido estricto (reglas, procedimientos e instituciones que determinan las formas de acceso a la cúspide del Estado). Incluye un índice de democracia electoral (IDE) que muestra que América Latina ha progresado notablemente en cuanto a la elección democrática de gobiernos, y una observación de otros indicadores de ciudadanía política.

b. Un conjunto de indicadores de ciudadanía civil que muestran que el progreso representado por el reconocimiento formal de los derechos no está necesariamente acompañado por su vigencia efectiva, y de indicadores de ciudadanía social donde se observan sólo pequeños avances en algunos temas y agudas deficiencias en otros.

c. Un análisis de la visión de los latinoamericanos sobre su democracia, a partir de una encuesta de opinión de 19.508 personas entrevistadas en los dieciocho países. El análisis revela una manifiesta preferencia por la democracia frente a otras formas de gobierno, pero también que esta preferencia no implica un claro y sostenido apoyo, tal como lo muestran el índice de apoyo ciudadano a la democracia (IAD) y los perfiles de intensidad ciudadana.

d. Un análisis de la ronda de consultas sobre aspectos centrales de la democracia, realizadas a 231 dirigentes políticos y sociales latinoamericanos, entre ellos un grupo destacado de presidentes y vicepresidentes. Las consultas incluyeron temas tales como la participación política, los controles al ejercicio del poder, el papel de los partidos políticos, los poderes fácticos, los poderesilegales, los poderes políticosformales, y la construcción de una agenda para el fortalecimiento de la democracia. 



\section{- Indicadores de desarrollo de la democracia}

\section{Ciudadanía política, civil y social}

Para esta sección se construyó un conjunto de indicadores quesirven para describir la situación actual dela democracia en América Latina. Su alcance, interpretación y uso deben enmarcarse en las notas metodológicas incluidas al final del Informe.

Es importante realizar al gunas aclaraciones acerca de los datos que aquí se presentan:

a. No ofrecen un sistema de calificación de los gobiernos latinoamericanos. Los indicadores intentan iluminar el escenario amplio en el que se desempeñan los funcionarios electos y otros actores, y por ello no deben interpretarse como calificaciones a las autoridades electas. Tampoco se trata de comparar a los diferentes países entre sí.

b. No construyen un solo índice o ránking de países. El marco teórico propone, como tesis fundamental, que la democracia incluye el régimen político, pero no se agota en él. Teniendo en cuenta este punto de partida, los indicadores señalan varios aspectos o dimensiones de la democracia, a través de diversos derechos políticos, civiles y sociales. Esta realidad compleja no puede resumirse adecuadamente en un solo índice. Además, dado que los indicadores siempre captan la realidad con un grado de incertidumbre, no se brindan clasificaciones precisas donde se presupone la inexistencia de errores. Por razones metodológicas básicas no se ofrece un índiceúnico ni una clasificación de países.

c. Presentan mediciones parciales de una realidad compleja. Para captar esa complejidad se reunieron diferentes indicadores, al gunos enfocados sobre procesos, otros sobre políticas y otros sobre resultados. Aunque en su conjunto pueden pintar un panorama detallado, ofrecen una visión parcial dela realidad y no agotan el significado de los conceptos medidos. Además, en más de un caso se dispone de información que cubre sólo una coyuntura y no un período largo sobre el cual se pueden indicar tendencias. Ciertos aspectos, algunos bastante esenciales para captar la singularidad de cada país, son extremadamente difíciles de incorporar a través de mediciones cuantitativas y se comprenden mejor con un enfoque cualitativo.

d. Refieren al momento en quefue realizada la medición y no deben ser considerados una calificación de la situación actual. Dado el lapso normal que se produce entre el momento de la medición y su posterior análisis y publicación, debe tomarse en cuenta este hiato temporal al momento de interpretar los datos. Este 
fenómeno adquiere particular relevancia cuando se producen mediciones únicas o iniciales, y disminuyesu relevancia cuando se cuenta con series históricas o mediciones reiteradas a lo largo de períodos prolongados.

e. Los nuevos índices que se presentan en esteInformeimplican una primera aproximación cuali-cuantitativa a fenómenos sociales y políticos complejos. Los datos seleccionados que componen los diversos indicadores responden al proceso de construcción del índice. Un cambio en los componentes que constituyen el índice podría modificar el valor del mismo. Los valores asignados a las variables que componen losíndices sefundamentan en un proceso de codificación realizado por analistas. A pesar del cuidado puesto para asignar valores similares a situaciones similares, existe un margen de variabilidad, vinculado a la apreciación que cada analista hace de la realidad en cuestión. En consecuencia, cuando se leen los resultados hay que tener en cuenta este complejo proceso de construcción.

\section{Ciudadanía política}

\section{Índice de Democracia Electoral}

El análisis del régimen electoral sehace inicialmente a partir del índice de democracia electoral (IDE), construido para el presente Informe. Esteíndice reúne mediciones que responden a las siguientes preguntas (para una explicación más detallada, ver el recuadro 20):

- ¿Se reconoce el derecho al voto?

- ¿Son limpias las elecciones?

- ¿Son libres las elecciones?

- ¿Son las elecciones el medio de acceso a cargos públicos?

EI IDE capta información sobre algunos de los componentes más básicos y necesarios del ré gimen democrático. Violaciones, aun parciales, de cual quiera de estos derechos ciudadanos políticos apuntan a restricciones muy importantes del régimen democrático. Pero es necesario re calcar que el IDE es una medida relativamente minimalista de la democracia. La conquista de una democracia electoral plena, medida deacuerdo con los criterios queusa el IDE, representa un avance significativo para los derechos ciudadanos. Pero el establecimiento de una democracia electoral es sólo un paso, que establece un piso mínimo, en la lucha más amplia por la expansión de los derechos ciudadanos.

La conclusión más evidente que surge del IDE es queAmérica Latina ha progresado notablementeen cuanto a la democratización del régimen de acceso al gobierno. Nunca antesAmé rica Latina contó con regímenes electorales tan democráticos y durables como a principios del siglo XXI.

Antes del inicio de la ola de transiciones a fines de la década de 1970, la mayoría de los países en la región tenían regímenes autoritarios. Desde entonces, el progreso ha sido muy marcado. El promedio del IDE (cuyo valor varía entre 0 y 1 ) paraAmérica Latina suberápidamente de 0,28 en 1977 a 0,69 en 1985, y a 0,86 en 1990, mejorando deahí en adelante para terminar el 2002 con 0,93.

Las experiencias varían bastante, como se puede ver en el gráfico 1. Los países del M ercosur y Chile, con la excepción de Paraguay, ya habían roto alrededor de 1990 con los regímenes militares. Desdeentonces mantuvieron regímenes democráticos.

Otra situación es la de la subregión Centroamérica y República Dominicana que, con excepción de Costa Rica y la República Dominicana, todavía estaban resolviendo conflictos armados en los años noventa. La democratización coincidió con la resolución pacífica de estos conflictos y avanzó a paso sostenido. En 2002, esta subregión era electoral mentela más democrática.

Una tercera situación es la de los países andinos, que al empezar la década de 1990 tenían regímenes democráticos de larga data (Colombia, Venezuela) o fueron los primeros casos de transición desde regímenes militares en América del Sur a fines de los setenta y principios de los ochenta (Ecuador, Perú, Bolivia). Sin embar- 


\section{El Índice de Democracia Electoral (IDE) Una contribución a la discusión sobre la democracia}

El índice de democracia electoral (IDE) es una nueva medida del régimen electoral democrático producida para este Informe. Este tipo de medición tiene una evolución prolongada en el mundo académico. Un paso importante en la discusión de esta metodología fue dado en la publicación del PNUD, Informe sobre desarrollo humano 2002, "Profundizar la democracia en un mundo fragmentado".

La construcción del IDE se apoya en los últimos avances en la materia, que se explican en la nota técnica del compendio estadístico. El IDE presenta una agregación de cuatro componentes considerados esenciales en un régimen democrático, tal como se refleja en el siguiente árbol conceptual:

\section{Índice de Democracia Electoral (IDE)}

\section{Derecho al voto}

¿Tienen todos los adultos en un país el derecho al voto?

\section{Elecciones limpias}

¿Se desenvuelve el proceso electoral sin irregularidades que constriñan la expresión autónoma de las preferencias de los votantes por candidatos y alteren el conteo fidedigno de los votos emitidos?
A su vez, la regla de agregación está expresada formalmente en la siguiente fórmula:

\section{Índice de Democracia Electoral (IDE) $=$ Derecho al voto $x$ Elecciones limpias $x$ Elecciones libres x Cargos públicos electos}

El IDE es un insumo para el proceso de discusión y análisis de la realidad latinoamericana y no debe ser considerado como una medida completa de la democracia. Recientemente se ha comenzado a debatir

\section{Elecciones libres}

¿Es ofrecido al electorado un rango de alternativas que no son constreñidas por restricciones legales 0 de hecho?

\section{Cargos públicos electos}

¿Son las elecciones el medio de acceso a los principales cargos públicos de un país, esto es, el Ejecutivo y Legislativo Nacional, y asumen sus cargos públicos y permanecen en sus cargos durante los plazos estipulados por la ley los que ganan elecciones?

el posible uso de mediciones de la democracia como uno de los criterios para identificar países que serían receptores de fondos destinados a la promoción del desarrollo. Un ejemplo es el Millenium Challenge Account (MCA) del Gobierno de los Estados Unidos, que utiliza, junto con otros datos, medidas de democracia y de estado de derecho elaborados por Freedom House y el Banco Mundial. El PRODDAL considera que todavía no existe suficiente consenso y una metodología probada y certera para justificar la toma de este tipo de decisiones sobre la base de medidas de democracia. 
GRÁFICO 1

\section{Índice de Democracia Electoral (IDE),} 1977, 1985, 1990-2002

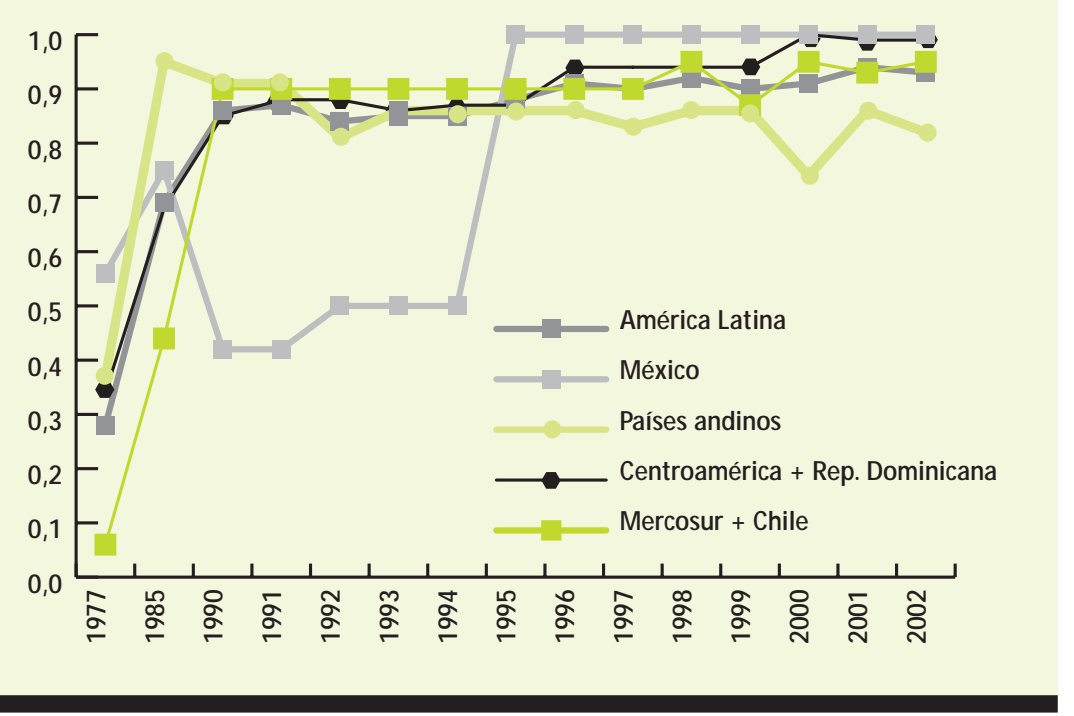

Nota: El gráfico se basa en datos presentados en el Compendio Estadístico del Informe.

go, durante la década de los noventa esta subregión comenzó a enfrentar serios problemas que llevaron, inclusive, a poner en peligro sus regímenes políticos.

Finalmente, M éxico registró una transición a la democracia lenta pero sostenida, queculmina con la presidencia de Ernesto Zedillo.

Otrasconclusiones, más específicas, surgen de una mirada más detallada, a nivel de los cuatro indicadoresquerecogeel IDE: derecho al voto, elecciones limpias, elecciones libres y las elecciones como el medio de acceso a los cargos públicos.

Un primer componente clave del régimen democrático es el derecho al voto: sin este derecho, los otros logros se vacían de contenido. Con respecto a este componente, existe poca variación en América Latina. Hoy en día en todos los países se reconoce el derecho universal al voto. De benotarseque aun en aquellos casos donde existelo que generalmente se llama el derecho al voto universal, pueden subsistir restricciones que afectan el derecho al voto de los militares y policías, el clero, residentes extranjeros y ciudadanos vi- viendo en el extranjero. ${ }^{55}$ Además, en algunos países existen barreras que impiden el fácil uso efectivo del derecho al voto.56 Pero el reconocimiento del derecho universal al voto es, sin duda, un logro importante, que vale la pena resaltar. Algunas de las luchas políticas más destacadas de la primera mitad del siglo XX secentraron en la extensión del sufragio a las clases trabajadoras, los sectores populares y las mujeres.

EI IDE también capta la medida en que las preferencias de los votantes son registradas fielmente por medio del proceso electoral. Como se puede ver en la tabla 4, entre 1990 y 2002 se han celebrado un total de setenta elecciones nacionales y en trece casos hubo problemas significativos. En dos oportunidades (República Dominicana 1994 y Perú 2000), la comunidad internacional consideró que los problemas fueron de tal magnitud que ponían en cuestión el carácter democrático del procedimiento electoral. Pero en la mayoría de los casos, las irregularidades no parecen haber sido decisivas para el resultado de las elecciones. Además, el número 


\begin{tabular}{|c|c|c|c|c|c|c|c|c|c|c|c|c|c|}
\hline \multicolumn{13}{|c|}{ ELECCIONES LIMPIAS, 1990-2002 } & \multirow{2}{*}{$\begin{array}{c}\text { TABLA } 4 \\
2002\end{array}$} \\
\hline País & 1990 & 1991 & 1992 & 1993 & 1994 & 1995 & 1996 & 1997 & 1998 & 1999 & 2000 & 2001 & \\
\hline Argentina & & 2 & & 2 & & 2 & & 2 & & 2 & & 2 & \\
\hline Bolivia & & & & 2 & & & & 2 & & & & & 2 \\
\hline Brasil & 2 & & & & 2 & & & & 2 & & & & 2 \\
\hline Chile & & & & 2 & & & & 2 & & 2 & & 2 & \\
\hline Colombia & 1 & 1 & & & 1 & & & & 1 & & & & $2-$ \\
\hline Costa Rica & 2 & & & & 2 & & & & 2 & & & & 2 \\
\hline Ecuador & & & 2 & & 2 & & 2 & & 2 & & & & 2 \\
\hline El Salvador & & 2 & & & 2 & & & 2 & & 2 & 2 & & \\
\hline Guatemala & 1 & & & & 1 & 1 & & & & 2 & & & \\
\hline Honduras & & & & 2 & & & & 2 & & & & 2 & \\
\hline México & & $2-$ & & & 2 & & & 2 & & & 2 & & \\
\hline Nicaragua & 2 & & & & & & 2 & & & & & 2 & \\
\hline Panamá & & & & & 2 & & & & & 2 & & & \\
\hline Paraguay & & & & 1 & & & & & 2 & & & & \\
\hline Perú & 2 & & 2 & & & 1 & & & & & $0 *$ & 2 & \\
\hline Rep. Dominicana & $1-*$ & & & & $0 *$ & & 2 & & 2 & & 2 & & 2 \\
\hline Uruguay & & & & & 2 & & & & & 2 & & & \\
\hline Venezuela & & & & 2 & & & & & 2 & & 2 & & \\
\hline
\end{tabular}

Número de casos de elecciones con irregularidades de alguna significación

$\begin{array}{llllllllllllll}\text { América Latina }(* *) & 3 & 1 & 0 & 1 & 3 & 2 & 0 & 0 & 1 & 0 & 1 & 0 & 0\end{array}$

Notas: Las elecciones son consideradas "limpias" cuando el proceso electoral se desarrolla sin irregularidades que limiten a los votantes para expresar autónoma y fielmente sus preferencias por algún candidato. No incluye cuestiones relacionadas con la competitividad del proceso electoral ni tampoco si se permite o no al ganador de las elecciones asumir su cargo público, ni si todos los cargos públicos son electivos.

Valores: 0 = graves irregularidades en el proceso electoral que tienen un efecto determinante sobre los resultados de las elecciones (por ejemplo, alteran el resultado de una elección presidencial y/o del balance de poder dentro del Parlamento); 1 = irregularidades significativas en el proceso electoral (por ejemplo, intimidación de los votantes, violencia contra los votantes, fraude electoral); 2 = falta de irregularidades significativas en el proceso electoral (por ejemplo, elecciones que pueden incluir irregularidades "técnicas" pero que carecen de un sesgo sistemático de peso significativo). Signos de más y menos son usados para indicar situaciones intermedias. Cuando en un año hay elecciones tanto para el Ejecutivo como para el Parlamento y las irregularidades se aplican sólo a las elecciones para el Ejecutivo, se indica esta situación con un asterisco (*). En esos casos el valor para las elecciones parlamentarias es un 2.

$(* *)$ Los datos para la región abarcan el número total de elecciones celebradas en un año dado con irregularidades significativas o mayores, esto es, que no reciben un puntaje de 202 .

Fuentes: Cerdas-Cruz, Rial y Zovatto 1992, Rial y Zovatto 1998, Middlebrook 1998, Montgomery 1999, Pastor 1999; Hartlyn, M cCoy y M ustillo 2003; informes de la Organización de Estados Americanos (OEA), la Unión Europea (UE), el Centro Carter y el Instituto Nacional Democrático; múltiples artículos del Journal of Democracy; y consultas con expertos.

de comicios problemáticos ha bajado considerablemente: mientras hubo diez de estos casos sobre un total detreinta y cinco elecciones en el período 1990-1996, este número bajó a dos sobre el mismo total para el período 1997-2002.

El tercer componente del IDE, las elecciones libres, introduce un elemento que no es captado directamente por los conceptos de derecho al voto y elecciones limpias: la libertad del votante de escoger entre alternativas. En esta materia subsisten algunos problemas, tal como surge de la tabla 5. Del total de setenta elecciones nacionales celebradas entre 1990 y 2002, hubo diez casos en los que la posibilidad de competir libremente en elecciones fue restringida de manera significativa. A pesar de esto, la tendencia es positiva. M ientras que en el período 19901996 hubo ocho casos de elecciones con restricciones significativas sobre un total de treinta y cinco elecciones, este número bajó a dos sobre el mismo total en el período 1997-2002.

Visto en perspectiva, el mejoramiento es notable. Ya no existen las proscripciones legales que en otra época afectaron a partidos mayoritarios como el Partido Justicialista (PJ) en la Argentina o la Alianza Popular Revolucionaria Americana (APRA) en el Perú, y a partidos de menor peso electoral, como los partidos comunistas de 


\begin{tabular}{|c|c|c|c|c|c|c|c|c|c|c|c|c|c|}
\hline \multicolumn{13}{|c|}{ ELECCIONES LIBRES, 1990-2002 } & \multirow{2}{*}{$\begin{array}{l}\text { TABLA } 5 \\
2002\end{array}$} \\
\hline País & 1990 & 1991 & 1992 & 1993 & 1994 & 1995 & 1996 & 1997 & 1998 & 1999 & 2000 & 2001 & \\
\hline Argentina & & 4 & & 4 & & 4 & & 4 & & 4 & & 4 & \\
\hline Bolivia & & & & 4 & & & & 4 & & & & & 4 \\
\hline Brasil & 4 & & & & 4 & & & & 4 & & & & 4 \\
\hline Chile & & & & 4 & & & & 4 & & 4 & & 4 & \\
\hline Colombia & 3 & 3 & & & 3 & & & & 3 & & & & 3 \\
\hline Costa Rica & 4 & & & & 4 & & & & 4 & & & & 4 \\
\hline Ecuador & & & 4 & & 4 & & 4 & & 4 & & & & 4 \\
\hline El Salvador & & 3 & & & 4 & & & 4 & & 4 & 4 & & \\
\hline Guatemala & 3 & & & & 3 & 3 & & & & 4 & & & \\
\hline Honduras & & & & 4 & & & & 4 & & & & 4 & \\
\hline México & & 4 & & & 4 & & & 4 & & & 4 & & \\
\hline Nicaragua & 4 & & & & & & 4 & & & & & $4-$ & \\
\hline Panamá & & & & & 4 & & & & & 4 & & & \\
\hline Paraguay & & & & 4 & & & & & 4 & & & & \\
\hline Perú & 4 & & 3 & & & 4 & & & & & 3 & 4 & \\
\hline Rep. Dominicana & 4 & & & & 4 & & 4 & & 4 & & 4 & & 4 \\
\hline Uruguay & & & & & 4 & & & & & 4 & & & \\
\hline Venezuela & & & & 4 & & & & & 4 & & 4 & & \\
\hline \multicolumn{14}{|c|}{ Número de casos de elecciones con restricciones de alguna significación } \\
\hline América Latina $(*)$ & 2 & 2 & 1 & 0 & 2 & 1 & 0 & 0 & 1 & 0 & 0 & 0 & 1 \\
\hline
\end{tabular}

Notas: Las elecciones son consideradas "libres" cuando se le ofrece al electorado una variedad de opciones que no esté limitada ni por restricciones legales ni por la fuerza. Esta medida no incluye factores que pueden afectar la capacidad de los partidos y candidatos para competir en igualdad de condiciones, tales como financiamiento público, acceso a los medios de comunicación y uso de los recursos públicos.

Valores: 0 = sistema de partido único; 1 = proscripción a un partido importante; 2 = proscripción a un partido menor; 3 = restricciones de naturaleza legal o práctica que afectan significativamente la capacidad de candidatos potenciales para presentarse a elecciones y/o la formación de partidos políticos (por ejemplo, asesinatos sistemáticos e intimidación a candidatos, proscripción de candidatos populares, restricciones de naturaleza legal o práctica que impiden la formación de partidos o que llevan a ciertos partidos a boicotear las elecciones); 4 = condiciones esencialmente irrestrictas para la postulación de candidatos y la formación de partidos. Signos de más y menos son usados para indicar situaciones intermedias.

${ }^{*}$ ) Los datos para la región abarcan el número total de elecciones celebradas en un año dado con restricciones significativas, esto es, que no reciben un puntaje de 404 -.

Fuentes: Cerdas-Cruz, Rial y Zovatto 1992; Rial y Zovatto 1998, Middlebrook 1998, Montgomery 1999, Pastor 1999; múltiples artículos en el Journal of Democracy, y consulta con expertos.

Brasil, Chiley Costa Rica. Estas restricciones-de uso reiterado desde fines de la década de 1940 hasta la década de 1960 en la mayoría de los casos, pero hasta 1985 en el caso de Brasil- han sido superadas. Asimismo, con la resolución de los conflictos armados en Centroamérica durantela década de 1990, las restricciones debido a la falta de capacidad estatal para garantizar la integridad física de los candidatos también han sido superadas, con excepción de Colombia.

Un cuarto componente del régimen democrático gira en torno de las elecciones como el medio de acceso a los cargos públicos. Aquí se plantean dos cuestiones básicas. Una es si los cargos públicos principales (presidentes y parla- mentarios) son ocupados o no por los ganadores en las elecciones. La otra es si quienes acceden a estos cargos permanecen en ellos durante los plazos estipulados por la ley o, en el caso de ser reemplazados, si se lo hace de acuerdo con las normas constitucionales. Este componente complementa la visión del proceso electoral, al introducir una consideración acerca de lo que realmente está en juego en las elecciones. Lo introducimos porque su violación determina que el régimen deje de ser democrático, aunque las elecciones en sí mismas hayan sido limpias.

Como se observa en la tabla 6, en esta materia la situación actual deAmérica Latina es muy positiva. Se ha establecido como criterio am- 


\begin{tabular}{|c|c|c|c|c|c|c|c|c|c|c|c|c|c|}
\hline \multicolumn{13}{|c|}{ ELECCIONES COMO EL MEDIO DE ACCESO A CARGOS PÚBLICOS, 1990-2002 } & \multirow{2}{*}{$\begin{array}{l}\text { TABLA } 6 \\
2002\end{array}$} \\
\hline País & 1990 & 1991 & 1992 & 1993 & 1994 & 1995 & 1996 & 1997 & 1998 & 1999 & 2000 & 2001 & \\
\hline Argentina & 4 & 4 & 4 & 4 & 4 & 4 & 4 & 4 & 4 & 4 & 4 & 4- & 4 \\
\hline Bolivia & 4 & 4 & 4 & 4 & 4 & 4 & 4 & 4 & 4 & 4 & 4 & 4 & 4 \\
\hline Brasil & 4 & 4 & 4 & 4 & 4 & 4 & 4 & 4 & 4 & 4 & 4 & 4 & 4 \\
\hline Chile & 3 & 3 & 3 & 3 & 3 & 3 & 3 & 3 & 3 & 3 & 3 & 3 & 3 \\
\hline Colombia & 4 & 4 & 4 & 4 & 4 & 4 & 4 & 4 & 4 & 4 & 4 & 4 & 4 \\
\hline Costa Rica & 4 & 4 & 4 & 4 & 4 & 4 & 4 & 4 & 4 & 4 & 4 & 4 & 4 \\
\hline Ecuador & 4 & 4 & 4 & 4 & 4 & 4 & 4 & $3+$ & 4 & 4 & 3 & 3 & 3 \\
\hline El Salvador & 4 & 4 & 4 & 4 & 4 & 4 & 4 & 4 & 4 & 4 & 4 & 4 & 4 \\
\hline Guatemala & 4 & 4 & 4 & 3 & 4 & 4 & 4 & 4 & 4 & 4 & 4 & 4 & 4 \\
\hline Honduras & 4 & 4 & 4 & 4 & 4 & 4 & 4 & 4 & 4 & 4 & 4 & 4 & 4 \\
\hline México & 4 & 4 & 4 & 4 & 4 & 4 & 4 & 4 & 4 & 4 & 4 & 4 & 4 \\
\hline Nicaragua & 4 & 4 & 4 & 4 & 4 & 4 & 4 & 4 & 4 & 4 & 4 & 4 & 4 \\
\hline Panamá & 4 & 4 & 4 & 4 & 4 & 4 & 4 & 4 & 4 & 4 & 4 & 4 & 4 \\
\hline Paraguay & 4 & 4 & 4 & 4 & 4 & 4 & 4 & 4 & 4 & $2+$ & 4 & 4 & 4 \\
\hline Perú & 4 & 4 & 2 & 4 & 4 & 4 & 4 & 4 & 4 & 4 & 4 & 4 & 4 \\
\hline Rep. Dominicana & 4 & 4 & 4 & 4 & 4 & 4 & 4 & 4 & 4 & 4 & 4 & 4 & 4 \\
\hline Uruguay & 4 & 4 & 4 & 4 & 4 & 4 & 4 & 4 & 4 & 4 & 4 & 4 & 4 \\
\hline Venezuela & 4 & 4 & 4 & 4 & 4 & 4 & 4 & 4 & 4 & 4 & 4 & 4 & $3-$ \\
\hline \multicolumn{14}{|c|}{ Número de casos con restricciones de alguna significación } \\
\hline América Latina & *) 1 & 1 & 2 & 2 & 1 & 1 & 1 & 2 & 1 & 2 & 2 & 2 & 3 \\
\hline
\end{tabular}

Notas: Las elecciones son consideradas el medio de acceso a los principales cargos públicos de un país, esto es, el Ejecutivo y Legislativo nacional, si los que ganan elecciones asumen sus cargos públicos y permanecen en sus cargos durante los plazos estipulados por la ley. En el caso de que sean reemplazados ocupantes de cargos públicos, se evalúa la forma de remoción del cargo y de selección de reemplazantes.

Valores: 0 = no se ocupa ninguno de los cargos públicos principales por medio de elecciones, o bien quienes ocupan todos los cargos políticos principales son removidos por la fuerza por gobernantes inconstitucionales; 1 = sólo algunos de los cargos públicos principales son ocupados por ganadores de elecciones, o la mayoría de los ocupantes de cargos públicos son removidos de sus cargos por la fuerza y reemplazados por gobernantes inconstitucionales; 2 = el presidente 0 el Parlamento no son electos o son removidos de su cargo por la fuerza y reemplazados por gobernantes inconstitucionales; 3 = el presidente 0 el Parlamento son elegidos, pero el presidente es removido del cargo y/o reemplazado por medios semiconstitucionales, o bien un número significativo de parlamentarios no son electos 0 son removidos de sus cargos por la fuerza; $4=$ todos los cargos políticos principales se completan a través de elecciones y ninguno de los ocupantes de estos cargos políticos principales es removido de su cargo a menos que su remoción y reemplazo esté basado en fundamentos constitucionales estrictos.

Signos de más y menos son usados para indicar situaciones intermedias.

${ }^{*}$ ) Los datos para la región abarcan el número total de elecciones celebradas en un año dado con restricciones significativas, esto es, que no reciben un puntaje de 404 -.

Fuentes: Domínguez y Lowenthal 1996, Domínguez 1998, Diamond et al. 1999, Walker y Armony 2000, Pérez-Liñán 2001 y 2003, y consulta con expertos.

pliamente aceptado que todos los cargos públicos principales (presidentes y parlamentarios) sean asignados por medio de elecciones y que los gobernantes electos permanezcan en sus cargos durante la duración entera de sus mandatos. El traspaso dela presidencia se ha convertido en una práctica normal. Esto contrasta con la situación en América Latina duranteel período 1950-1980 y es una de las señales más claras de los grandes avances democráticos que han transformado el marco político de la región.

Existen sin embargo dos excepciones quemerecen atención. Una es observableen Chile, a raíz de la institución de los senadores designados que limita la posibilidad de que las preferencias de la mayoría ciudadana se vean representadas en el Parlamento. La otra excepción, de relevancia más amplia, se refiere a los intentos de desplazar del poder a gobernantes electos de formas que no siguen estrictamente las reglas constitucionales. Ejemplos de ello son: la clausura del Parlamento por el presidenteFujimori en Perú en 1992, el intento fallido de emular a Fujimori por parte del presidente Serrano en Guatemala en 1993, la remoción del presidente Bucaram en Ecuador en 1997, el asesinato del vicepresidente Argaña en 
LA PARTICIPACIÓN ELECTORAL, 1990-2002

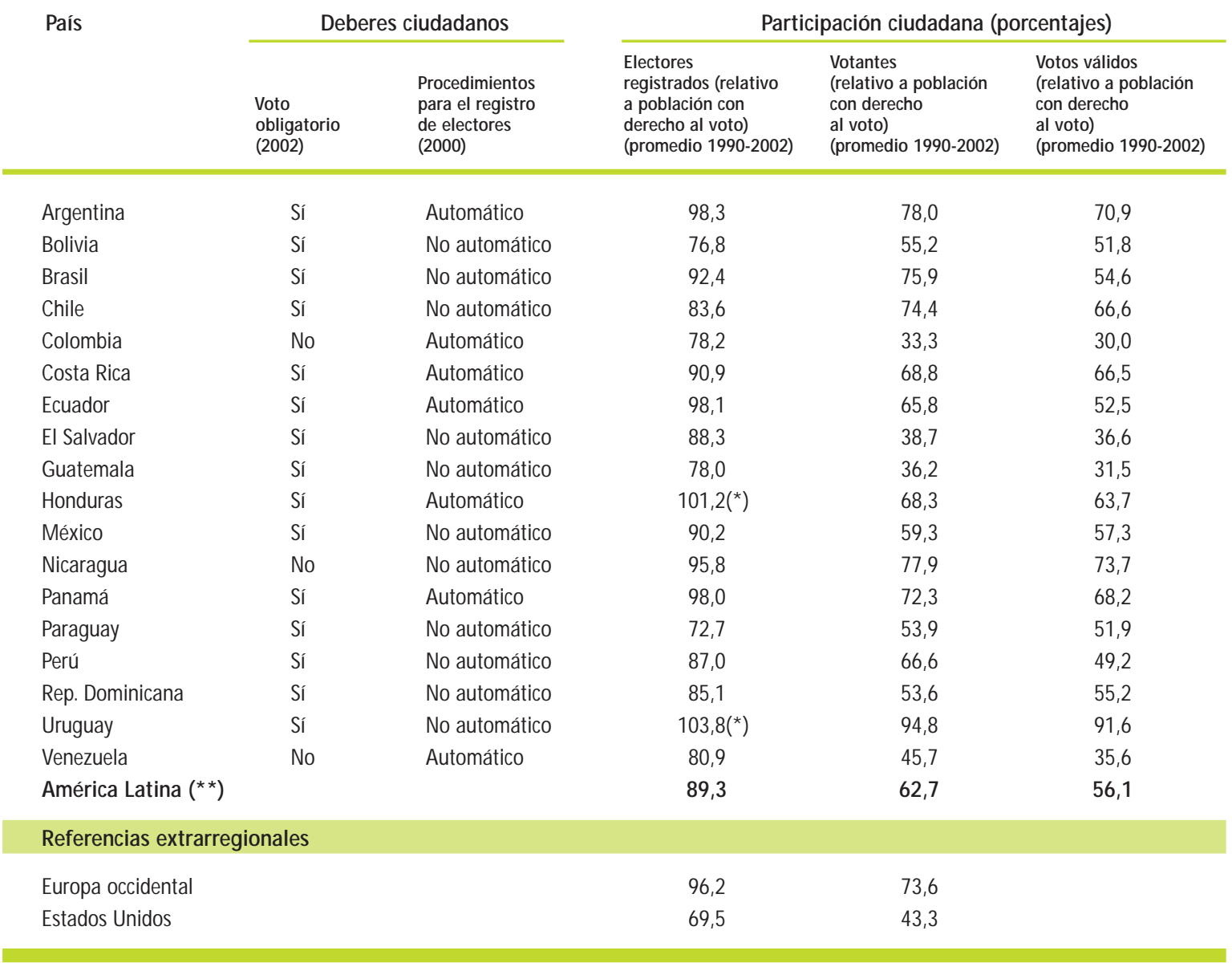

Notas:

$\left.{ }^{*}\right)$ Los números sobre electores registrados que exceden el 100 por ciento indican que el número de personas en los padrones electorales es mayor que el número de personas con el derecho al voto. Esta situación generalmente ocurre cuando los padrones electorales no han sido depurados adecuadamente.

$(* *)$ Los datos para la región son el promedio de todos los países.

Fuentes: Baeza 1998, EPIC 2002; Gratschew 2001 y 2002; International IDEA 2002b, León-Rosch 1998, Reyes 1998, varias Constituciones nacionales, y cálculos sobre la base de datos en el CD-ROM en Payne et al. 2002, y datos sobre las elecciones de 2001 y 2002 obtenidos de fuentes oficiales.

Paraguay en 1999, el desplazamiento del presidente Mahuad en Ecuador en 2000, la caída del presidente De la Rúa en la Argentina en 2001, y la crisis suscitada por el intento de remover al pre sidenteChávez en Venezuela en abril de2002. Estas situaciones no resultaron en clásicos golpes militares, como los que frecuentemente produjo la ruptura de regímenes democráticos en un pasado no tan lejano deAmérica Latina; sin embargo, ellos entrañan otra modalidad deinterrumpir el ejercicio del poder.

Los casos de restricción al principio de acceso democrático a los cargos públicos no son pocos. Entre 1990 y 2002, en seis de los dieciocho países hubo algún tipo de restricción de peso a este principio. La tendencia no es positiva, ya que los casos pasaron de uno en 1990 a tres en 2002.

\section{Otros indicadores del régimen democrático de acceso al gobierno}

M ás allá de los aspectos del régimen democrático incluidos en el IDE, existen otros indicadores relevantes.

\section{Participación electoral}

La participación ciudadana en el proceso electoral en América Latina, aunque con diferencias importantes entre países, es positiva. A nivel regional, 89,3 por ciento de los potenciales votantes están inscriptos en los registros elec- 
torales, 62,7 por ciento vota y 56,1 por ciento emite un voto válido. Estas cifras indican quees posible ganar elecciones sin que el candidato triunfante logre el respal do de la mayoría de los ciudadanos. Estos porcentajes de participación electoral se encuentran por debajo de los de Europa occidental pero por encima de los deEstados Unidos. Asimismo, los niveles latinoamericanos muestran tendencias estables durante períodos prolongados.

Algunos países de América Latina tienen muy baja participación electoral. El porcentaje de votantes en Venezuela $(45,7)$, El Salvador $(38,7)$, Guatemala $(36,2)$ y Colombia $(33,3)$ es bajo y motivo de preocupación. La participación en las elecciones de Bolivia, la República Dominicana y Paraguay, aunque mayor, es también baja. Si bien el abstencionismo no es un problema regional, ciertamente lo es en algunos países.

\section{Competencia electoral y selección de candidatos}

Otrosindicadores ofrecen información más detallada sobre el proceso de selección de los candidatos, una cuestión que afecta la competencia electoral. Se trata de un proceso complejo, que gira en torno de los partidos políticos. Éstos son, en toda la región, el vehículo privilegiado por el cual los candidatos se postulan para cargos públicos. Con relación a este tema, hay diferencias significativas entre los países latinoamericanos alrededor de tres cuestiones importantes:

- el monopolio de los partidos sobre las candidaturas a cargos públicos y la posibilidad de postulación de candidatos independientes;

- los requisitos para la formación de partidos nacionales;

- la exigencia legal de realizar elecciones internas en los partidos para la nominación de candidatos.

Como se observa en la tabla 8, un primer grupo de países presenta débiles barreras para la entrada de nuevos actores en la compe-
La participación ciudada na en el proceso electoral en América La tina, a unque con diferencias importantes entre países, es positiva.

tencia electoral y cierto desarrollo de una normativa y/o práctica de democracia partidaria interna. Ellos son: Colombia, Costa Rica, Honduras, M éxico, Paraguay, U ruguay y Venezuela. Un grupo intermedio está formado por la Argentina, Brasil, Chile, Ecuador, Panamá y la República Dominicana, donde barreras de entrada más altas coexisten con al gunos requisitos legales para la nominación de candidatos o con el poco uso de las primarias para escoger a los candidatos partidarios. En un tercer grupo de países, la selección de candidatos está altamente centralizada en manos de las elites partidarias: Bolivia, El Salvador, Guatemala, Nicaragua y Perú.

Ciertamente, los temas de barreras de entrada al proceso electoral y de democracia interna son complejos. Antes de ofrecer una evaluación comprensiva es necesario obtener mayor información que la actualmente disponible sobre candidaturas independientes, la formación de los partidos, los procedimientos seguidos por éstos para elegir sus candidatos, las condiciones bajo las cuales los precandidatos compiten en el interior de los partidos y las formas de fiscalización de las elecciones internas.

Un tema relevante que incide sobre la competencia electoral es la existencia de legislación que abra espacios políticos para las mujeres mediante la reserva de cupos de plazas en las listas partidarias para el Parlamento. En la última década, muchos países de la región han aprobado estetipo de legislación. Entre 1991 y 2003, once de dieciocho países en América Latina han introducido leyes de cupo que, por lo general, requieren que entre un 20 y un 40 por ciento de lugares en las listas parlamentarias partidarias sean asignados a mujeres. Esteme- 


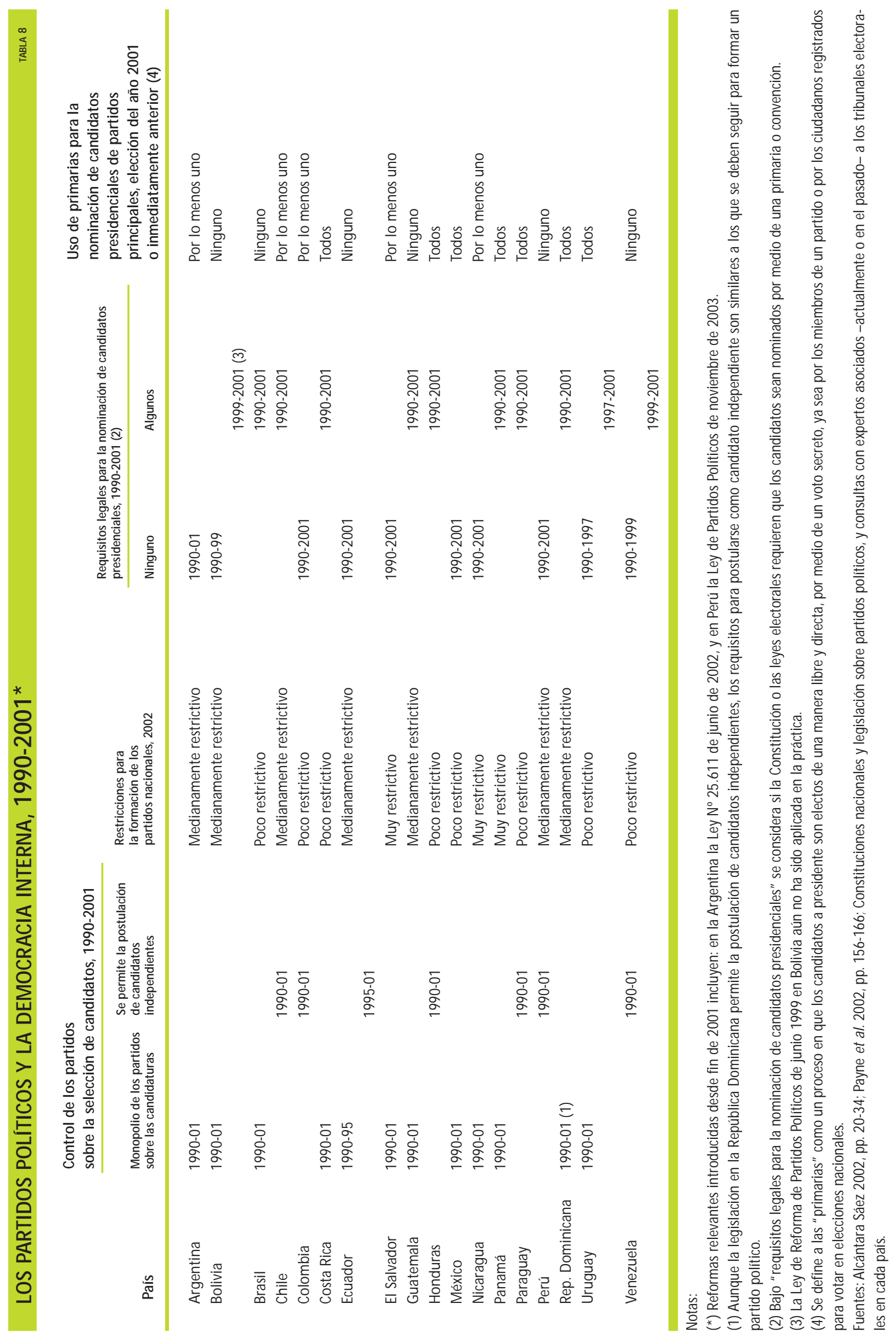




\begin{tabular}{|c|c|c|c|}
\hline \multicolumn{4}{|c|}{ CUPOS PARA CANDIDATAS A CARGOS } \\
\hline \multicolumn{3}{|c|}{ PARLAMENTARIOS, 2003} & \multirow{2}{*}{$\begin{array}{c}\text { TABLA } 9 \\
\text { Año } \\
\text { adoptado }\end{array}$} \\
\hline País & $\begin{array}{l}\text { Cámara baja } \\
\text { o única }\end{array}$ & Senado & \\
\hline Argentina & 30 & 30 & 1991 \\
\hline Bolivia & 30 & 25 & 1997 \\
\hline Brasil & 30 & 0 & 1997 \\
\hline Chile & 0 & 0 & - \\
\hline Colombia & 0 & 0 & - \\
\hline Costa Rica & 40 & - & 1996 \\
\hline Ecuador & 20 & - & 1997 \\
\hline El Salvador & 0 & - & - \\
\hline Guatemala & 0 & - & - \\
\hline Honduras & 30 & - & 2000 \\
\hline México & 30 & 30 & 2002 \\
\hline Nicaragua & 0 & - & - \\
\hline Panamá & 30 & - & 1997 \\
\hline Paraguay & 20 & 20 & 1996 \\
\hline Perú & 30 & - & 1997 \\
\hline Rep. Dominicana & 25 & - & 1997 \\
\hline Uruguay & 0 & 0 & - \\
\hline Venezuela & 0 & - & - \\
\hline
\end{tabular}

Notas: Los números son los porcentajes de las listas parlamentarias que cada partido debe asignar a mujeres. La información incluye sólo cupos mencionados en la legislación sobre partidos políticos y parlamentos, y excluye cuotas adoptadas en los reglamentos internos de los partidos. El signo menos indica que la información no se aplica.

Fuentes: CEPAL 1999, p. 69; M éndez-M ontalvo y Ballington 2002, OEA-Comisión Interamericana de Mujeres 2002, e International IDEA 2003.

canismo es una mejora importante, pues expresa un reconocimiento formal de la necesidad de crear mayores oportunidades para la inclusión de las mujeres. Sin embargo, es sólo un paso inicial en el tratamiento de las múltiples barreras que aún impiden que las mujeres compitan en la política en igualdad de oportunidades.

Otra cuestión relevante que afecta la competencia electoral son las reglas para el financiamiento político. Este tema tiene un impacto cada vez mayor sobre la naturaleza de la competencia el ectoral, porque tiene fuerte influencia sobre si las elecciones son, además de libres, justas, en tanto todos tienen la misma oportunidad de competir.

Los datos de financiamiento estatal revelan una situación muy variada. Para asegurar que el dinero no se convierta en un factor que desvirtúe el proceso electoral, algunos países recurren a la financiación pública de parte de la campaña electoral, pagando por voto emitido o facilitando el acceso a los medios de comunicación, sustancialmente la televisión. La mayoría de los países utiliza un sistema mixto de financiación, pero la tendencia es hacia mayores controles, siendo todavía difícil su instrumentación.

\section{Representación electoral}

Es importante también observar las características de las personas y los partidos que acceden a cargos públicos electos. En lo que respecta a las mujeres, la cantidad de parlamentarias ha aumentado. En poco más de una década, las mujeres han incrementado su nivel de representación de 8 a 15,5 por ciento, aunque con variaciones considerables entre los países.

El número deindígenas en las cámaras bajas 0 únicas del Poder Legislativo durante el período 2001-2002 ha sido de 0,8 por ciento (1 sobre un total de 120) en Perú; 3,3 por ciento ( 4 sobre 121) en Ecuador; 12,4 por ciento ( 14 sobre 113 ) en Guatemala, y 26,2 por ciento (34 sobre 130) en Bolivia. ${ }^{57}$ Estas cifras contrastan con el 43, 34,60 y 61 por ciento que representan aproximadamente las poblaciones indígenas en esos países, respectivamente. 58

Por último, el número de afrodescendientes en la cámara baja del Parlamento de Brasil fue de 0,8 por ciento ( 4 sobre un total de 479) entre 1983 y 1987; de 2,1 por ciento ( 10 sobre 487) entre 1987 y 1991; 3,2 por ciento (16 so-

57 Estas cifras pueden cambiar aun dentro del período indicado, según el criterio de apreciación de los observadores que se consulten. Comunicación personal, Luis Enrique López Hurtado, 2002, y Simón Pachano, FLACSO-Ecuador, 2003; y Estados Unidos, Departamento deEstado, 2001.

58 Estas cifras son un promedio de las estimaciones más altas y bajas que ofrecen M atos M ar, 1993, pp. 232-233; y M eentzen, 2002, p. 12. 


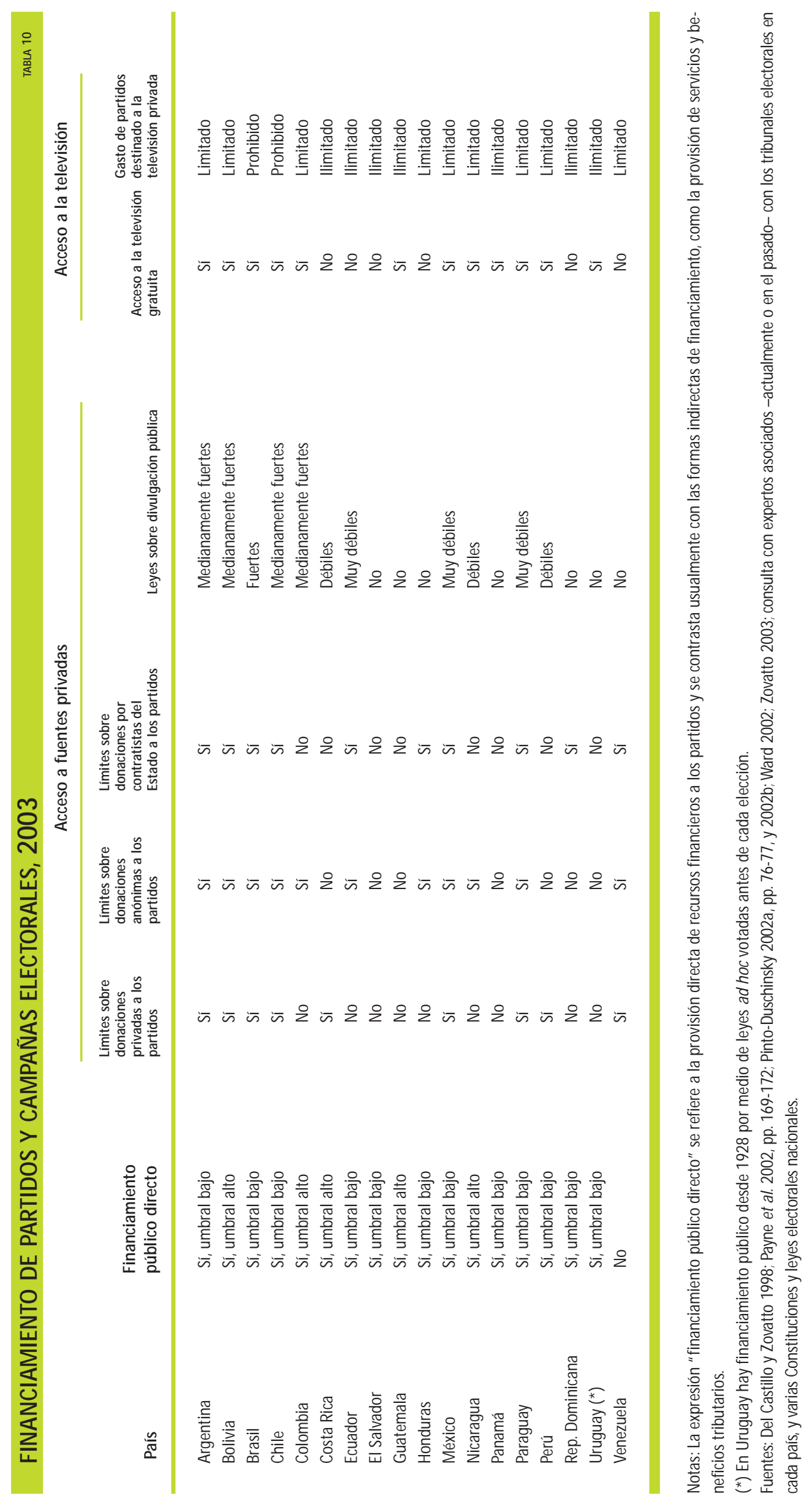




\begin{tabular}{|c|c|c|c|c|c|c|}
\hline \multirow[b]{2}{*}{ País } & \multicolumn{2}{|c|}{ Fines de la década de 1980} & \multicolumn{2}{|c|}{ Mediados de la década de 1990} & \multicolumn{2}{|c|}{ Última elección } \\
\hline & Año & $\%$ mujeres & Año & $\%$ mujeres & Año & $\%$ mujeres \\
\hline Argentina & 1989 & 6,3 & 1995 & 21,8 & 2003 & 34,1 \\
\hline Bolivia & 1989 & 9,2 & 1997 & 11,5 & 2002 & 18,5 \\
\hline Brasil & 1986 & 5,3 & 1994 & 7,0 & 2002 & 8,6 \\
\hline Chile & 1989 & 5,8 & 1997 & 10,8 & 2001 & 12,5 \\
\hline Colombia & 1986 & 4,5 & 1994 & 10,8 & 2002 & 12,0 \\
\hline Costa Rica & 1986 & 10,5 & 1994 & 14,0 & 2002 & 35,1 \\
\hline Ecuador & 1988 & 4,5 & 1994 & 4,5 & 2002 & 16,0 \\
\hline El Salvador & 1988 & 11,7 & 1994 & 10,7 & 2003 & 10,7 \\
\hline Guatemala & 1985 & 7,0 & 1994 & 7,5 & 2003 & 8,2 \\
\hline Honduras & 1989 & 10,2 & 1997 & 9,4 & 2001 & 5,5 \\
\hline México & 1988 & 12,0 & 1994 & 14,2 & 2003 & 22,6 \\
\hline Nicaragua & 1984 & 14,8 & 1996 & 9,7 & 2001 & 20,7 \\
\hline Panamá & 1989 & 7,5 & 1994 & 8,3 & 1999 & 9,9 \\
\hline Paraguay & 1989 & 5,6 & 1993 & 2,5 & 2003 & 8,8 \\
\hline Perú & 1985 & 5,6 & 1995 & 10,0 & 2001 & 17,5 \\
\hline República Dominicana & 1986 & 7,5 & 1994 & 11,7 & 2002 & 17,3 \\
\hline Uruguay & 1989 & 6,1 & 1994 & 7,1 & 1999 & 12,1 \\
\hline Venezuela & 1988 & 10,0 & 1993 & 5,9 & 2000 & 9,7 \\
\hline América Latina $(*)$ & & 8,0 & & 9,9 & & 15,5 \\
\hline
\end{tabular}

Notas: Los números son porcentajes de escaños obtenidos por mujeres en la Cámara baja o única del Parlamento. Los datos corresponden al resultado de la elección del año mencionado y pueden variar entre elecciones.

(*) Los datos para la región son el promedio de todos los países.

Fuente: IPU 1995, 2003.

bre 503) entre 1991 y 1995, y de 2,8 por ciento (15 sobre un total de 513 ) entre 1995 y 1999,59 mientras que los afrodescendientes son aproximadamente 44 por ciento de la población total de Brasil. 60

La representación puede ser examinada también desde la óptica de los partidos políticos, sobre los que presentamos varios indicadores relevantes. Una medida simple es el porcentaje de votos que reciben los partidos políticos que no logran obtener representación en la cámara baja o única del Parlamento. El promedio regional de 4,3 por ciento es relativamente bajo $y$, en varios países - Honduras, Uruguay, Paraguay y Brasil-, el porcentaje de votos válidos logrados por partidos sin representación parlamentaria es sumamente bajo. Pero en otros países - Costa Rica, Chile y Guatemala- , este porcentaje es al to, oscilan- do entre 7,8 y 12,3 por ciento. Similarmente, el índice de desproporcionalidad - una medida más compleja, que capta la relación de votos emitidos por partido y los escaños ganados en la cámara baja o única del Parlamento por estos partidos- muestra un panorama bastante positivo. El promedio regional, de 5,6 por ciento, es bastante moderado, indicando que existe un grado considerable de correspondencia o proporcionalidad entre la cantidad de votos y escaños recibidos por cada partido. Además, en varios países -Uruguay, Honduras, Nicaragua y Colombia-, este índice es particularmente bajo. Pero en otros países - Guatemala y Panamá-, el porcentaje es bastante alto, oscilando entre 11,9 y 13,9 por ciento. 


\begin{tabular}{|c|c|c|}
\hline \multicolumn{2}{|c|}{ PROPORCIONALIDAD EN LA } & TABLA 12 \\
\hline \multicolumn{3}{|c|}{ REPRESENTACIÓN VÍA PARTIDOS } \\
\hline \multicolumn{3}{|c|}{ POLÍTICOS, 1990-2002 } \\
\hline País & $\begin{array}{l}\text { Porcentaje de } \\
\text { votos ganados } \\
\text { por partidos sin } \\
\text { representación } \\
\text { parlamentaria } \\
\text { (promedio } \\
\text { 1990-2002) }\end{array}$ & $\begin{array}{l}\text { Índice de } \\
\text { desproporciona- } \\
\text { lidad electoral } \\
\text { (promedio } \\
\text { 1990-2002) }\end{array}$ \\
\hline Argentina & 3,8 & 6,7 \\
\hline Bolivia & 4,2 & 5,0 \\
\hline Brasil & 1,4 & 3,8 \\
\hline Chile & 8,9 & 7,2 \\
\hline Colombia & 4,8 & 3,0 \\
\hline Costa Rica & 7,8 & 5,0 \\
\hline Ecuador & 4,2 & 5,9 \\
\hline El Salvador & 2,2 & 4,7 \\
\hline Guatemala & 12,3 & 11,9 \\
\hline Honduras & 0,4 & 2,5 \\
\hline México & 3,7 & 5,7 \\
\hline Nicaragua & 2,4 & 2,7 \\
\hline Panamá & 4,9 & 13,9 \\
\hline Paraguay & 0,7 & 6,1 \\
\hline Perú & 3,5 & 5,2 \\
\hline Rep. Dominicana & 5,4 & 6,3 \\
\hline Uruguay & 0,5 & 0,6 \\
\hline Venezuela & 6,2 & 5,3 \\
\hline América Latina $(*)$ & 4,3 & 5,6 \\
\hline
\end{tabular}

Notas: La expresión "porcentajes de votos ganados por partidos sin representación parlamentaria" se refiere a votos emitidos en elecciones para la Cámara baja o única. La expresión "desproporcionalidad electoral" se refiere a la diferencia entre la cantidad de escaños y votos obtenidos por partidos. El índice de desproporcionalidad electoral se refiere a la Cámara baja o única, y es el resultado del método de mínimos cuadrados, que se calcula mediante la sumatoria de las diferencias entre los votos y los escaños obtenidos por cada partido, elevadas al cuadrado, y dividiendo el total entre dos. Finalmente, se toma la raíz cuadrada de este resultado. Una calificación baja puede ser interpretada como una indicación de que el número de escaños que obtienen los partidos es bastante proporcional al número de votos que reciben, mientras que una calificación alta indica que la relación entre escaños y votos es desproporcionada.

(*) Los datos para la región son el promedio de todos los países. Fuentes: Cálculos sobre la base de datos en CD-ROM en Payne et al. 2002, y datos sobre las elecciones de 2001 y 2002 obtenidos de fuentes oficiales.

\section{Balance del régimen de acceso democrático al gobierno}

De acuerdo con los componentes del IDE se observa que en América Latina:

- El derecho al voto es reconocido sin restricciones a los ciudadanos residentes en cada país.

- La práctica de elecciones limpias seha establecido como el patrón general. Es clara la tendencia hacia un mejoramiento en el componente de elecciones libres. Son aislados los episodios de irregularidades, fraude electoral eintimidación a votantes.

- Se han producido notables avances en lo que respecta a las elecciones como el medio de acceso a cargos públicos. Lo normal es que los cargos principales de la rama ejecutiva y legislativa del Estado (a nivel nacional) sean ocupados por medio de elecciones, y que la sucesión entre gobiernos sea de acuerdo con normas constitucionales, aun en los casos de crisis políticas o político-sociales que han incluido casos de renuncia de los primeros mandatarios electos. Pero existen excepciones a esta situación, especialmente al gunos intentos de desplazamiento de gobernantes electos por medios no constitucionales.

Entre los aspectos del régimen democrático no incluidos en el IDE observamos que:

- El nivel de participación ciudadana en procesos electorales es moderadamente alto en la región, aunque en al gunos países se detecta una tendencia hacia una menor participación electoral.

- No existen tendencias marcadas en cuanto a las barreras para entrar en la competencia electoral, ni sobre la participación ciudadana en la selección de los candidatos. Sin embargo, en varios países las elites partidarias centralizan las decisiones sobre la nominación de candidatos.

- Existeuna tendencia a introducir normas legales tendientes a crear mayores opor- 


\section{La petición ciudadana ante las instituciones públicas}

Aunque denieguen una petición ciudadana, el trato que dispensan los funcionarios públicos debe cumplir dos condiciones: respetar los derechos y la dignidad de las personas y amparar sus resoluciones dentro de un mando legal aprobado mediante normas democráticas. Lo contrario es el maltrato al ciudadano. Una proporción de los casos de maltrato puede deberse a razones contingentes, pero difícilmente éstas explican la existencia de patrones de maltrato en las interacciones entre ciudadanos y Estado. Por ello, el Informe explora si existen patrones de maltrato para indagar si ello obedece a una razón más estructural: la persistencia de modalidades poco democráticas en la organización y el funcionamiento de un Estado.

Un primer hallazgo del Informe es que, en 2002, una proporción minoritaria de las personas manifestó haber entrado en contacto con una institución pública para realizar algún tipo de trámite (39,9\%). De éstas, un muy alto porcentaje manifiesta haber recibido algún tipo de maltrato por parte de las y los funcionarios públicos (78\%). En la mayoría de los casos, se trató de experiencias de maltrato leves (tuvo que hacer largas filas, trámites innecesarios, le negaron información o le costó obtenerla). En estas experiencias pueden mediar factores como la falta de instalaciones adecuadas y la saturación de los servicios.

Un asunto preocupante es el extendido reporte de experiencias de maltrato "duro": casi una de cada cuatro personas que interactuaron con las instituciones públicas manifestaron haber sido humilladas, recibir trato irrespetuoso o habérsele solicitado una propina o coima (22,3\%). En estos casos, el derecho al trato equitativo y el respeto a la dignidad personal fueron, a los ojos de los entrevistados, vulnerados por las o los funcionarios públicos que los atendieron.

\begin{tabular}{|c|c|c|c|}
\hline \multicolumn{4}{|c|}{ EXPERIENCIAS DE TRATO A LAS PERSONAS } \\
\hline \multicolumn{4}{|c|}{ QUE HAN ACUDIDO A UNA ENTIDAD PÚBLICA } \\
\hline EN LOS ÚLTII & IOS 12 MESES, 2 & 002 & TABLA 13 \\
\hline Situación & $\begin{array}{l}\text { Experiencia en } \\
\text { el trato (1) }\end{array}$ & $\begin{array}{l}\text { Porcentaje } \\
\text { del total }\end{array}$ & $\begin{array}{l}\text { Porcentaje } \\
\text { de los que } \\
\text { han asistido }\end{array}$ \\
\hline \multirow[t]{5}{*}{ Han asistido } & $\begin{array}{l}\text { Malas experiencias } \\
\text { graves y leves }\end{array}$ & 6,1 & 15,4 \\
\hline & $\begin{array}{l}\text { Malas experiencias } \\
\text { graves }\end{array}$ & 2,8 & 6,9 \\
\hline & $\begin{array}{l}\text { Malas experiencias } \\
\text { leves }\end{array}$ & 22,2 & 55,7 \\
\hline & $\begin{array}{l}\text { Sin malas } \\
\text { experiencias (2) }\end{array}$ & 8,8 & 22,0 \\
\hline & Total & 39,9 & 100,0 \\
\hline No han asistido & & 60,1 & \\
\hline Total & & 100,0 & \\
\hline
\end{tabular}

Nota: La columna "porcentaje del total" se basa en los 19.536 entrevistados que indicaron haber asistido o no haber asistido a una institución pública en los últimos doce meses. La columna " porcentaje de los que han asistido" se basa únicamente en los 7.790 entrevistados que declararon haber asistido en los últimos doce meses a una institución pública y que, por lo tanto, son los que tienen experiencias en el trato recibido.

(1) Malas experiencias leves: largas filas, trámites innecesarios, le costó obtener información o se la negaron. Malas experiencias graves: le pidieron propina, se sintió humillado o fueron descorteses 0 irrespetuosos en el trato.

(2) Se supone que no tuvieron malas experiencias si en P12U respondieron que sí habían asistido a una institución pública y en P13U no responden. Ésto por cuanto la pregunta P13U solamente propone alternativas negativas.

Fuente: Procesamiento de pregunta P13U de la Sección Propietaria del PNUD en Latinobarómetro 2002. 
PODERES FORMALES PRESIDENCIALES, 2002

\begin{tabular}{|c|c|c|c|c|c|c|}
\hline \multirow{2}{*}{$\begin{array}{l}\text { País } \\
\text { Argentina }\end{array}$} & \multicolumn{2}{|c|}{ Poderes no legislativos (1) } & \multicolumn{2}{|c|}{ Poderes legislativos (2) } & \multicolumn{2}{|c|}{$\begin{array}{l}\text { Índice de poderes } \\
\text { presidenciales formales (3) }\end{array}$} \\
\hline & 0,38 & Medio bajo (*) & 0,44 & Medio alto $(*)$ & 0,41 & Medio alto $(*)$ \\
\hline Bolivia & 0,50 & Medio alto & 0,23 & Medio bajo & 0,37 & Medio bajo \\
\hline Brasil & 0,50 & Medio alto & 0,62 & Muy alto & 0,56 & Muy alto \\
\hline Chile & 0,50 & Medio alto & 0,66 & Muy alto & 0,58 & Muy alto \\
\hline Colombia & 0,00 & Muy bajo & 0,59 & Muy alto & 0,29 & Muy bajo \\
\hline Costa Rica & 0,50 & Medio alto & 0,23 & Medio bajo & 0,36 & Medio bajo \\
\hline Ecuador & 0,50 & Medio alto & 0,59 & Muy alto & 0,55 & Muy alto \\
\hline El Salvador & 0,50 & Medio alto & 0,33 & Medio bajo & 0,42 & Medio alto \\
\hline Guatemala & 0,25 & Medio bajo & 0,29 & Medio bajo & 0,27 & Muy bajo \\
\hline Honduras & 0,50 & Medio alto & 0,25 & Medio bajo & 0,38 & Medio bajo \\
\hline México & 0,50 & Medio alto & 0,24 & Medio bajo & 0,37 & Medio alto \\
\hline Nicaragua & 0,50 & Medio alto & 0,25 & Medio bajo & 0,38 & Medio bajo \\
\hline Panamá & 0,50 & Medio alto & 0,43 & Medio alto & 0,46 & Medio alto \\
\hline Paraguay & 0,50 & Medio alto & 0,19 & Muy bajo & 0,34 & Medio bajo \\
\hline Perú & 0,13 & Muy bajo & 0,50 & Medio alto & 0,31 & Medio bajo \\
\hline Rep. Dominicana & 0,50 & Medio alto & 0,37 & Medio bajo & 0,44 & Medio alto \\
\hline Uruguay & 0,38 & Medio bajo & 0,38 & Medio & 0,38 & Medio bajo \\
\hline Venezuela & 0,19 & Muy bajo & 0,30 & Medio bajo & 0,25 & Muy bajo \\
\hline América Latina & 0,41 & & 0,38 & & 0,40 & \\
\hline \multicolumn{7}{|c|}{ Referente extrarregional } \\
\hline Estados Unidos & 0,48 & Medio alto & 0,15 & Muy bajo & 0,31 & Medio bajo \\
\hline
\end{tabular}

Notas:

(1) Esta medida es el promedio entre los puntajes asignados según la capacidad de censura legislativa sobre el gabinete y la capacidad de disolución del Congreso por parte del Poder Ejecutivo. Las escalas se estandarizaron entre 0 y 1 para posibilitar su comparación.

(2) Promedio ponderado de los poderes legislativos del presidente.

(3) El índice general de los poderes presidenciales formales es un promedio de los poderes presidenciales no-legislativos y legislativos.

$\left(^{*}\right)$ El nivel de estos poderes es considerado desde una perspectiva regional comparada. Un nivel "muy alto" en cualquiera de las dimensiones de los poderes implica que ese país está por sobre la desviación estándar de la media regional. "M edio alto" implica que su calificación [score] cae entre el promedio regional y la desviación estándar positiva. El mismo método es utilizado para calificar a los niveles "medio bajo" y "muy bajo".

Fuentes: Shugart y Carey 1992, Mainwaring y Shugart 1997, Carey y Shugart 1998, Samuels 2000; Altman 2001 y 2002; Payne et al. 2002, y Universidad de Georgetown y OEA 2002.

tunidades de inclusión ciudadana. Éstees el caso de leyes promulgadas en la mayoría de los países latinoamericanos, queestablecen cupos de representación femenina en las listas parlamentarias.

- Entre el fin de la década de los ochenta y el presente, las mujeres han incrementado su nivel de representación en los Parlamentos deAmérica Latina, pero el nivel actual es todavía muy inferior al peso demográfico femenino. Las deficiencias son aun más significativas en la representación parlamentaria de los indígenas y afrodescendientes.
- Lossistemas electorales permiten un grado considerable de proporcionalidad entre la fuerza electoral y la representación parlamentaria de los partidos políticos.

- Pocos países han aprobado legislación sobrefinanciamiento departidos políticosy campañas electorales, que contemple un fácil acceso a fondos públicos y una regulación eficaz del dinero en la política.

\section{Otras dimensiones de la ciudadanía política}

La ciudadanía política no sólo gira en torno al vínculo entre votantes y tomadores de decisiones públicas, sino también a la orienta- 
ción de los que toman estas decisiones - electos o no-: hacia el bien público o hacia fines privados. Por ello, un aspecto importante a considerar es el del control de la gestión de los funcionarios públicos y su obligación de rendir cuentas de ella en debido tiempo y forma. En esta parte analizamos, en primer lugar, los poderes constitucionales clásicos (Ejecutivo, Legislativo y Judicial), luego los organismos públicos especializados en el control horizontal de las actividades del Estado y, por último, algunos mecanismos de democracia directa que pueden ofrecer oportunidades de participación ciudadana en el control y la formulación de políticas.

\section{Poderes constitucionales clásicos}

Un primer aspecto del tema del control dela política es la relación entre los poderes constitucionales clásicos. El control de la política es más eficaz cuando existe una verdadera división de poderes, cada uno de ellos legalmente dotado de facultades para controlar y sancionar la conducta de los otros.

La relación entre los poderes Ejecutivo y Legislativo es, quizá, la pieza más importante dela relación entre los poderes del Estado. Esto es particularmente cierto en América Latina debido a su tradición de presidencialismo, autoritario o no, y su tendencia a imponerse sobre el Congreso.

Anotamos que los poderes formales de los presidentes latinoamericanos siguen siendo relativamente altos comparados con el sistema presidencialista clásico, el de Estados Unidos.

Otro aspecto clave es el poder de la rama judicial del gobierno y su grado de independencia respecto de los otros poderes. Muchos países latinoamericanos han realizado reformas constitucionales y legales encaminadas a fortalecer la independencia del Poder Judicial. A pesar de estas reformas, en el proceso de nominación de los magistrados de la Corte Suprema, el Ejecutivo aún retiene importantes poderes en varios países. No obstante, el
El control de la política es más eficaz cua ndo existe una verdadera división de poderes, cada uno de ellos legalmente dotado de facultades para controla r y sancionar la conducta de los otros.

criterio cada vez más generalizado es que los magistrados sean identificados inicialmente por Consejos de la Judicatura, o M agistratura, un mecanismo que tiene el potencial -por cierto aún no plenamente demostrado- de reducir la politización del proceso de selección y aumentar el profesionalismo e independencia de este poder. En casi todos los países existe otro órgano, generalmente en el ámbito del Congreso, encargado de seleccionar los candidatos de una lista de nominados y ratificar estas nominaciones por mayoría simple o calificada.

En resumen, los indicadores de la tabla 14 sugieren que, al menos formalmente, la rama judicial del Estado cuenta con un grado considerable de poder e independencia en sus funciones. Sin embargo, la información disponible no nos permite formular un juicio cierto sobre la independencia real de los poderes judiciales en América Latina, ya que estos indicadores captan sólo aspectos formales y con frecuencia ignoran algunas realidades. Aún no se cuenta con una buena medida, ampliamente aceptada, respecto del grado de independencia del Poder Judicial. Como surge de diversas encuestas y de las opiniones de expertos, se han logrado en materia de independencia del Poder Judicial algunos avances notables, pero todavía subsisten graves problemas en América Latina. 61

Otro tema que deberá merecer consideración cuando exista adecuada información es el 
PODERES JUDICIALES, 2002

Condiciones para el nombramiento de magistrados

\begin{tabular}{|c|c|c|c|c|c|}
\hline País & $\begin{array}{l}\text { Textos } \\
\text { constitucionales }\end{array}$ & $\begin{array}{l}\text { Identificación inicial de } \\
\text { candidatos }\end{array}$ & $\begin{array}{l}\text { Selección y } \\
\text { nombramiento }\end{array}$ & $\begin{array}{l}\text { Período de } \\
\text { nombramiento }\end{array}$ & $\begin{array}{l}\text { Control de } \\
\text { constitucionalidad }\end{array}$ \\
\hline Argentina & $\begin{array}{l}\text { Constitución 1853, } \\
\text { reforma de } 1994\end{array}$ & $\begin{array}{l}\text { Ejecutivo nomina } \\
\text { candidatos }(*)\end{array}$ & $\begin{array}{l}\text { Senado nombra ( } 2 / 3 \\
\text { de votos) }\end{array}$ & $\begin{array}{l}\text { Vitalicio (retiro } \\
\text { obligatorio } \\
\text { a los } 75 \text { años) }\end{array}$ & Corte Suprema \\
\hline Brasil & $\begin{array}{l}\text { Constitución 1988, } \\
\text { reforma de } 1998\end{array}$ & $\begin{array}{l}\text { Ejecutivo nomina } \\
\text { candidatos }\end{array}$ & $\begin{array}{l}\text { Senado nombra } \\
\text { (mayoría absoluta) }\end{array}$ & $\begin{array}{l}\text { Vitalicio (retiro } \\
\text { obligatorio } \\
\text { a los } 70 \text { años) }\end{array}$ & $\begin{array}{l}\text { Tribunal Supremo } \\
\text { Federal }\end{array}$ \\
\hline Colombia & $\begin{array}{l}\text { Constitución 1991, } \\
\text { reforma de } 1997\end{array}$ & $\begin{array}{l}\text { Consejo Superior } \\
\text { de la Judicatura } \\
\text { presenta lista }\end{array}$ & $\begin{array}{l}\text { Corte Suprema } \\
\text { selecciona } \\
\text { de la lista y nombra } \\
\text { (mayoría absoluta) }\end{array}$ & 8 años, sin reelección & Corte Constitucional \\
\hline Costa Rica & $\begin{array}{l}\text { Constitución 1949, } \\
\text { reformas } \\
\text { de } 1954 \text { y de } 1993\end{array}$ & $\begin{array}{l}\text { Congreso identifica } \\
\text { candidatos }\end{array}$ & $\begin{array}{l}\text { Congreso selecciona } \\
\text { de la lista y nombra }\end{array}$ & $\begin{array}{l}8 \text { años, reelección } \\
\text { permitida }\end{array}$ & $\begin{array}{l}\text { Sala especializada de } \\
\text { Corte Suprema }\end{array}$ \\
\hline Guatemala & $\begin{array}{l}\text { Constitución 1985, } \\
\text { reforma de } 1994\end{array}$ & $\begin{array}{l}\text { Comisión de } \\
\text { Postulación, de } \\
\text { composición } \\
\text { gubernamental } \\
\text { y no gubernamental, } \\
\text { presenta lista }\end{array}$ & $\begin{array}{l}\text { Congreso selecciona } \\
\text { de la lista y nombra } \\
\text { (2/3 de votos) }\end{array}$ & $\begin{array}{l}5 \text { años, reelección } \\
\text { permitida }\end{array}$ & Corte Constitucional \\
\hline Honduras & $\begin{array}{l}\text { Constitución 1982, } \\
\text { reforma de } 2000\end{array}$ & $\begin{array}{l}\text { Junta Nominadora, } \\
\text { de presencia no } \\
\text { gubernamental, } \\
\text { presenta lista }\end{array}$ & $\begin{array}{l}\text { Congreso selecciona } \\
\text { de la lista y nombra } \\
\text { (2/3 de votos) }\end{array}$ & $\begin{array}{l}7 \text { años, reelección } \\
\text { sucesiva }\end{array}$ & Sala Constitucional \\
\hline México & $\begin{array}{l}\text { Constitución 1917, } \\
\text { reformas de 1992, } \\
1993 \text { y } 1994\end{array}$ & $\begin{array}{l}\text { Ejecutivo presenta } \\
\text { lista }\end{array}$ & $\begin{array}{l}\text { Senado selecciona de } \\
\text { la lista y nombra ( } 2 / 3 \\
\text { de votos presentes) }\end{array}$ & 15 años, sin reelección & Corte Suprema \\
\hline
\end{tabular}




\begin{tabular}{|c|c|c|c|c|c|}
\hline \multicolumn{5}{|c|}{ PODERES JUDICIALES, 2002} & \multirow[t]{2}{*}{ TABLA 15 (CONT, DE P. 94) } \\
\hline \multirow[b]{2}{*}{ País } & \multirow[b]{2}{*}{$\begin{array}{l}\text { Textos } \\
\text { constitucionales }\end{array}$} & \multicolumn{3}{|c|}{ Condiciones para el nombramiento de magistrados } & \\
\hline & & $\begin{array}{l}\text { Identificación inicial de } \\
\text { candidatos }\end{array}$ & $\begin{array}{l}\text { Selección y } \\
\text { nombramiento }\end{array}$ & $\begin{array}{l}\text { Período de } \\
\text { nombramiento }\end{array}$ & $\begin{array}{l}\text { Control de } \\
\text { constitucionalidad }\end{array}$ \\
\hline Panamá & $\begin{array}{l}\text { Constitución 1972, } \\
\text { reformas } \\
\text { de } 1978,1983 \text { y } 1984\end{array}$ & $\begin{array}{l}\text { Presidente y gabinete } \\
\text { presentan lista }\end{array}$ & $\begin{array}{l}\text { Congreso nombra } \\
\text { (mayoría absoluta) }\end{array}$ & $\begin{array}{l}10 \text { años, reelección } \\
\text { permitida }\end{array}$ & Corte Suprema \\
\hline Paraguay & Constitución 1992 & $\begin{array}{l}\text { Consejo de } \\
\text { Magistrados presenta } \\
\text { lista }\end{array}$ & $\begin{array}{l}\text { Senado nombra con } \\
\text { consentimiento del } \\
\text { Ejecutivo }\end{array}$ & $\begin{array}{l}5 \text { años, la reelección } \\
\text { implica período } \\
\text { vitalicio (retiro } \\
\text { obligatorio } 75 \text { años) }\end{array}$ & Corte Suprema \\
\hline Perú & Constitución 1993 & $\begin{array}{l}\text { Consejo Nacional de } \\
\text { la Magistratura } \\
\text { identifica candidatos }\end{array}$ & $\begin{array}{l}\text { Consejo Nacional de } \\
\text { la Magistratura } \\
\text { aprueba ( } 2 / 3 \text { de votos) }\end{array}$ & $\begin{array}{l}\text { Retiro obligatorio } \\
\text { a los } 70 \text { años }\end{array}$ & Tribunal Constitucional \\
\hline Rep. Dominicana & $\begin{array}{l}\text { Constitución 1966, } \\
\text { reforma de } 1995\end{array}$ & $\begin{array}{l}\text { Consejo Nacional de la } \\
\text { Judicatura identifica } \\
\text { candidatos }\end{array}$ & $\begin{array}{l}\text { Consejo Nacional de la } \\
\text { Judicatura nombra } \\
\text { (mayoría absoluta) }\end{array}$ & $\begin{array}{l}\text { Vitalicio (retiro } \\
\text { obligatorio } \\
75 \text { años) }\end{array}$ & Corte Suprema \\
\hline Uruguay & Constitución 1967 & $\begin{array}{l}\text { Congreso identifica } \\
\text { candidatos }\end{array}$ & $\begin{array}{l}\text { Congreso en pleno } \\
\text { (ambas Cámaras) } \\
\text { aprueba } \\
\text { (2/3 de votos) }\end{array}$ & $\begin{array}{l}10 \text { años, reelección } \\
\text { alterna } 5 \text { años luego } \\
\text { de concluido el } \\
\text { período (retiro } \\
\text { obligatorio } 75 \text { años) }\end{array}$ & Corte Suprema \\
\hline Venezuela & Constitución 1999 & $\begin{array}{l}\text { Comité de Postulaciones } \\
\text { Judiciales presenta } \\
\text { lista }\end{array}$ & $\begin{array}{l}\text { Congreso selecciona } \\
\text { de la lista y nombra }\end{array}$ & 12 años, sin reelección & $\begin{array}{l}\text { Tribunal Supremo de } \\
\text { Justicia }\end{array}$ \\
\hline
\end{tabular}

Nota:

(*) En la Argentina, el proceso de nombramiento de magistrados de la Corte Suprema ha sido modificado por el Decreto № 222 del 19 de junio de 2003.

Fuentes: Proyecto Estado de la Nación 1999, p. 199; Skaar 2001, Apéndice 1; PNUD 2002b, 78, 81; OEA-CIDH 2003; Instituto de Derecho Público Comparado 2003; Comisión Andina de Juristas 2003, y varias Constituciones nacionales.

uso que, al menos en algunos países, hace el Poder Judicial de su creciente independencia. Por sí misma, esa independencia no previene ( $y$, en varias hipótesis, puede facilitar) tentaciones corporativas de interés sectorial y hasta la corrupción de este poder. Esperamos que los ingentes esfuerzos y las abultadas sumas de ayuda internacional que se están dedicando a la reforma del Poder Judicial tomen con mayor cuidado que hasta ahora la preocupación que dejamos enunciada. La independencia, el creciente profesionalismo y un adecuado poder de esta rama del Estado adquieren pleno sentido cuando sirven generosamentea la instauración, no ya de un estado de derecho, sino de un estado democrático de derecho.

\section{Agencias especializadas de control}

Otras entidades estatales que contribuyen al control político son las especializadas en el control horizontal de las actividades del Estado. 62 Estos organismos se distinguen de los poderes constitucionales clásicos por sus funciones más delimitadas y específicas.

Un primer tipo de organismosson los encargados del control de la hacienda pública, es de- 


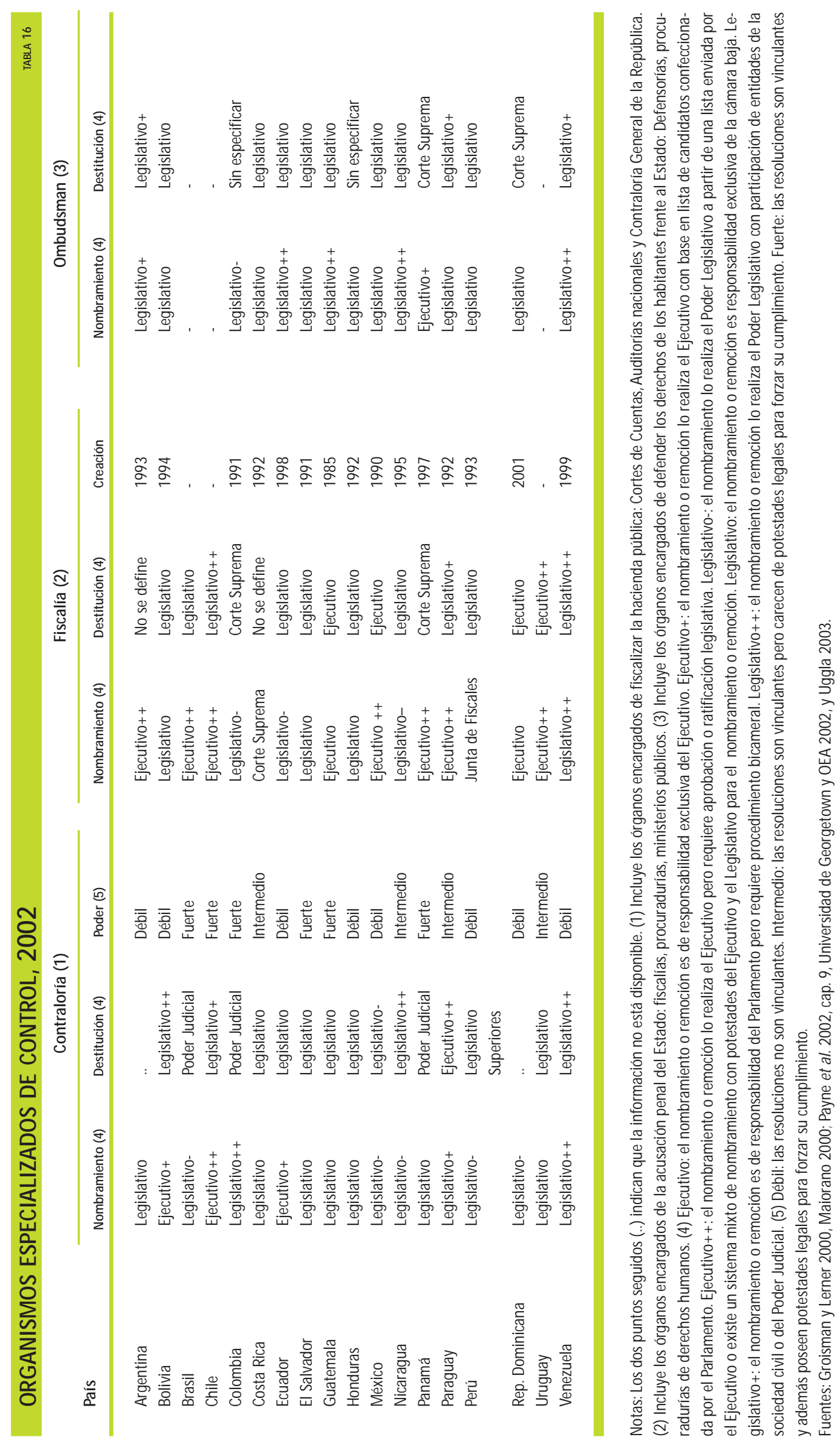


RECUADRO 22

\section{Experiencias de participación en gobiernos locales}

Durante la década de 1990 se produjo un proceso de descentralización que abrió canales nuevos para la participación ciudadana. Algunos de los ejemplos más notables son las experiencias de participación popular de Bolivia, de presupuesto participativo en Porto Alegre y Villa El Salvador, y de promoción de la cultura cívica en Bogotá. Estas experiencias tienen elementos comunes. Son el resultado de movimientos sociales fuertes. Tienen como objetivo el mejoramiento de la calidad de vida, las capacidades y la autonomía de sus participantes. Y, aunque se desenvuelven en un contexto de cultura patrimonialista, representan un claro quiebre con los mecanismos de distribución populista, una práctica común en América Latina que lleva a la cooptación política. Como parte de un proyecto del Programa de las Naciones Unidas para el Desarrollo (PNUD) orientado a promover una agenda de gobernabilidad local en América Latina, se han identificado y documentado muchas de estas experiencias exitosas de participación en gobiernos locales, que pueden consultarse en el sitio de Internet www.logos.undp.org.

cir, de que los fondos públicos se empleen de conformidad con las normas y los procedimientos legales: contralorías generales, auditorías y tribunales de cuentas. Todos los países latinoamericanos cuentan con instituciones que desempeñan estas funciones. Sin embargo, existen importantes diferencias en cuanto a la independencia de estos organismos del Poder Ejecutivo (el poder del Estado objeto principal de su control) y el peso real de la fiscalización. En la mayoría de los países de la región, las máximas autoridades de las contralorías son nombradas por el Poder Legislativo, con condiciones específicas tales como votación calificada, recomendación previa de la Corte Suprema y, en ciertos casos, recomendación de organismos no gubernamentales. Mientras que en tres países -Boli- via, Chile y Ecuador-, el Poder Ejecutivo nombra directamente a estas autoridades. En doce de los dieciocho países, los poderes de las contralorías son débiles o intermedios, sus resoluciones no son vinculanteso, si lo son, carecen de potestad legal para forzar su cumplimiento.

Un segundo tipo de organismos son las fiscalías, procuradurías o ministerios públicos, que se ocupan de la representación legal del Estado y, en varios países, tienen a su cargo la acción penal pública. Sobre ellas se cuenta con menos información. A diferencia de las contralorías, no todos los países tienen fiscalías. El Poder Ejecutivo intervienetanto en el nombramiento como en la remoción de su principal responsable.

Por último, desde 1990 se han creado defensorías del pueblo en casi toda la región, con excepción de Brasil, Chile y Uruguay. Estas oficinas son un nuevo órgano de control que se distingue de los descriptos más arriba por recibir denuncias ciudadanas, que potencialmente operan no sólo como agentes de control horizontal sino también de control vertical. En general, el nombramiento y remoción de sus responsables corresponden al Poder Legislativo. La consolidación y el éxito de las defensorías del pueblo en América Latina son muy diversos. 63

La existencia de estos órganos expresa una tendencia positiva. Sus tareas incluyen, formalmente, el control y, en algunos casos, la sanción defuncionarios públicos. Ofrecen canal es adicionales a los poderes constitucionales clásicos para el control de la gestión política, aunque en algunos países carecen de los recursos necesarios para cumplir sus funciones adecuadamente $y / 0$ sus actividades son de hecho controladas por el Poder Ejecutivo. Es por eso que la existencia de estos órganos por sí misma no puede interpretarse necesariamente como evidencia de mayor control efectivo de la gestión pública.

\section{Mecanismos de democracia directa}

Los mecanismos de democracia directa ofre cen a los ciudadanos oportunidades para con- 


\begin{tabular}{|c|c|c|c|c|c|c|c|c|}
\hline \multicolumn{8}{|c|}{ MECANISMOS DE DEMOCRACIA DIRECTA DESDE ARRIBA, 1978-2002 } & \multirow[t]{2}{*}{ TABLA 17} \\
\hline \multirow[b]{2}{*}{ País } & \multicolumn{4}{|c|}{ Plebiscito } & \multicolumn{3}{|c|}{ Plebiscito no vinculante } & \\
\hline & Existencia & Uso & Veces usado & Éxito en uso & Existencia & Uso & Veces usado & Éxito en uso \\
\hline Argentina & Sí & No & - & - & Sí & Sí & 1 & 1 \\
\hline Bolivia & No & - & - & - & No & - & - & - \\
\hline Brasil & Sí & Sí & 2 & 0 & .. & .. & .. & .. \\
\hline Chile & Sí & No & - & - & .. & .. & .. & .. \\
\hline Colombia & Sí & Sí & 1 & 1 & .. & .. & .. & .. \\
\hline Costa Rica & Sí & No & - & - & .. & .. & .. & .. \\
\hline Ecuador & Sí & Sí & $17(2)$ & 14 & Sí & Sí & $16(3)$ & 6 \\
\hline El Salvador & Sí (1) & No & - & - & .. & .. &.. & .. \\
\hline Guatemala & Sí & Sí & 5 & 1 & .. & .. & .. & .. \\
\hline Honduras & No & - & - & - & .. & .. & .. & .. \\
\hline México & No & - & - & - & .. & .. & .. & .. \\
\hline Nicaragua & Sí & No & - & - & .. & .. & .. & .. \\
\hline Panamá & Sí & Sí & 2 & 0 & .. & .. & .. & .. \\
\hline Paraguay & Sí & No & - & - & .. & .. & .. & .. \\
\hline Perú & Sí & Sí & 1 & 1 & .. & .. & .. & .. \\
\hline Rep. Dominicana & No & - & - & - & .. & .. & .. & .. \\
\hline Uruguay & Sí & Sí & 2 & 1 & No & - & - & - \\
\hline Venezuela & Sí & Sí & 3 & 3 &. & .. & .. &. \\
\hline América Latina $(*)$ & 14 & 8 & 33 & 21 & 2 & 2 & 17 & 7 \\
\hline
\end{tabular}

Notas: La información se refiere sólo a mecanismos de democracia directa oficiales y en el ámbito nacional. Las fechas cubiertas abarcan desde 1978 en adelante o desde que estos mecanismos fueron creados, pero sólo registra su uso dentro del contexto de regímenes democráticos. El guión corto (-) indica que la información no es relevante; los dos puntos seguidos (..), que la información no está disponible.

(1) Sólo con respecto a la integración centroamericana.

(2) Catorce de éstos fueron hechos en una fecha, en mayo de 1997.

(3) Quince de éstos fueron hechos en dos ocasiones, en agosto de 1994 y de noviembre 1995.

(*) Los datos para la región se refieren al total de países que permiten el uso de mecanismos de democracia directa y al total de veces que estos mecanismos han sido usados.

Fuentes: Altman 2002, p. 8, y varias Constituciones y leyes electorales nacionales.

tribuir a la fiscalización y gestión delos asuntos políticos. 64 Ellos pueden ser clasificados en dos tipos. El primero comprende procesos activados "desde arriba," es decir, por agentes del Estado, tales como los plebiscitos vinculantes y no vinculantes. El segundo tipo incluye procesos activados "desde abajo," por los propios ciudadanos, tales como iniciativas vinculantes y no vinculantes, referendos y peticiones de revocación de mandato.

En cuanto a la existencia legal y el uso de estos mecanismos, los datos permiten distinguir tres grupos de países:
- Aquellos donde los mecanismos de de mocracia directa simplementeno existen, como en Bolivia, Honduras, M éxico y la República Dominicana.

- Aquellos donde existen algunos de estos mecanismos, pero hasta ahora no han sido empleados, como en Chile, Costa Rica, El Salvador, Nicaragua y Paraguay.

- Los países donde estos mecanismos son reconocidos legalmente y se registran experiencias de uso. Aquí hallamos nueve casos, en la mayoría de los cuales -Brasil, Ecuador, Guatemala, Panamá,

64 Como indicamos, los ciudadanos también pueden contribuir indirectamenteal control político, por ejemplo, cuando presentan denuncias acerca de la conducta de agentes estatales y activan de esa forma investigaciones por parte de los respectivos organismos. 
MECANISMOS DE DEMOCRACIA DIRECTA DESDE ABAJ0, 1978-2002

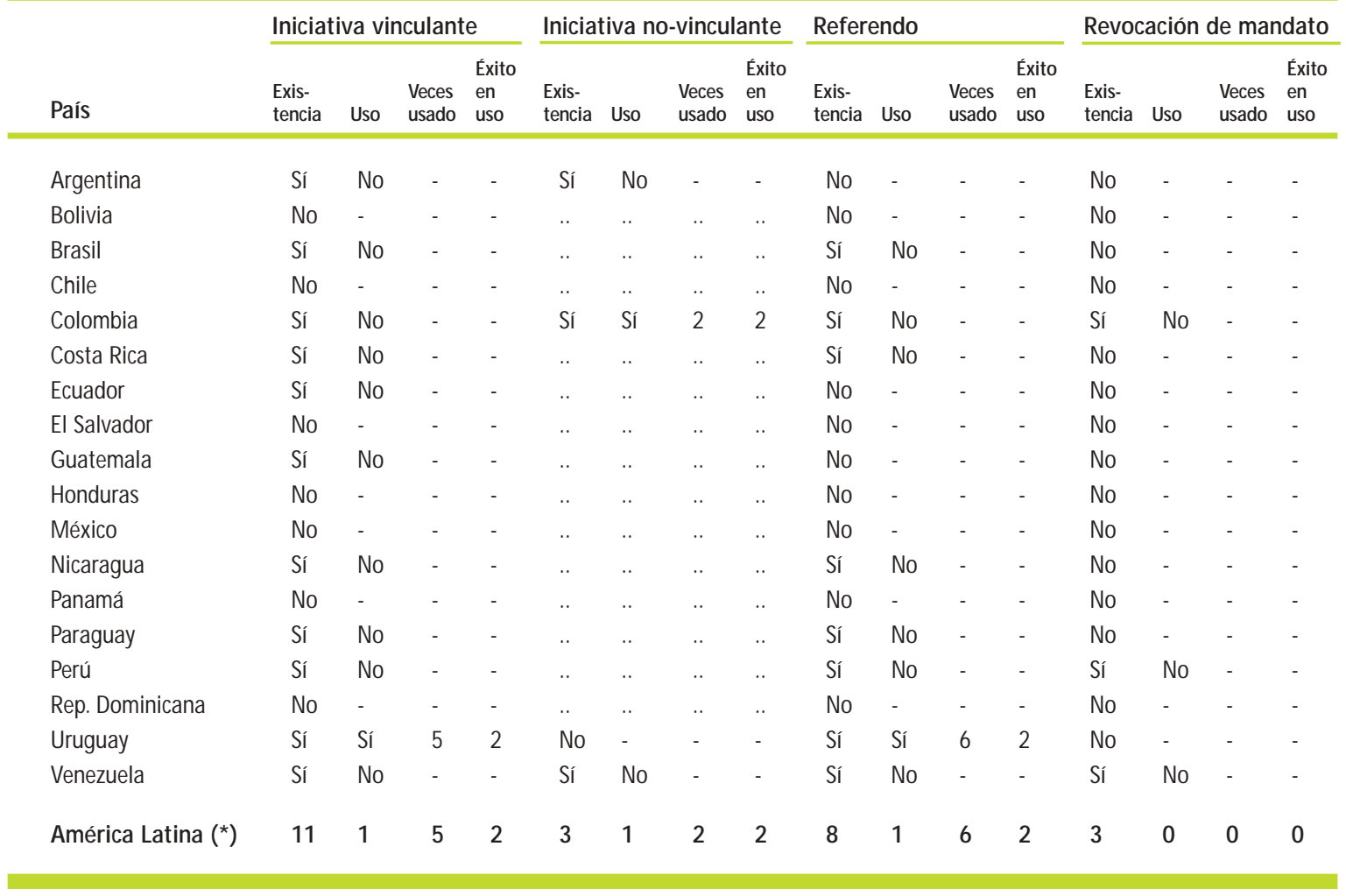

Notas: La información se refiere sólo a mecanismos de democracia directa oficiales y en el ámbito nacional. Las fechas cubiertas abarcan desde 1978 en adelante o desde que estos mecanismos fueron creados, pero sólo registra su uso dentro del contexto de regímenes democráticos. El guión corto (-) indica que la información no es relevante; los dos puntos seguidos (..), que la información no está disponible.

$\left(^{*}\right)$ Los datos para la región se refieren al total de países que permiten el uso de mecanismos de democracia directa y al total de veces que estos mecanismos han sido usados.

Fuentes: Altman 2002, p. 8, y varias Constituciones y leyes electorales nacionales.

Perú y Venezuela- sólo se han utilizado mecanismos de democracia directa "desde arriba".

\section{La corrupción en la función pública}

Un tema clave es el control de la corrupción en la función pública. La escasa información disponible hace difícil conocer su dimensión real, pero aporta cierta evidencia sobrela gravedad del problema.

Existen dos fuentes de información disponibles que son complementarias sobre las percepciones del nivel de corrupción (tabla 19).

La persistencia y la extensión de la corrupción en el ejercicio de la función pública encuentran un terreno fértil cuando los ciudadanos se resignan a ella o contribuyen a practicarla. Un fuerte rechazo ciudadano a las prácticas corruptas es una valiosa herramienta de fiscalización y favorece el funcionamiento de mecanismos eficaces de prevención, control y sanción.

En los dieciocho países latinoamericanos, el 41,9 por ciento de los consultados está de acuerdo con pagar el precio de cierto grado de corrupción con tal de que "las cosas funcionen". Un análisis del perfil social y político de las personas que toleran la corrupción indica que, para América Latina en su conjunto, esta actitud se encuentra de manera similar en todos los estratos sociales y demográficos (tabla 20).

\section{Clientelismo}

El clientelismo genera privilegios e implica un manejo discrecional delos recursos públicos. En la encuesta Latinobarómetro 2002 se pre- 


\begin{tabular}{|c|c|c|c|c|}
\hline \multirow[b]{2}{*}{ País } & \multicolumn{2}{|c|}{ Transparencia Internacional } & \multicolumn{2}{|c|}{ Foro Económico Mundial } \\
\hline & $1999-2001$ & 2002 & 2001 & 2002 \\
\hline Argentina & 3,5 & 2,8 & 4,28 & 4,42 \\
\hline Bolivia & 2,0 & 2,2 & 4,26 & 3,56 \\
\hline Brasil & 4,0 & 4,0 & 4,45 & 4,82 \\
\hline Chile & 7,5 & 7,5 & 6,35 & 6,34 \\
\hline Colombia & 3,8 & 3,6 & 4,73 & 5,14 \\
\hline Costa Rica & 4,5 & 4,5 & 4,60 & 4,41 \\
\hline Ecuador & 2,3 & 2,2 & 3,91 & 3,67 \\
\hline El Salvador & 3,6 & 3,4 & 4,47 & 5,16 \\
\hline Guatemala & 2,9 & 2,5 & 4,12 & 3,81 \\
\hline Honduras & 2,7 & 2,7 & 3,64 & 3,84 \\
\hline México & 3,7 & 3,6 & 4,40 & 4,82 \\
\hline Nicaragua & 2,4 & 2,5 & 3,76 & 4,31 \\
\hline Panamá & 3,7 & 3,0 & 4,26 & 4,52 \\
\hline Paraguay & .. & 1,7 & 2,77 & 3,55 \\
\hline Perú & 4,1 & 4,0 & 2,31 & 5,21 \\
\hline República Dominicana & 3,1 & 3,5 & 4,46 & 4,43 \\
\hline Uruguay & 5,1 & 5,1 & 4,78 & 5,88 \\
\hline Venezuela & 2,8 & 2,5 & 4,05 & 3,85 \\
\hline \multicolumn{5}{|l|}{ Región } \\
\hline América Latina & 3,6 & 3,4 & 4,37 & 4,52 \\
\hline Europa occidental & 7,1 & 7,8 & 6,07 & 6,08 \\
\hline
\end{tabular}

Notas: Los dos puntos seguidos (..) indican que la información no está disponible. Ambas organizaciones construyen su índice entrevistando a paneles de expertos que cada una de ellas selecciona. Obviamente, el resultado no tiene significación estadística numéricamente. Los datos de Transparencia Internacional consisten en una escala de 11 puntos, con números más altos indicando menos corrupción. La escala del Foro Económico Mundial es de 7 puntos, con números más altos indicando menor corrupción.

Fuentes: Lambsdorff 2001, pp. 234-236, y TI 2002.

guntó a los consultados si conocían casos de personas que hubieran recibido privilegios por ser simpatizantes del partido de gobierno. El 31,4 por ciento declara conocer uno o más casos de clientelismo (tabla 21).

\section{Conclusiones sobre la ciudadanía política: logros y deficiencias}

- La información que hemos presentado sobre ciudadanía política más allá de los procesos electorales muestra queen Amé rica Latina se han obtenido algunos logros significativos.

- Las bases institucionales de la independencia y profesionalización del Poder Judicial se han fortalecido a través de una serie de recientes reformas. Sin embargo, aún no es clara la contribución que ellas harán para la plena instauración de un estado democrático de derecho.

- Los organismos especializados en el control de la gestión de los funcionarios públicos, elegidos o no -algunos de ellos creados en la última década-, ofrecen nuevos canales para ejercer ese control que complementa la función de contralor que deben ejercer los poderes constitucionales clásicos. Sin embargo existen aún deficiencias que condicionan algunos de los logros obtenidos. En particular, se observan dificultades de diversos organismos de control para ejercerlo efectivamentey, llegado el caso, sancionar abusos cometidos por otras entidades del Estado.

- El uso de mecanismos de democracia directa es aún limitado. 


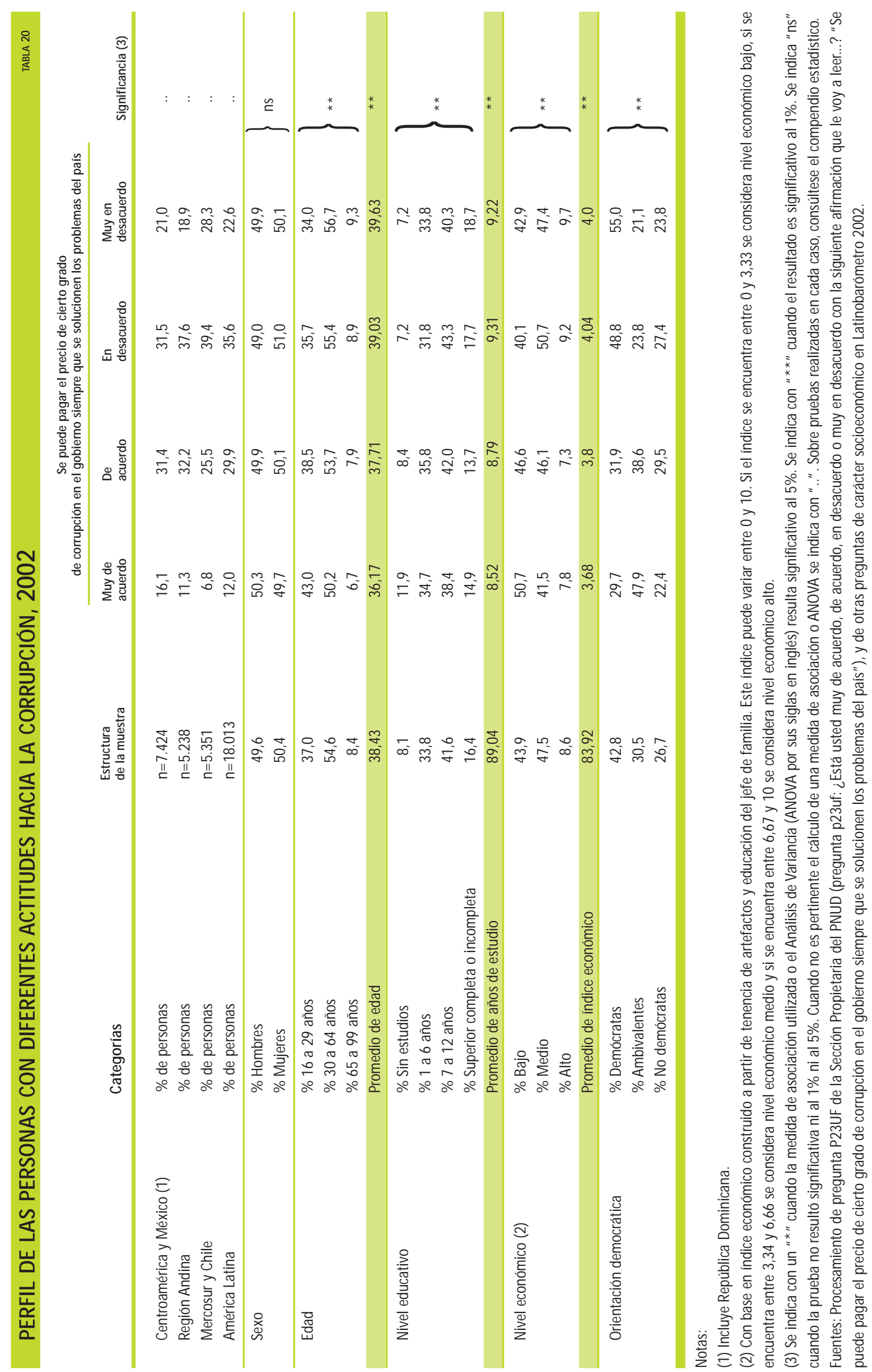




\begin{tabular}{ll}
\hline REDES CLIENTELISTAS, 2002 & País (2) \\
\hline Nivel de conocimiento (1) & TABLA 21 \\
\hline Bajo conocimiento de casos de clientelismo $(23,9)$, Colombia $(16,3)$, Chile $(16,0)$, \\
& Ecuador $(24,4)$, El Salvador $(23,3)$ \\
\hline Conocimiento intermedio de casos de clientelismo & $\begin{array}{l}\text { Argentina }(32,4), \text { Bolivia }(33,9), \text { Costa Rica }(27,2), \\
\text { Honduras }(36,7), \text { Nicaragua }(35,2), \text { Panamá }(27,4),\end{array}$ \\
& Paraguay $(34,0)$, Perú $(32,2)$, Uruguay $(32,3)$, Venezuela $(31,8)$ \\
\hline Alto conocimiento de casos de clientelismo & $\begin{array}{l}\text { Guatemala }(42,3), \text { México }(43,4), \\
\text { República Dominicana }(53,1)\end{array}$ \\
\hline Tradición democrática & Proporción de personas que conocen uno o más casos \\
& de clientelismo \\
\hline Democracias más viejas (3) & 24,7 \\
Democracias más nuevas & 34,0 \\
Promedio América Latina & 31,4 \\
\hline
\end{tabular}

Notas: $\mathrm{n}=19.366$.

(1) Bajo conocimiento: $25 \%$ o menos de los consultados manifestaron conocer uno o más casos de privilegios. Conocimiento intermedio: entre el $25 \%$ y el $40 \%$ de las personas dicen conocer uno o más casos de privilegios. Alto conocimiento: más de $40 \%$ tiene conocimiento.

(2) La cifra entre paréntesis después del país indica la proporción de personas que manifestaron conocer uno o más casos de privilegios.

(3) Democracias más viejas: incluye Colombia, Costa Rica y Venezuela.

Fuente: Procesamiento de pregunta P7U de la Sección Propietaria del PNUD (pregunta p7u: “ ¿Conoce usted personalmente un caso en que una persona haya recibido privilegios por ser simpatizante del partido de gobierno?”), en Latinobarómetro 2002.

- Aun cuando existen algunos mecanismos de control, la información de la que se dispone sugiere que todavía se observan prácticas decorrupción y clientelismo en la gestión de los asuntos públicos.

\section{Ciudadanía civil}

La ciudadanía civil es la dimensión de la ciudadanía que ha tenido el mayor desarrollo doctrinario y normativo. En términos generales, los principios que la animan son aparentemente contradictorios: por un lado, tratan de establecer límites a las acciones del Estado y, por otro, procuran establecer la garantía estatal de la igualdad jurídica y la libertad de las personas.

Para el análisis del desarrollo de los derechos civiles hemos tomado en consideración cuatro componentes: la igualdad legal y la protección contra la discriminación; el derecho a la vida, la integridad física y la seguridad; la administra- ción dejusticia, y la libertad de prensa y el derecho a la información.

\section{Igualdad legal y protección contra la discriminación}

Un punto de partida en el análisis de la igual dad legal de los ciudadanos y la protección contra la discriminación son las garantías constitucional o legalmente establecidas de la igualdad legal y, en particular, la aceptación por los países de las normas del derecho internacional en esta materia. Por medio de la ratificación de tratados internacionales, los Estados adquieren la obligación, no sólo frente a su población sino frente a la comunidad internacional, de velar por la protección de ciertos de rechos. Es un signo positivo que la mayoría de los países deAmérica Latina haya ratificado los principales tratados internacionales sobre derechos de la O rganización de las Naciones Unidas (ONU), la Organización Internacional del Trabajo (OIT) y la Organización de Estados Americanos (OEA). 


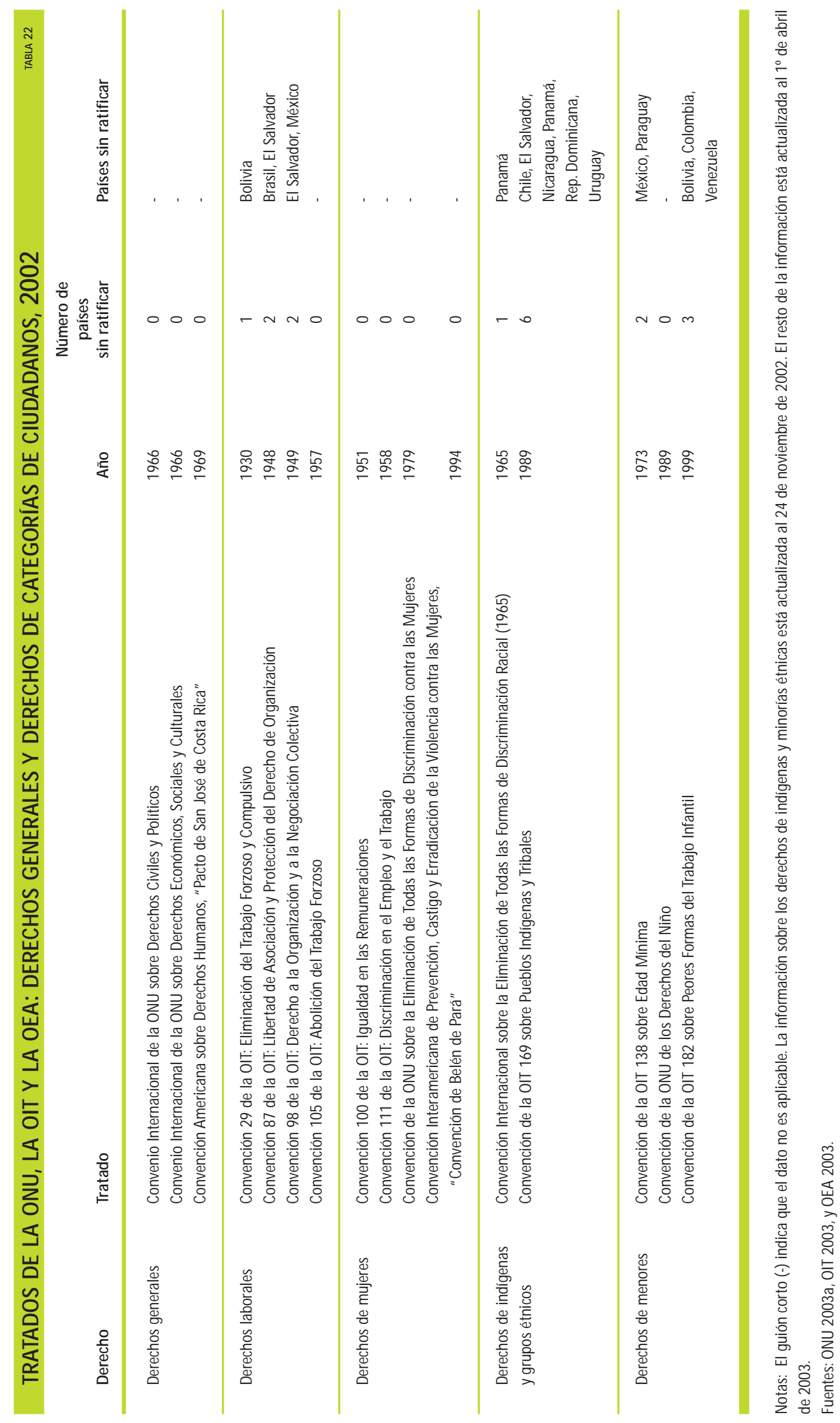


RECUADRO 23

\section{Dimensiones de la ciudadanía civil}

$\begin{array}{ll}\begin{array}{l}\text { Dimensión } \\ \begin{array}{l}\text { Igualdad legal y protección contra } \\ \text { la discriminación }\end{array}\end{array} & \begin{array}{l}\text { Tratados internacionales, legislación y aplicación de la legislación } \\ \text { relacionados con los derechos generales y la situación de los } \\ \text { trabajadores, las mujeres, los indígenas y los menores. }\end{array} \\ \begin{array}{l}\text { Derecho a la vida, a la integridad física } \\ \text { y a la seguridad }\end{array} & \begin{array}{l}\text { Tratados internacionales, legislación y aplicación de legislación } \\ \text { relacionados con derechos civiles fundamentales. }\end{array} \\ \begin{array}{l}\text { Administración de justicia } \\ \text { Recursos financieros destinados al sistema de justicia y medidas } \\ \text { orientadas a la defensa de los derechos de los acusados y personas } \\ \text { privadas de su libertad. }\end{array} \\ \begin{array}{l}\text { Libertad de prensa y el derecho } \\ \text { a la información }\end{array}\end{array}$

Los principales avances en materia de reconocimiento de derechos se encuentran en las áreas de los derechos generales, donde tres de los cuatro tratados han sido ratificados por todos los países, y de los derechos de las mujeres, donde existe una ratificación regional completa de los principales tratados. En otras áreas, el movimiento regional hacia el reconocimiento delos derechosestá próximo a completarse, como sucede con los instrumentos internacionales de los derechos laborales y de los niños. El mayor atraso se observa en relación con la Convención sobre los pueblos indígenas (Convención 169 de la OIT), que aún no ha sido ratificada por seis países.

Un segundo aspecto en el estudio sobre la discriminación se refiere a las reglas internas que los países han sancionado para proteger los derechos civiles, sea mediante la incorporación a la legislación nacional de cláusulas contenidas en los tratados internacionales ratificados o por iniciativa propia. Es destacable que en la última década ha habido un intenso desarrollo normativo en dos áreas: los derechos delas mujeres y los derechos de los indígenas. Respecto de las primeras, en todos los países se ha aprobado legislación orientada tanto a proteger a las mujeres detratos discriminatorios, como a afirmar proactivamente ciertos derechos. La protección de las mujeres frente a la violencia do- méstica ha sido un área particularmente activa en este plano.

A su vez, se han producido importantes avances en la protección de los derechos de los indígenas. Varias constituciones - especialmente las de países con numerosas poblaciones indígenas como Bolivia, Ecuador, Guatemala y Perú- reconocieron el carácter multinacional y pluriétnico de sus sociedades. En otros casos, como Brasil y Colombia, también hubo una expansión de los derechos de los indígenas. Sin embargo, en la mayoría de los países, los derechos constitucionalmente reconocidos a los pueblos indígenas distan de haber sido implementados mediante adecuada legislación y jurisprudencia, y las lenguas indígenas siguen sin ser reconocidas como idiomas oficiales por los respectivos Estados (tabla 23).

El tercer plano en el análisis de la igualdad legal está dado por la efectividad de las protecciones constitucionales o legales a los derechos civiles. En esta materia, la información disponible sugiere la existencia de graves y, en ocasiones, cada vez más severas desigual dades entrelas personas pertenecientes a distintos grupos dela población.

En el mundo laboral puede identificarse una creciente disparidad a lo largo de la década de 1990 entre la protección de los derechos de los 
RECUADRO 24

\section{Legislación sobre violencia contra la mujer, 2002}

País

Legislación sobre violencia doméstica y violencia contra la mujer

Argentina

Bolivia

Brasil

Chile

Colombia

Costa Rica

Ecuador

El Salvador

Guatemala

Honduras

México

Nicaragua

Panamá

Paraguay

Perú

Rep. Dominicana Uruguay

Venezuela
Ley 24.417 de protección contra la violencia familiar, diciembre 1994.

Acta 25.087 modificatoria del Código Penal, 1999.

Ley 1.674 contra la violencia doméstica y familiar, 1995.

Ley 1.678, que modifica el Código Penal respecto de las ofensas sexuales, 1995.

Decreto Legislativo 107, que da fuerza legal a la Convención Interamericana de Prevención, Castigo y Erradicación de la Violencia contra las Mujeres, 1995.

Artículo 226 de la Constitución Federal de 1988, y varios artículos del Código Penal.

Acta 19.325, que establece procedimientos estándar y penalidades por actos de violencia dentro de la familia, 1994.

Ley 19.617 sobre crímenes sexuales, 1999.

Ley 294 para prevenir, castigar y erradicar la violencia familiar, 1996

(modificada en parte por la Ley 575, 2000).

Ley 360 sobre ofensas contra la libertad sexual y la dignidad humana, 1997.

Ley 599 del Código Penal, referida a la violencia en el interior de las familias, 2000.

Acta 7.142, que promueve la igualdad social de las mujeres; incluye el capítulo 4 sobre violencia en la familia, 1990.

Ley 7.586, contra la violencia doméstica, 1996.

Ley 103, sobre violencia contra las mujeres y la familia, 1995.

Decreto-Ley 902, sobre violencia familiar, 1996.

Decreto-Ley 97-96, para prevenir, castigar y erradicar la violencia familiar, 1996.

Ley por la dignidad y la promoción integral de la mujer, 1999.

Decreto 132-97, para prevenir, castigar y eliminar la violencia contra las mujeres, 1997.

Ley preventiva contra la violencia familiar, 1996.

Decreto para reformar los códigos Civil y Penal en referencia a la violencia familiar y casos de violación, 1997.

Ley que contiene enmiendas y adiciones al Código Penal de 1996; y ley que crea el

Servicio de Policía

para mujeres y niños, incluidas en la legislación que establece el Servicio Nacional de Policía, 1996.

Ley 230, que establece la protección para las mujeres víctimas de violencia doméstica, 1996.

Acta 27, 1995.

Ley 4 sobre igualdad de oportunidades para las mujeres, 1999.

Ley 38 sobre violencia doméstica, 2001.

Ley 1600/00 contra la violencia doméstica, 2000.

Ley 26.260 , que establece la situación y políticas sociales sobre la violencia familiar, 1993 (modificada por la Ley 27.306, en 2000).

Ley 26.763 que establece mecanismos para proveer mayor protección a las víctimas, 1997.

Ley 26.770 que reforma el Código Penal, estableciendo que el casamiento no invalida

los fundamentos para el procesamiento de crímenes contra la libertad sexual, 1997.

Acta 27.115 que establece acción penal pública para los delitos contra la libertad sexua|, 1999.

Ley 24-97, que define las ofensas de violencia doméstica, hostigamiento sexual e incesto, 1997.

Acta 16.707 sobre seguridad ciudadana, agrega un artículo nuevo al Código Penal, define la violencia doméstica y establece penalidades, 1995.

Ley 17.514 sobre violencia doméstica, 2002

Ley de igualdad de oportunidades para la mujer, 1993.

Ley sobre la violencia contra las mujeres y la familia, 1998. 
DERECHOS DE LOS PUEBLOS INDÍGENAS, 2000

Derechos constitucionales

\begin{tabular}{|c|c|c|c|}
\hline \multirow[b]{2}{*}{ País } & \multirow[b]{2}{*}{ Constitución } & \\
\hline & & Derechos multiculturales & Existencia de derechos relacionados con el uso del idioma \\
\hline Argentina & $1853 / 1994$ & Débiles & No, pero no existe idioma oficial \\
\hline Brasil & 1988 & No & No, el portugués es el idioma oficial \\
\hline Chile $(*)$ & 1980 & No & No, pero no existe idioma oficial \\
\hline Colombia & 1991 & Sí & $\begin{array}{l}\text { Sí, el castellano es el idioma oficial, pero las } \\
\text { lenguas indígenas y los dialectos son oficiales en } \\
\text { sus territorios }\end{array}$ \\
\hline Costa Rica & 1949 & No & No, el castellano es el idioma oficial \\
\hline Ecuador & 1998 & Sí & $\begin{array}{l}\text { Sí, el castellano es el idioma oficial, pero las } \\
\text { lenguas indígenas son para uso oficial restringido }\end{array}$ \\
\hline El Salvador & $1983 / 1992$ & No & No, pero las "lenguas autóctonas" son respetadas \\
\hline México & $1917 / 1992$ & Sí & No, pero se promueven las lenguas indígenas \\
\hline Nicaragua & $1987 / 1995$ & Sí & $\begin{array}{l}\text { Sí, los idiomas de las comunidades de la costa } \\
\text { atlántica son oficiales en esas regiones }\end{array}$ \\
\hline Panamá & $\begin{array}{l}\text { 1972/1978/1983/ } \\
1993 / 1994\end{array}$ & Sí & $\begin{array}{l}\text { No, pero las "lenguas aborígenes" son conservadas } \\
\text { y difundidas }\end{array}$ \\
\hline Paraguay & 1992 & Sí & Sí, el guaraní es un idioma oficial \\
\hline Perú & 1993 & Sí & $\begin{array}{l}\text { Sí, el castellano es el idioma oficial, pero las } \\
\text { lenguas indígenas son de uso oficial en las áreas } \\
\text { en donde predominan }\end{array}$ \\
\hline
\end{tabular}

Notas: Las fechas de las constituciones se refieren a los documentos originales y a su última reforma o enmienda. Los derechos multiculturales se refieren a si las múltiples identidades étnicas son reconocidas por el Estado. Los derechos referidos en este cuadro son considerados, a veces, como derechos colectivos, y no estrictamente derechos civiles.

(*) En Chile la Ley Indígena № 19.253 de octubre de 1993 establece la promoción de las culturas e idiomas indígenas y sistemas de educación intercultural bilingüe (art. 39), y garantiza el uso de lenguas indígenas en juicios (art. 74).

Fuentes: OIT 2002b; Barié 2000, pp. 42, 572-574; Van Cott 2003, y Universidad de Georgetown y OEA 2002.

empresarios (ambiente general de negocios) y la de los trabajadores. Por un lado, se nota una tendencia a un mejoramiento sostenido en los dere chos de los empresarios, alcanzando niveles cercanos a los que caracterizan a Europa occidental ( gráfico 2). Por otro lado, la tendencia de los derechos de los trabajadores ha empeorado, con un incremento considerable de la diferencia entre América Latina y Europa occidental (gráfico 3).

Con respecto a las mujeres, en la región ha ocurrido un proceso generalizado de lenta equiparación con los hombres. Se nota una gradual incorporación delas mujeres al mercado de trabajo - de un 28,8 por ciento en 1990 a un 33,9 por ciento en 2000- y una reducción de la disparidad deingresos con respecto a los hombres. Pero estos mismos datos indican que la participación laboral femenina sigue siendo relativamente baja y que las mujeres tienen, en promedio, ingresos sustancialmente menores que los hombres (tabla 24).

Por último, las leyes orientadas a proteger a los niños en el área laboral son violadas frecuentemente. En particular, se registra una alta incorporación laboral de niños de entre 5 y 14 años de edad y una fuerte incidencia de algunas formas de abuso, como el tráfico de niños y la pornografía infantil (tabla 25). 


\section{Pueblos indígenas y ciudadanía}

Aunque resulte manifiesto, esta situación es fundamental para comprender los rasgos distintivos y la trayectoria del sistema político de América Latina que la distingue del Noroeste europeo. Por si hubiese necesidad de recordarlo, la segunda ola de expansión colonial, conjuntamente con la redefinición "científica" de las concepciones raciales y del subsistente tratamiento racista a los "indígenas" y "africanos" propició la asociación de los "criollos" -blancos- con los intereses que representaban los agentes económicos y políticos del Noroeste; asimismo, que aquellos se identificaran con la cultura oficial de los países metropolitanos, por lo que adoptaron formalmente sus valores e instituciones que, paradójicamente, contradecían las subsistentes y fortalecidas relaciones de signo patrimonial entre las jerarquías sociales que dieron lugar a la presencia de ciudadanos imaginarios.

Como es sabido, la consecuencia fue que se renovara y vitalizara el "dualismo" y la polarización social y cultural, lo que se proyectó en el "colonialismo interno" de la población "indígena" y de origen africano que, muchas veces, se justificaría en función de principios liberales; la fragmentación social y las dislocaciones que produjeran la ola de expansión metropolitana propiciaron intermitentes conflictos sociales y constantes represiones impregnados con una fuerte carga étnica, que respondía a los latidos del "corazón de las tinieblas".

Sin embargo, a pesar de los muchos y profundos cambios que los países de América Latina han experimentado al compás de las mudanzas de sus relaciones con el Noroeste a lo largo del tiempo, es significativo el hecho de que, cualquiera fuera el grado de desarrollo político y económico que alcanzaron, la incorporación nacional de la mayoría de la población y la consolidación del Estado de Derecho siguen constituyendo una asignatura pendiente, al tiempo que persiste el dualismo y la polarización socio-étnica en variados grados de intensidad, con raras excepciones. Por ejemplo, en Perú y Brasil al rededor del $60 \%$ de los indígenas y los negros, respectivamente, se encuentran debajo de la línea de pobreza, proporción que probablemente sea similar en otros casos latinoamericanos que tienen una parecida participación étnica. En el mismo sentido, es igualmente significativo que bajo cualquier régimen político, democrático o autoritario, las distintas políticas económicas, ortodoxas y heterodoxas, han contribuido a mantener $y$, muchas veces, a fortalecer esta situación estructural.

Julio Cotler, texto elaborado para el PRODDAL, 2002.

RECUADRO 26

\section{La democracia étnica y el multiculturalismo}

Como mujer maya y como ciudadana que ha trabajado en los procesos de construcción multicultural estoy consciente de lo que significa democracia, que se concibe desde el pueblo y para el pueblo. El problema principal de nuestras "democracias", al menos en América Latina, es que no son completas. Aparentan ser lo que no son, desde que fueron concebidas dentro de Estados monoculturales, excluyentes y con privilegios para unos pocos, en perjuicio de las mayorías. Nosotros, los indígenas y las indígenas, somos pacíficos, respetuosos y buscamos la armonía, no sólo entre los seres humanos sino también con otros seres y elementos de la naturaleza. Para los Pueblos Indígenas, la consulta, la participación y el consenso son un proceso de suma importancia para la toma de decisiones, por lo que en este sentido prevalece la decisión de la mayoría, como principio democrático, en donde todos los seres humanos somos iguales y tenemos los mismos derechos y obligaciones, por lo que deseamos que nuestros sistemas políticos se transformen para el beneficio de todos, en donde se les dé la igualdad de oportunidades y sin exclusiones de ninguna especie. Los Pueblos Indígenas colocan sus esperanzas en el futuro. Apuestan por la convivencia y coexistencia armoniosa y equitativa de las etnias, las culturas, las lenguas y las religiones. Que la Democracia sea incluyente, representativa, intercultural, es decir, respetuosa de las diferencias. La unidad de Guatemala y de otros países similares debe descansar en esa rica veta de la diversidad que se debe reflejar en una democracia étnica.

Otilia Lux de Cojti, ex ministra de Cultura de Guatemala; texto elaborado para el PRODDAL, 2004. 


\section{Ambiente de negocios.}

\section{América Latina y Europa occidental, 1990-2000}

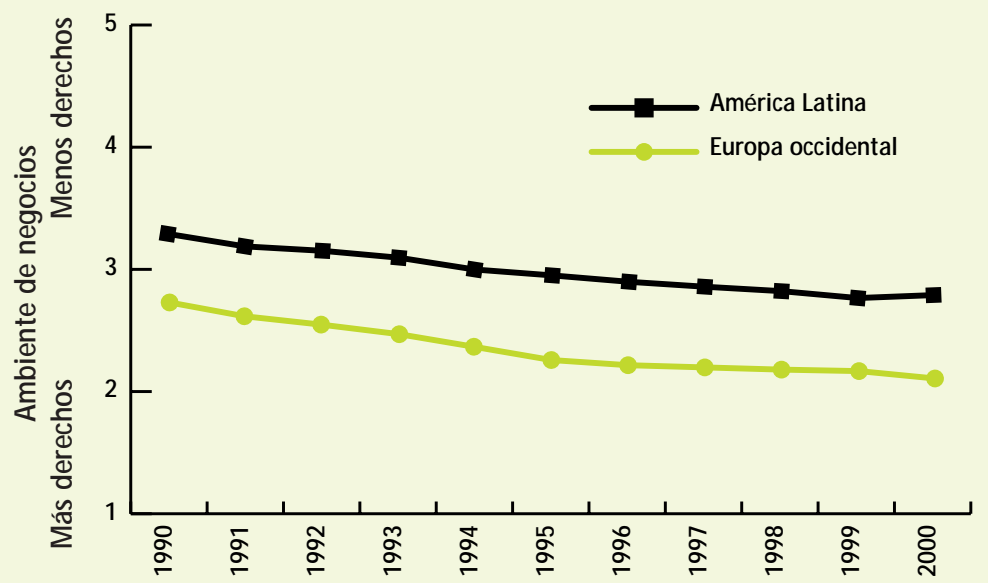

Notas: Los índices corresponden a una escala de cinco puntos; un índice bajo implica que el gobierno ha tenido éxito en asegurar un ambiente propicio para los negocios. Este índice se construyó a partir de un conjunto de variables que incluyen: la presión tributaria, la intervención gubernamental en la economía, y el derecho y las regulaciones a la propiedad. Los datos para el período 1994-2000 fueron tomados del índice de libertad económica de la Fundación Heritage; el índice para 1990 fue generado transformando los datos del Instituto Fraser a la escala utilizada por la Fundación Heritage. Los índices correspondientes a los años en los que faltaban datos fueron extrapolados por regresión lineal. Los datos del período 1994-2000 corresponden al período julio-junio. De este modo, los datos de 2000 corresponden al período de julio de 1999 a junio de 2000.

Fuentes: Para 1990, Gwartney et al. 2002; para 1994-2000, 0'Driscoll et al. 2002, pp. 14-18; y 0'Driscoll et al. 2003, pp. 13-17.

GRÁFICO 3

Derechos de los trabajadores. América Latina y Europa occidental, 1990-2000

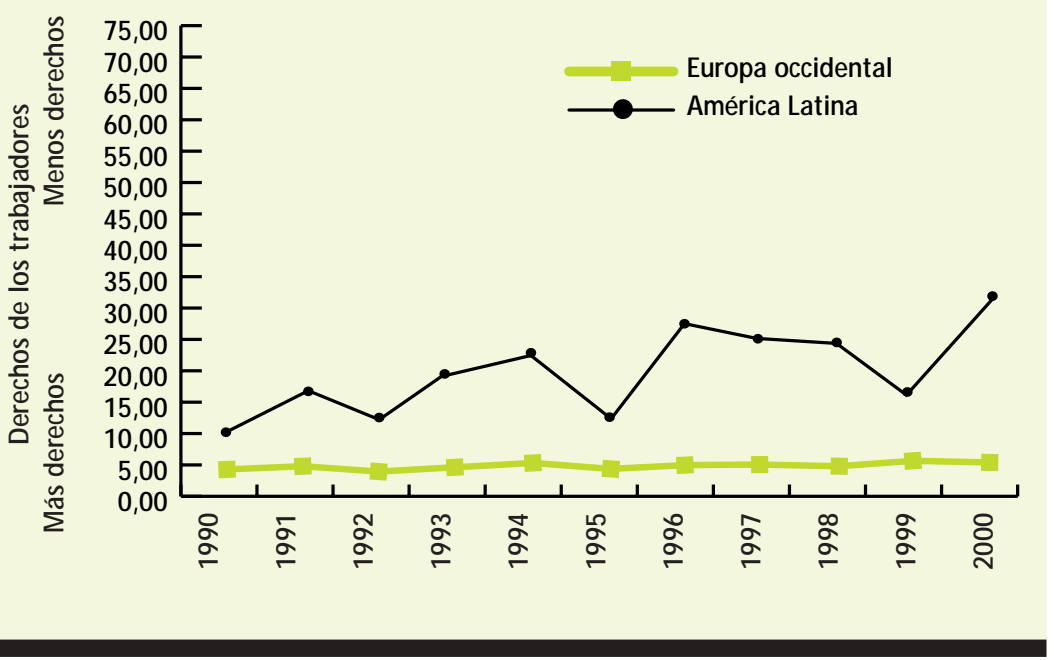

Notas: Los datos son una medida compuesta a base de múltiples indicadores, tales como la libertad de los trabajadores para organizarse, negociar colectivamente y declarar la huelga. Las calificaciones pueden ir desde 0 , que indica un alto grado de respeto por los derechos laborales, hasta 76,5, que indica un grado extremadamente alto de violación de esos derechos. Estas calificaciones se refieren a los derechos que son violados, pero no reflejan la frecuencia de su violación o la cantidad de trabajadores afectados por tales violaciones. Fuente: Mosley y Uno, 2002 
MUJERES EN EL MERCADO LABORAL, 1990-2000

Participación en la actividad económica

\begin{tabular}{ccccccccc} 
& 1990 & & & 1995 & & 2000 & & \\
Total & Hombres & Mujeres & Total & Hombres & Mujeres & Total & Hombres & Mujeres \\
\hline 49,37 & 70,30 & 28,81 & 50,77 & 70,55 & 31,32 & 52,23 & 70,86 & 33,93
\end{tabular}

Disparidad salarial por género

(ingreso promedio en áreas urbanas)

\begin{tabular}{cccccc}
\multicolumn{2}{c}{ Principios de los 90} & \multicolumn{2}{c}{ Mediados de los 90} & \multicolumn{2}{c}{ Finales de los 90} \\
PEA & asalariados & PEA & asalariados & PEA & asalariados \\
\hline 61,99 & 70,89 & 64,90 & 72,23 & 67,34 & 77,89
\end{tabular}

Notas: Los datos sobre disparidad salarial por género representan el porcentaje del ingreso masculino recibido por las mujeres. La columna PEA (Población Económicamente Activa) compara diferencias de ingreso entre hombres y mujeres en el contexto de la PEA global. La columna "asalariados" compara las diferencias salariales entre hombres y mujeres únicamente en el contexto de la población asalariada. Las cifras regionales son el promedio 0 término medio de todos los casos en los que existen datos para cualquier año.

Fuentes: CEPAL 2001a, pp. 201-202, cuadro 8; 2002b, pp. 201-202, cuadro 8; y 2003, pp. 20-21, cuadro 15.

INCIDENCIA DEL ABUSO A MENORES EN LAS DISTINTAS REGIONES TABLA 25

\section{DEL MUNDO, 2000}

\begin{tabular}{|c|c|c|c|c|c|c|c|}
\hline \multirow[b]{2}{*}{ Región } & \multicolumn{2}{|c|}{$\begin{array}{l}\text { Niños económicamente } \\
\text { activos (5-14 años) }\end{array}$} & \multicolumn{5}{|c|}{$\begin{array}{l}\text { Niños implicados en las peores formas } \\
\text { de trabajo infantil }\end{array}$} \\
\hline & $\begin{array}{l}\text { número de } \\
\text { niños } \\
\text { (en millones) }\end{array}$ & $\begin{array}{l}\text { proporción } \\
\text { que trabaja } \\
(\%)\end{array}$ & $\begin{array}{l}\text { tráfico } \\
\text { (en miles) }\end{array}$ & $\begin{array}{l}\text { trabajo } \\
\text { forzado } \\
\text { y servil } \\
\text { (en miles) }\end{array}$ & $\begin{array}{l}\text { conflicto } \\
\text { armado } \\
\text { (en miles) }\end{array}$ & $\begin{array}{l}\text { prostitución y } \\
\text { pornografía } \\
\text { (en miles) }\end{array}$ & $\begin{array}{l}\text { actividades } \\
\text { ilícitas } \\
\text { (en miles) }\end{array}$ \\
\hline Economías desarrolladas & 2,5 & 2 & .. & .. & 1 & 420 & 110 \\
\hline Asia y el Pacífico & 127,3 & 19 & 250 & 5.500 & 120 & 590 & 220 \\
\hline África subsahariana & 48,0 & 29 & .. & .. & .. & .. & .. \\
\hline Oriente Medio y Norte de África & 13,4 & 15 & .. & .. & .. & .. & .. \\
\hline África & .. & .. & 200 & 210 & 120 & 50 & .. \\
\hline América Latina y el Caribe & 17,4 & 16 & 550 & 3 & 30 & 750 & 260 \\
\hline
\end{tabular}

Notas: La proporción que trabaja se refiere al número de niños que trabajan en proporción al número total de niños. Las cifras sobre niños implicados en las "peores formas de trabajo" son estimaciones.

Fuentes: IPEC-SIM POC 2002, p. 17, cuadro 2, y p. 27, cuadro 10. 


\section{La percepción ciudadana acerca de la igualdad ante la ley}

Pese a los avances registrados en América Latina en la aprobación de normas constitucionales y legales para el reconocimiento y tutela de los derechos de las personas pertenecientes a grupos en desventaja social, las percepciones ciudadanas en esta materia sugieren que falta mucho por hacer para lograr condiciones razonables de igualdad ante la ley.

De acuerdo con los datos de Latinobarómetro 2002, la mayoría de las personas creen que los ricos siempre o casi siempre logran hacer valer sus derechos, con pocas variaciones entre sub-regiones y países. Por otra parte, mayorías similares opinan que los pobres, los inmigrantes y los indígenas experimentan serias desventajas legales. Esta situación está presente tanto en países con largas tradiciones democráticas como en aquellos de reciente transición a la democracia, así como en países con niveles distintos de logros en el Índice de Desarrollo Humano.

Las percepciones ciudadanas sobre la situación legal de las mujeres son marcadamente mejores. En todos los países la mayoría de las personas cree que, hoy en día, las mujeres siempre o casi siempre logran hacer valer sus derechos. Esta mayoría oscila entre un mínimo de $54,8 \%$ en México y Bolivia y un máximo de $78,4 \%$ en Uruguay.

Para examinar en conjunto las percepciones sobre la capacidad de las personas pertenecientes a grupos vulnerables para hacer valer sus derechos se creó el indicador de percepción sobre la igualdad legal (ver www.democracia.undp.org). En todos los países latinoamericanos, sólo una minoría de personas tiene la percepción de que los grupos vulnerables siempre o casi siempre logran hacer valer sus derechos (en ninguno la proporción supera el $31 \%$ ). El puntaje promedio del índice de percepción de igualdad legal en los países de América Latina tiende a ser bajo (2,19 puntos de 5 puntos posibles; mínimo, 1 punto).

\begin{tabular}{|c|c|c|c|c|}
\hline \multicolumn{5}{|c|}{ PERCEPCIÓN SOBRE LA IGUALDAD LEGAL DE } \\
\hline \multicolumn{4}{|c|}{ GRUPOS ESPECÍFICOS, 2002} & TABLA 26 \\
\hline \multirow[t]{2}{*}{ País } & \multicolumn{4}{|c|}{$\begin{array}{l}\text { Siempre o casi siempre logra } \\
\text { hacer valer sus derechos (1) }\end{array}$} \\
\hline & Mujer & Indígena & Pobre & Inmigrante \\
\hline Argentina & 69,7 & 9,1 & 7,9 & 21,4 \\
\hline Bolivia & 54,8 & 21,2 & 13,9 & 38,5 \\
\hline Brasil & 78,3 & 34,3 & 20,1 & 47,6 \\
\hline Chile & 68,9 & 33,5 & 19,9 & 27,2 \\
\hline Colombia & 70,3 & 22,1 & 18,1 & 24,1 \\
\hline Costa Rica & 59,8 & 23,2 & 13,7 & 21,3 \\
\hline Ecuador & 60,4 & 40,2 & 25,2 & 30,6 \\
\hline El Salvador & 72,0 & 32,3 & 32,4 & 30,9 \\
\hline Guatemala & 65,3 & 38,7 & 24,8 & 18,7 \\
\hline Honduras & 69,8 & 34,6 & 23,5 & 25,1 \\
\hline México & 54,8 & 7,5 & 5,6 & 9,9 \\
\hline Nicaragua & 60,3 & 23,5 & 17,7 & 21,5 \\
\hline Panamá & 65,6 & 10,5 & 10,7 & 21,0 \\
\hline Paraguay & 71,5 & 15,0 & 10,9 & 54,1 \\
\hline Perú & 61,9 & 16,0 & 11,6 & 55,4 \\
\hline República Dominicana & 76,4 & 11,5 & 22,2 & 40,2 \\
\hline Uruguay & 78,4 & 17,1 & 21,8 & 39,3 \\
\hline Venezuela & 73,7 & 28,2 & 26,1 & 30,3 \\
\hline Centroamérica y M éxico (2) & 66,4 & 22,2 & 18,9 & 23,3 \\
\hline Región Andina & 63,8 & 27,8 & 19,2 & 36,2 \\
\hline Mercosur y Chile & 71,2 & 19,2 & 14,6 & 36,2 \\
\hline \multicolumn{5}{|l|}{ Región } \\
\hline América Latina & 67,0 & 23,1 & 17,8 & 30,8 \\
\hline
\end{tabular}

Notas: El número de mujeres, indígenas, pobres e inmigrantes varía entre 18.040 y 19.596.

(1) Se incluyen las respuestas dadas a las alternativas "siempre" y "casi siempre" que se ofrecían en la pregunta.

(2) Incluye República Dominicana.

Fuente: Procesamiento de la pregunta P24U de la Sección Propietaria del PNUD (pregunta p24u: “Y siempre pensando en cómo funcionan las cosas en este país, ¿diría usted que en la práctica ['Una mujer', 'Un indígena', 'Un pobre', 'Un inmigrante'] logra hacer valer sus derechos siempre, casi siempre, casi nunca 0 nunca?" ), en Latinobarómetro 2002.
En resumen, la igualdad legal de los ciudadanos y la protección contra la discriminación aún no se aplican con la debida firmeza y extensión en América Latina. Existen mejoras nor- mativas importantes, pero las deficiencias son todavía notables y afectan a los sectores de la población más numerosos y débiles y, por lo tanto, necesitados de protección. 


\begin{tabular}{|c|c|c|c|}
\hline \multicolumn{3}{|c|}{ TRATADOS DE LA ONU Y LA OEA SOBRE } & \multirow[t]{2}{*}{ TABLA 27} \\
\hline \multicolumn{3}{|c|}{ DERECHOS CIVILES FUNDAMENTALES, 2003} & \\
\hline Tratado & Año & $\begin{array}{l}\text { Número de países } \\
\text { sin ratificar }\end{array}$ & $\begin{array}{l}\text { Países } \\
\text { sin ratificar }\end{array}$ \\
\hline $\begin{array}{l}\text { Convención de la ONU contra la tortura y otras } \\
\text { formas de trato y castigo crueles, } \\
\text { inhumanos o degradantes }\end{array}$ & 1984 & 2 & $\begin{array}{l}\text { Nicaragua, } \\
\text { República Dominicana }\end{array}$ \\
\hline $\begin{array}{l}\text { Convención Interamericana de la OEA para prevenir } \\
\text { y castigar la tortura }\end{array}$ & 1995 & 3 & $\begin{array}{l}\text { Bolivia, Honduras, } \\
\text { Nicaragua }\end{array}$ \\
\hline $\begin{array}{l}\text { Protocolo a la Convención Interamericana } \\
\text { de Derechos Humanos para abolir la pena de muerte }\end{array}$ & 1990 & 10 & $\begin{array}{l}\text { Argentina, Bolivia, Chile, } \\
\text { Colombia, El Salvador, } \\
\text { Guatemala, Honduras, } \\
\text { México, Perú, } \\
\text { República Dominicana }\end{array}$ \\
\hline Convención Interamericana sobre la Desaparición & 1994 & 9 & $\begin{array}{l}\text { Brasil, Colombia, Ecuador, } \\
\text { El Salvador, Honduras, } \\
\text { México, Nicaragua, Perú, } \\
\text { República Dominicana }\end{array}$ \\
\hline
\end{tabular}

Nota: La información está actualizada al 10 de abril de 2003.

Fuentes: ONU 2003, y OEA 2003.

\section{Derecho a la vida, la integridad física y la seguridad}

Un segundo componente de los derechos civiles es la efectiva protección de los derechos a la vida, la integridad física y la seguridad. Un importante número de países todavía no acepta las obligaciones internacionales en esta materia y se observan rezagos en la ratificación de los respectivos tratados.

La situación es particularmente preocupante con respecto al Protocolo sobre la abolición de la pena de muerte, pues diez de los dieciocho países no lo han ratificado y en Guatemala sigue vigente la pena de muerte para crímenes comunes. La Convención Interamericana sobre la Desaparición Forzada de Personas también tiene baja ratificación. Se destacan los casos de Nicaragua, que no ha ratificado ninguno de los cuatro tratados relevantes, y de Honduras y la República Dominicana, que a la fecha sólo han ratificado uno de ellos.
Por el lado positivo, en términos de violencia militar la situación de América Latina contrasta muy favorablemente con otras regiones del mundo. Al comenzar el siglo XXI, el número de muertos por 100.000 habitantes en nuestra región es sensiblemente inferior al de África, Europa y Asia.65 Hoy en día, Colombia es el único país latinoamericano donde subsiste un conflicto militar.

Desafortunadamente, otros tipos de violencia social y política siguen siendo un fenómeno común en la región, a pesar del advenimiento de regímenes democráticos. Uno de los temas centrales concierne a la capacidad de los Estados para garantizar los derechos humanos. En este plano, los datos muestran un mejoramiento respecto del período no democrático. Sin embargo, tratándose de derechos básicos que debe garantizar un estado democrático de derecho, se enciende una señal de alerta sobre esta situación en las democracias latinoamericanas. 


\begin{tabular}{|c|c|c|c|}
\hline \multicolumn{3}{|c|}{ HOMICIDIOS DOLOSOS EN AMÉRICA LATINA Y OTRAS PARTES } & TABLA 28 \\
\hline \multicolumn{4}{|c|}{ DEL MUNDO, C. 2000} \\
\hline País & Año & $\begin{array}{l}\text { № de } \\
\text { muertes }\end{array}$ & $\begin{array}{l}\text { № de muertes } \\
\text { por } 100.000 \\
\text { habitantes }\end{array}$ \\
\hline Argentina & 2001 & 3.048 & 8,2 \\
\hline Bolivia & 2000 & 2.558 & 32,0 \\
\hline Brasil & 2001 & 39.618 & 23,0 \\
\hline Chile & 2001 & 699 & 4,5 \\
\hline Colombia & 2000 & 29.555 & 70,0 \\
\hline Costa Rica & 1999 & 245 & 6,2 \\
\hline Ecuador & 1999 & 3.217 & 25,9 \\
\hline El Salvador & 2001 & 2.196 & 34,3 \\
\hline Guatemala & 1994 & 3.239 & 33,3 \\
\hline Honduras & 1998 & 9.241 & 154,0 \\
\hline México & 2000 & 13.829 & 14,0 \\
\hline Nicaragua & 1998 & 1.157 & 24,1 \\
\hline Panamá & 1998 & 54 & 2,0 \\
\hline Paraguay & 2001 & 890 & 15,6 \\
\hline Perú & 2001 & 1.298 & 5,0 \\
\hline Rep. Dominicana & 1998 & 1.121 & 15,8 \\
\hline Uruguay & 2000 & 154 & 4,6 \\
\hline Venezuela & 2000 & 8.022 & 33,2 \\
\hline América Latina & C. 1997 & 109.135 & 25,1 \\
\hline \multicolumn{4}{|c|}{ Referentes extrarregionales } \\
\hline Europa occidental & c. 2000 & 4.519 & 1,4 \\
\hline M editerráneo del este & c. $1995-1999$ & 31.000 & 7,1 \\
\hline Asia del sur y del este & C. $1995-1999$ & 78.000 & 5,8 \\
\hline África & C. $1995-1999$ & 116.000 & 22,2 \\
\hline Pacífico occidental & C. $1995-1999$ & 59.000 & 5,1 \\
\hline Mundo & C. $1995-1999$ & 521.000 & 8,8 \\
\hline
\end{tabular}

Notas: Las cifras regionales son la suma de todos los casos en los que existen datos disponibles, y reflejan un promedio no-ponderado. Para América Latina corresponde al año 1997. El número de homicidios para El Salvador y Honduras es estimado. Europa occidental no incluye a Luxemburgo ni al Reino Unido.

Fuentes: Interpol 2004, UNODC 2002; Krug 2002, pp. 274, 308-312, y ONU, División de Población, Departamento de Asuntos Económicos y Sociales, 2001, 2002.

Ciertamente, a partir del fin de los regímenes militares en el Cono Sur en la década de 1980 y la resolución de los conflictos armados en Centroamérica durante la década de 1990, se ha producido un mejoramiento en materia de privación injustificada de la libertad, tortura y asesinatos políticos. Con todo, la mejoría observada no ha tenido la magnitud que cabría esperar una vez eliminados los regímenes autoritarios y concluidas casi todas las situaciones de guerra. Existeuna salvedad sustancial: las violaciones no obedecen, en su inmensa mayoría, a la acción deliberada y planificada del Estado, sino a la incapacidad (o, a ve- ces, la falta de voluntad política) para asegurar la plena vigencia del estado de derecho y el monopolio de la fuerza por parte del Estado.

Otro tema relevantees la seguridad delos ciudadanosy la capacidad del Estado de proveer este bien público. Una seria deficiencia es queen no pocas de nuestras democracias el Estado no garantiza la seguridad física de amplios sectores de la población. Un indicador de esta situación es la alta tasa de homicidios dolosos, que en la región alcanza en promedio el nivel más alto del mundo, con 25,1 por 100.000 habitantes.

En resumen, aunque la violencia militar ha 
RECURSOS FINANCIEROS Y HUMANOS DEDICADOS AL SISTEMA

DE ADMINISTRACIÓN DE JUSTICIA, 2001

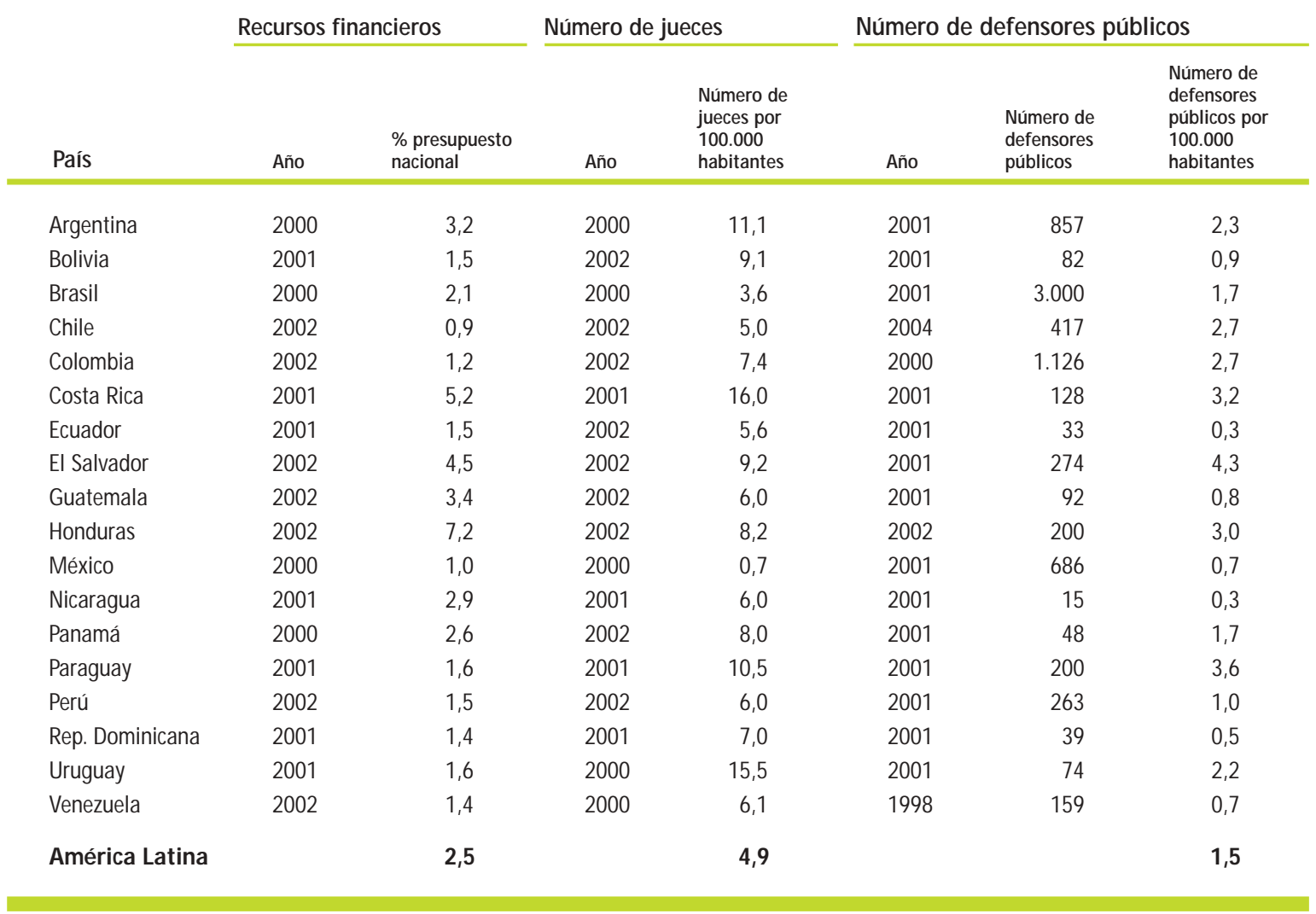

Notas: El número de jueces para M éxico se refiere únicamente al nivel federal. Los datos sobre abogados públicos para la Argentina se refieren al total del personal y para Brasil son estimados. Los datos regionales para el porcentaje del presupuesto no son ponderados; para el número de jueces y defensores públicos el promedio es ponderado.

Fuentes: Fuentes: Banco Mundial, Legal and Judicial Reform Practice Group, 2003; y CEJA, 2003a, $2003 b$.

disminuido significativamente, los notablesavances en la democratización de los regímenes no han sido acompañados por avances similares en lo que respecta a los derechos a la vida, la integridad, la discriminación y la seguridad. Las informaciones existentes, provenientes de diversas fuentes, ameritan realizar un cuidadoso seguimiento sobre la evolución de los derechos humanos y las distintas situaciones de violencia social en la región. Nos limitamos a señalar aquí, que más allá de los datos disponibles y sus metodologías de producción, sin duda existe una situación en torno al llamado núcleo básico delos derechos humanosque resulta preocupante. Esto constituyeun desafío para nuestrasinstituciones, para los gobiernos que forman parte del sistema y para el futuro delas democracias en América Latina.

\section{Administración de justicia}

El sistema de administración de justicia, un tercer componente de la ciudadanía civil, es una pieza clave para la protección de los derechos de la población. Los recursos, tanto financieros como humanos, dedicados a los sistemas de administración de justicia ofrecen indicios importantes acerca del grado en que los Estados latinoamericanos defienden estos derechos ciudadanos.

Como lo muestran los datos en la tabla 29, el promedio regional derecursos destinados a la justicia es del 2,5 por ciento del presupuesto de los gobiernos nacionales, y en al gunos casos es menor. Por otro lado, en ocho de los catorce países sobre los cuales existeinformación hay menos de un defensor público por cada 100.000 habitantes. 


\section{La petición ciudadana al sistema de administración de justicia}

Las expectativas de las ciudadanas y los ciudadanos en relación con el sistema de administración de justicia de sus respectivos países son buenas. Dos terceras partes de ellos $(66,5 \%)$ esperan que, de tener un problema que amerite acudir al sistema de justicia, éste se desempeñe positivamente en al menos una de las dimensiones de la justicia pronta y de la justicia cumplida.

La experiencia de quienes han entrado en contacto con el sistema de administración de justicia,

aproximadamente el $20 \%$ del total, es distinta. Menos de la mitad de ellos fue capaz de plantear una demanda o lograr completar el proceso $(40,3 \%)$. Las principales razones para desistir tienen que ver con la carencia de dinero, juicios lentos o tribunales alejados. Una tercera parte manifiesta que no fue tratada ni justa ni rápidamente, y manifiesta una extendida incidencia del "maltrato suave" (hacer largas filas, no le dieron información, trámites innecesarios). Sin embargo, sólo una minoría de personas con experiencia en el sistema de administración de justicia reporta haber sido víctima del "maltrato duro" (por ejemplo, coimas y discriminación). Finalmente, cuatro de cada diez dice haber acudido a las influencias o tenido que pedir dinero prestado para sus diligencias judiciales.

\begin{tabular}{|c|c|c|}
\hline \multicolumn{2}{|c|}{ EXPERIENCIA DE LOS CIUDADANOS CON EL SISTEMA } & \multirow[t]{2}{*}{ TABLA 30} \\
\hline \multicolumn{2}{|c|}{ DE ADMINISTRACIÓN DE JUSTICIA, 2002} & \\
\hline & Situación & Porcentaje \\
\hline \multirow[t]{2}{*}{ Necesidad del sistema (1) } & Ha requerido acudir al sistema de justicia & 20,0 \\
\hline & No ha tenido problemas que requieran una demanda & 80,0 \\
\hline \multirow[t]{2}{*}{ Resultado obtenido (2) } & No pudo plantear demanda o no pudo completar proceso & 59,7 \\
\hline & Planteó demanda y completó proceso & 40,3 \\
\hline \multirow[t]{3}{*}{ Razones para desistir (3) } & Barreras de acceso (8) & 49,8 \\
\hline & Sin confianza en la justicia & 11,3 \\
\hline & Otros(9) & 38,9 \\
\hline \multirow[t]{2}{*}{ Asistencia a tribunal (4) } & Ha asistido a tribunal & 17,4 \\
\hline & Nunca ha ido & 82,6 \\
\hline \multirow[t]{4}{*}{ Evaluación del proceso (5) } & No actuaron ni justa ni rápidamente & 33,0 \\
\hline & Actuaron rápidamente & 9,7 \\
\hline & Actuaron justamente & 24,7 \\
\hline & Actuaron justa y rápidamente & 32,5 \\
\hline \multirow[t]{4}{*}{ Evaluación del trato (6) } & Malas experiencias leves y graves & 12,4 \\
\hline & Malas experiencias graves (10) & 12,1 \\
\hline & Malas experiencias leves (11) & 40,5 \\
\hline & Sin malas experiencias (12) & 35,0 \\
\hline \multirow[t]{2}{*}{ Cosas que tuvo que hacer (7) } & Acudió a influencias o pidió dinero prestado & 39,1 \\
\hline & No necesitó influencia ni pedir dinero & 60,9 \\
\hline
\end{tabular}

Notas: $\mathrm{n}=14.035$ (necesidad del sistema); $\mathrm{n}=19.533$ (asistencia a tribunal).

(1) Según pregunta P15U. Se hace la consulta a todos los entrevistados. (2) Según pregunta P15U. Se basa únicamente en aquellas personas que sí han requerido acudir al sistema de justicia. (3) Según pregunta P16U. Se basa únicamente en aquellas personas que en la pregunta P15U indicaron que "no pudieron plantear la demanda o completar el proceso". (4) Según pregunta P17U. Se hace la consulta a todos los entrevistados. (5) Según pregunta P18U. Se basa únicamente en aquellas personas que han acudido a tribunales. (6) Según pregunta P19U. Se basa únicamente en aquellas personas que han acudido a tribunales. (7) Según pregunta P20U. Se basa únicamente en aquellas personas que han acudido a tribunales. (8) Agrupa las alternativas "Sin dinero", "Juicio tardaba mucho", "Tribunal alejado" y "No supo cómo hacerlo". (9) Agrupa las alternativas "M ejor un arreglo", "Varias de las anteriores" y "Ninguna de las anteriores" . (10) Agrupa "Le pidieron propina" y "Se sintió discriminado, humillado o fueron descorteses e irrespetuosos en el trato" . (11) Agrupa "Tuvo que hacer largas filas", "Le hicieron realizar trámites innecesarios" y "Le negaron información o le costó obtenerla". (12) Se supone que su experiencia fue positiva cuando el entrevistado no responde ninguna de las alternativas que se ofrecen en la pregunta.

Fuente: Procesamiento de preguntas incluidas en la Sección Propietaria del PNUD en Latinobarómetro 2002. 


\begin{tabular}{|c|c|c|c|c|c|}
\hline \multicolumn{5}{|c|}{ POBLACIÓN CARCELARIA, PRESOS SIN CONDENA Y HACINAMIENTO, 2002} & \multirow[b]{2}{*}{$\begin{array}{l}\text { Nivel de } \\
\text { ocupación (sobre } \\
\text { la base de la } \\
\text { capacidad oficial }\end{array}$} \\
\hline País & Año & $\begin{array}{l}\text { Total de } \\
\text { población } \\
\text { carcelaria } \\
\text { (incluye } \\
\text { detenidos } \\
\text { procesados y } \\
\text { detenidos sin } \\
\text { condena) }\end{array}$ & $\begin{array}{l}\text { Tasa de } \\
\text { población } \\
\text { carcelaria (por } \\
100.000 \\
\text { habitantes) }\end{array}$ & $\begin{array}{l}\text { Detenidos sin } \\
\text { proceso y } \\
\text { detenidos sin } \\
\text { condena } \\
\text { (porcentaje } \\
\text { de la población } \\
\text { carcelaria) }\end{array}$ & \\
\hline Argentina & 1999 & 38.604 & 107 & 55,2 & 119,9 \\
\hline Bolivia & 1999 & 8.315 & 102 & 36,0 & 162,5 \\
\hline Brasil & 2002 & 240.107 & 137 & 33,7 & 132,0 \\
\hline Chile & 2002 & 33.098 & 204 & 40,4 & 134,3 \\
\hline Colombia & 2001 & 54.034 & 126 & 41,1 & 136,5 \\
\hline Costa Rica & 1999 & 8.526 & 229 & 39,5 & 109,6 \\
\hline Ecuador & 2002 & 7.716 & 59 & 69,9 & 115,0 \\
\hline El Salvador & 2002 & 10.278 & 158 & 49,7 & 167,5 \\
\hline Guatemala & 1999 & 8.460 & 71 & 60,9 & 112,9 \\
\hline Honduras & 2002 & 11.502 & 172 & 78,5 & 207,6 \\
\hline M éxico & 2000 & 154.765 & 156 & 41,2 & 127,8 \\
\hline Nicaragua & 1999 & 7.198 & 143 & 30,8 & 113,0 \\
\hline Panamá & 2002 & 10.423 & 359 & 55,3 & 136,5 \\
\hline Paraguay & 1999 & 4.088 & 75 & 92,7 & 151,0 \\
\hline Perú & 2002 & 27.493 & 104 & 67,2 & 137,8 \\
\hline República Dominicana & 2001 & 15.341 & 178 & 64,5 & 175,3 \\
\hline Uruguay & 2002 & 5.629 & 166 & 72,5 & 150,8 \\
\hline Venezuela & 2000 & 15.107 & 62 & 57,5 & 97,2 \\
\hline América Latina & c. 2002 & 36.705 & 145 & 54,8 & 138,2 \\
\hline \multicolumn{6}{|c|}{ Referente extrarregional } \\
\hline Estados Unidos & 2001 & 1.962 .220 & 686 & 18,8 & 106,4 \\
\hline
\end{tabular}

Nota: Las cifras regionales son el promedio de los casos. La población carcelaria total para América Latina es 660.684 , y la población regional, 508 millones para 2002.

Fuentes: Centro Internacional para Estudios Penitenciarios, 2003. Los datos sobre nivel de ocupación para la Argentina son tomados de CELS 2001, cap. 2, fig. 2.4, y corresponden al año 2000.

Dado que la posibilidad de defensa en caso deun problema legal depende, para gran partedela población, de la existencia de defensores públicos, este indicador es preocupante y apunta a una limitación al derecho a la debida defensa.

La magnitud de las deficiencias de los sistemas de administración de justicia en América Latina emerge con mayor contundencia cuando se observan indicadores sobre población carcelaria, presos sin condena y capacidad carcelaria existente. La cantidad de personas privadas de libertad varía considerablemente de país a país. Algunos casos se destacan por la baja tasa de población carcelaria -Venezuela, Ecuador, Guatemala y Paraguay- $y$ otros, por el contrario, por su muy alta tasa -Panamá, Costa Rica y Chile-.
El número promedio de presos en América Latina es de 145 por 100.000 habitantes, muy por debajo de los 686 presos por 100.000 habitantes de Estados Unidos. Aun así, los países de América Latina hacen mucho menos por respetar los derechos de los acusados y los presos. La cantidad de presos sin condena o procesados que pue blan las cárceles latinoamericanas es simplemente escandalosa: 54,8 por ciento de la población carcelaria, en tanto que la cifra comparable para Estados Unidos es de 18,8 por ciento. En varios países-Paraguay, H onduras y Uruguay-, esta tasa se encuentra por encima del 70 por ciento.

Las condiciones de vida de los privados de libertad en los países latinoamericanos también son notablemente peores que en Estados 


\begin{tabular}{|c|c|c|}
\hline \multicolumn{2}{|c|}{ LIBERTAD DE PRENSA, } & TABLA 32 \\
\hline \multicolumn{3}{|l|}{ 2001-2002 } \\
\hline País & $\begin{array}{l}\text { Freedom } \\
\text { House } \\
2002\end{array}$ & $\begin{array}{l}\text { Reporteros } \\
\text { sin Fronteras } \\
2001-2002\end{array}$ \\
\hline Argentina & 39 & 12,0 \\
\hline Bolivia & 30 & 14,5 \\
\hline Brasil & 38 & 18,8 \\
\hline Chile & 22 & 6,5 \\
\hline Colombia & 63 & 40,8 \\
\hline Costa Rica & 14 & 4,3 \\
\hline Ecuador & 41 & 5,5 \\
\hline El Salvador & 38 & 8,8 \\
\hline Guatemala & 58 & 27,3 \\
\hline Honduras & 51 & .. \\
\hline México & 38 & 24,8 \\
\hline Nicaragua & 40 & .. \\
\hline Panamá & 34 & 15,5 \\
\hline Paraguay & 55 & 8,5 \\
\hline Perú & 35 & 9,5 \\
\hline Rep. Dominicana & 33 & .. \\
\hline Uruguay & 30 & 6,0 \\
\hline Venezuela & 68 & 25,0 \\
\hline América Latina & 40,4 & 15,2 \\
\hline
\end{tabular}

Notas: Las escalas de libertad de prensa de Freedom House y de Reporteros sin Fronteras van de 0 a 100, las cifras más bajas indican el mayor grado de libertad. La información de Reporteros sin Fronteras cubre el período septiembre 2001-octubre 2002. Los dos puntos seguidos (..) indican que la información no está disponible.

Fuentes: Karlekar 2003, y Reporteros sin Fronteras 2003.

Unidos. Un indicador básico, el de hacinamiento, señala que en América Latina la población carcelaria excede la capacidad instalada en 38,2 por ciento, seis veces más que en Estados Unidos.

\section{Libertad de prensa y derecho a la información}

La libertad de prensa y el derecho a la información, un cuarto componente de la ciudadanía civil, son derechos civiles clásicos, importantes en sí mismos pero también en cuanto afectan fuertemente el ejercicio de otros derechos ciudadanos. Por ejemplo, la teoría democrática pone énfasis en la libertad de prensa como una condición para que el proceso electoral sea democrático y, en particular, para quesea realmentecompetitivo. La libertad de prensa y el derecho a la información son condiciones necesarias para

\begin{tabular}{lcc}
\hline MUERTE DE PERIODISTAS, & TABLA 33 \\
\hline 1993-2002 & & \\
\hline País & 1993-1997 & $\mathbf{1 9 9 8 - 2 0 0 2}$ \\
\hline Argentina & 1 & 1 \\
Bolivia & 0 & 1 \\
Brasil & 6 & 4 \\
Chile & 0 & 0 \\
Colombia & 13 & 18 \\
Costa Rica & 0 & 1 \\
Ecuador & 0 & 0 \\
El Salvador & 1 & 0 \\
Guatemala & 2 & 2 \\
Honduras & 1 & 0 \\
México & 5 & 3 \\
Nicaragua & 0 & 0 \\
Panamá & 0 & 0 \\
Paraguay & 0 & 1 \\
Perú & 1 & 0 \\
Rep. Dominicana & 1 & 0 \\
Uruguay & 0 & 1 \\
Venezuela & 1 & 1 \\
Región & & \\
América Latina & $\mathbf{3 2}$ & \\
Europa occidental & & \\
& & \\
\hline
\end{tabular}

Nota: Los índices miden únicamente el número de casos claramente confirmados de periodistas asesinados en cumplimiento del deber, sea por represalia directa por su trabajo o por fuego cruzado. Fuente: CPI 2003.

que la sociedad tenga capacidad de fiscalizar al Estado y al gobierno, así como, en general, participar en los asuntos públicos. La situación en la región ha mejorado notoriamente en las últimas décadas a pesar de queen algunos casos hay percepciones un tanto desfavorables.

Una primera aproximación al tema, por medio de los datos de Freedom $\mathrm{H}$ ouse sobre libertad de prensa, arroja ciertas conclusiones importantes. El promedio para América Latina, en una escala de 100 puntos - que se construyeluego de consultar paneles designados por cada una de las organizaciones-, da cuenta de percepciones y opiniones, e indica para la última década una situación de estancamiento. El contraste entreAmérica Latina y Europa occi dental es significativo y señala que la libertad de prensa en América Latina todavía enfrenta un déficit importante. 


\begin{tabular}{|c|c|c|c|}
\hline \multicolumn{3}{|c|}{ DERECHO AL ACCESO A LA INFORMACIÓN } & TABLA 34 \\
\hline \multicolumn{4}{|c|}{ PÚBLICA Y HÁBEAS DATA, 2002} \\
\hline \multirow[b]{2}{*}{ País } & \multirow[b]{2}{*}{$\begin{array}{l}\text { Derecho al acceso } \\
\text { a la información pública }\end{array}$} & \multicolumn{2}{|c|}{ Hábeas data } \\
\hline & & $\begin{array}{l}\text { Opción } \\
\text { legal }\end{array}$ & Año de adopción \\
\hline Argentina & Sí & Sí & 1994 \\
\hline Bolivia & No & No & - \\
\hline Brasil & Sí & Sí & 1988 \\
\hline Chile & Sí, pero ambigua & No & - \\
\hline Colombia & Sí & Sí & 1997 \\
\hline Costa Rica & No & No & - \\
\hline Ecuador & No & Sí & 1996 \\
\hline El Salvador & No & No & - \\
\hline Guatemala & Sí & Sí & 1995 \\
\hline Honduras & Sí & No & - \\
\hline México & Sí & Sí & 2002 \\
\hline Nicaragua & Sí, pero ambigua & Sí & 1995 \\
\hline Panamá & Sí & Sí & 2002 \\
\hline Paraguay & No & Sí & 1992 \\
\hline Perú & Sí & Sí & 1993 \\
\hline Rep. Dominicana & Sí & No & - \\
\hline Uruguay & No & No & - \\
\hline Venezuela & Sí & Sí & 1999 \\
\hline
\end{tabular}

Notas: La expresión "derecho al acceso a la información pública" se refiere al derecho a obtener información de manos estatales sobre el manejo de los asuntos públicos. La expresión "Hábeas data" se refiere a una acción que garantice el acceso de cualquier individuo a la información contenida en bases de datos públicas o privadas, referida a su persona 0 a su propiedad, y en caso de ser necesaria la posibilidad de actualizar, corregir, remover o preservar tal información con el objeto de proteger ciertos derechos fundamentales.

Fuentes: OEA-CIDH, Relatoría para la Libertad de Expresión 2001, cap. 3, cuadro 1; y Guadamuz 2000 y 2001.

La situación varía entrelos países. En estesentido es importante señalar que, aun con las obvias dificultades de medir la libertad de prensa, existe un considerablegrado de acuerdo entrelos datos deFreedom House y de Reporterossin Fronteras -otra reconocida fuente deinformación sobreeste tema-, por lo menos con respecto a los casos más favorables y los más problemáticos.

Un aspecto cercanamente vinculado a este tema es el de la vida misma de los periodistas. Sólo en cuatro países dela región ningún periodista ha perdido la vida en losúltimos diez años. El contraste con Europa occidental es, otra vez, notable.

El derecho deacceso a la información pública es legalmente reconocido en toda la región, con excepción de cinco países.

En particular, en los últimos años se ha avanzado en cuanto al reconocimiento del hábeas data y hoy sólo restan siete países de América Latina donde este derecho aún no existe.
Un análisis más completo sobre estetema re queriría datos de los que hoy se carece, con el fin de tener una idea más precisa que la que hemos presentado acerca de las condiciones bajo las cuales las personas tienen acceso a este tipo de información.

\section{Conclusiones sobre la ciudadanía civil: logros y deficiencias}

- Los datos apuntan a ciertos logros significativos, especialmente en lo referenteal reconocimiento legal de los derechos civiles en general, de las mujeres y de los pueblos indígenas.

- También existen avances en el respeto a los derechos humanosy la libertad de prensa.

- La igualdad legal y la protección contra la discriminación se encuentran comprometidas por las disparidades de su aplicación entre distintas categorías de ciudadanos. 
- El derecho a la vida, a la integridad física y a la seguridad se ve limitado por los altos niveles deinseguridad ciudadana que se registran en la región.

- En general, el funcionamiento de la administración de la justicia no evita violaciones de los derechos de los acusados y los presos.

\section{Ciudadanía social}

La ciudadanía social refiere a aquellos aspectos de la vida de los ciudadanos que afectan el potencial para desarrollar sus capacidades básicas. A diferencia de los otros tipos de ciudadanía, la ciudadanía social no siempre tiene una clara base legal en las constituciones y legislaciones nacionales, y su aceptación internacional, mediante convenioso tratados, es menos difundida. 66 La acción constante de la sociedad civil, sin embargo, ha permitido no sólo avanzar en el debate, sino en la permanente movilización para lograr que la ciudadanía social sea un efectivo componente de la ciudadanía integral.

En ámbitos académicos y políticos existen debates acerca de cuáles deberían ser los contenidos de la ciudadanía social. Deesos debates ha surgido un cierto consenso respecto de los componentes básicos de esa ciudadanía. En este sentido, el aporte que han hecho los informes de desarrollo humano67 ha sido importante.

Los derechos a la salud y a la educación son considerados componentes bási cos de la ciudadanía social. A su vez, la falta de empleo, la pobreza y la desigual dad han sido ampliamentereconocidas como aspectos que obstaculizan la integración de los individuos en la sociedad. En condiciones de extrema pobreza y desigualdad se dificulta la efectividad de un presupuesto clave dela democracia: que los individuos son ciudadanos plenosqueactúan en una esfera pública donde se relacionan en condición de iguales.
RECUADRO 29

\section{Ciudadanos pobres y desiguales}

\begin{abstract}
Éste es un problema en todos lados. Vimos que es inherente a la dimensión burocrática del Estado; es más severo y sistemático cuando el "sujeto" de estas relaciones está afligido por pobreza y desigualdad severa y extendida. Estos males cultivan el autoritarismo social, extensamente practicado en América Latina por ricos y poderosos, y repercuten en la manera que las burocracias del Estado tratan a muchos individuos. Ésta es, creo, otra dimensión crucial de la calidad de la democracia; en América Latina, con sus profundas y persistentes desigualdades, esta dimensión es una de las más deficientes.
\end{abstract}

Guillermo O'Donnell, texto elaborado para el PRODDAL, 2002c.

A continuación presentamos algunosindicadores centrales de la ciudadanía social: salud, educación, empleo, pobreza y desigualdad, agrupados en las dos dimensiones indicadas en el recuadro 30. La lectura de estos indicadores nos dará una aproximación a la capacidad efectiva de ejercicio de la ciudadanía en América Latina.

RECUADRO 30

\section{Dimensiones de la ciudadanía social}

\begin{tabular}{ll} 
Dimensión & Cuestiones relevantes \\
\hline Necesidades básicas & Salud y educación \\
Integración social & Empleo, pobreza y desigualdad
\end{tabular}

66 Por ejemplo, el Protocolo Adicional a la Convención Interamericana de los Derechos Humanos en el área de los derechos económicos, sociales y culturales, denominado Protocolo de San Salvador fue suscripto recién en 1988. 67 Sobre el impacto de la desigualdad y la pobreza sobre las capacidades de los ciudadanos, ver Sen, 1999b, pp. 20-24 y capítulo 4. Sobre la salud y la educación como dos necesidades básicas, ver PNUD, 2002c, pp. 252-253. 


\begin{tabular}{|c|c|c|c|c|}
\hline \multicolumn{3}{|c|}{ DESNUTRICIÓN INFANTIL, 1985-2000 } & \multicolumn{2}{|r|}{ TABLA 35} \\
\hline \multirow[b]{2}{*}{ País } & \multicolumn{2}{|c|}{ Último año } & \multicolumn{2}{|c|}{ Tendencia reciente } \\
\hline & Año & Porcentaje & Años de comparación & Cambio porcentual \\
\hline Argentina & $1995 / 96$ & 12,4 & $1994-95 / 96$ & 7,7 \\
\hline Bolivia & 1998 & 26,8 & $1989-98$ & $-10,9$ \\
\hline Brasil & 1996 & 10,5 & $1989-96$ & $-15,4$ \\
\hline Chile & 1999 & 1,9 & $1986-99$ & $-7,7$ \\
\hline Colombia & 2000 & 13,5 & $1989-00$ & $-3,1$ \\
\hline Costa Rica & 1996 & 6,1 & $1989-96$ & $-3,1$ \\
\hline Ecuador & 1998 & 26,4 & $1986-98$ & $-7,6$ \\
\hline El Salvador & 1998 & 23,3 & 1993-98 & 0,2 \\
\hline Guatemala & 1999 & 46,4 & $1987-99$ & $-11,3$ \\
\hline Honduras & 1996 & 38,9 & $1991 / 92-96$ & 2,6 \\
\hline México & 1999 & 17,7 & $1988-99$ & $-5,1$ \\
\hline Nicaragua & 1998 & 24,9 & 1993-98 & 2,4 \\
\hline Panamá & 1997 & 18,2 & $1985-97$ & $-0,6$ \\
\hline Paraguay & 1990 & 13,9 & .. & .. \\
\hline Perú & 2000 & 25,4 & $1991 / 92-00$ & $-6,4$ \\
\hline Rep. Dominicana & 1996 & 10,7 & $1991-96$ & $-5,8$ \\
\hline Uruguay & 1992/93 & 9,5 & $1987-92 / 93$ & $-6,4$ \\
\hline Venezuela & 2000 & 12,8 & $1990-00$ & $-1,0$ \\
\hline América Latina & & 18,9 & & $-4,2$ \\
\hline
\end{tabular}

Notas: La baja talla para edad es una medida que compara la estatura de un niño de acuerdo con su edad en relación con la media de la población de referencia. Este indicador refleja un crecimiento acumulado deficiente y constituye una medida de bajos logros previos en el crecimiento físico. Está asociado con un conjunto de factores de largo plazo tales como una ingesta alimentaria crónicamente insuficiente, infecciones frecuentes, persistentes malas prácticas de alimentación y un bajo nivel económico del hogar.

Fuente: Cálculo basado en datos de la OMS, Departamento de Nutrición para la Salud y el Desarrollo 2002.

Los datos sobre la ciudadanía social muestran que la mayoría de los países deAmérica Latina exhibe severas deficiencias que afectan a importantes y, en ocasiones, mayoritarios segmentos de sus poblaciones. Todos los países de la región son más desiguales que el promedio mundial y dieciséis de un total de dieciocho pueden ser catal ogados como sumamente desiguales. Para el año 2002, en quince casos, más del 25 por ciento de la población vive bajo la línea de pobreza, y en siete, la proporción de pobres supera el 50 por ciento.

\section{Necesidad es básicas}

En esta dimensión se registran al gunos avances, aunque los indicadores continúan aún distantes de lo deseable. Se observan en la región mejoras en los indicadores de desnutrición infantil y analfabetismo y tres países - Chile, Costa Rica y U ruguay- se destacan por tener niveles relativamente bajos de estos problemas.
Específicamente, la desnutrición infantil ha disminuido en trece países, de manera notable en Brasil, Guatemala y Bolivia. Pero aún afecta a más del 5 por ciento de los niños en dieciséis de los dieciocho países y, en siete de éstos, al menos uno de cada cinco niños sufre de desnutrición.

La tasa de analfabetismo se redujo en todos los países de la región, registrándose los avances más grandes en Guatemala, Bolivia, El Salvador y Honduras. Sin embargo, el analfabetismo todavía alcanza a más del 5 por ciento de la población mayor de quince años en catorce de los dieciocho países, y en cuatro de ellos alcanza a 20 por ciento o más.

Los logros en materia de reducción de la desnutrición infantil y del analfabetismo evidencian que, en muchos casos, estas deficiencias relacionadas con la ciudadanía social han podido ser atendidas con resultados positivos en losúltimos años. 


\begin{tabular}{|c|c|c|c|c|}
\hline \multicolumn{4}{|c|}{ ANALFABETISMO EN MAYORES DE } & \multirow[t]{2}{*}{ TABLA 36} \\
\hline \multicolumn{4}{|c|}{15 AÑOS, 1970-2000 } & \\
\hline País & 1970 & 1980 & 1990 & 2000 \\
\hline Argentina & 7,0 & 5,6 & 4,3 & 3,2 \\
\hline Bolivia & 42,3 & 31,2 & 21,8 & 14,5 \\
\hline Brasil & 31,9 & 24,5 & 19,1 & 14,8 \\
\hline Chile & 12,2 & 8,5 & 5,9 & 4,2 \\
\hline Colombia & 22,1 & 15,9 & 11,5 & 8,3 \\
\hline Costa Rica & 11,8 & 8,3 & 6,1 & 4,4 \\
\hline Ecuador & 25,7 & 18,1 & 12,3 & 8,4 \\
\hline El Salvador & 42,0 & 34,1 & 27,5 & 21,3 \\
\hline Guatemala & 54,8 & 46,9 & 38,9 & 31,4 \\
\hline Honduras & 46,7 & 38,6 & 31,5 & 25,4 \\
\hline México & 25,1 & 17,7 & 12,1 & 8,6 \\
\hline Nicaragua & 45,5 & 41,2 & 37,2 & 33,5 \\
\hline Panamá & 20,8 & 15,2 & 11,0 & 8,1 \\
\hline Paraguay & 20,2 & 14,1 & 9,7 & 6,7 \\
\hline Perú & 28,5 & 20,5 & 14,5 & 10,1 \\
\hline Rep. Dominicana & 32,8 & 26,1 & 20,6 & 16,4 \\
\hline Uruguay & 7,0 & 5,1 & 3,4 & 2,3 \\
\hline Venezuela & 23,6 & 16,0 & 11,0 & 7,4 \\
\hline América Latina & 27,8 & 21,5 & 16,6 & 12,7 \\
\hline
\end{tabular}

Nota: Los datos representan la proporción de la población adulta que es analfabeta. Se refiere a la población de más de 15 años de edad que no es capaz de leer 0 escribir una breve frase en su vida cotidiana. Los datos para la región son el promedio de todos los casos. Fuente: UNESCO, Instituto de Estadísticas 2002a.

Otros indicadores, como mortalidad infantil, expectativa de vida y nivel de escolarización, también permiten observar algunos avances, aunque en ocasiones el nivel de la mejoría resulta escaso frente a la extensión y profundidad de los déficit existentes.

En materia de indicadores de salud y educación existe una tendencia general positiva en la región. No obstante, es necesario ser cautos en la valoración de estos indicadores. Hay otros datos disponibles que ponen en duda algunos de los indicadores aquí utilizados. En este sentido, el estudio "Aptitudes lingüísticas para el mundo de mañana", realizado por la OCDE y la UNESCO, que comprendió a cuarenta y un países, muestra que, aunque alfabetizados, un número importantísimo - más de la mitad- de los alumnos de Latinoamérica no tiene real capacidad de leer y entender lo que lee. Los seis países latinoamericanos incluidos en el estudio se encuentran entre los últimos lugares en los índices de calidad educativa y de desempeño de los alumnos.

\section{Integración social}

En esta dimensión se evidencian las más graves carencias de la ciudadanía social en América Latina. Los problemas de empleo, pobreza y desigualdad registran niveles muy altos. Tanto es así que aun cuando es posible notar ciertas mejorías, como en el caso de la pobreza, ello resulta insuficiente para dejar de caracterizar la situación como sumamente grave. La situación del empleo ha desmejorado y los niveles de desigualdad sehan mantenido estacionarios o han aumentado. El nivel de desempleo de América Latina se ubica entre los más al tos del mundo y el de desigualdad es el más alto del mundo.

En la medida que la ciudadanía social contiene un componente económico, el empleo constituye para la mayoría de la población un pilar básico de su ciudadanía. El trabajo es la forma en que los ciudadanos aportan a la producción de la sociedad y por la cual se hacen de los medios que les permiten gozar de sus derechos. Para la enorme mayoría de los latinoamericanos, el empleo es la vía para enfrentar la pobreza y salir de ella. Sin embargo, con frecuencia esta expectativa no se satisface, lo que constituye un tremendo desafío para la política y la democracia en la región.

RECUADRO 31

\section{Inserción genuina para los "supernumerarios"}

Casi todo el mundo recusa abiertamente el modelo de "sociedad dual". Pero muchos le abren las puertas celebrando cualquier realización -desde el desarrollo de un sector de "utilidad social" hasta la apertura de "nuevos yacimientos de empleo"siempre y cuando procure alguna actividad a los supernumerarios. Ahora bien, si uno se ubica en la problemática de la integración social, no se trata sólo de procurar ocupación a todos, sino también un estatuto.

Robert Castel, 1995, pp. 454-455. 
MORTALIDAD INFANTIL, 1970-2000

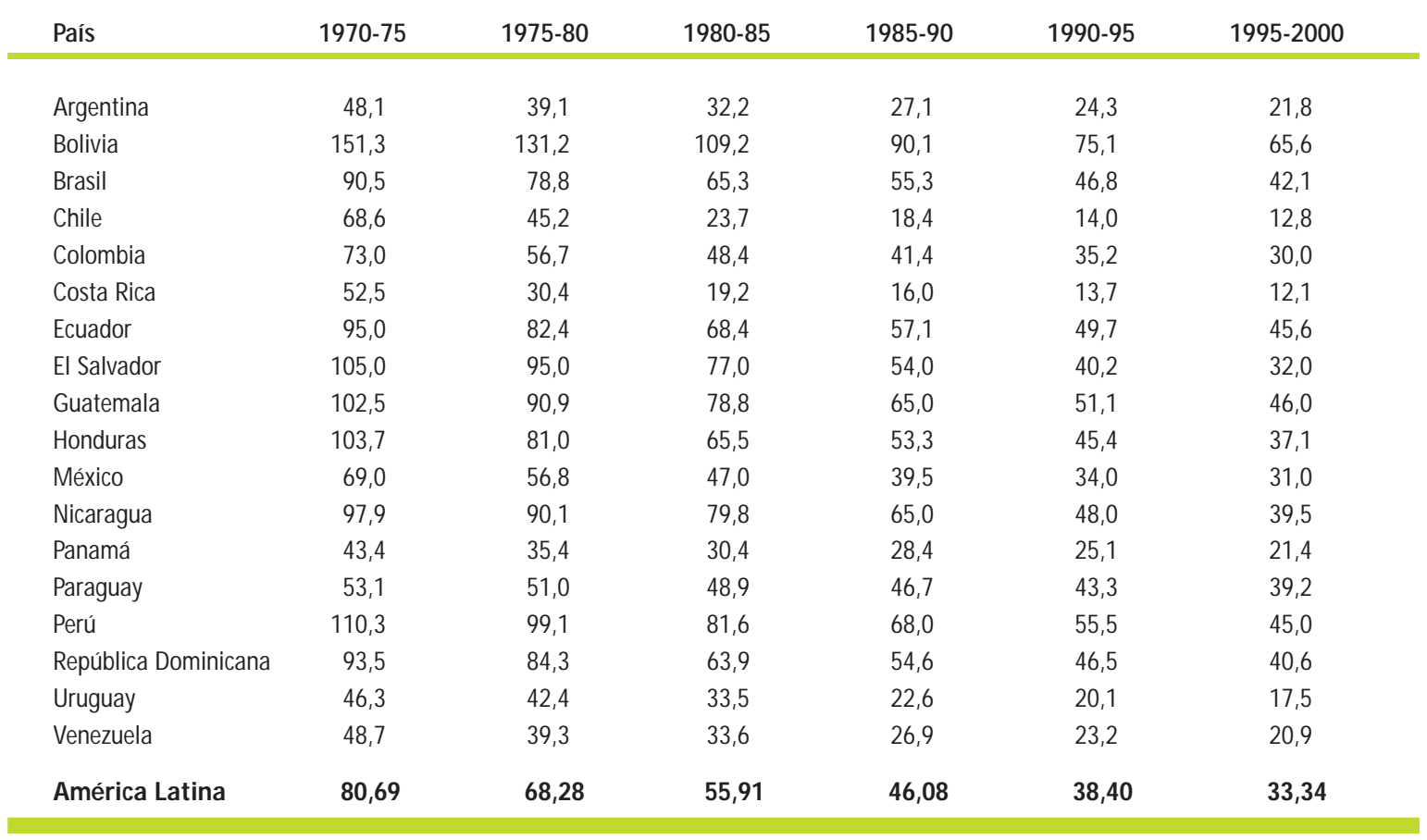

Nota: La mortalidad infantil se mide en términos de la probabilidad de muerte entre el nacimiento y el año de edad. Se expresa en términos de muertes cada 1.000 nacimientos. Los datos de la región son el promedio de todos los casos.

Fuente: Naciones Unidas, Departamento de Asuntos Económicos y Sociales, División de Población, 2001.

\begin{tabular}{|c|c|c|c|c|c|c|}
\hline \multicolumn{6}{|c|}{ ESPERANZA DE VIDA AL NACER, 1970-2000 } & \multirow{2}{*}{$\begin{array}{l}\text { TABLA } 38 \\
1995-2000\end{array}$} \\
\hline País & $1970-75$ & $1975-80$ & $1980-85$ & $1985-90$ & $1990-95$ & \\
\hline Argentina & 67,1 & 68,5 & 70,0 & 70,8 & 71,9 & 72,9 \\
\hline Bolivia & 46,7 & 50,0 & 53,7 & 56,8 & 59,3 & 61,4 \\
\hline Brasil & 59,5 & 61,5 & 63,1 & 64,6 & 66,0 & 67,2 \\
\hline Chile & 63,4 & 67,1 & 70,6 & 72,5 & 74,2 & 74,9 \\
\hline Colombia & 61,6 & 63,8 & 66,6 & 67,6 & 68,2 & 70,4 \\
\hline Costa Rica & 67,9 & 70,8 & 73,5 & 74,5 & 75,3 & 76,0 \\
\hline Ecuador & 58,8 & 61,3 & 64,3 & 66,8 & 68,5 & 69,5 \\
\hline El Salvador & 58,2 & 56,7 & 56,6 & 63,2 & 66,8 & 69,1 \\
\hline Guatemala & 53,7 & 56,0 & 58,0 & 59,6 & 62,5 & 64,0 \\
\hline Honduras & 53,8 & 57,3 & 60,9 & 64,3 & 65,0 & 65,6 \\
\hline México & 62,4 & 65,1 & 67,5 & 69,6 & 71,2 & 72,2 \\
\hline Nicaragua & 55,1 & 57,5 & 59,3 & 62,0 & 65,9 & 67,7 \\
\hline Panamá & 66,2 & 68,8 & 70,5 & 71,4 & 72,5 & 73,6 \\
\hline Paraguay & 65,9 & 66,5 & 67,1 & 67,6 & 68,5 & 69,6 \\
\hline Perú & 55,4 & 58,4 & 61,4 & 64,1 & 66,5 & 68,0 \\
\hline República Dominicana & 59,7 & 61,8 & 62,8 & 64,7 & 66,5 & 67,3 \\
\hline Uruguay & 68,7 & 69,5 & 70,8 & 71,9 & 72,8 & 73,9 \\
\hline Venezuela & 65,7 & 67,5 & 68,6 & 70,3 & 71,4 & 72,4 \\
\hline América Latina & 60,54 & 62,67 & 64,74 & 66,79 & 68,50 & 69,76 \\
\hline
\end{tabular}

Nota: Este indicador expresa, en años, la esperanza de vida al nacer. Los datos para la región son promedios de todos los casos. Fuente: Naciones Unidas, Departamento de Asuntos Económicos y Sociales, División de Población, 2001. 


\begin{tabular}{|c|c|c|c|}
\hline \multicolumn{3}{|c|}{ ESCOLARIZACIÓN PRIMARIA, } & TABLA 39 \\
\hline \multicolumn{4}{|c|}{ SECUNDARIA Y TERCIARIA, 1999} \\
\hline País & $\begin{array}{l}\text { Tasa neta de } \\
\text { escolarización } \\
\text { primaria }\end{array}$ & $\begin{array}{l}\text { Tasa neta de } \\
\text { escolarización } \\
\text { secundaria }\end{array}$ & $\begin{array}{l}\text { Tasa de } \\
\text { escolarización } \\
\text { terciaria }\end{array}$ \\
\hline Argentina & 100,0 & 76,0 & 48,0 \\
\hline Bolivia & 99,1 & .. & 32,9 \\
\hline Brasil & 96,5 & 68,5 & 14,8 \\
\hline Chile & 88,9 & 71,8 & 37,5 \\
\hline Colombia & 88,1 & 54,3 & 22,2 \\
\hline Costa Rica & 91,3 & 43,4 & .. \\
\hline Ecuador & 97,7 & 46,9 & .. \\
\hline El Salvador & 80,6 &.. & 18,2 \\
\hline Guatemala & 81,0 & 18,4 &.. \\
\hline Honduras & .. & .. & 13,0 \\
\hline México & 100,0 & 57,4 & 19,8 \\
\hline Nicaragua & 79,4 & .. & .. \\
\hline Panamá & 98,0 & 60,9 & .. \\
\hline Paraguay & 91,5 & 45,0 &.. \\
\hline Perú & 100,0 & 61,5 & 28,8 \\
\hline Rep. Dominicana & 90,6 & 40,0 &.. \\
\hline Uruguay & 93,6 & 77,4 & 33,6 \\
\hline Venezuela & 88,0 & 50,4 & 29,2 \\
\hline América Latina & 92,0 & 55,1 & 27,1 \\
\hline
\end{tabular}

Notas: Los dos puntos seguidos (..) indican que la información no está disponible. La tasa neta de escolarización primaria y secundaria es el porcentaje de niños en edad escolar (según la definición de cada país) efectivamente inscriptos en la escuela. Las tasas netas de escolarización terciaria no están disponibles. Los datos para El Salvador (todas las categorías) y Perú (secundaria y terciaria) son de 1998/1999, el resto se basan en información de 1999/2000. Los datos para la región son promedios de todos los casos disponibles. Fuente: UNESCO, Instituto de Estadísticas, 2002b, 2002c y $2002 d$.

En América Latina todo indica que el empleo ha perdido calidad y fuerza como medio de inserción social. Como señala la Comisión Económica para América Latina y el Caribe (CEPAL): "El empleo constituye el vínculo más importante entre desarrollo económico y desarrollo social por cuanto es la principal fuente de ingreso de los hogares (genera el 80 por ciento del total). La exclusión y la segmentación derivadas de la falta de acceso a empleos de calidad son, por ende, factores determinantes de la pobreza y las desigualdades sociales que se reproducen en el tiempo, expresadas en la elevada y

\begin{tabular}{|c|c|c|c|}
\hline \multicolumn{3}{|c|}{ CALIDAD EDUCATIVA Y } & TABLA 40 \\
\hline \multicolumn{4}{|c|}{ PERFORMANCE DEL ALUMNO, 2002} \\
\hline \multirow[b]{2}{*}{ País } & \multicolumn{3}{|c|}{ Porcentaje de alumnos en cada nivel } \\
\hline & Bajo & Mediano & Alto \\
\hline Argentina & 43,9 & 45,8 & 10,3 \\
\hline Brasil & 55,8 & 40,6 & 4,7 \\
\hline Chile & 48,2 & 46,6 & 5,3 \\
\hline México & 44,2 & 48,8 & 6,9 \\
\hline Perú & 79,6 & 19,4 & 1,1 \\
\hline Finlandia & 6,9 & 43,0 & 50,1 \\
\hline Corea del Sur & 5,7 & 55,4 & 36,8 \\
\hline Estados Unidos & 17,9 & 48,4 & 33,7 \\
\hline
\end{tabular}

Notas: Porcentaje de estudiantes en cada nivel de rendimiento en la escala combinada de capacidad de lectura. El concepto de alfabetismo empleado en el Programa para Evaluación de Estudiantes Internacionales (PISA) es más amplio que la noción tradicional, es decir, "poder leer y escribir". Aquí el alfabetismo se mide sobre un continuo, no como algo que un individuo posee o no posee, aun cuando puede ser necesario 0 deseable para algunos propósitos definir un punto en el continuo de alfabetismo por debajo del cual los niveles de competencia se consideran inadecuados. De hecho, no existe una línea que distinga entre una persona que es completamente alfabética y otra que no lo es. El PISA - test de capacidad de lectura- se realizó con alumnos de 15 años. El estudiante debía poder buscar la información, entender e interpretar los textos, reflexionar y evaluar sobre su contenido.

Fuentes: OCDE y UNESCO 2003, p. 274. persistente concentración del ingreso que prevalece en la región".68

Como ya hemos señalado, la situación del empleo se ha agravado en América Latina. $69 \mathrm{La}$ tasa de desocupación abierta (ponderada) en 2002 fue del 10,8 por ciento, el nivel más alto desde que se dispone de cifras confiables.

La tasa de desempleo urbano cayó en Colombia, Ecuador y, más levemente, en El Salvador y Chile. En cambio, aumentó en la Argentina, Bolivia, Costa Rica, M éxico, Nicaragua, Panamá, Paraguay, Perú, República Dominicana, Uruguay y Venezuela.

68 "Globalización y desarrollo social", alocución del secretario ejecutivo de la CEPAL, JoséAntonio O campo, en el II Encuentro de ex Presidentes Latinoamericanos, Santiago, Chile, 22-23 de abril de 2002.

69 OIT, O ficina Regional para las Américas, 2002. 
(TASAS ANUALES MEDIAS), 1985-2002

\begin{tabular}{lrrrrr} 
País & $\mathbf{1 9 8 5}$ & $\mathbf{1 9 9 0}$ & $\mathbf{1 9 9 5}$ & $\mathbf{2 0 0 0}$ & $\mathbf{2 0 0 2}$ \\
\hline Argentina & 6,1 & 6,1 & 16,4 & 15,1 & 19,7 \\
Bolivia & 5,7 & 7,2 & 3,6 & 7,5 & 8,7 \\
Brasil & 5,3 & 4,3 & 4,6 & 7,1 & 7,1 \\
Chile & 17,0 & 7,4 & 6,6 & 9,2 & 9,0 \\
Colombia & 13,8 & 10,5 & 8,8 & 20,2 & 16,2 \\
Costa Rica & 7,2 & 5,4 & 5,2 & 5,2 & 6,8 \\
Ecuador & 10,4 & 6,1 & 7,7 & 9,7 & 6,3 \\
El Salvador &. & 10,0 & 7,0 & 6,5 & 6,2 \\
Honduras & 11,7 & 6,9 & 6,6 &. & 5,9 \\
México & 4,4 & 2,8 & 6,2 & 2,2 & 2,7 \\
Nicaragua & 3,2 & 7,6 & 16,9 & 9,8 & 12,1 \\
Panamá & 15,7 & 20,0 & 16,4 & 15,3 & 16,4 \\
Paraguay & 5,1 & 6,6 & 5,3 & 10,0 & 14,7 \\
Perú & 10,1 & 8,3 & 7,9 & 7,0 & 9,4 \\
República Dominicana &.. &. & 15,8 & 13,9 & 17,2 \\
Uruguay & 13,1 & 9,2 & 10,8 & 13,6 & 17,0 \\
Venezuela & 14,3 & 11,0 & 10,3 & 13,9 & 15,9 \\
América Latina & $\mathbf{8 , 3}$ & $\mathbf{5 , 7}$ & $\mathbf{7 , 4}$ & $\mathbf{8 , 5}$ & $\mathbf{1 0 , 8}$
\end{tabular}

Notas: Los dos puntos seguidos (..) indican que la información no está disponible. Para Argentina, Bolivia, Costa Rica, El Salvador, Honduras, Nicaragua, Panamá, Uruguay y Venezuela la encuesta es nacional urbana. En Brasil se consideran seis regiones metropolitanas (no se incluye aquí una nueva serie para Brasil). En Chile, cubre el total del país. Para Colombia, sólo se toman bajo consideración siete áreas metropolitanas; desde 2000 el universo se expandió, incluyendo trece áreas metropolitanas. En Ecuador se toma el total del país hasta 1997; a partir de 1998, sólo Quito, Guayaquil y Cuenca están incluidos. En México se toman 39 áreas urbanas. La OIT no incluye datos para Guatemala. En Paraguay sólo se realizó la encuesta en Asunción. Los datos de República Dominicana incluyen desempleo oculto. Finalmente, para Perú se toma sólo en cuenta a Lima metropolitana. Desde 1996 a 2000 corresponde a nacional urbano. Las cifras a partir de 2001 corresponden a Lima metropolitana. Para América Latina los promedios fueron ponderados por la OIT.

Fuente: En base a la información de las Encuestas de Hogares de los países, OIT, Panorama Laboral 2003, Anexo Estadístico. Notar que los datos de esta tabla no coinciden necesariamente con los de la Tabla 2, que utilizan datos de CEPAL 2003.

Entre los jóvenes latinoamericanos, la tasa de desocupación, en la mayoría de los países de la región, duplica o casi duplica el promedio nacional de desocupación.

Por su parte, disminuyó la cobertura social a los trabajadores y creció el empleo informal: sie te de cada diez nuevos empleos creados en la región desde 1990 corresponden al sector informal. Además, sólo seis de cada diez nuevos empleos generados desde 1990 en el sector formal tienen acceso a algún tipo de cobertura social. Esta situación plantea una seria alarma sobre el futuro de nuestras sociedades: muchos de los latinoa- mericanos, además de las carencias que sufren actualmente, están afectados por el riesgo dedesprotección al llegar a la edad de retiro.

La expansión de la informalidad es un elocuente indicador de la crisis del empleo. Además, es una respuesta inapropiada para paliar el desempleo, ya que crea ocupaciones de baja calidad y baja utilidad social, queson generalmente insuficientes para constituirse en formas de integración social quegaranticen mínimosumbrales de bienestar.

Según datos de la OIT, en 1990 el déficit primario del trabajo decente 70 alcanzaba al 49,5

70 El déficit primario del trabajo decentees un indicador que elaboró y cal cula la OIT. Para ello examina la evolución de las brechas deempleo y seguridad social. Para estimar la brecha de empleo toma dos componentes: desempleo einformalidad. El primero corresponde a la diferencia de la tasa de desempleo real y el promedio de un período detreinta años (1950-1980) que arroja la denominada tasa de desempleo “histórica”. El segundo componente toma en cuenta los ocupados en actividades informales de baja calidad (baja productividad, niveles de ingresos volátiles y cercanos 


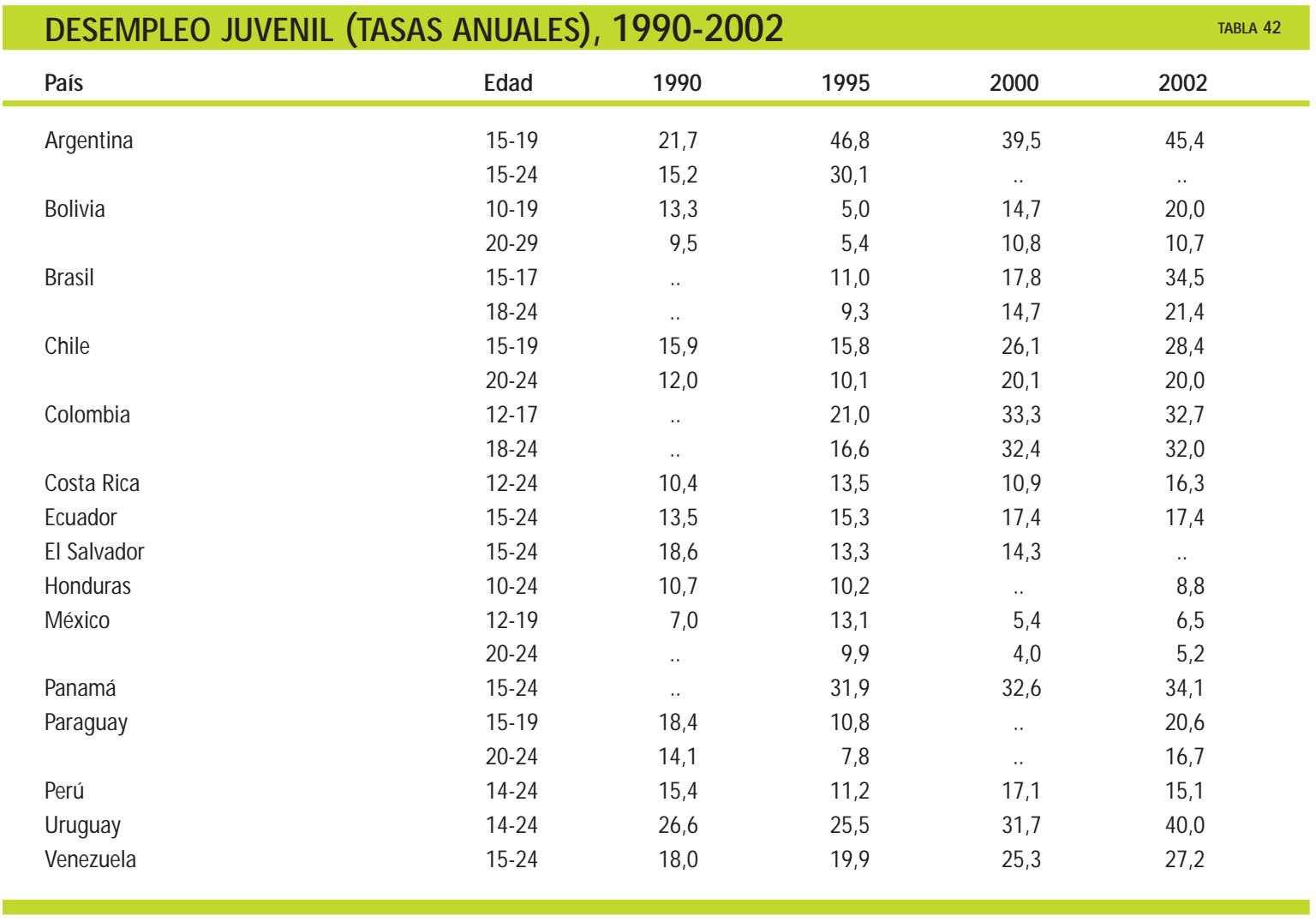

Notas: Los dos puntos seguidos (..) indican que la información no está disponible. En la Argentina la Encuesta de Hogares se realiza en el Gran Buenos Aires; en Bolivia, en áreas urbanas nacionales 1996 (15-25 años); en Brasil, en seis áreas metropolitanas (nuevas series a partir de 2001);en Chile, es el total nacional; en Colombia, en siete áreas metrolopitanas, en septiembre de cada año, y a partir de 2001 en trece áreas metropolitanas. En Costa Rica, Ecuador, El Salvador y Honduras los datos cubren el total nacional (urbano). En México la encuesta se realiza en 41 áreas urbanas; en Panamá, en la región metropolitana; y en Paraguay, en Asunción. Para Perú, a partir de 1996 los datos cubren el total nacional (urbano); y a partir de 2001 a Lima metropolitana. En Uruguay la encuesta cubre Montevideo; y los datos de Venezuela son nacionales urbanos. No se cuenta con datos de República Dominicana, Guatemala y Nicaragua.

Fuente: Basado en información de las Encuestas de Hogares de los países, OIT, 2003, Panorama Laboral 2003, Anexo Estadístico.

por ciento de la fuerza de trabajo urbana de América Latina. En 2002 subió al 50,5 por ciento. El aumento del déficit alcanza al 15,7 por ciento de la fuerza de trabajo. En 2002, el déficit primario de trabajo decente afectaba a 93 millones de trabajadores en la región, 30 millones más que en 1990. La brecha de empleo se amplió, afectando a 21 millones detrabajadores entre desempleados e informales y la brecha de protección social creció afectando a nueve millones de nuevos trabajadores ocupados (básicamente informales). ${ }^{71}$
Entre 1990 y 2002, la pobreza ha disminuido en doce países, en especial en Chile, Ecuador, M éxico, Panamá y Brasil. Pero en quince de los dieciocho países considerados, un cuarto de la población vive bajo la línea de pobreza, y en siete de éstos, más del cincuenta por ciento de la población es pobre (tabla 45).

Pero, como sostiene JoséN un, "el tema no se reduce al acceso marginal a los derechos de ciudadanía por parte de los 'pobres estructurales'. Abundan hoy en las áreas más modernizadas de América Latina mutaciones muy profundas en

a la línea de pobreza, inestabilidad laboral). Para el cálculo de la brecha de protección social se considera entre los empleados en los sectores formal e informal, aquellos que no cotizan a la seguridad social. La sumatoria de las bre chas de empleo y protección social determina el déficit primario de trabajo decente. OIT, Oficina Regional para las Américas, 2002, pp. 30-31.

71 OIT, O ficina Regional para las Américas, 2002, pp. 31-32. 


\begin{tabular}{|c|c|c|c|}
\hline \multicolumn{3}{|c|}{ AMÉRICA LATINA: } & TABLA 43 \\
\hline \multicolumn{4}{|c|}{ ESTRUCTURA DEL EMPLEO NO AGRÍCOLA } \\
\hline \multicolumn{4}{|c|}{ (PORCENTAJES), 1990-2002 } \\
\hline \multirow[b]{2}{*}{ Año } & & Sector informal & Sector formal \\
\hline & & Total & Total \\
\hline \multirow[t]{3}{*}{1990} & Total & 42,8 & 57,2 \\
\hline & Hombres & 39,4 & 60,6 \\
\hline & Mujeres & 47,4 & 52,6 \\
\hline \multirow[t]{3}{*}{1995} & Total & 46,1 & 53,9 \\
\hline & Hombres & 42,7 & 57,3 \\
\hline & Mujeres & 51,0 & 49,0 \\
\hline \multirow[t]{3}{*}{2000} & Total & 46,9 & 53,1 \\
\hline & Hombres & 44,5 & 55,5 \\
\hline & Mujeres & 50,3 & 49,7 \\
\hline \multirow[t]{3}{*}{2002} & Total & 46,5 & 53,5 \\
\hline & Hombres & 44,3 & 55,7 \\
\hline & Mujeres & 49,4 & 50,6 \\
\hline
\end{tabular}

Notas: Las Encuestas de Hogares tienen la siguiente cobertura: Argentina (urbana nacional), Brasil (área urbana), Chile (total del país), Colombia (diez áreas metropolitanas), Costa Rica (total del país), Ecuador (área urbana), México (área urbana), Panamá (total del país), Perú (Lima metropolitana), Uruguay (total del país) y Venezuela (área urbana). Fuente: En base a información de las Encuestas de Hogares de los países, OIT, Oficina Regional para las Américas, 2003.

los sistemas de producción y de empleo que conducen al incremento de la desocupación y de la subocupación y a una extendida crisis de los lazos sociales y políticos. Esto genera otra clase de baja calidad, provocada más bien por una suerte de desafiliación ciudadana de quienes ya estuvieron integrados, la de los 'nuevos pobres'".72

Entre 1991 y 2002, quince de los dieciocho países lograron avances en su crecimiento económico per cápita. Y doce países lograron alguna reducción en el nivel dela pobreza (dehecho, sólo la Argentina, Bolivia, Paraguay, Perú, República Dominicana y Venezuela empeoraron). Por otra parte, para 2002 sólo Guatemala, H onduras, M éxico, Nicaragua, Panamá y U ruguay lo-

\begin{tabular}{|c|c|c|c|c|}
\hline \multicolumn{4}{|c|}{ AMÉRICA LATINA: } & TABLA 44 \\
\hline \multicolumn{5}{|c|}{ ASALARIADOS QUE COTIZAN EN LA } \\
\hline \multicolumn{5}{|c|}{ SEGURIDAD SOCIAL (PORCENTAJES), } \\
\hline \multicolumn{5}{|c|}{$1990-2002$} \\
\hline Año & & $\begin{array}{c}\text { Sector } \\
\text { informal }\end{array}$ & $\begin{array}{l}\text { Sector } \\
\text { formal }\end{array}$ & Total \\
\hline 1990 & $\begin{array}{l}\text { Total } \\
\text { Hombres } \\
\text { Mujeres }\end{array}$ & $\begin{array}{l}29,2 \\
32,5 \\
27,0\end{array}$ & $\begin{array}{l}80,6 \\
79,1 \\
82,8\end{array}$ & $\begin{array}{l}66,6 \\
68,4 \\
65,1\end{array}$ \\
\hline \multirow[t]{3}{*}{1995} & Total & 24,2 & 79,3 & 65,2 \\
\hline & Hombres & 25,4 & 78,2 & 66,6 \\
\hline & Mujeres & 24,0 & 81,1 & 65,7 \\
\hline \multirow[t]{3}{*}{2000} & Total & 27,2 & 79,6 & 64,6 \\
\hline & Hombres & 26,6 & 78,4 & 66,0 \\
\hline & Mujeres & 27,9 & 81,5 & 62,9 \\
\hline \multirow[t]{3}{*}{2002} & Total & 26,2 & 78,9 & 63,7 \\
\hline & Hombres & 25,5 & 77,9 & 64,9 \\
\hline & Mujeres & 27,0 & 80,6 & 62,3 \\
\hline
\end{tabular}

Notas: Las Encuestas de Hogares tienen la siguiente cobertura: Argentina (urbana nacional), Brasil (área urbana), Chile (total del país), Colombia (diez áreas metropolitanas), Costa Rica (total del país), Ecuador (área urbana), México (área urbana), Panamá (total del país), Perú (Lima metropolitana), Uruguay (total del país) y Venezuela (área urbana). Fuente: En base a información de las Encuestas de Hogares de los países, OIT, Oficina Regional para las Américas, 2003.

graron bajar la desigualdad. $73 \mathrm{H}$ ay razones para sostener que sólo si se disminuye la desigualdad se podrá seguir disminuyendo la pobreza, así como que la disminución de la desigualdad tiende a mejorar la posibilidad de crecer económicamente a ritmos aceptables.

La posibilidad de mayor igualdad se vincula a la fortaleza de la democracia. El cumplimiento de los objetivos sociales del desarrollo, especialmente del desarrollo humano, no se puede lograr sólo mediante el funcionamiento de los mercados. El impulso por la igualdad no viene del mercado sino de la promesa implícita en la democracia. La igualdad de los ciudadanos fortalece y consolida la democracia.

72 Nun, José, texto producido para el PROD DAL, 2002.

73 Reducir el nivel dela pobreza significa bajar el porcentaje de la población con ingresos por debajo de la línea de pobreza (basado en la medida de la encuesta de hogares). La desigualdad se mide por el coeficiente de Gini. Ambas medidas se toman del año 1991 ( o año más cercano) y se contrastan con las de 2002. 


\section{El rol de la sociedad civil}

Los invisibles en las sociedades latinoamericanas [son] aquellos que no forman parte de las sociedades civiles, simplemente porque no tienen identidad, proyecto, organización social y forma de lucha para afirmarse, defenderse, para conquistar derechos y reconocimiento público. Son los políticamente destituidos de todo poder real. En aras de la verdad, es necesario reconocer el avance de la ciudadanía formal, aquella con derecho al voto, particularmente en el período de reciente democratización. Pero tener el derecho político al voto no es lo mismo que ser ciudadano, exactamente por lo que mencioné más arriba, en cuanto a la inclusión y a la garantía práctica de derechos fundamentales, no sólo civiles y políticos, sino también el derecho al trabajo y al ingreso, a comida, casa, salud, educación, etc. Entre el 30 y el $60 \%$ de la población de nuestros países padece alguna forma de exclusión social, negadora de su ciudadanía. Éstos, cuando no logran organizarse y luchar, para volver a incluirse políticamente y a tener alguna perspectiva de cambio en la situación generadora de desigualdad, pobreza y exclusión social, constituyen el enorme contingente de invisibles de nuestras sociedades. Pierden las sociedades civiles y pierde la democracia. Pero si por alguna razón los grupos de invisibles se organizan, gana la sociedad civil y gana la democracia, pues su presencia como actores concretos es la condición indispensable de su inclusión sostenida en la ciudadanía. [...]

[A]fianzar la democracia [...] pasa necesaria e indispensablemente por la sociedad civil, sobre todo por las posibilidades de volver visibles a los invisibles. Esto simplemente porque no pueden existir derechos de ciudadanía si no son para todas y todos. Derechos para algunos, por más numerosos que éstos sean, no son derechos, son privilegios. Ciudadanía es expresión de una relación social que tiene como presupuesto a todos, sin excepción. ¿Cómo incluirse en la relación de ciudadanía? Tomando nuestra realidad de millones y millones que aún permanecen fuera del sistema, sin que su ciudadanía haya sido reconocida; se trata de ver cómo y en qué condiciones pueden transformarse en sujetos históricos de su propia inclusión, iniciando un proceso virtuoso de rupturas y de refundación social, económica, política y cultural, de modo democrático y sostenido. Nunca está de más recordar que los grupos populares en situación de pobreza y desigualdad, casi en la exclusión social, no son ontológica o necesariamente democráticos. Al igual que todos los sujetos sociales, éstos necesitan tornarse democráticos con el proceso mismo por el cual se tornan sujetos. La cuestión crucial es el entramado social organizativo, en base al cual un grupo -de miembros de favelas o de campesinos sin tierra, por ejemplo- desarrolla su identidad, construye su visión del mundo, se hace consciente de los derechos y la importancia de su participación, formula propuestas y estrategias. En el proceso, literalmente, adquieren poder de ciudadanía, aun si están lejos de cambiar efectivamente el conjunto de relaciones que los excluyen. Entendiendo el empowering como conquista de poder ciudadano - de visibilidad de los hasta entonces invisibles en las relaciones constitutivas del poder- estamos hablando de lo que ganan el grupo, la sociedad civil y la democracia. El proceso de "empoderamiento" trae consigo nuevas organizaciones, una cultura democrática de derechos y una real capacidad de incidencia en la lucha política. Lo que se constata en América Latina es que el atropellamiento de la democratización por parte de la globalización neoliberal estancó e incluso hizo retroceder procesos consistentes de emergencia de nuevos sujetos. La lucha contra esta globalización, por el contrario, está destapando las contradicciones que permiten nuevamente la emergencia de estos sectores. Sin embargo, el cuadro es nuevo y depende de cómo la mayor segmentación producida entre incluidosy excluidos es vista y vivida en las diferentes sociedades. Las grandes ciudades de América Latina no están sólo constituidas por partes, como el Río de Janeiro del asfalto y de las favelas. Una parte puede darle la espalda a la otra, ignorándola y despreciándola.

Cândido Grzybowski, texto elaborado para el PRODDAL, 2002. 


\begin{tabular}{|c|c|c|}
\hline \multicolumn{2}{|c|}{ CIUDADANÍA SOCIAL: } & TABLA 45 \\
\hline \multicolumn{3}{|c|}{ DESIGUALDAD Y POBREZA, C. 2002} \\
\hline País & $\begin{array}{l}\text { Desigualdad: } \\
\text { coeficiente de } \\
\text { Gini, c. } 2002\end{array}$ & $\begin{array}{l}\text { Pobreza: } \\
\text { porcentaje bajo } \\
\text { la línea de } \\
\text { pobreza, c. } 2002\end{array}$ \\
\hline Argentina & 0,590 & 45,4 \\
\hline Bolivia & 0,614 & 62,4 \\
\hline Brasil & 0,639 & 37,5 \\
\hline Chile & 0,559 & 20,6 \\
\hline Colombia & 0,575 & 50,6 \\
\hline Costa Rica & 0,488 & 20,3 \\
\hline Ecuador & 0,513 & 49,0 \\
\hline El Salvador & 0,525 & 48,9 \\
\hline Guatemala & 0,543 & 59,9 \\
\hline Honduras & 0,588 & 77,3 \\
\hline México & 0,514 & 39,4 \\
\hline Nicaragua & 0,579 & 69,3 \\
\hline Panamá & 0,515 & 34,0 \\
\hline Paraguay & 0,570 & 61,0 \\
\hline Perú & 0,525 & 54,8 \\
\hline Rep. Dominicana & 0,544 & 44,9 \\
\hline Uruguay & 0,455 & 15,4 \\
\hline Venezuela & 0,500 & 48,6 \\
\hline
\end{tabular}

Nota: Las cifras más altas del coeficiente de Gini corresponden a un grado más alto de desigualdad. La información para la Argentina, Bolivia, Ecuador, Paraguay y Uruguay es de áreas urbanas. Los valores para el resto de los países corresponden al promedio nacional. El promedio mundial del coeficiente de Gini para 1999 es de 0,381. Pobreza: las cifras indican el porcentaje de individuos bajo la línea de pobreza. Los individuos pobres son aquellos cuyo ingreso es menor al doble del costo de la canasta básica de alimentos. Fuente: CEPAL, 2004.

\section{La sociedad civil como promotora de la ciudadanía social}

Los problemas y dificultades que han encontrado los estados de bienestar para seguir adelante con la protección de sus ciudadanos, así como la difusión de la acción de las grandes organizaciones no gubernamentales (ONG) que buscan atenuar los efectos de la pobreza, permitieron inicialmentela expansión de organizaciones voluntarias, que, poco a poco, extendieron el campo de su acción a una buena cantidad de áreas que preocupan respecto del bienestar de los ciudadanos.

El crecimiento de la sociedad civil recibió mayor impulso en los países afectados por dictaduras, donde los partidos políticos no podían expresar las demandas ciudadanas, o en las zo- nas, tanto urbanas como rurales, dondeel Estado dejó deatender adecuadamente necesidades básicas en salud, educación, apoyo a sectores en riesgo, entre otros.

Pero también ha florecido una cantidad importante de organizaciones dedicadas a la promoción de los valores cívicos que velan por la inscripción de losciudadanos, por la realización de elecciones limpias y trabajan para mejorar la acción de los partidos, los movimientos políticos y las instituciones representativas.

En el campo dela acción práctica para reducir la pobreza, muchas O NG (en rigor, diríamos no estatales) asumen funciones que hasta entonces se suponía eran responsabilidad del Estado. Actualmente, una parte relevante de las políticas públicas sociales son llevadas adelante por ONG en acuerdo con las instituciones estatales.

La acción de estas organizaciones ha aumentado el nivel participativo de los habitantes. En muchos casos, la organización de la sociedad civil apunta a promover valores democráticos en su práctica corriente y al canza también a la forma en que se toman decisiones.

Si bien se necesita una vigorosa acción estatal para recuperar políticas sociales universales, comprehensivas dela totalidad dela ciudadanía y que atiendan a las necesidades básicas de la población, deberían llevarse adelante incluyendo la dimensión participativa que aportan las diversas organizaciones dela sociedad civil, que pueden evitar los vicios burocráticos y promover la transparencia.

\section{Conclusiones sobre la ciudadanía social: logros y deficiencias}

Las deficiencias en el campo de la ciudadanía social constituyen uno de los desafíos más importantes que enfrenta la región. En ningún otro plano de la ciudadanía la democracia está más comprometida que en el de la ciudadanía social.

Por último, existen buenas razones para sostener que los ciudadanos que sufren exclusiones en una dimensión de la ciudadanía son los mismos que sufren exclusiones en otras dimensiones. La pobreza material de los ciudadanos incide negativamente en las oportunidades de 


\section{Distribución del ingreso en \\ América Latina, c. 2002}

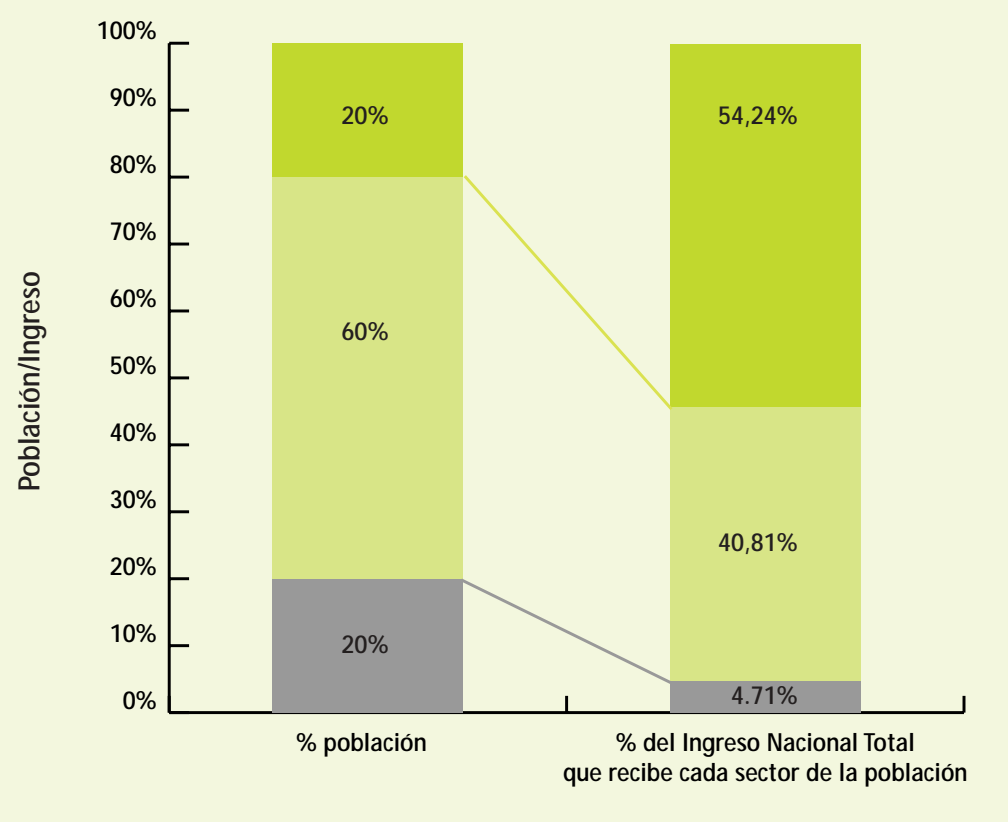

Notas: Los datos están ponderados por población y se elaboraron sobre la base de los últimos datos disponibles de distribución del ingreso de los hogares urbanos, por quintiles y deciles como porcentajes del ingreso nacional total. La información de la Argentina, Bolivia, Colombia, Costa Rica, Ecuador, Guatemala, Honduras, M éxico, Panamá, República Dominicana, Uruguay y Venezuela corresponde al año 2002. Para Brasil, El Salvador, Nicaragua y Paraguay se utilizaron datos de 2001. Finalmente, los datos de Chile corresponden al año 2000, mientras que los de Perú a 1999. La sumatoria de la columna de la distribución del ingreso no suma $100 \%$ debido a que la distribución del ingreso dividida por quintiles y deciles para algunos países tampoco suma $100 \%$.

Fuente: CEPAL, Unidad de Estadísticas Sociales, División de Estadística y Proyecciones Económicas.

RECUADRO 33

\section{La decencia como valor colectivo}

Lo que voy a sugerir es vincular la superación de la pobreza y la desigualdad con algo que se podría argumentar que constituye un interés público general: la democracia. Ahora bien, ¿por qué habría de interesarles la democracia a los privilegiados? [...] El argumento moral y político valedero es que la democracia se funda en valores que exigen una actitud respetuosa hacia la dignidad y la autonomía de cada ser humano; nada más y nada menos [... ] el principal aglutinante sólo puede ser un motivo ético: el tratamiento decente que merece todo ser humano. Un motivo adicional es de interés público: el mejoramiento de la calidad de nuestras democradias equivale a avanzar hacia el logro de esa decencia como un valor colectivo de toda la sociedad.

Guillermo O’Donnell, 1999c, p. 82.
RECUADRO 34

\section{Disfuncionalismos de la economía mundial}

Si el capitalismo, al excluir lo político, se tornara totalitario, correría el riesgo de desmoronarse [...]. Porque en ningún otro período de nuestra historia -con la excepción muy transitoria de los años treinta-, fueron tan graves como hoy los diffuncionalismos de la economía mundial: desocupación masiva, formidable incremento de las desigualdades $y$ de la pobreza en los países ricos; miseria insostenible y crisis recurrentes en numerosos países en desarrollo, y exacerbación de la desigualdad de los ingresos por habitante entre distintos países. La democracia no puede permanecer indiferente a todo esto.

Jean-Paul Fitoussi, texto elaborado para el PRODDAL, 2003. 


\section{Pobreza y desigualdad: poco cambio significativo}

[Se constatan] en varias oportunidades las relaciones que existen entre la desigualdad y la pobreza económicas, por un lado, y la calidad de la democracia, por el otro. [...] En este sentido, conviene leer con detenimiento resultados como los de un trabajo econométrico que viene de difundirse: “La conclusión más importante que es posible derivar del presente estudio es que el principal obstáculo que se interpone al éxito de los esfuerzos por reducir la pobreza en América Latina y el Caribe radica en que el mejor remedio para tratar la pobreza que aflige a la región -la reducción de la desigualdad- parece ser uno que le resulta muy difícil recetar. Una leve disminución de la desigualdad contribuiría mucho a reducir las privaciones extremas que se dan en la región. Sin embargo, al parecer son muy pocas las economías de la región que han sido capaces de lograrlo aun en pequeña medida" .74

José Nun, trabajo elaborado para el PRODDAL. educación, en las cuestiones nutricionales y de salud, en las oportunidades de empleo, en la capacidad para ejercer y hacer valer los derechos civiles, políticos y social es, etc. La educación, la salud y el empleo requieren de alimentación, vivienda y vestimenta. Todos ellos, a su vez, habilitan la libertad, el progreso y la justicia. Por debajo de ciertos mínimos de derechos sociales el concepto mismo de ciudadanía queda interpelado por la realidad. El panorama es aún más complejo si se tiene en cuenta que la expectativa de mejoría en alguno de estos temas suele estar vinculada a la evolución de alguno o de algunos de los otros aspectos.

En síntesis, el desarrollo de la democracia en América Latina requiere abordar decididamente los problemas que traban la vigencia y la expansión de la ciudadanía social. Para ello, parece necesario centrarse en el ataque a la pobreza y en la generación de empleo de buena calidad, teniendo presente que esto será muy difícil de lograr sin reducir también los enormes niveles de desigualdad existentes en la región.
Las deficiencias en el campo de la ciudadanía social constituyen uno de los desafíos más urgentes que enfrenta la región.

- Los datos, en su mayor parte, reflejan una grave situación. América Latina se caracteriza por sufrir extendidas carencias en múltiples aspectos de la ciudadanía social. Los avances que al gunos países han logrado en este plano, aunque significativos en sí mismos, son pequeños en comparación con la escala de los problemas.

- Existen exclusiones sociales superpuestas. Las privaciones en un componente de la ciudadanía social suelen coincidir con privaciones en otros campos. Esta situación sugiere la idea de déficit estructurales en materia de ciudadanía social.

- El panorama social regional es, por lo tanto, magro; la búsqueda de una mayor y mejor ciudadanía social, comenzando por la satisfacción de las necesidades básicas de la población, representa un desafío central para América Latina. 



\section{- Cómo ven los latinoamericanos a su democracia}

El apoyo que los ciudadanos dan a la democracia es un componente clave de su sustentabilidad. La experiencia histórica nos enseña que las democracias fueron derribadas por fuerzas políticas que contaban con el apoyo ( 0 , por lo menos, la pasividad) de una parte importante, y en ocasiones mayoritaria, de la ciudadanía. Las democracias se tornan vulnerables cuando, entre otros factores, las fuerzas políticas autoritarias encuentran en las actitudes ciudadanas terreno fértil para actuar. De ahí la importancia de conocer y analizar los niveles de apoyo con que cuenta la democracia en América Latina.
Con ese propósito, en mayo de 2002 se realizó una encuesta sobre las percepciones ciudadanas de la democracia. Incluyó 19.508 personas entrevistadas, cubriendo una población de más de 400 millones de habitantes en los dieciocho países comprendidos en el Informe.

Una primera mirada a las percepciones ciudadanas sobre la base de las anteriores encuestas de Latinobarómetro indica que hacia 1996 el 61 por ciento delos entrevistadosa nivel de la región prefería la democracia respecto de cualquier otro régimen; hacia 2002 era el 57 por ciento. Esa preferencia por la democracia no implica necesariamenteun firmeapoyo. En efecto, muchas perso-

\section{FRENTE A OTROS SISTEMAS DE GOBIERNO, 2002}

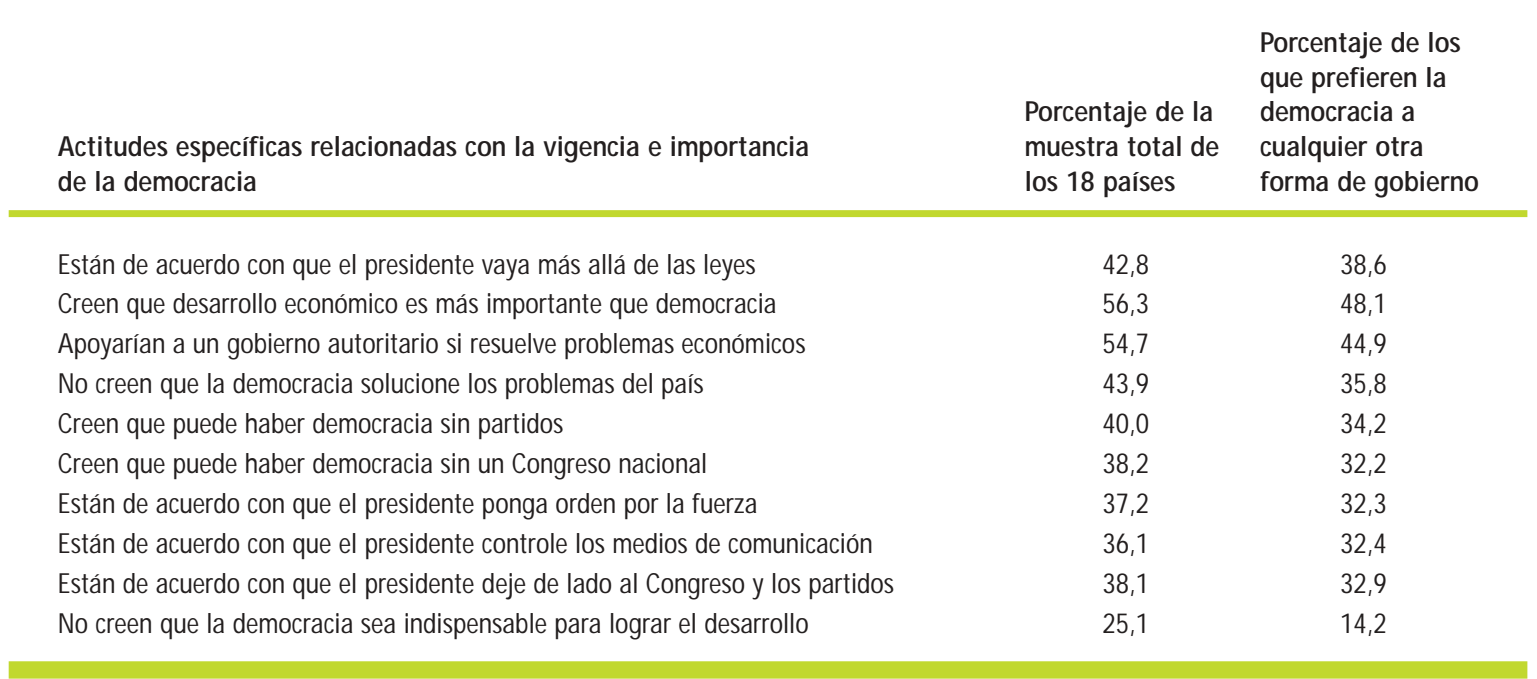

Nota: n varía entre 16.183 (puede haber democracia sin congreso) y 17.194 (democracia vs desarrollo económico).

Fuente: Elaboración propia con base en Latinobarómetro 2002. 
nas que dicen preferir la democracia frente a otros regímenes tienen actitudes poco democráticas en relación con diversas cuestiones sociales. En el año 2002, casi la mitad (48,1 por ciento) de los encuestados que decían que preferían la democracia a cualquier otro régimen, prefería igualmente el desarrollo económico a la democracia, y un porcentaje semejante ( 44,9 por ciento) que decía preferir la democracia estaba dispuesto a apoyar a un gobierno autoritario si éste resolvía los problemas económicos de su país.

Buena parte de las personas que manifiestan su preferencia por la democracia tiene actitudes contrarias a al gunas reglas básicas de este régimen. Aproximadamente uno de cada tres opina que la democracia puedefuncionar sin instituciones como el Parlamento y los partidos políticos.

Estas respuestas son un llamado de atención: una proporción sustancial de latinoamericanos valora al desarrollo económico por sobre la democracia y estaría dispuesta a dejar de lado la democracia en caso de que un gobierno no democrático pudiera solucionar sus problemas económicos.

Para avanzar en la comprensión de esta situación realizamos un análisis de las respuestas a once preguntas que reflejan no sólo preferencia por la democracia, sino también actitudes frenteal modo de ejercer el poder en democracia, las instituciones básicas de la misma y diversos temas sociales. 75

\section{Tres orientaciones hacia la democracia: demócratas, ambivalentes y no demócratas}

Hemos identificado tres orientaciones o perfiles principales en los que se agrupan las opiniones y actitudes de los latinoamericanos hacia la democracia: los demócratas, los ambivalentes y losno demócratas ( gráfico 5).

Los demócratas son personas que en todos los asuntos consultados dan respuestas favorables a la democracia. Prefieren la democracia ante cualquier "otra forma de gobierno" y apoyan la aplicación de las reglas democráticas en la gestión de gobierno incluso en épocas de dificultades. Puestos a escoger entre la democracia y el desarrollo, los demócratas responden que prefieren la primera o que ambas metas son igualmente importantes. M ás aún, opinan que "la democracia es indispensable para ser un país desarrollado". Los demócratas están en desacuerdo con posiciones de tipo delegativo 76 para resolver los problemas del país: se oponen a que

75 Ver metodología de elaboración del IAD. Las siguientes son las preguntas clave que guiaron este componente del estudio: A poyo a la democracia: (1) ¿Con cuál de las siguientes frases está usted más de acuerdo?: a) la democracia es preferible a cual quier otra forma de gobierno; b) en algunas circunstancias, un gobierno autoritario puede ser preferible; c) a la gente como uno nos da lo mismo un régimen democrático que uno no democrático. (2) Si usted tuviera que elegir entre la democracia y el desarrollo económico: a) el desarrollo económico es lo más importante; b) la democracia es lo más importante; c) ambas por igual. (3) ¿Usted cree que la democracia es indispensable para ser un país desarrollado?: a) la democracia es indispensable para ser un país desarrollado; b) no es indispensable, se puede llegar a ser un país desarrollado con otro sistema de gobierno que no sea la democracia. (4) No me importaría que un gobierno no democrático llegara al poder si pudiera resolver los problemas económicos: a) muy de acuerdo; b) de acuerdo; c) en desacuerdo; d) muy en desacuerdo. (5) Algunas personas dicen que la democracia permite que se solucionen los problemas: a) la democracia soluciona los problemas; b) la democracia no soluciona los problemas.

Apoyo a las instituciones democráticas: (6) a) sin Congreso Nacional no puede haber democracia; b) la democracia puedefuncionar sin Congreso Nacional. (7) a) Sin partidos políticos no puedehaber democracia; b) la democracia puede funcionar sin partidos.

Dimensión delegativa: Si el país tiene serias dificultades, ¿está usted muy deacuerdo, deacuerdo, en desacuerdo o muy en desacuerdo con queel presidente? (8) a) no selimite a lo que dicen las leyes; (9) b) ponga orden por la fuerza; (10) c) controle los medios de comunicación; (11) d) deje de lado al Congreso y los partidos.

$76 \mathrm{El}$ concepto de democracia delegativa fue acuñado O'D onnell (1994) para referirse para referirse a países en donde se celebran elecciones libres y limpias pero en los cuales los gobernantes (especialmente presidentes) sesienten autorizados a actuar sin restricciones institucionales. En esta concepción fuertemente mayoritaria y plebiscitaria del poder político, el gobernante no deja de ser democrático, en el sentido que surge de elecciones libres y limpias, y no 


\section{Perfil de las orientaciones hacia la democracia, América Latina, 2002 (1)}

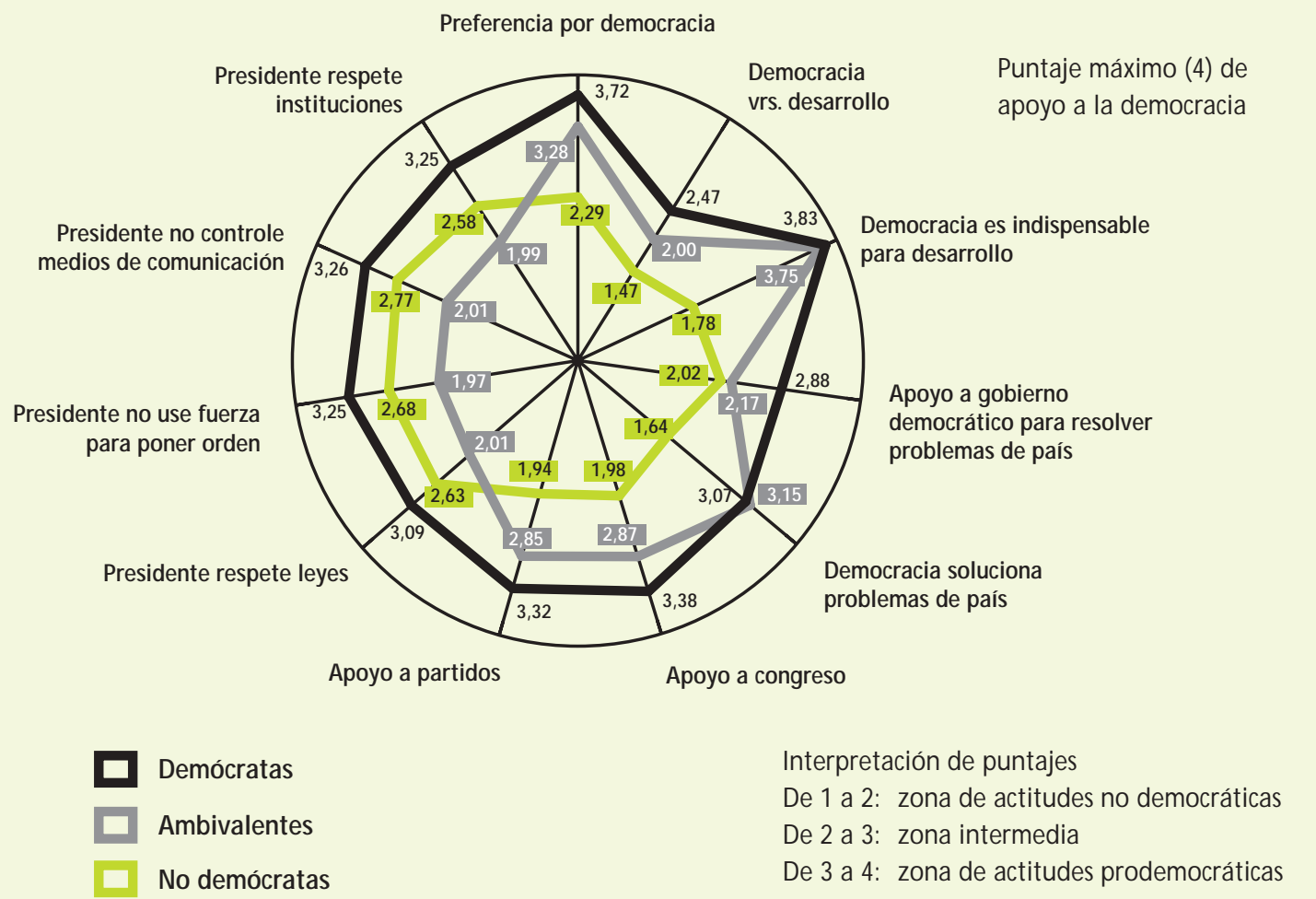

Notas: $\mathrm{n}=15.216$.

(1) Cada una de las preguntas fue recodificada para que su valor pudiese variar en un rango de 1 a 4 , de manera que el puntaje 4 siempre apunte hacia una actitud democrática. Todos los promedios se basan en un tamaño de muestra válida diferente. Para América Latina, la muestra válida general varía entre 14.532 y 15.216 personas.

Fuente: Elaboración propia en base a Latinobarómetro 2002.

el presidente prescinda del Parlamento, controle los medios de comunicación e imponga orden por la fuerza, aun en tiempos de crisis.

Los no demócratas son personas que en todos los asuntos consultados expresan opiniones contrarias a la democracia. Prefieren un régimen autoritario a uno democrático. Opinan quelograr el desarrollo del país es una meta más importante que preservar la democracia y no creen que ésta sea indispensable para alcanzar aquél. Puestos en la disyuntiva de escoger entre estas metas, optan por el desarrollo. Están de acuerdo con que "un gobierno no democrático llegue al poder si puede resolver los problemas

intenta suprimirlas en el futuro. Pero, por otro lado, no se siente obligado a aceptar las restricciones y los controles de otras instituciones constitucionales (Parlamento y Poder Judicial) ni de diversos organismos estatales o sociales de control; al contrario, suele dedicarsea ignorar, anular o cooptar esas instancias. La idea básica de esta concepción es que los votantes ven al presidente como el depositario exclusivo de la legitimidad democrática, al que en consecuencia delegan el derecho y la obligación de resolver los problemas del país a su leal saber y entender. Esta idea (que no excluye la de futuras elecciones libres y limpias en las que el presidente y su partido podrán ser cambiados) autoriza acciones anti institucionales del presidente así como, tal como se verá más adelante, decisiones "para poner orden" 0 "resolver crisis"deneto corte autoritario. Esto no implica, claro está, queel presidente delegativo sea omnipotente, ya que choca con los resabios de institucionalidad subsistentes, con diversas relaciones fácticas de poder y, dependiendo de las coyunturas, con movimientos opositores, sobre todo de rendición de cuentas societal. 


\section{Proporción de personas que sustentan las orientaciones hacia la democracia, promedios subregionales, 2002}

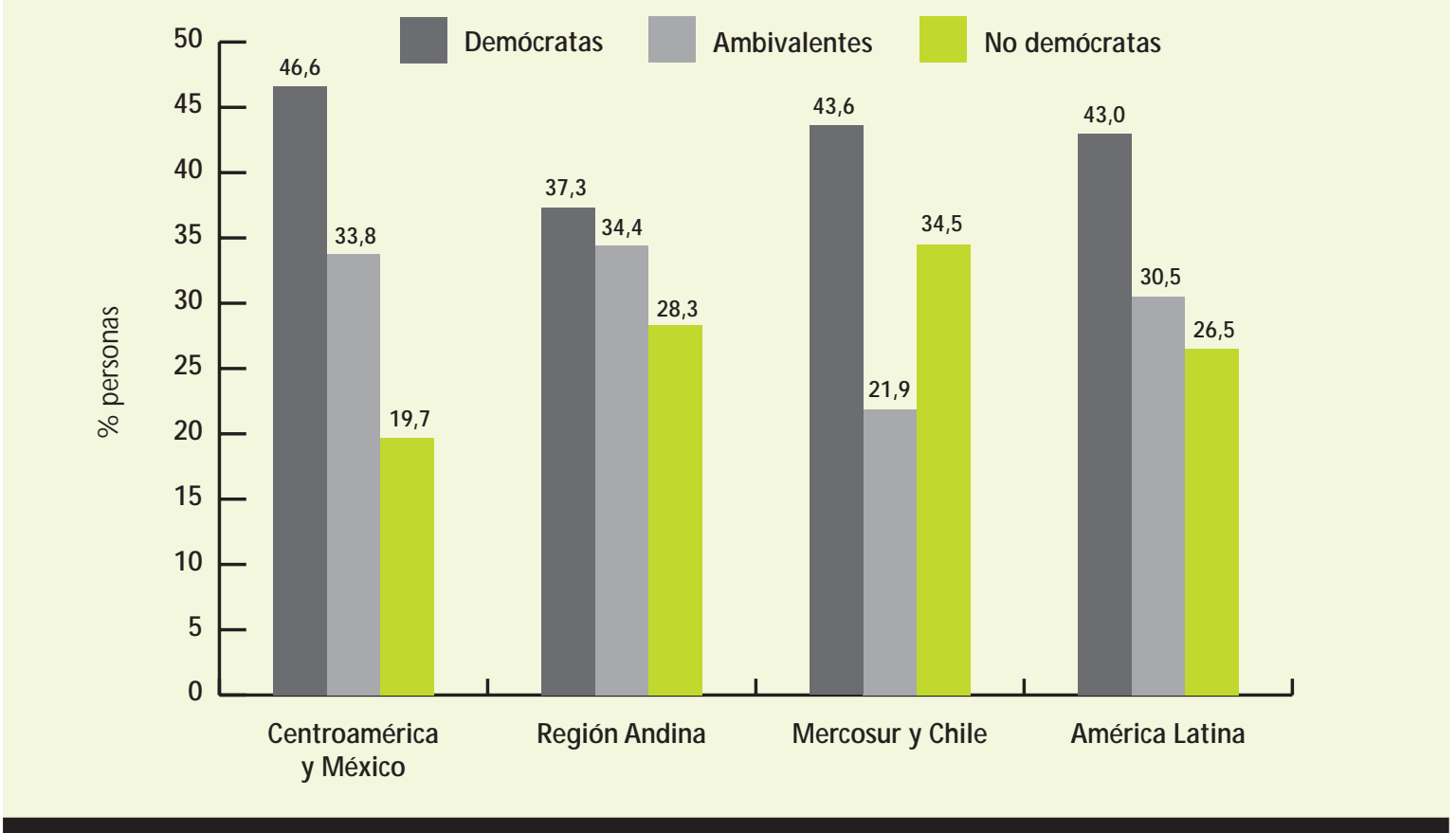

Nota: $n=15.216$. Las cifras indican porcentajes de la muestra válida. Fuente: Elaboración propia con base en Latinobarómetro 2002.

económicos". Están de acuerdo con que "el presidente deje de lado al Congreso y los partidos políticos si el país tiene serias dificultades". Finalmente, no parecen conceder mucha oportunidad a la solución de los problemas del país dentro de la democracia, aunque se trate de una democracia detipo delegativo. En síntesis, se inclinan a preferir la sustitución de cualquier tipo de democracia por otro sistema de gobierno.

Los ambivalentes son personas con opiniones ambiguas, si no contradictorias. Las opiniones que expresan son, en general, consistentes con concepciones delegativas de la democracia. Están en principio de acuerdo con la democracia, pero creen válido tomar decisiones antidemocráticas en la gestión de gobierno si, a su juicio, las circunstancias lo ameritan. En consecuencia, en algunos temas comparten las opiniones de los demócratas y en otros, las de los no demócratas. Lo mismo que los demócratas, manifiestan preferir un gobierno de- mocrático a uno autoritario, creen que "la democracia soluciona problemas" y que es indispensable para el desarrollo. Pero, por otro lado, en acuerdo con los no demócratas, opinan que lograr el desarrollo del país es más importante que preservar la democracia y no objetarían que un gobierno no democrático llegue al poder si pudiera resolver los problemas económicos. Además, los ambivalentes se distinguen de los otros dos grupos al aceptar que en tiempos de crisisel presidente imponga el orden por la fuerza, controle los medios de comunicación y prescinda del Parlamento y los partidos.

Puede parecer paradójico que los ambivalentes, que expresan preferir la democracia, manifiesten acuerdo con medidas de gobierno declaro corte autoritario. Creemos que estas opiniones derivan de la concepción delegativa de la democracia que estos consultados tienen. Esta comprobación es importante: la preferencia de los ambivalentes por un liderazgo de base democrá- 
tica pero con rasgos que aumenten la eficacia de su gestión aunque sean autoritarios, podría ser eventualmentecapitalizada por los adversarios de la democracia.

\section{Magnitud de las orientaciones hacia la democracia}

En el 2002, los demócratas fueron la orientación más extendida entre los latinoamericanos pero no alcanzaron a formar una mayoría ( gráfico 6). Sumaron el 43 por ciento de los consultados en los dieciocho países de América Latina. Pero para alcanzar apoyo mayoritario a la democracia se depende de los ambivalentes: éstos son la segunda orientación más difundida (30,5 por ciento). Finalmente, los no demócratasfueron la orientación menos difundida: 26,5 por ciento de los consultados.

Cada subregión muestra una situación distinta: ventaja para los demócratas, equilibrio y polarización. En Centroamérica y M éxico, los demócratas son casi la mitad de la población, superan en más del doblea los no demócratas y tienen amplia ventaja sobre los ambivalentes. En los países del Mercosur y Chile hay una situación polarizada: las orientaciones más difundidas son las opuestas, los demócratas y los no demócratas. La diferencia de magnitud entre ambos es, además, estrecha. Finalmente, en la Región Andina existe un equilibrio entre las tres orientaciones: la diferencia entre los demócratas y los ambivalentes es pequeña, y ninguna logra una ventaja amplia sobre los no demócratas.

\section{Distancia entre las orientaciones hacia la democracia}

¿Dequé orientación están más cerca los ambivalentes? En la mayor parte de los países latinoamericanos, la existencia de una mayoría que respalde a la democracia depende de la capacidad delos demócratas para atraer a sus posiciones a los ambival entes. La distancia entre las actitudes de estas dos orientaciones es relevante para considerar el efecto del tamaño dela orientación democrática.

En las preguntas respecto al apoyo a las instituciones representativas (Congreso nacional y
En la mayor parte de los países la tinoa mericanos, la existencia de una mayoría que respalde a la democracia depende de la capacidad de los demócra tas para a traer a sus posiciones a los a mbivalente.

partidos políticos), preferencia por la democracia, consideración de ésta como indispensable para el desarrollo y expectativa de que con la democracia se pueden resolver los problemas del país, las opiniones de los ambivalentes y los demócratas son sustancialmente más cercanas que entre los no demócratas y los ambivalentes. En dos temas en particular, "La democracia soluciona problemas" y “La democracia es indispensable para el desarrollo", prácticamenteno hay diferencias entre los ambivalentes y los demócratas. Además, en todos estos casos los ambivalentes se encuentran en la zona deactitudes democráticas con un alto puntaje en las escalas respectivas.

En cambio, en materia de las actitudes delegativas y en la tendencia a apoyar un gobierno no democrático si "así seresuelven los problemas del país", la situación se invierte. La distancia entre los no demócratas y los ambivalentes es sustancialmentemenor quela existente entre demócratas y ambivalentes. En dostemas en particular, la distancia de los ambivalentes con los demócratas es muy notable: en el apoyo a un presidente que deje de lado al Congreso y los partidos, y en el apoyo a un eventual gobierno no democrático.

Finalmente, respecto de la opción entre democracia y desarrollo, notamos que las tres orientaciones se han desplazado "hacia abajo": los demócratas se encuentran en la zona de actitudes intermedias ( puntaje promedio $=2,47$ ), los ambivalentes bordean la zona de actitudes no democráticas (puntaje promedio $=2$ ) y los no demócratas asumen una posición cerrada ( puntaje promedio $=1,47$ ).

Si bien las diferencias entre orientaciones se mantienen respecto de esta opción, el hecho de 


\section{¿Cuántos demócratas y no demócratas "puros" hay en América Latina?}

En toda la población entrevistada en los 18 países de América Latina, sólo se detectaron 7 no demócratas "puros" y 142 demócratas "puros" (entre los dos suman apenas el 1 por ciento de las personas). Un no demócrata "puro" es una persona que en todos los aspectos incluidos en el estudio de las orientaciones siempre escogió la respuesta más hostil a la democracia. Debido a que la escala de medición empleada varía entre 1 (actitud más hostil) y 4 (actitud más pro-democrática), estas personas obtuvieron un puntaje promedio igual a 1. Como era de esperarse, estos 7 recalcitrantes pertenecen a la orientación no demócrata. Por el contrario, un demócrata "puro" es una persona que en todos los casos escogió la respuesta más favorable a la democracia: su puntaje promedio fue el máximo (4). La inmensa mayoría de las y los entrevistados tienen puntos de vista un tanto más mezclados, menos extremos, aunque con tendencias daramente discernibles. Como ha sido señalado, los demócratas tienden a puntuar en la zona alta de las escalas para medir las actitudes democráticas en todos los temas considerados: $70 \%$ de los así dasificados tienen puntajes promedios entre 3,01 y 4 puntos, mientras que pocos ambivalentes $-9,8 \%$ del total- y ningún no demócrata obtienen esos puntajes. En cambio, en la zona de actitudes no democráticas, donde el puntaje promedio varía entre 1 y 2 puntos, predominan los no demócratas: constituyen el $75 \%$ de las personas que se encuentran en esa zona.

En la zona intermedia (puntajes promedio entre 2 y 3 puntos) puede apreciarse una situación menos definida, pues en ella coexisten importantes segmentos de las tres orientaciones. Sin embargo, aún así es posible identificar tendencias. En primer lugar, casi todos los ambivalentes están localizados en esa zona ( $84,2 \%$ del total). En segundo lugar, hay presencia importante de no demócratas en el tramo entre 2,01 y 2,50, por debajo del punto medio de la escala, y alguna concentración de demócratas en el tramo entre 2,51 a 3, un área por encima del punto medio. En ambos casos, se trata de áreas adyacentes a sus respectivas "zonas naturales". En resumen, aunque en la realidad hay pocos "tipos puros", las orientaciones logran agrupar a las personas según patrones de apoyo a la democracia.

\section{GRÁFICO 7 \\ Demócratas, ambivalentes y no demócratas según su ubicación en las escalas de actitud democrática. América Latina, 2002}

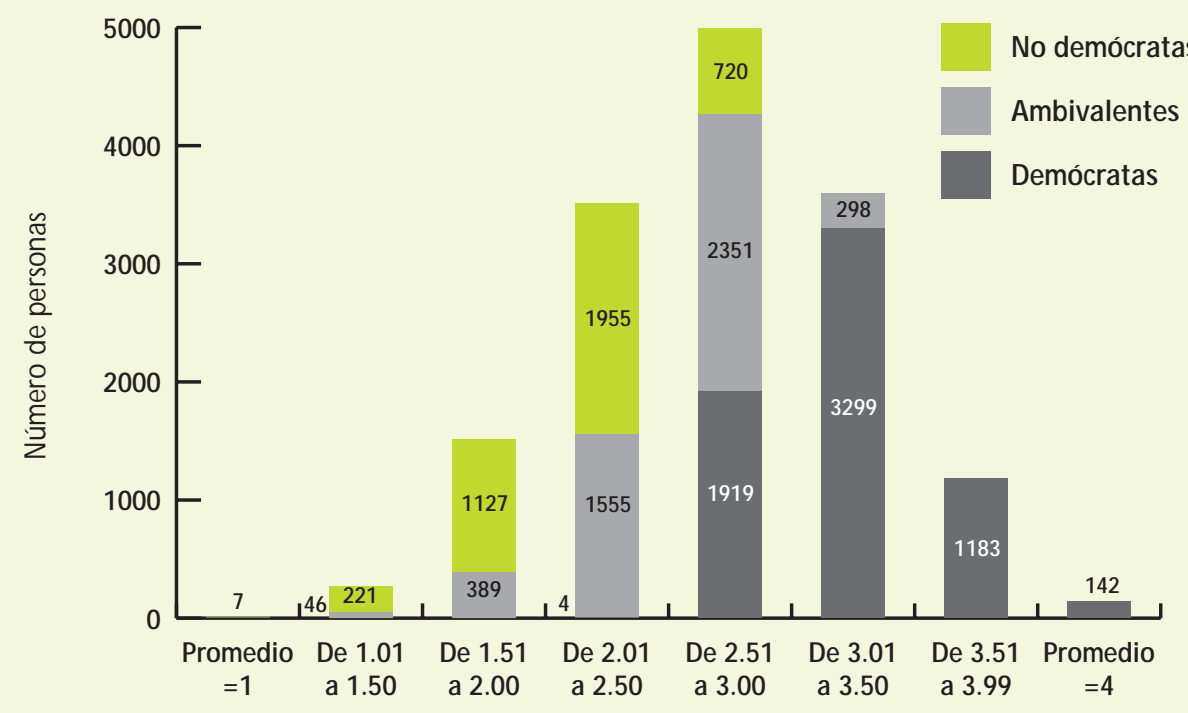

Nota: $n=15.216$ personas. Se trata del puntaje promedio en las escalas de actitud en las 11 variables consideradas para el estudio de las orientaciones hacia la democracia. Las escalas tienen un rango de variación entre 1 y 4, donde 1 es la respuesta más hostil a la democracia y 4 la más favorable.

Fuente: Elaboración propia con base en Latinobarómetro, 2002. 


\begin{tabular}{|c|c|c|c|c|}
\hline \multicolumn{4}{|c|}{ DISTANCIA ENTRE LAS ORIENTACIONES HACIA LA DEMOCRACIA } & TABLA 47 \\
\hline \multicolumn{5}{|c|}{ EN LOS DISTINTOS TEMAS ESTUDIADOS. AMÉRICA LATINA, 2002} \\
\hline \multirow[b]{2}{*}{$\begin{array}{l}\text { Puntaje en la escala de actitudes } \\
\text { democráticas (1) }\end{array}$} & \multicolumn{4}{|c|}{ Distancia entre orientaciones (2) } \\
\hline & $\begin{array}{l}\text { Más cercanía entre demócratas } \\
\text { y ambivalentes }\end{array}$ & $\mathrm{Di}$ & $\begin{array}{l}\text { Más cercanía entre no demócratas } \\
\text { y ambivalentes }\end{array}$ & $\mathrm{Di}$ \\
\hline \multirow{7}{*}{$\begin{array}{l}\text { Zona de actitudes democráticas } \\
\text { ( } 3 \text { a } 4 \text { puntos) }\end{array}$} & Prefieren la democracia & 0,45 & & \\
\hline & Democracia indispensable & & & \\
\hline & para el desarrollo & 0,04 & & \\
\hline & Democracia soluciona & & & \\
\hline & los problemas & 0,05 & & \\
\hline & Apoyo al Congreso & 0,57 & & \\
\hline & Apoyo a los partidos & 0,52 & & \\
\hline \multirow{7}{*}{$\begin{array}{l}\text { Zona intermedia } \\
\text { ( } 2 \text { a } 3 \text { puntos) }\end{array}$} & Democracia vs. desarrollo & 0,90 & Apoyo a gobierno democrático & \\
\hline & & & para resolver problemas & 4,61 \\
\hline & & & Presidente respete leyes & 1,76 \\
\hline & & & Presidente no use fuerza & 1,80 \\
\hline & & & Presidente no controle medios & 1,65 \\
\hline & & & Presidente deje de lado & \\
\hline & & & Congreso y partidos & 2,13 \\
\hline
\end{tabular}

Zona de actitudes no democráticas

(1 a 2 puntos)

Notas: Los n varían entre 14.532 (p41st) y 15.216 (p39st y p40st).

(1) El rango de variación de las escalas de medición de las actitudes democráticas en las preguntas empleadas para el estudio de las orientaciones hacia la democracia fue estandarizado. Un valor de 4 fue asignado a las actitudes más favorables para la democracia y el valor de 1, a las actitudes más negativas a la democracia.

(2) Consúltese explicación sobre el concepto de distancia y su indicador respectivo bajo el título “Tercera dimensión: distancia entre las orientaciones" de la Nota Técnica del IAD que aparece en Anexos (pág. 231).

Fuente: Elaboración propia con base en Latinobarómetro 2002.

que el puntaje sea menor en los tres casos es un llamado de atención: es en la opción entre desarrollo económico y democracia donde seevidencia una tensión mayor entre las preferencias de los latinoamericanos.

Desde un punto de vista general, la distancia entre las actitudes de los ambivalentes y los demócratas es casi igual a la existente entre los ambivalentes y los no demócratas. Los ambivalentes no seinclinan, por el momento, hacia uno u otro lado.

En resumen, la relativa equidistancia entre demócratas, ambivalentes y no demócratas parece ser resultado de una tensión: la mayor cercanía entre ambivalentes y demócratas en el tema del apoyo a la democracia y sus instituciones compensa la mayor cercanía de los ambivalentes con los no demócratas en materia de las actitudes delegativas.

\section{Perfil social de las personas que sustentan las orientaciones hacia la democracia}

La base social de las orientaciones hacia la democracia es heterogénea; las personas que sustentan una orientación determinada no pertenecen mayoritariamente a un grupo o clase social. En particular, la composición social de los demócratas muestra que el apoyo a la democracia se arraiga de un modo bastante parejo en los distintos sectores de la sociedad. Aun así, se observan las siguientes relaciones:

- Las personas con educación superior (completa o incompleta) son más proclives a ser demócratas.

- No hay, en cambio, mayores diferencias entre las personas con educación primaria y secundaria. 
PERFIL SOCIOECONÓMICO DE LAS PERSONAS SEGÚN SU ORIENTACIÓN

HACIA LA DEMOCRACIA, 2002

TABLA 48

\begin{tabular}{|c|c|c|c|c|c|c|}
\hline & \multirow[t]{2}{*}{ Categorías } & \multirow[t]{2}{*}{$\begin{array}{l}\text { Estructura } \\
\text { de la muestra }\end{array}$} & \multicolumn{3}{|c|}{ Orientación hacia la democracia } & \multirow[t]{2}{*}{$\begin{array}{l}\text { Significanci } \\
\text { (5) }\end{array}$} \\
\hline & & & Demócratas & Ambivalentes & No demócratas & \\
\hline Centroamérica y México (1) & $\%$ de personas & $n=6.402$ & 46,6 & 33,8 & 19,7 & .. \\
\hline Región Andina & $\%$ de personas & $n=4.377$ & 37,3 & 34,4 & 28,3 & .. \\
\hline Mercosur y Chile & $\%$ de personas & $n=4.438$ & 43,6 & 21,9 & 34,5 & .. \\
\hline América Latina & $\%$ de personas & $n=15.217$ & 43,0 & 30,5 & 26,5 & .. \\
\hline \multirow[t]{2}{*}{ Sexo } & $\%$ hombres & 51,5 & 52,9 & 50,8 & 50,0 & \multirow{2}{*}{$* *$} \\
\hline & $\%$ mujeres & 48,5 & 47,1 & 49,2 & 50,0 & \\
\hline \multirow[t]{4}{*}{ Edad } & $\% 16$ a 29 años & 37,6 & 35,1 & 38,5 & 40,8 & \multirow{3}{*}{$* *$} \\
\hline & \% 30 a 64 años & 54,3 & 56,3 & 53,3 & 52,2 & \\
\hline & $\% 65$ a 99 años & 8,0 & 8,6 & 8,1 & 7,0 & \\
\hline & Promedio de edad & 38,16 & 39,24 & 37,83 & 46,8 & $* *$ \\
\hline \multirow[t]{6}{*}{ Nivel educativo } & $\%$ sin estudios & 7,2 & 6,3 & 8,5 & 7,2 & \multirow{5}{*}{$* *$} \\
\hline & $\% 1$ a 6 años & 32,0 & 30,4 & 34,2 & 31,8 & \\
\hline & $\% 7$ a 12 años & 43,1 & 41,9 & 43,2 & 45,0 & \\
\hline & $\%$ superior completa & & & & & \\
\hline & o incompleta & 17,7 & 21,4 & 14,1 & 16,0 & \\
\hline & Promedio de años de estudio & 9,33 & 9,69 & 8,84 & 9,29 & $* *$ \\
\hline \multirow[t]{5}{*}{ Nivel económico (2) } & $\%$ bajo & 41,5 & 40,0 & 44,8 & 40,2 & \multirow{3}{*}{$*$} \\
\hline & $\%$ medio & 49,2 & 49,5 & 47,3 & 50,9 & \\
\hline & $\%$ alto & 9,3 & 10,5 & 7,9 & 8,9 & \\
\hline & Promedio de índice económico & 4,01 & 4,12 & 3,84 & 4,05 & $* *$ \\
\hline & $\begin{array}{l}\text { Promedio de movilidad } \\
\text { económica ocurrida (4) }\end{array}$ & $-0,44$ & $-0,42$ & $-0,38$ & $-0,52$ & $* *$ \\
\hline \multirow[t]{6}{*}{ Cohorte (3) } & \% socializado en & & & & & \multirow{5}{*}{\}$_{* *}$} \\
\hline & régimen autoritario & 51,8 & 48,8 & 53,3 & 55,1 & \\
\hline & \% socializado en & & & & & \\
\hline & período de transición & 11,6 & 11,9 & 11,0 & 11,9 & \\
\hline & $\begin{array}{l}\text { \% socializado en } \\
\text { democracia }\end{array}$ & 36,6 & 39,4 & 35,7 & 33,0 & \\
\hline & $\begin{array}{l}\text { Promedio de años de socialización } \\
\text { en no democracia }\end{array}$ & 6,36 & 6,04 & 6,49 & 6,74 & $* *$ \\
\hline
\end{tabular}

Notas:

(1) Incluye República Dominicana.

(2) Con base en el índice económico que se elabora a partir de la tenencia de artefactos y la educación del jefe de familia. Este índice puede variar entre 0 y 10. Si el índice se encuentra entre 0 y 3,33 se considera nivel económico bajo, si se encuentra entre 3,34 y 6,66 se considera nivel económico medio y si se encuentra entre 6,67 y 10 se considera nivel económico alto.

(3) De acuerdo con el número de años de socialización en los que vivió bajo un régimen autoritario, se determina si una persona fue socializada en democracia, en un período de transición o en un régimen autoritario. Se considera que el número de años de socialización de una persona es de once años (entre los 7 y los 17 años de edad).

(4) El índice de movilidad económica se elabora a partir de la valoración de los entrevistados sobre la situación económica de sus padres y la comparación de ésta en relación con su situación actual.

(5) Se indica con un $(*)$ cuando la medida de asociación utilizada o el Análisis de Variancia (ANOVA por sus siglas en inglés) resulta significativo al 5\%. Se indica con $(* *)$ cuando el resultado es significativo al $1 \%$. Cuando no es pertinente el cálculo de una medida de asociación o ANOVA se indica con dos puntos seguidos (..). Sobre las pruebas realizadas en cada caso, consúltese el Compendio Estadístico.

Fuente: Procesamiento de varias preguntas de Latinobarómetro 2002. 
- Los demócratas han experimentado mayor movilidad educativa en relación con sus padres.

- Hay una mayor presencia relativa de jóvenes entre los no demócratas.

- Los no demócratas son, en promedio, personas que perciben haber experimentado una movilidad económica descendente más intensa que los otros grupos en relación con sus padres.

- Los no demócratas son los que más tienden a esperar que sus hijos tengan una menor movilidad económica ascendente.

Poco más de la mitad de las personas de América Latina fueron socializadas bajo regímenes autoritarios (51,8 por ciento). Cuando se examina a los demócratas, esta proporción baja a 48,8 por ciento; entre los no demócratas la proporción aumenta a 55,1 por ciento.

\section{Heterogeneidad}

El estudio de opiniones en otros ámbitos de interés permite explorar si, además de compartir las opiniones en relación con la democracia, las personas de una misma orientación comparten actitudes relacionadas con lo que en un país debería hacerse y a quién debería apoyarse electoralmente.

Los datos relevados señalan que las orientaciones son políticamente heterogéneas. En particular, las personas que comparten una orientación positiva hacia la democracia no se concentran en fuerzas políticas determinadas ni manifiestan opiniones muy distintas de las del resto de los consultados. Sin embargo, hay al gunas diferencias interesantes:

- Los no demócratas tienden con más fre cuencia que el resto a opinar que su problema prioritario no se está solucionando o que el país va para atrás en su solución.

- Los no demócratas tienden a percibir con más frecuencia queel sector político al que pertenecen no tiene igualdad de oportunidades para llegar al poder.

- Los no demócratas tienden a estar menos satisfechos con la democracia que los de- mócratas y los ambivalentes (sólo el 19 por ciento de ellos está satiffecho, frenteal 40 y al 43,9 por ciento, respectivamente).

- Los no demócratas tienden a confiar menos que los demás en las instituciones y los actores.

- Losno demócratas creen con másfrecuencia que el resto que los políticos mienten con tal de ganar las elecciones.

- Los demócratas tienden a favorecer un papel más protagónico del Estado en el desarrollo del país que los no demócratas y los ambivalentes.

- No hay mayores diferencias de opinión acerca de los problemas prioritarios que deben ser solucionados en el país: demócratas, ambivalentes y no demócratas coinciden en escoger los problemas de pobreza y desempleo como los más importantes.

Del análisis del perfil delos no demócratas y sus percepciones sobre la realidad política y económica es posible también comprobar que esa orientación está asociada con menor educación, socialización en períodos autoritarios, baja movilidad social respecto de sus padres, menores perspectivas positivas respecto del futuro de sus hijos y acerca de la solución de sus problemas públicos, y una gran desconfianza en las instituciones y los políticos.

\section{Modos de participación ciudadana en la vida política}

Si bien no es posible determinar de modo general el nivel óptimo de participación que debería existir en una democracia, toda democracia requiere de al gún nivel de participación ciudadana. En las más dinámicas, las personas encuentran múltiples caminos para ejercer ese derecho.

M ediante el examen dela participación ciudadana puede determinarse cuál de las orientaciones ya examinadas es más activa y así agregar un nuevo elemento de juicio para el estudio sobre el apoyo a -y la vulnerabilidad de- las democracias en la región. 
PERFIL POLÍTICO DE LAS PERSONAS SEGÚN SU ORIENTACIÓN

HACIA LA DEMOCRACIA, 2002

TABLA 49

\begin{tabular}{|c|c|c|c|c|c|c|}
\hline & \multirow[t]{2}{*}{ Categorías } & \multirow[t]{2}{*}{$\begin{array}{l}\text { Estructura } \\
\text { de la muestra }\end{array}$} & \multicolumn{3}{|c|}{ Orientación hacia la democracia } & \multirow[t]{2}{*}{$\begin{array}{l}\text { Significancia } \\
\text { (2) }\end{array}$} \\
\hline & & & Demócratas & Ambivalentes & No demócratas & \\
\hline Centroamérica y México (1) & $\%$ de personas & $n=6.402$ & 46,60 & 33,80 & 19,70 & .. \\
\hline Región Andina & $\%$ de personas & $n=4.377$ & 37,30 & 34,40 & 28,30 & .. \\
\hline Mercosur y Chile & $\%$ de personas & $n=4.438$ & 43,60 & 21,90 & 34,50 & .. \\
\hline América Latina & $\%$ de personas & $n=15.217$ & 43,00 & 30,50 & 26,50 & .. \\
\hline \multirow[t]{7}{*}{ Voto } & \% votó en la & & & & & \\
\hline & última elección & 78,3 & 82,3 & 76,9 & 73,6 & $* *$ \\
\hline & $\begin{array}{l}\% \text { no votó por } \\
\text { desencanto } 0\end{array}$ & & & & & \\
\hline & desinterés & 8,9 & 7,2 & 10,2 & 10,2 & $* *$ \\
\hline & $\%$ manifiesta tener & & & & & \\
\hline & un partido & 47,5 & 51,7 & 46,6 & 41,7 & $* *$ \\
\hline & $\begin{array}{l}\text { Promedio de índice de eficacia } \\
\text { del voto }\end{array}$ & 3,01 & 3,03 & 3,13 & 2,84 & $* *$ \\
\hline \multirow[t]{4}{*}{ Democracia } & $\begin{array}{l}\% \text { da significado } \\
\text { negativo de }\end{array}$ & & & & & \\
\hline & democracia & 5,4 & 2,4 & 3,8 & 12,8 & $* *$ \\
\hline & $\begin{array}{l}\% \text { satisfecho con el } \\
\text { funcionamiento }\end{array}$ & & & & & \\
\hline & de la democracia & 35,6 & 40,0 & 43,9 & 19,0 & $* *$ \\
\hline \multirow[t]{5}{*}{ Otras actitudes políticas } & $\begin{array}{l}\text { \% opina no tener } \\
\text { igualdad de } \\
\text { oportunidades }\end{array}$ & & & & & \\
\hline & políticas & 32,5 & 29,5 & 31,0 & 39,3 & \\
\hline & $\begin{array}{l}\text { \% opina que se debe } \\
\text { ser cuidadoso en el } \\
\text { trato con los demás }\end{array}$ & 80,7 & 79,0 & 78,9 & 85,5 & $* *$ \\
\hline & Promedio en escala izquierda-derecha & 5,93 & 5,77 & 6,33 & 5,75 & $* *$ \\
\hline & $\begin{array}{l}\text { Promedio de índice de confianza en } \\
\text { instituciones y actores políticos }\end{array}$ & 1,93 & 1,97 & 2,03 & 1,77 & $* *$ \\
\hline \multirow[t]{7}{*}{ Estrategias de desarrollo } & $\begin{array}{l}\text { \% opina: instituciones } \\
\text { públicas sin solución }\end{array}$ & & & & & \\
\hline & o privatizar & 5,0 & 3,8 & 5,1 & 6,8 & \\
\hline & $\begin{array}{l}\% \text { a favor de medidas } \\
\text { administrativas }\end{array}$ & & & & & \\
\hline & de reforma & 42,0 & 41,8 & 43,6 & 40,7 & $* *$ \\
\hline & $\begin{array}{l}\% \text { a favor de } \\
\text { mejoramiento de } \\
\text { accountability en }\end{array}$ & & & & & \\
\hline & Estado & 53,0 & 54,4 & 51,3 & 52,6 & \\
\hline & $\begin{array}{l}\text { Promedio índice de intervención } \\
\text { económica del Estado }\end{array}$ & 3,82 & 4,05 & 3,55 & 3,76 & $* *$ \\
\hline
\end{tabular}


PERFIL POLÍTICO DE LAS PERSONAS SEGÚN SU ORIENTACIÓN

HACIA LA DEMOCRACIA, 2002

TABLA 49 (CONT. DE P. 140)

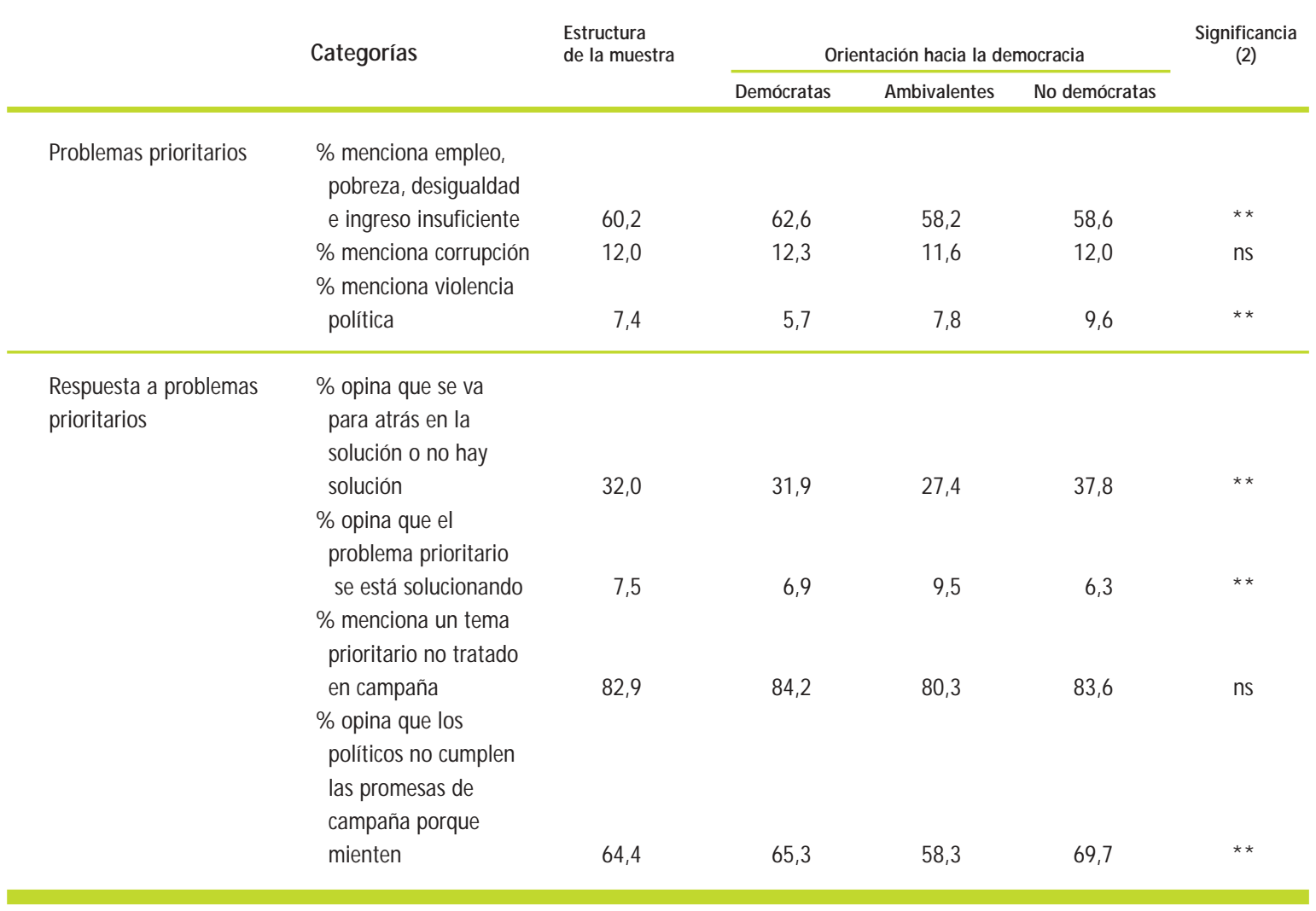

Notas:

(1) Incluye República Dominicana.

(2) Se indica con un $(*)$ cuando la medida de asociación utilizada o el Análisis de Variancia (ANOVA por sus siglas en inglés) resulta significativo al $5 \%$. Se indica con $(* *)$ cuando el resultado es significativo al $1 \%$. Se indica (ns) cuando la prueba no resultó significativa ni al $1 \%$ ni al $5 \%$. Cuando no es pertinente el cálculo de una medida de asociación o ANOVA se indica con (..). Sobre pruebas realizadas en cada caso, consúltese el compendio estadístico.

Fuente: Procesamiento de varias preguntas en Latinobarómetro 2002.

La mayoría de los ciudadanos en América Latina no son personas desconectadas de la vida política y social de sus países. Sólo una pequeña minoría de los consultados, 7,3 por ciento del total, no realizó ningún acto de participación ciudadana en los años recientes. Un 22,1 por ciento adicional se limitó a ejercer el voto en la última elección presidencial desu país. En conjunto, alrededor del 30 por ciento de las personas puede ser catal ogado como ciudadano desmovilizado: o no ejercesus derechos de participación o lo hace de manera intermitente, en la modalidad de participación política quemenos esfuerzo personal requiere, el voto.

Casi cuatro de cada diez personas entrevistadas (37,6 por ciento) intervienen en la vida pública de su país más allá de la participación electoral. Además de votar, contactan autoridades públicas cuando hay problemas que afectan a sus comunidades, participan en manifestaciones públicas y colaboran con tiempo, trabajo 0 dinero en la resolución de los problemas comunales. Éstos son ciudadanos que ejercitan activamente sus derechos.

Entreellos, se distinguen dos grupos. En primer lugar, existe un sector al tamente participativo, compuesto por personas que, literal mente, "hacen de todo". Ellas registraron actividad en todos los ámbitos de participación ciudadana investigados ( participación electoral, contactando autoridades, en manifestaciones colectivas y en instituciones sociales). En América Latina, 


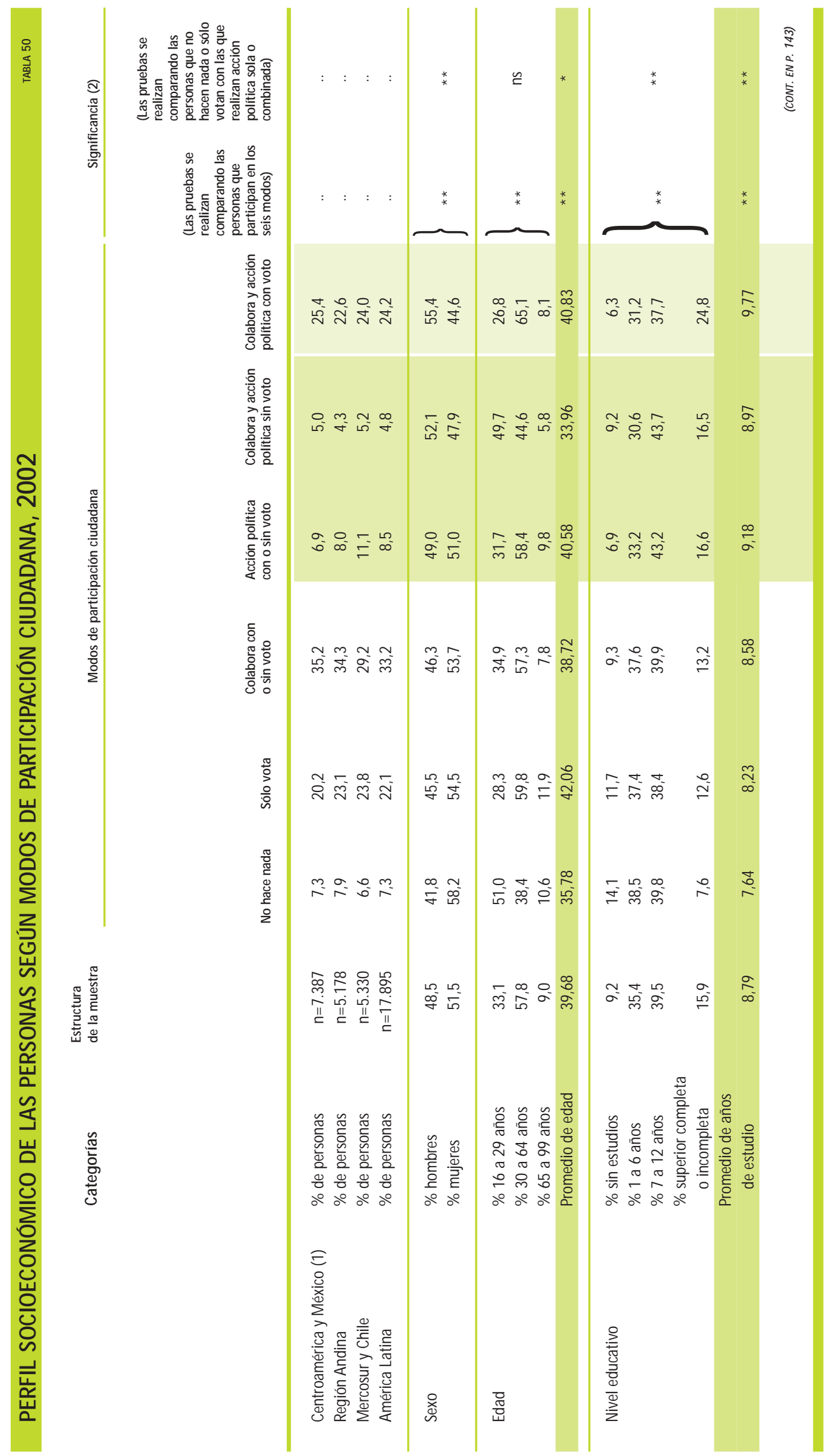




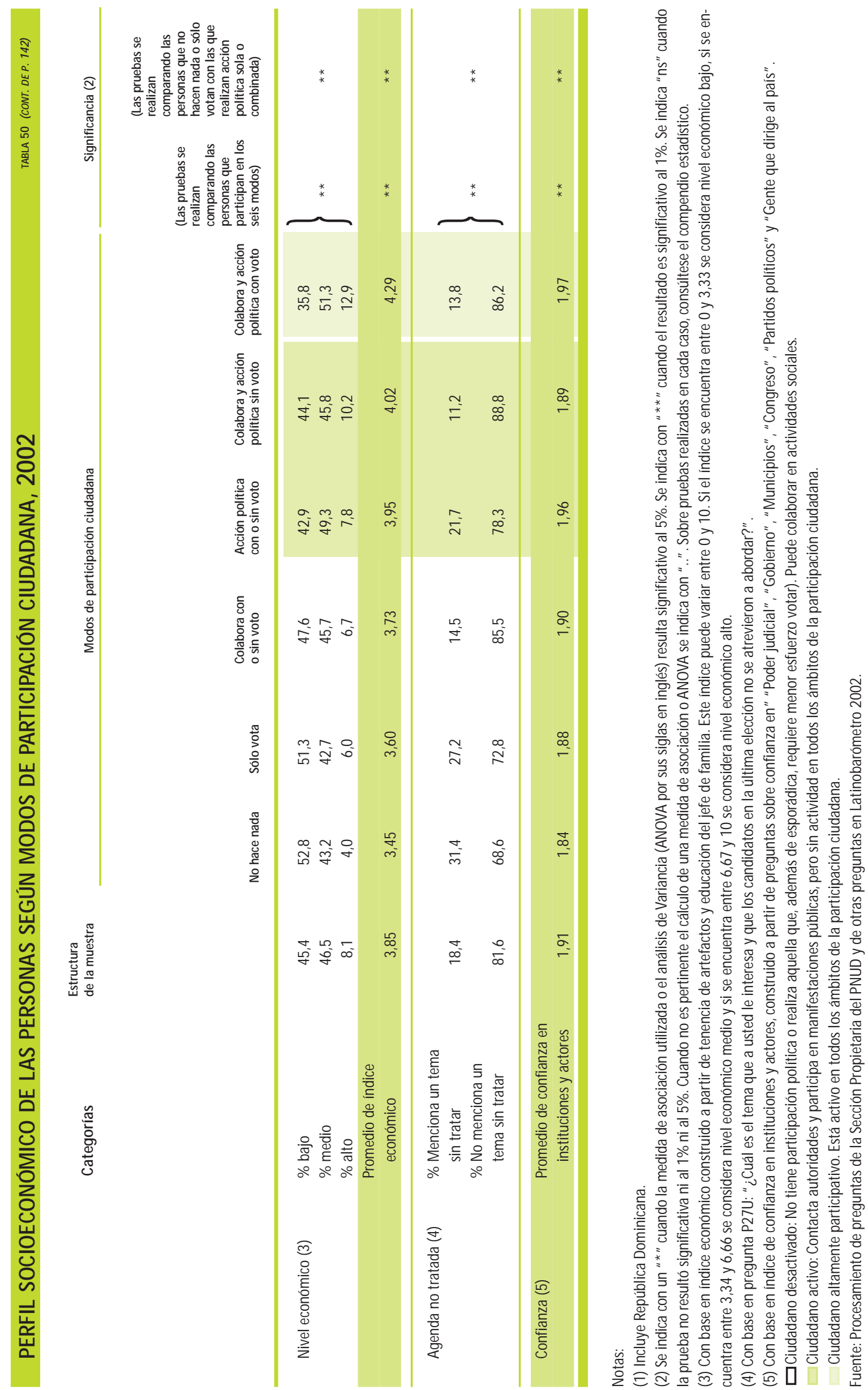


estos ciudadanos son aproximadamente 25 por ciento del total, un tamaño ligeramenteinferior al de los ciudadanos desmovilizados.

Un segundo sector, compuesto por cerca de una de cada ocho personas (13,3 por ciento), también realiza actividades de participación política más allá de la electoral, pero sin alcanzar el nivel y la diversidad de las acciones de los ciudadanos altamente participativos. Estas personas combinan el ejercicio del sufragio con al menos otra modalidad de participación política: votan y contactan autoridades, votan y participan en manifestaciones públicas y en algunos casos pueden, además, colaborar con la comunidad. No están, sin embargo, activos en todos los frentes. Dentro de ellos, un sector desarrolla actividades políticas no electorales de participación ciudadana: se abstiene de votar pero contacta autoridades públicas y participa en manifestaciones públicas (4,9 por ciento).

Finalmente, un tercio (33,2 por ciento) de los latinoamericanos son personas socialmente activas, la mayoría de las cuales tiene a lo sumo una intervención esporádica en la política por medio del voto. Las personas en este grupo se encuentran en una posición intermedia entre los ciudadanos desmovilizados y los políticamente activos. Por una parte, colaboran con organizaciones de su comunidad y, en este sentido, ejercitan su derecho departicipar en aqueIlas actividades de su interés. Por otra parte, esa actividad se desarrolla principalmente en un ámbito no político.

\section{Participación ciudadana y orientaciones hacia la democracia}

Un último aspecto en el análisis de la participación es su vínculo con las orientaciones hacia la democracia. En América Latina, los demócratas tienden levemente a participar más activamente en la vida política de sus países que los ambivalentes y los no demócratas. El 43 por ciento de los demócratas realizan otras actividades políticas, tales como contactar autoridades y funcionarios públicos y manifestarse pública- mente, además de, casi todos ellos, votar; el 37 por ciento de los no demócratas puede clasificarse como activos y también el 39 por ciento de los ambivalentes. Una comprobación importante es que no siempre los demócratas son los más participativos.

\section{Perfiles de intensidad de la ciudadanía}

El análisis integrado del tamaño, la distancia y el activismo de las orientaciones hacia la democracia ayuda a proporcionar una estimación del grado de respaldo ciudadano con que ella cuenta. Con este propósito preparamos el índice de apoyo a la democracia (IAD), que ofrece una visión sintética sobre el apoyo y la posible vulnerabilidad de las democracias latinoamericanas.

Esteíndice permite valorar el balance actual de fuerzas y el potencial para crear coaliciones ciudadanas amplias en apoyo de la democracia, incluyendo a los sectores ambivalentes. Es una herramienta que distingue las situaciones políticas favorables de las desfavorables y riesgosas. En las situaciones favorables hay un balance de fuerzas positivo para la democracia, pues los demócratas son mayoría, son los políticamente más activos, y los ambivalentes están relativamente cercanos a las posiciones de los demócratas. En el caso opuesto, cuando el balance de fuerzas es negativo, los no demócratas son mayoría, son más activos y son los que tienen más cerca a los ambivalentes. Con el IAD se podrá, mediante futuras mediciones, examinar los cambios en la situación política y en la presunta solidez de las bases de estabilidad democrática en la ciudadanía.

Las fuentes de información del IAD también pueden ser empleadas para estudiar la intensidad de la ciudadanía, es decir, cómo las personas ejercitan, si lo hacen, su estatus de ciudadano o ciudadana.

El concepto de intensidad ciudadana proviene del término ciudadanía de baja intensidad, acuñado por O'D onnell. 77 Por intensidad ciudadana seentiende el librey activo ejercicio delos

77 O'D onnell, 1993. 
derechos y el cumplimiento de los deberes ge néricos propios del estatus de ciudadanía. La he rramienta utilizada para aproximarse a este tema es una tipología de perfiles de intensidad ciudadana, que permite clasificar a las personas de acuerdo con la manera como ejercitan su estatus de ciudadanos.

Sobre la base de la información de las orientaciones a la democracia y los modos de participación ciudadana en América Latina, las personas pueden clasificarse de acuerdo con cuatro perfiles de intensidad ciudadana:

- los demócratas participativos;

- los demócratas desmovilizados;

- Ios ambivalentes y no demócratas desmovilizados;

- los ambivalentes y no demócratas participativos.

Los dos primeros grupos comparten una orientación democrática pero difieren en su nivel de participación en la vida política. Los dos últimos grupos comparten su ausencia de compromiso con la democracia y también difieren en su nivel de participación política.
A proximadamente, una de cada cinco personas en América Latina (18,9 por ciento) puede catalogarse como demócrata participativa. Poco más de un tercio de los consultados (34,9 por ciento) son ambivalentes o no demócratas desmovilizados. Estas personas dudan o se oponen a la democracia pero están retirados de la vida política. Los ambivalentes y no demócratas participativos son una proporción muy similar a los demócratas participativos. Según nuestros datos, en América Latina aproximadamente una de cada cinco personas (21,6 por ciento) puede catalogarse con este perfil: personas que dudan o se oponen a la democracia y son políticamente activas.

Las características sociales de las personas de cada uno de los perfiles de intensidad ciudadana son similares a las descriptas para la base social de las orientaciones hacia la democracia, pero desde la presente perspectiva, el panorama se puede observar con mayor precisión. En términos generales pueden formularse dos conclusiones: los dos grupos socialmente más parecidos entre sí son, paradójicamente, los que podrían enfrentarse en caso de una crisis que amenace la estabilidad de una democracia: Ios

RECUADRO 37

\section{Ciudadanía de baja intensidad}

En 1993, O’Donnell planteó que en América Latina una proporción considerable de las ciudadanas y los ciudadanos no pueden ejercer sus derechos civiles y son discriminados, pese a que sus derechos políticos están razonablemente protegidos. Denominó a ese fenómeno 'ciudadanía de baja intensidad', y lo atribuyó a barreras objetivas, como la debilidad del Estado democrático de derecho y el efecto de las desigualdades sociales extremas. Un estudio de la ciudadanía de baja intensidad requiere, pues, la utilización de diversas fuentes de información, tanto percepciones como registros institucionales. Además de esos obstáculos, la intensidad en el ejercicio de la ciudadanía puede ser afectada por el grado en que las personas se sientan obligadas a cumplir con sus deberes y a ejercer sus derechos. Ésta es precisamente la perspectiva investigada en este capítulo, con la información de Latinobarómetro. Se trata de una perspectiva inspirada en el pensamiento de O'Donnell, aunque distinta, pues se centra en el estudio de las actividades y los comportamientos de los individuos. Una democracia en la cual una proporción importante de la ciudadanía decide no ejercer sus derechos ni cumplir con sus deberes se encuentra en problemas. Para avanzar sobre este tema, se preparó una tipología de perfiles de intensidad ciudadana, que clasifica a las personas combinando los siguientes criterios:

- En la perspectiva de los deberes ciudadanos, el deber de aceptar la vigencia de las normas democráticas. Para esto se utilizó el estudio de las orientaciones hacia la democracia.

- En la perspectiva de los derechos ciudadanos, el grado en que las personas participan en la vida política, para lo cual se utilizó el estudio sobre los modos de participación ciudadana. 
demócratas participativos y los ambivalentes o no demócratas participativos. Ambos grupos tienen estructuras de edad, nivel de instrucción y nivel económico más parecidos entre sí que con los otros dos grupos.

La segunda conclusión es que los ambivalentes o no demócratas desmovilizados parecen concentrar, en mayor proporción que los otros grupos, a las personas más jóvenes y de menor nivel económico. Los jóvenes son más numerosos en este grupo que entre los demócratas participativos (38,4 por ciento de los primeros y 30 por ciento de los segundos). Las personas sin estudios o con escuela primaria completa o incompleta (1 a 6 años de escolaridad) tienen una distribución similar: proporcionalmente tienden a agruparse más entre los ambivalentes o no demócratas desmovilizados. En cambio, las personas con educación superior completa o incompleta son más numerosas entre los demócratas participativos.

\section{El Índice de Apoyo ciudadano a la Democracia}

El resultado del IAD para la región tendió a ser positivo para la democracia. Los demócratas, en términos decorrelación de fuerzas, están en mejor posición quesus contrarios, los no demócratas. En efecto, los demócratas constituyen la orientación hacia la democracia más difundida y tendieron (aunque levemente) a participar más en la vida política y social de sus países que las personas con otras orientaciones. Asimismo, tuvieron a los ambivalentes ligeramente más cerca de sus posiciones que los no demócratas (gráfico 8). El IAD agregado para la región arrojó un valor de 2,03.

En todo caso, los ambivalentes son un grupo clave a observar, pues en la mayoría de los países los demócratas requieren de su apoyo para formar mayorías ciudadanas. Es preciso también tomar nota de los factores que se asocian más fuertementecon los no demócratas, ya que están relacionados con carencias de la ciudadanía social y con bajas perspectivas de movilidad económica y educativa, cuestiones en las que, como hemos visto, la región tiene aún serios déficit.

Resumiendo los resultados de este análisis, encontramos:

- Procesando datos de la encuesta de Latinobarómetro de 2002, quienes tenían una orientación prodemocrática eran el $43 \%$ de los entrevistados, siendo la más extendida.

\section{El Índice de Apoyo a la Democracia (IAD)}

La elaboración del IAD se basa en los siguientes elementos:

- Las orientaciones hacia la democracia.

- El tamaño de cada orientación y, luego, la proporción entre demócratas y no demócratas.

- La distancia promedio en las actitudes entre cada orientación, si los demócratas o los no demócratas están más cerca de los ambivalentes.

- El nivel de activismo político de las personas que sustentan las orientaciones y la situación de los demócratas y los no demócratas.

- El IAD, entonces, pondera el tamaño de las orientaciones con la distancia y el activismo. Una explicación más detallada puede encontrarse en la nota técnica sobre la encuesta en el Compendio Estadístico.

- En las situaciones favorables a la democracia, el IAD arroja un valor bastante superior a 1. Cuando el IAD tiene un valor que ronda 1 , resume situaciones de equilibrio político entre las orientaciones demócrata y no demócrata. Son situaciones con un potencial de inestabilidad, pues el apoyo ciudadano a la democracia no está garantizado. Cuando el IAD asume valores muy inferiores a 1 y cercanos a cero, el apoyo ciudadano a la democracia es precario. En caso de emerger una crisis política severa, el futuro de la democracia podría verse fácilmente comprometido por la precariedad del apoyo ciudadano. 


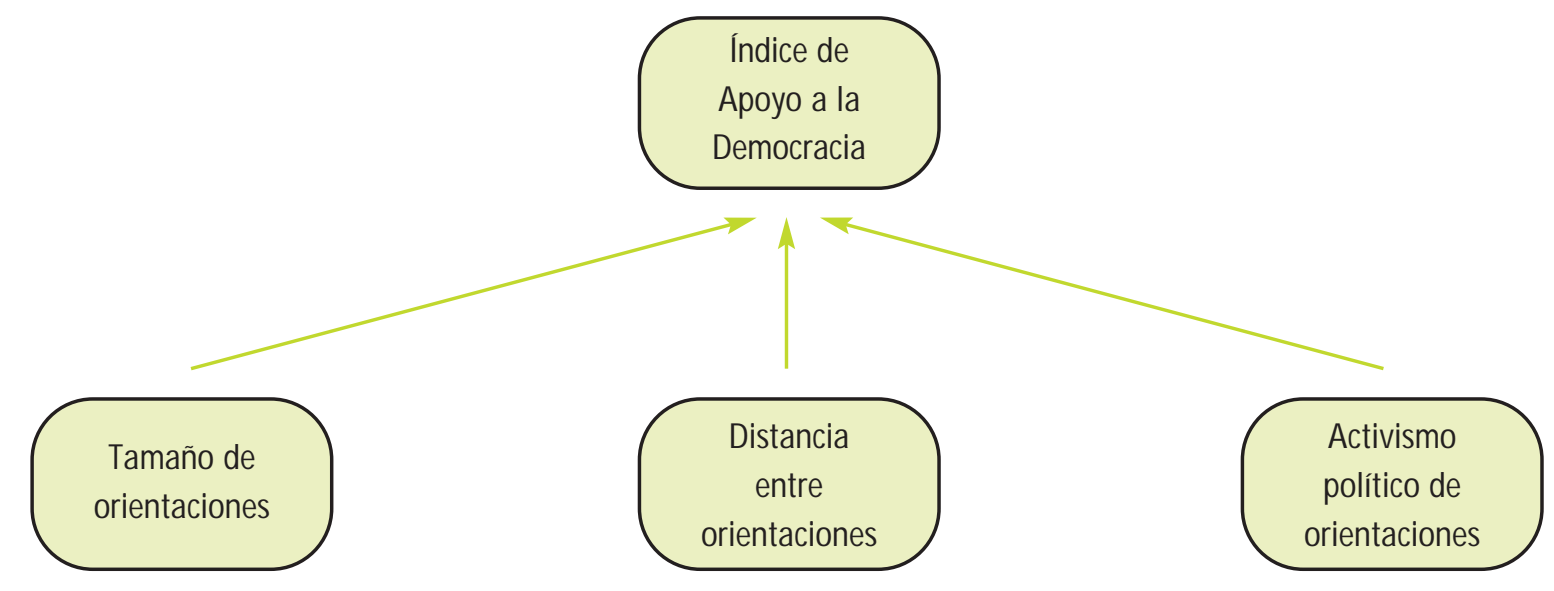

- Cuando se pregunta acerca de la alternativa entre desarrollo económico y democracia, se evidencia una tensión. Muchos parecería que prefieren la primera.

- Los entrevistados pertenecientes a países donde hay menores niveles de desigualdad social tienden a ser más favorables a la democracia.

- Del análisis del perfil de los denominados "no demócratas" surge que esta orientación tiene mayores adeptos entre los sectores con menos educación, los que tienen una socialización proveniente de períodos autoritarios, los que tienen una percepción de baja movilidad social respecto de sus padres y bajas expectativas en cuanto a futura mejoría para sus hijos, y aquellos que tienen mayor desconfianza en las instituciones.

- La mayoría de los ciudadanos no está desconectada de la vida política y social de sus países.

- En promedio, los demócratas tienden levemente a participar más activamente en la vida política de sus países.

GRÁFICO 8

Panorama regional del IAD, 2002

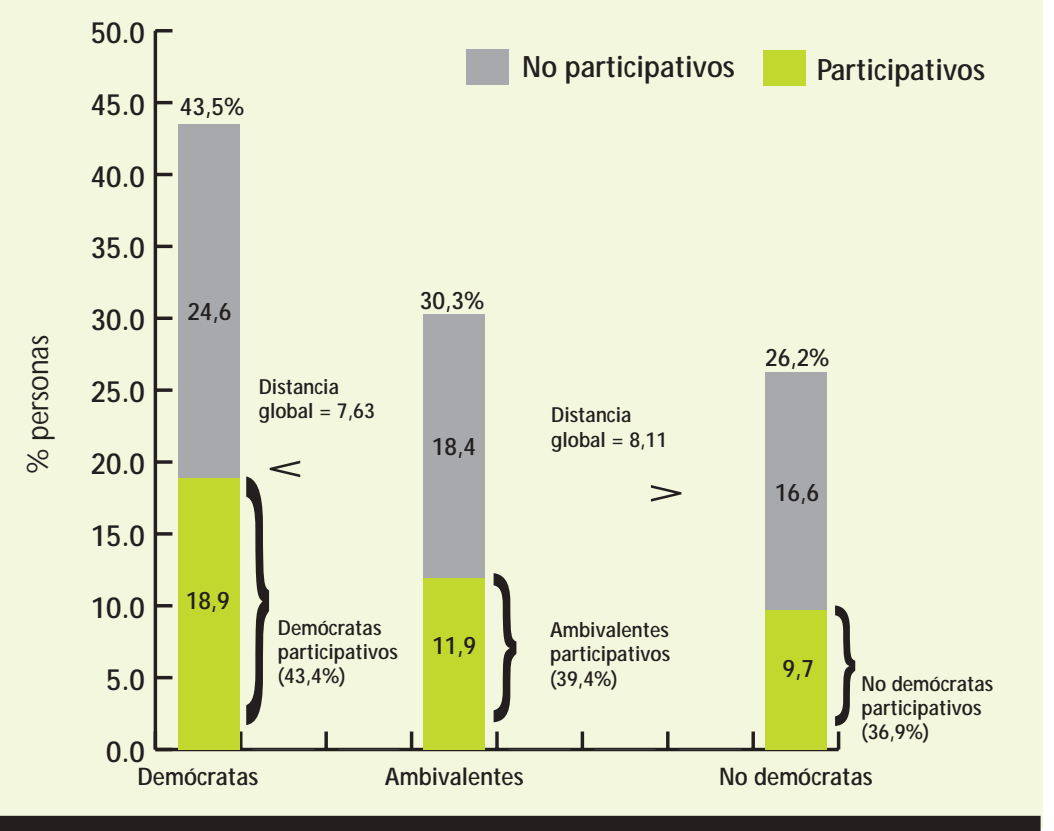

Nota: Los porcentajes de personas en cada orientación no coinciden con los mostrados en gráficos anteriores, pues al combinar la información de orientaciones con la de participación, la ausencia de respuesta aumenta y provoca que dichos porcentajes varíen. Fuente: Elaboración propia con base en Latinobarómetro 2002. 



\section{- La percepción de la dirigencia latinoamericana}

La indagación sobre el desarrollo de la democracia en América Latina se enriquece con las percepciones y opiniones de quienes toman las decisiones quemás impactan en la vida política de la región.

Este parte exponey sistematiza las opiniones que surgen de la ronda de consultas a 231 líderes latinoamericanos, incluidos 41 presidentes y vicepresidentes actuales y precedentes.

Analizamos aquí sus percepciones sobre el grado de desarrollo de nuestras democracias, poniendo el acento en la participación ciudadana, los límites del poder democrático, la confianza en las instituciones - particularmente en los partidos políticos- y las relaciones con los poderes fácticos nuevos o tradicionales. También se observaron la tensión entre pobreza/desigualdad/democracia, los problemas en torno a la elaboración de la agenda pública y los desafíos que enfrentan las democracias.

Expresamos nuestro agradecimiento a las 231 personalidades que se brindaron con generosidad para que pudiéramos realizar las consultas, y lamentamos no haber podido hacer todas las que deseábamos, lo que ha hecho que se omitiera a importantes dirigentes.

\section{Perfil de los actores consultados}

Para la realización de las consultas - que tuvieron lugar entrejulio de 2002 y junio de 2003seguimos dos criterios: a) hicimos no menos de media docena de consultas por país, y b) lleva- mos a cabo más consultas en los países más grandes (en particular, los dos grupos más numerosos de consultados son los brasileños, con treinta y cuatro líderes consultados, y los mexicanos, con veinticinco).

Ésta no es una muestra al azar y, por lo tanto, los datos no tienen representatividad estadística. La meta es relevar juicios fundamentales sobre las democracias de la región por parte de un conjunto relevante de líderes. Buscamos detectar las maneras de ver y pensar expresadas en las respuestas de los líderes, en una entrevista cuya agenda les era previamente desconocida.

Al final del Informe aportamos más información sobre la metodología y los criterios de procesamiento empleados. Aquí importa tener en cuenta que el estudio no pretende sustituir sino complementar otros tipos de estudios de opinión. La pregunta a contestar es: ¿cuáles son las opiniones y formas de pensar de un grupo de 231 personas que ejercen funciones de liderazgo en América Latina? Se trata de actores protagónicos dela vida política, económica, social y cultural latinoamericana, que integran una muestra cuya significación surge de la relevancia de sus trayectorias: a) líderes políticos quedetentan o detentaron el poder en su máximo nivel institucional, en jefaturas partidarias, parlamentarios, funcionarios de al to rango 0 alcaldes; b) protagonistas sociales en un amplio espectro que incluye líderes sindicales, empresarios, académicos, periodistas, religiosos y dirigentes de movimientos u organizaciones sociales, y c) miembros de las Fuerzas Armadas. 
Hay coincidencia en que más

participa ción a tra vés de los

pa rtid os políticos es sa luda b le

para la democracia.

El 51 por ciento delos consultados son políticos. Entre los restantes se observa un peso importante de empresarios (11 por ciento) e intelectuales (14 por ciento). Las demás categorías se distribuyen en: sindicalistas ( 7 por ciento), periodistas ( 6 por ciento), líderes dela sociedad civil ( 7 por ciento), religiosos ( 2,5 por ciento) y militares (1,5 por ciento).

\section{El punto de partida conceptual}

Los testimonios coinciden en subrayar un diagnóstico que puede resumirse así: nunca antes hubo tanta democracia en América Latina ni estuvo tan controlado el peligro degolpe de Estado, pero de todos modos la democracia está expuesta a fragilidades, como las que derivan del bajo prestigio de los partidos políticos y de la llamada crisis de la sociedad política. 78 En la actualidad, todos los países cumplen con los requerimientos del régimen democrático y éstos son especialmente valorados por los consultados, en contraste con el pasado autoritario. Desde esta perspectiva, la conquista y afirmación de los atributos básicos de la democracia son consideradas una etapa necesaria y un progreso significativo. Esta visión deja abierta una gama de cuestiones a abordar y de objetivos inalcanzados, dentro de un acuerdo generalizado en señalar el carácter inacabado de la construcción de la democracia en América Latina, incluso allí donde dicho proceso histórico tiene más larga duración.

\section{Condiciones necesarias para la democracia}

Aunque no las entienden exactamente del mismo modo, los líderes latinoamericanos consideran que la participación política y los controles al ejercicio del poder son dos condiciones básicas de la democracia, y que ambas se han fortalecido a lo largo de la última década.

\section{La expansión de la participación política}

Si bien la palabra participación tiene diferentes significados políticos, en un sentido más estrecho se suele restringir su al cance a la participación electoral. En su sentido más amplio, suponeal guna forma estable de conexión con la toma de decisiones públicas, principalmente a través de la mediación de los partidos políticos 0 de las organizaciones de la sociedad civil. Algunos sentidos intermedios aluden a formas más o menos activas de ejercicio de la ciudadanía, tales como la participación en consultas populares o en ámbitos deliberativos a nivel local.

La casi unanimidad de las personas consultadas piensa que una mayor participación en cualquiera de sus formas tiende a fortalecer el funcionamiento de las instituciones democráticas. En este sentido amplio, más participación aparece en general como preferible a menos participación. Sin embargo, como veremos más abajo, este juicio genérico se relativiza cuando buena parte de los consultados se refiere a formas más específicas de participación. También hay coincidencia en que más participación a través de los partidos políticos es saludable para la democracia. Los líderes consultados tienden a compartir esta idea, aun cuando son escépticos respecto de si los partidos están funcionando adecuadamente como canales de participación ciudadana o si podrían recuperar protagonismo en este terreno.

Asimismo, para la gran mayoría de los consultados, la participación de la población en sentido amplio (es decir, tanto en lo que refiere a la elección de los gobiernos como a la defini- 
ción de sus políticas) ha aumentado significativamente durante la última década.

En el momento de considerar el acto electoral como una expresión de la participación política, existen dos tendencias. En los países con menor raigambre democrática se visualiza el voto como un acto que hace a la participación, ya que permite expresar una posición crítica hacia viejas estructuras patrimonialistas y, eventualmente, un premio o un castigo a los gobernantes. Se identifica el incremento de la concurrencia electoral con el progreso de la participación. En cambio, en las democracias que han tenido mayor continuidad, el hecho de votar es visto como algo habitual, que no es considerado al momento de evaluar el nivel de participación, ya que para los consultados en estos países la participación implica formas más activas de ejercicio de los derechos ciudadanos.

En casi toda América Latina, el aumento de la participación se percibe como una de las caras más visibles del proceso de construcción democrática. En cambio, la disminución o el estancamiento dela participación que señalan los líderes chilenos, uruguayos y costarricenses parece propia de democracias que se ven a sí mismas como profundamente arraigadas históricamente. Esto no significa que estos países estén libres de dificultades (de hecho, dos de ellos padecieron duras experiencias de regímenes autoritarios); aun así, se trata de un problema diferente de los que enfrentan países donde ese arraigo es menor o más reciente.

Un dirigente consultado en Chileagrega detalles: “La participación quesuponela democra-
En casi toda América Latina, el a umento de la participación se percibe como una de las caras más visibles del proceso de construcción democrá tica.

cia era más institucionalizada [desde mediados del siglo pasado hasta el golpe de Estado de 1973], fundamentalmente a través de las organizaciones políticas y sociales. [...] Hoy día, la realidad chilena es muy preocupante: [...] en las votaciones y en las elecciones ha ido disminuyendo progresivamente el interés dela ciudadanía y aumentado la abstención electoral. [...] [Ahora] hay una participación más desordenada, más circunstancial [...]. Los partidos han perdido presencia y representatividad".

Por su lado, un líder brasileño destaca la expansión de la participación: "La pobreza es difusa, no organizada [...]. Cuanto más se perfecciona el poder democrático, más aumentan las presiones de abajo hacia arriba [ para que sus problemas sean tenidos en cuenta]. Y eso es lo que ocurre [...], [hay] más organizaciones democráticas, más organizaciones de la sociedad y más presión de abajo hacia arriba. Es la prueba que ahora deberemos pasar".

Una diferencia significativa entre los países con democracias históricamente más arraigadas y el resto son los canales a través de los que se ejercela participación. Los consultados tienden,

\section{¿AUMENTÓ LA PARTICIPACIÓN EN AMÉRICA LATINA?}

La participación no aumentó ni disminuyó

La participación disminuyó
Costa Rica

Uruguay, Chile

Notas: Los países están ordenados según "balances de opinión”, es decir, la diferencia entre quienes dicen que la participación aumentó y quienes dicen que la participación disminuyó. El primer país es el que tiene un mayor balance positivo, es decir, aquel en el que la diferencia es más favorable a quienes piensan que la participación aumentó. Luego se ordenan por orden decreciente de este balance.

Fuente: PRODDAL, Ronda de consultas con líderes de América Latina, 2002. 
Nota: Los países están ordenados según "balances de opinión”, es decir, la diferencia entre quienes dicen que los controles aumentaron y quienes dicen que disminuyeron. El primer país en la primera ubicación es el que tiene el balance más positivo, es decir, aquel en el que la diferencia es más favorable a quienes piensan que los controles aumentaron. Los restantes se ordenan a medida que disminuye el balance.

Fuentes: PRODDAL, Ronda de consultas con líderes de América Latina, 2002.

en los primeros, a presuponer que los partidos son uno de los canales naturales (no el único pero sí uno de los importantes). En cambio, en varios países con tradiciones democráticas menos arraigadas, al gunos consultados opinan que la mayor participación se produce cuando los ciudadanos actúan fuera de los partidos, ya sea porque toman la distancia suficiente como para hacer un ejercicio independiente del voto ( por ejemplo, apoyando a candidatos independientes) o porque se incorporan a organizaciones de la sociedad civil que se presentan como alternativa a los partidos. Según estos consultados, no sólo se trata de que los partidos tengan mala imagen, sino que son vistos como un obstáculo para la participación.

Siempre según los consultados, este fenómeno de mayor participación por canales alternativos a las estructuras partidarias aparece frecuentemente asociado a otra tendencia vigorosa, el fortalecimiento de las instancias de deliberación y de decisión a nivel local. Es a esa escala (la aldea, el distrito rural, la ciudad, la provincia) donde aparecerían dirigentes capaces de generar niveles importantes de adhesión y donde mejor funcionarían las organizaciones de la sociedad civil que con más facilidad consiguen involucrar a los ciudadanos. Así lo describe uno de los líderes consultados en Colombia: “En Bogotá [...] gobiernos sucesivos [...] generaron una transformación radical de la ciudad: [...] las políticas públicas se convirtieron en una esencia vital, [...] lo público pasó a tener el asiento de adelante frente a lo privado, que no era como se veía antes, [...] los resulta- dos hacia los ciudadanos generaron un convencimiento y una continuidad en política, [pero] casi no de los partidos, porque los últimos tres candidatos que han sido elegidos son independientes".

La percepción sobrela participación social es heterogénea entre los consultados. Los nuevos movimientos sociales y el crecimiento de la participación por fuera de los partidos llevan a que los primeros sean vistos, por no pocos de los consultados, como una amenaza a la gobernabilidad. Existe también desacuerdo sobre la institucionalización de la participación social. Ciertos países cuentan con canales institucionales a través de los cuales pueden viabilizar y negociar las demandas. Para al gunos consultados, la resistencia a desarrollar mecanismos de participación institucional izada afecta negativamente el desarrollo de la democracia; otros objetan estos procesos por considerarlos particularistas y por generar consensos contingentes que limitan el pluralismo de la democracia.

\section{La expansión de los controles al ejercicio del poder}

En la mayoría de los países latinoamericanos, la idea predominante es que los gobiernos están más controlados y limitados que en el pasado. Esto es percibido en general como un hecho positivo, porque implica la presencia de una ciudadanía más atenta y decidida a hacer valer sus derechos ( lo que es consistente con la percepción de una mayor participación). La idea de que los controles al ejercicio del poder se han perfeccionado predomina entre los líderes de 
doce de los dieciocho países estudiados. Los políticos y funcionarios de gobierno son los que más frecuentemente piensan que los controles han aumentado.

Varios líderes consultados también mencionan la presencia de tradiciones desfavorables a los controles del ejercicio del poder en algunos países centroamericanos, donde la ausencia de controles eficaces aparece asociada a problemas de larga data.

Por otra parte, los consultados relacionan el ejercicio del control con el fortalecimiento dela sociedad civil (sobretodo a partir del papel asumido por las ONG) y el de los medios de comunicación. Éstos son considerados simultáneamente un control y un grupo de presión, lo que permite comprender su paradójica percepción: ser una condición sine qua non de la democracia a la vez que un instrumento de grupos de poder que ejercen indebida influencia en la toma de decisiones públicas.

De manera general, la existencia de medios de comunicación independientes es vista como un factor que ha contribuido decisivamente al aumento de los controles. Numerosos líderes consultados insisten en la capacidad de los medios de detectar irregularidades y excesos (o simples errores y dificultades) y de darles difusión pública. Pero esta misma relevancia de los medios es vista como un peligro por la mayoría de los líderes consultados: apoyados en la popularidad que les aportan las denuncias, ciertos medios terminan por construir su propia agenda y perseguir intereses particulares (los del grupo económico al que pertenecen o los de ciertos sectores de poder a los que están asociados). Para muchos de nuestros consultados, un grave problema es que no existen mecanismos eficaces para controlar los eventual es excesos, al menos en la medida en que no se quiere atentar contra la libertad de prensa. Sin embargo, tanto en sus mejores como peores versiones, los medios son vistos por los líderes como uno de los principales contrapesos del poder político.

\section{Opiniones sobre el carácter de la democracia}

Los líderes latinoamericanos creen que las condiciones políticas necesarias para la demo-
De manera general, la existencia de medios de comunicación ind epend ientes es vista

como un factor que ha contribuido decisiva mente al a umento de los controles.

cracia avanzaron significativamente durante la última década. Consideremos la definición dela democracia que dio un entrevistado en Guatemala: "Si nosotros hubiéramos preguntado en 1986 a los guatemaltecos qué era para ellos la democracia, nos hubieran dicho 'que el gobierno sea civil y que sea electo popularmente', y eso es básicamente lo que debe suceder en toda América Latina". Presuponiendo que esta definición es aceptable, no hay duda de que la gran mayoría de los consultados coincidiría en que sus países son democráticos.

La pauta de las consultas preveía que al cabo de una conversación extensa, los consultadosfueran invitados a responder sobre la presencia o ausencia de democracia en su país ( "Teniendo todo en cuenta, ¿usted diría quesu país hoy es una democracia?"). Sólo 14 por ciento de los consultados respondió inequívocamente ( 6 por ciento que sí, 8 por ciento que no). Para los demás fue necesario precisar y desagregar el concepto.

Tenemos entonces que explorar el sentido de esos condicionamientos y relativizaciones. Para el 6 por ciento, como se dijo, en su país existe una "democracia plena"; para un robusto 66 por ciento, en su país existe una democracia con pocas 0 algunas limitaciones; un 17 por ciento piensa que en su país hay numerosas limitaciones, y otro 8 por ciento opina que su país no es una democracia.

Por lo tanto, al menos como una primera aproximación, el grueso de los consultados (casi nueve de cada diez) acepta el término "democracia" para describir sus respectivas situaciones nacionales, aunque lo haga complementándolo con varias especificaciones adicionales.

Esta observación puede parecer trivial, pero ratifica todo lo que se ha avanzado en los últi- 
Por primera vez en la historia del continente, los líd eres de todos los países incluid os en el estudio ven que sus países satisfacen la definición mínima de democracia.

mos años. Por primera vez en la historia del continente, los líderes de todos los países incluidos en el estudio ven que sus países satisfacen la definición mínima de democracia: hay competencia genuina, los gobiernostienen al menos al gunos límites a su poder y los consultados creen que en estos dos planos se ha progresado significativamente. La respuesta predominante podría sintetizarse de este modo: "Se puede hablar de democracia, sí, sobre todo comparando con el pasado, pero...". Por otro lado, para el 25 por ciento de los consultados, en su país"todavía falta" para poder decir que se vive en democracia.

En algunos casos, las personas consultadas insisten en que la debilidad de la democracia no tiene tanto que ver con bloqueos políticos, problemas de legitimidad o cuestiones de diseño institucional (aunque estos problemas también son mencionados), sino con las condiciones de vida de la población: “Desde el punto de vista económico y social, realmente tenemos unos gravísi mos problemas de distribución de la riqueza, de participación de los panameños [...]. ¿Cómo puede haber democracia en estas condiciones?". La idea de la desigualdad y de la segmentación social como impedimento para la construcción cabal de la democracia aparece muy frecuentemente asociada a los juicios más pesimistas. En el conjunto de las consultas, el comentario más frecuentemente ligado a un juicio escéptico sobre el grado de fortaleza o de realización de la democracia se refiere, usualmente, a las condiciones de vida de la población.

Uno de los consultados en Nicaragua afirma, por ejemplo: "N os ha costado llegar donde llegamos: muertos, luchas intestinas [...]. Hemosavanzado más que muchos países en cuanto a la consolidación dela democracia, pero nos falta mucho por hacer, porque la democracia plena en pobre za y miseria no es concebible. M ientras la única libertad quetenga uno sea la de morirse [...] es difícil". La misma idea apareceen este resumen formulado por uno delos líderes consultados en $\mathrm{Pe}$ rú: "El 54 por ciento de la población vive por debajo de la línea de pobreza extrema y el 23 por ciento por debajo de la línea de pobreza extremaextrema [...]. Esa gente participa en política en el sentido de ir a votar el día de la elección, porque es obligatorio y tiene que pagar una multa si no lo hace, pero eso no es democracia. La democracia no es un acto político electoral. No puede ser libre aquel que esta noche se va a dormir sin saber si mañana tendrá algo que comer".

En el otro extremo, las respuestas más positivas se encuentran especialmente entre personalidades provenientes de las democracias más arraigadas y en los países más grandes. Como señala uno de los consultados en Brasil, las recientes elecciones contribuyen a un clima de confianza en la democracia: "Estamos viendo un momento en que una persona [Luiz Inácio Lula da Silva] sale de la extrema pobreza nordestina y llega al poder máximo del país; [...] la movilidad social es uno de los ingredientes de la democracia: [...] cuanto más posibilidades tenga cada uno de atravesar las barreras [entre las clases sociales], creo que más democracia hay".

Estos casos indican que en América Latina el vínculo entre condiciones socioeconómicas y actitudes hacia la democracia no es automático ni necesariamente determinante. Lo que distingue las actitudes de los liderazgos de estos países no radica, entonces, en las condiciones socioeconómicas "objetivas" de sus países, sino en su grado de confianza en la capacidad delasinstituciones democráticas de convivir con, y en el mediano plazo modificar, esas situaciones de pobreza y exclusión. Para quienes ven las cosas deeste modo, la pobreza y la exclusión son problemas que se deben solucionar por un sistema político inequívocamente democrático.

"H emos alcanzado la república y aún debemos construir la democracia. La república es la que nos preserva las libertades individuales, evita que nos mateun gobierno despótico, quenos 
lleve preso [...], pero además de estas libertades Ilamadas negativas están las otras libertades, las positivas de la democracia, concentradas en los derechos sociales" (ex presidente).

\section{Causas de las limitaciones de las democracias latinoamericanas}

\section{Poderes institucionales y poderes fácticos}

Un problema tradicional de los países latinoamericanos ha sido el divorcio entre los poderes institucionales y los poderes fácticos: si bien los textos constitucionales otorgan gran peso al Poder Ejecutivo y una importante capacidad deacción al Legislativo y al Judicial, el poder real suele residir en instituciones a las que las normas asignan otras funciones (como fue el caso, en el pasado reciente, de las Fuerzas Armadas) o en grupos que no forman parte del orden político-institucional (familias tradicionales, grupos económicos y otros).

La tensión entre poderes institucionales y poderes fácticos sigue estando presente en la realidad latinoamericana. Hay información

\section{La tensión entre poderes instituciona les y poderes fácticos sigue estando presente en la rea lidad la tinoa merica na.}

que sugiere, y las consultas realizadas confirman, que en las últimas décadas, a pesar del fortalecimiento de las instituciones democráticas, los poderes fácticos siguen jugando un papel muy importante.

Las Fuerzas Armadas son vistas como el factor de poder más importante para algunos consultados en Guatemala y la República Dominicana y en menor medida en Ecuador, Chile y Venezuela. Pero las Fuerzas Armadas no son mencionadas en los restantes países, incluyendo a los que experimentaron recientemente crisis políticas agudas (Argentina, Colombia y Paraguay). Este fuerte debilitamiento de las Fuerzas Armadas como factor político es una importante novedad para la democracia latinoamericana.

\begin{tabular}{|c|c|c|c|}
\hline \multicolumn{4}{|c|}{ ¿QUIÉNES EJERCEN PODER EN AMÉRICA LATINA?, } \\
\hline \multicolumn{2}{|c|}{ SEGÚN MENCIONES DE LOS LÍDERES CONSULTADOS } & \multirow[b]{2}{*}{$\begin{array}{l}\text { Cantidad de } \\
\text { menciones }\end{array}$} & \multirow{2}{*}{$\begin{array}{l}\text { TABLA } 53 \\
\text { consultados } \\
\text { mencionan }\end{array}$} \\
\hline & & & \\
\hline Poderes fácticos & Los grupos económicos/ empresarios/ El sector financiero & 150 & $(79,8 \%)$ \\
\hline & Los medios de comunicación & 122 & $(64,9 \%)$ \\
\hline \multirow{3}{*}{ Poderes constitucionales } & Poder Ejecutivo & 68 & $(36,2 \%)$ \\
\hline & Poder Legislativo & 24 & $(12,8 \%)$ \\
\hline & Poder Judicial & 16 & $(8,5 \%)$ \\
\hline \multirow[t]{2}{*}{ Fuerzas de seguridad } & Las Fuerzas Armadas & 40 & $(21,3 \%)$ \\
\hline & La Policía & 5 & $(2,7 \%)$ \\
\hline \multirow{2}{*}{$\begin{array}{l}\text { Instituciones políticas } \\
\text { y líderes políticos }\end{array}$} & Partidos políticos & 56 & $(29,8 \%)$ \\
\hline & Los políticos/ operadores políticos/ líderes políticos & 13 & $(6,9 \%)$ \\
\hline \multirow{4}{*}{$\begin{array}{l}\text { Factores } \\
\text { extraterritoriales }\end{array}$} & EE.UU./ La embajada norteamericana & 43 & $(22,9 \%)$ \\
\hline & Organismos multilaterales de crédito & 31 & $(16,5 \%)$ \\
\hline & El factor internacional/ el factor externo & 13 & $(6,9 \%)$ \\
\hline & Empresas transnacionales/ multinacionales & 9 & $(4,8 \%)$ \\
\hline
\end{tabular}

Nota: $\mathrm{n}=188$. El total no suma $100 \%$ porque se permitieron respuestas múltiples. Fuente: PRODDAL, Ronda de consultas con líderes de América Latina, 2002. 
Sin embargo, algunos líderes consultados identifican tres riesgos principales que podrían amenazar el buen funcionamiento del orden democrático:

1. Según los líderes de los países más grandes y de aquellos con tradiciones democráticas más arraigadas, las limitaciones provienen de dos orígenes. En lo interno, dela proliferación de controles institucionales inadecuados, así como de la multiplicación de grupos de interés (en especial empresariales) quefuncionan como poderosos lobbies. En lo externo, las limitaciones provienen básicamente del comportamiento delos mercadosinternacionales (en especial, pero no exclusivamente, los financieros), de la vigilancia de las calificadoras de riesgo y del papel de los organismos internacionales de crédito.

Por su parte, en países más pequeños o con tradiciones democráticas menos arrai gadas, los consultados también destacan limitaciones externas e internas, pero las describen de manera diferente. En lo interno mencionan los grupos de interés (particularmente empresarios y terratenientes), pero los métodos empleados ya no son sólo lobbies, sino prácticas tales como la compra de votos y la "fabricación" decandidatos. En lo externo mencionan la dependencia de los organismos internacionales de crédito, a la que agre gan la desmesurada influencia de empresas extranjeras instaladas en los propios países.

2. El segundo tema considerado es la amenaza del narcotráfico. Como es natural, la importancia que los líderes latinoamericanos asignan a estefactor está directamenteligada al grado de desarrollo que tiene el fenómeno en sus respectivos países. Sin embargo, casi todas las opiniones recogidas confluyen al señalar que el narcotráfico implicaun dobledesafío. Esun desafío directo porque intenta controlar partedel aparato estatal y partes significativas del territorio, al tiempo que crea fuertes incentivos para el pasaje de la economía formal a la informal. El narcotráfico crea asi mismo desafíos indirectos, entre los que los consultados destacan dos. El primero es que, al atraer la atención del gobierno de Estados Unidos, genera nuevas formas de presión externa quelimitan aún más la esfera de acción de los gobiernos nacionales. El segundo tiene que ver con la corrupción: el "dinero sucio" tiene efectos devastadores sobre el comportamiento de una parte de los dirigentes políticos y sobreel funcionamiento delas instituciones.

3. El tercer factor al que se le atribuyen limitaciones al poder de las instituciones políticas son los medios de comunicación. Esta gran influencia de los medios es vista como parte del aumento de los controles que han permitido democratizar el ejercicio del gobierno, pero también, según lo perciben principalmente los políticos consultados, como una restricción al proceso democrático. Los medios tienen la capacidad de generar agenda, de predisponer a la opinión pública a favor 0 en contra de diferentes iniciativas y deerosionar la imagen de figuras públicas mediante la manipulación de denuncias.

Existe amplio consenso entre los consultados en cuanto a que la gran influencia de los medios limita el poder de las instituciones políticas. En realidad, siempre tuvieron mucha influencia y los políticos intentaron servirse de ella. Lo nuevo, además de la mayor exposición del público a losmedios, esque seha salido de una época en la queestaban mayoritariamente vinculados a los partidos políticos y, en algunos casos, éstos ejercían cierto control sobre aquéllos; actualmente muchos medios se han independizado delas estructuras partidariasy han pasado a formar parte de grupos económicosno subordinados al poder político y con intereses muy diversificados.

\section{El papel de los partidos políticos}

Según los líderes consultados, los partidos políticos, actores fundamentales para el funcionamiento de las democracias contemporáneas, sufren una seria crisis. Un dato revelador es queno sólo la mayor partede los líderes consultados cree que los partidos no están cumpliendo adecuadamente su función; además, esta opinión es am- 
pliamente predominante (59 por ciento) entre los propios políticos consultados. En estecaso, los juicios favorables ("claramente sí" y "más bien si") representan el 18 por ciento y los juicios neutros ("en partesí, en parte no") el 16 por ciento.

Este escepticismo generalizado oculta diferencias importantes de país a país. En algunos casos (Argentina y Ecuador), el desprestigio de los partidos alcanza un grado extremo. En otros casos (H onduras, Uruguay y, aunque en menor medida, Chile), los partidos aparecen en condiciones bastante mejores. De manera general puede decirse que, salvo excepciones, el escepticismo hacia los partidos está muy extendido y la disposición a vincularse a ellos tiende a disminuir en toda América Latina. Estas opiniones re fieren a la coyuntura política del año 2002 y comienzos del 2003. Una nueva ronda de consultas presumiblemente daría nuevos resultados.

¿Cuáles son las razones que fundamentan este juicio? La acusación más frecuente es el personalismo y la ausencia de democracia interna. En palabras de un líder costarricense: "Son las mismas caras, es la misma gente en los últimos cuarenta años, es darle vuelta a la misma masa, es que el que hoy es diputado mañana es embajador, y otra vez le toca un ministerio [y luego] de nuevo le toca a él".

Este rechazo a las oligarquías partidarias puede deberseen partea una modernización de las expectativas de los ciudadanos (el viejo caudillismo y el viejo estilo patrimonialista tienen más dificultades en ser aceptados). Además, el agudo deterioro que por varias razones ha sufrido el Estado en buena parte de nuestros países ha llevado al debilitamiento de uno de los atractivos que los partidos pudieron tener en el
De manera general puede decirse que, salvo excepciones, el escepticismo hacia los partidos está muy extendido y la disposición a vincularse a ellos tiende a disminuir en toda América La tina.

pasado: al menosa ojos de una parte importante de la ciudadanía, los partidos ya no consiguen, mediante su influencia en diversos segmentos del Estado, "resolverle los problemas a la gente". Pero al mismo tiempo que este atractivo clientelar se debilita, los partidos no han conseguido modernizarse en el grado suficiente como para destacarse por su capacidad de propuesta ni por la consistencia de sus equipos degobierno. En palabras de un entrevistado pe ruano: "Los partidos políticos no han sido capaces de tomarle el pulso a América Latina".

Los partidos políticos atraviesan una fuerte crisis de representación queincideen la disminución de la participación electoral y en su canalización por otras vías (en general, organizaciones de la sociedad civil). Sin embargo, casi todos los líderes reconocen la centralidad de los partidos políticos y la necesidad de que asuman un papel de mayor responsabilidad. "Nuestras sociedades han atravesado una rápida metamorfosis debajo de la mesa y los políticos no la hemos monitoreado decerca y entonces hay un gran desencuentro" (presidente). "La gente quiere participar y sientequeel formalismo del voto en lasurnas, por más transparentes que sean las elecciones, no le da ese sentimiento de participación [...]. La de

Sí, o más bien sí Uruguay, Honduras

No, o más bien no

Chile, Perú, M éxico, República Dominicana, El Salvador, Bolivia, Panamá, Brasil, Guatemala, Paraguay, Venezuela, Argentina, Colombia, Ecuador, Nicaragua, Costa Rica

Nota: Los países están ordenados según "balances de opinión” , es decir, la diferencia entre quienes dicen que los partidos están cumpliendo su papel y quienes dicen que no. El primer país es el que tiene un mayor balance positivo, es decir, aquel en el que la diferencia es más favorable a quienes piensan que los partidos cumplen su papel adecuadamente. Luego se ordenan a medida que disminuye el balance. Fuente: PRODDAL, Ronda de consultas con líderes de América Latina, 2002. 
Los pa rtid os políticos a tra viesa n

una fuerte crisis de

representación que incide en la

disminución de la participación

electora I y en su ca nalización

por otras vías.

mocracia necesita de los partidos políticos, pero yo no puedo ir a participar en uno porque cada partido tiene dueño" (empresario).

Nuestros consultados vinculan esta crisis de representación a la ausencia de democracia interna en los partidos, la lógica clientelar de manejo del electorado que incentiva los personalismos, el olvido de las plataformas político-partidarias (falta de diferenciación ideológica, carencia de programas), la generación de escisiones personalistas y no ideológicas, su vinculación a poderes fácticos y alianzas en las que se confunden las identidades políticas.

Por estas razones, la mayoría de los consultados entiende que los partidos -en particular los tradicionales- no han tenido éxito como canalizadores de las demandas de la ciudadanía. A su vez, las oposiciones políticas aparecen fragmentadas y su discurso se conforma más en contra de figuras políticas controvertidas que a partir de propuestas programáticas. En general, lejos de expresar una voluntad mayoritaria dela población, según estas opiniones los partidos actúan en función de intereses particularistas y sufren demasiadas presiones de los grupos de poder, tanto legales como ilegales.

"[Los partidos] tienen muchas dificultades para estar en contacto con las demandas de la gente porque la carrera política depende más que nada de la dirigencia partidista y no tanto de los ciudadanos. Es curioso, hay una partidocracia más o menos sólida y los partidos tienen un buen porcentaje de los votos aunque la genteno tenga una buena opinión de ellos" (académico).

Ciertos actores, en particular los periodistas, perciben a los partidos políticos como instituciones frágiles, divorciadas de las necesidades ciudadanas, sometidos a caudillismos, que se ocupan sólo de la sociedad incluida y pierden contacto con sus bases sociales - actúan, a veces, como verdaderas mafias-. Por su parte, los académicos tienden a vincular la crisis de representación de los partidos políticos a los déficit institucionales que presenta cada país. La revisión del sistema de proporcionalidad en algunos países, de las fuerzas que aparecen representadas en el Parlamento y de los mecanismos de promoción de candidaturas intra o extra partidarias, son las dimensiones más resaltadas. Según ese punto de vista, los problemas de la representación política descansarían más en la forma institucional de funcionamiento del sistema de representación, que en la credibilidad de los partidos políticos frente a la ciudadanía.

Por su parte, según nuestros consultados, el descreimiento de la población en los partidos políticos ha favorecido la expansión y la diversificación de las organizaciones de la sociedad civil, así como la capacidad de éstas de encaminar las demandas. El desequilibrio entre los niveles de participación alcanzados por los partidos y por las organizaciones de la sociedad civil genera miradas críticas en relación con el papel que ambos desempeñan en el proceso democrático.

Los consultados de ONG expresan fuertes críticas hacia los partidos, basadas fundamentalmente en su corrupción, su distanciamiento respecto de los intereses sociales y su búsqueda del poder como afianzamiento de intereses particularistas.

Sin embargo, para al gunos de los consultados más cercanos a los partidos, el problema no es tanto que los partidos no se hayan modernizado plenamente, sino que no consiguieron que esto fuera percibido. Así lo expresa un líder consultado en Chile: "Creo queaquí hay quehacer un mea culpa. Creo que los partidos no han tenido la capacidad de clarificar ante la opinión pública sus proposiciones, la alternativa que representan, el camino que ofrecen". Las explicaciones de estetipo no son suficientes para los consultados de países que enfrentan crisis muy severas. Entre ellos, una idea recurrente es que no es la ciudadanía la que les dio la espalda a los partidos, sino que fueron los partidos los que le dieron la espalda a la 
gente. En palabras de un entrevistado argentino: "Los políticos hablan mucho más de candidaturas, de internas, de elecciones, de mecanismos electorales, y hablan muy poco de desempleo, de pobreza, de marginación, deinseguridad pública, que son los temas que están preocupando a la gente. [...] Esta crisis provino de una dirigencia política que se negó a aceptar ninguna responsabilidad y ningún esfuerzo, básicamente. El único objetivo fuedurar el mayor tiempo posible".

De las consultas surgen también elementos para evaluar la situación de otras instituciones de la democracia. La baja confianza en estas instituciones expresada por la ciudadanía (ver el capítulo precedente) es percibida por los líderes. Algunos señalan un agotamiento de la capacidad de representación y lo vinculan a la elevada influencia de los poderes no electos. Al tiempo que los consultados reconocen, con diferentes matices, el carácter central de los partidos políticos como instrumentos de representación en una democracia de buena calidad, señalan que los partidos sufren de modo particular la influencia de los poderes fácticos.

Existe gran coincidencia entre los consultados en torno al poder acumulado por los grandes empresarios, el sector financiero y los medios de comunicación en la última década. Según aquellos, éstos constituyen el principal factor de poder en las democracias de la región. También resal tan la influencia que ejercen los organismos multilaterales de crédito. Existe amplio consenso en cuanto a que la agenda de los gobiernos es determinada centralmente por los temas y las perspectivas que promueven esos actores.

\section{Los poderes fácticos}

\section{Empresas}

El 80 por ciento de los consultados en América Latina resalta el poder que han acumulado los empresarios, el sector financiero y los medios ${ }^{79}$ en la última década. Ellos constituyen el principal grupo de poder quelimita el poder de decisión de los gobiernos.
El condicionamiento impuesto por los poderes fácticos a los regímenes democráticos favorece la percepción de que se cuenta con gobiernos y partidos políticos que no pueden responder a las demandas de la ciudadanía. "EI gran poder fáctico de la incipiente democracia es el poder económico privado. Integrado por los grupos de presión que condicionan la conducta del presidente, de legisladores, jueces y otros funcionarios gubernativos y de la administración pública” (ex presidente). "Nosotrostenemos una democracia desvinculada del interés general y, fundamentalmente, vinculada a factores fácticos que terminan por oligarquizar la economía del país y cambiar el gobierno democrático por un gobierno plutocrático" (político).

Los líderes subrayan que la relevancia del sector empresarial descansa en su capacidad de lobby frente a los gobiernos, defendiendo y promoviendo sus intereses y direccionando acciones políticas en su beneficio. "El gobierno está al servicio de la empresa privada y de quienes toman las decisiones [...], los multimillonarios son los que deciden qué es lo que se hace o deja de hacer en el país" (religioso). "El poder del dinero se convierterápidamente en poder político, con capacidad de limitar al poder político democrático" (presidente). "Su capacidad de influencia se basa [...] en el hecho de que financian las campañas electorales" (político). "El mundo empresarial tiene un poder muy fuerte. Como los empresarios toman las decisiones de inversión, y sin inversión no hay desarrollo y no hay crecimiento, tienen ahí un poder de veto. [...] El poder de la dirección empresarial con sus capitales y el poder de veto que conduce al desempleo, no cabe duda que es muy fuerte" (político).

En la opinión de algunos presidentes consultados, en el Cono Sur preocupa el peso de corporaciones que aparecen como un obstáculo para una democracia más amplia, por el otorgamiento de privilegios a ciertos grupos en un contexto de partidos débiles y de un Estado que debería ser más republicano. En países más pe queños, como los de Centroamérica, se señalala

79 A diferencia del resto de los países de América Latina, en Brasil no se hace mención a la vinculación entre el sector económico financiero y los medios. Sin embargo, se reconoce su gran incidencia sobre la opinión pública. 
"[La prensa] sofistica los

mecanismos de engaño, pero,

por otro lado, opera como límite"

(periodista).

presión que ejerce el sector privado -ligado a una estructura oligárquica de poder- sobre el presidentey la cooptación dealtos funcionarios, que permite a algunos de los consultados hablar de un proceso de captura del Estado.

La estrecha vinculación entre grupos económicos y medios de comunicación es destacada por la mayoría de los consultados. A través de los medios, los empresarios concentran aún más poder, ya sea porque son sus propietarios o porque imponen condiciones a través del manejo de las pautas publicitarias. Esta alianza les otorga gran capacidad de generar opinión, determinar temas de agenda eincidir sobrela imagen pública delos funcionarios, partidos políticos e instituciones.

\section{Los medios de comunicación}

Los medios son caracterizados como un control sin control, que cumple funciones que exceden el derecho a la información. "Forman la opinión pública, determinan las encuestas y, en consecuencia, son los que más influyen en la gobernabilidad" (político). "Actúan como suprapoderes, [...] han pasado a tener un poder que excede al Ejecutivo y los poderes legítimamente constituidos, [...] han reemplazado totalmente a los partidos políticos" (político).

La mayoría de los periodistas consultados percibe al sector económico-financiero y los medios de comunicación como los principales grupos de poder. Los medios tienen la peculiaridad de operar como mecanismo de control o límite a las acciones de los tres poderes constitucionales y de los partidos políticos, independientemente de quiénes sean los propietarios de esos medios. "La verdadera vigilancia que se ejercees la de la prensa" (periodista). Asimismo, reconocen que actúan como una corporación que define los temas de la agenda pública e incluso delinea la agenda presidencial.
En general, los consultados consideran problemática la relación entre los medios de comunicación y los políticos. "Aquí la clase políticales teme. Porque pueden deshacer una figura pública en cualquier momento" (sindicalista). "La forma en que se construyeron las concesiones y los intereses con los que se tejió toda la estructura de los medios de comunicación, los tiene convertidos en un poder" (político).

Para algunos, sin embargo, la influencia que ejercen los medios es positiva: "Gracias a los medios todavía podemos estar hablando de democracia" (empresario). Valoran su rol fiscalizador: "Está claro quesi no fuera por la vigilia dela prensa, las cosas serían mucho peores". "[La prensa] sofistica los mecanismos de engaño, pero, por otro lado, opera como límite" (periodista).

\section{Los factores extraterritoriales}

El papel que juegan Estados Unidos y los organismos multilaterales de crédito (Banco M undial, BM ; Fondo M onetario Internacional, FM I; Banco Interamericano de Desarrollo, BID) como factores de gran influencia son mencionados por aproximadamentela mitad delos consultados. Ellos señalan la injerencia que los organismos tienen sobre cuestiones internas y la pérdida de autonomía. La dependencia apareceexpresada en las prioridades de la agenda pública, particularmente en la coincidencia entre las sugerencias ofrecidas por estos organismos y las pautas de reformas económicas, fiscales y estatales previstas en el corto y mediano plazo.

"El rumbo, la dirección, los ritmos de la cosa están predeterminados por condicionamientos externos [...] con el Fondo, con los bancos, con el BID" (periodista). "El visto bueno del gobierno de Estados Unidos ante los organismos multilaterales es esencial. Sin una visión favorable del FMI, del BM y del BID, la economía del país colapsaría a corto plazo, por la situación de endeudamiento [...]. La ayuda norteamericana es vital para la correlación defuerzas internas en este período" (político).

"La política económica no es manejada democráticamente [...]. H ay una sola pauta para la región. Y el quequiera salirse de eso tienequeenfrentarse con que no puede hacerlo, o si lo hace, 
lo hace a su propio riesgo. [Ésta es la] limitación del carácter internacional y global delos vectores económicos" (alto funcionario) . "La gente votay las instituciones que surgen de ese voto son facilitadores de decisiones que vienen tomadas de otro lado [...]. Gradualmentesevan allanando las fronteras en aras de esos poderes fácticos quehacen que las decisiones del Parlamento, del Poder Ejecutivo, delaJusticia, de cada jurisdicción sean más bien pintadas" (periodista).

Si bien los consultados reconocen la influencia de estos poderes, al gunos consideran que el poder político mantiene capacidad de autonomía. "El desafío es cómo adaptar las instituciones democráticas a la existencia de los poderes fácticos. Probablemente no haya ninguna manera de institucionalizarlos, sino que hay que saber que existen, que influyen y que esas influencias pesan" (político).

En este contexto y desde una mirada que se proyecta hacia el futuro, un presidente identifica el desafío que supone dirimir el vínculo entre los factores extraterritoriales y las prioridades nacionales, queincluyen la superación de la pobreza y el consecuente fortalecimiento de la democracia: “Este cuadro nos plantea un enorme reto, a saber, si los gobernantes de la región somos o no capaces de que funcione con eficacia y visión de futuro el manejo responsable de las políticas económicas".

\section{Las iglesias}

La mitad de los consultados considera que las iglesias tienen influencia, aunque decreciente respecto del pasado. Se señala que la expansión de las iglesias evangélicas está minando el poder de las católicas. "Creo que la I glesia católica todavía continúa siendo la hegemónica. [...] Los sectores más conservadores se fortalecieron, [...] los que más avanzaron son algunos grupos pentecostales, evangélicos que hoy tienen gran influencia, porque controlan medios de comunicación, [...] tienen un discurso que atrae a las personas como solución a sus problemas y que es extremadamente alienante desde el punto de vista de la conciencia democrática [...]. La gente no necesita participar para construir la democracia, tienequeir allá a rezar y Dios sabe lo que hace. Además, esas iglesias se están transformando en un poder económico extraordinario" (líder de la sociedad civil).

En algunos casos se mencionan autoridades de la I glesia católica, que en épocas de campaña electoral expresan opiniones políticas en sus homilías. "Ellos son los que en la campaña electoral, desde el púlpito, van a influir o insinuar por quién votar" (política). "Esto ha significado que la I glesia católica no ejerza sólo una función estrictamente pastoral sino que adicionalmente ejerza una influencia real en el proceso de la toma de decisiones políticas" (funcionario de alto rango).

\section{El sindicalismo}

El sindicalismo es reconocido por aproximadamente un tercio de los consultados como factor de poder, particularmente por su capacidad de veto a través de presiones y movilizaciones, así como por su influencia en la construcción de la agenda pública relativa a temas laborales. Se menciona en especial a los sindicatos del sector público, resaltando su vinculación al poder político, al mismo tiempo quesealudea los del sector privado como factor de poder decreciente.

\section{Los poderes ilegales}

El peso de los poderesilegales constituye una especial preocupación en algunos países. Estos grupos están relacionados con todo tipo de actividades ilícitas: tráfico de drogas, contrabando, prostitución, juego clandestino, etcétera.

"Algunos sectores del crimen organizado son un poder creciente. En grandes centros urbanos muy vinculados al tráfico de drogas, cuentan con el brazo de los policías y con otros recursos como el dinero abundante. Entonces, ese poder es realmente una amenaza a la democracia" (empresario).

“En la próxima elección se van a presentar por primera vez, en forma directa, representantes directos de esos grupos mafiosos. Antes tenían sus contactos con el poder político, ahora tienen sus representantes. En las listas de candidatos a senadores y diputados podemos reconocer, por ejemplo, al hijo, al yerno, al cuñado y en algunos casos, hasta al propio líder del gru- 
La influencia de los grupos

ilegales ha sido favorecida por

los cambios en la economía y por

un Estado débill, al que pueden

permea r. po mafioso [...]. Son los grupos de mayor influencia y de mayor capacidad de maniobra en operaciones al margen de la ley relacionadas con la falsificación, es decir, todo el comercio de frontera y ese tipo de actividades que son las que dan mayor lucro en la actualidad en nuestro país" (alcalde).

Se destaca la influencia que estos grupos ejercen sobre los poderes del Estado y sobre las empresas. "[En ciertas zonas] donde hay una producción importante de coca, el narcotráfico tiene influencias, desde luego turbias, secretas, a través de la corrupción de las autoridades" (presidente). "Setrata de un poder agresivo, antidemocrático y terrible [...]: compra todo, jueces, fronteras, policías, instituciones enteras" (funcionario de alto rango).

La influencia de los grupos ilegales ha sido favorecida por los cambios en la economía y por un Estado débil, al que pueden permear: "Estos grupos extralegales tienen el poder que tienen porque hay un Estado débil, unas instituciones desprestigiadas como el Congreso [...]. En un alto porcentaje, el narcotráfico fue capaz de corromperlas, y siguen corruptas [...]. En el Congreso sigue habiendo gente pagada por el narcotráfico [que] llegó a corromper la cúpula de los partidos tradicionales [...]. Son las fuentes de financiación de la insurgencia y de los paramilitares" (sindicalista).

\section{Los poderes políticos formales}

\section{El Poder Ejecutivo}

Un fuerte presidencialismo caracteriza a la mayoría de los regímenes democráticosen Amé rica Latina. Es interesante reconocer que los presidentes de Centroamérica y el Caribe refuerzan esta caracterización incluyendo al Ejecutivo en la identificación de los grupos con mayor poder.

Aproximadamente un tercio de los consultados considera que el Ejecutivo es un poder fuerte en América Latina. Sin embargo, esta vaIoración asume diferentes matices. Por un lado, se lo considera un poder positivo, que favorece la construcción de acuerdos y permite la gobernabilidad. Por otro, se destaca que, a pesar de su capacidad de iniciativa, está condicionado y subordinado a factores extraterritoriales y fácticos.

M ás allá de sus atribuciones y restricciones constitucionales, los presidentes intentan mantener primacía sobre el Congreso y el Poder Judicial. "Han tratado de tener más injerencia sobre la Corte y la Asamblea [... ]. Éstees un ré gimen presidencialista y se tiene que hacer lo que el presidente dice[... ]. Tiene un poder que va mucho más allá de los muy fuertes poderes que le da la Constitución" ( presidente). "Cuando uno tiene un liderazgo fuertey gana las elecciones arrasadoramente [...], no hay cosa alguna en que el Congreso controle al presidente" (presidente).

\section{Las Fuerzas Armadas}

Aproximadamente una quinta parte de los consultados atribuye a las Fuerzas Armadas una importante influencia. No obstante, tienden a considerar que han perdido peso, debido a que se encuentran en un proceso de institucionalización y, en algunos casos, a las consecuencias de disputas internas, que también han minado el gran poder que tuvieron en épocas pasadas. En sólo dos países -Ecuador y Venezuela- se comenta que actúan como control de la democracia, cuentan con fuerte reconocimiento público, han construido bases de apoyo vinculadas a las organizaciones sociales y la política social, y están relacionadas con el movimiento indígena. En este contexto, las Fuerzas Armadas aparecen politizadas. Se señala como indicador relevante la militarización de la administración pública, mediante la incorporación a ella de personal militar en servicio activo. "Cuando hay alguna amenaza, ese poder militar va a la calle" (periodista). 


\section{La visión de los presidentes y vicepresidentes}

Los testimonios de quienes han sido o son presidentes y vicepresidentes (en adelante, "Ios mandatarios") deAmérica Latina tienen una importancia particular: sus reflexiones están íntimamente ligadas al ejercicio concreto del poder político en su máxima expresión institucional.

\section{Valoración de la figura del presidente en el mapa del poder de cada región}

Como ya vimos, hay amplia coincidencia en que un presidencialismo fuerte caracteriza los regímenes democráticos en América Latina. Los mandatarios de Centroamérica y el Caribe refuerzan esta caracterización incluyendo al Ejecutivo en la identificación de los grupos con mayor poder. Según uno de ellos: "Todavía la presidencia tiene un poder muy fuerte [que se manifiesta en] las actitudes del presidente, en su misión, su comportamiento, su manera de entender las cosas".

En algunos países aparecen críticas al desempeño presidencial: se perciben prácticas personalistas que confunden la identidad de los partidos con la figura presidencial. Otros mandatarios reconocen el poder presidencial, pero no lo consideran irrefutable, identificando ciertas fisurasen él; este debilitamiento les parece preocupante.

Otros mandatarios observan que el régimen electoral distorsiona su base de apoyo político. Asimismo, el contexto del ejercicio del poder también impone condicionamientos. Entre los mandatarios del Cono Sur, se percibe una brecha entre el poder formal del presidente y su efectiva capacidad de ejercerlo. Según ellos, la imagen del presidente como "caudillo" o "monarca criollo" dista en gran medida de la realidad. "El presidentees un tipo bastantelimitado en su capacidad, en general."

Otro mandatario de un país del Mercosur agrega queel mayor número de controles a partir de mecanismos de democracia directa y dela creación de nuevas instituciones debida a reformas constitucionales, genera mayor legitimidad en el ejercicio del papel presidencial y un consecuente fortalecimiento de la democracia. "Yo goberné en un marco institucional que me permitió legislar." El desafío principal se centra en la capacidad presidencial de dirigir o no el proceso político: "Lo grave es cuando no se tienela capacidad de proponer una dirección".

\section{Presiones de los poderes fácticos sobre la autoridad presidencial}

Los mandatarios consultados analizan el ejercicio de la presidencia frente a la presión de diversos poderes fácticos. Al abordarlo aparecen referencias y reflexiones de carácter personal en torno a la capacidad de imponer decisiones.

"Al ejercer la presidencia no me sentí muy presionado. Tal vez porque estábamos empezando, porque la base de sustentación del gobierno democrático tenía mucha fuerza; tal vez porque, sin falsa modestia, la gente me conoce, y sabían que a mí no me iban a presionar."

Pero, por otro lado, es una característica de la experiencia de gobierno de los mandatarios la presión ejercida por poderes extraterritoriales, centrados fundamental mente en el gobierno de Estados U nidos y los organismos multilaterales de crédito.

Las presiones sobre la autonomía de las decisiones presidenciales son valoradas negativamente en todos los casos. Según varios mandatarios consultados, "es un poder ejercido de manera negativa, es el poder de perturbación más que de decisión". "Estamos totalmentecondicionados, nos imponen las reglas [... ]. Los gobiernos soberanos están dependiendo de la calificación deuna agencia privada de riesgo, de la decisión de un organismo internacional, 'teayudo o no teayudo'." "Los gobiernos tienen más limitaciones para ejercer el poder. H emos perdido capacidad de decisión nacional, puesto que los organismos internacionales de crédito establecen condiciones que atentan contra el propio crecimiento $y$, en fin, contra la democracia, cuando se lesionan derechos humanos fundamentales." "Tú tienes entonces un presidente de la República, con una presión bilateral brutal y con una influencia de la cooperación internacional, no diré brutal, pero muy significativa." "Los organismos bilaterales, con sus exigencias por seguir modelos y programas determinados 
"Este cuadro nos plantea un

enorme reto, a saber, si los

goberna ntes de la región somos

o no capaces de que funcione con

eficacia y visión de futuro el

ma nejo responsable de las

política s eco nómica s." con condiciones políticamente inviables, no son responsables ante el resultado político que esas obligaciones traen, que te imponen [...]. 0 sea, viene un burócrata internacional y, siguiendo las directivas de su organismo, marca una línea y después ese señor cumple su misión y se va."

\section{El papel de los medios de comunicación}

Los mandatarios identifican la intervención omnipresente de los medios de comunicación como un contrabalance a su poder, en la medida quela opinión pública tiendea orientarse básicamente por la opinión y evaluación que los medios realizan de las acciones gubernamentales. "El medio decomunicación informa, opina, juzga y condena [... ]. Es un factor de poder que se puede ejercer bien o mal, y que está influido por intereses económicos, por pasiones, por sentimientosy por ideas, y a su vez no está sometido a ningún control. [... ] Entonces, es por eso queel gobernante se siente hostilizado por la prensa [... ]. No interesa la coloración del gobierno, siempre va a sentirse hostilizado."

Asimismo, se reconoce a los medios una enorme capacidad para incidir en el destino de un gobierno: "La incidencia mediática puede volver inútil una formulación sólida institucional si tiene ataques o rivales desde ese sector"."La prensa tiene una influencia decisiva sobre el Congreso [... ]. Si la prensa se mueve en contra de una ley, es muy difícil que salga."

A pesar de que los mandatarios valoran el papel de los medios como control del poder, ellos evalúan con cierta inquietud el creciente papel que, sin estar sometidos a ningún control, los medios han asumido como expresión de in- tereses de grupos económicos. "No podemos descartar en este paisaje el papel que han cumplido los medios de comunicación más desarroIlados, más profesionalizados en cuanto a las tareas de denuncia y control, [...] pero hay también mayor interferencia en el libre discurrir de la vida democrática. [...] El gran capital es un factor de poder mucho más real hoy, porque se ha venido apoderando delos instrumentos mediáticos, entonces eso les permite no sólo tener poder sino ejercerlo."

La falta de controles estatales sobre la prensa, quecomo vimos es un elemento propio dela democracia, puede transformarse para los mandatarios en una amenaza a su desempeño. Su crítica se centra en la falta de responsabilidad con que los medios difunden información, avalados por su posicionamiento en el mapa de poder de cada país. "Los medios son de una influencia enorme, quizá, los más fuertes y consistentes. [... ] Caen en la estrategia del sensacionalismo fácil y dificultan la gobernabilidad y la consistencia de gestión. [... ] No creo que esté claro en la sociedad lo que esto implica. Estuve hablando con mandatarios de la región y todos sentimos el mismo problema."

La presión que los medios ejercen se refleja también en el gran peso que tienen en la construcción dela agenda pública. "Losmedios decomunicación están atravesando un proceso deevolución en el quetenemosuna confusión de poder como nuncajamás han tenido en su historia, que es el poder total y la responsabilidad cero [... ]. Los medios hoy tienen un poder que puedetumbar un ministro, que puede influir en una política y que está marcando la agenda, a veces en una sobredimensión injusta."

Los elementos resultantes de lo ya expuesto aparecen conjugados por un líder que resume las percepciones de no pocos mandatarios de América Latina: “Los medios de comunicación han pasado a ser suprapoderes [... ], vinculados a los sectores económicos, por supuesto, tienen más poder que el poder militar, que el Ejecutivo, que la propia I glesia y los partidos políticos. Han reemplazado totalmente a los partidos políticos. Se han instalado en el centro de la sociedad, lo que es bueno para el control delos otros 
poderes, pero, al mismo tiempo, si existe un control, ese poder puede convertirse en una inquietante perversión".

\section{Valoración de las organizaciones sociales en la vida política del país}

En el momento de evaluar el papel de estas organizaciones sociales, varios mandatarios perciben a los partidos en una relación de competencia y hasta oposición con diversas organizaciones de la sociedad civil. La tensión es expresada por un mandatario al señalar que: "Se han conformado muchas ONG que son útiles y generan participación, que realizan asambleas y escuchan a la gente, que incrementan en lo posible una democracia representativa $[\ldots]$, pero en general hay una cierta posición antipolítica y eso es malo, del mismo modo que en la política hay una cierta tensión con las ONG. Eso tiene que ser superado con el avance de una tarea común que costará llevar adelante".

Otro mandatario se expresa con más firmeza sobre este tema: "Nos encontramos con un fenómeno que es de toda América, que es peligroso si no lo sabemos organizar, que es el delas ONG y la mal denominada sociedad civil. [... ] Los partidos se están enfrentando a la competencia de $O N G$ y de organizaciones intermedias que no tienen la legitimidad que tienen los partidos. Entonces, esa legitimidad tenemos que fortalecerla porque los partidos son la única organización que, a través del ejercicio del poder, puede aprobar normas, actos, reglas, obligatorios para la sociedad".

El conjunto de organizaciones sociales conforma un espectro amplio y diverso, no claramente definido según los consultados. Esto inclina a algunos mandatarios a considerarlas preocupantes factores de poder. "La sociedad civil está aumentando en importancia. Nadie tiene muy claro quiénes son y qué representan todavía y ésa es una de las preocupaciones."

Para otro mandatario, ese poder se encuentra incluido en los marcos de la gl obalización. "Vino una ola desde las grandes potencias y hubo una ola de las exigencias del poder mundial; había que minimizar los gobiernos, había que delimitar el Estado y había que fortalecer las ONG."

El papel delas ONG también es cuestionado en cuanto a la representación que pretenden asumir de los intereses populares. "Las ONG son privilegiadas pero no se piensan a sí mismas. Hablan en nombre del pueblo, pero lo hacen en contra de reformas que son para el bien del pueblo."

En la visión de estos mandatarios, las controversias entre partidos políticosy organizaciones de la sociedad civil se proyectan en las concepciones sobre democracia representativa y participativa. Junto a ellas se entrelazan los planteos sobre los al cances de la democracia en sentido institucional y/o su fortalecimiento a partir desu contenido de equidad social. "Si uno quiere recuperar la base democrática, más que decirlea la genteque se organice, que participe, lo que tiene que hacer es incluirla y la inclusión no es sólo un problema de canales para que la gente hable o proteste, sino que es ir al concepto de libertad sobre la base de la solución de la necesidad [... ], es la inversión social, es ampliar la cobertura, la calidad de la educación [... ]. Participación es que la gente se sienta parte, forme parte del Estado." “El gran secreto para que haya participación es acercarte lo más posible a los problemas de la gente, que son básicamente salud, educación, cultura y deporte."

\section{El fortalecimiento de la democracia}

Luego de haber presentado algunas opiniones de los mandatarios, volvemos ahora al conjunto de los consultados. A ellos les preguntamos qué pasos deberían seguirse para fortalecer la democracia en los próximos años. Esta pregunta dio lugar a una dispersión relativamente importante de respuestas. Sin embargo, un grupo de respuestas, agrupableen tres grandes bloques, fue mencionado por las dos terceras partes de los consultados.

El primer bloque reúne la necesidad de realizar una reforma política para fortalecer las instituciones, incluso los partidos políticos. Las características de esta reforma varían de país a 


\begin{tabular}{|lc}
\hline PROBLEMAS A ENFRENTAR PARA & \\
\hline FORTALECER LA DEMOCRACIA & TABLA 55 \\
\hline & $\begin{array}{c}\% \text { de } \\
\text { consultados }\end{array}$ \\
\hline Reforma política & 45 \\
Aumentar participación & 13 \\
Institucionales, partidarias & 32 \\
Combatir inequidad & 18 \\
Políticas sociales & 8 \\
Políticas económicas & 10 \\
Educar para la democracia & 11 \\
Combatir la corrupción & 9 \\
Otros & 17 \\
Total & 100 \\
\hline
\end{tabular}

Nota: Los valores son la proporción de consultados que mencionan en primer lugar este problema.

Fuente: PRODDAL, Ronda de consultas con líderes de América Latina, 2002.

país: algunos hablan de reforma electoral, otros de reforma del Congreso, otros de reforma del Estado o de fortalecimiento general de las instituciones. Pero la idea compartida es que un mejor diseño de los dispositivos e incentivos institucionales podría mejorar, y mucho, el funcionamiento dela democracia. Una proporción importante de estas respuestas señala que la reforma política debería construir nuevos canales que faciliten la participación de la sociedad civil organizada. Para muchos de los líderes consultados, la apatía ciudadana y la desconfianza hacia las instituciones se revierten mejorando los canales de participación y ampliando su número y alcances.

Este primer grupo de respuestas es el más frecuentemente mencionado por los consultados y sugiere que, a diferencia de lo que ocurría hace al gunas décadas, las instituciones no son vistas como un reflejo secundario de lo esencial, sino como parte de lo esencial. Lo mismo ocurreen relación con los partidos políticos. Si bien muchos consultados coinciden en que los partidos no están desempeñando su papel de manera adecuada, una cantidad similar señala la necesidad de fortal ecerlos. El interés de esta respuesta radica en que la constatación de las dificultades que enfrentan los partidos no lleva a adoptar posturas de rechazo 0 a buscar canales alternativos: los partidos están mal, pero se los debe mejorar.

El segundo bloquederespuestasincluyelanecesidad de tomar medidas sustantivas (no "puramente institucionales") que ayuden a enfrentar las profundas inequidades de las sociedades latinoamericanas. Ellas conspiran contra el fortalecimiento dela democracia y se perciben tanto en términos económicos (pobreza extrema y falta de recursos mínimos, como la alimentación) como en aspectos culturales (marginación de sectores campesinos y urbanos, marginación de indígenas). Incorporar genuinamente a toda la población a la política democrática requiere derrotar esas formas de exclusión. Para ello es necesario desarrollar políticas sociales y económicas que conduzcan a un mejoramiento generalizado de los niveles de vida.

El tercer bloque refiere a la necesidad de fortalecer la educación en general (no sólo el acceso a ella, sino su calidad) y la cultura democrática en particular. Al menos parte de los problemas políticos que enfrentan las sociedades latinoame ricanas se debe a un débil conocimiento de las re glas del juego democrático o, más frecuentemente, a un conocimiento superficial de esas reglas, que no va acompañado de una adhesión suficientementefirme a los valores democráticos. Los consultados creen que un esfuerzo deliberado por desarrollar la educación, en particular la educación para la democracia, podría mejorar o revertir esta situación.

Un último punto en el quecoincidieron varios consultados fue la necesidad de intensificar la lucha contra la corrupción. Esto es coherente con su propio diagnóstico. Si la corrupción es uno de Ios problemas que más afecta a la democracia y la deslegitima antela ciudadanía, la lucha contra ella debe ser una de las metas fundamentales.

Conviene agregar que las opiniones de los consultados sobre los principales problemas a enfrentar para fortalecer la democracia difieren según su visión acerca del estado actual de sus respectivos países. Los consultados que afirman que su país es una democracia o una democracia con pocas limitaciones ponen énfasis en la necesidad de reformas institucionales y partidarias. Este énfasis disminuye entre los que perci- 
ben varias limitaciones y disminuye aún más entre los que ven muchas limitaciones a sus democracias ( 0 , simplemente, creen que no hay democracia). Con las opiniones favorables a una mayor participación ocurrea la inversa: son más frecuentes donde no se percibe democracia o se la ve muy limitada, y mucho menos en el extremo opuesto.

\section{La construcción de la agenda pública en América Latina}

Las opiniones de los consultados acerca de la agenda política actual presentan significativas variaciones. La corrupción es el tema más mencionado (36 por ciento). El papel deficiente de los partidos políticos y su reforma es referido por el 20 por ciento de los consultados.

En relación con la agenda económica, el tema de la reactivación -incluyendo el uso de recursos productivos, las privatizaciones y las reformas financieras- aparece como el más mencionado (53 por ciento). La deuda externa y la integración regional son planteadas por el 23 por ciento de los líderes consultados.

En la agenda social, el desempleo y la violencia (34 por ciento) definen las prioridades.

Asimismo, se observa un quiebre en la homogeneidad de las percepciones acerca de los grupos influyentes y de los temas de la agenda. Los consultados confluyen ampliamente en señalar a los grupos empresariales (80 por cien-
Para muchos de los líderes consultados, la apatía ciudadana y

la desconfianza hacia las

instituciones se revierten mejorando

los ca nales de participación y a mpliando su número y alcances.

to) y a los medios de comunicación (65 por ciento) como los grupos con mayor capacidad de modelar e imponer la agenda. Por su lado, los consensos más frecuentes aparecen en torno a la necesidad de reactivación económica.

Las prioridades de agenda de los líderes no políticos no se alejan de las del conjunto de los consultados; para ellos el tema central de la agenda económica es también la reactivación (57 por ciento), pero el resto de las cuestiones económicas recibe escasas menciones. Con respecto a la agenda social, cuestiones tales como la violencia y la seguridad ciudadana, así como las reformas sectoriales en salud y educación, son mencionadas principalmente por los acadé micos, mientras que el desempleo y la pobreza aparecen como problemas prioritarios para los periodistas.

Si consideramos la perspectiva de las mujeres líderes, la reforma fiscal alcanza los mismos

\begin{tabular}{|c|c|c|c|}
\hline \multicolumn{4}{|c|}{ PROBLEMAS A ENFRENTAR PARA FORTALECER LA DEMOCRACIA, } \\
\hline \multicolumn{3}{|c|}{ SEGÚN JUICIO SOBRE ESTADO DE LA DEMOCRACIA EN SU PAÍS } & \multirow{2}{*}{$\begin{array}{l}\text { DABLA } 56 \\
\text { Democracia con } \\
\text { muchas limitaciones, } \\
\text { o no es democracia }\end{array}$} \\
\hline & $\begin{array}{l}\text { Democracia plena, } \\
\text { o democracia con } \\
\text { pocas limitaciones }\end{array}$ & $\begin{array}{l}\text { Democracia } \\
\text { con varias } \\
\text { limitaciones }\end{array}$ & \\
\hline Reforma política & 45 & 46 & 45 \\
\hline Aumentar participación & 3 & 14 & 19 \\
\hline Institucionales, partidarias & 42 & 32 & 26 \\
\hline Combatir inequidad & 22 & 16 & 20 \\
\hline Educar para la democracia & 12 & 13 & 7 \\
\hline Combatir corrupción & 10 & 8 & 10 \\
\hline Otros & 11 & 17 & 18 \\
\hline Total & 100 & 100 & 100 \\
\hline
\end{tabular}

Nota: Los valores son la proporción de consultados que mencionan en primer lugar este problema.

Fuente: PRODDAL, Ronda de consultas con líderes de América Latina, 2002. 


\begin{tabular}{|c|c|c|}
\hline \multirow{2}{*}{$\begin{array}{l}\text { AGENDA ACTUAL SEGÚN TEMA } \\
\text { Temas }\end{array}$} & \multicolumn{2}{|c|}{ TABLA 5} \\
\hline & \multicolumn{2}{|c|}{$\begin{array}{l}\text { № de actores } \\
\text { que mencionan }\end{array}$} \\
\hline \multicolumn{3}{|l|}{ Agenda económica } \\
\hline \multicolumn{3}{|l|}{ La reactivación económica (debate sobre uso de recursos productivos: } \\
\hline gas, petróleo, coca; privatizaciones, reforma financiera) & 80 & $(53 \%)$ \\
\hline Cuestión fiscal & 24 & $(16 \%)$ \\
\hline Deuda externa & 9 & $(6 \%)$ \\
\hline Integración regional andina/M ercosur/ALCA & 9 & $(6 \%)$ \\
\hline Tratados de libre comercio & 8 & $(5 \%)$ \\
\hline Acuerdo con el FMI & 3 & $(2 \%)$ \\
\hline \multicolumn{3}{|l|}{ Agenda social } \\
\hline Desempleo & 52 & $(34 \%)$ \\
\hline Violencia, delincuencia, seguridad ciudadana & 51 & $(34 \%)$ \\
\hline Reforma de la educación/Salud & 40 & $(26 \%)$ \\
\hline Pobreza & 37 & $(24 \%)$ \\
\hline \multicolumn{3}{|l|}{ Agenda política } \\
\hline La corrupción & 55 & $(36 \%)$ \\
\hline Reforma política/ Papel de los partidos/ Descentralización & 30 & $(20 \%)$ \\
\hline Reforma del Estado (apertura, modernización) & 23 & $(15 \%)$ \\
\hline \multicolumn{3}{|l|}{ Resolución del conflicto político institucional/ Reconstrucción institucional/ } \\
\hline Debilidad institucional & 12 & $(8 \%)$ \\
\hline Lavado de dinero y narcotráfico. El tema de la coca & 12 & $(8 \%)$ \\
\hline Reforma del sistema judicial. Estado de derecho. Seguridad jurídica & 11 & $(7 \%)$ \\
\hline Reforma constitucional & 9 & $(6 \%)$ \\
\hline Relación gobierno-sociedad, conciliación nacional & 6 & $(4 \%)$ \\
\hline
\end{tabular}

Nota: Esta tabla se elaboró sobre la base de los 152 entrevistados que efectivamente respondieron las preguntas sobre el tema. El total no suma $100 \%$ porque se permitieron respuestas múltiples.

Fuente: PRODDAL, Ronda de consultas con líderes de América Latina, 2002.

niveles de importancia que la reactivación económica (45 por ciento). En el caso de la agenda social, la pobreza asciende al segundo lugar (27 por ciento) y disminuyen las menciones acerca de la violencia ( 21 por ciento), que asumen valores iguales a los de las reformas de salud y educación (21 por ciento). La agenda política mantiene, en cambio, el mismo orden de prioridades que el del conjunto de consultados, aunque las mujeres líderes mencionan con menos frecuencia la corrupción (22 por ciento).

\section{La agenda futura}

La agenda futura que se identifica con los intereses y las preocupaciones de los consultados no presenta variaciones significativas con respecto a la agenda actual. En el eje económico, la reactivación concentra el 42 por ciento de las respuestas y las problemáticas ligadas a la integración regional, el 24 por ciento, valores semejantes a los que al canzan en la agenda actual.

En relación con la agenda social, se mantiene la dispersión de respuestas, aun cuando se perfilan con más prioridad las reformas sectoriales de salud y educación, y los temas de pobreza y desigualdad, mencionados por aproximadamenteun tercio de los líderes. El desempleo y la violencia pierden importancia relativa.

La agenda política se centra en un conjunto amplio de temas. El tema prioritario es la reforma política, pero sólo es mencionada por el 35 por ciento de los consultados. Los temas que involucran la defensa de las libertades y los derechos humanos son considerados como temas de agenda por el 10 por ciento de los consultados. 


\begin{tabular}{|c|c|c|}
\hline \multirow{2}{*}{$\begin{array}{l}\text { Temas } \\
\text { Agenda económica }\end{array}$} & \multicolumn{2}{|c|}{$\begin{array}{c}\text { № de actores } \\
\text { que se mencionan }\end{array}$} \\
\hline \multirow{2}{*}{\multicolumn{3}{|c|}{ La reactivación económica, debate sobre uso de recursos productivos }} \\
\hline & & \\
\hline (gas, petróleo, coca; privatizaciones, reforma financiera) & 66 & $(42,3 \%)$ \\
\hline Cuestión fiscal & 28 & $(17,9 \%)$ \\
\hline Deuda externa & 13 & $(8,3 \%)$ \\
\hline Tratados de libre comercio & 4 & $(2,5 \%)$ \\
\hline Papel del FMI, Banco Mundial, BID & 1 & $(0,6 \%)$ \\
\hline Desempleo & 26 & $(16,6 \%)$ \\
\hline Violencia, delincuencia, seguridad ciudadana & 13 & $(8,3 \%)$ \\
\hline \multicolumn{3}{|l|}{ Agenda política } \\
\hline Reforma política/ Papel de los partidos/ Descentralización & 55 & $(35,2 \%)$ \\
\hline Reforma del Estado (apertura, modernización, reforma administrativa) & 33 & $(21,1 \%)$ \\
\hline Reforma constitucional & 9 & $(16,0 \%)$ \\
\hline Reforma del sistema judicial. Estado de derecho. Seguridad jurídica & 15 & $(9,6 \%)$ \\
\hline \multicolumn{3}{|l|}{ Seguridad democrática (defensa de libertades democráticas, derechos } \\
\hline
\end{tabular}

Nota: Esta tabla se elaboró sobre la base de los 156 entrevistados que efectivamente respondieron las preguntas sobre el tema. El total no suma $100 \%$ porque se permitieron respuestas múltiples.

Fuente: PRODDAL, Ronda de consultas con líderes de América Latina, 2002.

Resulta llamativo quela mención a las reformas - tanto en la agenda social como en la políticano alude al contenido de las mismas.

Los académicos coinciden mayoritariamente con los porcentajes generales respecto de los temas de la agenda futura. Sin embargo, mientras queel 32 por ciento de los consultados considera quela reforma educativa y la salud deberían ingresar en la agenda futura, sólo el 17 por ciento de los académicos se expresa en este sentido. Éstos tienden a priorizar una estrategia vinculada a la estabilidad del régimen democrático y sus instituciones. Por estas razones, la reforma política, el replanteo del papel de los partidos políticos y la descentralización concentran sus prioridades, que llegan al 48 por ciento de las menciones contra el 36 por ciento que los consultados en general asignan a este punto. Un panorama similar es presentado por la reforma judicial, el funcionamiento del estado de derecho y la seguridad jurídica, que concentran el 22 por ciento de las menciones de los actores académicos contra el 15 por ciento de las menciones generales.

En el caso de los presidentes y ex presidentes, la centralidad que cobra la cuestión de la reactivación económica en la región se destaca tanto en la agenda actual como en la futura. Otros temas como la cuestión del desempleo y la violencia, que concentran sus opiniones sobre los temas de la agenda actual, se sostienen débilmente en la agenda futura. La agenda po- 
lítica, si se tiene en cuenta la cantidad de menciones, aparece como la menos relevante para estos mandatarios.

\section{Los desafíos}

¿Quépasos deberían seguirse para fortalecer el desarrollo de la democracia en los próximos años? Un grupo de respuestas, agrupables en tres bloques, fue mencionado por las dos terceras partes de los consultados. En lo quesigueresumimos las opiniones de los consultados acerca de los pasos futuros a dar; esto implica cierta repetición respecto de sus señalamientos sobre la situación actual.

El primer bloque se refiere a la necesidad de realizar una reforma política que fortalezca las instituciones, incluso los partidos políticos. Las características de las reformas propuestas varían de país a país: algunos hablan del sistema electoral, otros del Congreso y otros del Estado. Pero de manera general la idea es que un mejor diseño de los dispositivos e incentivos institucionales debería mejorar el funcionamiento de la democracia. Nuevamente, las instituciones no son vistas como un reflejo secundario delo esencial, sino como parte esencial de la democracia.

El segundo bloque incluye la necesidad de fortalecer la educación en general y la cultura democrática en particular, así como la necesidad de enfrentar las profundas inequidades de las sociedades latinoamericanas. El primer aspecto debería encararse mediante un esfuerzo de educación cívica y, en términos más generales, elevando el nivel educativo de la población. Se cree que un esfuerzo deliberado por desarrollar la educación, y en particular la educación para la democracia, podría mejorar o revertir esta situación. La desigual dad educativa, en particular, es una de las caras más visibles e importantes del problema. Para incorporar genuinamente a toda la población a la sociedad y a la defensa de la democracia es necesario enfrentar esas desigualdades.

El tercer bloque señala la necesidad de construir nuevos canales quefaciliten la participación de la sociedad civil organizada. Para muchos de los líderes consultados, la apatía ciudadana y la desconfianza hacia las instituciones se revierten mejorando los canales de participación y ampliando su número y alcances.

Un último aspecto de coincidencia, más puntual que los anteriores, es la necesidad de intensificar la lucha contra la corrupción como una prioridad para fortalecer el orden democrático.

\section{Alcances de la democracia en América Latina. Un balance}

¿Cuál es la visión de la democracia que pre valece? La sustentabilidad y expansión de la democracia en América Latina es altamente valorada por todos los consultados. Esta visión reconoce como grandes logros de los procesos democráticos en curso la vigencia de las libertades y la regularidad de las elecciones (en algunos casos, con alternancia en el poder entre oficialismo y oposición). También reconoce las reformas constitucionales que habilitaron mecanismos de democracia directa y reformularon y/o crearon mecanismos de control.

Sin embargo, se observa una fuerte tensión entre los alcances de la democracia y los niveles de pobreza y exclusión social. Entre los consultados aparece como tema central la capacidad - 0 incapacidad- de las democracias para lograr niveles aceptables de integración social. Instituciones políticas que pierden credibilidad y la persistencia de las situaciones de pobreza y exclusión social constituyen un escenario complejo que torna a las democracias vulnerables frente a la injerencia de los poderes fácticos.

Las dificultades para lograr un nivel aceptable deintegración social son visibles en el divorcio entre, por un lado, el diagnóstico que hacen los consultados sobre el funcionamiento y las debilidades dela democracia, y, por otro, los temas actual mente vigentes en la agenda pública. Las restricciones para formular una agenda a largo plazo dan cuenta de las dificultades para pensar un "proyecto de país" - también de región- que prevea respuestas programáticas a los graves problemas existentes. Asimismo, las limitaciones para formular una agenda socialmen- 
tecompartida suscitan el riesgo de queestas democracias se tornen "irrelevantes".

\section{¿Cómo se ejerce el poder en estas democracias?}

Según hemos visto, en opinión de muchos denuestros consultados, el Poder Ejecutivo suele encontrar limitaciones en el ejercicio de sus funciones que se deben principalmente a la injerencia de poderes fácticos. No cuenta con partidos políticos sólidos que lo sustenten ni con una oposición que contribuya a fortal ecer la institucionalidad democrática.

En el mapa del poder que trazan nuestros consultados se destaca el gran peso de ciertos poderesfácticos, en particular del sector económico-financiero y de los medios de comunicación. Entre nuestros consultados existe la percepción de que los condicionamientos impuestos por estos poderes conducen a la existencia de gobiernos que tienen serias limitaciones para responder a las demandas de la ciudadanía. Ellos también recalcan que los partidos no logran formular proyectos colectivos que les permitan convertirse en expresión auténtica de la ciudadanía, así como la influencia de poderes extraterritoriales que, entre otros aspectos, se expresa en la importancia relativamente baja que se asigna en la agenda a la integración entre países de la región.

Por otra parte, la institucionalización de los procesos de participación social es percibida como débil o incipiente. M uchos de los consultados afirman la importancia de fortalecer la participación social; sin embargo, cuando ésta se materializa, son pocos los que señalan los beneficios que entraña. Esto al parecer se vincula a la carencia de canales institucionales adecuados para esa participación.

\section{Síntesis de la ronda de consultas}

El resumen que hemos presentado permite enunciar al gunas conclusiones so bre las opiniones predominantes entre los líderes latinoamericanos en torno al desarrollo de la democracia en la región.
1. Una primera constatación es que América Latina ha dado pasos muy importantes en el camino hacia la democratización. El aumento de la participación y de los controles institucionales es reconocido como un paso decisivo en este sentido.

2. Para los líderes consultados, toda la región es, al menosformalmente, democrática. Esta se gunda constatación señala algo que antes nunca existió en la región y que está asociado a una idea muy importante: si bien los líderes latinoamericanos opinan mayoritariamente que los aspectos institucionales no son suficientes para afirmar que hay democracia, también piensan que éstos son necesarios. La dimensión institucional no se ve como un epifenómeno delo que realmenteimporta, sino como parte constitutiva de la democracia.

3. Algunas de las amenazas tradicionales a las democracias latinoamericanas han desaparecido o se han debilitado significativamente. La casi desaparición de los riesgos de insubordinación militar es el caso más notable, pero también importa el debilitamiento de las prácticas patrimonialistas y de los personalismos que advierten los consultados.

4. Si bien las amenazas tradicionales se han desvanecido o atenuado, han aparecido otras que siguen poniendo en cuestión la continuidad y expansión de la democracia. La más ostensible de esas amenazas es el narcotráfico, con sus secuelas de poder paralelo, violencia, corrupción y destrucción de la economía formal.

5. Otras amenazas que pesan sobre la democracia latinoamericana son políticas. Las más importantes están interrelacionadas: la reducida autonomía de decisión de los poderes institucionales y el debilitamiento de los partidos políticos.

6. La crisis de los partidos no ocurre debido a una pérdida de la voluntad ciudadana de participación, más bien se da en un contex- 
to de aumento de la misma. Los partidos latinoamericanos no enfrentan la versión regional de un problema más general (como la fuga hacia lo privado que ocurre en otras regiones); enfrentan un problema nuevo $y$, en cierta medida, específico, que combina tres elementos distintos: una voluntad de mayor participación y control del poder político, un rechazo bastante generalizado de los partidos como canales de participación, y un traslado de la participación y el ejercicio de controles hacia otros tipos de organizaciones, en general pertenecientes a la sociedad civil.

7. Los líderes consultados, pese a percibir estos problemas con claridad, no están buscando solucionesfuera dela política sino dentro de ella. Están persuadidos de que es importante tener partidos fuertes y gobiernos con capacidad de decisión, y se preguntan sobre los caminos que permitirán lograr ambas metas.

8. Estos resultados generales no ocultan, claro está, al gunas diferencias entre los países. Una de ellas es la que separa los juicios de los liderazgos de los países mayores de la región (Brasil y M éxico), de los juicios de los consultados en otras democracias jóvenes. Tanto en Brasil como en M éxico se en- cuentra más optimismo sobre el progreso de las condiciones necesarias para la democracia y más satisfacción con los logros ya obtenidos.

9. De lo anterior puede concluirse que, según nuestros consultados, un primer desafío de la democracia latinoamericana es encontrar soluciones políticas a sus problemas políticos. Esto supone buscar nuevas maneras de canalizar la participación, el control, la gestión de agendas y la construcción de acuerdos políticos, en el marco de una situación caracterizada por una creciente "globalización delas influencias" y una "transnacionalización de los problemas". En parte, éste es un problema universal, pero adquiere matices específicos en América Latina.

10. Un segundo desafío de la democracia latinoamericana es encontrar soluciones a la desigualdad, la pobreza y la actual imposibilidad de acceso de gran parte de la población a los niveles de bienestar necesarios para el pleno ejercicio de los derechos. En el pasado, estos lamentables problemas fueron esgrimidos como razón para justificar la búsqueda de caminos alternativos a la democracia. Hoy son tomados como los grandes desafíos que la propia democracia debe resolver. 


\section{Hacia la democracia de ciudadanía}

urante casi dos décadas, pero particularmente en los años noventa, la agenda latinoamericana ha incluido el fortalecimiento democrático, la crisis de la política, las reformas del Estado, las reformas estructurales de la economía y el impacto de la globalización en la región. Sin embargo, aunque se abordaron aspectos sustantivos de estas cuestiones, el debate marginó otros que, a la luz del análisis realizado, deben volver a colocarse en el centro de la discusión.

El Informe llega a la conclusión de que el desarrollo de la democracia está íntimamente vinculado a la búsqueda de mayor igualdad social, la lucha eficaz contra la pobreza y la expansión de los derechos de los ciudadanos. Así, es esencial revisar las políticas y acciones implementadas hasta el presente, aprender de las experiencias históricas recientes, auscultar las realidades sociales emergentes y explorar nuevos caminos. Ello posibilitará abrir el horizonte hacia fórmulas que permitan recrear el debate acerca de la política y su lugar en América Latina, por ejemplo, a través de los siguientes temas:

- La necesidad de una nueva estatalidad: ¿cuál es el papel del Estado en el fortalecimiento de la democracia?

- La economía vista desde la democracia, ¿qué políticas económicas favorecen el desarrollo de la democracia?

- Las democracias latinoamericanas en el contexto de la globalización actual, ¿qué espacios de autonomía requieren para su expansión? 



\section{- Cuatro temas para una agenda de debate}

En esta sección abordamos las consideraciones para elaborar una agenda ampliada para el desarrollo de la democracia. Entendemos por agenda, a los efectos de este Informe, la presentación de los temas que requieren ser debatidos. No es, por lo tanto, una enumeración de acciones o políticas públicas.

El significado y alcance de estas contribuciones son el resultado de tres caminos convergentes: una cierta concepción de la democracia, el reconocimiento dela singularidad latinoamericana y el conjunto de datos que resulta de nuestra investigación empírica.

Se trata de temas que constituyen preocupaciones comunes a la región latinoamericana. En cambio, las políticas que de ellos puedan derivarse deben expresar lo original y singular de cada situación nacional.

En la sección anterior hemos dado cuenta del estado de la ciudadanía en la región. Frente a esta realidad se han propuesto muchas veces recetas, principios técnicos y programas ambiciosos de reforma. Algunos han sido implementados con cierto éxito y han obtenido logros significativos. Sin embargo, tras una década de reformas, las carencias de ciudadanía no han sido resueltas. Es preciso encontrar otros criterios de acción que permitan avanzar hacia las soluciones que nuestras sociedades reclaman.

Toda democracia encierra la promesa de libertad, justicia y progreso para sus ciudadanos y, como sostiene Rosanvallon, "es necesario considerar lo no cumplido, las fracturas, las tensiones, los límites y las denegaciones que desdibu-

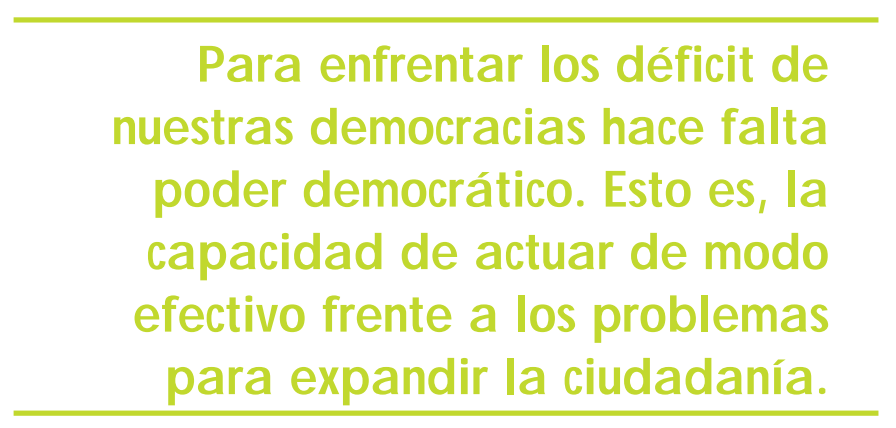

jan la experiencia de la democracia". En la distancia que media entreesa promesa y la realidad descripta en la sección segunda, surgen con fuerza los grandes temas que componen la agenda del desarrollo de la democracia.

Pero ¿qué quedaría de la libertad ejercida al el egir democráticamentea los gobiernossi grandes esferas de la vida social que hacen a los más básicos derechos ciudadanos permanecen fuera del alcance de la deliberación pública y de la voluntad ciudadana, si los gobiernos no pueden ejecutar las políticas decididas democráticamente? ¿O si aun contando con gobiernos y Estados eficientes y eficaces no es posible ejercer el mandato electoral porque otros poderes internos o externos lo impiden?

Para enfrentar los déficit de nuestras democracias hace falta poder democrático. Esto es, la capacidad de actuar de modo efectivo frente a los problemas para expandir la ciudadanía. Para construir ese poder es indispensable la política. Pero es preciso que la política sea relevante, que proponga caminos para abordar lostemas clavede 
Se trata, en fin, de llenar de

política a la sociedad y,

consecuentemente,

de sociedad a la política.

la sociedad, quelosemprenda con la firmeza dela voluntad de los líderes y ciudadanos y los sostenga con la idoneidad de losinstrumentos para la acción colectiva, entre los cuales los partidos políticos son actores centrales aunque no los únicos.

Las propuestas de acción de los partidos políticos tienen en las instituciones representativas y degobierno del Estado el principal instrumento para su ejecución. El poder democrático se construye también desde la estatalidad. Al mismo tiempo, la sociedad civil, que constantementecrea nuevas organizaciones de voluntarios que aumentan la participación, es otro de los instrumentos sustanciales para la expansión de la ciudadanía y, consiguientemente, de la democracia.

Detrás de todo derecho hay un Estado quelo garantiza. Y detrás de todo derecho trunco hay un Estado que no llega a tornarlo efectivo. Esta defección del Estado tienequever con la calidad de sus instituciones $y$, fundamental mente, con el poder que fluye a través de ellas y la consecuente capacidad -o incapacidad- del Estado para llevar a cabo sus fines.

Así, los problemas del desarrollo de la democracia que hemos visto en las secciones precedentes aparecen en una amalgama en la que se conjugan los límites del Estado, con las exigencias del crecimiento económico y sus resultados frecuentementegeneradores de desigualdades, con la impotencia dela política para encarnar las aspiraciones de la ciudadanía en poder democrático, con las tensiones de sociedades fracturadas, con la existencia de poderes fácticos que evaden la legalidad, trafican influencias y permean las más altas instancias de decisión, con la evidencia de una globalización queacota el espacio propio dela democracia al escamotear del campo de la voluntad ciudadana lostemas centrales que atañen al futuro de la sociedad.
En otros términos, la agenda que nos ocupa tiene que ver con los complejos caminos quehabilitan y obturan la expansión de la ciudadanía y la reconstrucción de la sociedad política en el marco de las democracias latinoamericanas. Se trata de abordar la discusión de las condiciones que permitan a nuestras democracias encarar la solución de los problemas que hemos anotado, mediante la expansión de los instrumentos que brinda la misma democracia.

En síntesis, los problemas evidenciados que constituyen los desafíos para el desarrollo de la democracia en América Latina se desenvuelven en esas cuatro esferas centrales (la política, el Estado, la economía, la globalización), todas ellas atravesadas por la cuestión del poder, condición inexcusable para que la voluntad general setraduzca en políticas que transformen la realidad.

Los criterios que aquí se presentan son un punto de partida, procuran desencadenar un debate, son su inicio no su culminación. Proponemos que esa agenda incluya: cómo pasar de una democracia cuyo sujeto es el elector a una cuyo sujeto es el ciudadano que tiene derechos y deberes expandidos, en el campo político, civil y social; cómo pasar de un Estado de legalidad trunca a un Estado con alcance universal en todo el territorio y cuyo principal objetivo sea garantizar y promover los derechos - un Estado de y para una Nación de ciudadanos-; cómo pasar de una economía concebida según los dogmatismos del pensamiento único a otra con diversidad de opciones, y cómo construir un espacio de autonomía en la globalización. Se trata, en fin, de llenar de política a la sociedad y, consecuentemente, de sociedad a la política.

\section{La política, primera condición}

La política cumple una función vital en el proceso democrático: concibe las políticas públicas para atacar los problemas que considera centrales y las plasma en proyectos que constituyen las opciones básicas de la sociedad; ofrece los dirigentes que puedan ejecutarlos; agrupa los millones de voluntades ciudadanas en comunes denominadores que permiten elegir 
entreun número razonable de alternativas electorales, y finalmente construye el poder público necesario para ejecutar los proyectos que presenta a la sociedad.

En definitiva, la política encarna las opciones, agrupa las voluntades y crea poder. Éstas son tres condiciones inexcusables para el desarrollo dela democracia. Una política que no cumpla con ellas pone en peligro la sustentabilidad democrática. En América Latina hay crisis de la política y crisis de representación porque estas tres condiciones sólo se cumplen parcialmentey, en ocasiones, no existen. El debate sobre la política debe centrarse en cómo superar esa situación, de la cual no sólo se deriva una crisis de representación sino también un peligro para la democracia.

Para ello, se requieren instituciones eficaces, partidos políticos y prácticas transparentes y responsables. Estas condiciones distan de cumplirse en muchos países de la región, lo que debilita peligrosamente la función de los partidos como los principales constructores de la política para la democracia.

Sobre esta carencia, notoria y difundida, se centró la mayor parte del debate público sobre la política. Pero, aun siendo central, ese debate desplazó la discusión sobre otras cuestiones que parecen más decisivas que las debilidades institucionales: la crisis de contenido de la política y la dificultad para construir poder democrático.

Incluso si contáramos con instrumentos institucionales óptimos, si no se recupera la capacidad de la política para construir opciones sustantivas y poder, tanto la democracia electoral como la democracia de ciudadanía tenderán a ser no sustentables eirrel evantes para los ciudadanos. Una política que no nutre a la sociedad deopciones y poder carece de representatividad.

En el análisis que realizamos en el Informe, en la Segunda Sección, resulta llamativo quelos diversos instrumentos de estudio empírico hayan permitido coincidir en un conjunto semejante de los déficit que aquejan a nuestras democracias. Ellos deben estar en el centro de los esfuerzos para la renovación de los contenidos de la política. En este sentido, se han señalado las siguientes cuestiones:
- Los problemas de expresión de la ciudadanía política son los menos marcados. Si bien en algunos países la participación electoral aún es baja, se están buscando mecanismos para incrementar esa participación, por vía de la mejora en los modos de empadronamiento electoral y la incorporación defacilidades para acudir a los lugares de votación. Prácticamenteno hay casos de fraudeflagrantey la intimidación de los votantes ha disminuido notoriamente. Como en todo país, siempre hay márgenes para la manipulación de cierto número de electores. Todavía, en muchos casos, las cúpulas partidarias siguen dominando el esquema denominación de candidatos. Ha mejorado la normativa quepermitela discriminación positiva de género para acceder a cargos representativos. Poco a poco, se aprueban normas para controlar el efecto de las donaciones privadas sobre la acción política, aunque en muchos casos todavía falta que este control tenga relevancia práctica.

- En toda América Latina la fórmula política está centrada en la figura del presidente constitucional y la institución presidencial suele tener poderes formales relativamente altos. Esto no siempre se traduce en eficacia en la acción gubernativa, lo que crea otra fuente de descontento de la ciudadanía y frustración para los políticos. El Parlamento, por su parte, carece de prestigio entre la masa ciudadana y se considera que es una instancia poco eficaz para representar y defender los intereses de la mayoría. Aunquela rama judicial del Estado goza de independencia formal, en varios países subsisten severas limitaciones para su cabal desempeño cotidiano. Los organismos especializados de control de la gestión pública, tales como las contralorías de cuentas, o los organismos de promoción o defensa de derechos ciudadanos, como las fiscalías especiales o las defensorías del pueblo, a veces no tienen la independencia necesaria y otras, carecen de poder para ejercer sus funciones. Como es sabido, las defensorías del pueblo no pueden tener poder propio en el campo judicial o administrativo, pues invadirían el área de competen- 
La política, especialmente la

política democrática, es el

á mbito donde se gestan las

diferentes a lterna tiva s y

proyectos de una sociedad.

cia señalada a otros poderes estatales. Los mecanismos de democracia directa, si bien han ampliado el campo de la participación política de la ciudadanía, en más de un caso han contribuido a la desestabilización política y no queda claro si han sido un instrumento eficaz para el desarrollo de la democracia.

- Más allá de los avances fundamentales en materia de derechos humanos, cuya violación sistemática caracterizó a la región en los períodos autoritarios y de guerra civil, siguen registrándoseabusos a los derechos a la vida ya la integridad física, en particular provenientes de la incapacidad del Estado de controlar la violencia y el uso dela fuerza pública. La libertad de prensa ha mejorado notoriamente y aunque se están dando los primeros pasos para asegurar el derecho de acceso a la información en poder del Estado, éste es un desafío en el que es preciso avanzar.

- Los déficit de la ciudadanía social relacionados con la estatalidad y la economía son los más notorios: subsisten niveles altos de desigualdad y pobreza, y en muchos países las desigualdades sociales no sólo no se han reducido sino que han aumentado. Persisten los niveles deinsatisfacción de necesidades básicas en un número considerable de países.

Estas comprobaciones coinciden con la percepción de la ciudadanía, que expresa en el estudio de opinión que los principales problemas son: el desempleo, la pobreza, desigualdad eingresos insuficientes, la delincuencia y las drogas, la corrupción, y los servicios e infraestructura insuficientes.

De modo también coincidente, los líderes consultados mencionan como los problemas de
RECUADRO 39

\section{El poder de los medios de comunicación}

Evidentemente, en todos los grandes grupos de los que tenemos algunos datos, el control sobre la comunicación se encuentra distribuido de una manera tan desigual que algunos individuos poseen una influencia considerablemente mayor que otros [...] aquí tenemos un problema formidable [...] el número de individuos que ejerce un control importante sobre las alternativas programadas constituye solamente, en la mayoría de las organizaciones, una

fracción muy reducida del total de los miembros. Parece que este es el caso, incluso, en las organizaciones más democráticas, si su membresía es considerable.

Robert Dahl, 1987, pp. 97-98.

la agenda: la reactivación económica, la corrupción, el desempleo, la violencia y la delincuencia, la salud y la educación.

Llenar la política de contenido implica no sólo lograr que los déficit anotados se hagan "visibles": es indispensable también construir el abanico de opciones sustantivas para solucionarlos de modo efectivo y colocarlas en el eje de la discusión pública. Resumimos algunos temas de ese debate en los enunciados que siguen:

1. La política, especialmentela política democrática, es el ámbito donde se gestan las diferentes alternativas y proyectos de una sociedad. La política es representación, reivindicación social y búsqueda colectiva de sentido. Sin embargo, hoy advertimos una seria incapacidad de la política para articular proyectos colectivos. La política pasó a ser casi exclusivamente una actividad poco vinculada a las identidades, los intereses y las aspiraciones de la sociedad.

2 La crisis de la política se expresa en la ruptura que existe entre los problemas que la ciudadanía reclama resolver y la capacidad que aquélla tiene para enfrentarlos. La política 
RECUADRO 40

\section{Sociedad civil, política y participación}

Las personas que se organizan a través de entidades independientes de la sociedad civil superan la dicotomía entre autonomía pública y privada. Ejercen la ciudadanía civil, pero no sólo para proteger sus propios intereses sino también para ampliar las posibilidades de protección de los intereses de otros menos afortunados. Ejercen también la ciudadanía política, pero no sólo al votar y decidir en función de sus intereses personales, sino también cuando amplían las posibilidades de acceso y participación de los relegados por el sistema político. Por ello, encarnan en sí mismos toda la potencialidad del ser humano como agente, porque abarcan tanto la dimensión personal como la social de la ciudadanía.

En América Latina hay un crecimiento impresionante de las organizaciones independientes de la sociedad civil. Especialmente en el ámbito de los derechos humanos, la transición a la democracia resultó en la renovación generacional de organismos nacidos para luchar contra la represión ilegal de las dictaduras, y también en la aparición de nuevas entidades dedicadas a los derechos de la mujer, de los niños, de los pueblos indígenas, de los afro-descendientes y de diversos sectores excluidos. [...] La sociedad entiende la política en un sentido más amplio y más rico que el de la competencia electoral.

Juan Méndez, texto elaborado para el PRODDAL, 2002.

tiende entonces a vaciarse, con lo que no logra construir el poder y los instrumentos que permitan hacer frente a los principales desafíos de nuestros países. Ahí radica buena parte de los problemas de confianza y legitimidad que, en América Latina, enfrentan la democracia, la política, sus instituciones básicas y sus líderes.

3. Es preciso entonces preguntarse acerca de cuál debería ser el lugar de la política en una América Latina que, al mismo tiempo que conquistó el importante derecho de gozar de elecciones libres, limpias y periódicas, está atravesada por el proceso de globalización, presenta graves problemas sociales y tiene Estados deficitarios para garantizar y expandir ciudadanía. ¿Puede la política encarnar las aspiraciones ciudadanas de reducción de la pobreza y la desigualdad, de expansión del empleo y la solidaridad? ¿Puede ayudar a construir un horizonte de progreso para nuestros países y nuestros ciudadanos?

4. Muchos de los temas que antes eran propios de la política y los Estados nacionales hoy son tratados y decididos en otras esferas. La economía, los poderes fácticos y al gunos medios de comunicación han ocupado buena parte del lugar de aquéllos. La política tiende a perder contenido por tres vías vinculadas entresí:

- Los Estados nacionales pierden soberanía interior. Lo hacen, por un lado, frente a los poderes fácticos y los ilegales, y, por el otro, como consecuencia de los déficit que limitan la capacidad estatal por ineficiencia e ineficacia de sus organizaciones burocráticas.

- Hay un desequilibrio en la relación entre la política y el mercado, quetiendea estrechar el espacio de la primera y limitarla a los ámbitos de menor relevancia, sustrayendo, por ejemplo, importantes problemas económicos de las decisiones y la deliberación política. Esta sustracción es inconsistente con la democracia y con los derechos de ciudadanía que ella implica.

- Un orden internacional que limita la capacidad de los Estados para actuar con grados razonables de autonomía y, por lo tanto, restringe las opciones nacionales. Estos problemas debilitan la vocación transformadora de la política, situación especialmente grave en América Latina. En este contexto, a las privaciones materiales actuales se agrega una cierta pérdida de la idea de progreso, de la propia posibilidad de proyectos colectivos viables. La aparente impotencia de la política debilita seriamente a la democracia, no só- 
RECUADRO 41

\section{La dimensión asociativa de la democracia}

La calidad de la democracia está determinada tanto por quienes están involucrados en prácticas asociativas como por quienes están excluidos de ellas. Suele suceder en toda América Latina que un mundo hobbesiano de segmentos totalmente desorganizados de la población convive con un mundo mucho más pequeño inspirado en Tocqueville. En este sentido, se presentan dos problemas: uno que tiene que ver con la definición del espacio público mediante la silenciosa acción cotidiana de quienes manejan el acceso al aparato estatal. De ahí la necesidad de democratizar la cultura de elites y sus resultados vinculados con la apropiación del espacio público por parte de intereses especiales organizados. El segundo problema concierne a una evaluación de los patrones asociativos en sí mismos, tanto en términos de su difusión como de su contenido y calidad. Suponiendo que se produzcan consecuencias institucionales positivas del capital social, debe considerarse la dinámica de asociación como un ingrediente esencial de la democracia.

Renato Boschi, texto elaborado para el PRODDAL, 2002.

Io en sus posibilidades de expansión sino también - tal vez- en su sustentabilidad.

5. En América Latina, las instituciones democráticas básicas, sobre todo los partidos y el Parlamento, tienen una baja estima. Aproximadamente el 36 por ciento de los latinoamericanos (Latinobarómetro 2002) está de acuerdo con que, si es necesario, el presidentedeje delado a los partidos políticosy al Parlamento a la hora de gobernar. La mayor parte de los latinoamericanos opina que no hay democracia sin partidos y Parlamento, pero su funcionamiento genera insatisfacción.
6. Los medios de comunicación en ocasiones aparecen ocupando el vacío de representación que se origina en la crisis de la política y sus instituciones; este vacío subsistirá mientras la política no asuma sus facultades frente a los temas relevantes y los partidos se muestren incapaces de articular proyectos colectivos y de alcanzar la conducción del Estado.

7. Cuando la política se vacía de contenidos, cuando el Estado ignora las grandes cuestiones de la ciudadanía, la sociedad los recupera. En estos años, en paralelo a la crisis derepresentación y a la deserción del Estado, surgieron, de manera creciente y en las formas más diversas, organizaciones de la socie dad que ocuparon el espacio de las demandas no resueltas o ignoradas. Se trata de un sistema autoorganizado de grupos intermediarios que son relativamente independientes del Estado y delas empresas privadas, que es capaz de deliberar y llevar adelante acciones colectivas en defensa y promoción de sus intereses y pasiones, en un marco de respeto a la estructura legal y civil existente. 80

8. El ciudadano y las organizaciones de la sociedad civil desempeñan un rol central en la construcción democrática, en el control de la gestión gubernamental, en la expresión de demandas y en el fortalecimiento del pluralismo que toda democracia promueve y necesita. Ellos son actores relevantes de la democracia de ciudadanía. Su papel es complementario al de los actores políticos tradicionales de la democracia. A pesar de las dificultades y los obstáculos que suele conllevar la aceptación de la sociedad civil como ámbito de participación y fortalecimiento de la democracia, su importancia en la democratización de América Latina debe ser claramente reconocida. En este sentido, la política no sólo debe recuperar sus contenidos

80 Consiguientemente, no pueden incluir organizaciones que tienden a la ilegalidad para lograr sus objetivos, sean "mafias" u organizaciones políticas subversivas, o actores con fines más precisos que son parte de la sociedad, como los sindicatos, los medios en tanto organismos de información y entretenimiento, los partidos, los hogares o las I glesias formales, pero sí incluye los organismos colaterales que entran en la definición adoptada. 


\section{Política, partidos y democracia en América Latina}

Al hablar de una transformación de las relaciones entre Estado y sociedad estamos hablando de una transformación de la política. Si la sociedad entera se ve afectada por esta crisis de la política que afecta la calidad y relevancia de las democracias nuevas, más aún se afectan los actores principalmente políticos, es decir, los partidos que aparecen juzgados muy severamente por la opinión pública.

En el nuevo escenario generado por las transformaciones sociales, estructurales y culturales de las últimas décadas que descomponen la unidad de la sociedad-polis, tiende a desaparecer la centralidad exclusiva de la política como expresión de la acción colectiva. Pero ella adquiere una nueva centralidad más abstracta, por cuanto le corresponde abordar y articular las diversas esferas de la vida social, sin destruir su autonomía. Así, hay menos espacio para políticas altamente ideologizadas, voluntaristas 0 globalizantes, pero hay una demanda a la política por "sentido", lo que las puras fuerzas del mercado, el universo mediático, los particularismos o los meros cálculos de interés individual o corporativos, no son capaces de dar.

La gran tarea del futuro es la reconstrucción del espacio institucional, la polis, en que la política vuelve a tener sentido como articulación entre actores sociales autónomos y fuertes y un Estado que recobra su papel de agente de desarrollo en un mundo que amenaza con destruir las comunidades nacionales. La opción es el fortalecimiento, autonomía y complementariedad entre el Estado, el régimen, los partidos y los actores sociales autónomos, es decir, una nueva matriz socio-política.

Manuel Antonio Garretón, texto elaborado para el PRODDAL, 2003. centrales para que el pasaje a la democracia de ciudadanía se viabilice, sino que, además, debecuidadosamente mirar su tarea incompleta, asumiendo las demandas de una sociedad que se organizó para reclamar, controlar y proponer.

9. En América Latina, los espacios conquistados por la sociedad civil han sido fundamentales para abrir caminos políticos que se presentaban cerrados y excluyentes para la construcción democrática. En estesentido, la sociedad civil amplía el espacio público a través de la participación, la expresión de identidades y demandas, y la organización ciudadana. Actualmente, serequieren formas alternativas de representación que sin reemplazar a las tradicionales (partidos políticos, elecciones, Parlamentos), Ias complementen y fortalezcan, respondiendo a necesidades nuevas, a las particularidades de los sectores excluidos o subrepresentados, a la necesidad de agregación política quegenera la saludabley crecienteexpresión de la diversidad y a la imprescindible reapropiación ciudadana de los espacios de construcción de voluntad democrática.
10. Esta cuestión se vincula a ciertos ámbitos de poder donde se toman decisiones que afectan gravemente a una sociedad sin que ésta pueda partici par. Esos claustros cerrados de decisión económica y los poderes fácticos legales e ilegales, nacionales o extraterritoriales, contribuyen a vaciar la política. La democracia abrecamino e invita a la participación ciudadana; sin embargo, si los ámbitos en los que esa participación ocurretienen escaso peso en las grandes decisiones nacionales, la consecuencia tiende a ser una generalizada apatía y desconfianza.

\section{La necesidad de una nueva estatalidad}

Es indispensable ampliar el debate sobre el Estado en América Latina. M ientras que durante los últimos veinte años el énfasis fue puesto en cuestiones tales como las privatizaciones, el tamaño y gasto del Estado y la modernización de sus burocracias, fueron dejados de lado dos temas principales: el poder efectivo del Estado para aplicar el mandato electoral y el poder para democratizar, es de- 
RECUADRO 43

\section{La democracia como principio de organización de la sociedad}

El orden social ya no puede descansar sobre una regulación exclusivamente estatal de la convivencia, pero tampoco opera como un sistema autorregulado. El problema de fondo consiste pues en replantear la coordinación social en una sociedad en que el Estado y la política han dejado de ser las principales instancias de coordinación.

Es en este contexto que, a mi juicio, ha de situarse la discusión acerca de la "cuestión democrática" en América Latina. Mientras que la tendencia actual apunta a una "democracia electoral", cabe preguntarse, en cambio, acerca del papel de la democracia como un ámbito privilegiado de coordinación social. En lugar de restringirla a un principio de legitimación, habría que explorar su potencial como principio de organización. De hecho, las instituciones y los procedimientos democráticos siempre tuvieron la función de mediación de intereses y opiniones plurales con el fin de decidir "adónde vamos".

Norbert Lechner, 1996.

cir, su capacidad para alcanzar de manera universal en todo su territorio a todas las clases sociales. Esta última cuestión es la condición necesaria para lograr que, en todos lados y para todos, los derechos y las obligaciones tengan vigencia efectiva. Si estas condiciones no se cumplen, resultará un déficit de estatalidad: serias fallas en la vigencia del estado de derecho afectarán directamente la sustentabilidad y el desarrollo de la democracia.

Con la excusa de la aplicación de las reformas institucionales que permitirían el mejor funcionamiento de los mercados, estas cuestiones fueron ignoradas u ocultadas. Un Estado para la democracia busca igualar la aplicación de derechos y deberes, lo cual -inexorablemente- modifica las relaciones de poder, en particular en regiones como América Latina, donde la fuerte concentración de ingresos lleva a la concentración del poder.

Éste es un debate urgente, porque en América Latina existe una crisis de estatal idad, a la que entendemos como la capacidad del Estado para cumplir con sus funciones y objetivos independientemente del tamaño y la forma de organización de sus burocracias. En muchos casos, los Estados latinoamericanos han perdido capacidad como centro de la toma de decisiones legítimas, eficaces y eficientes, orientadas a resolver los problemas que las sociedades reconocen como relevantes.

Es imperioso recuperar esta capacidad para promover las democracias. No existe democracia sin Estado y no existe desarrollo de la democracia sin un Estado para todos capaz de garantizar y promover universalmente la ciudadanía. Si esta condición no se cumple, la democracia deja de ser una forma de organización del poder, capaz de resolver las relaciones de cooperación y conflicto. El poder escapa a la democracia y ella se queda sin sustancia.

Recuperar un Estado para la ciudadanía es un desafío central del desarrollo de la democracia en América Latina. Con Estados débiles y mínimos sólo puede aspirarse a conservar de mocracias electorales. La democracia de ciudadanía requiere una estatalidad que asegure la universalidad de los derechos. 81

$\mathrm{H}$ ace falta un Estado capaz de conducir el rumbo general de la sociedad, tramitar los conflictos conforme a princi pios democráticos, garantizar eficazmente el funcionamiento del sistema legal (derechos de propiedad y derechos de ciudadanía simultáneamente), regular los mercados, establecer equilibrios macroeconómicos, establecer sistemas de protección social basados en el principio de universalidad de la ciudadanía y asumir la preeminencia de la democracia como principio de organización dela sociedad.

La estatalidad es una condición indispensable para que una democracia aspire a desarroIlarse más allá del plano electoral, para que sea capaz de enfrentar de modo efectivo los desa-

81 Cualquiera sea la definición de ciudadanía queadoptemos, el vínculo entre ciudadanía y democracia conlleva siempre la idea de universalidad. 
fíos democráticos. A partir de esta proposición enunciamos los temas que consideramos debería contemplar una agenda ampliada sobre la expansión de la estatalidad democrática:

1. La agenda de reformas democráticas debe considerar al Estado en sus tres dimensiones: como conjunto de entes burocráticos, como sistema legal y como ámbito de identidad colectiva. Estas tres dimensiones varían históricamente. En la mayor parte de América Latina, ellas exhiben deficiencias. Las burocracias estatales carecen frecuentemente de poder y eficacia, la efectividad del sistema legal es social y territorialmente limitada, y las pretensiones de ser un Estado-para-la- $\mathrm{Na}$ ción, dedicado seriamente al logro del interés general, no son creíbles para muchos de sus ciudadanos. Estas deficiencias están en el origen del escaso poder quelos gobiernos latinoamericanos tienen para democratizar.

2 Cada país de la región tiene sus peculiaridades, pero en casi todos hay una amplia proporción de la población quese encuentra por debajo de un piso mínimo de desarrollo humano, en términosno sólo debienes materiales y de acceso a servicios públicos, sino también de derechos básicos. La solución deestos lamentables problemas no requiere sólo -obviamente- adecuadas políticas económicas y sociales, también demanda un Estado abarcador y comprensivo, así como razonablemente eficaz, efectivo y creíble. También requiereuna sociedad civil pujante, que por la vía de la participación apunte a complementar la implementación de políticas públicas.

3. El problema del Estado latinoamericano no es sólo el tamaño de sus burocracias, sino su ineficiencia e ineficacia, la inefectividad de su sistema legal y la escasa credibilidad del Estado y los gobiernos. Esto contrasta con la fuerte demanda ciudadana de presencia estatal, que surge, entre otros elementos, de la encuesta informada en la sección segunda de este Informe.
Recuperar un Estado para la ciudada nía es un desafío centra I del desarrollo de la democracia en América La tina.

4. Sin perjuicio dela eliminación de burocracias innecesarias y, en general, dela racionalización de procesosadministrativos, un problema que evidencian algunos Estados latinoamericanos essu al to grado defragmentación y la frecuente falta de distinción entreel interés público y el privado. Cuando esto ocurre, el Estado se desvirtúa y se transforma en una serie de agencias inconexas con funcionarios y políticos ocupados en la búsqueda de rentas.

5. Existeun problema particularmenteinquietante: la existencia de grandes y en algunos casos crecientes áreas en las cuales la legalidad del Estado no tiene alcance o lo tiene de manera intermitente. Es llamativo cómo una cuestión de esta naturaleza es frecuentemente desatendida en los programas de reforma del Estado. El problema central del Estado en América Latina es el de un Estado inconcluso, débil, con escasa capacidad para ser efectivo de modo universal.

6. Otra dimensión deesteproblemaesla presencia de varios tipos de "legalidad" efectiva, de carácter informal, patrimonial y delictivo. A veces, estas "legalidades" sefundan en regímenes discrecionales subnacionales que coexisten con regímenes que, en el nivel nacional, son democráticos. Los actores se desempeñan sobre la base de instituciones informales tales como el personalismo, familismo, prebendalismo, caciquismo y similares. Estos circuitos de poder se basan en la desaparición de la frontera entre lo privado y lo público, y en el truncamiento de la legalidad del Estado.

Por su parte, el clientelismo - un entramado derelaciones por medio del cual un "patrón" logra el apoyo de otros a cambio de ciertos beneficios- genera privilegios y exclusiones, 
RECUADRO 44

\section{Privatización perversa del Estado}

Un detenido diagnóstico del desarrollo de la región puede dar cuenta de un crónico déficit democrático que, frecuentemente, se ha traducido en fenómenos de autoritarismo, dientelismo, amiguismo y, en casos extremos, de nepotismo, que han sido la expresión, a nivel del régimen político, de una "captura" de las instituciones y políticas públicas por intereses particulares (de un partido político, o gremio, o grupo económico, o una familia, o intereses regionales y locales). Esa suerte de "privatización perversa" del Estado, que ha estado en la base de los fenómenos de corrupción, ha conducido a intervenciones estatales desincentivadoras de un funcionamiento eficiente del mercado y promotoras del rentismo y la especulación.

Enrique V. Iglesias, texto elaborado para el PRODDAL, 2003.

y suele implicar un manejo discrecional de recursos públicos.

7. Una función fundamental del Estado es proteger a las personas contra la violencia privada. La democracia supone la existencia de un Estado que ha logrado el control sobre la violencia en su territorio. Sin embargo, ése no es el caso en algunas regiones de América Latina. En ellas operan bandas terroristas, organizaciones delictivas, "paramilitares" y otros fenómenos similares. Estos grupos tienen sus códigos legales, cobran sus propios "impuestos" y algunas veces logran casi el monopolio de la coerción en "su" territorio. Este tipo de violencia privada, no controlada por el Estado, es una de las principales fuentes deviolación de derechos fundamentales de la población.

8. La protección de los ciudadanos por parte del Estado democrático está comprometida también por la violencia asociada a los delitos contra las personas y la propiedad. Su ni- vel y persistencia ponen de relieve la debilidad de un Estado incapaz de cumplir con sus funciones de modo universal. Esta situación es aún más grave en el entorno social de la región, signado por la pobreza y la desigualdad, en el que los ciudadanos más pobres son los que más sufren la violencia.

9. Entre otras consecuencias de lo quellevamos anotado es preciso mencionar la aguda reducción de autonomía del Estado; de hecho, existe un conjunto muy restringido de políticas que pueden ser definidas e implementadas al margen de poderes fácticos localese internacionales que influyen decisivamente sobre el aparato estatal.

10. Una agenda de un Estado para la democracia debería vertebrarse a partir de la idea de Nación para la cual se pretende que el Estado actúe. Debería tener en cuenta al Estado en tanto centro de toma de decisiones legítimas, eficaces y eficientes orientadas a enfrentar los problemas que las sociedades reconocen como más relevantes.

11. Para ello es preciso debatir las cuestiones que en América Latina ponen en duda la eficiencia y eficacia de sus burocracias, la efectividad de su sistema legal y la propia credibilidad del Estado. Éstas son:

- Ineficiencia de la acción del Estado y la reducción de su autonomía, que deriva de su colonización por intereses particularistas (corrupción).

- Inefectividad del sistema legal como consecuencia de la presencia de sistemas legales patrimonialistas.

- Incapacidad de algunos Estados para alcanzar al conjunto de su territorio y a todos sus habitantes, que genera una legalidad trunca (desigualdad ante la ley, vigencia asimétrica de los derechos ciudadanos).

- Falta de un efectivo monopolio de la fuerza por parte de al gunos Estados, que se ha traducido, entre otros efectos, en la 
persistencia del nivel de violación de los derechos humanos.

- Incapacidad estatal para asumir la representación de la diversidad en el interior de la sociedad.

- Pérdida de credibilidad que proviene de la falta de transparencia y responsabilidad (rendición de cuentas) del Estado ante los ciudadanos.

- La cuestión política, más abarcadora, de la capacidad estatal de construir su propio poder, de manera de ejercer soberanamente el mandato popular.

El Estado es uno de los rostros de la democracia: un Estado sin poder es una democracia sin poder.

\section{Una economía para la democracia}

Los problemas de la ciudadanía social atentan directamente contra la perduración de la democracia en América Latina. La sustentabilidad democrática depende en gran parte de la resolución de esta cuestión. Para ello, el debate sobre la economía y la diversidad de formas de organización del mercado debe ingresar en la agenda pública y en la opción ciudadana, porque es en la economía donde anida la solución de buena parte de los déficit de ciudadanía social.

Al comienzo de este Informe sostuvimos que un rasgo singular e históricamente novedoso de América Latina es el de ser la primera región enteramente democrática compuesta por sociedades con muy altos niveles de pobreza y la mayor desigualdad social del mundo. Así, nos referimos al triángulo democracia electoral-pobreza-desi gualdad para sintetizar la naturaleza de estas democracias y la necesidad de impulsar un nuevo pensamiento que diera cuenta de esta realidad. No tendremos respuestas útiles a los interrogantes sobre sustentabilidad democrática latinoamericana si se ignoran los desafíos peculiares que nacen de la coexistencia de esos tres fenómenos.
RECUADRO 45

\section{La economía y la política}

Sin descartar la importancia de instancias técnicas en todo buen ordenamiento del Estado y sin perjuicio de reconocer el trasfondo científico del análisis económico, la economía debe estar sujeta a la política y, en particular, a procesos políticos democráticos, porque ésta es la forma en que la sociedad dirime sus controversias.[...] Es necesario contar con partidos políticos sólidos que ofrezcan a la ciudadanía opciones alternativas de ordenamiento económico y social.

José Antonio Ocampo, texto elaborado para el PRODDAL, 2003.

Cuando describimos los resultados delas indagaciones empíricas en la sección segunda del Informe, la cuestión de las condiciones materiales de vida de los latinoamericanos aparecía claramente como el mayor déficit de la "democracia de ciudadanía". Tal es la dimensión de los problemas de la ciudadanía social que una y otra vez reiteramos una pregunta dramática: ¿cuánta pobreza resiste la libertad?

Sin embargo, el debate sobre la democracia margina la cuestión económica y se plantea, frecuentemente, en términos de las restricciones institucionales que la democracia implica para el crecimiento económico. El debate sobre la economía, con la excusa de su complejidad técnica, se retira crecientemente de la discusión pública y de las opciones reales de los ciudadanos al momento de votar. A la luz de estas realidades parecería útil quea la consabida frase "las cuestiones técnicas no se votan", opongamos la de que "el bienestar de una sociedad no se decideen un laboratorio de técnicos", por másilustrados que estos sean.

Éste no es un problema exclusivo de nuestra región. La tendencia creciente en ciertos países centrales al desarrollo de instituciones económicas con niveles de autonomía casi totales afecta directamente su transparencia y, por ende, su responsabilidad (accountability) frentea la sociedad, lo que deriva en su pérdida de credibilidad 
RECUADRO 46

\section{Una economía para la democracia}

La economía política dásica ha creado un mundo económico que no existe, un Guterwelt, un mundo aislado que es siempre idéntico a sí mismo y en el cual los conflictos entre fuerzas puramente individuales se solucionan de acuerdo con leyes económicas incambiables. En realidad es en el interior de colectividades que son bastante diferentes unas de otras donde los individuos tratan de enriquecerse, y tanto la naturaleza como el éxito de estos esfuerzos cambian junto con la naturaleza de la colectividad en la cual aparecen [...] ello torna siempre indispensable la acción del Estado para organizar los mercados, garantizar los contratos, fijar los patrones de moneda y crédito, la oferta de mano de obra, las relaciones laborales, los servicios de infraestructura, el comercio exterior, las pautas de distribución del ingreso, las cargas impositivas, etcétera.

José Nun, texto elaborado para el PRODDAL, 2002.

ante la opinión pública. Decisiones económicas sustantivas escindidas de la voluntad general presagian, en la visión de Jean-Paul Fitoussi, un siglo en el que la crisis dela democracia será dominante. 82 En América Latina, donde los déficit de ciudadanía social alcanzan la dimensión que hemos señalado, esta cuestión asume una importancia y una urgencia aún mayores, al punto que cuestiones como el nivel de desarrollo de la democracia, la sustentabilidad del sistema y la resolución de la crisis de representación política dependen de nuestra capacidad para incorporar a la economía y sus opciones como un tema de la democracia y de la sociedad.

La economía es una cuestión clave para la democracia. Esta afirmación no implica confundir dos formas de organizaciones sociales claramente diferenciadas: la democracia, que organiza relaciones de poder; la economía, que organiza relaciones de producción, reproduc- ción eintercambio. Sin embargo, el resultado de la organización económica es una cuestión decisiva para la democracia, especialmente para la democracia de ciudadanía, como la hemos definido en este Informe.

La economía es una cuestión de la democracia porque de ella depende el desarrollo de la ciudadanía social y porque genera y altera las relaciones de poder. Por lo tanto, la agenda de la sustentabilidad democrática debe incluir el debate sobre la diversidad posible de políticas y organización del mercado y la cuestión del rol regulador del Estado.

En América Latina se aprendió que el Estado no puede manejar la economía con ligereza: el Estado (democrático) tiene un ineludible rol rector sobre la economía, lo que implica una fuerte capacidad de hacer política económica.

Existen cinco funciones quelas instituciones públicas deberían ofrecer para que los mercados funcionen adecuadamente: la protección de derechos de propiedad, la regulación del mercado, la estabilización macroeconómica, el seguro social y el manejo de conflictos de intereses. $83 \mathrm{EI}$ Estado y el mercado son susceptibles de ser combinados en maneras diferentes dando origen a la diversidad de formas que puede adoptar la economía de mercado.

Una concepción de los mercados como un conjunto de instituciones que "están dadas por la naturaleza" Ileva a la aceptación del funcionamiento dela economía de modo totalmenteautónomo de las decisiones tomadas democráticamente. Desdeun punto de vista democrático, sin embargo, las políticas económicas son parte de los instrumentos con que cuentan las sociedades para alcanzar la ciudadanía plena. Por ello, la economía debe ser uno de los temas dentro del debate político y no ser excluida como una cuestión que "contextualiza" la organización del Estado. Esto es así porque:

- La eventual eliminación dela desigualdad no es un problema económico marginal, resultante (o residual) de una buena política eco- 
RECUADRO 47

\section{Democracia y mercado}

El avance de la democracia y el establecimiento de reglas macroeconómicas claras y fuertes no deben verse como situaciones antagónicas, sino como complementarias.

José Antonio Ocampo, texto elaborado para el PRODDAL, 2003.

nómica. Más bien, la distribución afecta la eficiencia y la sobrevivencia misma del sistema económico.

- El Estado tiene un rol sumamente importanteen la distribución del ingreso vía el fisco, regulación de los mercados, y subsidios o promoción de ciertos sectores o políticas delargo plazo. Este rol implica tener un Estado fuerte y capaz, no raquítico. Hacer dar un paso atrás al Estado, la consigna dominante en los años noventa, que implicaba que su papel no pasaba de mantener la estabilidad económica y proveer algunos bienes públicos, fue un error grave cuyos resultados están a la vista.

- Si esterol estatal no se asume, la democracia se vuelve irrelevante y no creíble para desarrollar la ciudadanía social.

- La democracia ofrecela garantía más efectiva de buena gobernabilidad, tanto en la esfera económica como en la política. Los derechos civiles, la libertad política y los procedimientos participativos son la mejor
La economía es una cuestión de la democracia porque de ella depende el desarrollo de la ciudadanía social y porque genera y altera las relaciones de poder.

manera de asegurar estándares laborales, sustentabilidad medioambiental y estabilidad económica. El desempeño de las democracias en todas estas áreas ha sido superior a los regímenes con participación política restrictiva.

- Cuanto más amplio el dominio de la disciplina de mercado, más ancho será el espacio para la gobernabilidad democrática. En principio, y en la medida en que la disciplina de mercado esté basada en lo que se denomina los fundamentales (economic fundamentals) y en consideraciones de largo plazo, no tiene por quéhaber conflicto entre los mercados y la gobernabilidad democrática. Pero la realidad está lejos de este ideal. El trade-off es auténtico, no sólo porque los mercados se manejan por razones puramente financieras, sino porque son excesivamente volátiles y dominados por consideraciones cortoplacistas. En esta situación, la reafirmación de la primacía de la disciplina democrática por sobre la disciplina de los mercados debería ser clara y frecuente.

\section{Modelo único de desarrollo}

El "fetichismo" de las reformas que ha implantado el "fundamentalismo de mercado", una de cuyas expresiones fue el "Consenso de Washington", se niega a reconocer la diversidad implícita en la democracia [...]. Detrás del discurso del llamado "Consenso de Washington" se encuentra el supuesto de la existencia de un modelo único de desarrollo, aplicable a todos los países cualesquiera sean sus circunstancias, y una visión de la "economía de mercado" como antagónica al intervencionismo estatal. Esta idea es "ahistórica", nociva y contraria a la democracia.

José Antonio Ocampo, texto elaborado para el PRODDAL, 2003. 


\section{La agenda ciudadana: principales problemas,}

\section{América Latina 2002}

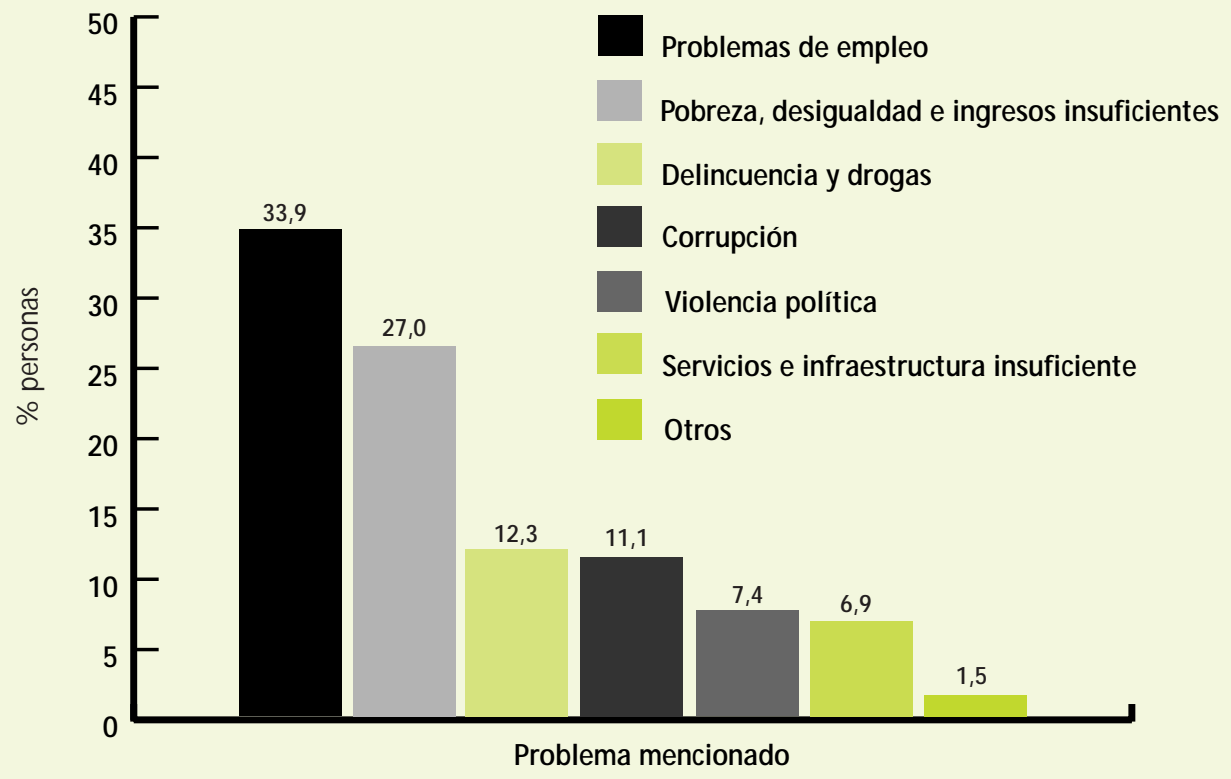

Notas: Muestra válida $n=18.843$, en base a las respuestas a la pregunta P4ST del cuestionario. La categoría "Problemas de empleo" agrupa las respuestas: "inestabilidad en el empleo", " desocupación/desempleo" y "falta de oportunidades para la juventud" . La categoría "Pobreza, desigualdad e ingresos insuficientes" agrupa las respuestas: "bajos salarios", "inflación/aumento de precios" y "pobreza". La categoría "Delincuencia y drogas" agrupa las respuestas: "narcotráfico", "delincuencia/seguridad pública" y "consumo de drogas" . La categoría "Violencia política" agrupa las respuestas: "terrorismo/violencia política/guerrilla" y "violación de los derechos humanos". La categoría "Servicios e infraestructura insuficiente" agrupa las respuestas: "transporte", " problemas de educación", " problemas de vivienda/habitación" y " problemas de salud". La categoría "Otros" agrupa las respuestas: "problemas del medio ambiente", "discriminación racial" y "otros".

Fuente: Elaboración propia con base en Latinobarómetro 2002. Procesamiento de la pregunta P4ST de Latinobarómetro 2002.

- Los mercados requieren gobernabilidad y reglas. La buena gobernabilidad sólo se asegura por vía de la democracia. Y la democracia sigue siendo coextensiva con el Estado-Nación. 84

Por ello la agenda de la sustentabilidad democrática debe incluir, a riesgo de vaciarse de contenido, estas cuestiones de la economía, sus opciones y su diversidad.

Las opciones económicas deben ser parte del contenido renovado de la política, ellas son un componente sustancial de la agenda pública, así como el debate sobre la diversidad es una necesidad imperiosa para reunir la mejor combinación entreel papel del mercado, el Estado y el contexto histórico de cada uno de nuestros países. Por el contrario, el pensamiento único, la receta universal y atemporal atentan contra el desarrollo de la democracia y de la propia economía.

A continuación, desagregamos los temas que, desdeel punto de vista adoptado en este Informe, deben ser parte de una agenda centrada en una visión de la economía a partir de las necesidades del desarrollo de la democracia deAmérica Latina:

1. En ningún otro período de la historia mundial -con la excepción transitoria dela década de 1930- fueron tan graves como hoy los problemas dela economía mundial: desocu- 
RECUADRO 49

\section{Cuatro ventajas económicas de la democracia}

Además, quienes sostienen la primera posición, suelen considerar indiferente para la economía el tipo de régimen político existente en cada caso. Sin embargo, [Dani Rodrik] plantea la hipótesis de que la democracia posee por lo menos cuatro ventajas sobre los regímenes autoritarios: la variancia del crecimiento a largo plazo es menor; la estabilidad macroeconómica de corto y mediano plazo era mayor; las crisis exógenas son mejor controladas y el nivel de los salarios (y de su participación en el ingreso nacional) es más elevado.

Dani Rodrik, 1997, p. 15.

pación masiva, incremento de las desigualdades y la pobreza en los países ricos, extensa miseria y crisis recurrentes en numerosos países en desarrollo, exacerbación dela desigualdad entre países.

2 La democracia no puede permanecer indiferentea esto. No debemos olvidar quevivimos simultáneamenteen democracias y en economías de mercado. Existe por ello, ineluctablemente, tensión entre dos dimensiones: por un lado, el individualismo y la desigualdad que tiendea resultar del funcionamiento del mercado; por el otro, las igualdades que consagra la ciudadanía democrática y la consiguiente necesidad de existencia de un espacio público para la toma decisiones, no ya individuales sino colectivas. Esto obliga a la búsqueda de una conciliación entre ambas esferas.

3. La tensión entre ambos principios es dinámica, porque permite que el sistema se adapte, en lugar de quebrarse, como lo hacen en general sistemas regidos por un único principio de organización (por ejemplo, el sistema soviético). Sólo logran sobrevivir lasfor- mas en movimiento; las otras, sucumben a la esclerosis. Dicho de otro modo, el capitalismo no ha sobrevivido como forma dominante de organización económica a pesar de la democracia, sino gracias a ella.

4 Existen dos corrientes queseenfrentan en el debate sobre las relaciones entre el mercado y la democracia. Según la primera, hoy dominante, la extensión dela esfera del mercado exigiría la limitación del campo de la democracia. La se gunda corriente postula quela tensión siempre existente entre mercado y democracia, y su aspiración de igualdad deberían resolverse me diante la búsqueda de su complementariedad.

5. No pocas delas teorías hoy prevalecientes sostienen quelasintervenciones del Estado suelen reducir la eficacia de la economía. El discurso de los que abogan por más y más mercado es claramenteantiestatal: "El Estado es un mal ne cesario, es preciso limitar radicalmente su capacidad de intervención". En cambio, este Informe sostiene que un Estado ajustado a la democracia -eficaz, eficiente y creíble- es un componenteindispensable del desarrollo.

6. La democracia presupone una jerarquía entre la política y el sistema económico y, por ende, autonomía de la sociedad en la elección de las formas en que organiza su mercado.

7. La democracia, en su búsqueda por limitar las exclusiones que provoca el mercado, aumenta la legitimidad del sistema económico; el mercado, al limitar el poder del Estado y la política sobre la vida de los ciudadanos, permite una mayor adhesión a la democracia. La libertad colectiva necesita apoyarse sobre las libertades individuales, y viceversa. Tanto una como las otras están en relación iterativa, mostrando que la democracia es una forma en movimiento. "La historia prueba quela de mocracia realizada nunca es más que un momento del movimiento democrático. Un movimiento que no se detiene jamás".85 
RECUADRO 50

\section{Complementariedad entre democracia y mercado}

Las relaciones entre democracia y mercado son entonces más complementarias que conflictivas. La democracia, al impedir la exclusión por el mercado, aumenta la legitimidad del sistema económico y el mercado, al limitar el poder de la política sobre la vida de la gente, permite una mayor adhesión a la democracia. De este modo, cada uno de los principios que rigen las esferas política y económica encuentra su limitación, a la vez que su legitimación, en el otro.

Jean-Paul Fitoussi, texto elaborado para el PRODDAL, 2003.

8. Las sociedades nacionales -inclusive, por cierto, las de los países centrales- no tienen los mismos sistemas de equidad social; hay, de hecho, gran diversidad en estos sistemas. Esto no debe sorprendernos: la democracia implica diversidad; existen diferentes"variedades de capitalismo", diferentes combinaciones entre Estado y mercado, y en las formas de accionar del Estado. Ésta es una importante verdad que, contra toda evidencia, el pensamiento único niega.

9. La apertura de las economías favorece a los factores más móviles, no sólo el capital financiero sino también algunos tipos de conocimientos. El incremento de la movilidad de estos factores tiene por efecto transferir a los factores menos móviles - es decir, sobre todo al trabajo- el peso de la inseguridad económica. Esto encierra el riesgo de reducir la adhesión de las poblaciones a la democracia y al propio mercado.

10. Frente a esta situación, conviene pasar revista a algunos criterios sobre políticas económicas y su relación con la democracia, tal como surge de las experiencias latinoamericanas de las últimas décadas:
- Es necesario un debate que identifique políticas que redistribuyan el ingreso sin distorsionar severamente el funcionamiento de los mercados, evitando así el "populismo" o el "facilismo" tan presentes en la historia de América Latina.

- La búsqueda demayores niveles debienestar para la población exige un crecimiento económico sostenido, pero éste resulta insuficientecuando esacompañado por consecuencias redistributivas desfavorables.

- La experiencia internacional demuestra que las ventajas competitivas basadas en bajos salarios son frágiles e inestables. Para competir en el mundo actual esfundamental la producción eficiente, la innovación de procesos, el diseño y la diferenciación de productos, y el desarrollo de servicios de apoyo adecuados. Para ello, es esencial contar con un capital humano calificado. A su vez, la política social debe guiarse por cuatro principios básicos: universalidad, solidaridad, eficiencia e integralidad.

- Los límites a la gran propiedad y empresa privada se relacionan con los niveles de desigualdad que una sociedad está dispuesta a tolerar, así como a las modalidades desu tributación. Un segundo tipo de límite se relaciona con el posibleabuso del poder de mercado que pueden lograr los grandes propietarios y empresas. El tercero se refiere a la capacidad de esas empresas y propietarios de extender su influencia más allá de los mercados, gracias a su capacidad de lobby y a la extensión de su control hacia otras esferas del poder típicas de la sociedad contemporánea -los medios de comunicación, en particular-.

- Un acuerdo político de los distintos sectores sociales sobre qué debe hacer el Estado ayuda a legitimar el nivel, la composición y la tendencia del gasto público y de la carga tributaria necesaria para su financiamiento.

Finalmente, anotamos que nuestros datos muestran dos aspectos de gran importancia práctica. El primero de ellos es que muchos latinoamericanos comparten una visión suma- 


\section{Posición frente a la intervención del Estado en la economía, América Latina, 2002}

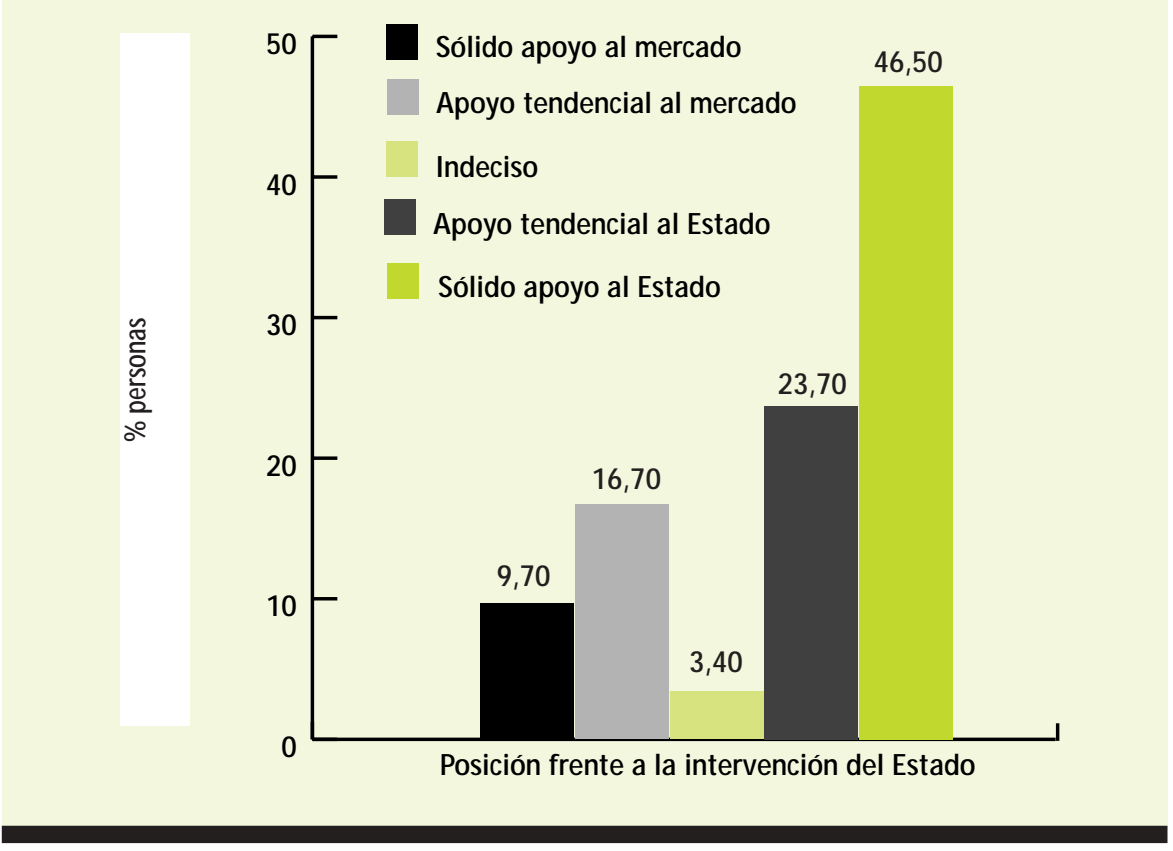

Notas: Muestra válida, $\mathrm{n}=17.646$. Para la construcción de esta variable se recodificaron las preguntas P21N02, P22STA, P22STB, P22ESSD Y P22ESSE de Latinobarómetro 2002. Para mayor información, ver nota a la tabla 142 del Compendio Estadístico del Informe. Fuente: Elaboración propia con base en Latinobarómetro 2002.

mente crítica sobre el funcionamiento de la economía de mercado. El segundo aspecto - seguramente contracara de la frustración recién anotada- es la mayoritaria opinión favorable a la intervención del Estado en la economía.

\section{Poder y políticas democráticas en la globalización}

Una agenda ampliada sobre la gl obalización debe incluir un debate sobre su naturaleza política y militar, su restricción a la diversidad y las fuertes limitaciones al poder estatal. La globalización plantea crudamente las cuestiones del poder de los Estados nacionales y del poder dentro de los Estados. Deotra manera se expresa aquí nuevamente el problema vital de la democracia: la existencia o no de poder para ejecutar la voluntad mayoritaria.
El debate que naturalmente se desarrolló hasta ahora ha puesto el énfasis en los asuntos financieros y comerciales de la globalización y ha marginado relativamente su dato dominante: los poderes exteriores han dejado de ser exteriores, son tan interiores como los locales. Condicionan o determinan las decisiones del Estado y su campo no se limita a las finanzas o el comercio. Abarcan crecientemente las cuestiones políticas, de seguridad y organización interior, de los sistemas de seguridad sociales, educativos y de salud.

Es necesario, en consecuencia, ampliar el debatesobrela globalización en dos áreas: por un lado, para dimensionar el impacto real en términos de la soberanía interior de los Estados; en segundo lugar, cómo concebir las estrategias posibles para aumentar las capacidades nacionales y regionales, para queel poder nacional no seextinga en nombre deun incontrolable poder global. 
La globalización ha hecho que el mundo exterior esté en el interior de nuestras sociedades. El mundo está en todas partes. Pero el poder del mundo no.

La globalización ha hecho que el mundo exterior esté en el interior de nuestras sociedades. El mundo está en todas partes. Pero el poder del mundo no. Sin embargo, y a la vez que esto sucede, reconocer la naturaleza de las relaciones querigen el mundo en el que vivimos no debería hacernos abandonar la idea de un orden mundial regido por normas. U na cosa es la realidad que nos circunda; otra, nuestras aspiraciones, utopías si se quiere, aunque no quimeras.

La lucha por un sistema internacional democrático de derecho no debería dejar de ser una reivindicación permanente de una civilización que muestra como una de sus conquistas a la democracia y a la idea de que las conductas se rigen por normas destinadas a preservar el derecho igualitario de todos, individuos y Estados.

En efecto, en el mundo quesurgió tras la terminación de la posguerra fría, las relaciones de poder, básicamente militares y económicas, regulan el sistema internacional. En estas condiciones, el tema queemerge como prioridad es la contradicción entre la necesidad de la diversidad-que demanda un importantegrado deautonomía de los países y un sistema mundial basado en normas claras y compartidas- y un mundo homogeneizado por relaciones de poder que dejan a los actores nacionales la capacidad de regulación normativa sólo en cuestiones relativamente marginales. ¿Qué elección sobre cuestiones sustantivas pueden hacer los ciudadanos en estas condiciones? ¿Qué posibilidad existe de que lo que hayan decidido se ejecute?

En torno a esta cuestión central, el Informe presenta a continuación un conjunto de reflexiones y temas que deberían nutrir el debate sobre la globalización y el desarrollo dela democracia:
1. Al tiempo queha promovido la democracia, la globalización ha impuesto restricciones, incluso a los Estados más fuertes y desarroIlados. En América Latina, estas restricciones ponen en duda la credibilidad del Estado como constructor de sociedad y promotor de ciudadanía; asimismo, conllevan importantes consecuencias sobre el tipo de políticas posibles para los gobiernos de la región. La acción aislada de la mayor parte de los Estados nacionales latinoamericanos resulta insuficiente para influir, controlar, regular o beneficiarse de este proceso o para resistir sus tendencias.

2 Paradójicamente, la globalización, mientras ha erosionado la capacidad de acción de los gobiernos, en particular la efectividad de sus instrumentos de regulación económica, dejó en manos de los Estados nacionales la compleja tarea de mantener la cohesión social, pero con menores márgenes de acción para lograrlo. M ás aún, como resultado del peso creciente de la condicionalidad impuesta por los organismos internacionales de crédito $y$, en general, por la movilidad del capital financiero, se han venido reduciendo los espacios para la diversidad de modelos de organización social y económica que implica la democracia.

3. Sin embargo, hay una importante distancia entre esa constatación y la pasividad gubernamental. El reconocimiento de las restricciones existentes no necesariamenteimpone aceptar el statu quo. La construcción de un espacio de autonomía de los Estados nacionales frente a la globalización constituye un desafío propio de la política democrática, la que, como hemos aseverado a lo largo de este Informe, debe proponerse como meta central la construcción y expansión de diversas ciudadanías.

4. Es peligroso caer en el fatalismo frente a la globalización, sosteniendo que la asimetría de fuerzas es tal que no hay lugar para políticas autónomas. Ese fatalismo, desafortuna- 
RECUADRO 51

\section{Globalización e impotencia de la política}

No solamente la globalización aumenta la participación del mercado en el sistema de equidad y reduce la de la democracia, sino que lo hace en nombre de la eficacia del mercado y de un orden superior al de la democracia. Es lo que se ha dado en llamar impotencia de lo político.

Jean-Paul Fitoussi, texto elaborado para el PRODDAL, 2003.

damente muy difundido, ignora los espacios reales de negociación que existen en el mundo así como que esos espacios pueden ser ampliados si existe una voluntad política consistente y sostenida de construcción de instancias regionales.

5. Los lugares institucionales de realización de la ciudadanía política siguen siendo esencialmente nacionales. Esto implica que el reconocimiento de la democracia como valor universal sólo adquiere pleno sentido si se permite que los procesos nacionales de representación, de participación y de toma de decisiones determinen las estrategias de desarrollo económico y social, y ejerzan una mediación eficaz con las tensiones propias de la globalización.

6. Por su lado, desdela perspectiva del desarrollo de la democracia es también necesario debatir la construcción de los espacios deautonomía mencionados en el punto anterior; ellos son necesarios para que las democracias latinoamericanas puedan adquirir sólido sustento y expandirse.

7. La democracia es severamente afectada por la creciente traslación de importantes decisiones a ámbitos que están fuera del alcance del control de los ciudadanos. Esto tiende a poner en cuestión nada menos quela relevancia que la democracia realmente tiene para los ciudadanos, lo cual a su vez tiene mucho peso en la lealtad de éstos a aquélla. Esta preocupación debe ser recalcada, porque podemos estar dirigiéndonos a una política que maneja agendas acotadas, que tarde 0 temprano pueden conducirnos a agendas irrelevantes 0 negadoras de la diversidad de caminos y criterios que debería reflejar la especificidad de cada uno de nuestros países.

8. Delo antedicho deriva que la cuestión de cómo aumentar la capacidad de autonomía en la definición y solución de los grandes problemas quenos afectan no sólo atañea cada país, sino también a la región en su conjunto.

9. Esto implica debatir también políticas dealcance regional quehagan posibleun aumento compartido de esa autonomía. Para ello cobra sentido y urgencia el renacimiento político de los esfuerzos regionales que, más allá de esfuerzos meramente comerciales, re creen y aumenten los espacios políticos de decisión propia, nacionales y ciudadanos.

10. Ello no implica necesariamente la creación de nuevas organizaciones para encarar esas tareas ni, menos, que tengan carácter supranacional. Lo central es que los Estados de la región decidan abordar el tratamiento de esos temas en el plano político. Para ello, las actuales instituciones regionales y subregionales ofrecen una razonable base de acción, con los ajustes de agenda y estructura que será indispensable introducir.

11. Así planteada, la integración política tiene como tarea la construcción de la Nación y la construcción de la región, una región de naciones en la que unas y otras se complementan y refuerzan. Es decir, una asociación política de Estados soberanos.

12 El ordenamiento internacional debería ser respetuoso de la diversidad de los países (entreellosy en cada uno de ellos), dentro de los límites de la interdependencia. Pero las prácticas de poder imperantes en las relaciones 
internacionales no tienden a tomar en cuenta esa necesidad.

13. La capacidad de construcción autónoma en un mundo globalizado con una sola potencia hegemónica implica nuevos desafíos. No se trata sólo de los problemas clásicos de la relación entre el centro y la periferia, el imperio y sus zonas de control, sino, además, de esas re laciones en el contexto de la globalización actual. En ella, losfenómenos exteriores son tan inmediatos y cotidianos como los que se producen en el mismo territorio de las naciones.

14. La posguerra fría concluyó el 11 de septiembre de 2001, con el ataque terrorista a Estados Unidos. El tema de seguridad volvió al centro de la escena, convirtiéndose en la cuestión prioritaria de la política mundial. A su vez, los hechos que se produjeron desdeentonces han marcado un cambio sustancial en las relaciones mundiales, con fuerte impacto sobre los sistemas multilaterales de defensa colectiva.

15. La centralidad del tema seguridad en la agenda internacional plantea una tensión con la democracia y las libertades. Los países centrales tienen mejores contrapesos que los nuestros para resolver esa tensión.

16. La experiencia que tuvimos en América Latina en las décadas anteriores al fin de la guerra fría es un buen ejemplo de lo que sucede cuando la cuestión de seguridad se convierte en la óptica central a partir de la cual se observan la política y las relaciones internacionales.

17. Por su parte, la región tiene una fuerte carga deantecedentes en esta materia. En el pasado reciente ha sido objeto de varios atentados terroristas graves. Además, durante varias décadas al gunos países latinoamericanos han sufrido gran violencia, tanto de grupos insurgentes como del propio Estado. Por lo tanto, el peligro de la violencia terrorista no es una hipótesis abstracta para la región.
18. Recientemente, las relaciones de poder militar han marcado de manera decisiva los vínculos mundiales. La idea de que la globalización había trasladado el centro de las relaciones internacionales de las cuestiones militares y de seguridad a las financieras, que la economía reemplazaba a la política, se desvaneció. La preeminencia del tema del terrorismo traeal análisis, por un lado, el impacto sobre las capacidades estatales de una potencial agresión terrorista y, por el otro, las consecuencias de respuestas inapropiadas sobre esas capacidades y sobre la propia democracia. La respuesta apropiada se refiere a la capacidad estatal de responder eficazmente al peligro de agresión y, a la vez, evitar que esa respuesta debilite su capacidad de democratizar o disminuya la calidad de la democracia.

19. Es fundamental para la democracia que los problemas de seguridad no vengan como parte de una agenda impuesta sino asumirlos con soluciones propias. En este sentido, el tema de seguridad adquiere centralidad. Una posición pasiva en esta materia puedetornarnos al tamente vulnerables a estrategias exteriores, definidas sin tomar en cuenta importantes intereses propios de nuestra región.

20. Los países de la región deben formular, a la luz de lo sucedido el 11 de septiembre y sus consecuencias, así como de la singularidad de sus democracias, criterios propios para inspirar sus opciones de respuesta al peligro planteado por el terrorismo.

\section{En síntesis}

El Informe ha planteado que la democracia entendida en forma minimalista, como la posibilidad de ejercer el derecho del voto periódicamente para elegir gobernantes, dentro de un marco donde esté plenamente vigente el estado de derecho, no sólo es importante sino una condición sinequa non para poder calificar a un ré gimen de democrático. Pero el Informe va más allá. Considera que debe ampliarse el horizonte 
de la democracia perfeccionando no sólo los mecanismos institucionales de la política y la implementación efectiva de los derechos civiles para todos los ciudadanos, sino atendiendo a la expansión efectiva de la ciudadanía social.

Se trata de discutir cómo se puede avanzar hacia una ciudadanía integral, lo que supone poner en el centro a la política como forma de que el ciudadano y más precisamente la comunidad de ciudadanos, pueda participar en decisiones sustanciales. La globalización es un dato, pero no se trata pura y exclusivamente de admitir que todo lo que ocurre como consecuencia de la transformación tecnológica y de la expansión de los mercados debe aceptarse sin reflexión y sin acción. Hay que entender la transformación constante y rápida que se da en el mundo de hoy, hay que convivir con incertidumbres, pero también hay que actuar para modificar esas macrotendencias en la circunstancia de cada país. Se trata de implementarla regional y localmente con una actitud proacti- va y no meramente pasiva, para su arraigo regional y local. De este modo, la economía no es tampoco un dato a asumir pasivamente; no hay una sola manera de pensar y hacer funcionar el mercado. Ya se sabe que hay diversas formas históricas exitosas que han convivido en marcos culturales diferentes.

Esta comunidad de ciudadanos debe, entonces, promover una nueva legitimidad para el Estado, ese organismo que debe no sólo proporcionar la maquinaria burocrática administrativa decada país, sino también respetar y ampliar las instituciones políticas y el estado de derecho, y poner las bases para asegurar la equidad para poder tener políticas sociales que apunten a la ampliación de la ciudadanía social. Crear una visión integral dela ciudadanía, articular el funcionamiento de la economía con las decisiones políticas de la comunidad de los ciudadanos son al gunos de los temas que emergen de estel nforme para suscitar una nueva forma de debatir la democracia en la región Latinoamericana. 



\section{Reflexiones finales}

\section{El eterno desafío}

En uno de sus célebres ensayos, Isaiah Berlin nos recuerda que "hace más de cien años el poeta alemán Heine advirtió a los franceses que no debían subestimar el poder de las ideas: los conceptos filosóficos alimentados en el silencio del estudio de un académico podían destruir toda una civilización".

La América Latina ha sido hija de una idea y ella sigue siendo el corazón de su visión de futuro: construir una sociedad democrática. Su proceso de independencia estuvo indisolublemente ligado a la concepción republicana y a ella volcaron su esfuerzo los libertadores. El devenir histórico ha mostrado, sin embargo, un extraño periplo, Ileno de contradicciones, interrupciones y reanudaciones, atardeceres y alboradas. A veces han sido los hechos, sociales, económicos, militares, los quehan desbordado los marcos de los principios, pero también las ideas han caído en sus propias trampas, pues cada vez que la libertad y la justicia se conjugaron por separado, ambas quedaron en riesgo. Así ocurrió, infortunadamente, cuando se soñó con superar el núcleo central de la idea democrática, que no es otro que asegurar las libertades y organizar un gobierno representativo del pueblo, capaz por lo tanto de lograr que esa libertad se concilie con el máximo posible de igualdad de las gentes.

¿Cuánto se ha logrado, en los hechos, de construcción de ese ideal? ¿Q ué debe hacerse para asegurar lo al canzado y seguir avanzando? Desafiados por esos básicos interrogantes es que se lanzó este trabajo hace dos años, consultando, preguntando, removiendo, despertando intereses, tratando de encontrar algunos métodos objetivos para medir realidades siempre más complejas que cualquier estadística. Idea y realidad viven una constante tensión. Si nos replegamos exclusivamente al territorio de la idea, podemos traicionarla en los hechos. Si la perdemos de vista en una lucha acuciosa contra las realidades injustas, arriesgamos caer en un peligroso e inconexo empirismo. Hace falta, entonces, definir conceptos y contrastarlos, en pasos aproximativos, con la realidad.

Debemos recordar que si esto es posible hoy para el PNUD es porque la región ha alcanzado un nivel de desarrollo de la democracia como nunca antes. En los años setenta estaba cerrado todo camino para un trabajo de esta naturaleza, porque el mapa latinoamericano seensombrecía con tantas dictaduras que no mediaban las condiciones para que la organización 
internacional intentara una reflexión en profundidad sobre la cuestión. Desde esta premisa esperanzadora se abrió entonces el trabajo y él contó con la colaboración, sin excepción, de gobiernosy partidos, actores políticos y civiles, protagonistas económicos y académicos. Reuniones, seminarios, entrevistas, informes, estudios, investigaciones estadísticas fueron poblando un gran conjunto que, además de su valor intrínseco, generó en toda la región un interés en el tema, una convicción de que es necesario -y posible- actuar sobre nuestra situación.

El propósito inicial de generar un clima estimulante a la reflexión fue ganando cuerpo. Y hoy se llega a este Informe sobre la democracia con la convicción de que, más allá de sus inevitables limitaciones y necesarias imperfecciones, se pone a disposición de toda la sociedad latinoamericana un instrumento de trabajo. No está aquí la tomografía computada de ningún Estado concreto. Tampoco el análisis específico dealguna patología determinada. Lo que sí se define es una idea general de la salud democrática, una aproximación sobre realidades que merecen preocupación y la configuración de algunos instrumentos para que la constante revisión nos permita a todos seguir construyendo.

Como nos lo ha dicho Pierre Rosanvallon, "Ia democracia formula una pregunta que permanece continuamente abierta: parecería que ninguna respuesta adecuada podría dársele". Esta urticante sensación de que nunca nada está terminado hace a la idea misma de la libertad, y con ella hemos de convivir. Cada vez que se quiso intentar, en nombre de la democracia, algún sistema con todas las respuestas, se construyó un totalitarismo. El siglo pasado ha sido, quizás, el que mayores tragedias generó en esa búsqueda. Herederos de esa experiencia, hoy asumimos que la realidad nunca nos conformará, porque comparada con la idealidad pura, siempre será insatisfactoria; pero también sabemos que siendo la democracia "antes que nada un ideal", como nos dice Giovanni Sartori, debemos procurar, siempre y a toda hora, sin prisa pero sin pausa, su constante perfeccionamiento.

La pobreza, las desigualdades sociales, el choque étnico, el divorcio entre las expectativas y las realidades, en un tiempo histórico en que una revolución científica nos cambia todos los días la vida, introducen notas de inestabilidad. De ahí la necesidad constante de prevenir. Si este Informe contribuye a instalarla en la preocupación afirmativa de todos sus actores, habrá logrado su propósito fundamental, que no es juzgar a nadie sino estimular a todos. El PNUD lo hizo con el Índice de Desarrollo Humano y logró que se asumiera en la sociedad ese modo de evaluar que iba más allá del parcial e insuficiente PBI. En la misma línea innovadora, hoy se procura que la mejoría democrática no sea simplemente una expresión retórica, siempre cuestionable, sino una realidad sobre la que se actúa, registrando avances y retrocesos que puedan mirarse con objetividad. Esos avances, esas búsquedas responden a la idea de que democracia y desarrollo humano son apenas dos caras de la misma medalla.

Subestimar el progreso alcanzado coleccionando déficit y carencias es desanimar a la sociedad en su necesario y constante perfeccionamiento. Regodearnos en él, cayendo en la ilusión de una meta alcanzada, sería poner todo en riesgo. Por eso aquí, simplemente, se está abriendo una nueva etapa en el camino.

Formidable ha sido el esfuerzo de las últimas dos décadas y deben mostrarse con toda plenitud sus logros. Ese esfuerzo debe proseguirse y bien puede abrirse aquí, a partir de estos instrumentos elaborados, un procedimiento permanente de observación y análisis, al mis- 
mo tiempo que de difusión de experiencias y prevención de riesgos. La conciencia alerta es el único estado de ánimo para que la democracia siga su vida, adaptándose a los tiempos. Ella permanece, después de todo, como la más revolucionaria de las ideas y, por lo mismo que siempre inacabada, la más desafiante. No habrá respuestas definitivas para sus interrogantes, pero siempre habrá, como en el destino del hombre, oportunidades para hacer el bien a los semejantes.

Julio María Sanguinetti

Ex Presidente de la República Oriental del U ruguay

Presidente dela Fundación Círculo de M ontevideo 



\section{Agradecimientos}

Este Informe no se habría podido preparar sin la generosa colaboración de muchas personas y organizaciones a quienes expresamos nuestro agradecimiento.

Deseamos extender un especial reconocimiento a la Unión Europea, en particular a Chris Patten, Comisario de Relaciones Exteriores de la Comisión Europea, Eneko Landaburu, Director General, Fernando Valenzuela, Director General Adjunto y Tomas Dupla del M oral, Director de América Latina, Dirección de Relaciones Exteriores, y Fernando Cardesa, Director de América Latina de EUROPEAID, como a todos los funcionarios de la Dirección General de Relaciones Exteriores y de la Oficina de Cooperación EuropeAid que colaboraron en este proyecto, por el respaldo e interés demostrado para la publicación y difusión de este Informe.

\section{Instituciones que colaboraron en \\ la elaboración y discusión del Informe}

Comisión Económica para América Latina y el Caribe (CEPAL), Banco Interamericano de Desarrollo (BID), Organización de Estados Americanos (OEA), Club de Madrid, Círculo deM ontevideo, Corporación Latinobarómetro, Fundación Chile XXI, Universidad de Bolonia, Centro de Estudios Sociales y Ambientales, Instituto para la Democracia y Asistencia Electoral (IDEA) y Asociación Civil Transparencia (Perú).

\section{Autores de artículos sobre temas de la agenda}

Manuel Alcántara, Raúl Alconada Sempé, Willem Assies, Natalio Botana, Fernando Calderón, Dante Caputo, Fernando Henrique Cardoso, Jean-Paul Fitoussi, Eduardo Gamarra, Marco Aurélio Garcia, Manuel Antonio Garretón, César Gaviria, Julio Godio, FelipeGonzález, Rosario Green, Cândido Grzybowski, Osvaldo Hurtado, Enrique I glesias, José Antonio O campo, Celi Pinto, Augusto Ramírez Ocampo, Rubens Ricupero, Lourdes Sola, Joseph Stiglitz, Cardenal Julio Terrazas y Francisco Thoumi.

\section{Participantes en la Ronda de Consultas}

Argentina: Raúl Alfonsín, Jaime Campos, Elisa Carrió, Jorge Casaretto, Víctor De Genaro, Fernando de la Rúa, José Manuel de la Sota, Jorge Elías, Rosendo Fraga, Aníbal Ibarra, Ricardo López Murphy, Juan Carlos Maqueda, Joaquín Morales Solá, Hugo Moyano, Adolfo Rodríguez Saá, Rodolfo Terragno, H oracio Verbitsky y O scar Vignart.

Bolivia: Esther Balboa, Carlos Calvo, Carlos Mesa, Gustavo Fernández Saavedra, Martha García, Fernando M ayorga, Jaime Paz Zamora, Jorge Quiroga Ramírez, Edgar Ramírez, y Gonzalo Sánchez de Losada.

Brasil: Frei Betto, Luiz Carlos Bresser-Pereira, José M árcio Camargo, Fernando HenriqueCardoso, Suely Carneiro, M arcos Coimbra, Fábio K. Comparato, Paulo Cunha, Joaquim Falcão, José Eduardo Faria, Ruben César Fernandes, Argelina Figueiredo, Luiz Gonzaga Belluzo, O ded 
Grajew, Cândido Grzybowski, Helio Jaguaribe, M iriam Leitão, Ives M artins, Filmar M auro, Henrique M eirelles, Antônio Delfim N eto, Jarbas Passarinho, João C. Pena, Celso Pinto, M árcio Pochmann, João Paulo dos Reis Velloso, Clóvis Rossi, M aria O smarina M arina Silva Vaz de Lima, Pedro Simon, Luiz E. Soares, Luiz Suplicy H afers, Vicentinho, Arthur Virgílio y Ségio Werlang.

Chile: Andrés Allamand, Patricio Aylwin, Benito Baranda, Edgardo Boeninger, Eduardo Frei, Juan Pablo Illanes, Jorge Inzunza, Ricardo Lagos, N orbert Lechner, Arturo M artínez, Jovino Novoa, Ricardo Nuñez, Carlos Ominami, y Carolina Tohá.

Colombia: Ana Teresa Bernal, Belisario Betancur, Héctor Fajardo, Guillermo Fernández de Soto, Luis Jorge Garay, Hernando Gómez Buendía, Julio Roberto Gómez, Carlos H olguín, Fernando Londoño, Antonio Navarro, Sabas Pretelt de la Vega, Jorge Rojas, Ernesto Samper, Francisco Santos, Horacio Serpa, Álvaro Valencia Tovar y Luis Carlos Villegas.

Costa Rica: Oscar Arias, Leonardo Garnier, Eduardo Lizano, Elizabeth Odio Benito, Ottón Solis, Albino Vargas y Samuel Yankelewitz.

Ecuador: Rodrigo Borja, M arena Briones, Joaquín Cevallos, José Eguiguren, Ramiro González, Susana González, Lucio Gutiérrez, Osvaldo Hurtado, Miguel Lluco, Alfredo Negrete, Jaime Nebot, Benjamín Ortiz, Alfredo Palacio, Rodrigo Paz, Gustavo Pinto, M esías Tatamuez M oreno, Luis Verdesoto y Jorge Vivanco.

República Dominicana: M anuel Esquea Guerrero, Leonel Fernández Reyna, Antonio Isa Conde, Carlos Guillermo León, Hipólito M ejía y Jacinto Peynado.

El Salvador: Armando Calderón Sol, Gregorio Rosa Chávez, Humberto Corado, David Escobar Galindo, M auricio Funes, Salvador Samayoa, H éctor Silva y Eduardo Zablah Touché.

Guatemala: M arco Vinicio Cerezo, M arco Augusto García, Gustavo Porras, Alfonso PortiIlo, Rosalina Tuyuc y Raquel Zelaya.

H onduras: I saías Barahona, Rafael Leonardo Callejas, Miguel Facusse, Carlos Flores Facusse, Ricardo M aduro y Leticia Salomón.

México: Sergio Aguayo, Luis H . Álvarez, M anuel Arango, Raúl Benitez, Gilberto Borja Na- varrete, Luis Felipe Bravo M ena, Felipe Calderón Hinojosa, Cuauhtémoc Cárdenas, Jorge G. Castañeda, Eugenio Clariond, Rolando Cordera, Santiago Creel, Carlos Elizondo, VicenteFox, Juan Ramón de la Fuente, Amalia García, Francisco Hernández, Felipe de Jesús Cantú, Santiago Levy, Carmen Lira, Soledad Loaeza, Andrés M anuel López O brador, Roberto M adrazo, Lorenzo Meyer, Arturo Montiel, Arturo Núñez, Mariano Palacios Alcocer, José Francisco Paoli Bolio, Beatriz Paredes, JoséLuis Reina, Jesús Reyes Heroles, Rosario Robles, Juan Sánchez Navarro, Sergio Sarmiento, Bernardo Sepúlveda, Luis Téllez, César Verduga, José Woldenberg y Ernesto Zedillo.

Nicaragua: Carlos Fernando Chamorro, Violeta Granera, Wilfredo Navarro M oreira, René Núñez Tellez, Sergio Ramírez M ercado y JoséRizo Castellón.

Panamá: M iguel Candanedo, Norma Cano, Guillermo Endara, Angélica M aytin, M artín Torrijos y Alberto Vallarino.

Paraguay: M artín Almada, N elson Argaña, Nicanor Duarte Frutos, Pedro Fadul, Ricardo Franco, Cristina Muñoz, Enrique Riera, Milda Rivarola, Humberto Rubin, M iguel Abdón Saguier y Aldo Zucolillo.

Perú: Julio Cotler, Jorge Del Castillo, Carlos Ferrero Costa, Lourdes Flores Nano, Gastón Garatea Vori, Diego García-Sayán, Juan José Larrañeta, Roberto Nesta, Valentín Paniagua, Rafael Roncagliolo, Javier Silva Ruete, Luis Solari de la Fuente, Alejandro Toledo y Alan Wagner.

Uruguay: Diego Balestra, Jorge Batlle, Héctor Florit, LuisAlberto Lacalle, José M ujica, Romeo Pérez, Juan José Ramos, Julio M aría Sanguinetti, Liber Seregni y Ricardo Zerbino.

Venezuela: JoséAlbornoz, Alejandro Armas, Carlos Fernández, Eduardo Fernández, Guillermo García Ponce, Alberto Garrido, Janet Kelly, Enrique M endoza, Calixto Ortega, Teodoro Petkoff, Leonardo Pisani, José Vicente Rangel, Cecilia Sosa, Luis Ugalde y Ramón Velásquez.

\section{Participaciones especiales}

Belisario Betancur, ex Presidente de CoIombia; Rodrigo Borja, ex Presidente deEcuador; Kim Campbell, ex Primer M inistro deCa- 
nadá y Presidente del Club de M adrid; Aníbal Cavaco Silva, ex Primer M inistro de Portugal; Fernando H enrique Cardoso, ex Presidente de Brasil; Eduardo Frei, ex Presidente de Chile; Felipe González, ex Presidente del Gobierno Español; Antonio Guterres, ex Primer M inistro de Portugal; Osvaldo Hurtado, ex Presidente de Ecuador; Valentín Paniagua, ex Presidente de Perú; Jorge Quiroga Ramírez, ex Presidente de Bolivia; Carlos Roberto Reina, ex Presidente de H onduras; M iguel Ángel Rodríguez, ex Presidente de Costa Rica; Ernesto Zedillo, ex Presidente de M éxico; Julio M aría Sanguinetti, ex Presidente de U ruguay y Presidente de la Fundación Círculo de M ontevideo; César Gaviria, ex Presidente de Colombia y Secretario General dela OEA; Enrique Iglesias, Presidente del BID; José Antonio Ocampo, ex Secretario Ejecutivo dela CEPAL y actual Subsecretario General de la ONU para Asuntos Económicos y Sociales; Fernando Valenzuela, Director General Adjunto de Relaciones Exteriores de la Unión Europea; Guillermo de la D ehesa, ex Secretario de Estado de Economía de España; M iguel Ángel Fernández-Ordoñez, ex Secretario de Estado de Economía de España; Ernesto Garzón Valdés, Presidente Club de Tampere; Antonio Álvarez-Couceiro, Secretario General del Club de Madrid; Fernando Carrillo-Florez, Consejero Principal Oficina BID en Europa y Lucinio M uñoz, Adjunto al Secretario General del Club de Madrid.

Se agradece especialmente a J acques Le Pottier, Decano de la Facultad de Ciencias Económicas de la Universidad de Toulouse Le M irail, quien brindó su apoyo y facilitó el acceso a los recursos de esa universidad.

\section{Funcionarios de la Oficina \\ del Administrador del PNUD}

Se agradece a los funcionarios de la Oficina del Administrador del PNUD, especialmente a M arck Suzman, Jessica Faietta, William O rme y Victor Arango de la Oficina de Comunicaciones del Administrador.
Funcionarios de la Dirección para América Latina y el Caribe del PNUD

El personal del proyecto agradece particularmentela estrecha colaboración de los funcionarios del PNUD, en especial deFreddy Justiniano, Myriam M éndez-M ontalvo, Enrique Ganuza, y Gilberto Flores, Jacqueline Carbajal, Isabel Chang, Elisabeth Díaz, Cristina Fasano, Elena García-Ramos, Lydia Legnani, Cielo Morales, Susana Pirez, Juan M anuel Salazar, LuisFrancisco Thais, M aría- Noel Vaeza y Gemma Xarles.

\section{Funcionarios de la Oficina de Enlace del PNUD en Bruselas}

Se agradece a los funcionarios de la Oficina deEnlace del PNUD en Bruselas, O mar Baquet, M aría N oel Vaeza y Susana Etcheverry.

\section{Funcionarios de la Oficina del PNUD \\ en la Argentina}

La O ficina del PNUD en la Argentina, lugar Sede del proyecto, brindó una inestimable colaboración, y apoyo organizativo y administrativo, especialmente Carmelo Angulo Barturen, Jessica Fai eta, Silvia Rucks, Susana Gatto, Pablo Vinocur, José I gnacio López, Gerardo Noto, Liliana De Riz, Elba Luna, Sonia U rriza, Aldo García, Ana Inés Mulleady, M aría Angélica Wawrzyk, Ana Edmunds, Pablo Basz, M arcelo Bagnasco, Beatriz M artínez, Saioa Royo, Itziar Abad, M ercedes Ansotegui, Natalia Aquilino, Andrea Botbol, Cecilia Del Río, Daniela Del Río, Myriam Di Paolo, Claudio Flichman, Oscar González, Guillermo Iglesias, Beatriz López, M aría Inés Jezzi, Vivian Joensen, Juan Carlos Magnaghi, Marina Mansilla Hermann, Jorge Martínez, Santiago Redecillas, Walter Ricciardi, Ricardo Salas y Geraldine Watson, a quienes expresamos nuestro agradecimiento.

\section{Representantes Residentes, Adjuntos y Auxiliares de las Oficinas del PNUD en América Latina}

Jeffrey Avina, Kim Bolduc, Katica Cekalovic, Renata Claros, Juan Pablo Corlazzoli, Jorge Chediek, Juan Carlos Crespi, Ligia Elizondo, Jafet Enríquez, Niki Fabiancic, Elisabeth Fong, Walter Franco, Roberto Galvez, Susana 
Gatto, Peter Grohmann, Elizabeth H ayek, José Manuel Hermida, Henry Jackelen, Lorenzo Jiménes de Luis, Thierry Lemaresquier, Carlos Lopes, Carlos Felipe Martínez, Pablo M artínez, Alfredo Marty, César Miquel, Antonio Molpeceres, Roberto M onteverde, Bruno M oro, Clemencia Muñoz, Lucien M uñoz, Adelina Paiva, Barbara Pesce-M onterio, I rene Phillip, Benigno Rodríguez, Beat Rohr, M artín Santiago, Rosa Santizo, Ilona Szemzo, Aase Smedler, Claudio Tomasi, RenéM auricio Valdés, Jan-Jilles Van der Hoeven, Alfredo Witschi-Cestari.

\section{Los funcionarios de las Oficinas}

del PNUD en América Latina

Bolivia: Patricia Cusicanqui, Christian Jetté y Cecilia Ledesma.

Brasil: Johanna Clarke deVoest Silva, Gilberto Chaves, José Carlos Libânio, Filipe Nasser y Wilson Pires Soares.

Chile: Alejandra Cáceres, Josefa Errázuriz, Eugenio Ortega, O scar Muñoz, Carla Pietrantoni y M aría Teresa Vergara.

Colombia: Adriana Anzola, Alice Ayala, Carlos Mauricio García, Hernando Gómez
Buendía, Daniel Igartua, Patricia Lizarazu, Amalia Paredes, M auricio Ramírez y M aría del Pilar Rojas.

Costa Rica: Vera Brenes, Henry González y Arlene M éndez Solano.

Ecuador: José Balseca, Santiago Burbano y Norma Guerrero.

El Salvador: Esther López y M orena Valdez.

Honduras: Fátima Cruz, Doris Rivas, Karina Servellón y Lesly M aría Sierra.

Guatemala: Juan Alberto Fuentes, Myriam deLópez, Ingrid M elgar, Carmen M orales y Cecilia Zúñiga.

México: Arturo Fernández, Luz Patricia Herremann y Patricia M arrón.

Nicaragua: GloriaAltamirano y Dina García.

Panamá: M arta Alvarado.

Paraguay: Inés Brack y M aría Clavera.

Perú: Pilar Airaldi, Carolina Aragón y M ario Solari.

República Dominicana: Solange Bordas y Martha Elizabeth M artínez Correa.

Uruguay: Verónica Nori y M ónica Voss.

Venezuela: M ayra Cartaya y A Iberto Fuenmayor.

\section{Participantes en seminarios y reuniones}

En el diseño del compendio estadístico y la construcción de índices contamos con comentarios de Kenneth Bollen, Fernando CarrilloFlorez, M ichael John Coppedge, Freddy Justiniano, Fernando Medina, John Mark Payne, Adam Przeworski, Arodys Robles Soto, Michael Smithson, Jay Verkuilen, Gemma Xarles y Daniel Zovatto.

En una reunión para revisar el Índice de De mocracia Electoral aportaron sus conocimientos Horacio Boneo, Dante Caputo, Leandro Garcia Silva, Hernando Goméz Buendía, Freddy Justiniano, Juan Fernando Londoño, M yriam M endez-M ontalvo, Simón Pachano, Juan Rial, Elisabeth Spehar, M aria Hermínia Tavares deAImeida y JoséWoldenberg.

En el análisis del estado actual y las perspectivas de la democracia en América Latina participaron Héctor Aguilar Camín, Raúl Alconada
Sempé, Soledad Alvear, Julio Angel, Sergio Bitar, Dante Caputo, Jorge Castañeda, M arcelo Contreras, Nicolás Eyzaguirre, Álvaro Díaz, M arco Aurélio Garcia, M anuel Antonio Garretón, Gabriel Gaspar, Rodolfo Gil, Alonso González, Eduardo Graeff, Katty Grez, Jorge Heine, José M iguel Insulza, Ricardo Lagos, Thierry Lemaresquier, Edgardo Lepe, Jorge Levi M attoso, Ester Levinsky, Rodolfo M ariani, Elena M artínez, Guttemberg M artínez, Gonzalo M artner, Heraldo M uñoz, JoséAntonio O campo, Carlos O minami, Verónica Oyarzún, Augusto Ramírez Ocampo, Juan Ramírez, Jorge Reyes, Camila Sanhueza, Julio M aría Sanguinetti, Joseph Stiglitz, Federico Storani, Juan Gabriel Valdéz e Isabel Vásquez.

En la discusión sobre la crisis de la política, junto con el Círculo de M ontevideo, participaron Carmelo Angulo Barturen, Danilo Arbilla, 
Dante Caputo, Antonio Álvarez Cruceiro, Joaquín Estefanía, Aníbal Fernández, Eduardo Frei, Felipe González, O svaldo H urtado, Elena M artínez, Bartolomé M itre, Alfredo Negrete, Andrés O ppenheimer, Rodrigo Pardo, J. C. Pereyra, Rafael Poleo, Julio M aría Sanguinetti, M artín Santiago, Enrique Santos, Thomas Scheetz, Javier Solanas y Ernesto Tiffenberg.

En el análisis sobre democracia y Estado contribuyeron con su participación Diego Achard, Giorgio Alberti, Raúl Alconada Sempé, Antonio Álvarez Couceiro, José Luis Barros, Rodrigo Borja, Dante Caputo, Fernando Henrique Cardoso, Elisa Carrió, M arcelo Contreras Nieto, Alberto Couriel, Sonia Draibe, Gilberto Dupas, Gustavo Fernández Saavedra, Walter Franco, M anuel Antonio Garretón, Rodolfo Gil, George Gray M olina, Edmundo Jarquín, José Carlos Libânio, Rodolfo Mariani, Elena Martínez, Marcus M elo, Arturo O'Connell, Guillermo O'D onnell, Beatriz Paredes, Celi Pinto, Eduardo Piragibe Graeff, M árcio Pochmann, Augusto Ramírez Ocampo y Lourdes Sola.

En el debate sobre sociedad civil y narcotráfico participaron Carlos Basombrío, Fernando Calderón, Eduardo Gamarra, LuisJ orge Garay, Gonzalo Perez del Castillo, Elías Santana, Edelberto Torres Rivas, Franciso Thoumi y LuisVerdesoto.

En la discusión sobre democracia y multiculturalismo nos acompañaron Álvaro Artiga, Willem Assies, Santiago Bastos, Antonio Cañas, Julieta Castellanos, I sis Duarte, Galo Guardián, Francesca Jessup, Carlos Benjamín Lara, Carlos M endoza, Arodys Robles Soto, I gnacio Rodríguez, Gonzalo Rojas, M anuel Rojas, Leticia Salomón, Edelberto Torres Rivas, Jorge Vargas y Agatha Williams.

En el análisis sobre democracia y economía participaron Raúl Alconada Sempé, Alberto Alesina, Carlos Amat y León, José Luis Barros, M aría Elisa Bernal, Tim Besley, Dante Caputo, Alberto Couriel, Ricardo French-D avis, Enrique Ganuza, Innocenzo Gasparini, Rebeca Grynspan, Eugenio Lahera, Oscar Landerretche, Thierry Lemaresquier, M anuel M arfán, Juan M artín, Elena M artínez, Gonzalo M artner, Oscar Muñoz, Arturo O'Connell, José Antonio O campo, Carlos O minami, Torsten Persson,
Thomas Scheetz, Jorge Schvarzer, Andrés Solimano y Guido Tabellini.

En el análisis sobre democracia y globalización, junto con el Club deM adrid, participaron Andrés Allamand, Antonio Alvarez-Couceiro, Rodrigo Borja, DanteCaputo, Fernando Henrique Cardoso, Fernando Carrillo-Florez, Aníbal Cavaco Silva, Tarcísio Costa, M iguel Darcy, Guillermo de la Dehesa, M iguel Ángel FernándezOrdóñez, Eduardo Frei, Ernesto Garzón Valdés, FelipeGonzález, Antonio Guterres, Carlos Lopes, Elena M artínez, Lucinio M uñoz, Carlos Ominami, Beatriz Paredes, Jorge Quiroga Ramírez y Fernando Valenzuela.

En la discusión sobre condiciones para la estabilidad de las instituciones democráticas en Centroamérica participaron: Alberto Arene, $\mathrm{M} \mathrm{i-}$ guel Ángel Barcárcel, Rafael Guido Béjar, M arcia Bermúdez, M iguel Antonio Bernal, Roberto Cajina, Antonio Cañas, Zenayda Castro, Carlos Cazzali, Elvira Cuadra, Jorge Chediek, Francisco Díaz, M irna Flores, Dina García, Jorge Giannareas, Ricardo Gómez, Valdrack Jaentschke, FrancescaJ Jessup, Walter Lacayo, Semiramis López, José Raúl Mulino, Isabela Orellana, Alfonso Peña, Kees Rade, Juan Carlos Rodríguez, M aría del Carmen Sacasa, Gabriela Serrano, H éctor Hérmilo Soto, Edelberto Torres Rivas, Arnoldo Villagrán, Knut Walter.

\section{Reunión con el Secretario General de la ONU}

Participaron en la reunión con el Secretario General de la ONU, Sr. Kofi Annan, en Nueva York el 12 de noviembre de 2002, Belisario Betancur, ex Presidente de Colombia; Kim Campbell, Presidente del Club de M adrid (ex Primer M inistro deCanadá); Eduardo Frei, ex Presidente de Chile; Jorge Quiroga Ramírez, ex Presidente de Bolivia; Carlos Roberto Reina, ex Presidente de Honduras; Julio M aría Sanguinetti, ex Presidente de Uruguay; Ernesto Zedillo, ex Presidentede M éxico; Zéphirin Diabré, Administrador Asociado del PNUD; Shoji Nishimoto, Administrador Auxiliar y Director de Desarrollo de Políticas, PNUD; Elena M artínez, Administradora Auxiliar y Directora Regional para América Latina y el Caribe(DRALC) del PNUD; JoséAn- 
tonio O campo, ex Secretario Ejecutivo, Comisión Económica para América Latina y el Caribe (CEPAL) y actual Subsecretario General para Asuntos Económicos y Sociales de la ONU; Danilo Türk, Secretario General Asistente, Departamento de Asuntos Políticos (DPA); M arta M aurás, Directora dela Oficina del Secretario General Adjunto (EOSG); Michael Moller, Director de Asuntos Humanitarios, Políticos y de Mantenimiento de la Paz (EOSG); Angela Kane, Directora División para las Américas y Europa (DPA); Freddy Justiniano, Coordinador del Programa Regional, DRLAC/PNUD; y el siguientepersonal del Proyecto: Dante Caputo, Gonzalo Pérez del Castillo, Edelberto Torres Rivasy Augusto Ramírez Ocampo.

\section{Reunión con el Administrador del PNUD}

Participaron en la reunión con el Administrador del PNUD, Mark Malloch Brown, el 4 de noviembre de 2003, Elena M artínez, Administradora Auxiliar y Directora Regional para América Latina y el Caribe del PNUD; Víctor Arango, Especialista en Comunicaciones para América Latina y el Caribe, Oficina del Administrador; Magdy Martínez-Solimán, Jefe de Oficina, Práctica de Gobernabilidad, BDP/PNUD; William Orme, Jefe dela Sección M edios, Oficina del Administrador; Stefano Pettinato, Asesor en Políticas, Oficina del Informe de Desarrollo Humano del PNUD; Carmelo Angulo Barturen, Representante Residente del PNUD en la Argentina; Dante Caputo, Director del Proyecto; Freddy Justiniano, Coordinador del
Programa Regional, DRLAC, PNUD; Myriam M éndez-M ontalvo, Asesora de Gobernabilidad del Programa Regional, DRALC, PNUD; Leandro García Silva, Consultor Seguimiento Técnico y Académico del Proyecto, y Luis Francisco Thais, Consultor del Programa Regional, DRALC, PNUD.

\section{Apoyo en la preparación de reuniones y seminarios}

Agradecemos la especial colaboración de Isabel Vásquez, del Círculo de M ontevideo; Katty Grez y Verónica Oyarzún, de la Fundación Chile XXI; Ángeles M artínez e Irene Fraguas, del Club de M adrid; Bernardita Baeza, Carolina Ries y ValerieBiggs de CEPAL.

\section{Producción y traducción}

Para la desgrabación de las entrevistas de la Ronda de Consultas se ha contado con la colaboración de Maximiliano Bourel, M arcelo Burello, M aría Eva Cangiani, Valentina Farrell, Virginia Gallo, Guadalupe Guzmán, Erika M oeykens, Josefina Pittaluga, Julia Ramos, Natalia Rosenberg, Gisela Urriza y Geral dine Watson. La depuración del sonido de la grabación de las consultas fue realizada por Federico $M$. Guido Calvo.

La labor de traducción fue realizada por Marcelo Canosa, María Esperanza Clavell, YvonneFisher, Liliana Hecht, Gabriela I ppólito, Claudia Martínez y M erril Stevenson. La corrección de estilo estuvo a cargo de $\mathrm{H}$ inde Pomeraniec.

Hemos querido expresar nuestro agradecimiento a cada una de las personas que han contribuido a la realización de este Informe. Esperamos sepan disculpar cualquier posible omisión, sin lugar a duda totalmente involuntaria. 


\section{Nota técnica sobre el Índice de Democracia Electoral (IDE)}

Esta nota describe los pasos dados y las pruebas estadísticas realizadas para la construcción del Índice de Democracia Electoral (IDE), una medida compuesta sobre los derechos políticos relacionados con la elección de los gobiernos. Se presentan además aclaraciones sobre su interpretación y utilización.

\section{Construcción del IDE}

\section{La elección de los componentes}

El primer paso para la construcción del IDE, y probablementeel más importante, consistió en la elección de sus cuatro componentes: sufragio, elecciones limpias, elecciones libres y cargos públicos electos. Ellos fueron seleccionados considerando los elementos centrales tradicionalmenteinvocados por los teóricos sobrela democracia para la definición de un régimen democrático, y abarcan una serie detemas queen general han sido considerados centrales, incluso necesarios, para cualquier evaluación sobre el carácter democrático de un régimen político (figura 1).

En segundo lugar, estos elementos se refieren a derechos de la ciudadanía, cuya vigencia es responsabilidad del Estado, y que pueden ser interpretados claramente en términos

FIGURA 1

\section{El Índice de Democracia Electoral (IDE). Componentes}

\begin{tabular}{|c|c|c|c|}
\hline \multicolumn{4}{|c|}{ Índice de Democracia Electoral (IDE) } \\
\hline & & & \\
\hline erecho al voto & Elecciones limpias & Elecciones libres & Cargos públicos electos \\
\hline $\begin{array}{l}\text { país el derecho al } \\
\text { pas los adultos }\end{array}$ & $\begin{array}{l}\text { ¿Se desenvuelve el } \\
\text { proceso electoral sin } \\
\text { irregularidades que } \\
\text { constriñan la expresión } \\
\text { autónoma de las } \\
\text { preferencias de los } \\
\text { votantes por candidatos } \\
\text { y alteren el conteo } \\
\text { fidedigno de los votos } \\
\text { emitidos? }\end{array}$ & $\begin{array}{l}\text { ¿Es ofrecido al electorado } \\
\text { un rango de alternativas } \\
\text { que no son constreñidas } \\
\text { por restricciones legales o } \\
\text { de hecho? }\end{array}$ & $\begin{array}{l}\text { ¿Son las elecciones el } \\
\text { medio de acceso a los } \\
\text { principales cargos } \\
\text { públicos de un país, esto } \\
\text { es, el Ejecutivo y } \\
\text { Legislativo Nacional, y } \\
\text { asumen sus cargos } \\
\text { públicos y permanecen en } \\
\text { sus cargos durante los } \\
\text { plazos estipulados por la } \\
\text { ley los que ganan } \\
\text { elecciones? }\end{array}$ \\
\hline
\end{tabular}


de la teoría de la democracia vigente. De este modo, se evitan problemas asociados con elementos tales como la concurrencia de los votantes a las urnas o la desproporcionalidad el ectoral, que reflejan tanto las acciones estatales como las de los ciudadanos. Ello permite garantizar que el índice pueda ser interpretado claramente como una medida del grado en que el Estado garantiza los derechos de la ciudadanía referidos al régimen político, de modo diferenciado de la acción de los ciudadanos. De la misma manera, se evitan problemas relacionados con medidas de significación poco claras respecto del grado de democracia de un régimen, tales como la diferencia entre reglamentaciones electorales proporcionales y mayoritarias, o entre sistemas presidencialistas o parlamentaristas. Estos aspectos no carecen ciertamente de importancia, pero no están tan claramente conectados con el grado de democracia de un régimen como los cuatro el egidos.

En tercer lugar, estos elementos posibilitan contar con datos válidos y confiables del último año calendario. En este sentido, se ha puesto énfasis en la medición de componentes estrictamente observables, evitando el uso de encuestas sobre percepciones. Así, algunos componentes que podrían haber sido incluidos fueron dejados de lado por razones "prácticas".

Por último, se analizó un conjunto de factores que podrían haber sido incluidos y no lo fue ron, en gran parte debido a la dificultad de desarrollar mediciones apropiadas y a tiempo para este primer informe. Ello incluye factores asociados al ejercicio del derecho al voto, tales como el proceso de obtención de documentos de identidad, la inscripción o registro para votar y la votación misma, y las condiciones para la competencia libre, afectada por factores tales como el financiamiento de partidos y campañas, el uso de recursos públicos, el acceso a los medios de comunicación y la libertad de prensa. Otras cuestiones importantes involucran a las prácticas electorales en el nivel subnacional y a la estabilidad del régimen. Se deja como tema para futuras discusiones, la conveniencia de la construcción de nuevos índices.
La medición de los componentes

El segundo paso en la construcción del IDE - la medición de sus cuatro componentes- re quirió tomar dos decisiones clave. La primera tiene que ver con las reglas del proceso de codificación y la segunda, con el proceso de codificación en sí.

En cuanto a las reglas del proceso de codificación, las escalas - tres ordinales de cinco puntos y una ordinal de tres puntos- se construyeron determinando primero los puntos finales teóricamente significativos, y luego identificando distintos valores de escala lo más alejados conceptualmente como fuera posible, comenzando con el punto medio. Los valores de la escala fueron elegidos para reflejar distinciones relevantes de la bibliografía, evitando pequeñas variaciones entre casos, aunque fueran verificables. En los casos que no correspondían con precisión a ninguno de los puntos de las escalas ordinales, se introdujo el uso de signos más y menos como modo de registrar valores intermedios. Las escalas se construyeron también de manera que cada punto se correspondiera con situaciones y acontecimientos relativamente concretos, y que las decisiones de su codificación pudieran ser tomadas estrictamente sobre la base de observables. No se han incluido en el índice datos basados en encuestas sobre percepciones.

M ás aún, como una forma de asegurar la replicabilidad del ejercicio de codificación, y frente a posibles arbitrariedades, se subrayó la importancia de documentar las bases de las decisiones de codificación a través de la referencia a fuentes de información disponibles públicamente. No se han requerido puntajes para cada caso en cada año. Antes bien, sólo fueron requeridos los puntajes para tres de los componentes - derecho al voto, elecciones limpias y elecciones libres- para los años en los que se celebraron elecciones. Las condiciones para las elecciones están afectadas por acontecimientos y decisiones tomadas entre las elecciones, y la codificación ha tomado información entrelos períodos electivos. Pero la significación de estos acontecimientos y decisiones para el proceso por el cual los actores obtienen el acceso a los cargos 
gubernamentales, que es el interés central del ejercicio de medición, se cristaliza en el acontecimiento electoral en sí mismo. Así, aunque los puntajes fueron asignados a algunos componentes sólo durantelos años de elecciones, estos puntajes han sido entendidos como síntesis de procesos más amplios.

El segundo conjunto de decisiones se refiere al proceso de codificación en sí. En estesentido, se han utilizado dos procedimientos complementarios para codificar los casos. Un codificador particular realizó una codificación basándose en una investigación extensa y en consultas con numerosos expertos, a lo largo de un período de muchos meses. Los puntajes asignados fueron presentados y discutidos en profundidad en varios encuentros, incluido uno con un grupo de participantes invitados que trabajaban en diversos contextos ( política, academia, organizaciones internacionales), provenientes de diferentes países de las Américas (Argentina, Brasil, Canadá, Colombia, Ecuador, Estados Unidos, M éxico y Uruguay). Estas discusiones condujeron a la identificación de desacuerdos que llevaron a sucesivas investigaciones y más discusiones grupales. Finalmente, luego de este proceso iterativo, emergió un al to grado de consenso en lo que respecta a la codificación de las cuatro dimensiones del IDE.

\section{La generación de una base de datos rectangular con escalas normalizadas}

El tercer paso en la construcción del IDE fue la transformación de los puntajes en las escalas de los componentes en una base de datos rectangular, es decir, una base de datos que incluye puntajes numéricos para todos los casos en todas las variables y todos los años, con escalas normalizadas.

Este paso implicó una serie de procedimientos. Primero, se enfrentaron aspectos bastante mecánicos. Los signos más y menos fueron convertidos en números, agregando y sustrayendo 0,33 del puntaje base (por ejemplo, un 3+ fue convertido en un 3,33). Los guiones (-) utilizados para indicar quela asignación de un puntaje no era aplicable, debido a que el gobierno no provenía deuna elección, seconvirtieron en ce- ros (0). Además, los puntajes de dos de los componentes a los que se les asignaron puntajes sólo para los años en los que se celebró una elección -sufragio y elecciones libres- fueron extendidos a los años intermedios, simplemente trasladando el puntaje de un año dado a los años subsiguientes, hasta que se asignara un nuevo puntaje (ya sea porque se hubiera celebrado una elección luego de un período en el que existía un gobierno no electo, o porque se celebrara una nueva elección, o porque el proceso electoral se hubiera interrumpido). La justificación para este procedimiento es quela forma en la que un gobierno se origina continúa siendo una característica que afecta su naturaleza más allá del momento de su instalación.

En el caso de las elecciones limpias, se siguió un proceso ligeramente más complejo. En la codificación de este ítem se utilizó una escala de tres puntos para facilitar la interpretación. Sin embargo, el 1 de esta escala no representa en realidad un punto medio; es mucho más cercano al 2. Así, cada 1 fue convertido en un 3 y cada 2 en un 4. Además, debido a que este elemento distingue los valores asignados a las elecciones presidenciales y parlamentarias, los puntajes no han sido simplemente trasladados de elección a elección. Los puntajes son un promedio de los puntajes de las elecciones presidenciales y parlamentarias.

Un segundo aspecto considerado fue la asignación de un solo puntaje por país y por año. Esta práctica habitual obedece a razones de parsimonia, y está bien justificada. Después de todo, el objetivo de generar un índice es ofrecer una síntesis de la situación de un país. Pero ello implica varios problemas, debido a que la situación de un país cambia en el curso de un año, y se utiliza un solo puntaje para caracterizar todo el período anual. En algunos casos la solución es relativamente simple, cuando un acontecimiento clave -como la celebración de una elección- tenía lugar hacia fines de un año, el cambio de estatus debido a ese acontecimiento fue registrado en el año siguiente. Por ejemplo, cuando en 1985 se celebraron en Guatemala las elecciones que terminaron con un período de gobiernos dominados por los 
militares, esas elecciones tuvieron lugar a fines de año, y el cambio de gobierno se realizó en enero de 1986. Por tanto, aún cuando los puntajes para los elementos componentes fueron registrados en 1985, al computar el IDE esos puntajes fueron ingresados en 1986. Cuando los acontecimientos sucedieron en la primera mitad del año, fueron computados para tal año. Por ejemplo, las elecciones de 1994 en El Salvador se celebraron en marzo, y el cambio de gobierno en junio, por lo tanto el cambio fue registrado en 1994.

En otros casos la solución fue más complicada, ya que cuando un acontecimiento ocurrió en la segunda mitad del año fue registrado en ese año. Éste es el caso, por ejemplo, de las elecciones fraudulentas celebradas en mayo en la República Dominicana, y la nueva presidencia que asumió en agosto. También fueron problemáticos los casos en los que ocurrió más de un acontecimiento crítico en el mismo año. Por ejemplo, en el año 2000 Perú celebró dos elecciones fuertemente cuestionadas, en abril y mayo, que llevaron en julio a la asunción de Fujimori a la presidencia y luego a su renuncia en noviembre. En este caso, las elecciones problemáticas fueron registradas en el año 2000 y la rectificación de la situación en el año 2001.

En tercer lugar, se normalizaron las escalas de los componentes, es decir, fueron trasladadas a una métrica común, a través de una normalización lineal simple del intervalo unidad:

\section{valor normalizado = valor de escala original $/$ máximo valor posible en escala original}

Prácticamente cualquier opción que se hubiera tomado habría sido algo arbitraria, dado que no existen unidades de medida para la libertad electoral ampliamente aceptadas y comparables a unidades como kilogramoso dólares. Sin embargo, la elección del procedimiento de normalización tal como fue aplicado a las escalas ordinales de cinco puntos - con la modificación introducida en el elemento elecciones limpias, al transformar los puntajes de las escalas componentes en una base de datos rectangular, todas las escalas utilizadas para medir los cua- tro componentes son escalas ordinales de cinco puntos- es transparente y justificable.

Por un lado, todas las escalas tienen puntos finales con significación teórica, y puede suponerse que caen en el intervalo unidad, en el que 0 indica ausencia total de la propiedad y 1 indica presencia total de la propiedad. El valor inferior de la escala ordinal corresponde a la negación de la propiedad en cuestión, mientras que el valor superior corresponde a su presencia completa. Un caso con valor de derecho al voto 0 no presenta derecho al voto en absoluto, mientras que un caso con valor de derecho al voto 1 luego de la normalización tiene derecho al voto adulto completo, el estándar teóricamente establecido. Así, el problema de la distancia se refiere únicamentea los puntos comprendidos entreel punto inicial y el punto final.

Por otro lado, la mayor parte de las escalas fueron construidas de modo que cada punto de la escala fuera interpretable teóricamente y que los distintos valores de la escala estuvieran lo más alejados conceptualmente entre sí como fuera posible. Los valores de la escala fueron el egidos para reflejar distinciones identificadas como relevantes en la bi bliografía, evitando variaciones menores entre los casos verificables. Por lo tanto, la probabilidad de introducción de un error importante es relativamente pequeña. Aunque podrían utilizarse otros métodos psicométricos más sofisticados, éstos son más complicados, menos accesibles, fuertemente dependientes de los datos, y frecuentemente no funcionan mucho mejor que este procedimiento simple.

\section{La elección de reglas de agregación}

El cuarto paso para la construcción del IDE - la elección de reglas de agregación para formalizar la relación entre los elementos componentes del índice- fue resuelto a través del uso de una regla de agregación simple. La idea central utilizada para ello es la opinión bien establecida de que los cuatro elementos componentes del IDE son partes que constituyen un sistema en virtud de la forma en que están combinadas, y más aún, que estos cuatro componentes son tan fundamentales para la caracterización glo- 
bal de un régimen que su ausencia lo tornaría directamente no-democrático. Por ejemplo, como han argumentado largamente los teóricos sobre la democracia, el hecho de que los sistemas de tipo soviético tuvieran elecciones con sufragio completo carece de significación desde la perspectiva de la democracia, debido a que el electorado no tenía opción entre candidatos alternativos y debi do a que esas el ecciones no llevaron al acceso a cargos que ejerciesen efectivamente poder estatal.

Por lo tanto, los cuatro elementos componentes del IDE son postulados como condiciones individualmentenecesarias, insustituibles y de igual peso. Esta concepción queda formalizada calculando el producto del valor de cada uno de los elementos componentes. En términos formales, el IDE se calcula siguiendo la siguiente ecuación:

\section{Índice de Democracia Electoral $=$ Derecho al Voto $\mathrm{x}$ Elecciones Limpias $\mathbf{x}$ Elecciones Libres $\mathbf{x}$ Cargos Públicos Electos}

Esta ecuación recoge una idea clave de la teoría sobre la democracia: cuando un elemento componente se encuentra por completo ausente, el régimen debe ser considerado como nodemocrático. En la práctica, esta operación asegura que un valor cero en cualquiera de los cuatro elementos componentes lleva a clasificar el caso como no-democracia.

Éste es un estándar "duro", que puede ser visto como menos "perdonador" que otras reglas de agregación. La concepción de que los elementos componentes del IDE son condiciones individualmente necesarias es al tamente exigente, por ello ha sido utilizada conjuntamente con un criterio conservador en la asignación de ceros a los elementos componentes. Esto es así tanto para las escal as construidas de modo tal que un cero sea utilizado sólo en casos extremos, en los cuales se encuentra totalmente ausente una propiedad ampliamente considerada como vital para la existencia de la democracia, como en el sentido de que la evidencia necesaria para asignar un cero debe ser convincente. Por lo tanto, sólo cuando las nor- mas democráticas han sido indiscutiblemente dejadas de lado el IDE calificará a un país como no-democrático.

\section{Probando el IDE}

\section{Confiabilidad entre codificadores \\ y estimación de error}

Por razones de tiempo no se realizó una prueba formal de confiabilidad entre codificadores. Sin embargo, para saber si otros codificadores podrían haber tenido asignación de valores diferentes de los el ementos componentes del IDE, se llevó a cabo un análisis de sensibilidad. Este análisis se basa en perturbaciones a las codificaciones asignadas, de acuerdo con un diseño experimental y el examen del índice global "replicado" resultante. Así, utiliza las matemáticas para crear codificadores "virtuales" sesgados de diversos modos; por ejemplo, sesgados en una valoración inferior de uno o más componentes.

Los resultados de esta prueba mostraron que el IDE es bastante estable - las correlaciones de rango con todas las otras "réplicas" fueron 0,99 o mayores- y los cambios en la media y la dispersión fueron bastante predecibles, mostrando un sesgo negativo o positivo esperado según el diseño experimental. Esta prueba también proporcionó algunos márgenes de error básicos del IDE sobre la base de las "réplicas". Para valores del índice entre 0,25 y 0,75, un ancho de banda generoso es aproximadamente de $\pm 0,07$, y un ancho debanda razonablemente conservador es de $\pm 0,1$. De acuerdo con el estándar más conservador posible, los valores del IDE están dentro de $\pm 0,2$. Esteancho es razonablemente constante a lo largo del intervalo citado, pero los límites precisos dependen del valor del índicey en general son más estrechos cerca de los puntos finales. Se realizó un control matemático utilizando la inversión de la conocida y muy conservadora prueba deKolmogorov-Smirnov para la función de distribución - basada en matemáticas completamente diferentes- y se obtuvieron resultados similares. 
La so lidez de las reglas de agregación

Se realizó una prueba de comparación de cuatro reglas posibles de agregación para combinar los elementos componentes del IDE: el producto de los cuatro componentes utilizados en el IDE, el valor mínimo de los cuatro componentes de la escala, la media geométrica de los cuatro componentes y la media aritmética de los cuatro componentes. Los resultados mostraron que, sin importar qué regla se utilizaba, las correlaciones de rango son siempre muy altas, lo que indica que se preserva el ordenamiento general de los casos. Pero existen diferencias entrelos índices, siendo por un lado la media aritmética y la geométrica similares entre sí, y por otro lado, también similares entre sí el valor mínimo y el IDE. La diferencia más importante se encuentra entre las medias y las desviaciones estándar (DE). Las medias geométrica y aritmética son de 0,92 y 0,91, respectivamente, y DE de 0,20 y 0,21 respectivamente. En cambio, el valor mínimo y el IDE tienen medias de 0,84 y 0,82 respectivamente, y $D E$ de 0,26 y 0,28 respectivamente. Esto sugiere que aplicando estas últimas reglas es mejor la dispersión de los casos para evitar el conglomerado de casos que hace difícil interpretar sus diferencias con claridad.

\section{El carácter dimensional de los elementos componentes}

La prueba de escalabilidad de los cuatro elementos componentes del IDE dio como resultado un alfa de Cronbach de 0,92; lo que sugiere que el IDE es una medida de un fenómeno unidimensional. Sin embargo, cuando se realizó una prueba en dos períodos (1960-1985 y 1990-2002), los alfas de Cronbach resultantes fueron de 0,95 y 0,23 respectivamente. Esto indica que, mientras que en el primer período los componentes fueron unidimensionales, esto ya no resulta válido en el período posterior a 1990. Este resultado es consistente con la teoría utilizada al seleccionar las reglas de agregación para el IDE. En efecto, es importante notar que los modelos de medición aditivos estándar descansan en la presunción de que la agregación opera en múltiples mediciones paralelas. En contraste, dado que los componentes del IDE son, por teoría, considerados insustituibles, la decisión de agregarlos a un puntaje único no está invalidada por ninguna desviación potencial de la unidimensionalidad. De este modo, la prueba de escalabilidad proporciona aún más validación de la elección de las reglas de agregación propuestas en vez de la muy habitual regla de adición.

\section{Interpretando y usando el IDE}

El IDE es una escala de 0,00-1,00; en la cual 0,00 indica un régimen no democrático y cualquier número mayor a 0,00 un grado de democracia, siendo los puntajes más al tos indicativos de un mayor grado de democracia. Para evitar confusiones, es importante notar que el índice no debe ser interpretado como una evaluación de las acciones del gobierno. Más bien es una medida del estado de un sistema, que se ve afectado por la acción o inacción de un gobierno, así como por otros agentes estatales y actores sociales. Además, se debe resaltar queel concepto que se mide es el de democracia electoral. Este concepto no es tan estrecho como algunos lo consideran. Por lo tanto, aunque se focaliza completamente en la celebración de elecciones inclusivas, libres y limpias, abarca más que "simples elecciones". No sólo se ven afectadas las condiciones para celebrar tales elecciones por lo que sucede entre las elecciones. Además, lleva a considerar lo que ocurre con los mismos gobiernos entre las elecciones.

EI IDE no es ciertamente una medida amplia de la democracia. Es más bien una medida de una concepción del régimen político democrático basada en los postulados más ampliamente compartidos en cuanto a los derechos políticos fundamentales. Esto es muy significativo. Por un lado, implica que cualquier defecto detectado por el IDE debe ser considerado como una restricción importante a los derechos políticos de los ciudadanos. Por otro lado, el hecho de que un país haya recibido un puntaje perfecto de 1,00 no debe interpretarse en el sentido de que no pueda mejorar tanto las dimensiones no incluidas en el índice 
como los estándares más exigentes de los elementos componentes del IDE.

El IDE puede ser utilizado para propósitos comparativos, tanto para comparar un país consigo mismo o con otros países. De estas dos formas, la comparación de un país consigo mismo en diferentes momentos es en general la más simple para interpretar. Después de todo, un país bien puede haber introducido mejoras notables y sin embargo quedar en inferioridad frente a otros países, si estos han hecho avances mayores. Sin embargo, es importante notar que cualquier comparación debe basarse en diferencias considerables y no menores. La razón de ello es que el IDE, como cualquier índice, tiene un cierto grado de error de medición y dentro de los límites de ese error se desaconseja realizar cualquier afirmación contundente sobre diferencias. De hecho, como fue estimado a través del análisis de sensibilidad, para los valores de IDE entre 0,25 y 0,75; un ancho de banda de error generoso es aproximadamente de $\pm 0,07$. Así, cualquier par de casos que difieran en menos de este valor - por ejemplo, un país con un IDE de 0,85 y otro con uno de 0,92- están demasiado cerca como pa- ra poder distinguirlos con validez. Por tanto, es metodológicamente injustificable ofrecer un ránking demasiado preciso de países, como es habitual en el contexto de otros índices, que simplemente transforman los puntajes del IDE en un ránking sin tomar en consideración los grados de incertidumbre asociados con los mismos. La identificación de casos de referencia que sean representaciones prototípicas de los rasgos asociados con una gama de puntajes puede ayudar a brindar mayor concreción al significado de cada número.

EI IDE puede ser utilizado también como señal, en el sentido de que los puntajes específicos de cada país invitan al lector a volver a los cuadros de los elementos componentes para identificar precisamente qué aspecto 0 aspectos dan cuenta de ese puntaje. De este modo, el IDE puedeser usado como una herramienta analítica valiosa, en cuanto ofrece un puntaje resumido que permite a quienes lo usen identificar el carácter distintivo del régimen político de cada país, en términos de sus elementos componentes pero también en términos de la relación entre las partes constitutivas del régimen y su contribución al conjunto. 



\section{Nota técnica sobre los índices derivados del análisis de la encuesta Latinobarómetro 2002}

\section{La construcción del Índice de Apoyo a la Democracia (IAD)}

\section{Presentación}

La presente nota técnica describe la fuente de información, el diseño metodológico y los procedimientos estadísticosaplicados en la elaboración delos principalesíndices eindicadores empleados para el análisis de las percepciones y los comportamientos de las ciudadanas y los ciudadanos en América Latina. Explica el sentido, la utilidad y el alcance deestosíndices eindicadores. Las descripciones contenidas en este documento complementan los cuadros presentados en el Compendio estadístico. Para explicaciones más detalladas es conveniente consultar la memoria del proceso metodológico y estadístico aplicado, compuesta por nueve documentos más extensos, disponible en la página web del Informe La Democracia en América Latina: www.democracia.undp.org (Benavides y Vargas Cullell, 2003; Gómez, 2003; Kikut, Gómez y Vargas Cullell, 2003a, 2003b; Kikut y Vargas Cullell, 2003; Vargas Cullell, Benavides y Gómez, 2003a, 2003b; Vargas Cullell y Benavides, 2003; Vargas Cullell y Gómez, 2003).

El documento contiene dos secciones. La primera, que introduce el estudio de opinión sobre la democracia, presenta una valoración general sobre la encuesta Latinobarómetro como fuente de información, e indicaciones sobre los datos y métodos de análisis empleados en el estudio. En la segunda sección se describe, con de talle, el proceso metodológico para la elaboración del Índice de A poyo a la Democracia (IAD) y sus partes componentes, que constituyen la principal innovación del estudio.

\section{Estudio de opinión sobre la democracia}

La sección del Informe "Cómo ven los Latinoamericanos a su democracia" se basa en el trabajo realizado por un equipo coordinado por Jorge Vargas Cullel e integrado por M iguel Gómez, Lorena Kikut y Tatiana Benavides. Este equipo elaboró el marco conceptual y metodológico a partir del cual fueron definidos los índices e indicadores respectivos, y efectuó el análisis de la información cuyo objetivo principal fue posibilitar un estudio comparativo sobre el ejercicio de los derechos y deberes ciudadanos en América Latina e indagar sobreel apoyo ciudadano a la democracia.

Esta sección describe las fuentes de datos en las que se basa al análisis presentado en el Informe. Invitamos al lector especializado que desee ampliar la información a consultar la documentación detallada sobreel planteo conceptual y las decisiones metodológicas del análisis en el sitio web de PRODDAL, www.democracia.undp.org.

Los datos del PRODDAL son elaborados a partir de desarrollos conceptuales propios y procedimientos metodológicos y aplicaciones técnicas que permiten arribar a resultados específicos, que no son necesariamente coincidentes con los de lasfuentesutilizadas. Losíndices eindicadores sobre percepciones y comportamientos ciudadanos aplican información extraída de tres fuentes, en el marco de un convenio entreel PNUD y Latinobarómetro: 


\section{Latinobarómetro como fuente de Información}

Latinobarómetro es un estudio comparativo que periódicamente se realiza en todos los países de la región. En el año 2002, mediante un convenio entre el PNUD y Latinobarómetro se incorporaron a la encuesta 28 preguntas (62 variables), aproximadamente una tercera parte del cuestionario, dedicadas a temas definidos por el PRODDAL. La encuesta se aplicó en idioma español en 18 países (por primera vez se realizó en la República Dominicana), utilizando el mismo cuestionario y libro de códigos. Se entrevistaron 19.508 personas, y las muestran varían entre 1.000 y 1.200 personas por país. Todos los diseños emplean alguna versión del muestreo polietápico y, prácticamente en todos, la selección final de los entrevistados se realiza sobre la base del muestreo de cuota. Debido a ello, las muestras pueden estar afectadas por las limitaciones y los sesgos conocidos del muestreo de cuota (ver CD/Compendio Estadístico, Segunda Parte, "Estudio de Opinión sobre la Democracia").
- La sección regular del estudio de opinión realizado por la Corporación Latinobarómetro en el año 2002.

- La sección propietaria del PNUD.1

- La seriehistórica de preguntas de Latinobarómetro, de modo secundario.

A partir de estas fuentes y sobre la base del planteamiento conceptual y metodológico, se elaboró el Índice de Apoyo a la Democracia (IAD). Para su construcción fue necesario analizar:

- La cuestión general del apoyo ciudadano a la democracia, su modo de medición y las fragilidades del método más ampliamente utilizado.

- Las orientaciones de los ciudadanos hacia la democracia, su determinación y la clasificación de las opiniones.

- El tamaño de cada una de las orientaciones, su activismo político y la distancia relativa.

- La regla deagregación del Índice y su validación estadística.
Estos temas se presentan en el apartado que sigue.

\section{Datos y metodología}

El objetivo principal de la sección propietaria del PNUD fue posibilitar un estudio comparativo sobre el ejercicio de los derechos y deberes ciudadanos en América Latina. Ello complementó la indagación quela sección regular de Latinobarómetro efectúa sobre las actitudes políticas en un amplio conjunto de temas. Los índices e indicadores sobre las percepciones y los comportamientos ciudadanos utilizan información de tres fuentes: la sección regular, la sección propietaria dePNUD y, secundariamente, de la serie de tiempo. La información proveniente de la sección propietaria está reflejada en los cuadros del Compendio estadístico. En cambio, la información proveniente de la sección regular únicamente se presenta en forma ya procesada, como parte de un determinado indicador o índice.

\section{Diseño de las muestras}

El Informe metodológico del Latinobarómetro 2002 permite un comentario sobre las muestras utilizadas en Latinobarómetro 2002, con el fin de identificar aspectos relevantes para el adecuado uso de su información. Se trata de una valoración simple, pues el texto

1 La sección propietaria del PNUD, de uso exclusivo, comprende las preguntas P1U a P28U del cuestionario utilizado para el estudio de opinión. 
no presenta la información necesaria para una auditoría técnica de las muestras, lo que impide poner atención sobre algunas eventual es debilidades del planteamiento técnico. ${ }^{2}$ Por consiguiente, las observaciones de esta sección son de carácter general e inevitablemente insuficientes. Aun así, permiten precisar ciertas precauciones para el manejo ulterior de los datos.

Del examen de las principales características de los diseños utilizados en cada uno de los países se derivan las siguientes conclusiones generales:

- Todos los diseños emplean alguna versión del muestreo polietápico y, prácticamente en todos, la selección final de los entrevistados se realiza usando el muestreo de cuota. En un par de casos se emplea la técnica al eatoria "último cumpleaños" pero, en la práctica, se procede a reemplazar al seleccionado si no está presente en la vivienda o no aparece en un plazo corto. Debido a ello, todas las muestras están afectadas por las limitaciones y sesgos conocidos del muestreo de cuota, particularmente por una subestimación de las personas que tienen menor disponibilidad - en especial aquellas que tienen trabajos de jornada completa- y una sobrestimación de las que trabajan por cuenta propia o en su domicilio.

- Prácticamente todos los diseños emplean estratificación geográfica y según el tamaño de las localidades y ciudades. La mitad de las muestras utiliza afijación desproporcionada. Cabe señalar que esto, por sí mismo, no plantea problemas, porque luego se emplean factores de ponderación para obtener resultados en proporción a la población de referencia.
- Para al gunos países existe un sesgo muestral hacia la población urbana, lo cual implica, en estos casos, una sobrerrepresentación de las opiniones de la población urbana en los promedios de esos países.

En resumen, puede decirse que, aunque Latinobarómetro refleja para algunos países fundamentalmente la opinión de la población urbana-lo cual puede producir una distorsión en los datos finales-, es sin lugar a duda la fuente de información que mejor muestra las opiniones de la población dela región en su conjunto. Por consiguiente, en este Informe se adoptó esa base de datos para el análisis de la opinión sobre la democracia en América Latina.

\section{Análisis estadísticos}

En el análisis estadístico realizado para el Informe La Democracia en América Latina, sobre la base de Latinobarómetro, se utilizó el software SPSS, versión 11. Los métodos de análisis estadístico empleados fueron simples. Para establecer la asociación entre dos variables numé ricas se aplica el coeficiente de correlación de Pearson, cuyos valores oscilan entre 0 y 1 . Para establecer la asociación entre variables nominales se empleó la medida V de Crammer y, cuando se trata de una variable ordinal y otra nominal, se utilizó Tau-c.

Para integrar la información de preguntas que, a primera vista, parecen referirse a un mismo tema, en todos los casos se hicieron análisis factoriales con el fin de determinar dimensiones implícitas, y se elaboraron escalas por simplesuma. Como indicador de la consistencia o confiabilidad interna de las escalas así construidas se aplica el coeficiente Alfa de Crombach (coeficientes de 0,70 o más se consideran confiables y consistentes). Si no sealcanza este valor, se desecha la escala respectiva. Cuando ello ocurre, se utilizó cada una de las variables de manera independiente (como se hizo con el Índice de Apoyo a la Democracia).

2 Para un análisis crítico del Latinobarómetro 2002 consultar el documento preparado por Miguel Gómez para el Informe Democracia en América Latina (Gómez, 2003). 
Durante el proceso de análisis dela información se emplearon técnicas de profiling (perfil), para examinar si los valores de una variable dependiente estaban asociados a determinados factores sociodemográficos y actitu des políticas. Se destacó aquellas que tuvieran un nivel de significación igual o inferior al 1\% (ver Compendio estadístico).

\section{Unidad de análisis}

Las unidades de análisis para el estudio del tema del apoyo a la democracia y, en particular, el Índice de Apoyo a la D emocracia (IAD) y sus componentes fueron los países. Se obtuvieron también valores para América Latina en su conjunto (18 países) y para tres subregiones: a) M éxico, República Dominicana y Centroamérica (que incluye a Guatemala, El Salvador, Honduras, Nicaragua, Costa Rica y Panamá); b) Región andina (Venezuela, Colombia, Ecuador, Perú y Bolivia); c) M ercosur y Chile (Brasil, U ruguay, Argentina, Paraguay y Chile). Estos valores expresan promedios del grupo de países dentro de la unidad mayor, considerando cada país como una unidad con un mismo peso. En consecuencia, no se ponderó la muestra con las respectivas poblaciones para arribar a conclusiones categóricas sobre "América Latina" o para una de las subregiones antes indicadas, por las siguientes razones:

- Las ciudadanas y los ciudadanos formulan opiniones y valoraciones en relación con el sistema político del cual forman parte y no en relación con una "macrounidad" política latinoamericana. La mayoría de los asuntos a los que ellas se refieren son problemas de orden nacional (por ejemplo, el desempeño de la democracia). De ahí que las diferencias nacionales son todas de igual peso/valoración. Si, para efectos del estudio, se ponderase la muestra por población para obtener tendencias a nivel latinoamericano, éstas básicamente reflejarían las opiniones y valoraciones de brasileños y mexicanos (aproximadamente 60 por ciento de la población total). Así, no obstante el peso que tendrían dentro de la muestra ponderada, tanto unos como otros referirían sólo a la experiencia de sus países particulares, y no a los de América Latina.

- Los tamaños de muestra originales para cada país no fueron establecidos por la Corporación Latinobarómetro, para facilitar un análisis posterior que, al mismo tiempo que obtuviese resultados representativos para la población de América Latina en su conjunto, arrojase resultados representativos para cada uno de los países incluidos en el estudio. Si se ponderase la base de datos consolidada actual por población, a los países de menor tamaño (por ejemplo, Uruguay, Nicaragua, Costa Rica) les correspondería una cuota muy pequeña.

- Los diseños muestrales en los países incluidos en el estudio son claramente distintos. Como fue indicado en secciones anteriores, unas muestras son nacionales, otras son urbanas e, incluso, en algunos países cubren sólo ciertos centros urbanos. Por ejemplo, el universo de la muestra de Brasil contempla ciertas ciudades y no toda la población; si se ponderara la muestra de Brasil por su población, en realidad, se estaría dando un peso excesivo a los habitantes de los centros urbanos en comparación con los habitantes de otros países donde las muestras parecen ser un poco más "nacionales".

Cuando se efectuó el profiling de las personas con diversa orientación a la democracia, se utilizó la muestra en su conjunto, sin ponderar. En estos casos, los resultados reflejan la situación de la población entrevistada en su conjunto, y no de "las y los latinoamericanos". 
Precisión de los resultados 33

Toda encuesta por muestreo está afectada por dos tipos de errores: los de no muestreo 4 y los de muestreo. 5 Debido a que no se conocen los resultados de una auditoría técnica de Latinobarómetro 2002, no es posible referirse a los errores de no muestreo. Por otra parte, el análisis de los errores de muestreo es muy limitado debido a quela información contenida en el Informe metodológico 2002 no permite presentar los errores de muestreo (errores estándar, EE) y los efectos de diseño (ED) para índices y preguntas seleccionados. Se carece, en consecuencia, de información a nivel de la unidad primaria de observación, por lo cual no es posible presentar un dictamen sobre la razonabilidad de la precisión de las estimaciones.

En términos muy generales, puede decirse que en casos como los de Costa Rica, las naciones centroamericanas y Brasil, donde el tamaño promedio del conglomerado final no es muy alto -alrededor de 13 entrevistados-, si se suponen valores de roh usuales de 0,02 a 0,04, el ED alcanza como máximo 1,50; lo cual significa que la conglomeración aumenta la variancia de $p$ en un $50 \%$, y el error de muestreo, en un $22 \%$, magnitudes totalmentetolerables. N o obstante, en otros casos, como el de Ecuador, el procedimiento de seleccionar ciudades o municipios y luego submuestrearlos, produce niveles deconglomeración elevados (50 o más entrevistados), y el ED puedeser de 3 o 4, lo cual implica errores de muestreo de 1,73 o 2 veces los obtenidos aplicando la fórmula usual.

\section{Muestras totales, muestras válidas y no respuestas}

El tamaño de la muestra total de Latinobarómetro 2002 en los 18 países donde se realizó el estudio es de 19.508 casos. $^{6} \mathrm{~A}$ los datos de Paraguay se les dio una ponderación doble con el fin de simular una muestra de 1.200 personas en ese país. Después de ponderar la muestra total, el tamaño de la muestra ponderada pasó de 19.501 a 20.101 (cuadro 1). Todos los cálculos y estimaciones se realizaron sobre la base de esta muestra, que incluye la ponderación doble de Paraguay. Los motivos que justificaron esta decisión fueron los siguientes:

- Permitir a Paraguay tener un peso similar en el estudio que el resto de los 18 países; de lo contrario, pesaría como "medio país" cuando se agrega información para analizar la situación regional (América Latina) o subregional (Mercosur y Chile).

3 La explicación sobre los errores de muestreo y no muestreo es tomada literalmente de la redacción efectuada por Luis Rosero-Bixby para el estudio sobre Cultura democrática en Costa Rica 2004, del Proyecto de O pinión Pública de la Universidad deVanderbilt (Vargas Cullell y Rosero-Bixby, 2004).

4 Los errores de no muestreo son aquellos que se cometen durante la recolección y el procesamiento de la información; éstos se pueden controlar construyendo un adecuado instrumento de medición, entrenando a los encuestadores para una correcta aplicación del instrumento, supervisando el trabajo de campo, creando un programa de captura de datos eficiente, revisión de cuestionario y adecuada codificación, así como una limpieza del archivo, entreotros. Estos errores no se pueden cuantificar. Sin embargo, la comparación de los resultados de la muestra con los de la población da una idea de si esos errores han generado sesgos que le restan representatividad.

5 Los errores de muestreo son producto del azar y resultan del hecho de entrevistar una muestra y no el total de la población. Cuando se selecciona una muestra, ésta es una de las tantas muestras posibles a seleccionar de la población. La variabilidad que existe entre todas esas posibles muestras es el error de muestreo, el cual podría medirse si uno dispusiese de todas esas muestras, situación obviamente irreal. En la práctica, lo que se hacees estimar ese error sobre la variancia obtenida a partir de la misma muestra. Para estimar el error de muestreo de un estadístico (promedios, porcentajes, diferencias y totales), se calcula el error estándar, que es la raíz cuadrada de la variancia poblacional del estadístico. Esto permite medir el grado de precisión con que ese estadístico se aproxima al resultado obtenido al haber entrevistado todos los elementos de la población bajo las mismas condiciones. Para el cálculo de esteerror es muy importante considerar el diseño con el que se seleccionó la muestra.

6 Cuando el estudio cubría 17 países, el tamaño de la muestra no ponderada era de 18.508 casos. Al incluirse República Dominicana se agregaron 1.000 registros más. 


\begin{tabular}{ll}
\hline Número de entrevistas o tamaño de la muestra no ponderada (17 países) & 18.508 \\
\hline Tamaño de la muestra ponderada (17 países) & 18.501 \\
\hline Tamaño de la muestra ponderada (18 países, luego de incluir a la República Dominicana) & 20.101 \\
\hline Tamaño de la muestra ponderada (18 países con doble ponderación para Paraguay)
\end{tabular}

Fuente: Elaboración propia con base en Latinobarómetro 2002.

- Si se hubiese empleado una muestra de 1.200 personas en las mismas localidades en donde se aplicó la encuesta, los resultados no tendrían que ser muy distintos de los queefectivamentese obtuvieron con el estudio de 600 personas, si seutilizaran los mismoscriteriosy se aplicaran apropiadamente las técnicas de muestreo estadístico.

\section{La decisión de omitir la "no respuesta"}

Desde el inicio del análisis se decidió no considerar la "no respuesta". Los "no sabe" y "no responde" se unieron para declararlos como missing (valores faltantes). Esto se hace también en el cálculo de las orientaciones hacia la democracia, en el marco del Índice de Apoyo a la Democracia (IAD). En este caso, la supresión de la "no respuesta" es necesaria para efectos de análisis, con el fin de no hacer supuestos acerca de las actitudes de las personas que se ubicaron en esa categoría.

La decisión adoptada es consecuente y consistente con el contenido total de los textos. Para llevar a cabo los análisis multivariados y la construcción de índices complejos, la no consideración de la "no respuesta" como alternativa fue sistemática. Para evitar la inducción a error de la no consideración de la "no respuesta", para todos los resultados se incluye el tamaño de muestra en la que están basados, o muestra efectiva (" $n$ " de respuestas válidas). De esta manera, siempre es posible la reconstrucción de los valores originales y deducir, así, el volumen de "no respuesta".
Al dar mayor peso a Paraguay, se modifican muy levemente los resultados promedio del conjunto de los países de América Latina (en décimas de punto porcentual) y cambian un poco los resultados promedio de los países de la subregión del Mercosur y Chile (dos a tres puntos porcentuales), en relación con los que se obtendrían de no haber ponderado la muestra de Paraguay. Sin embargo, se supone, por lo antes dicho, que estos cambios serían los esperados de haberse realizado un estudio sobre la base de 1.200 personas consultadas.

En la práctica, debido a las "no respuestas", las muestras válidas son menores que el total, y distintas según la variable bajo consideración. Las tablas del Compendio estadístico presentan las muestras totales y las váli das para la mayoría de las variables que fueron empleadas en el análisis. En algunos casos el porcentaje de no respuesta es bajo - por ejemplo, cuando se trata de variables sociodemográficas como la edad, el sexo o el nivel de educación del entrevistado-. Sin embargo, en otros casos el porcentaje de no respuesta es elevado, especialmente cuando se agruparon preguntas para formar los índices que se emplean en el análisis de resultados, lo que produce un tamaño de muestras válidas inferiores. El cuadro 2 presenta esa diferencia en relación con el Índice de Apoyo a la Democracia, que se analizará en detalle en la sección que sigue. 


\begin{tabular}{|c|c|c|c|}
\hline \multicolumn{4}{|c|}{ MUESTRAS TOTALES Y MUESTRAS VÁLIDAS PARA EL ÍNDICE DE APOYO } \\
\hline \multicolumn{4}{|c|}{ A LA DEMOCRACIA EM PLEADO EN EL ANÁLISIS DE LATINOBARÓMETRO } \\
\hline \multirow[t]{2}{*}{ País } & \multirow[t]{2}{*}{ Muestra total } & \multicolumn{2}{|c|}{ Índice de Apoyo a la Democracia } \\
\hline & & Muestra válida* & $\%$ de "no respuesta"* \\
\hline Argentina & 1.200 & 964 & 19,7 \\
\hline Bolivia & 1.242 & 886 & 28,7 \\
\hline Brasil & 1.000 & 663 & 33,7 \\
\hline Colombia & 1.200 & 768 & 36,0 \\
\hline Costa Rica & 1.006 & 808 & 19,7 \\
\hline Chile & 1.188 & 873 & 26,5 \\
\hline Ecuador & 1.200 & 938 & 21,8 \\
\hline El Salvador & 1.014 & 577 & 43,1 \\
\hline Guatemala & 1.000 & 703 & 29,7 \\
\hline Honduras & 1.005 & 747 & 25,7 \\
\hline México & 1.210 & 1.031 & 14,8 \\
\hline Nicaragua & 1.016 & 833 & 18,0 \\
\hline Panamá & 1.010 & 794 & 21,4 \\
\hline Paraguay & 1.200 & 1.011 & 15,8 \\
\hline Perú & 1.224 & 856 & 30,1 \\
\hline Rep. Dominicana & 1.000 & 909 & 9,1 \\
\hline Uruguay & 1.187 & 926 & 22,0 \\
\hline Venezuela & 1.200 & 928 & 22,7 \\
\hline América Latina** & 20.101 & 15.217 & 24,3 \\
\hline
\end{tabular}

Notas:

* Luego del rescate de casos, por medio de los procedimientos que se indican en los siguientes documentos: Kikut, Gómez y Vargas Cullell, 2003a, 2003b; Vargas Cullell y Kikut, 2003.

** Los valores para la región difieren de la suma de los totales por país por razones de redondeo de los totales ponderados, hecho automáticamente por el programa estadístico. Las cifras de las muestras totales por país indicadas en el cuadro fueron obtenidos tras aplicar ponderación. Fuente: Compendio estadístico.

\section{Presentación de resultados}

En el texto principal del Informe, los porcentajes de cuadros y gráficos se refieren a las muestras válidas y no a las muestras totales. En todos los casos, se incluye el tamaño de muestra en la que están basados, o muestra efectiva, por lo que siempre es posible la reconstrucción de los valores originales y deducir así el volumen de "no respuesta".

En el caso de los cuadros y gráficos referidos al IAD y a los modos de participación ciudadana, la muestra válida incluye los casos rescatados mediante el procedimiento descrito en el texto metodológico respectivo (Kikut, Gómez y Vargas, 2003, pp. 13-16). Se excluyen los valores faltantes, o de "no respuesta" (no sabe y no responde). La exclusión de la "no respuesta" de los resultados en el análisis de los datos es necesaria a fin de no hacer supuestos acerca de las actitudes de las personas que se ubicaron en esa categoría, que pueden influir sobre los resultados de los análisis multivariados y la construcción de los índices.

\section{El método de medición del apoyo ciudadano a la democracia y sus fragilidades \\ En la encuesta Latinobarómetro se ha em- pleado una pregunta para dar seguimiento a la lealtad de las ciudadanas y los ciudadanos lati- noamericanos hacia la democracia. ${ }^{7}$ La pregun- ta dice:}

7 En círculos académicos, políticos y periodísticos se trata esta pregunta como una medida-resumen del apoyo ciudadano a la democracia e, indirectamente, de la "salud" de ésta; año tras año se observan con especial atención sus resultados. 
PROPORCIÓN DE PERSONAS QUE APOYAN LA DEMOCRACIA CON RESPUESTAS

"INESPERADAS" EN RELACIÓN CON EL APOYO A MEDIOS

AUTORITARIOS PARA RESOLVER PROBLEMAS

CUADRO 3

\begin{tabular}{|c|c|c|}
\hline & & Pregunta P32ST \\
\hline Pregunta & ¿Está usted de acuerdo...? & $\begin{array}{l}\text { Porcentaje que apoya el sistema democrático y que } \\
\text { está de acuerdo con... }\end{array}$ \\
\hline P28UA & Con que el presidente no se limite & \\
\hline \multirow[t]{2}{*}{ P28UB } & Con que el presidente ponga orden & \\
\hline & por la fuerza & 32,3 \\
\hline P28UC & Con que el presidente controle los medios & \\
\hline P28UD & Congreso y a los partidos & 32,9 \\
\hline \multirow[t]{3}{*}{ P38STB } & No me importaría que un gobierno & \\
\hline & no democrático llegara al poder si resolviera & \\
\hline & los problemas del país & 44,9 \\
\hline
\end{tabular}

Notas: No se incluyen respuestas NS/NR. En el caso de las personas que manifiestan apoyar un sistema democrático, se suman las respuestas "en desacuerdo" y "muy en desacuerdo" con cada una de las afirmaciones.

Fuente: Elaboración propia con base en Latinobarómetro 2002.

¿Con cuál de las siguientes frases está usted más de acuerdo?

1. La democracia es preferible a cualquier otra forma de gobierno.

2. En algunas circunstancias, un gobierno autoritario puede ser preferiblea uno democrático.

3. A la gente como uno, nos da lo mismo un régimen democrático que uno no democrático.

Así, las personas que escogen la respuesta 1 ("Ia democracia es preferible") son las queapoyan la democracia; las que eligen la respuesta 2 son las que apoyarían su reemplazo por un sistema auto- ritario, y las que seleccionan la respuesta 3 tienen un comportamiento ambivalente, potencialmente problemático. Si a lo largo del tiempo la frecuencia de la respuesta 1 aumenta, se supone que el apoyo a la democracia se incrementa; si disminuye, dicho apoyo declina. La mejor situación para la democracia de un país sería aquella en quela ca si totalidad de los entrevistados escoge la respuesta 1 y, por el contrario, la peor sería aquella en que la mayoría se inclina por la respuesta 2.

La pregunta - codificada en la encuesta Latinobarómetro 2002 con la claveP32ST - hasido criticada como medida del apoyo a la democracia8 (Seligson, 2000). No obstante, es útil como pun-

8 Seligson argumenta que, al no especificar la idea de democracia que las personas poseen, la pregunta P32ST tiene un componente de indeterminación. Propone, en cambio, explorar el apoyo al sistema mediante una batería alternativa de preguntas (Seligson, 2000). Aunquesu observación plantea la necesidad de mantener una actitud cautelosa en la interpretación de los resultados, su crítica no necesariamente invalida la pregunta como punto de entrada al examen del apoyo ciudadano a la democracia. La debilidad apuntada por Seligson puede ser resuelta examinando la pregunta P32ST en relación con otras del mismo Latinobarómetro, en particular la P30ST ("Para usted, ¿quésignifica democracia?") y la P31ST ("La gente a menudo difiere en sus puntos de vista sobre las características más importantes de la democracia. De la lista, escoja una sola característica que para usted sea la más esencial en una democracia"). 


\begin{tabular}{|c|c|}
\hline \multicolumn{2}{|c|}{ PROPORCIÓN DE PERSONAS QUE APOYAN LA DEMOCRACIA CON RESPUESTAS } \\
\hline \multicolumn{2}{|c|}{ "INESPERADAS" EN RELACIÓN CON SU VALORACIÓN SOBRE LA DISYUNTIVA } \\
\hline \multicolumn{2}{|c|}{ ENTRE DEMOCRACIA Y DESARROLLO } \\
\hline & Pregunta 32ST \\
\hline Pregunta 35ST & Porcentaje que apoya el sistema democrático y que está de acuerdo con... \\
\hline Democracia es más importante & 32,8 \\
\hline Ambas por igual & 20,7 \\
\hline Desarrollo es más importante & 46,4 \\
\hline
\end{tabular}

Nota: No se incluyen respuestas NS/NR.

Fuente: Elaboración propia con base en Latinobarómetro 2002.

to de entrada al tema, pues las personas adoptan una posición, prima facie, frentea su idea de la democracia. Si bien la pregunta P32ST es un punto de entrada útil, como medida-resumen inicial al tema de la lealtad ciudadana con la democracia, ello no significa que, por sí misma, sea suficiente para un tratamiento en profundidad del apoyo ciudadano, o una buena medida indirecta de la "salud" de la democracia.

Cuando se relaciona la pregunta P32ST con otras que miden el apoyo o la aceptación de reglas democráticas, surgen resultados que, a primera vista, pueden parecer inesperados 0 simplemente inconsistentes. Una significativa proporción de las personas que dicen apoyar la democracia muestra, al mismo tiempo, actitudes contrarias al funcionamiento deinstituciones básicas de la democracia (como el Congreso y los partidos) y apoyo a gobernantes que utilicen me dios autoritarios para resolver los problemas del país. Respuestas igualmente "inesperadas" surgen cuando se examina el apoyo declarado a la democracia en relación con, por ejemplo, la valoración de ésta como un buen sistema de gobierno, o su prioridad frentea otros valores socialmenterelevantes, como en la alternativa entre desarrollo y democracia (cuadros 3 y 4 ).

Ante estas respuestas inesperadas pueden adoptarse básicamente dos posiciones. Por una parte, puede empleárselas como evidencia para argumentar la veleidad del apoyo declarado por las personas a un régimen. Si la preferencia por la democracia es sólo retórica, se tendría que de sechar la pregunta P32ST como medida de la lealtad ciudadana al régimen, debido a su escaso interés analítico. Correspondería, entonces, buscar otras variables que muestren comportamientos más estables. A juicio de este estudio, tal posición es equivocada. Implica no sólo asumir que las respuestas inesperadas son siempre el reflejo de actitudes inconsistentes, cosa que no es necesariamente cierta, sino que lo inesperado carece de interés para el análisis.

En sentido contrario a la posición anterior, las respuestas inesperadas pueden emplearse como punto de partida para un estudio de las leal tades ciudadanas a la democracia. Si éstefuera el caso, la pregunta P32ST, queindaga sobre el apoyo "en general" a la democracia, debería ser analizada en relación con otras preguntas que exploran dimensiones más concretas de ese apoyo, con el fin de determinar si las respuestas "inesperadas" obedecen a actitudes meramente inconsistentes de las y los ciudadanoso si, vistas en su conjunto, revelan patrones de opinión. En principio, la idea sería examinar si es posible distinguir los sectores queconsistentemente tienen actitudes democráticas, tanto en términos generales como en asuntos específicos, de aquellos quemuestran actitudes pro autoritarias. Esta segunda posición es la adoptada en el Informe.

Desdeun punto devista inductivo, explorar la interrelación entre variables plantea la necesidad de contar con un concepto que permita estudiar 
si las actitudes de apoyo o de rechazo al régimen democrático llegan a conformar posiciones determinadas. Este concepto, además, debería ser una herramienta que-adaptando el enfoque de Linzhaga posibleel análisis de la vulnerabilidad delas democracias latinoamericanas. Para cumplir con ambos fines, se plantea el concepto de "orientaciones hacia la democracia".

Cabe agregar un último comentario sobre la fuente de información disponible. El estudio de las orientaciones hacia la democracia en América Latina utiliza información provenientedeuna encuesta de opinión pública. Aunque se trata deun material valioso, debetenerseen cuenta que, a veces, las opiniones reflejan sólo de manera aproximada el pensamiento delas personas. Los individuos pueden encubrir sus verdaderos puntos de vista; las preguntas y escalas de medición pueden tener defectos queles impiden cumplir con el fin para el que fueron diseñadas $y$, aun cuando las y los entrevistados contesten con honestidad y las preguntas funcionen bien, no necesariamente lo que las personas responden refleja los valores $y$ creencias que sustentarán sus reacciones ante situaciones concretas.

\section{El Índice de Apoyo a la Democracia (IAD)}

El Índice de apoyo a la democracia (IAD), elaborado para el Informe, es la medida-resumen para estudiar el respaldo ciudadano a la democracia. ${ }^{9}$ Combina los indicadores de tamaño, activismo político y distancia de las orientaciones hacia la democracia. Es la al ternativa metodológica al análisis de este tema basado en la lectura de variables por separado. ${ }^{10}$ Esta sección seinicia con una descripción del procedimiento y pruebas aplicadas para determinar estas orientaciones y luego describe el IAD y sus componentes.

Las orientaciones hacia la democracia son posiciones de apoyo o rechazo a la democracia, identificadas a partir de un conjunto de actitudes acerca de la preferencia por la democracia y la aceptación de las normas en las que ésta se basa. Este concepto surge de una adaptación de la teoría de Juan Linz sobre la quiebra de las democracias (Linz, 1978). Linz plantea que, en relación con la permanencia o sustitución de un régimen democrático, pueden encontrarse en la ciudadanía tres alineamientos: las fuerzas políticas que son leales al sistema; las desleales, que procuran derribarlo, y las semileales, que tienen actitudes ambivalentes y contradictorias. Además, estipula las condiciones propicias para el quiebre de la democracia; afirma que una crisis de régimen derriba a una democracia cuando los desleales son capaces de atraer hacia sus posiciones a los semileales. Las orientaciones hacia la democracia conservan el significado delos alineamientos de Linz (leal, semileal y desleal). Sin embargo, para facilitar la comprensión del análisis a los lectores no especializados se rebautizaron las orientaciones de la siguientemanera: a los leales se los denominó "demócratas"; a los semileales, "ambivalentes", y a los desleales, "no demócratas".

El análisis de las orientaciones procura responder los siguientes interrogantes: iexisteentre los ciudadanos latinoamericanos una corriente deopinión contraria a la democracia que puede constituirse en la base de apoyo social de una fuerza política "desleal"?, ¿quétan extendida está esa corriente de opinión vis-à-vis aquella que

9 En la elaboración del IAD se procuró ser congruentes con el concepto amplio de democracia que preconiza el informe (la democracia es más que un régimen político). En efecto, las preguntas que se consideraron para determinar las orientaciones de las personas sobre la democracia, base sobre la cual se erige el IAD, incluyen tanto actitudes sobre la democracia como régimen político y sus instituciones políticas representativas, que refieren, en palabras de M azzuca, a la dimensión de acceso al poder, como sobre la democracia más allá del régimen político, o dimensión de ejercicio del poder.

10 La lectura de frecuencias simples de las variables fueron el punto de entrada para el análisis pero no son su pilar. Toda pregunta debe ponerse en contexto, examinarse en relación con otras, para tener una mejor aproximación al significado de los datos. De lo contrario, se corre el riesgo deformular interpretaciones antojadizas basadas en la "espectacularidad" o la conveniencia de una cifra. Evitar este riesgo es precisamente no de los propósitos del análisis de las orientaciones. 
apoya a la democracia?, ¿quiénes son las personas más activas en la vida política de un país: los opositores al sistema o los que lo apoyan?, ¿cuán amplio es el segmento con actitudes ambivalentes?; desdeel punto de vista de sus actitudes, ¿están los ambivalentes más cerca de los opositores al sistema?; ¿cómo varía el tamaño de la base social de estas corrientes de opinión?

El concepto de orientaciones hacia la democraciano es, sin embargo, idéntico al delosalineamientos políticos de Linz. En primer lugar, Linz estudia situaciones históricas para extraer de ahí una teoría comparativa. Las orientaciones son una herramienta para aproximarse al tema de la vulnerabilidad dela democracia antela eventualidad deuna crisis de régimen, estudiando el apoyo ciudadano a ella. En segundo lugar, las orientaciones identifican los patrones deactitud de lasy los ciudadanos, pero no posibilitan una observación directa del comportamiento de estos actores.

El punto de partida para la identificación de las orientaciones hacia la democracia fue la revisión del cuestionario de Latinobarómetro 2002. Se aplicaron sucesivos análisis factoriales a un amplio conjunto de preguntas que, en principio, miden actitudes sobre la democracia, el desarroIlo, los valores y la confianza interpersonal. El propósito fue identificar las preguntas directamente relacionadas con el tema de las actitudes de apoyo a la democracia. ${ }^{11}$ Este proceso permitió seleccionar once preguntas (cuadro 5).

En todos los análisis, las preguntas seleccionadas se agruparon consistentemente en tres factores (cuadro 6). El factor 1 forma la dimensión de actitudes delegativas. Explica un 23,5 por ciento de variancia. El factor 2 compone la dimensión de apoyo a la democracia como siste- ma de gobierno (16,5 por ciento de la variancia), y el factor 3 se ubica en una dimensión de apoyo a instituciones de la democracia representativa ( 13,8 por ciento de la variancia). La variancia explicada acumulada fue de 53,8 por ciento. 12 Las pruebas de confiabilidad mostraron que no era conveniente usar índices sumativos derivados de las dimensiones generadas por el análisis factorial, por lo que se trabajó de manera independiente con cada una de las variables.

La técnica sel eccionada para determinar, con base en estas preguntas, la ubicación de los entrevistados y entrevistadas en una u otra orientación hacia la democracia, fue el análisis de conglomerados o clusters. Ésta es una herramienta exploratoria que se utiliza con el fin de resolver problemas declasificación, pues contribuye a revelar asociaciones y estructuras presentes en los datos que no son observables previamente. Su objetivo es asignar los casos a grupos, denominados clusters, de manera quelos miembros de un mismo grupo sean similares entre sí en cuanto a las características seleccionadas, mientras quelos miembros de diferentes grupos sean relativamente diferentes.

El análisis de conglomerados puede realizarse de diversas maneras, dependiendo de la medida de similaridad y el método empleado. En estecaso, debido a la magnitud de la base de datos con que se cuenta, se trabajó calculando la distancia euclidiana como medida de similaridad y utilizando luego el método de partición dek-medias. Este procedimiento requiere que el investigador determinea priori el número $(\mathrm{k})$ deconglomerados que desea obtener 13 la teoría de Linz permitió definir $k=3)$. En general, es deseable fundamentar el número de conglomerados en una

11 El coeficiente de Kaiser-M eyer-OIkin de adecuación de la muestra para estas once variables fue de 0,77 ; y selo considera apropiado para proceder a utilizarlo en un análisis factorial.

12 La agrupación de las once variables de interés en los tres factores indicados cumple con el método Kaiser-Guttman (eigenvalores mayores a uno), si bien la variancia explicada por ellos no es particularmente alta. Se consignan los porcentajes obtenidos en el factorial aplicado con las variables de interés, sin incluir el resto de las variables inicialmente consideradas.

13 El algoritmo de análisis de clusters encontrará grupos una vez que se hayan definido las variables que entrarán en juego y se haya establecido la instrucción del número de clusters que se desea obtener. Es importante, entonces, contar con un modelo que respalde la identificación de esos grupos y luego validar sus resultados teórica y empíricamente, de acuerdo con las características de los individuos asignados a cada uno de ellos. 


\begin{tabular}{|c|c|}
\hline \multicolumn{2}{|c|}{ ONCE PREGUNTAS EMPLEADAS PARA IDENTIFICAR LAS ORIENTACIONES } \\
\hline HACIA LA D & IOCRACIA \\
\hline Pregunta p32st: & $\begin{array}{l}\text { ¿Con cuál de las siguientes frases está usted más de acuerdo? "La democracia es preferible a cualquier otra } \\
\text { forma de gobierno", "En algunas circunstancias, un gobierno autoritario puede ser preferible a uno } \\
\text { democrático", "A la gente como uno, nos da lo mismo un régimen democrático que uno no democrático". }\end{array}$ \\
\hline Pregunta p35st: & $\begin{array}{l}\text { Si usted tuviera que elegir entre la democracia y el desarrollo económico, ¿qué diría usted que es más } \\
\text { importante? }\end{array}$ \\
\hline Pregunta p37no2: & $\begin{array}{l}\text { ¿Usted cree que la democracia es indispensable como sistema de gobierno para que este país pueda ser un } \\
\text { país desarrollado?, o ¿usted cree que no es indispensable; es posible llegar a ser un país desarrollado con otro } \\
\text { sistema de gobierno que no sea la democracia? }\end{array}$ \\
\hline Pregunta p38stb: & $\begin{array}{l}\text { ¿Está muy de acuerdo, de acuerdo, en desacuerdo o muy en desacuerdo con la siguiente afirmación? "No me } \\
\text { importaría que un gobierno no democrático llegara al poder, si pudiera resolver los problemas económicos". }\end{array}$ \\
\hline Pregunta p39st: & $\begin{array}{l}\text { Hay gente que dice que sin Congreso Nacional no puede haber democracia, mientras que hay gente que dice } \\
\text { que la democracia puede funcionar sin Congreso Nacional. ¿Cuál frase está más cerca de su manera de } \\
\text { pensar? }\end{array}$ \\
\hline Pregunta p40st: & $\begin{array}{l}\text { Hay gente que dice que sin partidos políticos no puede haber democracia, mientras que hay otra gente que } \\
\text { dice que la democracia puede funcionar sin partidos. ¿Cuál frase está más cerca de su manera de pensar? }\end{array}$ \\
\hline Pregunta p41st: & $\begin{array}{l}\text { Algunas personas dicen que la democracia permite que se solucionen los problemas que tenemos en el país. } \\
\text { Otras personas dicen que la democracia no soluciona los problemas. ¿Cuál frase está más cerca de su manera } \\
\text { de pensar? }\end{array}$ \\
\hline Pregunta p28ua: & $\begin{array}{l}\text { Si el país tiene serias dificultades, ¿está muy de acuerdo, de acuerdo, en desacuerdo o muy en desacuerdo con } \\
\text { que el presidente... "no se limite a lo que dicen las leyes"? }\end{array}$ \\
\hline Pregunta p28ub: & $\begin{array}{l}\text { Si el país tiene serias dificultades, ¿está muy de acuerdo, de acuerdo, en desacuerdo o muy en desacuerdo con } \\
\text { que el presidente... "ponga orden por la fuerza"? }\end{array}$ \\
\hline Pregunta p28uc: & $\begin{array}{l}\text { Si el país tiene serias dificultades, ¿está muy de acuerdo, de acuerdo, en desacuerdo o muy en desacuerdo con } \\
\text { que el presidente... "controle los medios de comunicación"? }\end{array}$ \\
\hline Pregunta p28ud: & $\begin{array}{l}\text { Si el país tiene serias dificultades, ¿está muy de acuerdo, de acuerdo, en desacuerdo o muy en desacuerdo con } \\
\text { que el presidente... "deje de lado al Congreso y los partidos"? }\end{array}$ \\
\hline
\end{tabular}

Fuente: Latinobarómetro 2002.

teoría existente, pues ello permite describir cada uno de ellos y, sobre todo, contar con elementos de juicio para entender sus implicaciones.

El método seleccionado de k-medias está orientado a la clasificación de variables cuantitativas. Las once preguntas utilizadas en la determinación delas orientaciones hacia la democracia tienen una escala de medición que no llega a alcanzar el nivel de intervalo. No obstante, todas ellas evidencian una clara direccionalidad relacionada con la actitud hacia la democracia de las personas entrevistadas. Por ello se juzgó apropiado emplear este método. Con este fin, las variables fueron recodificadas para darles a sus escalas de medición un mismo rango y dirección. Posteriormente, las respuestas recodificadas se aplicaron en el análisis de conglomerados. ${ }^{14}$

Las pruebas de estabilidad y confiabilidad de

14 Zhexue Huang (1997) indica que "el procedimiento habitual de convertir datos categóricos en valores numéricos 


\begin{tabular}{|c|c|c|c|c|}
\hline \multicolumn{5}{|c|}{ CARGAS FACTORIALES PARA ONCE PREGUNTAS DE INTERÉS EN LA DETERMINACIÓN } \\
\hline \multicolumn{4}{|c|}{ DE LAS ORIENTACIONES HACIA LA DEMOCRACIA } & \multirow{2}{*}{$\begin{array}{l}\text { CUADRO } 6 \\
\text { Factor } 3\end{array}$} \\
\hline Dimensión & Pregunta & Factor 1 & Factor 2 & \\
\hline \multirow[t]{4}{*}{ Actitudes delegativas } & Presidente más allá de leyes & 0,74 & & \\
\hline & Presidente ponga orden por la fuerza & 0,81 & & \\
\hline & Presidente controle medios & 0,80 & & \\
\hline & Presidente deje de lado partidos y Congreso & 0,77 & & \\
\hline \multirow{5}{*}{$\begin{array}{l}\text { Apoyo a la democracia } \\
\text { como sistema de gobierno }\end{array}$} & Preferencia por democracia & & 0,67 & \\
\hline & Democracia o desarrollo & & 0,58 & \\
\hline & Democracia indispensable para desarrollo & & 0,69 & \\
\hline & No importa gobierno autoritario si soluciona problemas & & 0,48 & \\
\hline & Democracia soluciona problemas & & 0,57 & \\
\hline \multirow{3}{*}{$\begin{array}{l}\text { Apoyo a las instituciones } \\
\text { representativas }\end{array}$} & Democracia sin congreso & & & 0,84 \\
\hline & Democracia sin partidos & & & 0,85 \\
\hline & Variancia explicada & 23,50 & 16,50 & 13,80 \\
\hline
\end{tabular}

Nota: Se incluyen sólo cargas factoriales mayores a 0,450.

Fuente: Elaboración propia con base en Latinobarómetro 2002.

Ios clusters arrojaron resultados satisfactorios. Por una parte, diferentes órdenes de la base de datos arrojaron variaciones muy pequeñas en los centroides de las once variables: 50 por ciento tenían desviaciones estándar menores a 0,03. Por otra parte, para asegurar que los resultados fueran confiables, se calculó el promedio de 42 resultados, con el fin de utilizar esta información como los "centroides" iniciales que se le proporcionan al algoritmo del análisis de conglomerados. 15 Además, se diseñó una metodología para rescatar los casos con una o dos respuestas faltantes, lo que permitió elevar de 12.020 a 14.308 los casos habilitados para el estudio ( 74,9 por ciento de la muestra total).

El cluster 1 es consistentemente positivo en sus valores estandarizados, por lo que puede decirse que los individuos ubicados en este grupo tienen una orientación demócrata. El cluster 2 puede calificarse como de personas ambivalentes, pues tiende a presentar valores positivos en las dimensiones de apoyo a la democracia y de apoyo a las instituciones de la democracia representativa, pero valores negativos en la dimensión de actitudes delegativas. Por último, el cluster 3 presenta centroides negativos en diez de las variables, siendo el único valor positivo muy cercano a cero, por lo que se puede afirmar que las y los ciudadanos clasificados en este grupo tienen una orientación no demócrata (cuadro 7).

Con el propósito de verificar la importancia delas diferencias de las medias de los conglomerados en las variables empleadas para definirlos, seusó un análisis de variancia por cluster. Se efectuó un estudio post hoc con la prueba de Scheffé al 5 por ciento de significancia. ${ }^{16} \mathrm{El}$ resultado fue que las diferencias son significativas para las once variables en los tres conglomerados. Es de-

no necesariamente produce resultados interpretables en aquellos casos en que los dominios categóricos no están ordenados". Sin embargo, tal como se ha mencionado, en este caso los datos sí tienen una direccionalidad y, como se verá posteriormente, los resultados son relevantes.

15 Es importante indicar que, una vez introducidos los centroides iniciales, el resultado del análisis de clusters no varía ante diferentes órdenes de la base de datos.

16 Cuando, al llevar a cabo un análisis de variancia, se rechaza la hipótesis nula, se acepta que al menos una delas medias de los grupos es diferente. Para conocer la relación entre esas medias y determinar cuál o cuáles de ellas son di- 


\begin{tabular}{|c|c|c|c|c|c|c|c|}
\hline \multicolumn{8}{|c|}{ CENTROIDES OBTENIDOS PARA CADA UNA DE LAS VARIABLES RELACIONADAS } \\
\hline \multicolumn{7}{|c|}{ CON LA DEMOCRACIA, POR CLUSTER IDENTIFICADO } & \multirow{2}{*}{$\begin{array}{l}\text { CUADRO } 7 \\
\text { n }\end{array}$} \\
\hline \multirow[b]{2}{*}{ Dimensión } & \multirow[b]{2}{*}{ Pregunta } & \multicolumn{3}{|c|}{$\begin{array}{c}\text { Centroides } \\
\text { estandarizados }\end{array}$} & \multicolumn{2}{|c|}{$\begin{array}{l}\text { Centroides sin } \\
\text { estandarizar }\end{array}$} & \\
\hline & & $\begin{array}{l}\text { Cluster } 1 \\
\text { Positivo }\end{array}$ & $\begin{array}{l}\text { Cluster } 2 \\
\text { Central }\end{array}$ & $\begin{array}{l}\text { Cluster } 3 \\
\text { Negativo }\end{array}$ & $\begin{array}{l}\text { Cluster } 1 \\
\text { Positivo }\end{array}$ & $\begin{array}{l}\text { Cluster } 2 \\
\text { Central }\end{array}$ & $\begin{array}{l}\text { Cluster } 3 \\
\text { Negativo }\end{array}$ \\
\hline \multirow[t]{6}{*}{ Actitudes delegativas } & Presidente más allá de leyes & 0,511 & $-0,707$ & $-0,004$ & 3,09 & 2,01 & 2,63 \\
\hline & Presidente ponga orden & & & & & & \\
\hline & por la fuerza & 0,609 & $-0,816$ & $-0,010$ & 3,25 & 1,97 & 2,68 \\
\hline & Presidente controle medios & 0,582 & $-0,812$ & 0,037 & 3,26 & 2,01 & 2,77 \\
\hline & Presidente deje de lado partidos & & & & & & \\
\hline & y Congreso & 0,612 & $-0,755$ & $-0,107$ & 3,25 & 1,99 & 2,58 \\
\hline Apoyo a la democracia & Preferencia por democracia & 0,464 & 0,080 & $-0,772$ & 3,72 & 3,28 & 2,29 \\
\hline \multirow[t]{5}{*}{ como sistema de gobierno } & Democracia o desarrollo & 0,345 & $-0,017$ & $-0,438$ & 2,47 & 2,00 & 1,47 \\
\hline & $\begin{array}{l}\text { Democracia indispensable para } \\
\text { desarrollo }\end{array}$ & 0,455 & 0,383 & $-1,090$ & 3,83 & 3,75 & 1,78 \\
\hline & No importa gobierno autoritario & & & & & & \\
\hline & si soluciona problemas & 0,514 & $-0,268$ & $-0,416$ & 2,88 & 2,17 & 2,02 \\
\hline & Democracia soluciona problemas & 0,274 & 0,326 & $-0,691$ & 3,07 & 3,15 & 1,64 \\
\hline \multirow{2}{*}{$\begin{array}{l}\text { Apoyo a instituciones } \\
\text { representativas }\end{array}$} & Democracia sin congreso & 0,379 & 0,006 & $-0,595$ & 3,38 & 2,87 & 1,98 \\
\hline & Democracia sin partidos & 0,372 & 0,029 & $-0,572$ & 3,32 & 2,85 & 1,94 \\
\hline
\end{tabular}

Nota: En todas las variables el rango de la escala es de 1 (actitud más contraria a la democracia) a 4 (actitud más favorable a la democracia). Las preguntas de la dimensión de apoyo a instituciones representativas son binarias y esto les resta poder de discriminación.

Fuente: Elaboración propia con base en Latinobarómetro 2002.

cir, todas las preguntas incluidas en el análisis son útiles para diferenciar los tres grupos.

Se validó la agrupación del análisis de conglomerados por medio del análisis discriminante. Con este fin se tomó una muestra aleatoria deaproximadamenteel 30 por ciento delos datos, a la que se le proporcionó información de los grupos de pertenencia de los casos de acuerdo con lo obtenido en los clusters. Con base en ello se obtuvieron las funciones discriminantes, las cuales fueron aplicadas al restante 70 por ciento de los casos para determinar en cuáles grupos se ubicarían. En el 30 por ciento de la muestra utilizada, el 93,4 por ciento de los datos se ubicó correctamente en el grupo asignado por el análisis de conglomerados con base en las funciones discriminantes generadas. En el 70 por ciento de los datos empleados para validación se obtuvo que un 92,6 por ciento delos casos fue asignado correctamente, para una asignación certera de la muestra global del 92,9 por ciento. Puede decirse que dicho porcentajees alto y determina la validez de la agrupación realizada por el análisis de conglomerados. ${ }^{17}$

ferentes y cuáles iguales entre sí, se utilizan los procedimientos post hoc. Este tipo de técnica se emplea para probar las diferencias entre los datos comparando todos los posibles pares de medias, con el fin de determinar aquellas que son diferentes. Existe una amplia variedad de pruebas post hoc. La planteada por Scheffées útil para probar la significancia de todos los posibles pares de medias y es la que se recomienda emplear cuando se comparan grupos con diferente número de casos, como ocurre en el presente ejercicio (Steel y Torrie, 1996).

17 El total de casos usados por el análisis discriminante se reduce a 12.020 individuos que contestaron las once preguntas de interés, por cuanto este análisis se realiza únicamente con aquellos casos que tienen toda la información. No se esperarían grandes diferencias en la ubicación de aquellos datos "rescatados" por tener una o dos preguntas con no respuesta, en virtud de que se comprobó que el perfil de estos individuos no difiere mucho de las personas que sí tenían valores en las once variables de interés. 
Las tres dimensiones del IAD

El Índice de Apoyo a la Democracia (IAD) es una medida-resumen del apoyo ciudadano a la democracia. Se elabora a partir de la asignación de las personas a cada uno de los clusters que identifican las tres orientaciones hacia la democracia. Combina tres dimensiones que responden a las siguientes cuestiones:

- ¿Cuál es el tamaño de las orientaciones hacia la democracia en la ciudadanía? La mejor situación para una democracia es aquella en la que la orientación demócrata agrupa a la mayoría de las y los ciudadanos.

- ¿Cuál es el grado de activismo político de las orientaciones? La mejor situación para una democracia es aquella en la que la orientación demócrata esno sólo la demayor tamaño sino, además, la más activa.

- ¿Cuál es la distancia, o magnitud de las diferencias de opinión, entre las orientaciones? El punto crítico es determinar si, en términos generales, los ambivalentes están más cerca de la orientación demócrata o de la no demócrata. La mejor situación es aquella en que la distancia entre los ambivalentes y los demócratas es bastante más pequeña que la existente entre los primeros y los no demócratas.

Los indicadores eíndices de apoyo ciudadano son escalas de intervalo. No tienen cero absoluto; los valores expresan una mayor o menor cercanía con respecto a una situación pero no expresan proporciones. Por ser herramientas en proceso de depuración, no se tienen criterios para categorizarlas y crear escalas de intensidad.

\section{Primera dimensión: tamaño de una orientación}

Por tamaño de una orientación hacia la democracia se entiende la cantidad de personas que pertenecen a un cluster. Para medir esta dimensión el IAD emplea el indicador de proporción de demócratas con respecto a los no demócratas. 18 Este indicador ilustra una situación crítica: si, aun siendo minoría, la orientación demócrata es o no de mayor tamaño que la no demócrata, sus adversarios "naturales". 19

(1) Proporción demócratas a no demócratas = Qd / Qnd

donde Q $\mathrm{d}$ = cantidad de personas con orientación demócrata; $\mathrm{Q}$ nd = cantidad de personas con orientación no demócrata.

Cuando en un país o subregión los demócratas son más que los no demócratas - una condición mínimamente deseable-, el indicador toma un valor superior a 1. La peor situación se da cuando estos indicadores tienen un valor inferior a 1 y cercano a 0 . Existen, por otra parte, diversas situaciones de equilibrio político que arrojan valores cercanos a 1 .

\section{Segunda dimensión: activismo político de las orientaciones}

Por activismo de una orientación hacia la democracia se entiende la proporción de sus miembros que participa activamente en la vida política del país. Una orientación es más activa cuanto mayor sea la proporción de ciudadanos participativos que la componen.

En esta dimensión se aplicó un procedi-

$18 \mathrm{H}$ ay otros dos indicadores detamaño cuyos resultados se comentan en el Informe, pero que no fueron empleados para el IAD. El primero es el indicador de mayoría democrática. Este indicador expresa la proporción de demócratas en relación con el resto (ambivalentes y no demócratas) y determina si los demócratas son una mayoría, o no. El indicador es igual o mayor a 1 cuando la proporción de demócratas es igual o superior al 50 por ciento de la ciudadanía. El segundo indicador es el tamaño relativo de la orientación demócrata con respecto a la ambivalente. Cuando adopta valores mayores a 1 , indica que los demócratas son más que los ambivalentes.

19 Esta idea se adoptó del análisis financiero, en donde existe un indicador denominado "prueba ácida". Ésta determina, en el corto plazo, la vulnerabilidad de una empresa, es decir, si ésta tiene capacidad para pagar sus deudas de corto plazo. Se define como la razón entre el activo circulante y el pasivo circulante. 


\begin{tabular}{|c|c|c|c|c|}
\hline \multicolumn{5}{|c|}{ PROCEDIMIENTO APLICADO PARA DETERMINAR LOS MODOS } \\
\hline \multicolumn{5}{|l|}{ DE PARTICIPACIÓN CIUDADANA } \\
\hline Dimensión & & & & Descripción \\
\hline \multirow[t]{2}{*}{ Participación electoral } & $\mathrm{PE}$ & 0 & $=$ & No vota \\
\hline & & 1 & $=$ & Vota \\
\hline \multirow[t]{2}{*}{ Participación social } & PSO & 0 & $=$ & No colabora \\
\hline & & 1 & $=$ & Colabora en al menos 1 actividad \\
\hline \multirow[t]{2}{*}{ Participación contactando autoridades } & PCO & 0 & $=$ & No contacta \\
\hline & & 1 & $=$ & Contacta al menos a 1 autoridad \\
\hline \multirow[t]{2}{*}{ Participación en manifestaciones colectivas } & PMC & 0 & $=$ & No participa \\
\hline & & 1 & $=$ & Participa en al menos 1 manifestación colectiva \\
\hline \multirow[t]{2}{*}{ Participación violenta } & PVI & 0 & $=$ & No participa \\
\hline & & 1 & $=$ & $\begin{array}{l}\text { Participa en al menos } 1 \text { acto violento, } \\
\text { independientemente de } 001 \text { en el resto }\end{array}$ \\
\hline
\end{tabular}

Estas dimensiones no pueden ser jerarquizadas sin recurrir a supuestos adicionales. Los números 0 y 1 se emplean para denotar la presencia 0 ausencia de actividad.

miento quecomprende dos pasos. El primero es la determinación del activismo político de cada orientación. EI IAD toma esta información de la variable "M odo de participación ciudadana" (M PC). Esta variable distingue los distintos tipos de intervención de las personas en la vida social y política de un país y permite elaborar diversas clasificaciones según el interés del investigador.

Losmodos departicipación ciudadana (M PC) son los tipos de intervención que las ciudadanas y los ciudadanos realizan en la vida social y política. Un modo describe un perfil característico de actividades de un ciudadano. Se reconstruye examinando las cosas que las personas hacen en las distintas dimensiones de participación ciudadana. Ésta es una clasificación nominal, cuyas categorías no fueron planteadas pensando en ordenarlas sobre la base de un criterio que permita jerarquizarlas; aun así, el orden de su presentación expresa la aplicación flexible de ciertos criterios. ${ }^{20}$

\section{Clasificación de modos de participación}

Se distinguieron así 8 modos de participación ciudadana, tal como muestra el cuadro 9.

(2) Activismo $(\mathrm{OX})=(\mathrm{Q} \operatorname{mpcX}) / \mathrm{QX}$

donde: $\mathrm{Q}$ mpcX = cantidad de personas dela orientacion " $X$ " queejercitan la articipación política más allá del voto: modos de participación ciudadana en donde hay establecimiento de contactos con autoridades y participación en manifestaciones públicas; $Q X$ = cantidad de personas que sustentan la orientación " $X$ ". $X$ puede ser la orientación demócrata, la ambivalente o la no demócrata.

El segundo paso es comparar el activismo de las orientaciones adversarias - demócrata y no demócrata- y conocer cuál de ellas es la más activa. Esteindicador, denominado "activismo democrático" (AC), es el que se toma para el IAD. Se obtiene al dividir el activismo de la orienta-

20 En términos generales, el orden de presentación inicia con las categorías en las que hay menor costo personal (inversión de tiempo, dinero), compromiso y liderazgo, y concluye con las categorías que implican mayor costo personal, compromiso y liderazgo. Al final se pone una categoría que responde a otros criterios. 


\begin{tabular}{|c|c|}
\hline CLASIFICACIÓN DE & MODOS \\
\hline \multicolumn{2}{|c|}{ DE PARTICIPACIÓN CIUDADANA } \\
\hline Nombre & Descripción \\
\hline No hace nada & $\begin{array}{l}\text { Tiene un } 0 \text { en todas las } \\
\text { dimensiones de participación } \\
\text { ciudadana }\end{array}$ \\
\hline Sólo vota & $\begin{array}{l}1 \text { en PEL y } 0 \text { en PSO, } \\
\text { PCO y PMC }\end{array}$ \\
\hline Vota y colabora & $\begin{array}{l}1 \text { en PEL y PSO; } 0 \text { en } \\
\text { PCO y PMC. }\end{array}$ \\
\hline Sólo acción política & $\begin{array}{l}1 \text { en PCO y PMC; } 0 \text { en } \\
\text { PEL y PSO }\end{array}$ \\
\hline Vota y acción política & $\begin{array}{l}1 \text { en PEL, PCO y PMC; } \\
0 \text { en PSO }\end{array}$ \\
\hline Colabora y acción política & $\begin{array}{l}1 \text { en PSO, PCO y PMC; } \\
0 \text { en PEL }\end{array}$ \\
\hline $\begin{array}{l}\text { Vota, colabora y } \\
\text { acción política }\end{array}$ & $\begin{array}{l}1 \text { en todas las dimensiones } \\
\text { de participación ciudadana }\end{array}$ \\
\hline Participación violenta & $\begin{array}{l}\text { Cualquier combinación en } \\
\text { la que participación violenta } \\
\text { sea } 1\end{array}$ \\
\hline
\end{tabular}

ción demócrata entre el activismo de la orientación no demócrata.

(3) AC = activismo D/activismo ND

donde: $A C=$ activismo democrático, $D=$ demócratas, ND = no demócratas.

Si la división arroja un valor mayor a 1, los demócratas son más activos que los no demócratas, una situación favorable para la democracia; si el valor es inferior a 1, los no demócratas están más activos que los demócratas, una situación poco conveniente; si el resultado es 1 , el activismo de estas orientaciones es el mismo.21

\section{Tercera dimensión: distancia entre las orientaciones}

Por distancia seentiendela mayor o menor diferencia deopinión en lasactitudes deapoyo o re- chazo a la democracia, entre personas que pertenecen a orientaciones distintas. En cada una delas variables que componen una orientación, el indicador examina la afinidad promedio en las respuestas de los miembros de dos orientaciones. A mayor afinidad, menor es la distancia, y viceversa.

El procedimiento para incorporar la dimensión de distancia al IAD es similar al empleado pa ra la dimensión del activismo. Primero se calcula la distancia delos ambivalentes en relación con cada una de las orientaciones adversarias. Para calcular la distancia entre dos orientaciones se debe obtener, para cada una de las variables, el valor absoluto de las diferencias entre sus centroides (valores promedio estandarizados según el análisis de conglomerados) y luego sumar estos valores.

$$
\text { (4) } \operatorname{Di}(O x / A)=\hat{A}|C x v i-C a v i|
$$

donde: $\mathrm{Di}=$ distancia, $\mathrm{Ox}=$ orientación demócrata o no demócrata, $A=$ orientación ambivalente. Cxi=centroide de la orientación demócrata o no demócrata en la variablei; Cavi=centroide dela orientación ambivalente en la variable i.

Posteriormente, se comparan los resultados delos demócratas y los no demócratas, mediante el indicador de distancia (ID). Esteindicador expresa la distancia promedio entrelas orientaciones no demócrata y ambivalente como una proporción de la distancia entre las orientaciones demócrata y ambivalente.

(5) IDD $=\mathrm{Di}(\mathrm{D} / \mathrm{A}) / \mathrm{Di}(\mathrm{ND} / \mathrm{A})$

donde: IDD = Distancia de los demócratas como proporción de la distancia de losno demócratas. $\mathrm{Di}(\mathrm{D} / \mathrm{A})=$ distancia entre orientaciones demócrata y ambivalente; $\mathrm{Di}(\mathrm{ND} / \mathrm{A})=$ distancia entre orientaciones no demócrata y ambivalente.

Si la división arroja un valor mayor a 1, los ambivalentes están más cercanos a las posicio-

21 Existen otras dos situaciones que no se analizan: a) cuando el activismo es similar en todas las orientaciones (distribución uniforme), y b) cuando el activismo de las orientaciones adversarias (demócratas y no demócratas) es similar y muy superior al de los ambivalentes. Ambas son situaciones políticas potencial mente inestables para una democracia, pues los demócratas no tienen una particular ventaja. 
nes no demócratas; si el valor es inferior a 1, los ambivalentes están más cerca de los demócratas; si el resultado es 1, existe una equidistancia de los ambivalentes con respecto a las orientaciones contrarias. Al contrario de los indicadores de tamaño y de activismo, en los cuales los mayores valores a favor de los demócratas apuntan a situaciones óptimas para la democracia, en materia de distancia lo ideal es que los ambivalentes tengan una distancia pequeña con los demócratas (indica actitudes más afines).

\section{La regla de agregación del IAD}

El IAD combina el tamaño, el activismo y la distancia delas orientaciones. En el índicetodos los factores tienen igual peso. Se carece de una teoría que jerarquice estos elementos o de investigaciones previas que ofrezcan criterios para ponderar la importancia de cada factor. Para no introducir supuestos difícilmente justificables, se escogió la opción que, de manera más senciIla, expresa el planteamiento conceptual.

(6) IAD = Tamaño [AD] *

(Activismo [AC] / Distancia [ID])

Si en un país la mayoría de los ciudadanos es leal a la democracia, y éstos son más participativos que el resto de las personas y tienen una pequeña distancia con respecto a los ambivalentes, puede concluirsequela democracia goza de respaldo ciudadano. En estas situaciones el IAD arroja un valor bastantesuperior a 1. En cambio, si en un país la mayoría delosciudadanos es no demócrata, los no demócratas son más participativos que el resto de las personas y tienen una pequeña distancia con respecto a los ambivalentes, puede concluirse que el respaldo a la democracia es frágil. En estas situaciones el índiceasumevaloresmuy inferiores a 1 y cercanos a 0. La inferencia es que un sistema político con estas características es más vulnerable a una crisis queuno quecuente con un fuerterespaldo ciudadano. Pueden darse diferentes combinaciones de tamaño, activismo y distancia, que configuran situaciones intermedias de fortaleza y debilidad de la democracia. En situaciones de equilibrio, el valor del IAD ronda 1.
La interpretación del IAD

Dada la fórmula empleada para calcular el IAD, los valores del índice pueden oscilar entre 0 y un número extremadamente alto (tiende a infinito en un país donde casi todos los demócratas sean participativos y los pocos ambivalentes estén muy cerca de sus posiciones). A este punto del conocimiento sobre el tema, no se tienen suficientes elementos de juicio para estandarizar esta variación en un rango quevaríe, por ejemplo, entre 0 y 1 , ni para categorizar los valores en una escala de intensidad. La estandarización requeriría aplicar procedimientos relativamente sofisticados sobre la base de supuestos adicionales.

La creación de una escala de intensidad, además, implicaría justificar los puntos de corte entre las categorías que se definan, cosa posible de realizar cuando se disponga de más observaciones que las que se tienen en la actualidad (medición de 18 países en un año). No obstante, la observación del comportamiento del IAD ante al gunas situaciones hipotéticas permite realizar un primer ejercicio deinterpretación (cuadro 10).

\section{Validación y confiabilidad del IAD}

No se conocen estudios previos que hayan aplicado esta metodología para estudiar el respaldo ciudadano a la democracia. El análisis de las orientaciones hacia la democracia no puede replicarse en la serie de tiempo de Latinobarómetro. Algunas de las variables empleadas para el análisis pertenecen a la sección regular de Latinobarómetro, pero no son incluidas todos los años; otras preguntas fueron elaboradas específicamente para la sección propietaria del PNUD en la encuesta, por lo que se carece de observaciones previas.

Algunas preguntas empleadas para las orientaciones tienen limitaciones que afectan la medición. Las preguntas con escalas de respuesta de dos o tres alternativas no se ajustan plenamente a los requisitos de un análisis de conglomerados. En estas variables, además, la desviación estándar fue superior al resto de las variables. Estas dificultades son particularmente pal pables en el caso de las preguntas de la dimensión de apoyo 
Cuando el IAD asume valores superiores o cercanos a 5, las condiciones son muy favorables a la democracia. Es decir, los demócratas tienden a ser mayoría, a ser más políticamente activos que sus adversarios y a tener a los ambivalentes mucho más cercanos a sus posiciones.

La situación contraria sería cuando las condiciones tienden a ser desfavorables para la democracia: los no demócratas son mayoría, están políticamente más activos y tienen a los ambivalentes mucho cerca de sus posiciones. Un valor de 0,15 del IAD correspondería a esta situación.

Cuando el IAD adopta valores superiores a 1 pero no muy lejanos a esta cifra, la situación tiende a ser favorable para la democracia, pero más atenuadamente. En alguna dimensión o componente del índice, la situación es desfavorable para la democracia, pero ello es más que compensado por resultados favorables en las otras dimensiones; o bien puede ser que en las tres dimensiones la situación sea favorable para la democracia, aunque por márgenes relativamente estrechos. Por ejemplo, un valor de 1,43 del IAD resume una situación en la que los demócratas son los más numerosos (pero no la mayoría), tienen a los ambivalentes ligeramente más cerca de sus posiciones, pero son políticamente menos activos que los no demócratas.

EI IAD es una herramienta que requiere ser refinada. Su algoritmo actual, basado en el supuesto de que los tres componentes del IAD son independientes entre sí y pesan igual, no funciona apropiadamente en ciertas situaciones. ${ }^{22}$ Se requiere más investigación para encontrar respuestas metodológicas válidas a los problemas que la sencilla formulación del IAD no puede resolver. Sin embargo, cabe recordar que la observación de los resultados del IAD en el 2002 para los distintos países de América Latina sugiere que, pese a estas limitaciones, el índice no arrojó resultados inesperados. Por otra parte, ninguno de los componentes del IAD tuvo un comportamiento "anómalo" tal que introdujera distorsiones en el resultado global del índice.

a las instituciones de la democracia representativa, cuyas escalas de respuesta son binarias. A pesar de estas limitaciones, como ha sido explicado, los resultados obtenidos fueron robustos.

Se efectuó un examen de la validez externa del análisis de las orientaciones. Seutilizó la pregunta “Estaría usted dispuesto a defender la democracia si seviera amenazada?", quefueincluida en los Latinobarómetro 1996 y 1998. Se correlacionaron los resultados obtenidos por país con el tamaño delas orientaciones en el 2002. En general, en 1996 y 1998, los países dondemás personas estaban dispuestas a defender la democracia fueron los países donde en el 2002 había más demócra$\operatorname{tas}(r=0,27$ y $r=0,25$, respectivamente); la correlación con el porcentaje de no demócratas es inversa $(r=-0,29 \mathrm{y} r=-0,36)$.

\section{Supuestos y limitaciones del IAD}

La metodología descansa sobre tres supuestos. El primero es que las orientaciones hacia la democracia son relativamente estables en el tiempo. No se descartan las fluctuaciones anteel efecto acumulado, e.g., del deterioro económico de un país; empero, por tratarse de actitudes relacionadas con el apoyo difuso ( 0 rechazo) a la democracia se infiere que las variaciones son menos pronunciadas que las que exhibirían las percepciones relacionadas con la satisfacción con el funcionamiento de las instituciones o los resultados económicos y sociales del sistema. 23

El segundo supuesto es que, aunque las personas de una orientación no necesariamente constituyan una fuerza política con capacidades organizativas y conducción ideológica propia,

22 Por ejemplo, un país donde la cantidad de demócratas sea apenas la mitad de los no demócratas ( $A D=0,5$ ), los no demócratas estén políticamente más activos que los demócratas $(A C=0,5)$, pero donde los ambivalentes se encuentran abrumadoramente más cerca de las posiciones demócratas que de las no demócratas (ID $=0,2$ ), obtendría un IAD $=12,5$. Esta situación está lejos de ser favorable para la democracia, como el resultado del IAD parece sugerir. Q uizá se trate de una situación poco probable, pero, ciertamente, una que puede ocurrir.

23 La serie de tiempo de Latinobarómetro no permite valorar la estabilidad de las orientaciones hacia la democracia. Pruebas con la pregunta sobre la situación económica del hogar, con las de la preferencia por la democracia y la satisfacción con la democracia para distintos años (1996, 1997, 2001 y 2002) arrojan quela preferencia por la democracia no varía según la mala o buena situación económica del hogar, pero sí la satisfacción con su funcionamiento. 
pueden llegar a serlo en caso de enfrentar un evento político polarizador.24 Debe recordarse que las orientaciones no ayudan a predecir el comportamiento de las personas en términos de la subversión o defensa del sistema. Existe una serie de factores, difíciles de determinar a priori, que influyen sobre la transformación de las actitudes en comportamientos.

En tercer lugar, se supone que, en materia de defensa u oposición al sistema democrático, los ambivalentes no tienen iniciativa propia. Son, por tanto, pasto de la disputa entre las orientaciones demócrata y no demócrata. Adicionalmente, se asume que la resistencia ofrecida por los ambivalentes, aunque de magnitud desconocida, es la misma ante ambas orientaciones. Estos dos supuestos son una herencia y una implicación lógica del planteamiento de Linz, que es la fuente de inspiración de este análisis. Cuando la cuestión política del día es la supervivencia de la democracia, no hay una "tercera vía": 0 se defiende o se subvierte el régimen. No obstante, mientras la vida política no enfrente la disyuntiva de la supervivencia o la muerte de la democracia, estos supuestos no son necesariamente ciertos. En la práctica, los ambivalentes pueden tener iniciativa política propia sobre un amplio rango de asuntos, aunque no formen una fuerza política determinada. 25

Por último, ciertas características delas muestras de Latinobarómetro aconsejan prudencia en la valoración del IAD, especialmenteen ciertos países. Se desconocen los efectos de una eventual inclusión del "mundo rural" y de los segmentos urbanos más empobrecidos sobre sus resultados.

Los datos de la encuesta de opinión utilizada en este Informe fueron aportados por Latinobarómetro, en el marco de una relación contractual de trabajo y de cooperación con el PNUD. En el año 2002, Latinobarómetro incrementó un tercio su estudio anual con preguntas específicas requeridas por el PNUD para el presente Informe. Dentro del acuerdo interinstitucional, Latinobarómetro puso a disposición del PNUD las series de tiempo con datos de encuestas previas, que también se utilizaron como uno de los antecedentes incluidos en la base empírica del Informe.

24 Por evento político polarizador se entiende una crisis económica, social o política que genere la posibilidad de reemplazo del sistema democrático por otro tipo de régimen.

25 Establecer el perfil político y social de los ambivalentes es uno de los puntos más importantes de este estudio. 


\section{Bibliografía}

Ackerman, Bruce, 1980, Social Justice in the Liberal State, New Haven, Yale University Press.

- - - , 2004, “¿H acia una síntesis latinoamericana?", texto preparado para PRODDAL, en PNUD, La democracia en América Latina. Hacia una democracia de ciudadanas y ciudadanos. Anexo: El debate conceptual sobre la democracia (CD ROM ), Buenos Aires, Aguilar, Altea, Taurus, Alfaguara.

Acuña, Carlos, y Smulovitz, Catalina, 1996, "Adjusting the Armed Forces to Democracy: Successes, Failures, and Ambiguities in the Southern Cone", en Jelin, Elizabeth, y Hershberg, Eric (comps.), Constructing Democracy. Human Rights, Citizenship, and Society in Latin America, Boulder, Colorado, Westview Press.

Adrianzen, Alberto, 1993, Democracia, etnicidad y violencia política en los países andinos, Lima, Instituto de Estudios Peruanos.

Aguilar Camín, Héctor, 1996, D espués del milagro, M éxico, Cal y Arena.

- - - , 1999, "El M éxico vulnerable", en N exos, marzo.

Aguilar Camín, Héctor, y M eyer, Lorenzo, 1990, A la sombra de la Revolución M exicana. Un ensayo de historia contemporánea de M éxico, 1910-1989, 3aedición, M éxico, Cal y Arena.

Alcántara Sáez, M anuel, 2002, “Experimentos de de- mocracia interna: Las primarias de partidos en Amé rica Latina", en Helen Kellogg Institute for International Studies working paper, 293, Notre Dame, Indiana, The Helen Kellogg Institute for Interna-tional Studies at the University of N otre Dame.

- - - , 2004, “Partidos políticos en América Latina: precisiones conceptuales, estado actual y retos futuros", texto preparado para PRODDAL, en PNUD La democracia en América Latina. Hacia una democracia de ciudadanas y ciudadanos: Contribuciones para el debate, Buenos Aires, Aguilar, Altea, Taurus, Alfaguara.

Alconada Sempé, Raúl, 2004, “Seguridad jurídica y Estado democrático de derecho", texto preparado para PRODDAL, en PNUD La democracia en América Latina. Hacia una democracia de ciudadanas y ciudadanos: Contribuciones para el debate, Buenos Aires, Aguilar, Altea, Taurus, Alfaguara.

Almaraz Paz, Sergio, 1979, Para abrir el diálogo, La Paz, LosAmigos del Libro.

Almond, G., 1980, "The Intellectual History of the Civic Culture Concept", en Almond, G., y Verba, S. (comps.), The Civic Culture Revisited, Boston, Little, Brown \& Co.

Almond, G., y Verba, S., 1963, The Civic Culture, Princeton, University Press.

Altman, David, 2001, “The Politics of Coalition Formation and Survival in Multiparty Presidential 
Regimes", tesis doctoral, Notre Dame, Indiana, Departamento de Estudios Gubernamentales e Internacionales, Universidad de Notre Dame.

- - - - 2002, "Prospects for E-Government in Latin America: Satisfaction with Democracy, Social Accountability, and Direct Democracy", en International Review of PublicAdministration 7 (2), pp. 5-20.

Amnesty International, 2002, "Amnesty International Website Against the Death Penalty. Abolitionist and Retentionist Countries" [http://web.amnesty.org/ rmp/dplibrary.nshf/index?openview].

Anderson, Benedict, 1991, Imagined Communities, Londres, Nueva York, Verso.

_- - - , 1993, Comunidades imaginadas. Reflexiones sobre el origen y la difusión del nacionalismo, México, Fondo de Cultura Económica.

Anderson, Perry, 1974, Lineages of the Absolutist State, Londres, New Left Books.

Andrade, Vera Regina, 1999, Cidadania: do Direito aos Direitos Humanos, San Pablo, Acadêmica.

Annan, Kofi, 2003, Implementation of the United Nations M illennium Dedaration. Report of theSecre tary-General, A/58/323.

Aragón Reyes, M anuel, 1998, “Derecho Electoral: Sufragio activo y pasivo", en Nohlen, Dieter; Picado, Sonia, y Zovatto, Daniel (comps.), Tratado de derecho electoral comparado de América Latina, M éxico, Fondo de Cultura Económica.

Arato, Andrew, 1993, Civil Society and Polital theory, Cambridge, MIT Press.

- - - , 2004, "Algunos comentarios sobre la Tesis।", texto preparado para PRODDAL, en PNUD, La democracia en América Latina. Hacia una democracia de ciudadanas y ciudadanos. Anexo: El debate conceptual sobre la democracia (CD ROM), Buenos Aires, Aguilar, Altea, Taurus, Alfaguara.
Arbós, Xavier, 1996, La gobernabilidad: ciudadanía y democracia en la encrucijada mundial, 2a edición, M éxico, Siglo XXI.

Arditi, Benjamín, 1992, "Elecciones municipales y democratización en Paraguay", en Nueva Sociedad, $\mathrm{N}^{\circ} 117$.

Aristóteles, 1968, ThePolitics, edición deErnest Baker, Oxford, Oxford University Press. (Edición en español: 1975, La política, 5ạ edición, Barcelona, Emecé.)

Arriagada, Genaro, 2002, “Diez proposiciones para encarar la crisis de los Partidos", en asuntospublicos.org (informes 201 y 206).

Assies, Willem, 2004, "Diversidad, Estado y democracia: unos apuntes", texto preparado para PRODDAL, en PNUD, La democracia en América Latina. Hacia una democracia de ciudadanas y ciudadanos: Contribuciones para el debate, Buenos Aires, Aguilar, Altea, Taurus, Alfaguara.

Baeza, Fernández, 1998, "El voto obligatorio", en NohIen, Dieter; Picado, Sonia, y Zovatto, Daniel (comps.), Tratado de derecho electoral comparado deAmérica Latina, M éxico, Fondo de Cultura Económica.

Banco Mundial, Legal and Judicial Reform Practice Group, 2003, Worldwide Legal and Judicial Indicators Database [http://www4.worldbank.org/legal/databa se/Justice/].

Barié, Cletus Gregor, 2000, Pueblosindígenasy derechos constitucionales en América Latina: un panorama, Mé xico DF, Instituto Indigenista Interamericano.

Barro, Robert J., y Jong-Wha Lee, 2000, “International Data on Educational Attainment: Updates and Implications", CID working paper, 42

[http://www.cid.harvard.edu/ciddata/ciddata.html].

Bazdresch, Carlos, y Loaeza, Soledad, 1993, M éxico, auge, crisis y ajuste, 3 tomos, M éxico, Fondo de Cultura Económica.

Beitz, C. R., 1989, Political Equality. An Essay in Democratic Theory, Princeton, Princeton University Press. 
Bello, Álvaro, y Rangel, M arta, 2002, “La equidad y la exclusión de los pueblos indígenas y afrodescendientes en América Latina y el Caribe", en Revista de la CEPAL 76, pp. 39-54 (abril).

Bellomo, M., 1995, The Common Legal Past of Europe, 1000-1800, Washington DC, Catholic University of America Press.

Benavides, T., y Vargas Cullell, J., 2003, Nota conceptual sobre participación ciudadana, San José, documento preparado para el Proyecto sobre D esarrollo Democrático de América Latina del PNUD, junio de 2003.

Bendix, R., 1964, Nation-Building and Citizenship. Studies of our Changing Social O rder, Nueva York, John Wiley \& Sons.

Berger, Peter, y Luckman, T., 1966, The Social Construction of Reality. A Treatise in the Sociology of Knowledge, Nueva York, Doubleday.

Berlin, Isaiah, 1969, Four Essays on Liberty, Oxford, Oxford University Press.

Berman, H. J., 1993, Law and Revolution: TheFormation of theWestern Legal Tradition, Cambridge, Harvard University Press.

Blondet, Cecilia, 1998, La emergencia de las mujeres en el poder. ¿H ay cambios en Perú?, IN CLUDEPICTURE "C:||D ocuments and Settings||rblacguest2|| My Documents||DEM OCRACY REPORTI|iconos|| trans.gif"|*M ERGEFORM ATINET Id"Lima, IEP.

Bobbio, Norberto, 1989, Democracy and Dictatorship. The Nature and Limits of State Power, M inneapolis, University of M innesota Press.

_- - - , 1992, El futuro de democracia, Colombia, Fondo de Cultura Económica.

Bobbio, Norberto, y M atteucci, N ., 1988, Diccionario de Política, 5a edición, M éxico, Siglo XXI.

Boneo, Horacio, y Torres Rivas, Edelberto, 2001, ¿Por quéno votan los guatemaltecos? Estudio de par- ticipación y abstención electoral, Guatemala, IDEA/ IFE/PNUD.

Borón, Atilio A., 1997, Estado, capitalismo y democracia en América Latina, 3a edición, Buenos Aires, Oficina de Publicaciones del CBC.

- - - - 2000, "América Latina: crisis sin fin o fin de la crisis", en López Segrera y Filmus, Daniel (comp.), América Latina 2020. Escenarios, alternativas, estrategias, Buenos Aires, Unesco-Flacso-Temas Grupo Editorial.

Boschi, Renato, 2004, “Desarrollo democrático en América Latina: su condición, las percepciones de sus ciudadanos, indicadoresy agenda", texto preparado para PRODDAL, en PNUD, La democracia en América Latina. Hacia una democracia deciudadanasy ciudadanos. Anexo: El debateconceptual sobrela democracia (CD ROM ), Buenos Aires, Aguilar, Altea, Taurus, Alfaguara.

Botana, Natalio, 2004, "Dimensiones históricas de las transiciones a la democracia en América Latina", texto preparado paraPRODDAL, en PNUD, La democracia en América Latina. Hacia una democracia de ciudadanasy ciudadanos: Contribuciones para el debate, Buenos Aires, Aguilar, Altea, Taurus, Alfaguara.

Bourdieu, Pierre, 1996, "Espíritus de Estado. Génesis y estructura del campo burocrático", en Sociedad 8, pp. 5-29.

Breuilly, J., 1993, Nationalism and the State, M anchester, M anchester University Press.

Brown, M ark M alloch, 2002, Deepening Democracy in theD eveloping World: An Agenda for Action in the N ew Millennium, Washington DC, Center for Global Development, 21 de octubre [http://www.undp.org/dpa/ statements/administ/2002/october/21oct02.html].

Brubaker, R., 1992, Citizenship and Nationhood in France and Germany, Cambridge, Massachusetts, Harvard University Press.

- - - - , 1996, Nationalism Reframed. Nationhood and the National Question in New Europe, Cambridge, Cambridge University Press. 
Burdeau, Georges, 1985, “Democratie”, en Encyclopaedia Universalis, Paris.

Burns, N ., et al., 2001, The Private Roots of Public Action, Cambridge, Harvard University Press.

Calderón, Fernando, 2000, Sociedad y globalización, La Paz, PNUD, Cuadernos del Futuro.

- - - - , (comp.) , 2003, ¿Es sostenible la gl obalización en América Latina? D ebates con M anuel Castells, 2 volúmenes, Buenos Aires, Fondo de Cultura Económica.

- - - - ,2004a, "Las condiciones sociales dela de mocracia: el Estado y el régimen", texto preparado para PRODDAL, en PNUD, La democracia en Amé rica Latina. Hacia una democracia de ciudadanas y ciudadanos. Anexo: El debate conceptual sobre la democracia (CD ROM ), Buenos Aires, Aguilar, Altea, Taurus, Alfaguara.

- - - , 2004b, "N otas sobre la crisis de legitimidad del Estado y la democracia", texto preparado para PRODDAL, en PNUD, La democracia en Amé rica Latina. Hacia una democracia de ciudadanas y ciudadanos: Contribuciones para el debate, Buenos Aires, Aguilar, Altea, Taurus, Alfaguara.

Calvo, E., y Abal M edina, J. M . (h) (comps.), 2001, El federalismo electoral argentino. Sobrerrepresentación, reforma política y gobierno dividido en la Argentina, Buenos Aires, INAP/Eudeba.

Camargo, Pedro Pablo, 1996, Derechos humanos y democracia en América Latina, Bogotá, Grupo Editorial Leyer.

Canovan, M ., 1996, Nationhood and Political Theory, Londres, Edward Elgar.

Caputo, Dante, 2004, “Globalización, hegemonía y Democracia", texto preparado para PRODDAL, en PNUD, La democracia en América Latina. Hacia una democracia de ciudadanas y ciudadanos: Contribuciones para el debate, Buenos Aires, Aguilar, Altea, Taurus, Alfaguara.
Cardoso, Fernando Henrique, 1993, A construçao da Democracia, San Pablo, Siciliano.

- - - , 2004, “D emocracia y globalización", texto preparado para PRODDAL, en PNUD, La democracia en América Latina. Hacia una democracia de ciudadanas y ciudadanos: Contribuciones para el de bate, Buenos Aires, Aguilar, Altea, Taurus, Alfaguara.

Carey, John M., y Soberg Shugart, M atthew (comps.), 1998, Executive DecreeAuthority, Nueva York, Cambridge University Press.

Carey, John; Amorin N eto, Octávio y Soberg Shugart, M atthew, 1997, "Appendix: Outlines of Constitutional Powers in Latin America", en Mainwaring, Scott, y Soberg Shugart, M atthew (comps.), Presidentialism and Democracy in Latin America, Cambridge, Cambridge University Press.

Carranza, Elías, 2001, “Sobrepoblación penitenciaria en América Latina y el Caribe: Situación y respuestas posibles", artículo presentado en el Seminario Técnico de la Red de Programas de Institutos de la ONU, Viena, Austria, 10 de mayo.

Carvalho, José M urilo de, 2001, A Cidadania no Brasil: 0 Longo Caminho, Río de Janeiro, Civilização Brasileira.

Castel, Robert, 1995, La metamorfosis de la cuestión social, Buenos Aires, Paidós.

Castells, M anuel, 1998, La era dela información. Economía, sociedad y cultura, Madrid, Alianza.

Cavarozzi, M ., y Abal M edina, Juan (comps.), 2002, El asedio a la política. Los partidos latinoamericanos en la era neoliberal, Rosario, Argentina, Homo Sapiens Ediciones, Konrad Adenauer Stiftung.

Cavarozzi, M., y Garretón, M. A. (comps.), 1989, Muerte y resurrección, los partidos políticos en el autoritarismo y la democratización en el Cono Sur, Santiago de Chile, Flacso. 
CEJA (Centro de Estudios de Justicia de las Américas), 2003a, "Reporte sobre el Estado de la Justicia en las Américas 2002-2003", Santiago de Chile, CEJA.

- - - - 2003b, "Primer Encuentro Interamericano deD efensorías Públicas" [http://www.cejamericas.org/ newsite/ingles/index_in.htm].

CELS (Centro de Estudios Legales y Sociales), 2001, Derechos H umanos en Argentina: Informeanual 2001, Buenos Aires, Eudeba.

Centro Internacional para Estudios Penitenciarios, 2003, "World Prison Brief"

[http://www.kcl.ac.uk/depsta/rel/icps/].

CEPAL (Comisión Económica para América Latina), 1997, Síntesis. Estudio económico de América Latina y el Caribe, 1996-1997, Santiago deChile, Naciones Unidas.

- - - - , 1999, Participation and Leadership in Latin America and the Caribbean: Gender Indicators, Santiago de Chile, CEPAL.

,---- 2000 , The Challenge of Gender Equity and Human Rights on the Threshold of the Twenty-First Century, Santiago de Chile, Unidad de Mujer y Desarrollo, 27, mayo.

- - - , 2001a, Panorama social de América Latina 2000-2001, Santiago de Chile, Naciones Unidas.

- - - - 2001b, Estudio económico para América Latina y el Caribe 2000-2001, Santiago de Chile, Naciones Unidas.

- - - - , 2002a, Anuario estadístico de América Latina y el Caribe 2001, Santiago de Chile, Naciones Unidas.

- - - , 2002b, Panorama social de América Latina 2001-2002, Santiago de Chile, Naciones Unidas.

- - - , 2002c, Balance preliminar de las economías deAmérica Latina y el Caribe 2002, Santiago de Chile, Naciones Unidas.
- - - , 2002d, Estudio económico deAmérica Latina y el Caribe, 2001-2002, Anexo estadístico en CD-ROM [http://www.eclac.cl/DE/proyectos/eee/ eee2002/index.htm].

- - - - , 2003, Anuario estadístico de América Latina y el Caribe 2002, Santiago de Chile, Naciones Unidas.

,---- 2004 , Panorama Social de América Latina 2002-2003, Santiago de Chile, Naciones Unidas.

CEPAL, IPEA, PNU D, 2003, $\mathrm{H}$ acia el objetivo del miIenio: Reducir la pobreza en América Latina y el Caribe, Santiago de Chile.

Cerdas-Cruz, Rodolfo; Rial, Juan, y Zovatto, Daniel (comps.), 1992, Elecciones y democracia en América Latina, 1988-1991. Una tarea inconclusa, San Joséde Costa Rica, Instituto Interamericano de Derechos Humanos-Centro Interamericano de Asesoría y Promoción Electoral.

Coleman, D., 1990, Foundations of Social Theory, Cambridge, Cambridge University Press.

Collier, David, y Levitsky, Steven, 1996, “Democracy with Adjectives: Conceptual Innovation in Comparative Research", H elen Kellogg Institute for International Studies working paper, 230, Notre Dame, Indiana, The Helen Kellogg Institute for International Studies at the University of Notre Dame.

- - - - , 1997, “Democracy With Adjectives: Conceptual Innovation in Comparative Research", en World Politics 49 (3), pp. 430-451 (abril).

Comisión Andina de Juristas, 2000, La reforma judicial en la región andina. ¿Q ué se ha hecho, dónde estamos, adónde vamos?, Lima, Comisión Andina de Juristas.

- - - - , 2003, "Red de información jurídica. Sistemas judiciales" [http://www.cajpe.org.pe/rij/].

Comparato, Fabio Konder, 1989, Para viver a democracia, San Pablo, Brasiliense. 
Conaghan, Catherine, 2004, “M ás allá del minimalismo: una agenda para unir democracia y desarrollo", texto preparado para PRODDAL, en PNUD, La democracia en América Latina. $\mathrm{H}$ acia una democracia deciudadanas y ciudadanos. Anexo: El debate conceptual sobre la democracia (CD ROM ), Buenos Aires, Aguilar, Altea, Taurus, Alfaguara.

Conway, M ., 1985, Political Participation in the United States, Washington DC, Congressional Quarterly Inc.

Córdova M acías, Ricardo, 2000, Una propuesta para la reforma del Estado en El Salvador, San Salvador, Fundación Dr. Guillermo M anuel Ungo.

Cornelius, Peter K., y Schwab, Klaus (comps.), 2003, The Global Competitiveness Report 2002-2003, Nueva York, Oxford University Press.

Cornelius, W.; Eisenstadt, T., y H indley, J., 1999, Subnational Politics and Democratization in M exico, San Diego, Center for US-M exican Studies, Universidad deCalifornia.

Corrigan, P., y Sayer, D., 1985, The Great Arch. English StateFormation as Cultural Revolution, Londres, Basil Blackwell.

Cortina, Adela, 1997, Ciudadanos del mundo: hacia una teoría de la ciudadanía, Madrid, Alianza Editorial.

Cotler, Julio, 1978, Clases, Estado y nación en el Perú, Lima, IEP.

- - - - , 2004, “La nacionalización y democratización del Estado, la política y la sociedad", texto preparado para PRODDAL, en PNUD, La democracia en América Latina. Hacia una democracia de ciudadanas y ciudadanos. Anexo: El debate conceptual sobre la democracia (CD ROM ), Buenos Aires, Aguilar, Altea, Taurus, Alfaguara.

Cotterrell, R., 1995, Law's Community. Legal Theory in Sociological Perspective, Oxford, Clarendon Press.

- - - , 1996, "The Rule of Law in Transition: Revisiting Franz Neumann's Sociology of Legality", en Social \& Legal Studies 5 (4), pp. 451-470.
CPJ (Comité para la Protección de los Periodistas), 2003, "Journalists Killed in the Line of Duty During the Last Ten Years" [http://www.cpj.org/killed/Ten_ Year_Killed/Intro.html].

Crotty, W., 1991, “Political Participation: M apping the Terrain", en William, C., Political Participation and American Democracy, Westport, Greenwood Press.

Dahl, R., 1966, Political Oppositions in Western De mocracies, New Haven, Yale University Press.

- - - , 1971, Poliarquía, participación y oposición, M éxico, Rey. (Edición en español de 1993.)

- - - - , 1987, Un prefacio a la teoría democrática, Ediciones Gernika.

- - - - , 1989, Democracy and Its Critics, New Haven, Yale University Press.

_- - - , 1999, La democracia, BuenosAires, Taurus.

Dalton, R. J., 1996, “Political Support in Advanced Industrial Democracies", en Norris, P. (comp.), Critical Citizens. Global Support for Democratic Governance, Oxford, Oxford University Press.

Dasgupta, P., 1993, An Inquiry into Well-Being and Destitution, Oxford, Clarendon Press.

De Riz, Liliana, 1992, "El debate sobre la reforma electoral en Argentina", en D esarrollo Económico, 126, julio-septiembre.

- - - , 1995, Radicales y peronistas en el Congreso Nacional: 1983-1989, Buenos Aires, Centro Editor.

De Soto, Hernando, 1984, El Otro Sendero, Lima, El Barranco.

Defensoria Pública da União, Brasil, 2001, “Relatório de Gestão"

[http://www.mj.gov.br/defensoria/default.htm].

Deininger, Klaus, y Squire, Lyn, 1998, The Deininger and Squire Data Set. A N ew Data Set M easuring Income Inequality, Washington DC, Banco Mundial. 
Del Castillo, Pilar y Zovatto, Daniel G. (comps.), 1998, La financiación de la política en Iberoamérica, San José de Costa Rica, IIDH -CAPEL.

Dellasoppa, E.; Bercovich, A., et al., 1999, “Violencia, Direitos Civis e Demografía no Brasil na Década de 80: 0 Caso da Area M etropolitana do Rio deJanei-ro", en Revista Brasileira de Ciencias Sociais, 14 (39), pp. 155-176.

Di Tella, Torcuato (comp.), 1998, Crisis de representatividad y sistemas de partidos políticos, Buenos Aires, ISEN

Diamint, Rut (comp.), 1999, Control civil y fuerzas armadas en las nuevas democracias latinoamericanas, Buenos Aires, Grupo Editor Latinoamericano.

Diamond, Larry, 1999, Developing Democracy. Toward Consolidation, Baltimore, Johns Hopkins University Press.

- - - , 2004, "Sobre los atributos de la democracia como régimen político", texto preparado para PRODDAL, en PNUD, La democracia en Amé rica Latina. Hacia una democracia de ciudadanas y ciudadanos. Anexo: El debate conceptual sobre la democracia (CD ROM), Buenos Aires, Aguilar, Altea, Taurus, Alfaguara.

Diamond, Larry, et al. (comps.), 1997, Consolidating the Third Wave Democracies: Themes and Perspectives, Baltimore, Johns Hopkins University Press.

Diamond, Larry; H artlyn, Jonathan; Linz, Juan, y Lipset, Seymour M artin (comps.), 1999, Democracy in Developing Countries: Latin America, 2aedición, Boulder, Colorado, Lynne Rienner.

Domingo, P., 1999, "Judicial Independenceand Judicial Reform in Latin America", en Schedler, A., Diamond, L., y Plattner, M . (comps.), The Self-Restraining State. Power and Accountability in $\mathrm{New}$ Democracies, Boulder, Colorado, Lynne Rienner.

Domínguez, Jorge, 1998, Democratic Politics in Latin America and the Caribbean, Baltimore, The Johns Hopkins University Press.
Domínguez, Jorge, y Lowenthal, Abraham (comps.), 1996, Constructing Democratic Governance. Latin America and the Caribbean in the 1990s, Baltimore, The Johns Hopkins University Press.

Dornbusch, Rudiger, y Edwards, Sebastián, 1994, “La macroeconomía política del populismo latinoamericano", en Dornbusch, Rudiger, y Edwards, Sebastián (comps.), La macroeconomía del populismo en América Latina, M éxico, Fondo de Cultura Económica.

Durkheim, E., 1983, Professional Ethics and Civic M orals, Londres, Routledge.

Dworkin, R., 1986, Law's Empire, Cambridge, Massachusetts, $\mathrm{H}$ arvard University Press.

Easton, D., 1965, A System Analysis of Political Life, Nueva York, John Wiley \& Sons.

- - - , 1975, "The Concept of Political Support", en The British Journal of Political Science 5, Londres.

Eisenstadt, S. N ., 1999, Paradoxes of Democracy. Fragility, Continuity, and Change, Baltimore, Johns Hopkins University Press.

- - - , 2000, "Multiple M odernities", en Daedalus, 129 (1), pp. 1-29.

Ely, J., 1980, Democracy and M istrust. A Theory of Judicial Review, Cambridge, M assachusetts, Harvard University Press.

EPIC (Colección Informativa sobre Procesos Electorales), 2002, EPIC website

[http://www.epicproject.org].

Epp, C., 1998, The Rights Revolution. Lawyers, Activists, and Supreme Courts in Comparative Perspective, Chicago, Chicago University Press.

Estados Unidos, Departamento de Estado, 2001, Guatemala Country Report on Human Rights Practices 2001 [http://www.state.gov/g/drl/rls/hrrpt/2001/ wha/8344.htm] . 
Eurostat, PCM -BDU. PCM (Panel Communautairede ménages), BDU (Base de données des utilisateurs).

Evans, P.; Rueschemer, D., y Skocpol, T. (comps.), 1985, Bringing the State Back In, Cambridge, Cambridge University Press.

Fábre, C., 1998, “Constitutionalising Social Rights", en The Journal of Political Philosophy 6 (3), pp. 263-284.

Feinberg, J., 1973, Social Philosophy, Englewood Cliffs, Prentice-Hall.

- - - - 1986, Harm to Self. The M oral Limits of the Criminal Law, Nueva York, Oxford University Press.

Fishkin, J., 1991, Democracy and Deliberation. New Directions for Democratic Reform, N ew Haven, Yale University Press.

Fitch, J. Samuel, 1998, The Armed Forces and De mocracy in Latin America, Baltimore, The Johns Hopkins University Press.

Fitoussi, Jean-Paul, 2002, La règle et le choix, Paris, Editorial LeSeuil, Colección La république des idées.

- - - , 2004, "Globalización, mercado y democracia", texto preparado para PRODDAL, en PNUD, La democracia en América Latina. Hacia una democracia de ciudadanas y ciudadanos: Contribuciones para el debate, Buenos Aires, Aguilar, Altea, Taurus, Alfaguara.

Flathman, R., 1995, "Citizenship and Authority: A Chastened View of Citizenship", en Beiner, R., Theorizing Citizenship, Nueva York, State University of New York Press.

FMI (Fondo M onetario Internacional) (varios años), Government Financial Statistics Yearbook, Washington DC, FMI.

Forewaker, J., y Landman, T., 1999, Social M ovements and Citizenship Rights, Oxford, Oxford University Press.
Fox, J., 1994, "The Difficult Transition from Clientelism to Democracy", en World Politics 46 (2), pp. 154-184.

Franck, T., 2001, "Are Human Rights Universal?", en Foreign Affairs, 80 (1), pp. 191-204.

Freedom H ouse, 2002, "Press Freedom Survey" [www.freedomhouse.org].

Freidenberg, Flavia, y Sánchez López, Francisco, 2002, "¿Cómo se eligeun candidato a presidente? Reglas y prácticas en los partidos políticos deAmérica", en Revista deEstudios Políticos 118, pp. 321-361, octubre-diciembre.

Frohlich, N., y O ppenheimer, J., 1992, Choosing Justice. An Experimental Approach to Ethical Theory, Berkeley, University of California Press.

Fuentes, Carlos, 1998, Conferencia M agistral, Facultad de Derecho y Ciencias Sociales de la Universidad de Buenos Aires, septiembre.

Fuentes, Claudio, 1996, El discurso militar en la transición chilena, Santiago de Chile, Flacso.

Fukuda-Parr, Sakiko, y Shiva Kumar, A. K. (comps.), 2002, Human Development: Concepts and M easures. Essential Readings, Nueva York, Oxford University Press.

Fuller, L., 1964, The M orality of Law, New Haven, Yale University Press.

Furet, F., 1998, "Democracy and U topia", Journal of Democracy 9 (1), pp. 65-81.

Gamarra, Eduardo, 2004, "La democracia y las drogas en América Latina y el Caribe", texto preparado para PRODDAL, en PNUD, La democracia en Amé rica Latina. Hacia una democracia de ciudadanas y ciudadanos: Contribuciones para el debate, Buenos Aires, Aguilar, Altea, Taurus, Alfaguara.

García, M arco Aurélio, 2004, “Democracia política y desarrollo en América Latina", texto preparado para PRODDAL, en PNUD, La democracia en América La- 
tina. Hacia una democracia de ciudadanasy ciudadanos: Contribuciones para el debate, Buenos Aires, Aguilar, Altea, Taurus, Alfaguara.

Garretón, M anuel A., 1987, Reconstruir la política. Transición y consolidación democrática en Chile, Santiago de Chile, Editorial Andante.

_ - - - , 1997, “Revisando las Transiciones democráticas en América Latina", en Nueva Sociedad (148), pp. 20-29.

- - - - 2000, Política y sociedad entre dos épocas. América Latina en el cambio del siglo, Rosario, Homo Sapiens.

- - - - , 2004a, "Comentario al documento 'Discusión de tres tesis para un marco teórico para el proyecto sobre el Desarrollo de la democracia en América Latina: estado, percepciones ciudadanas, indicadores y agentes'", texto preparado para PRODDAL, en PNUD, La democracia en América Latina. Hacia una democracia de ciudadanas y ciudadanos. Anexo: El debate conceptual sobre la democracia (CD ROM ), BuenosAires, Aguilar, Altea, Taurus, Alfaguara.

- - - - , 2004b, “La indispensabley problemática re lación entre partidosy democracia en América Latina", texto preparado para PRODDAL, en PNUD, La democracia en América Latina. Hacia una democracia de ciudadanas y ciudadanos: Contribuciones para el debate, Buenos Aires, Aguilar, Altea, Taurus, Alfaguara.

Garzón Valdés, E., 1993a, “Acerca de los conceptos de publicidad, opinión pública, opinión de la mayoría y sus relaciones recíprocas", en Doxa 14, pp. 77-95.

— - - - 1993b, Derecho, ética y política, M adrid, Centro de Estudios Constitucionales.

_ - - - 1997, "Some Remarks on the Concept of Toleration", en Ratio Juris 10 (2), pp. 127-138.

- - - - , 1999, “Derecho y democracia en América Latina", en Anales de la Cátedra Francisco Suárez, 33, pp. 133-157.
- - - , 2001, “Prólogo” a Rodolfo Vázquez, Liberalismo, estado de derecho y minorías, 11-26, M éxico, Paidós.

Gavíria, César, 2004, “La Carta de Navegación de las Américas", texto preparado para PRODDAL, en PNUD, La democracia en América Latina. Hacia una democracia deciudadanasy ciudadanos: Contribuciones para el debate, Buenos Aires, Aguilar, Altea, Taurus, Alfaguara.

Geertz, Clifford, 1980, N egara: The Theatre State in Nineteenth-Century Bali, Princeton, Princeton University Press.

- - - - , 1985, "Centers, Kings, and Charisma: Reflections on the Symbolics of Power", en Wilentz, S. (comp.), Rites of Power. Symbolism, Ritual, and Politics since the M iddleAges, Philadel phia, University of Pennsylvania Press.

Gewirth, A., 1978, Reason and Morality, Chicago, University of Chicago Press.

- - - - 1996, The Community of Rights, Chicago, University of Chicago Press.

Gibson, E., 1997, "The Populist Road to Market Reform: Policy and Electoral Coalitions in M exico and Argentina", en World Politics 49 (3), pp. 339-370.

Gibson, E.; Calvo, G., y Falleti, T., 1999, “Federalismo redistributivo: Sobrerrepresentación territorial y transferencia de ingresos en el hemisferio occidental", en Política y Gobierno 6 (1), pp. 15-44.

Godio, Julio, 2004, “El componente 'parlamentarista' en lossistemas presidenciales. Ejercicio desimulación: caso Argentina", texto preparado para PRODDAL, en PNUD, La democracia en América Latina. Hacia una democracia de ciudadanasy ciudadanos: Contribuciones para el debate, Buenos Aires, Aguilar, Altea, Taurus, Alfaguara.

Goldstein, R., 1983, Political Repression in Europe, Londres, Croom Helm. 
Gómez, M ., 2003, O bservaciones generales sobre las muestras de los países incluidos en Latinobarómetro 2002, San José, documento preparado para el Proyecto sobre Desarrollo Democrático deAmérica Latina del PNUD, junio de 2003.

González Casanova, Pablo, y Roitman Rosenmann, Marcos (coords.), 1996, Democracia y Estado multiétnico en América Latina, Madrid, Colección La democracia en M éxico, La Jornada, Centro de Investigaciones Interdisciplinarias en Ciencias y Humanidades/U NAM .

González, Felipe, 2004, “Crisis de la política: causas y respuestas eficientes", texto preparado para PRODDAL, en PNUD, La democracia en América Latina. Hacia una democracia de ciudadanas y ciudadanos: Contribuciones para el debate, Buenos Aires, Aguilar, Altea, Taurus, Alfaguara.

González, Luis E., 1991, Polítical Structure and De mocracy in U ruguay, Notre Dame, NDU Press.

Gratschew, M aría, 2001, "Compulsory Voting” [http://www.idea.int/vt/analysis/Compulsory_ Voting.cfm].

- - - , 2002, "Compulsory Voting", en LópezPintor, Rafael; Gratschew, M aría, et al., Voter Turnout Since 1945: A Global Report, Estocolmo, IDEA Internacional.

Gray, J., 2000, The Two Faces of Liberalism, Nueva York, Free Press.

Green, Rosario, 2004, "La crisis de la política en América Latina", texto preparado para PRODDAL, en PNUD, La democracia en América Latina. Hacia una democracia de ciudadanas y ciudadanos: Contribuciones para el debate, Buenos Aires, Aguilar, Altea, Taurus, Alfaguara.

Greenfeld, L., 1992, Nationalism. Five Roads to M 0dernity, Cambridge, Massachusetts, Harvard University Press.

Groisman, Enrique, y Lerner, Emilia, 2000, “Responsabilización por los controles clásicos”, en La responsabilización en la nueva gestión pública latinoamericana, Buenos Aires, Centro Latinoamericano deAdministración para el Desarrollo (CLAD) y BID.

Grzybowski, Cândido, 2004, “D emocracia, sociedad civil y política en América Latina: notas para un debate", texto preparado para PRODDAL, en PNUD, La democracia en América Latina. Hacia una democracia de ciudadanas y ciudadanos: Contribuciones para el debate, Buenos Aires, Aguilar, Altea, Taurus, Alfaguara.

Guadamuz, Andrés, 2000, “H abeas Data: The LatinAmerican Response to Data Protection", en The Journal of Information, Law and Technology (JILT) 2 [http://elj.warwick.ac.uk/jilt/00-2/guadamuz.html].

- - - , 2001, "Habeas Data vs. the European Data Protection Directive", en The Journal of Information, Law and Technology (JILT) 3

[http://elj.warwick.ac.uk/jilt/01-3/guadamuz.html].

Gutiérrez Saxe, Miguel, 1998, Auditoría ciudadana sobre la calidad de la democracia: propuesta para su ejecución en Costa Rica, San José de Costa Rica, Proyecto Estado de la Nación.

Gutiérrez, C.J., 2000, “Ciudadanía”, en Diccionario Electoral, Tomo I, San José de Costa Rica, IID H -CAPEL.

Gwartney, James; Lawson, Robert; Block, Walter; Wagh, Smita; Edwards, Chris, y Veronique de Ruby, 2002, Economic Freedom of the World: 2002 Annual Report, Vancouver, Instituto Fraser.

Habermas, Jurgen, 1996, Between Facts and N orms, Cambridge, M assachusetts, M IT Press.

- - - - , 1998a, "The European Nation-State: On the Past and Future of Sovereignty and Citizenship", en Cronin, C., y Grieff, P. D. (comps.), The Inclusion of the Other. Studies in Political Theory, Cambridge, Massachusetts, MIT Press.

,$---- 1998 b$, "On the Relation Between the Nation, the Rule of Law, and Democracy", en Cronin, C., y Grieff, P. D. (comps.), The Inclusion of the Other. 
Studies in Political Theory, Cambridge, M assachusetts, MIT Press.

- - - - , 1998c, "Individuation through Socialization: On George M ead's Theory of Subjectivity", en Habermas, J., Postmetaphysical Thinking: Philosophical Essays, Cambridge, M assachusetts, M IT Press.

- - - - 1999, "Introduction", en Ratio Juris 12 (4), pp. 329-335.

Hague, R., et al., 1998, Comparative Government and Politics, 4ae edición, Londres, M acmillan Press.

Hair, J., et al., 1987, M ultivariate Data Analysiswith Reading, Nueva York, M acmillan Publishing Company.

Halperin Donghi, Tulio, 1994, La larga agonía de la Argentina peronista, Buenos Aires, Espasa-Ariel.

Hamburger, P. A., 1989, "The Development of the Nineteenth-Century Consensus Theory of Contract", en Law and H istory Review 7 (2), pp. 241-329.

Hammergren, Linn, 2002, “Quince años de reforma judicial en América Latina: Dóndeestamos y por qué no hemos progresado más"

[http://www.oas.org/Juridico/spanish/adjusti.htm].

Hampshire, S., 2000, Justice is Conflict, Princeton, Princeton University Press.

Hansen, M. H., 1991, TheAthenian Democracy in the Age of Demosthenes, 0 xford, Oxford University Press.

Hardin, R., 1989, “Why a Constitution?", en Grofman, B., y Wittman, D. (comps.), The Federalist Papers and the N ew Institutionalism, 100-120, Nueva York, Agathon Press.

Harsanyi, J., 1975, "Can the Maximin Principle Serve as a Principle Morality?", en American Political Science Review 69 (2), pp. 690-705.

Hart, H. L. A., 1961, The Concept of Law, Oxford, Clarendon Press.
Hartlyn, Jonathan, y Valenzuela, Arturo, 1994, “Democracy in Latin America since 1930", en Bethell, Leslie (comp.), TheCambridge H istory of Latin America, Vol. VI: Latin America since 1930, parte 2: "Politics and Society", Nueva York, Cambridge University Press.

Hartlyn, Jonathan; M cCoy, Jennifer, y M ustillo, Thomas J., 2003, “The'Quality of Elections' in Contemporary Latin America: Issues in M easurement and Explanation", artículo presentado en el XXIV Congreso Internacional delaAsociación deEstudios Latinoamericanos (LASA), Dallas, Texas, 27-29 de marzo.

Held, David, 1987, M odels of Democracy, Stanford, Stanford University Press.

- - - - , 1999, “Conclusions”, en Held, David; McGrew, A., et al., Global Transformations. Politics, Economics and Culture, Stanford, Stanford University Press.

- - - - , 2004, "El estado de la democracia en América Latina", texto preparado para PRODDAL, en PNUD, La democracia en América Latina. Hacia una democracia de ciudadanas y ciudadanos. Anexo: El debate conceptual sobrela democracia (CD ROM ), Buenos Aires, Aguilar, Altea, Taurus, Alfaguara.

Held, David, y Guibernau, M ., 2001, “Cosmopolitan Democracy. An Interview with David Held", en Constellations 8 (4), pp. 427-440.

Held, David; Hermet, Guay; Loaeza, Soledad; Prud'homme, Jean-Francois (comps.), 2001, Del populismo de los antiguos al populismo de los modernos, M éxico, Colegio de M éxico, Centro de Estudios Internacionales.

Hill, C., 1997, Liberty against the Law. Some Seventeenth-Century Controversies, Londres, Penguin Books.

Hirschman, A., 1970, Exit, Voice, and Loyalty. Responses to Decline in Firms, Organizations, and States, Cambridge, $\mathrm{H}$ arvard University Press.

- - - - 1991, The Rethoric of Reaction, Cambridge, Belknap Press of Harvard University Press. 
Hodess, Robin; Banfield, Jessie, y Wolfe, Toby (comps.), 2001, Global Corruption Report 2001, Berlín, TI.

Hoffman, M., 2000, Empathy and M oral Development. Implications for Caring and Justice, Cambridge, Cambridge University Press.

Holmes, S., 1995, Passions \& Constraint. On the Theory of Liberal Democracy, Chicago, University of Chicago Press.

Holmes, S., y Sunstein, C. R., 1999, The Cost of Rights. Why Liberty D epends on Taxes, Nueva York, W. W. Norton.

Hooker, M. B., 1975, Legal Pluralism: An Introduction to Colonial and Neo-Colonial Laws, Oxford, Oxford University Press.

Hosle, V., 1998, O bjective Idealism, Ethics, and Politics, Notre Dame, Indiana, University of Notre Dame Press.

Houtzager, P., y Crook, R., 2001, “We M ake the Law and the Law Makes Us. Some Ideas on a Law in Development Research Agenda", en IDS Bulletin 32 (1), pp. 8-18.

H sieh, C.-C., y Pugh, M. D., 1993, "Poverty, Income Inequality, and Violent Crime: A M eta-Analysis of Recent Aggregate Data Studies", en Criminal Justice Review 18 (2), pp. 182-202.

Huang, Zhexue, 1997, "A fast clustering algorithm to cluster very large categorical data sets in data mining" [http://www.cmis.au/Graham.Williams/papers/ sigmodfn.pdf].

Huber, E., y Stephens, J. D., 1999, “The Bourgeoisie and Democracy: Historical and Comparative Perspectives", en Social Research 66 (3).

Huber, E.; Rueschemeyer, D., y Stephens, J. D., 1997, "The Paradoxes of Contemporary Democracy: Formal, Participatory, and Social Democracy", en Comparative Politics 29 (3), pp. 323-342.
Huntington, S., 1991, The Third Wave: Democratization in the Late Twentieth Century, Norman, University of Oklahoma Press.

Hurtado, Osvaldo, 2004, "Cultura y democracia, una relación olvidada", texto preparado para PRODDAL, en PNUD, La democracia en América Latina. Hacia una democracia de ciudadanasy ciudadanos: Contribuciones para el debate, Buenos Aires, Aguilar, Altea, Taurus, Alfaguara.

Iazzetta, 0., 2002, Estado y democracia: Una revisión sobre un vínculo necesario, Rosario, Universidad Nacional de Rosario.

IDEA Internacional (Instituto para la Democracia y la Asistencia Electoral), 2002a, "Voter Turnout From 1945 to Date. A Global Report on Political Participation" [http://www.idea.int/vt/index.cfm].

- - - , 2002b, "Compulsory Voting” [http://www. idea.int/vt/analysis/Compulsory_Voting. cfm].

- - - , 2003, "Global Database of Quotas for Women" [http://www.idea.int/quota/index.cfm].

Iglesias, Enrique, 2004, “Democracia y desarrollo: la política importa", texto preparado para PRODDAL, en PNUD, La democracia en América Latina. Hacia una democracia de ciudadanas y ciudadanos: Contribuciones para el debate, Buenos Aires, Aguilar, Altea, Taurus, Alfaguara.

Inglehart, R., 1990, Culture Shift in Advanced Industrial Society, Princeton, Princeton University Press.

Instituto de Derecho Público Comparado (Universidad de Carlos III de Madrid), 2003, Justicia Constitucional en Iberoamérica [http://www.uc3m.es/ uc3m/inst/M GP/JCl/00-portada.htm].

Inter-American Dialogue, 2003, "Afro-D escendants in Latin America: How M any?", en Race Report, Washington $\mathrm{DC}$, Inter-American Dialogue, enero.

INTERPO L, 2004, "Internacional Crime Statistics" [http://www.interpol.int/Public/Statistics/ICS/ downloadList.asp]. 
IPEC (Programa Internacional para la Erradicación del Trabajo Infantil) y SI M POC (Programa Estadístico de Información y Monitoreo sobre Trabajo Infantil), 2002, Every Child Counts: N ew Global Estimates on Child Labour, Ginebra, OIT.

IPU (Unión Interparlamentaria), 1995, Women in Parliaments 1945-1995: A World Statistical Survey, Ginebra, Unión Interparlamentaria.

- - - - 2003, IPU Women in National Parliaments. Statistical Archive website

[http://www.ipu.org/wmne/classif-arc.htm].

Jarquín, Edmundo, y Carrillo, Fernando (comps), 1998, Justice Delayed: Judicial Reform in Latin America, Washington DC, Inter-American Development Bank.

Jelin, Elizabeth, y Hershberg, Eric, 1996, Construir la democracia: derechos humanos, ciudadanía y sociedad en América Latina, Caracas, Nueva Sociedad.

Jessop, B., 1990, State Theory. Putting Capitalist States in their Place, University Park, Pennsylvania, Pennsylvania State University Press.

Johnson III, Ollie A., 1998, "Racial Representation and Brazilian Politics: Black M embers of the National Congress, 1983-1999", en Journal of Inter-american Studies and World Affairs, Vol. 40, № 4 (invierno), pp. 97-118.

Jones, M ark P., 1995, "A Guide to the Electoral Systems of theAmericas", en Electoral Studies 14 (1), pp. 5-21.

- - - - , 1997, "A Guide to the Electoral Systems of theAmericas: An U pdate", en Electoral Studies 16 (1), pp. 13-15.

Jones, P., 1994, Rights, Nueva York, St. M artin's Press.

Karlekar, Karin Deutsch, 2003, Freedom of the Press 2003. A G lobal Survey of M edia Independence, Nueva York-Lanham, Freedom House y Rowman \& Littlefield Publishers, Inc.

Kavanagh, D., 1983, Political Science and Political Be haviour, Londres, Allen \& Unwin.
Kelsen, Hans, 1945, General Theory of Law and State, Cambridge, M assachusetts, H arvard University Press.

- - - , 1967, Pure Theory of Law, Berkeley, University of California Press.

Keohane, N. O., 1980, Philosophy and the State in France. The Renaissance to the Enlightment, Princeton, Princeton University Press.

Kertzer, D., 1988, Ritual, Politics \& Power, New Haven, Yale University Press.

Kikut, L.; Gómez, M ., y Vargas Cullell, J., 2003a, Metodología empleada para determinar las orientaciones hacia la democracia de las y los ciudadanos deAmérica Latina, San José, documento preparado para el Proyecto sobre Desarrollo Democrático de América Latina del PNUD, junio de 2003.

- - - , 2003b, Anexo: M etodología para determinar las orientaciones hacia la democracia de las y los ciudadanos de América Latina a partir deíndices sumativos, San José, documento preparado para el Proyecto sobre Desarrollo Democrático de América Latina del PNUD, junio de 2003.

Kikut, L., y Vargas Cullell, J., 2003, Variables empleadas en el análisis de las orientaciones hacia la democracia y otras actitudes, San José, documento preparado para el Proyecto sobre Desarrollo Democrático de América Latina del PNUD, junio de 2003.

Kinzo, M aría Dálva, 1996, PM DB: Partido do M ovimento Democrático Brasileiro, San Pablo, Konrad Adenuar Stiftung.

Kornblith, M iriam, 1994, "La crisis del sistema político venezolano", en N ueva Sociedad N ${ }^{\circ} 134$.

Krug, E. G., et al. (comps.), 2002, World Report on Violenceand H ealth, Ginebra, Organización Mundial de la Salud.

Krygier, M., 1997, Between Fear and Hope. Hybrid Thoughts on Public Values, Sidney, ABC Books. 
Kucera, David, 2001, “The Effect of Core Worker Rights on Labour Costs and Foreign Direct Investment: Evaluating the 'Conventional Wisdom'", en IILS Decent Work Research Programme Working Paper, Discussion Paper 130.

Kymlicka, W., 1996, Multicultural Citizenship, Nueva York, Oxford University Press.

Laakso, M arkku, y Taagapera, Rein, 1979, “Effective Number of Parties: A M easure with Application to Western Europe", Comparative Political Studies 12 (1), pp. 3-27.

Lacey, N., 2001, "Responsibility and M odernity in Criminal Law", en The Journal of Political Philosophy 2 (3), pp. 149-176.

Lagos, Ricardo; Lechener, N orbert, y Gert, Rosenthal, 1991, Las Ciencias Sociales en el proceso de democratización, Santiago de Chile, Flacso, Cuadernos de Difusión.

Lagroye, J., 1993, Sociologie politique, París, Presses de la Fondation Nationale des Sciences Politiques y Dalloz.

Lambsdorff, Johann Graf, 2001, "Transparency International 2001 Corruption Perceptions Index", en Hodess, Robin; Banfield, Jessie, y Wolfe, Toby (comps.), Global Corruption Report 2001, Berlín, TI.

Lamounier, Bolivar, 1989, Partidos e Utopia. 0 Brasil nio Limiar dos anos 90, San Pablo, Loyola.

- - - , (org.), 1990, De Geisel a Collor. O Balanco da Transica, San Pablo, IDESP/CN Pq.

Lamounier, Bolivar, y M enegeghello, Rachel, 1986, Partidos y Consolidaçao democratica, San Pablo, Brasilense.

Lamounier, Bolivar, y Sadek, M aria Teresa, 1991, De pois da Transicao: Democracia e Eleicoes no Governo Collor, San Pablo, Loyola.

Landi, Oscar, 1992, Devórame otra vez. Quéhizo la TV con la gente. Quéhizo la gente con la TV, Buenos Aires, Planeta.
Lane, R., 1988, "Procedural Goods in a Democracy: How One is Treated Versus What One Gets", en Social Justice Research 2 (3), pp. 177-192.

Langton, S., 1978, “W hat is Citizen Participation”, en Langton, S., Citizen Participation in America, Lexington, Lexington Books.

Lechner, Norbert, 1981, “Epílogo”, en Lechner, Norberto (comp.), Estado y Política en América Latina, México DF, Siglo XXI.

_- - - , 1991, Capitalismo, democracia y reformas, Santiago de Chile, Flacso.

- - - - ,1994, “Los nuevos perfiles de la política. Un bosquejo", en Nueva Sociedad, № 130, marzo-abril.

- - - - , 1995, "La problemática innovación de la sociedad civil”, en Espacios, SJCR-Flacso, $\mathrm{N}^{\circ} 4$.

- - - - 1996, "Estado y sociedad en una perspectiva democrática" , en Estudios Sociales 11, Universidad Nacional del Litoral, Rosario.

- - - - 2000, “Desafios de un desarrollo humano: Individualización y capital social", en Instituciones y Desarrollo 7, pp. 7-34.

León-Rosch, M arta, 1998, "Los registros electorales", en Nohlen, Dieter; Picado, Sonia, y Zovatto, Daniel (comps.), Tratado de derecho electoral comparado de América Latina, M éxico, Fondo deCultura Económica.

Levi, M., 1997, Consent, Dissent, and Patriotism, Cambridge, Cambridge University Press.

Lijphart, Arend, 1984, Democracies. Patterns of M ajoritarian and Consensus Government in Twenty- $O$ ne Countries, New Haven, Yale University Press.

- - - , 1997, "Unequal Participation: Democracy's Unresolved Dilemma", en American Political Science Review 91 (1), pp. 1-14.

Linz, Juan, 1978, The Breakdown of Democratic Regimes. Crisis, Breakdown \& Reequilibration, Baltimore, Johns Hopkins University Press. 
Linz, Juan, y Stepan, A., 1996, Problems of D emocratic Transition and Consolidation. Southern Europe, South America, and Post-Communist Europe, Baltimore, Johns Hopkins University Press.

López Jiménez, Sinesio, 2002, Ciudadanía informada y democracia: el caso peruano, Lima, Comisión Andina de Juristas.

López-Pintor, Rafael, 2000, Electoral M anagement Bodies as Institutions of Governance, Nueva York, PNUD, Oficina de Políticas de Desarrollo.

Lora, Eduardo, 2001, "Structural Reforms in Latin America: What $\mathrm{H}$ as Been Reformed and How to M easure It", en Research D epartment Working Paper 466 , Washington DC, Inter-American Development Bank (diciembre).

MacAdam, D.; Tarrow, S., y Tilly, C., 2001, Dynamics of Contention, Nueva York, Cambridge University Press.

Maier, C., 1981, Recasting Bourgeois Europe. Stabilization in France, Germany, and Italy in the Decade after World War I, Princeton, Princeton University Press.

Mainwaring, Scott, y Soberg Shugart, M atthew (comps.), 1997, Presidentialism and Democracy in Latin America, Nueva York, Cambridge University Press.

M ainwaring, Scott; Brinks, Daniel, y Pérez-Liñán, Aníbal, 2001, "Classifying Political Regimes in Latin America, 1945-1999", en Studies in Comparative International Development 36 (1), pp. 37-65 (primavera).

Maiorano, Jorge Luis, 2000, "The Defensor del Pueblo in Latin America", en Gregory, Roy, y Giddings, Philip (comps.), Righting Wrongs. The O mbudsman in Six Continents, Washington DC, IOS Press.

Maíz, R., 2002a, Nacionalismo y movilización política: Hacia un análisis pluridimensional dela construcción de las naciones, Santiago de Compostela, Universidad de Santiago de Compostela.
- - - , , 2002b, "N acionalismo, federalismo y acomodación en Estados multinacionales", en Safran, W., y M aíz, R., (comps.) , I dentidad y autogobierno en sociedades multiculturales, Barcelona, Ariel.

M alloy, J. M., 1991, “Politica económica e o problema de governabilidade democrática nos Andes Centrais", en Sola, L. (comp.), Estado, M ercado eD emocracia: Politica eeconomía comparada, San Pablo, Paz eTerra.

M ansbridge, J., 1983, Beyond Adversary Democracy, Chicago, Chicago University Press.

- - - , 1999, "On the Idea that Participation MakesBetter Choices", en Elkin, S., y Soltan, K. E. (comps.), Citizen Competence and Democratic Institutions, University Park, Pennsylvania, Pennsylvania State University Press.

Margalit, A., 1996, The Decent Society, Cambridge, Massachusetts, Harvard University Press. (Edición en español: La sociedad decente, 1997, Barcelona, Paidós.)

Marshall, T.H., 1965, "Citizenship and Social Class", en Marshall, T. H. (comp.), Class, Citizenship and Social Development, Nueva York-Garden City, Doubleday (1949).

Martínez, N éstor Humberto, 1997, “Estado de derecho y eficiencia económica", en Jarquín, Edmundo, y Carrillo, Fernando (comps.), La economía política de la reforma judicial, Washington DC, BID.

Marx, Karl, 1963, Early Writings, edición de T. B. Bottomore, Nueva York, M cGraw-Hill.

Matos M ar, José, 1993, "Población y grupos étnicos de América, 1994", en América Indígena 53 (4): 155234, octubre-diciembre.

Mayorga, René Antonio, 1992, Democracia y gobernabilidad en América Latina, Caracas, Nueva Sociedad.

Mazzuca, S., 1998, "¿Qué es y no es la democratización?", en Estudios Políticos (19), pp. 73-122. 
- - - , 1999, "Acceso al Poder versusEjercicio del Poder", Berkeley, Universidad de California, multicopiado.

,---- 2000 , “Access to Power versus Exercise of Power: Democratization and Bureaucratization in Latin America", documento mimeografiado, Berkeley, Departamento de Ciencia Política de la Universidad de California.

McCoy, Jennifer, 2004, "Sobre tesis III. Sobre la de mocracia como organización social", texto preparado para PRODDAL, en PNUD, La democracia en América Latina. Hacia una democracia de ciudadanas y ciudadanos. Anexo: El debate conceptual sobre la democracia (CD ROM ), Buenos Aires, Aguilar, Altea, Taurus, Alfaguara.

Mead, G. H., 1967, M ind, Self, and Society. From the Standpoint of a Social Behaviorist, Chicago, University of Chicago Press, (1934).

M eentzen, Angela, 2002, Estrategias de desarrollo culturalmenteadecuadas para mujeres indígenas, Washington DC, BID, Departamento de Desarrollo Sustentable, Unidad de Pueblos Indígenas y Desarrollo Comunitario.

M éndez, Juan, 2004, “Sociedad civil y calidad de la democracia", texto preparado para PRODDAL, en PNUD, La democracia en América Latina. Hacia una democracia deciudadanas y ciudadanos. Anexo: El debate conceptual sobre la democracia (CD ROM), Buenos Aires, Aguilar, Altea, Taurus, Alfaguara.

M éndez, J., O'D onnell, G., y Pinheiro, P. S. (comps.), 1999, The Rule of Law and the Underprivileged in Latin America, Notre Dame, Indiana, University of Notre Dame Press.

M éndez-M ontalvo, M yriam, y Ballington, Julie (comps.), 2002, M ujeres en el Parlamento. M ás allá de los números, Estocolmo, IDEA Internacional.

Mesa, Carlos, 1999, Presidentes de Bolivia: Entre urnas y fusiles, La Paz, Gisbert.

Middlebrook, Kevin J. (comp.), 1998, Electoral O bservation and Democratic Transitions in Latin Ame- rica, La Jolla, Center for U.S.-Mexican Studies, Universidad de California.

Mill, John Stuart, 1962, On Liberty, Glasgow, Collins/ Fontana. (Edición en español: Sobre la libertad, Bue nos Aires, Aguilar, 1954.)

M oisés, Jose Álvaro, y Guilhon Albuquerque, J. A. (org.), 1989, Dilemas da Consolidaçao da Democracia, Río de Janeiro, Paz e Terra.

M ontgomery, Tommie Sue (comp.), 1999, Peacemaking and Democratization in Central America, Boulder, Colorado, Lynne Rienner.

M ora y Araujo, M anuel, 1997, Los actores sociales y políticos en los procesos detransformación en América Latina, Buenos Aires, CIED LA.

Moreira Cardoso, Aldalberto, y Eisenberg, José, 2004, "Esperanza entrampada: Las perspectivas para la democracia en América Latina", texto preparado para PRODDAL, en PNUD, La democracia en América Latina. Hacia una democracia de ciudadanas y ciudadanos. Anexo: El debate conceptual sobre la democracia (CD ROM ), Buenos Aires, Aguilar, Altea, Taurus, Alfaguara.

M orley, Samuel, 2001, The Income Distribution Problem in Latin America and the Caribbean, Santiago deChile, Cepal.

M orley, Samuel; M achado, Roberto, y Pettinato, Stefano, 1999, "Indexes of Structural Reform in Latin America”, en Serie Reformas Económicas № 12, Santiago de Chile, ECLAC, LC/L.1166/I, enero.

M osley, Layna, y Uno, Saika, 2002, Dataset of Labor Rights Violations, 1981-2000, Notre Dame, Indiana, Universidad de Notre Dame.

M ouffe, Chantal, 1996, "Democracy, Power, and the 'Political'", en Benhabib, S. (comp.), D emocracy and Difference. Contesting the Boundaries of the Political, Princeton, Princeton University Press.

- - - , 2000, The Democratic Paradox, Londres, Verso. 
Moulián, Tomás, 1983, Democracia y socialismo en Chile, Santiago de Chile, Flacso.

- - - , 2002, En la brecha. Derechos humanos. Críticas y alternativas, Santiago de Chile, Lom.

Munck, Gerardo L., 2004, Concepts, Indicators, and Indices. M ethodological Foundations of the Statistical Com-pendium of the Report on Democratic D evelopment in Latin America, manuscrito inédito.

Munck, Gerardo L., y Verkuilen, Jay, 2002, “Conceptualizing and Measuring Democracy: Evaluating Alternative Indices", en Comparative Political Studies 35 (1), pp. 5-34, febrero.

Murilo deCarvalho, J., 1991, A Cidadanía no Brasil. 0 Longo Camino, Río de Janeiro, Civilizacão Brasileira.

Nanda, Ved P.; Scarritt, James, y Shepherd, George Jr. (comps.), 1981, Global Human Rights: Public Policies, Comparative M easures, and NGO Strategies, Boulder, Colorado, Westview Press.

Newey, G., 1998, “Value.Pluralism in Contemporary Liberalism", en Dialogue 37, pp. 493-522.

Nohlen, Dieter, y Grotz, Florian, 2000, “External Voting: Legal Framework and Overview of Electoral Legislation", en Boletín M exicano de D erecho Comparado 99, pp. 1115-1145, septiembre-diciembre.

Nohlen, Dieter; Picado, Sonia, y Zovatto, Daniel (comps.), 1998, Tratado de derecho electoral comparado de América Latina, M éxico, Fondo de Cultura Económica.

Nozick, Richard, 1974, Anarchy, State, and U topia, Nueva York, Basic Books. (Edición en español: Anarquía, Estado y utopía, 1988, México DF, Fondo de Cultura Económica.)

Nun, José, 2001, Democracia. ¿Gobierno del pueblo 0 delos políticos?, Buenos Aires, Fondo de Cultura Económica.

- - - - , 2004, “Estado y ciudadanía”, texto preparado para PRODDAL, en PNUD, La democracia en
América Latina. Hacia una democracia de ciudadanas y ciudadanos. Anexo: El debate conceptual sobrela democracia (CD ROM ), Buenos Aires, Aguilar, Altea, Taurus, Alfaguara.

Nussbaum, M., 1997, "Capabilities and Human Rights", en Fordham Law Review 66 (2), pp. 273-300.

- - - - , 2000a, "Aristotle, Politics, and Human Capabilities: A Response to Antony, Arneson, Charlesworth, and Mulgan", en Ethics 111, pp. 102-140.

- - - - , 2000b, Women and Human Development. The Capabilities Approach, Cambridge, Cambridge University Press.

O'Donnell, G., 1982, El Estado burocrático-autoritario. 1966-1973. Triunfos, derrotas y crisis, 2a edición, Buenos Aires, Editorial de Belgrano.

- - - - , 1993, "On the State, Democratization and SomeConceptual Problems: A Latin American View with Glances at Some Postcommunist Coun-tries", en World Development 21 (8), pp. 1355-1369.

- - - - , 1994, “D el egative Democracy”, en Journal of Democracy 5 (1), pp. 94-108.

- - - - 1997a, H orizontal Accountability and N ew Polyarchies, Notre Dame, Indiana The Helen Kellogg Institute for International Studies at the University of Notre Dame.

_- - - , 1997b, Contrapuntos. Ensayos escogidos sobreautoritarismo y democratización, BuenosAires, Paidós.

- - - , 1998a, "Horizontal Accountability and New Polyarchies", en Schedler, A.; Diamond, L., y Plattner, M . (comps.), The Self-Restraining State: Power and Accountability in N ew Democracies, Boulder, Colorado, Lynne Rienner.

- - - , 1999a, Democratic Theory and Comparative Politics, NotreDame, Indiana, The Helen Kellogg Institute for International Studies at the University of Notre Dame. 
- - - , 1999b, "Polyarchies and the (Un)Rule of Law in Latin America", en M éndez, J.; O'D onnell, G., y Pinheiro, P. S. (comps.), The Rule of Law and the Underprivileged in Latin America, Notre Dame, Indiana, University of N otre Dame Press.

- - - , 1999c, "Pobreza y desigualdad en América Latina. Algunas reflexiones políticas", en Tokman, Víctor, y O'Donnell, Guillermo (eds.), Pobreza y desigualdad en América Latina. Temasy nuevos desafíos, Buenos Aires, Paidós.

- - - , 2000, “Democracy, Law, and Comparative Politics", en H elen Kellogg Institute for International Studies working paper, 274, Notre Dame, Indiana, The Helen Kellogg Institute for International Studies at the University of N otre Dame. Versión resumida en Studies in International Comparative D evelopment 36(1), pp. 5-36 (2001).

- - - , 2001a, Human Development, Human Rights, Democracy, documento preparado para el taIler "Calidad de la Democracia", celebrado en San José, Costa Rica.

- - - , 2001b, "Reflections on Contemporary Latin American Democracies", Journal of Latin American Studies, 67-82 (otoño).

- - - , 2002a, "Human Development/Democracy/Human Rights", ponencia presentada en el taller "Calidad dela Democracia y Desarrollo Humano en América Latina", celebrado en Heredia, Costa Rica. Disponible en www.estadonacion.org.cr.

- - - , 2002b, "N Notas sobre varias 'accountabilities' y sus interrelaciones", en Peruzzotti, E., y Smulovitz, C. (comps.), Controlando la política. Ciudadanos y medios en las nuevas democracias, Buenos Aires, Temas.

,$---- 2002 c$, N otes on the State of Democracy in Latin America, documento preparado para el proyecto "El estado de la democracia en América Latina", patrocinado por la División Regional para América Latina y el Caribe del Programa de Naciones Unidas para el Desarrollo.
- - - , 2003a, "H orizontal Accountability: The Legal Institutionalization of M istrust", en Mainwaring, S., y Welna, C. (comps.), Accountability, Democratic Governance, and Political Institutions in Latin America, Oxford, Oxford University Press.

- - - , 2004a, "Acerca del Estado en América Latina contemporánea: diez tesis para discusión", texto preparado para PRODDAL, en PNUD, La democracia en América Latina. Hacia una democracia de ciudadanas y ciudadanos: Contribuciones para el de bate, Buenos Aires, Aguilar, Altea, Taurus, Alfaguara.

- - - , 2004b, "Notas sobre la democracia en América Latina", texto preparado para PRODDAL, en PNUD, La democracia en América Latina. $\mathrm{Ha}$ cia una democracia de ciudadanas y ciudadanos. Anexo: El debate conceptual sobre la democracia (CD ROM ), Buenos Aires, Aguilar, Altea, Taurus, Alfaguara.

O'D onnell, G., et al., 1986, Transitions from Authoritarian Rule: Comparative Perspectives, Baltimore, Johns Hopkins University Press.

O'D onnell, G., y Schmitter, P., 1986, Transitionsfrom Authoritarian Rule: Tentative Conclusions About Uncertain Democracies, Baltimore, Johns Hopkins University Press.

O'D riscoll, Jr., Gerald; Edwin Feulner, J.; O'Grady, Mary Anastasia; Eiras, Ana, y Shaefer, Brett (comps.), 2003, The 2003 Index of Economic Freedom, Washington DC, Fundación H eritagey D ow Jones \& C o., Inc.

O'D riscoll, Jr., Gerald; Kim, Holmes, y O'Grady, M ary Anastasia (comps.) , 2002, 2002 Index of Economic Freedom, Washington DC, Fundación Heritage y Dow Jones \& Co. Inc.

Ocampo, José A., 2004, "Economía y democracia”, texto preparado para PRODDAL, en PNUD, La de mocracia en América Latina. Hacia una democracia de ciudadanas y ciudadanos: Contribuciones para el de bate, Buenos Aires, Aguilar, Altea, Taurus, Alfaguara.

OCDE (Organización de Cooperación y Desarrollo Económico) y UNESCO (Organización de las Na- 
ciones Unidas para la Educación, la Ciencia y la Cultura), 2003, Literacy Skills for theWorld of Tomorrow, París, OCDE, UNESCO.

OEA (Organización de Estados Americanos), 2003, "Appendix: Inter-American Treaties: Status of Signatures and Ratifications Classified by Treaty, Country and Subject M atter" [http://www.oas.org/juridico/ english/study_appendix.doc].

OEA-CIDH (Comisión Interamericana deDerechos Humanos), Relatoría para la Libertad de Expresión, 2001, Annual Report of the Special Rapporteur for Freedom of Expression 2001 [http://www.cidh.org/ Relatoria/English/AnnualReports.htm].

- - - , 2003, "Special Reports/Informes Especiales" [http://www.cidh.oas.org/countryrep/pais. esp.htm].

OEA-Comisión Interamericana de Mujeres, 2002, "Quota Laws"

[http://www.oas.org/cim/English/Laws-Cuota.htm].

- - - , 2003, "Violence Laws"

[http://www.oas.org/cim/English/LawsViolence.htm].

Office of the Comptroller and Auditor General of India, 2003, "M andates of SAls [Special Audit Agencies]" [http://www.cagindia.org/mandates.htm].

OIT (Organización Internacional del Trabajo), 2002a, "ILOLEX Database on International Labour Standards" [http://www.ilo.org/ilolex/english/convdisp2.htm].

,$---- 2002 b$, "Pueblos Indígenas"

[http://www.indigenas.oit.or.cr/].

- - - , 2003, Panorama Laboral 2003, Anexo Estadístico.

- - - , 2003, “ILOLEX Database on International Labour Standards. Ratifications of the Fundamental Human Rights Conventions by Country" [http://ilolex.ilo.ch:1567/english/docs/decl-world.htm].

OIT-O ficina Regional para las Américas, 2001, 2001 Labour O verview, Lima, OIT-Oficina Regional para las Américas.
- - - , 2002, Panorama laboral 2002, Lima, OITOficina Regional para las Américas.

OM S (Organización M undial de la Salud)-UN ICEF (Fondo de las Naciones Unidas para la Infancia), 2000, Global Water Supply and Sanitation Assessment 2000 Report, Nueva York, Organización Mundial de la Salud y UNICEF.

OMS, Departamento de Nutrición para la Salud y el Desarrollo, 2002, WHO Global Database on Child Growth and Malnutrition, Ginebra [http://www.who.int/nutgrowthdb/].

ONU (Organización de Naciones Unidas), 1948, Declaración Universal de Derechos Humanos, adoptada y proclamada por la Asamblea General en su resolución 217 A (III), 10 de diciembre.

- - - , 2003a, “M ultilateral Treaties Deposited with the Secretary General"

[http://untreaty.un.org/].

- - - - 2003b, Implementation of the United Nations M illenium Declaration. Report of the Secretary General, A/58/323.

ONU (Organización de Naciones Unidas), Comisión de Derechos Humanos, 1999, Resolución de la Comisión de Derechos Humanos 1999/57 sobre la "Promoción del derecho a la democracia”.

ONU (Organización de Naciones Unidas), División de Población, D epartamento de Asuntos Económicosy Sociales, 2001, World Population Prospects: The 2000 Revision, Nueva York, Naciones Unidas.

- - - - 2002, World U rbanization Prospects: The 2001 Revision, Nueva York, Naciones Unidas.

Ortega R., Eugenio, y M oreno, Carolina (comps.), 2002, ¿La Concertación desconcertada? Reflexiones sobresu historia y su futuro, Santiago de Chile, Lom.

Ostwald, M ., 1986, From Popular Sovereignty to the Sovereignty. Law, Society, and Politics in Fifth-Century Athens, Berkeley, University of California Press. 
Pachano, Simón (comp.), 1998, M odernización de las instituciones democráticas: El Congreso, Q uito, Flacso.

- - - , (comp.), 2003, Ciudadanía e identidad, Quito, Flacso.

Paniagua, Vicente, 2000, “El fraude en marcha”, en QuéH acer, $\mathrm{N}^{\circ}$ 118, Lima.

Pastor, Robert A., 1999, "The Role of Electoral Administration in Democratic Transitions: Implications for Policy and Research", en Democratization 6 (4), pp. 1-27 (invierno).

Patterson, O., 1991, Freedom. Volume I. Freedom in the M aking of the Western World, Nueva York, Basic Books.

Paxton, Pamela; Bollen, Kenneth; Lee, D eborah, yHyojoung, Kim, 2003, "A Half-Century of Suffrage: New Data and a Comparative Analysis", en Studies in Comparative International Development 38 (1), pp. 93-122.

Payne, J.; Zovatto, Daniel; Carillo Floréz, Fernando, yAllamand Zavala, Andrés, 2002, D emocracies in De velopment. Politics and Reform in Latin America, Washington DC, BID eIDEA Internacional.

Pease García, H enry (comp.), 2003, La autocracia fujimorista: del Estado intervencionista al Estado mafioso, Lima, Pontificia Universidad Católica del Perú, Fondo de Cultura Económica.

Pedersen, M ogens N ., 1983, "Changing Patterns of Electoral Volatility in European Party Systems, 19481977: Explorations in Explanation", en Daalder, Hans, y M air, Peter (comps.), Western European Party Systems: Continuity and Change, Beverly H ills, Sage.

Pennington, K., 1993, The Prince and Law, 12001600. Sovereignty and Rights in the Western Legal Tradition, Berkeley, University of California Press.

Pérez-Liñán, Aníbal, 2001, “C risis presidenciales: Gobernabilidad y estabilidad democrática en América Latina, 1950-1996", en Institucionesy D esarrollo, Barcelona, 8 y 9, pp. 281-298.
- - - , 2003, "Presidential Crises and Political Accountability in Latin America, 1990-1999", en Eckstein, Susan, y Wickham-Crowley, Timothy (comps.), What Justice? Whose Justice? Fighting for Fairness in Latin America, capítulo 4, Berkeley, University of California Press.

Perry, Guillermo Francisco; Ferreira, H. G.; Walton, Michael, et al., 2004, Inequality in Latin America and the Caribbean: Breaking with History?, Washington DC, Banco Mundial.

Peruzzotti, Enrique, y Smulovitz, Catalina, 2002a, "Accountability social: la otra cara del control", en Peruzzotti, E., y Smulovitz, C. (comps.), Controlando la política. Ciudadanos y medios en las nuevas democracias, Buenos Aires, Temas.

- - - , (comps.), 2002b, Controlando la política. Ciudadanosy medios en las nuevas democracias, Bue nos Aires, Temas.

Peschard, Jacqueline, 1997, La cultura política democrática, Cuadernos de divulgación de la cultura democrática, 2, M éxico, IFE.

Pinto, Céli Regina Jardim, 2004a, "Ciudadanía y democracia: los aportes desde una perspectiva de género", texto preparado para PRODDAL, en PNUD, La democracia en América Latina. Hacia una democracia de ciudadanas y ciudadanos: Contribuciones para el de bate, Buenos Aires, Aguilar, Altea, Taurus, Alfaguara.

- - - - , 2004b, "El objetivo de una perspectiva degé nero", texto preparado para PRODDAL, en PNUD, La democracia en América Latina. Hacia una democracia de ciudadanasy ciudadanos. Anexo: El debateconceptual sobre la democracia (CD ROM ), Buenos Aires, Aguilar, Altea, Taurus, Alfaguara.

Pinto-D uschinsky, M ichael, 2002a, "Financing Politics: A Global View", en Journal of Democracy, 13 (4), pp. 69-86.

- - - , 2002b, M oney and Politics Handbook: A Guideto Increasing Transparency in Emerging D emocracies, Washington, Office of Democracy and Governance, Technical Publications Series. 
Pion-Berlin, David (comp.), 2001, Civil-M ilitary Relationsin Latin America. N ew Analytical Perspectives, Chapel Hill, Carolina del Norte, University of North Carolina Press.

PNUD (Programa de las Naciones Unidas para el Desarrollo), 1998a, Integrating Human Rights with Sustainable Human Development. A UNDP Policy Document, Nueva York, PNUD.

— - - - , 1998b, U N DP Poverty Report 1998. O vercoming Human Poverty, Nueva York, PNUD.

- - - - , 2000a, H uman D evelopment Report 2000.

Human Rights and Human Development, Nueva York, Oxford University Press.

- - - , 2000b, Poverty Report 2000. O vercoming Human Poverty, Nueva York, PNUD.

- - - , 2000c, Informe sobre desarrollo humano 2000, M adrid, Ediciones M undi-Prensa.

_- - - , 2001, Human D evelopment Report 2001, Nueva York, PNUD y Oxford University Press.

- - - - , 2002a, Arab Human Development Report 2002. Creating O pportunity for Future Generations, Nueva York, PNUD, Oficina Regional deEstadosÁrabes.

- - - - , 2002b, Informe sobre desarrollo humano. $\mathrm{H}$ onduras 2002. Por una democracia incluyente, Tegucigalpa, PNUD.

- - - - , 2002c, Informe sobre desarrollo humano 2002. Profundizar la democracia en un mundo fragmentado, M adrid, Ediciones M undi-Prensa.

- - - - , 2003, Informe sobre desarrollo humano 2003. Millenium Development Goals: A Compact Among $N$ ations to End Human Poverty, New York, Oxford University Press.

- - - - 2004, La democracia en América Latina. Hacia una democracia de ciudadanas y ciudadanos: Contribuciones para el debate, Buenos Aires, Aguilar, Altea, Taurus, Alfaguara.
Poder Judicial, República O riental del U ruguay, División de Planeamiento y Presupuesto, Departamento de Estadísticas Judiciales, 2002, Actividad de D efensorías de O ficio en todo el país. Año 2001

[http://www.poderjudicial.gub.uy/].

Popkin, Margaret, 2001, "Informe comparativo sobre la independencia judicial en América Latina", trabajo presentado en la Conferencia Internacional: Perspectiva Global, Regional y Nacional, Lima, Perú, 29-30 de noviembre.

Porter, Michael; Sachs, Jeffrey; Cornelius, Peter; M cArthur, John, y Schwab, Klaus, 2002, The Global Competitiveness Report 2001-2002, Nueva York, Oxford University Press.

Portes, Alejandro, 1995, En torno a la informalidad. Ensayos sobre teoría y medición de la economía no regulada, Quito, Flacso.

Prebisch, Raúl, 1997, "La industrialización de América Latina”, en López Segrera, Francisco (comp.), El pensamiento social latinoamericano en el siglo XX, Tomo I, Caracas, UNESCO.

Preuss, U., 1986, "The Concept of Rights and the Welfare State", en Teubner, G. (comp.), Dilemmas of Law in theWelfareState, Nueva York-Berlín, Gruyter.

- - - , 1996a, "The Political M eaning of Constitutionalism", en Bellamy, R. (comp.), Constitutionalism, Democracy, and Sovereignty: American and European Perspectives, Aldershot, Avebury.

- - - , 1996b, "Two Challenges to European Citizenship", en Political Studies 44 (3), pp. 534-552.

Prillaman, William C., 2000, The Judiciary and Democratic Decay in Latin America. Dedining Confidence in the Rule of Law, Westport CT, Praeger.

Programa Integral de Reforma Judicial, 2003 [http://www.reformajudicial.jus.gov.ar/estadisticas/ america.htm]. 
Proyecto Estado de la Nación, 1999, Estado de la región. Un informe desde Centroamérica y para Centroamérica, San José de Costa Rica, Proyecto Estado dela Nación.

- - - - (en prensa), Estado dela región. II Informe deD esarrollo Humano Sustentableen Centroamérica, San José de Costa Rica, Proyecto Estado de la Nación.

Proyecto Estado de la Nación en Desarrollo Humano Sustentable, 2001, Informe de la auditoría ciudadana sobrela calidad dela democracia en Costa Rica, San Joséde Costa Rica, Proyecto Estado de la Nación.

- - - , 2002, "Políticas públicas de combateal racismo y la discriminación en Centroamérica", San José de Costa Rica, Proyecto Estado de la Nación.

Przeworski, Adam, 1991, Democracy and the M arket: The Political and Economical Reforms in Eastern Europe and Latin America, Nueva York, Cambridge University Press.

Przeworski, Adam, y Sprague, J., 1986, Paper Stones. A H istory of Electoral Socialism, Chicago, University of Chicago Press.

Przeworski, Adam; Álvarez, M ichael E.; Cheibub, José Antonio, y Limongi, Fernando, 2000, Democracy and Development: Political Institutions and Well-Be ing in theWorld, 1950-1990, Cambridge, Cambridge University Press.

Przeworski, Adam; M anin, B., y Stokes, S. (comps.), 1999, Democracy, Accountability, and Representation, Nueva York, Cambridge University Press.

Putnam, R., 1993, M aking Democracy Work, Princeton, Princeton University Press.

- - - , 1995, "Tunning In, Tunning Out: The Strange Disappearance of Social Capital in America", en Political Scienc \& Politics, $\mathrm{N}^{\circ} 4$.

- - - , 2000, Bowling Alone: The Collapseand Revival of American Community, Nueva York, Simon \& Schuster.
Ramírez Ocampo, Augusto, 2004, “La defensa colectiva de la Democracia", en PNUD, La democracia en América Latina. Hacia una democracia deciudadanas y ciudadanos: Contribuciones para el debate, Buenos Aires, Aguilar, Altea, Taurus, Alfaguara.

Rawls, John, 1971, A Theory of Justice, Cambridge, M assachusetts, Harvard University Press.

- - - - , 2001, Justice as Fairness. A Restatement, Cambridge, M assachusetts, Belknap Press of $\mathrm{Har}$ vard University Press.

Raz, J., 1986, The M orality of Freedom, Oxford, Clarendon Press.

- - - , 1994, Ethics in the Public D omain. Essays in the M orality of Law and Politics, Oxford, Clarendon Press.

Reporteros sin Fronteras, 2003, “Worldwide Press Freedom Index"

[http:// www.rsf.org/article.php3?id_article=4116].

Reyna, José Luis, 1999, América Latina a fines de siglo, Buenos Aires-M éxico, Paidós.

Rial, Juan, 2000, "Instituciones de democracia directa en América Latina" [www.ndipartidos.org/pdf/ gobernando/democraciadirecta.pdf].

Rial, Juan, y Zovatto, Daniel (comps.), 1998, Elecciones y democracia en América Latina, 1992-1996, San José de Costa Rica, Instituto Interamericano de De rechos Humanos-Centro Interamericano deAsesoría y Promoción Electoral.

Ribeiral, Tatiana B., y Dantas, Humberto, 2003, Participação Política eCidadania, Belo Horizonte, Editora Lê.

Ricupero, Rubens, 2004, “N otas sobreel impacto del comercio internacional en el desarrollo de las economías latinoamericanas", texto preparado para PRODDAL, en PNUD, La democracia en América Latina. H acia una democracia deciudadanas y ciudadanos: Contribuciones para el debate, Buenos Aires, Aguilar, Altea, Taurus, Alfaguara. 
Richards, D. A., 1996, "Autonomy in Law", en Christman, J. (comp.), The Inner Citadel. Essays on Individual Autonomy, Oxford, Oxford University Press.

Rivarola, D omingo, 1993, La sociedad conservadora, Asunción, CPES.

Rivero, Oswaldo de, 2001, El mito del desarrollo: los países inviables en el siglo XXI, Lima, Fondo de Cultura Económica.

Rodrik, Dani, 1997, “D emocracy and Economic Performance", Universidad de Harvard University, diciembre.

- - - - 2000, "D evelopment strategies for the next century", Universidad de Harvard, febrero.

- - - , 2001, "Four simple principles for democratic governance of globalization", Universidad de Harvard, mayo.

Roncagliolo, Rafael, 2000, "Elecciones del 2000: Caja de sorpresas para una teoría del fraude electoral", en Quéhacer, $N^{\circ} 118$, Lima.

Rosanvallon, Pierre, 1992, LeSacrédu Citoyen. Histoire du Suffrage Universel en France, París, Gallimard.

- - - , 1995, "The H istory of the Word 'Democracy' in France", en Journal of Democracy 6 (4), pp. 140-154.

_- - - , 2004, "Las dimensiones social y nacional de la democracia: hacia un marco de comprensión ampliada", texto preparado para PRODDAL, en PNUD, La democracia en América Latina. Hacia una democracia deciudadanas y ciudadanos. Anexo: El debate conceptual sobre la democracia (CD ROM), Buenos Aires, Aguilar, Altea, Taurus, Alfaguara.

Rose, Richard (comp.), 2000, International Encyclopedia of Elections, Washington DC, CQ Press.

Rothstein, B., 1998, Just Institutions M atter. The M oral and Political Logic of the Universal Welfare State, Cambridge, Cambridge University Press.
Rouquié, Alain; Lamounier, Bolivar, y Schvarzer, Jorge, 1985, Cómo renacen las democracias, San Pablo, Brasiliense.

Rueschemeyer, D., y Evans, P., 1985, “The State and Economic Transformation: Toward an Analysis of the Conditions Underlying Effective Intervention", en Evans, P.; Rueschemeyer, D., y Skocpol, T. (comps.), Bringing the State Back In, Cambridge, M assachusetts, Cambridge University Press.

Rueschemeyer, D.; Huber, E., y Stephens, J., 1992, Capitalist Development \& Democracy, Cambridge, Polity Press.

Sagasti, Francisco; Patrón, Pepi; Hernández, M ax, y Lynch, Nicolás, 1999, Democracia y buen gobierno. Agenda Perú, Lima, Agenda Perú.

Salomón, Leticia, 1994, Democratización y sociedad civil en H onduras, Tegucigalpa.

- - - - , (comp.), 1994, Los retos de la democracia, Tegucigalpa, Cedoh.

Samuels, David, 2000, “Fiscal Horizontal Accountability? Toward a Theory of Budgetary 'C hecks and Balances' in Presidential Systems", artículo presentado en la Conferencia "H orizontal Accountability in New Democracies", The Helen Kellogg Institute for International Studies at the University of N otre Dame.

Santos, Wanderley Guilherme dos, 1979, Cidadania ejusticia, Río de Janeiro, Campus.

Sartori, Giovanni, 1967, Democratic Theory, Nueva York, Praeger Publishers.

- - - - 1987a, The Theory of Democracy Revisited. I: The Contemporary D ebate, Chatham, Chatham House Publishers.

- - - - 1987b, The Theory of Democracy Revisited. II: The Classical Issues, Chatham, Chatham House Publishers. 
- - - , 1991, “D emocracia”, en Revista de Ciencia Política, Vol. XIII, № 1 y 2, Instituto de Ciencia Política-Pontificia Universidad Católica de Chile.

Sartorius, R., 1983, Paternalism, M inneapolis, University of M innesota Press.

Scott, J. C., 1985, Weapons of the Weak. Everyday Forms of Peasant Resistance, New Haven, YaleU niversity Press.

Scheiber, H. N. (comp.), 1998, The State and Freedom of Contract, Stanford, Stanford University Press.

Schlozman, K., et al., 1999, "Civic Participation and the Equality Problem", en Skocpol, T., y Fiorina, M., Civic Engagement in American Democracy, Washington DC, Brookings Institution Press.

Schmitter, P., 1992, "The Consolidation of Democracy and Representation of Social Groups", American Behavioral Scientist 35 (4 y 5), pp. 422-449.

Schneewind, J. B., 1998, The Invention of Autonomy. A History of M odern M oral Philosophy, Cambridge, Cambridge University Press.

Seider, R., 2000, Legal Pluralism and the Politics of State Formation in M esoamerica, Londres, Institute for Latin American Studies.

Seligson, M itchell, y Córdova, P., 2000, Auditoría de la Democracia: Ecuador, Quito, USAID-Proyecto de Opinión Pública de la Universidad de Pittsburgh.

Seligson, M itchell; Conroy, Annabelle; Córdova M acías, Ricardo; Pérez, Orlando, y Stein, Andrew, 1995, "Who Votes in Central America? A Comparative Analysis", en John Booth y M itchell Seligson (comps.), Elections and Democracy in Central America, edición revisada, Chapel Hill, Carolina del Norte, The University of North Carolina Press.

Sen, Amartya, 1985, "Well-Being, Agency and Freedom. The Dewey Lectures 1984", en The Journal of Philosophy, 82 (4), pp. 169-221.
- - - , 1992, Inequality Reexamined, Cambridge, M assachusetts, $\mathrm{H}$ arvard University Press.

- - - , 1999a, "D emocracy as a Universal Value", en The Journal of Democracy 10 (3), pp. 3-17.

- - - , 1999b, Development as Freedom, New York, Alfred Knopf. (Edición en español: Desarrollo y libertad, Buenos Aires, Planeta, 2000.)

- - - , 2000, "East and West. The Reach of Reason", en New York Review 47 (12), pp. 33-38.

- - - - 2003, La libertad individual como compromiso social, La Paz, Ildis. Introducción de Marc Saint-U péry.

Serrano, Claudia, 2002, "Pobreza, Capital Social y Ciudadanía"

[http://www.asesorias.tie.cl/documentos.htm].

Shapiro, I., 1996, Democracy's Place, Ithaca, Cornell University Press.

Shklar, J. N ., 1989, "The Liberalism of Fear", en Rosenblum, N. L. (comp.), Liberalism and the M oral Life, 21-38, Cambridge, M assachusetts, H arvard University Press.

Shue, H ., 1996, Basic Rights. Subsistence, Affluence, and U.S. Foreign Policy, Princeton, Princeton University Press.

Shugart, M atthew Sobert, y Carey, John, 1992, Presidents and Assemblies: Constitutional Design and Electoral Dynamics, Nueva York, Cambridge Univer-sity Press.

Skaar, Elin, 2001, "Judicial Reform in Latin America. Why?", artículo presentado en la Conferencia Anual de Ciencia Política de N oruega, Hønesfoss, enero.

Skinner, Quentin, 1984, "The I dea of Negative Liberty: Philosophical and Historical Perspectives", en Rorty, Richard (comp.), Philosophy in History, Cambridge, Cambridge University Press.

Smith, A. D., 1991, National Identity, Reno, University of N evada Press. 
Smulovitz, Catalina, y Peruzzotti, E., 2000, “Social Accountability in Latin America", Journal of Democracy 11 (4), pp. 147-158.

Snyder, Richard, 2001, Politics after Neoliberalism. The Politics of Reregulation in M exico, Cambridge, Cambridge University Press.

Snyder, Richard, y Samuels, David, 2001, “D evaluing the Vote in Latin America", en Journal of Democracy 12 (1), pp. 146-159, enero.

Sola, Lourdes, 2004, “Democratización, Estado eintegración a la economía global. ¿Cuál es el lugar de la política democrática? La experiencia brasileña en perspectiva", texto preparado para PRODDAL, en PNUD, La democracia en América Latina. Hacia una democracia deciudadanas y ciudadanos: Contribuciones para el debate, Buenos Aires, Aguilar, Altea, Taurus, Alfaguara.

Soros, George, 2001, “Capitalismo frente a la democracia" , en El País, M adrid, 21 de diciembre.

Stavenhagen, R., 1996, Ethnic Conflicts and the Nation-State, Londres, M acM illan Press.

Steel, R., y Torrie, J., 1996, Principles and Procedures of Statistics: A Biomedical Approach, Nueva York, McGraw-Hill.

Stein, P., 1999, Roman Law in European History, Cambridge, Cambridge University Press.

Stepan, A., 2000, "Religion, Democracy, and the Twin Tolerations", en Journal of D emocracy 11 (4), pp. 37-57.

Stiglitz, J oseph, 2004, “Globalización, organismos financieros internacionales y las economías latinoamericanas", texto preparado para PRODDAL, en PN UD, La democracia en América Latina. Hacia una democracia de ciudadanas y ciudadanos: Contribuciones para el debate, Buenos Aires, Aguilar, Altea, Taurus, Alfaguara.

Stoelting, E. (en prensa), "Informal Arrangements and the Public Space: Structural O bstacles to Empirical Research", en Brie, M. (comp.), Formal Institutions and Informal Institutional Arrangements.
Stolcke, V., 1997, "The 'Nature' of Nationality", en Blader ,V. (comp.), Citizenship and Exclusion, Londres, MacMillan Press.

Strasser, Carlos, 1999, Democracia y desigualdad. Sobre la "democracia real" a fines del siglo XX, Buenos Aires, Clacso-ASDI.

Suny, R., 2001, "Constructing Primordialism: Old Histories for N ew Nations", en The Journal of M odern History 73, pp. 862-896.

Suprema Corte deJusticia, República de El Salvador, 2003, "Organization and Responsabilities [http://www.csj.gob.sv/organiza.htm].

Sypnowich, C., 2000, "The Culture of Citizenship", en Politics \& Society 28 (4), pp. 531-555.

Tamayo, Eduardo, 1996, M ovimientos sociales: la riqueza de la diversidad, Quito, Agencia Latinoamericana de Información.

Tamir, Y., 1993, Liberal Nationalism, Princeton, Princeton University Press.

- - - , 1995, "The Enigma of Nationalism", World Politics 47, pp. 418-440.

Tanaka, M artín, 1998, Los espejismos de la democracia: el colapso de un sistema de partidos en el Perú, 1980-1995, en perspectiva comparada, Lima, IEP.

- - - , 2002, "Las relaciones entre Estado y sociedad en el Perú: desestructuración sin reestructuración, un ensayo bibliográfico", en América Latina H oy 31 , 189-218, agosto.

Tarrow, Sidney, 2000, "National Unification, National Disintegration, and Contention: A Paired Comparison of Unlikely Cases", M adrid, Centro de Estudios Avanzados en Ciencias Sociales.

Taylor, Charles, 1985, "What's Wrong with Negative Liberty", en Taylor, Charles, Philosophy and the Human Sciences. Philosophical Papers 2, 211-229, Cambridge, Cambridge University Press. 
Terrazas, Julio, 2004, “Avances y límites dela democracia en América Latina, en los últimos veinte años", texto preparado para PRODDAL, en PNUD, La democracia en América Latina. Hacia una democracia de ciudadanasy ciudadanos: Contribuciones para el debate, Buenos Aires, Aguilar, Altea, Taurus, Alfaguara.

Thompson, E. P., 1975, Whigs and H unters. The O rigins of the Black Act, Nueva York, Pantheon Books.

Thoumi, Francisco, 2004, "N otas sobre corrupción y drogasilegales", texto preparado para PRODDAL, en PNUD, La democracia en América Latina. Hacia una democracia de ciudadanas y ciudadanos: Contribuciones para el debate, Buenos Aires, Aguilar, Altea, Taurus, Alfaguara.

TI (Transparencia Internacional), 2002, “2002 Corruption Perceptions Index"

[http://www.transparency.org/surveys/index.html].

Tierney, B., 1997, The Idea of $\mathrm{N}$ atural Rights. Studies on Natural Rights, Natural Law and Church Law, 1150-1625, Atlanta, Scholars Press.

Tilly, Charles, 1975, The Formation of National States in Western Europe, Princeton, Princeton University Press.

- - - , 1985, “War M aking and StateM aking as Organized Crime", en Evans, P. B.; Rueschemeyer, D., y Skocpol, T. (comps.), Bringing the State Back In, Cambridge, Massachusetts, Cambridge University Press.

_- - - , 1990, Coercion, Capital and European States, Cambridge, Blackwell.

- - - - 1996, Citizenship, Identity and Social H istory, Cambridge, Cambridge University Press.

- - - , 1998a, Durable Inequality, Berkeley, University of California Press. (Edición en español: La desigualdad persistente, 2000, Buenos Aires, M anantial.)

- - - , 1998b, "Where do Rights Come From?", en Skocpol, T. (comp.), Democracy, Revolution, and History, Ithaca, Cornell University Press.
- - - , 1999, “N ow Where?”, en Steinmetz, George (comp.), State/Culture. State Formation after the Cultural Turn, Ithaca, Cornell University Press.

Tironi, Eugenio, 1999, La irrupción de las masas y el malestar de las elites, Santiago de Chile, Grijalbo.

Tokman, V., y O'Donnell, G. (comps.), 1998, Poverty and Inequality in Latin America. Issues and $\mathrm{New}$ ChaIlenges, Notre Dame, Indiana, University of Notre Dame Press.

Torre, Juan Carlos, 1998, El proceso político de las re formas en América Latina, Buenos Aires, Paidós.

Torres, Cristina, 2001, "Ethnicity and Health: Another Perspective Toward Equity", en Organización Panamericana dela Salud, Equity in Health: From an Ethnic Perspective, Washington DC, OPS.

Torres Rivas, E., 1981, “La nación: problemas teóricos ehistóricos", en Lechner, Norberto (comp.), Estado y política en América Latina, México DF, Siglo XXI.

Touraine, Alain, 1994, Qu'est-ce que la Démocratie?, París, Fayard.

- - - - 1997, Pourrons-nous vivre ensemble? Égaux et differents, París, Fayard. (Edición en español: 1999, ¿Podremos vivir juntos?, San Pablo, Fondo deCultura Económica.)

- - - , 2000, “El Sistema y los Actores", en Reforma y Democracia 18, pp. 7-24.

- - - , 2004, "Los caminos sinuosos de la democracia”, texto preparado para PRODDAL, en PNUD, La democracia en América Latina. Hacia una democracia de ciudadanas y ciudadanos. Anexo: El debate conceptual sobre la democracia (CD ROM), Buenos Aires, Aguilar, Altea, Taurus, Alfaguara.

Turner, B. S., 1986, Citizenship and Capitalism. The Debate over Reformism, Londres, Allen \& Unwin.

Tyler, T., 1990, Why People O bey the Law, New Haven, Yale University Press. 
- - - - 1994, "Governing and Diversity: The Effect of Fair Decision making procedures on the Legitimacy of Government", en Law and Society Review 28 (4), pp. 809-831.

U.S. D epartment of State, 2002, Guatemala Country Report on Human Rights Practices 2001

[http://www.state.gov/g/drl/rls/hrrpt/2001/wha/ 8344.htm].

Uggla, Fredrik, 2003, "The O mbudsman in Latin America. (The U ses of a Toothless Watchdog)", artículo presentado en la Conferencia "Diagnosing Democracy: M ethods of Analysis, Findings and Remedies", Santiago de Chile, 11-13 de abril.

UNESCO (Organización de las Naciones Unidas para la Educación, la Ciencia y la Cultura), Instituto deEstadísticas, 2002a, Literacy and Non Formal Education Sector, Estimates and Projections of Adult Illiteracy for Population Aged 15 Years Old and Above, by Country and by Gender 1970-2010, January 2002 assessment [http://www.uis.unesco.org/en/stats/stats0.htm] .

- - - , 2002b, Education Sector, Gross and Net Enrolment Ratio at Primary Level by Country and by Gender for theSchool Years 1998/1999 and 1999/2000, October 2002

[http://portal.unesco.org/uis/ev.php?url_i $d=5187$ url_do=do_topicurl_section $=201]$.

- - - , 2002c, Education Sector, Gross and Net Enrolment Ratio at Secondary Level by Country and by Gender for the School Years 1998/1999 and 1999/2000, 0 ctober 2002

[http://portal.unesco.org/uis/ev.php?url_id= 5187url_do=do_topicurl_section $=201]$.

- - - , 2002d, Education Sector, Gross and Net Enrolment Ratio at Tertiary Level by Country and by Gender for the School Years 1998/1999 and 1999/2000, O ctober 2002 [http://portal.unesco.org/uis/ev.php?url_id $=5187$ url_do=do_topicurl_section $=201]$.

Universidad de Georgetown y Organización deEstados Americanos (OEA), 2002, "Base de Datos Políticos de las Américas" [http://www.georgetown.edu/pdba/spanish.html].
UNODC (Oficina de las Naciones Unidas contra la Droga y el Delito), 2002, United Nations Surveys of Crime Trends and Operation of Criminal Justice Systems [http://www.unodc.org].

Valenzuela, J. S., 1992, “D emocratic Consolidation in Post-Transitional Settings: Notion, Process, and Facilitating Conditions", en M ainwaring, S.; O'Donnell, G., y Valenzuela, J. S. (comps.), I ssues in Democratic Consolidation: TheN ew South American Democracies in Comparative Perspective, Notre Dame, Indiana, The Helen Kellogg Institutefor International Studies at the University of N otre Dame.

Van Cott, Donna Lee, 2003, "Latin American Constitutions and Indigenous Peoples"

[http://web.utk.edu/ dvancott/constitu.html].

Varga, C., 1991, Codification as a Socio-Historical Phenomenon, Budapest, Akadémiai Kiadó.

Vargas Cullell, J.; Benavides, T., y Gómez, M ., 2003a, M edición de la participación ciudadana en América Latina, San José, documento preparado para el Proyecto sobre Desarrollo Democrático de América Latina del PNUD, junio de 2003.

- - - - , 2003b, Nota conceptual y planteamiento analítico sobre las orientaciones hacia la democracia de las y los ciudadanos en América Latina, San José, documento preparado para el Proyecto sobre Desarrollo Democrático de América Latina del PNUD, junio de 2003.

Vargas Cullell, J., y Benavides, T., 2003, N ota conceptual y metodológica sobre intensidad ciudadana, San José, documento preparado para el Proyecto sobre Desarrollo Democrático de América Latina del PNUD, junio de 2003.

Vargas Cullell, J., y Gómez, M ., 2003, M edición delas percepciones sobreel apego a las normas legales con base en Latinobarómetro 2002, San José, documento preparado para el Proyecto sobre Desarrollo Democrático deAmérica Latina del PNUD, junio de 2003.

Vargas Cullel, J., y Gutiérrez Saxe, M., 2001, Auditoría ciudadana dela calidad dela democracia, San José 
de Costa Rica, Proyecto Estado de la Nación en Desarrollo Humano Sustentable.

Vargas-Cullell, J., y Rosero-Bixby, L., Cultura democrática en Costa Rica: 2004, San José, informe preparado para el Proyecto de O pinión Pública de la Universidad deVanderbilt (en prensa).

Vázquez, R., 2001, Liberalismo, estado de derecho y minorías, M éxico DF, Paidós.

Verba, S., et al., 1978, Participation and Political Equality, Cambridge, Cambridge University Press.

Verba, S.; Schlozman, K. L., y Brady, H ., 1995, Voice and Equality. Civic Voluntarism in American Politics, Cambridge, M assachusetts, Harvard University Press.

Verdesoto C., LuisF., 1989, “El sistema departidos políticos y la sociedad civil en Ecuador", en Los sistemas políticos en América Latina, coordinación de Lorenzo M eyer y José Luis Reyna, M éxico DF, Siglo XXI Editores; Tokio, Universidad de las Naciones Unidas.

Villey, M ., 1968, La Formation dela Pense'eJuridique M oderne, París, M ontchrestien.

Waldron, J., 1999, Law and Disagreement, Oxford, Clarendon Press.

Walker, Thomas, y Armony, Ariel (comp.), 2000, Re pression, Resistance, and Democratic Transition in Central America, Wilmington, Delaware, Scholarly Resources.

Wallack, Jessica; Gaviria, Alejandro; Panizza, Ugo, y Stein, Ernesto, 2003, "Electoral systems data set" [http://www.stanford.edu/ jseddon/].

Ward, Gene, 2002, "Requisitos de divulgación en el financiamiento de partidos políticos y campañas electorales", artículo presentado en el Foro Interamericano sobre Partidos Políticos, Vancouver, 4-6 de diciembre.

Weale, A., 1983, Political Theory and Social Policy, Nueva York, St. Martin's Press.
Weber, M ., 1978, Economy and Society. An Outline of Interpretative Sociology, 1, Berkeley, University of California Press. (Edición en español: 1944, Economía y sociedad, M éxico, Fondo de Cultura Económica.)

- - - , 1997, El político y el científico, Madrid, Alianza.

Weffort, Francisco, 1981 ¿Por qué democracia?, San Pablo, Brasiliense.

Whitehead, L., 2001, "Some Significant Recent Developments in theField of Democratization", trabajo presentado en el Congreso M undial de Ciencia Política, Quebec, Canadá.

- - - , 2002a, Democratization. Theory and Experience, Oxford, Oxford University Press.

- - - - , 2002b, "N otes on Human Development, Human Rights, and Auditing the Quality of Democracy", comentarios escritos presentados al taller sobre Calidad de la Democracia y Desarrollo Humano en América Latina, Heredia, Costa Rica.

- - - , 2004, "Comentario sobre las tres tesis", texto preparado para PRODDAL, en PNUD, La democracia en América Latina. Hacia una democracia deciudadanas y ciudadanos. Anexo: El debate conceptual sobre la democracia (CD ROM ), Buenos Aires, Aguilar, Altea, Taurus, Alfaguara.

Wightman, J., 1995, Contract: A Critical Commentary, Londres, Pluto Press.

Wilkie, JamesW. (comp.), 2001, Statistical Abstract of Latin America, vol. 37, Los Ángeles, UCLA Latin American Center.

Willis, Eliza; Garmen, Christopher, y Haggard, Stephan, 1998, "The Politics of Decentralization in Latin America", en Latin American Research Review 34 (1), pp. 7-56.

Young, I. M ., 1995, "Polity and Group Difference: A Critique of the Ideal of Universal Citizenship", en Beiner, R., Theorizing Citizenship, Nueva York, State University of New York Press. 
Yrigoyen Fajardo, R., 1999, Pautas de coordinación entreel Derecho Indígena y el Derecho Estatal, Guatemala, Fundación Myrna Mack.

Zermeño, Sergio, 1978, M éxico, una democracia utópica, M éxico, Siglo XXI.

- - - - 1998, La sociedad derrotada, Centro de Investigaciones interdisciplinarias en Ciencias y Humanidades/UNAM.
Zovatto G., Daniel, 2003, “Dinero y política en América Latina: Una visión comparada", en Instituto Federal Electoral de M éxico (comps.), Dinero y contienda política electoral, M éxico, Fondo de Cultura Económica. 



\section{Abreviaturas}

$\mathrm{BM}$

BID Banco Interamericano de Desarrollo

CEJA Centro de Estudios de Justicia de las Américas

CELADE Centro Latinoamericano y Caribeño de Demografía

CEPAL Comisión Económica para América Latina

CLAD Centro Latinoamericano de Administración para el Desarrollo

EPIC Colección Informativa sobre Procesos Electorales

FMI Fondo M onetario Internacional

IDEA Instituto para la Democracia y la Asistencia Electoral

IPEC Programa Internacional para la Erradicación del Trabajo Infantil

IPU Unión Interparlamentaria

LASA Asociación de Estudios

Latinoame ricanos
OCDE Organización de Cooperación y Desarrollo Económicos

OEA Organización deEstados Americanos

OIT Organización Internacional del Trabajo

OMS Organización Mundial de la Salud

ONU Organización de las Naciones Unidas

PNUD Programa de las Naciones Unidas para el Desarrollo

SIMPOC Programa Estadístico de Información y M onitoreo sobre Trabajo Infantil

$\mathrm{TI}$

Transparencia Internacional

UNESCO Organización de las Naciones Unidas para la Educación, la Ciencia y la Cultura

UNICEF Fondo de las Naciones Unidas para la Infancia

UNODC Oficina de las Naciones Unidas contra la Droga y el Delito 



\section{- Índice de recuadros}

35 RECUADRO 1

La democracia: una búsqueda permanente

36 RECUADRO 2

La democracia: un ideal

45 RECUADRO 3

La democracia y la promesa de los derechos ciudadanos

46 RECUADRO 4

Declaración Universal de Derechos Humanos

46 RECUADRO 5

Los derechos democráticos

47 RECUADRO 6

La democracia requiere más que elecciones

$50 \quad$ RECUADRO 7

Los cimientos de la democracia

52 RECUADRO 8

Ciudadanía y comunidad de ciudadanos

53 RECUADRO 9

La democracia: una construcción permanente

54 RECUADRO 10

Democracia e igualdad

54 RECUADRO 11

Democracia y soberanía

56 RECUADRO 12

Una definición de poliarquía

58 RECUADRO 13

Democracia y responsabilidad de los gobernantes

64 RECUADRO 14

Estado liberal y Estado democrático 
65 RECUADRO 15

El Estado: presupuesto de la democracia

66 RECUADRO 16

Estado y globalización

69 RECUADRO 17

Los Objetivos de Desarrollo del Milenio

71 RECUADRO 18

La democracia: una tensión entre hechos y valores

72 RECUADRO 19

La información: una necesidad básica

79 RECUADRO 20

El Índice de Democracia Electoral (IDE)

Una contribución a la discusión sobre la democracia

91 RECUADRO 21

La petición ciudadana ante las instituciones públicas

97 RECUADRO 22

Experiencias de participación en gobiernos locales

104 RECUADRO 23

Dimensiones de la ciudadanía civil

105 RECUADRO 24

Legislación sobre violencia contra la mujer, 2002

107 RECUADRO 25

Pueblos indígenas y ciudadanía

107 RECUADRO 26

La democracia étnica y el multiculturalismo

110 RECUADRO 27

La percepción ciudadana acerca de la igualdad ante la ley

114 RECUADRO 28

La petición ciudadana al sistema de administración de justicia

118 RECUADRO 29

Ciudadanos pobres y desiguales

118 RECUADRO 30

Dimensiones de la ciudadanía social

120 RECUADRO 31

Inserción genuina para los "supernumerarios"

126 RECUADRO 32

El rol de la sociedad civil

128 RECUADRO 33

La decencia como valor colectivo

128 RECUADRO 34

Disfuncionalismos de la economía mundial 
129 RECUADRO 35

Pobreza y desigualdad: poco cambio significativo

136 RECUADRO 36

¿Cuántos demócratas y no demócratas "puros" hay en América Latina?

145 RECUADRO 37

Ciudadanía de baja intensidad

146 RECUADRO 38

El Índice de Apoyo a la Democracia (IAD)

178 RECUADRO 39

El poder de los medios de comunicación

179 RECUADRO 40

Sociedad civil, política y participación

180 RECUADRO 41

La dimensión asociativa de la democracia

181 RECUADRO 42

Política, partidos y democracia en América Latina

182 RECUADRO 43

La democracia como principio de organización de la sociedad

184 RECUADRO 44

Privatización perversa del Estado

185 RECUADRO 45

La economía y la política

186 RECUADRO 46

Una economía para la democracia

187 RECUADRO 47

Democracia y mercado

187 RECUADRO 48

Modelo único de desarrollo

189 RECUADRO 49

Cuatro ventajas económicas de la democracia

190 RECUADRO 50

Complementariedad entre democracia y mercado

193 RECUADRO 51

Globalización e impotencia de la política 



\section{— Índice de tablas}

40 TABLA 1

Democracia, pobreza y desigualdad

42 TABLA 2

Reformas y realidades

51 TABLA 3

Percepciones sobre razones de incumplimiento de promesas electorales por gobernantes, América Latina, 2002

81 TABLA 4

Elecciones limpias, 1990-2002

82 TABLA 5

Elecciones libres, 1990-2002

83 TABLA 6

Elecciones como el medio de acceso a cargos públicos, 1990-2002

84 TABLA 7

La participación electoral, 1990-2002

86 TABLA 8

Los partidos políticos y la democracia interna, 1990-2001

87 TABLA 9

Cupos para candidatas a cargos parlamentarios, 2003

88 TABLA 10

Financiamiento de partidos y campañas electorales, 2003

89 TABLA 11

Escaños en el Congreso ganados por mujeres, 1990-2003

90 TABLA 12

Proporcionalidad en la representación vía partidos políticos, 1990-2002

91 TABLA 13

Experiencias de trato a las personas que han acudido a una entidad pública en los últimos 12 meses, 2002

92 TABLA 14

Poderes formales presidenciales, 2002 
94 TABLA 15

Poderes judiciales, 2002

96 TABLA 16

Organismos especializados de control, 2002

98 TABLA 17

Mecanismos de democracia directa desde arriba, 1978-2002

99 TABLA 18

Mecanismos de democracia directa desde abajo, 1978-2002

100 TABLA 19

Indicadores de percepciones sobre corrupción, 2002

101 TABLA 20

Perfil de las personas con diferentes actitudes hacia la corrupción, 2002

102 TABLA 21

Redes clientelistas, 2002

103 TABLA 22

Tratados de la ONU, la OIT y la OEA: derechos generales y derechos de categorías de ciudadanos, 2002

106 TABLA 23

Derechos de los pueblos indígenas, 2000

109 TABLA 24

Mujeres en el mercado laboral, 1990-2000

109 TABLA 25

Incidencia del abuso a menores en las distintas regiones del mundo, 2000

110 TABLA 26

Percepción sobre la igualdad legal de grupos específicos, 2002

111 TABLA 27

Tratados de la ONU y la OEA sobre derechos civiles fundamentales, 2003

112 TABLA 28

Homicidios dolosos en América Latina y otras partes del mundo, c. 2000

113 TABLA 29

Recursos financieros y humanos dedicados al sistema de administración de justicia, 2001

114 TABLA 30

Experiencia de los ciudadanos con el sistema de administración de justicia, 2002

115 TABLA 31

Población carcelaria, presos sin condena y hacinamiento, 2002

116 TABLA 32

Libertad de prensa, 2001-2002

116 TABLA 33

Muerte de periodistas, 1993-2002

117 TABLA 34

Derecho al acceso a la información pública y hábeas data, 2002 
119 TABLA 35

Desnutrición infantil, 1985-2000

120 TABLA 36

Analfabetismo en mayores de 15 años, 1970-2000

$121 \quad$ TABLA 37

Mortalidad infantil, 1970-2000

$121 \quad$ TABLA 38

Esperanza de vida al nacer, 1970-2000

122 TABLA 39

Escolarización primaria, secundaria y terciaria, 1999

122 TABLA 40

Calidad educativa y performance del alumno, 2002

123 TABLA 41

Desempleo abierto urbano (tasas anuales medias), 1985-2002

124 TABLA 42

Desempleo juvenil (tasas anuales), 1990-2002

125 TABLA 43

América Latina: estructura del empleo no agrícola (porcentajes), 1990-2002

125 TABLA 44

América Latina: asalariados que cotizan en la seguridad social (porcentajes), 1990-2002

127 TABLA 45

Ciudadanía social: desigualdad y pobreza, c. 2002

131 TABLA 46

Fragilidades de la preferencia por la democracia frente a otros sistemas de gobierno, 2002

137 TABLA 47

Distancia entre las orientaciones hacia la democracia en los distintos temas estudiados.

América Latina, 2002

138 TABLA 48

Perfil socioeconómico de las personas según su orientación hacia la democracia, 2002

140 TABLA 49

Perfil político de las personas según su orientación hacia la democracia, 2002

142 TABLA 50

Perfil socioeconómico de las personas según modos de participación ciudadana, 2002

$151 \quad$ TABLA 51

¿Aumentó la participación en América Latina?

152 TABLA 52

¿Aumentaron los controles al poder en América Latina?

155 TABLA 53

¿Quiénes ejercen poder en América Latina?, según menciones de los líderes consultados

157 TABLA 54

¿Los partidos están cumpliendo su papel? 
TABLA 55

Problemas a enfrentar para fortalecer la democracia

167 TABLA 56

Problemas a enfrentar para fortalecer la democracia, según juicio sobre estado de la democracia en su país

168 TABLA 57

Agenda actual según tema

169 TABLA 58

Agenda futura según tema 


\section{— Índice de gráficos}

80 GRÁFICO 1

Índice de Democracia Electoral (IDE), 1977, 1985, 1990-2002

108 GRÁFICO 2

Ambiente de negocios. América Latina y Europa occidental, 1990-2000

108 GRÁFICO 3

Derechos de los trabajadores. América Latina y Europa occidental, 1990-2000

128 GRÁFICO 4

Distribución del ingreso en América Latina, c. 2002

133 GRÁFICO 5

Perfil de las orientaciones hacia la democracia, América Latina, 2002

134 GRÁFICO 6

Proporción de personas que sustentan las orientaciones hacia la democracia, promedios subregionales, 2002

136 GRÁFICO 7

Demócratas, ambivalentes y no demócratas según su ubicación en las escalas de actitud democrática. América Latina, 2002

147 GRÁFICO 8

Panorama regional del IAD, 2002

188 GRÁFICO 9

La agenda ciudadana: principales problemas, América Latina, 2002

191 GRÁFICO 10

Posición frente a la intervención del Estado en la economía, América Latina, 2002 



\title{
- Contenido del CD-Rom que acompaña este Informe
}

\author{
INFORME: LA DEMOCRACIA EN AMÉRICA LATINA
}

\section{COMPENDIO ESTADÍSTICO}

11 Introducción

\section{PRIMERA PARTE}

13 Indicadores de desarrollo de la democracia

21 Índice de democracia electoral

23 Tabla 1. Índice de democracia electoral (IDE), 1960, 1977, 1985, 1990-2002

24 Tabla 2. Derecho al voto, 1960, 1977, 1985, 1990-2002

25 Tabla 3. Elecciones limpias, 1960, 1977, 1985, 1990-2002

26 Tabla 4. Elecciones libres, 1960, 1977, 1985, 1990-2002

27 Tabla 5. Cargos públicos electos, 1960, 1977, 1985, 1990-2002

28 Nota Técnica sobre el índice de democracia electoral (IDE)

35 Democracia y ciudadanía política: derechos políticos Derecho al voto (tablas 6-8)

37 Tabla 6. Elecciones regulares: Elecciones para presidente y congreso, 1990-2002

38 Tabla 7. Requisitos legales, 2002

39 Tabla 8. Proporción de ciudadanos con derecho al voto, 1990-2000

\section{Obligaciones de los votantes (tablas 9-15)}

40 Tabla 9. Voto obligatorio, 1990-2002

41 Tabla 10. Procedimientos de registro de votantes, c. 2000

42 Tabla 11. Votantes registrados con relación a la población en edad de votar, 1990-2002

43 Tabla 12. Concurrencia con relación a los votantes registrados, 1990-2002

44 Tabla 13. Concurrencia con relación a la población en edad de votar, 1990-2002 
Tabla 15. Votos válidos relativos a la población en edad de votar, 1990-2002

Elderecho a una competencia libre y limpia (tablas 16A-22)

47 Tabla 16A. Requisitos personales para postulación a cargos, 2002

48 Tabla 16B. Requisitos personales para postulación a cargos, 2002

49 Tabla 17. Control partidario del proceso de selección de candidatos, 1990-2001

50 Tabla 18. Procedimiento de inscripción de partidos, 2002

52 Tabla 19. Acceso a fondos públicos directos, 1990-2001

53 Tabla 20. Acceso a fuentes privadas, 1990-2001

54 Tabla 21. Acceso a tiempo en TV, 1990-2001

55 Tabla 22. Independencia de los cuerpos de Administración electoral, 1990-2001

Democracia interna de los partidos (tablas 23-26)

Tabla 23. Designación de candidatos presidenciales: Requisitos legales, 1990-2001

57 Tabla 24. Designación de candidatos presidenciales: Realización de elecciones primarias, 1990-2001

Tabla 25. Designación de candidatos parlamentarios: Métodos de selección y elección de candidatos, 1990-2002

59 Tabla 26. Designación de candidatos parlamentarios: Cuotas para candidatas parlamentarias femeninas, 2002

\section{Reglamento electoral (tablas 27A-29)}

60

61

Tabla 27A. Normas para la elección presidencial, 1990-2002

Tabla 27B. Normas para la elección presidencial, 1990-2002

Tabla 28. Normas para la elección de la cámara baja o única, 1990-2002

Tabla 29. Normas para la elección de la cámara alta, 1990-2002

\section{El sistema de partidos políticos (tablas 30A-35)}

Tabla 30A. Número de partidos y distribución de bancas en el Parlamento, 1990-2002

Tabla 30B. Número de partidos y distribución de bancas en el Parlamento, 1990-2002

Tabla 31. Índice de número efectivo de partidos sobre la base del porcentaje de votos, 1990-2002

Tabla 32. Índice de número efectivo de partidos sobre la base del porcentaje de bancas, 1990-2002

Tabla 33. Evolución del apoyo electoral a los principales partidos, c. 1980-2002

Tabla 34. Índice de volatilidad electoral sobre la base del porcentaje de votos, 1990-2002

Tabla 35. Índice de volatilidad electoral sobre la base del porcentaje de bancas, 1990-2002

Derecho a un voto de igual valor (tablas 36-39)

Tabla 36. Índice de distribución no proporcional de bancas, 1990-2002

Tabla 37. Índice de desproporcionalidad electoral, 1990-2002

Tabla 38. Votos para partidos que no lograron obtener bancas, 1990-2002

Tabla 39. Bancas obtenidas por mujeres, 1990-2003 
77 Tabla 40. La división de poderes, 2002

78 Tabla 41. Condiciones de ocupación de cargos del Ejecutivo, 2002

79 Tabla 42. Condiciones de ocupación de cargos legislativos, 2002

80 Tabla 43. Poderes presidenciales legislativos, 2002

82 Tabla 44. Poderes presidenciales partidistas, c. 2001

83 Tabla 45. Poderes presidenciales globales, c. 2002

84 Tabla 46. Términos de acceso a la Corte Suprema, 2002

85 Tabla 47. Facultades del Poder Judicial, 2002

Organismos especializados de control (tablas 48A-50A)

Tabla 48A. Agencias de auditoria, 2002

Tabla 48B. Agencias de auditoria, 2002

Tabla 49. Ministerio público, 2002

Tabla 50A. Instituciones de Defensoría del Pueblo, 2002

Mecanismos de democracia directa (tablas 50B-54)

91 Tabla 50B. Instituciones de Defensoría del Pueblo, 2002

92 Tabla 51. Mecanismos "desde abajo" I: iniciativas legislativas populares, 2002

93 Tabla 52. Mecanismos "desde abajo" II: referéndum, 2002

94 Tabla 53. Mecanismos "desde abajo" III: revocatoria, 2002

95 Tabla 54. Mecanismos "desde arriba": plebiscito, 2002

\section{Democracia y ciudadanía civil: derechos civiles}

Igualdad y protección frente a la discriminación (tablas 55A-63)

Tabla 55A. Tratados de las Naciones Unidas

Tabla 55B. Tratados de las Naciones Unidas

Tabla 56A.Tratados de la Organización Internacional del Trabajo

102

Tabla 56B.Tratados de la Organización Internacional del Trabajo

Tabla 57A. Tratados interamericanos

Tabla 57B. Tratados interamericanos

Tabla 58. Ambiente favorable para los negocios, 1980-2002

Tabla 59. Estándares laborales, 1990-2000

107

Tabla 60. Legislación sobre violencia contra las mujeres, 1990-2001

108 Tabla 61. Disparidad salarial por género, 1989-1999

109 Tabla 62. Trabajo infantil, 2000

110 Tabla 63. Tratados internacionales y derechos multiculturales y lingüísticos, 2002 
Derecho a la vida, a la integridad física y a la seguridad (tablas 64-65)

111

112

113

114

Tabla 64. Homicidios, c. 2000

Tabla 65. Pena de muerte, 1990-2002

Derecho a la justicia (tablas 66-67B)

Tabla 66. Acceso a la justicia, c. 2001

Tabla 67A. Población carcelaria, presos sin sentencia, hacinamiento y categorías de prisioneros, c. 2000.

Tabla 67B. Población carcelaria, presos sin sentencia, hacinamiento y categorías de prisioneros, c. 2000.

Derecho a la libertad de prensa y de información (tablas 68-70)

Tabla 68. Libertad de prensa, 1993-2002

Tabla 69. Violencia contra periodistas, 1990-2002

Tabla 70. Derecho al acceso a la información pública y habeas data, 2002

\section{Democracia y ciudadanía social: derechos sociales}

\section{Pobreza e indigencia (tablas 71-74)}

Tabla 71. Pobreza e indigencia I. Hogares e individuos, 1980-1999

Tabla 72A. Pobreza e indigencia II. Individuos, 1989/1990-2001

Tabla 72B. Pobreza e indigencia II. Individuos, 1989/1990-2001

Tabla 73A. Pobreza e indigencia III. Hogares, 1977-2000

Tabla 73B. Pobreza e indigencia III. Hogares, 1977-2000

Tabla 74. Pobreza e indigencia IV. Hogares pobres en áreas urbanas y rurales, 1989-2000

\section{Desigualdad (tablas 75-76)}

Tabla 75. Coeficientes Gini, total, urbana y rural, 1989-2000

Tabla 76. Distribución del ingreso por quintiles en hogares urbanos, 1979-2000

\section{Trabajo (tablas 77-81)}

Tabla 77. Tasa de desempleo abierto en áreas urbanas I. Total, 1990-2002

Tabla 78. Tasa de desempleo abierto en áreas urbanas II. Hombres y mujeres, 1990-2000

Tabla 79. Salarios mínimos urbanos reales, 1990-2001

Tabla 80. Salarios industriales reales, 1990-2001

Tabla 81. Tamaño del sector informal por categoría de trabajadores, c. 2000

\section{Salud (tablas 82A-86)}

Tabla 82A. Mortalidad infantil (total, hombres y mujeres), 1970-2000

Tabla 82B. Mortalidad infantil (total, hombres y mujeres), 1970-2000

Tabla 83A. Expectativa de vida (total, hombres y mujeres), 1970-2000

Tabla 83B. Expectativa de vida (total, hombres y mujeres), 1970-2000

Tabla 84. Desnutrición infantil (total, hombres y mujeres, urbana y rural), 1980-2000

Tabla 85. Suministro de agua e instalaciones sanitarias (total, urbana y rural), 1990-2000

Tabla 86. Gastos públicos en salud, 1980-2000 


\section{Educación (tablas 87-90)}

143 Tabla 87. Analfabetismo adulto (total, hombres y mujeres), 1970-2001

144 Tabla 88. Matrícula educativa en los niveles primario, secundario y terciario, c. 1999

145 Tabla 89. Promedio de años de escolarización, 1990-2000

146 Tabla 90. Gasto público, 1980-2000

147 Factores socioeconómicos relacionados

\section{Desarrollo humano y reformas económicas (tablas 91-92)}

149 Tabla 91. Índice de desarrollo humano, 1975-2001

150 Tabla 92. Índice de reforma económica, 1985-2000

\section{Ingreso (tablas 93-95)}

151 Tabla 93. Ingreso bruto nacional (IBN) e IBN per capita, 2001

152 Tabla 94A. Crecimiento anual del producto bruto interno (PBI), 1951-2002

153 Tabla 94B. Crecimiento anual del producto bruto interno (PBI), 1951-2002

154 Tabla 95. Crecimiento anual del producto bruto interno (PBI) per capita, 1980-2002

\section{Inflación (tablas 96A-96B)}

155 Tabla 96A. Variación anual del índice de precios al consumidor (IPC), 1980-2002

156 Tabla 96B. Variación anual del índice de precios al consumidor (IPC), 1980-2002

\section{Cuentas fiscales nacionales (tablas 97-101)}

157 Tabla 97. Ingresos tributarios como \% del PBI, 1980-2000

158 Tabla 98. Origen de los impuestos I. Impuestos al ingreso y a las ganancias de capital como $\%$ de Ingresos tributarios, 1980-2000

159 Tabla 99. Origen de los impuestos II. Impuestos a la propiedad como \% de ingresos tributarios, 1980-2000

160 Tabla 100. Impuestos sobre compañías, sociedades de capital o empresas como \% de ingresos tributarios, 1980-2000

161 Tabla 101. Déficit/superávit presupuestario global, 1990-2000

\section{Sector externo (tablas 102-109)}

162 Tabla 102. Importaciones como porcentaje del PBI, 1980-2001

163 Tabla 103. Exportaciones como porcentaje del PBI, 1980-2001

164 Tabla 104. Balance exportaciones-importaciones, 1980-2001

165 Tabla 105. Inversión extranjera directa neta, 1992-2002

166 Tabla 106. Financiamiento externo como porcentaje de la inversión bruta interna, 1980-2001

167 Tabla 107. Deuda externa desembolsada total, 1990-2002

168 Tabla 108. Deuda externa desembolsada total como porcentaje de las exportaciones de bienes y servicios, 1991-2002

169 Tabla 109. Transferencia neta de recursos, 1980-2002 


\section{Mercado laboral (tablas 110-112)}

\section{SEGUNDA PARTE}

191

193

215 Latina y subregiones

Tabla 110. Estructura de la población económicamente activa, 1985-2000

Tabla 111. Composición por sector de actividad, 1970-90

Tabla 112. Composición por sector de actividad y sexo, 1970-90

\section{Medio ambiente (tablas 113-115)}

Tabla 113. Índices de sistemas ambientales y de reducción del impacto ambiental, c. 2000

Tabla 114. Emisiones de dióxido de carbono, c. 2000

Tabla 115. Biodiversidad, c. 2000

\section{Demografía (tablas 116-122)}

Tabla 116. Total de población, hombres y mujeres, urbana y rural, 2000-01

Tabla 117. Crecimiento total de población, 1970-2000

Tabla 118. Urbanización: crecimiento de la población urbana, 1970-2000

Tabla 119. Estructura etaria: coeficiente de dependencia, 1970-2000

Tabla 120. Análisis general desglosado de grupos étnicos, c. 2000

Tabla 121. Pueblos indígenas con respecto a la población nacional, c. 1993-2000

Tabla 122. Grupos indígenas más importantes, c. 1993

\section{Referencias a fuentes de indicadores}

\section{Estudio de opinión sobre la democracia}

\section{Nota técnica sobre los índices derivados del análisis de la encuesta Latinobarómetro 2002 \\ La construcción del Índice de Apoyo a la Democracia (IAD)}

\section{Índice de apoyo a la democracia}

Tabla 123. Perfil político de las personas según su orientación hacia la democracia, 2002

Tabla 124. Perfil socioeconómico de las personas según su orientación hacia la democracia, 2002

Tabla 125. Perfil de las personas con distintas actitudes hacia la corrupción, 2002

Tabla 126. Indicadores de tamaño, distancia y activismo, por país y región (IAD)

Tabla 127. Promedio y desviación estándar de las preguntas utilizadas en la determinación de las orientaciones

Tabla 128A. Modos de participación ciudadana, por país y región

Tabla 128B. Modos de participación ciudadana, por país y región

Tabla 129. Perfil socioeconómico y político de las personas según su modo de participación ciudadana, América

Tabla 130A. Tipo de organización en la que colaboran, ya sea con dinero, trabajo o reuniones, por región y país Tabla 130B. Tipo de organización en la que colaboran, ya sea con dinero, trabajo o reuniones, por región y país 
231

233

234

Tabla 131A. Votación en las últimas elecciones presidenciales y razones de no voto de abstencionistas, por país y región

Tabla 131B. Votación en las últimas elecciones presidenciales y razones de no voto de abstencionistas, por país y región

Tabla 132. Percepción de eficacia del voto, por país y región

Tabla 133. Identificación electoral con partidos, por país y región

Tabla 134. Perfil socioeconómico de las personas según su identificación electoral partidaria, América Latina y subregiones

Tabla 135. Presiones electorales en las últimas elecciones presidenciales por país y región

Tabla 136. Perfil socioeconómico de las personas según experiencia de presiones electorales, América Latina y subregiones

Tabla 137. Entrevistados según razones por las que consideran que los gobernantes no cumplen sus promesas de campaña

Tabla 138. Cumplimiento de promesas electorales, por país y región

Tabla 139A. Problema prioritario y abordaje en campaña electoral, por país y región

Tabla 139B. Problema prioritario y abordaje en campaña electoral, por país y región

Tabla 140. Conocimiento de casos de clientelismo, por país y región

Tabla 141. Índice de confianza en instituciones y actores políticos, por país y región

Tabla 142. Posición ante la intervención económica del Estado, por país y región

Tabla 143. Posición ante la intervención económica del Estado en el desarrollo, por país y subregión

Tabla 144A. Actitud ante la reforma del Estado, por país y región

Tabla 144B. Actitud ante la reforma del Estado, por país y región

Tabla 145. Perfil socioeconómico de las personas según opinión sobre la reforma de Estado, América Latina y subregiones

\section{Ciudadanía civil}

Tabla 146. Experiencia en las gestiones en las instituciones públicas, por país y región Tabla 147A. Capacidad de grupos vulnerables de hacer valer sus derechos, por país y región Tabla 147B. Capacidad de grupos vulnerables de hacer valer sus derechos, por país y región Tabla 147C. Capacidad de grupos vulnerables de hacer valer sus derechos, por país y región Tabla 148. Expectativa del trato del sistema de administración de justicia, por país y región Tabla 149. Necesidad del sistema de administración de justicia para resolver un problema, por país y región

Tabla 150. Razones para no acudir a la justicia o no concluir un proceso judicial, por país y región

Tabla 151. Razones para acudir al sistema de justicia, por país y región

Tabla 152. Cumplimiento del precepto de justicia pronta y cumplida, por país y región

Tabla 153. Experiencia en el sistema de administración de justicia, por país y región

Tabla 154. Uso y barreras de acceso al sistema de justicia, por país y región 
271 Tabla 155. Situación laboral y preocupación de perder su trabajo para aquellos que están laborando, por país y región

Tabla 156. Percepción de la desigualdad social, por país y región

Tabla 157. Percepción de situación del hogar y nivel económico, por país y región

Tabla 158. Movilidad económica intergeneracional ocurrida y esperada, por país y región Tabla 159. Nivel educativo y movilidad educativa con respecto a sus padres, por país y región Tabla 160. Perfil socioeconómico de las personas según preocupación de quedar desempleado en los próximos doce meses, América Latina y subregiones Tabla 161. Porcentaje: primera mención en ¿quién cree usted que tiene más poder en este país? Tabla 162. Porcentaje: conteo de menciones en las tres alternativas de ¿quién cree usted que tiene más poder en este país?

\section{EL DEBATE CONCEPTUAL SOBRE LA DEMOCRACIA}

$7 \quad$ El debate conceptual sobre la democracia

$9 \quad$ Presentación. El debate conceptual sobre la democracia

PRIMERA PARTE

11 Notas sobre la democracia en América Latina Guillermo O'Donnell

83 Documento anexo. Siete tesis sobre el Estado en América Latina

$87 \square$ ¿Hacia una síntesis latinoamericana? Bruce Ackermann

103 Las condiciones sociales de la democracia: el Estado y el régimen Fernando Calderón

107 Más allá del minimalismo: una agenda para unir democracia y desarrollo Catherine Conaghan

La nacionalización y democratización del Estado, la política y la sociedad Julio Cotler

127 El estado de la democracia en América Latina David Held

$131 \square$ Sociedad civil y calidad de la democracia Juan E. Méndez

139 Esperanza entrampada: las perspectivas para la democracia en América Latina Adalberto Moreira Cardoso y José Eisenberg 
177 El objetivo de una perspectiva de género

Céli Regina Jardim Pinto

193 Las dimensiones social y nacional de la democracia: hacia un marco de comprensión ampliada

Pierre Rosanvallon

\section{SEGUNDA PARTE}

199 Tres tesis, elaboradas por el Informe, sobre el desarrollo democrático en América Latina

201 Documento base. Discusión de tres tesis para un marco teórico del proyecto "Desarrollo de la democracia en América Latina: estado, percepciones ciudadanas, indicadores y agenda"

209 Algunos comentarios sobre la Tesis I Andrew Arato

215 Desarrollo democrático en América Latina: su condición, las percepciones de sus ciudadanos, indicadores y agenda Renato Boschi

223 Sobre los atributos de la democracia como régimen político Larry Diamond

225 Comentario al documento: "Discusión de tres tesis para un marco teórico para el proyecto sobre el desarrollo de la democracia en América Latina: estado, percepciones ciudadanas, indicadores y agenda" Manuel Antonio Garretón

233 Sobre Tesis III. Sobre la democracia como organización social Jennifer McCoy

$241 \square$ Los caminos sinuosos de la democracia Alain Touraine

247 Comentarios sobre las tres tesis Laurence Whitehead

\section{LIBRO LA DEMOCRACIA EN AMÉRICA LATINA}

HACIA UNA DEMOCRACIA DE CIUDADANAS Y CIUDADANOS

\section{CONTRIBUCIONES PARA EL DEBATE}

$9 \quad$ Introducción

\section{Política para la democracia}

30 Dimensiones históricas de las transiciones a la democracia en América Latina Natalio Botana 
Marco Aurelio García

Crisis de la política: causas y respuestas eficientes Felipe González

Democracia, sociedad civil y política en América Latina: notas para un debate Cândido Grzybowski

72 La indispensable y problemática relación entre partidos y democracia en América Latina Manuel Antonio Garretón

98 Partidos políticos en América Latina: precisiones conceptuales, estado actual y retos futuros Manuel Alcántara Sáez

122 La crisis de la política en América Latina Rosario Green

El componente "parlamentarista" en los sistemas presidenciales. Ejercicio de simulación: caso Argentina Julio Godio y equipo

\section{Estado para la democracia}

148 Acerca del estado en América Latina contemporánea: diez tesis para discusión

Guillermo O’Donnell

$192 \square$ Notas sobre la crisis de legitimidad del estado y la democracia Fernando Calderón

214 Democratización, Estado e integración a la economía global. ¿Cuál es el lugar de la política democrática?: La experiencia brasileña en perspectiva Lourdes Sola

$228 \square$ Diversidad, Estado y democracia: unos apuntes Willem Assies

244 La democracia y las drogas en América Latina y el Caribe Eduardo Gamarra

Notas sobre corrupción y drogas ilegales Francisco E. Thoumi

$264 \square$ Ciudadanía y democracia: los aportes de una perspectiva de género Celi Jardim Pinto

278 Avances y límites de la democracia en América Latina, en los últimos veinte años

Cardenal Julio Terrazas 
282 Seguridad jurídica y estado democrático de derecho Raúl Alconada Sempé

Cultura y democracia, una relación olvidada

Osvaldo Hurtado

\section{Economía para la democracia}

310 Globalización, mercado y democracia Jean-Paul Fitoussi

Economía y democracia

José Antonio Ocampo

314 Globalización, organismos financieros internacionales y las economías latinoamericanas Joseph E. Stiglitz

Democracia y desarrollo: la política importa Enrique V. Iglesias

\section{Globalización y democracia}

Democracia y globalización

Fernando Henrique Cardoso

Notas sobre el impacto del comercio internacional en el desarrollo de las economías latinoamericanas (Contribución de la UNCTAD para el Informe del PNUD "Desarrollo de la Democracia en América Latina") Rubens Ricupero

460 La Carta de Navegación de las Américas César Gavíria

La defensa colectiva de la democracia Augusto Ramírez Ocampo

Globalización, hegemonía y democracia Dante Caputo

Melios y atenienses 